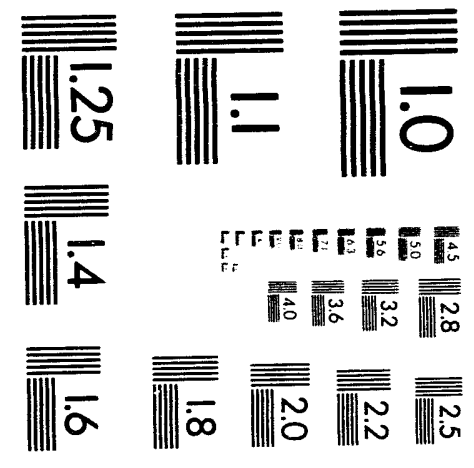



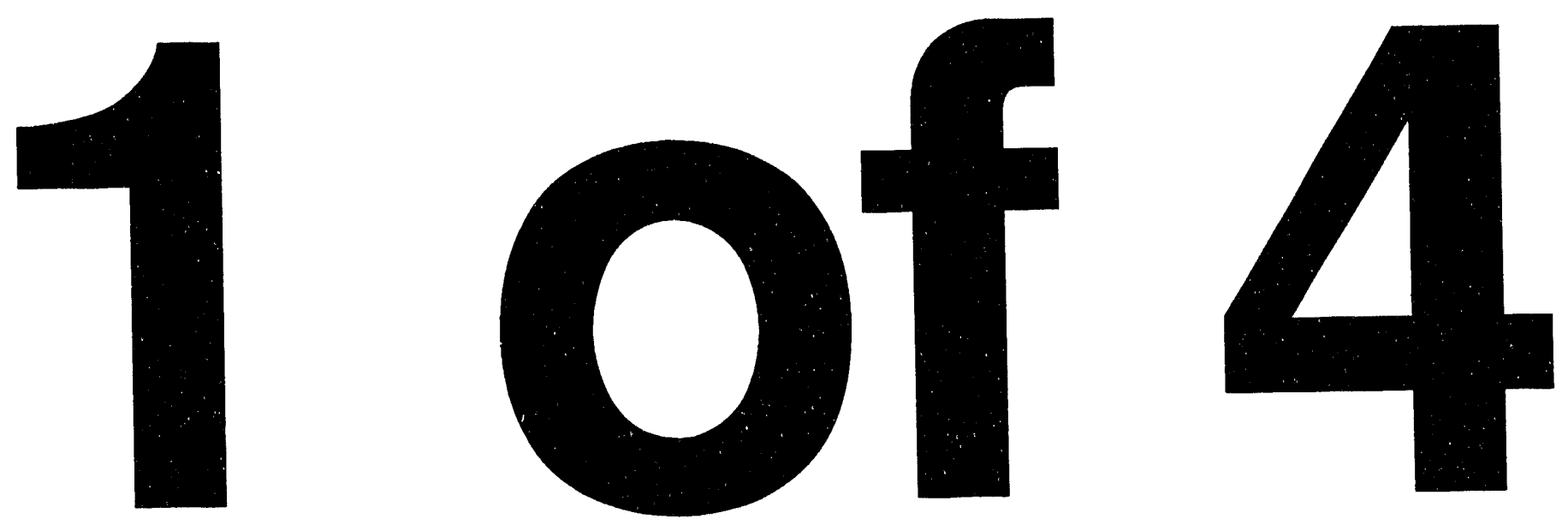


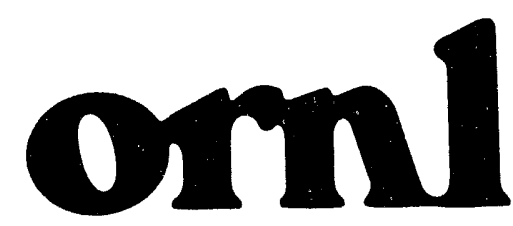

OAK RIDGE

NATIONAL

LABORATORY

MARTIN MARUEZTA

\author{
ENVIRONMENTAL SCIENCES DIVISION
}

Third Report on the Oak Ridge National Laboratory Biological Monitoring and Abatement Program for White Oak Creek Watershed and the Clinch River

\author{
J. M. Loar
}
S. M. Adams
R. D. Bailey
B. G. Blaylock
H. L. Boston
W. R. Hill
M. A. Huston
B. D. Jimenez
J. M. Loar
L. Meyers-Schöne
D. A. Mohrbacher
M. J. Peterson
C. M. Pettway
M. G. Ryon
E. M. Schilling
K. L. Shepard
L. R. Shugart
J. G. Smith
G. R. Southworth
A. J. Stewart
C. $\mathrm{K}$. Valentine
B. T. Walton
A. E. Waters

Environmental Sciences Division Publication No. 4255

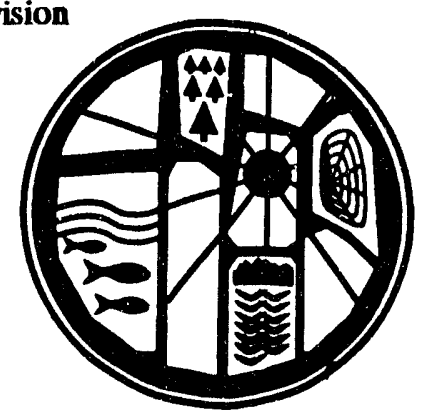


This report has been reproduced directly from the best available copy.

Available to DOE and DOE contractors from the Office of Scientific and Technical Information, P.O. Box 62, Oak Ridge, TN 37831; prices available from (615) 576-8401, FTS 626-8401.

Available to the public from the National Technical Information Service, U.S. Department of Commerce, 5285 Port Royal Rd., Springfield, VA 22161.

This report was prepared as an account of work sponsored by an agency of the United States Government. Neither the United States Government nor any agency thereof, nor any of their employees, makes any warranty, express or implied, or assumes any legal liability or responsibility for the accuracy, completeness, or usefulness of any information, apparatus, product, or process disclosed, or represents that its use would not infringe privately owned rights. Reference herein to any specific commercial product, process, or service by trade name, trademark, manufacturer, or otherwise, does not necessarily constitute or imply its endorsement, recommendation, or favoring by the United States Government or any agency thereof. The views and opinions of authors expressed herein do not necessarily state or reflect those of the United States Government or any agency thereof. 
ENVIRONMENTAL SCIENCES DIVISION

\title{
Third Report on the Oak Ridge National Laboratory Biological Monitoring and Abatement Program for White Oak Creek Watershed and the Clinch River
}

\section{Editor}

\author{
J. M. Loar
}

S. M. Adams
R. D. Bailey
B. G. Blaylock
H. L. Boston
W. R. Hill
M. A. Huston
B. D. Jimenez
J. M. Loar

\section{Contributors}

L. Meyers-Schöne ${ }^{2}$

D. A. Mohrbacher ${ }^{3}$

L. R. Shugart

M. J. Peterson

J. G. Smith

C. M. Pettway ${ }^{4}$

G. R. Southworth

M. G. Ryon

E. M. Schilling

A. J. Stewart

C. K. Valentine ${ }^{6}$

B. T. Walton

K. L. Shepard

A. E. Waters ${ }^{7}$

\section{Environmental Sciences Division}

Publication No. 4255

\footnotetext{
'University of Puerto Rico, San Juan

${ }^{2}$ Frankfurter, TTR 63A, 6080 Gross-Gerau, Germany

${ }^{3}$ Automated Sciences Group, Inc., Oak Ridge

'Knoxville College, Knoxville, Tennessee

'Advanced Sciences, Inc., Oak Ridge

${ }^{6}$ Office of Environmental Compliance and Documentation, ORNL

${ }^{7}$ Breedlove, Dennis, \& Assoc., Winter Park, Fla.
}

\section{Date of Issue - March 1994}

\author{
Prepared for \\ C. E. Nix, Leader \\ Environmental Compliance Group \\ Environmental Monitoring and Compliance Section \\ and \\ L. D. Bates, Manager \\ Remedial Action Program \\ Oak Ridge National Laboratory \\ Prepared by the \\ OAK RIDGE NATIONAL LABORATORY \\ Oak Ridge, Tennessee 37831-6285 \\ managed by \\ MARTIN MARIETTA ENERGY SYSTEMS, INC. \\ for the \\ U.S. DEPARTMENT OF ENERGY \\ under contract DE-AC05-84OR21400
}




\section{CONTENTS}

LIST OF FIGURES $\ldots \ldots \ldots \ldots \ldots \ldots \ldots \ldots \ldots \ldots \ldots \ldots \ldots \ldots \ldots$ vii

LIST OF TABLES $\ldots \ldots \ldots \ldots \ldots \ldots \ldots \ldots \ldots \ldots \ldots \ldots \ldots \ldots \ldots \ldots \ldots$

LIST OF ACRONYMS $\ldots \ldots \ldots \ldots \ldots \ldots \ldots \ldots \ldots \ldots \ldots \ldots \ldots \ldots \ldots \ldots \ldots$

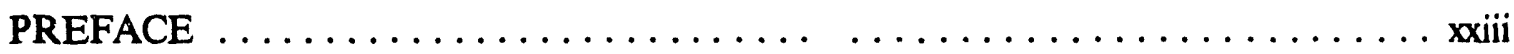

ACKNOWLEDGMENTS $\ldots \ldots \ldots \ldots \ldots \ldots \ldots \ldots \ldots \ldots \ldots \ldots \ldots \ldots \ldots$

EXECUTIVE SUMMARY $\ldots \ldots \ldots \ldots \ldots \ldots \ldots \ldots \ldots \ldots \ldots \ldots \ldots \ldots \ldots$ xxii

1. INTRODUCTION (J. M. Loar) $\ldots \ldots \ldots \ldots \ldots \ldots \ldots \ldots \ldots \ldots \ldots \ldots \ldots \ldots$

1.1 OBJECTIVES $\ldots \ldots \ldots \ldots \ldots \ldots \ldots \ldots \ldots \ldots \ldots \ldots \ldots \ldots \ldots \ldots \ldots \ldots \ldots \ldots \ldots, 1$

2. DESCRIPTION OF WHITE OAK CREEK WATERSHED $\ldots \ldots \ldots \ldots$

2.1 GEOHYDROLOGY (J. M. Loar) ..................... 2-1

2.2 WATER QUALITY (J. M. Loar, H. L. Boston, and R. D. Bailey) ...... 2-8

2.2.1 Description of ORNL Effluents .................... 2-8

2.2.2 Wastewater Modifications for Pollution Abatement......... 2-12

2.2.3 NPDES Water Quality Monitoring Program $\ldots \ldots \ldots \ldots \ldots \ldots .2-12$

2.2.4 BMAP Water Quality Sampling Program ............. 2-21

2.3 SUBSTRATE AND COVER (M. G. Ryon and J. G. Smith) . . . . . . . 2-28

2.3.1 Introduction $\ldots \ldots \ldots \ldots \ldots \ldots \ldots \ldots \ldots \ldots \ldots \ldots \ldots \ldots \ldots \ldots \ldots, 28$

2.3.2 Methods $\ldots \ldots \ldots \ldots \ldots \ldots \ldots \ldots \ldots \ldots \ldots \ldots \ldots \ldots \ldots \ldots \ldots, 28$

2.3 .3 Results ................................ 2-29

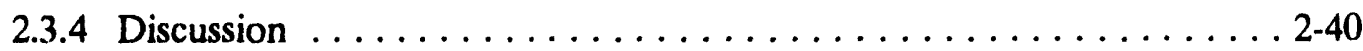

3. TOXICITY MONITORING . ......................

3.1 POINT-SOURCE AND AREA-SOURCE CONTRIBUTIONS

TO AMBIENT TOXICITY (A. J. Stewart $) \ldots \ldots \ldots \ldots \ldots \ldots \ldots, 3-1$

3.1.1 Point-Source Contributions to Toxicity $\ldots \ldots \ldots \ldots \ldots \ldots \ldots, 3-2$

3.1.2 Area-Source Contributions to Ambient Toxicity .............

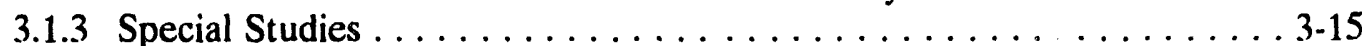

3.1.4 Future Studies ............................ 3-24

3.2 IN-STREAM MONITORING OF THE PERIPHYTON

COMMUNITY (H. L. Boston and W. R. Hill) $\ldots \ldots \ldots \ldots \ldots \ldots \ldots .25$

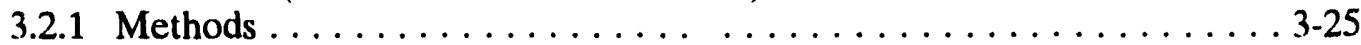

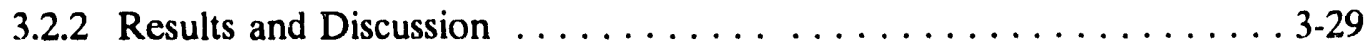

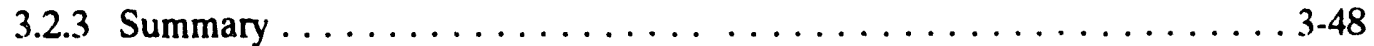

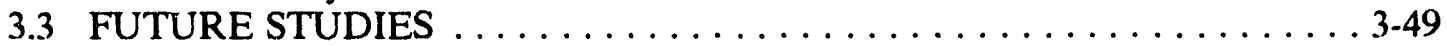


4. BIOACCUMULATION STUDIES (G. R. Southworth and M. J. Peterson) .... . 4-1

4.1 IDENTIFICATION OF CONTAMINANTS THAT

ACCUMULATE IN AQUATIC BIOTA $\ldots \ldots \ldots \ldots \ldots \ldots \ldots \ldots$ 4-1

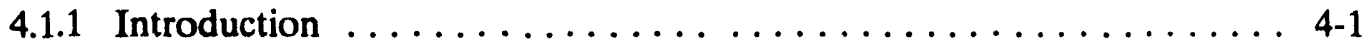

4.1 .2 Methods ........................... 4-1

4.1 .3 Results ........................... 4-3

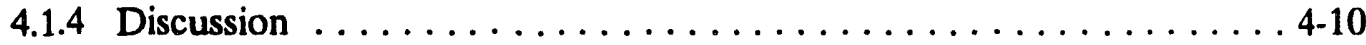

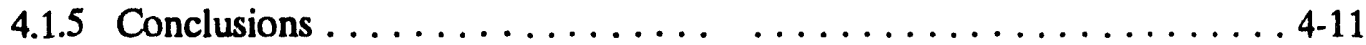

4.2 EVALUATION OF PCB CONTAMINATION IN WHITE OAK

CREEK EMBAYMENT CLINCH RIVER . . . . . . . . . . . . . . . 4-11

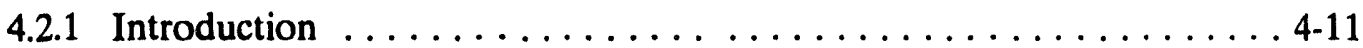

4.2 .2 Methods . . . . . . . . . . . . . . . . . . . . 4-12

4.2 .3 Results ........................... . 4-14

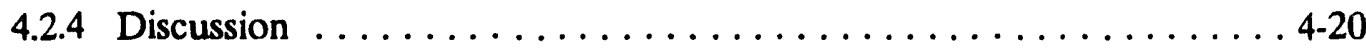

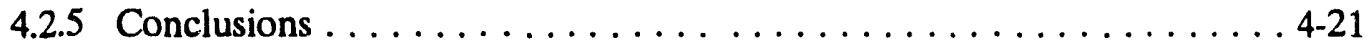

4.3 INTEGRATION OF WATER QUALITY AND

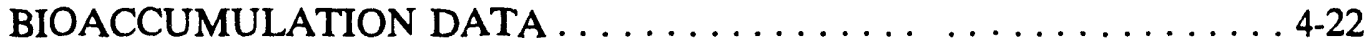

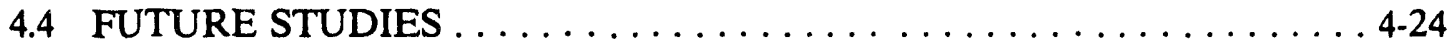

5. BIOLOGICAL INDICATORS OF CONTAMINANT-RELATED STRESS

(S. M. Adams, K. L. Shepard, B. D. Jimenez, and L. R. Shugart) . . . . . . . 5-1

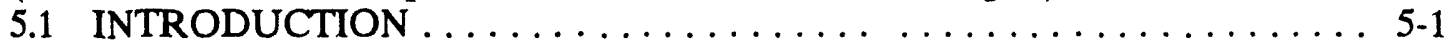

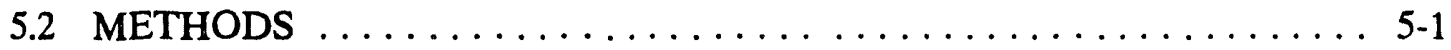

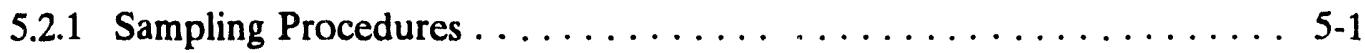

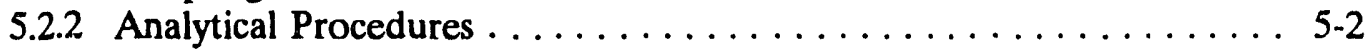

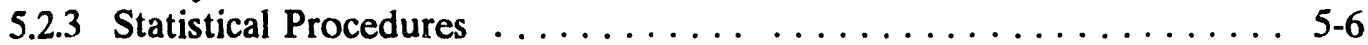

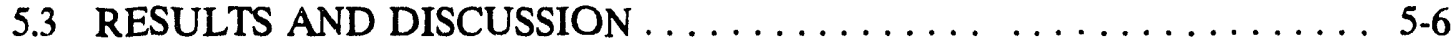

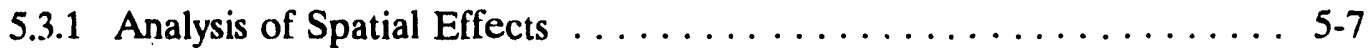

5.3 .2 Temporal Analysis . . . . . . . . . . . . . . . . . 5-20

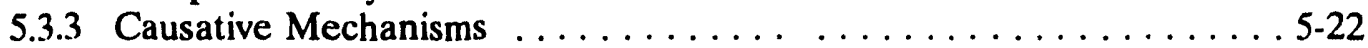

5.3.4 Indicators of Contaminant Exposure . . . . . . . . . . 5-26

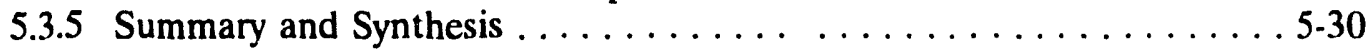

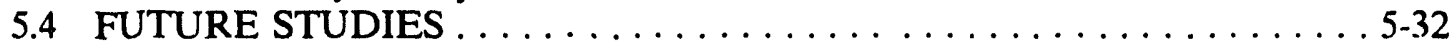

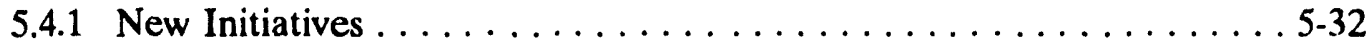

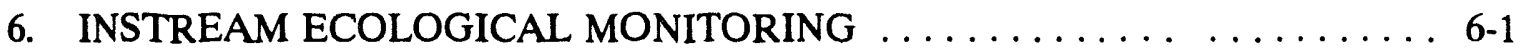

6.1 BENTHIC MACROINVERTEBRATES (J. G. Smith) . . . . . . . . . . 6-1

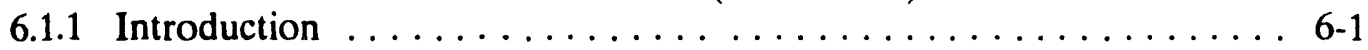

6.1 .2 Materials and Methods ...................... 6-1

6.1 .3 Results ........................... $6-3$

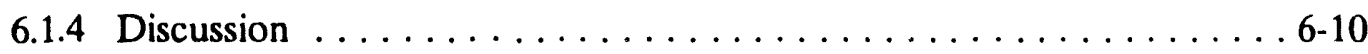

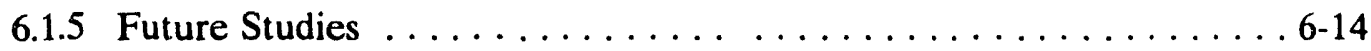

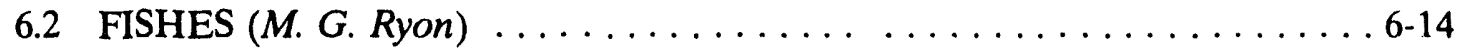

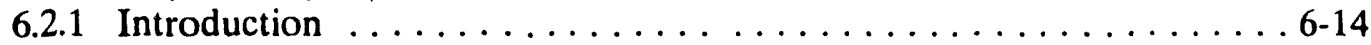

6.2 .2 Methods ............................ . 6-15

6.2 .3 Results and Discussion ................... 6-17

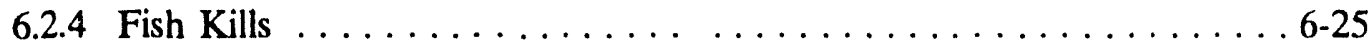


6.2.5 Conclusions . . . . . . . . . . . . . . . . . . . . . . 6-26

6.2.6 Future Studies . . . . . . . . . . . . . . . . . . . . . . . 6-27

6.3 INTERPRETATION OF BIOTIC CHANGES (M. A. Huston) $\ldots \ldots \ldots$. . 6-28

7. ASSESSMENT OF CONTAMINANTS IN THE TERRESTRIAL

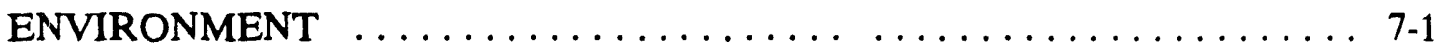

7.1 REVIEW OF PREVIOUS STUDIES (B. T. Walton) . . . . . . . 7-1

7.2 FRESHWATER TURTLES AS MONITORS OF RADIONUCLIDE

AND HEAVY METAL CONTAMINANTS (L. J. Meyers-Schone

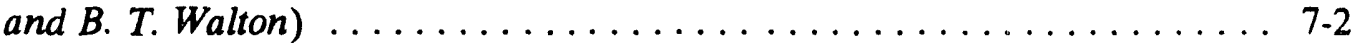

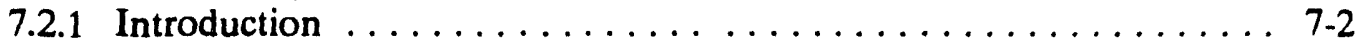

7.2 .2 Study Sites . . . . . . . . . . . . . . . . . . . . 7.2

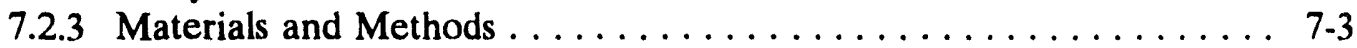

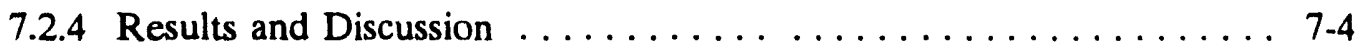

7.2 .5 Conclusions . . . . . . . . . . . . . . . . . . . . . . . . 7 7-10

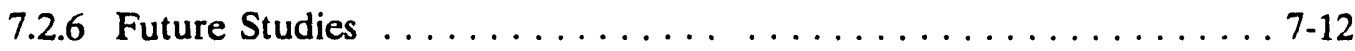

8. RADIOECOLOGY OF WHITE OAK LAKE $\ldots \ldots \ldots \ldots \ldots \ldots \ldots \ldots$

8.1 RADIONUCLIDES IN THE WHITE OAK LAKE

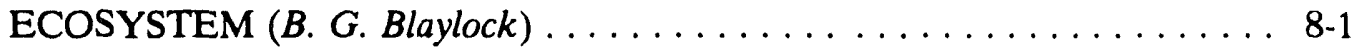

8.2 RADIOECOLOGY OF MACROFLORA IN WHITE

OAK LAKE (D. A. Mohrbacher, H. L. Boston, and B. G. Blaylock) . . . . . 8-2

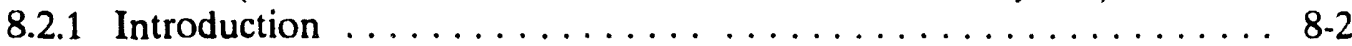

8.2 .2 Methods . . . . . . . . . . . . . . . . . . . . . 8 8-4

8.2.3 Results and Discussion $\ldots \ldots \ldots \ldots \ldots \ldots \ldots \ldots$ 8.6 . . . . . . . . . . .

8.2 .4 Summary . . . . . . . . . . . . . . . . . . . . 8 13

8.3 WATERFOWL POPULATIONS ASSOCIATED WITH ORNL

LAKES AND PONDS (A. E. Waters and B. G. Blaylock) . . . . . . . . 8-14

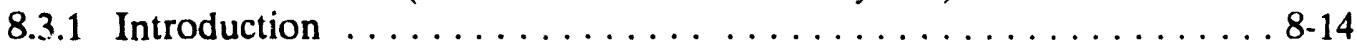

8.3.2 Materials and Methods . . . . . . . . . . . . . . . . . 8-14

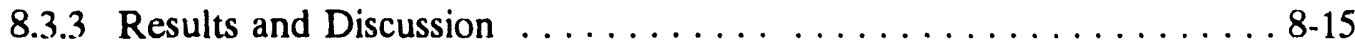

8.4 RADIONUCLIDES IN FISH IN WHITE OAK CREEK

(B. G. Blaylock) . . . . . . . . . . . . . . . . . . . . . . . . 8-20

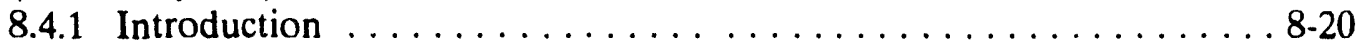

8.4 .2 Methods ... . . . . . . . . . . . . . . . . . . . . 8-21

8.4.3 Results and Discussion . . . . . . . . . . . . . . . . . 8-21

8.5 FUTURE STUDIES (B. G. Blaylock, D. A. Mohrbacher,

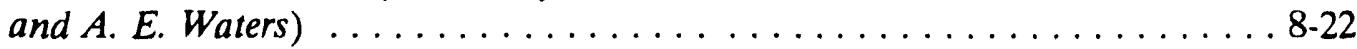

8.5.1 Radionuclides in White Oak Lake Ecosystem . . . . . . . . . 8 8-22

8.5.2 Preliminary Screening of Contaminants in White Oak Lake . . . . . 8 8-23

8.5.3 Role of Aquatic Macroflora in the Radioecology of White

Oak Lake . . . . . . . . . . . . . . . . . . . . . . . 8-23

8.5.4 Waterfowl Populations Associated with ORR Lakes and Ponds . . . 8 8-23

8.5.5 Radionuclides in Fish from White Oak Creek . . . . . . . . . . . 8-24

9. ABATEMENT PROGRAM $(C . K$ Valentine $) \ldots \ldots \ldots \ldots \ldots \ldots \ldots \ldots \ldots$

9.1 CHLORINE REDUCTION $\ldots \ldots \ldots \ldots \ldots \ldots \ldots \ldots \ldots \ldots \ldots . \ldots \ldots$

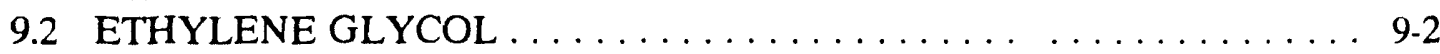




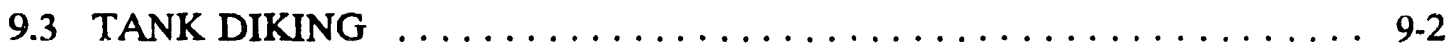

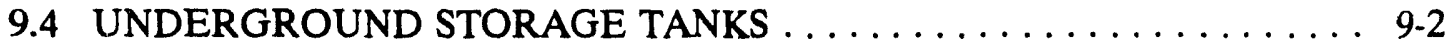

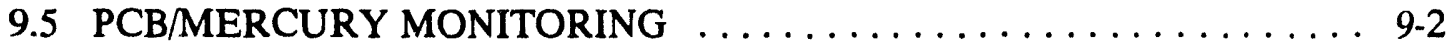

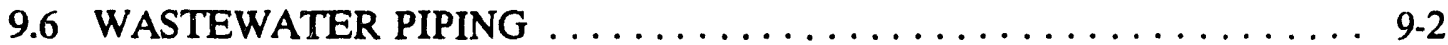

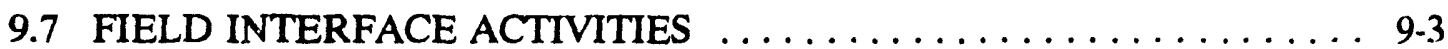

9.8 NONRADIOLOGICAL WASTEWATER TREATMENT PROJECT . . . 9-3

9.9 AQUATIC RESOURCES ALTERATION PERMIT PROGRAM . . . . . 9 9-3

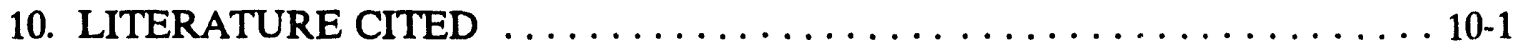

APPENDIX A. RESULTS OF QA/QC ANALYSES OF MERCURY, PCBS, AND ORGANICS IN FISH SAMPLES $\ldots \ldots \ldots \ldots \ldots \ldots \ldots$ A-1

APPENDIX B. CONCENTRATIONS OF CONTAMINANTS IN AQUATIC BIOTA FROM WHITE OAK CREEK AND TRIBUTARIES, WHITE OAK, AND THE CLINCH RIVER NOVEMBER 1987-

AUGUST $1988 \ldots \ldots \ldots \ldots \ldots \ldots \ldots \ldots \ldots \ldots$. . . . . . . . . . .

APPENDIX C. PRODUCTION/BIOMASS RATIOS AND COHORT PRODUCTION INTERVALS FOR ESTIMATING BENTHIC INVERTEBRATE ANNUAL PRODUCTION . . . . . C

APPENDIX D. METHODOLOGY FOR INDEX OF BIOTIC INTEGRITY $\ldots \ldots$ D-1

APPENDIX E. FISH DENSITY, BIOMASS, AND CONDITION FACTORS

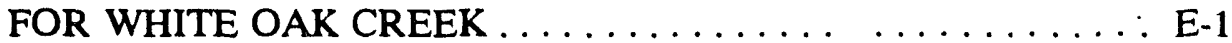

APPENDIX F. FOOD HABITS, CONTAMINANT CONCENTRATIONS $\left({ }^{137} \mathrm{Cs}\right.$, ${ }^{60} \mathrm{Co},{ }^{90} \mathrm{Sr}$, AND MERCURY), AND PERCENTAGE OF DOUBLESTRANDED DNA LEVELS OF YELLOW-BELLIED SLIDER TURTLES (Pseudemys scripta) AND COMMON SNAPPING TURTLES (Chelydra serpentina) FROM WHITE OAK LAKE AND BEARDEN CREEK EMBAYMENT . . . . . . . . F-1 


\section{FIGURES}

2.1 Map of the White Oak Creek watershed above White Oak Dam . . . . . 2-2

2.2 Map showing locations of (1) liquid and solid waste disposal areas;

(2) NPDES ambient monitoring stations on Melton Branch, White Oak

Creek, and White Oak Dam; and (3) sampling sites for benthic

invertebrates and fish in White Oak Creek watershed $\ldots \ldots \ldots \ldots \ldots \ldots$ 2-3

2.3 Mean weekly stream flow in (1) Melton Branch at USGS gage 03537100

near MEK 1.9 and at NPDES station X13 near MEK 0.16 and (2) White

Oak Creek at NPDES station X14 near WCK $2.65 \ldots \ldots \ldots \ldots \ldots \ldots$

2.4 Location of NPDES effluent (Sites 1-9 and 13-14) and ambient

(Sites 10-12) water quality monitoring stations

2.5 Mean weekly temperatures in White Oak Creek at sites above and below

ORNL and at two sites in Melton Branch, January-December $1988 \ldots \ldots$. . . 2-15

2.6 Mean weekly temperatures in three tributaries of White Oak Creek,

January-December $1988 \ldots \ldots \ldots \ldots \ldots \ldots \ldots \ldots$. . . . . . . . . . . . . . .

2.7 Water temperatures at NPDES monitoring stations X13 on lower Melton

Branch and X14 on lower White Oak Creek ............. 2-21

3.1 Conductivity in Melton Branch (NPDES station X13) and White Oak Creek

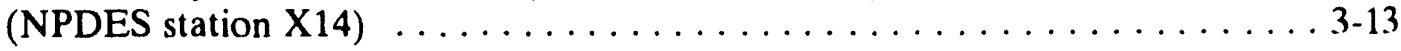

3.2 Alkalinity to hardness ratios for water samples from Melton Branch

(NPDES station X13) and White Oak Creek (NPDES station X14) ...... 3-14

3.3 Periphyton monitoring sites in the White Oak Creek watershed . . . . . . . 3-27

3.4 Periphyton chlorophyll $a$ and periphyton primary production,

on small flat rocks in shallow riffle areas at reference site WCK 6.8

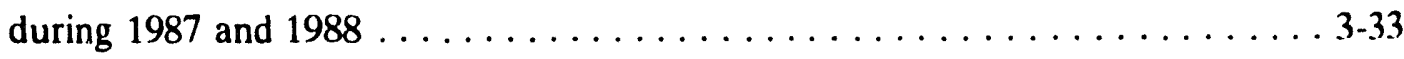

3.5 Periphyton chlorophyll $a$ and periphyton primary production,

on small flat rocks in shallow riffle areas at downstream site WCK 2.3

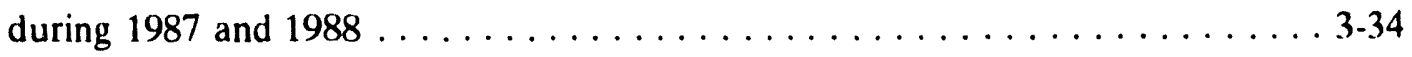

3.6 Monthly least square means for chlorophyll-adjusted production, based

on an ANCOVA for $1987 \ldots \ldots$. . . . . . . . . . . . . . . . . . . . . . 3-40 
3.7 Monthly least square means for chlorophyll-adjusted production, based

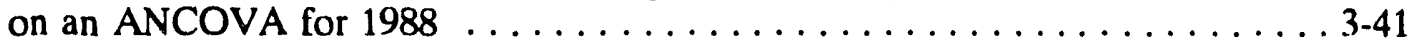

3.8 Periphyton colonization or accumulation (as micrograms of chlorophyll $a$ per square centimeter) on ceramic tiles placed at seven sites in the White Oak Creek watershed $\ldots \ldots \ldots \ldots \ldots \ldots \ldots \ldots \ldots . \ldots \ldots . \ldots \ldots$

3.9 Chlorophyll $a$ on new tiles and tiles preconditioned by placement at WCK 6.8 or WCK 3.4 for one week prior to placement at WCK 3.9,

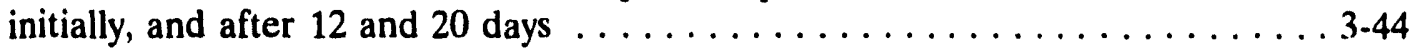

3.10 Chlorophyll $a$ on rocks placed at WCK 3.9 following either brushing or

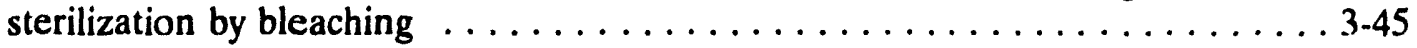

3.11 Chlorophyll $a$ and primary production on clay pots with agar only (C), pots elevated to exclude grazers $(\mathrm{G})$, pots with agar amended with $\mathrm{N}$ and $P(N)$, pots elevated with nutrient-enriched agar (NG), pots amended with three concentrations of malathion $\left(I_{1}, I_{2}, I_{3}\right)$, and pots with

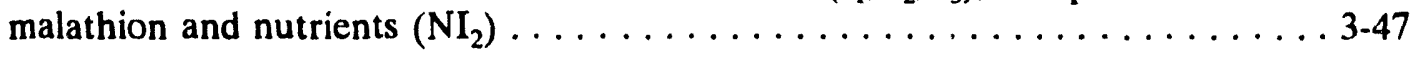

3.12 Chlorophyll $a$ and primary production on clay pots with agar only (C), with agar amended with $\mathrm{N}$ and $\mathrm{P}(\mathrm{N})$, with agar amended with malathion $\left(\mathrm{I}_{2}\right)$, and with agar amended with malathion and nutrients $\left(\mathrm{NI}_{2}\right) \ldots \ldots \ldots .48$

4.1 Mean concentrations of polychlorinated biphenyls in bluegill (Lepomis macrochirus) collected at sites in the White Oak Creek drainage and nearby reaches of the Clinch River $\ldots \ldots \ldots \ldots \ldots \ldots \ldots \ldots$

4.2 Location of sites on the Oak Ridge Reservation where channel catfish and gizzard shad were collected for polychlorinated biphenyl analysis in July/August

5.1 Relative differences in the response of the carbohydrate-protein for redbreast and bluegill sunfish at each of the White Oak Creek System sites compared with the reference site, Brushy Fork

5.2 Relative differences in the response of the organ dysfunction indicators for redbreast and bluegill sunfish at each of the White Oak ${ }^{\top}$ Creek System sites compared to the reference site, Brushy Fork

5.3 Relative differences in the response of the detoxification enzymes for redbreast and bluegill sunfish at each of the White Oak Creek System sites compared with the reference site, Brushy Fork . 
5.4 Relative differences in the response of the lipid metabolism parameters for redbreast and bluegill sunfish at each of the White Oak Creek System sites compared with the reference site, Brushy Fork . . . . . . . . 5-13

5.5 Relative differences in histological condition for redbreast and bluegill sunfish at each of the White Oak Creek System sites compared with the reference site, Brushy Fork . . . . . . . . . . . . . . . . . . 5-14

5.6 Relative differences in the condition indices of redbreast and bluegill sunfish at each of the White Oak Creek System sites compared

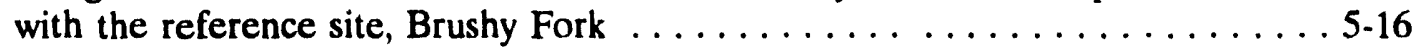

5.7 Seasonal differences in bioindicator responses between each of the White Oak Creek System sites and the reference site, Brushy Fork . . . . . . . . 5-18

5.8 Segregation of integrated health responses for bluegill sunfish from four sites in the White Oak Creek System and Brushy Fork using bioindicators measured from fall 1987 and spring $1987 \ldots \ldots \ldots \ldots$. . . . 5-20

5.9 Chronic-level responses of fish to sublethal contaminant stress, emphasizing the relative importance of the direct and indirect pathways and the status of the lipid pool in influencing responses at the organism, population, and community levels .

5.10 Health status of percentage of redbreast and bluegill sunfish at all White Oak Creek System sites ranked in the lowest quartile for at

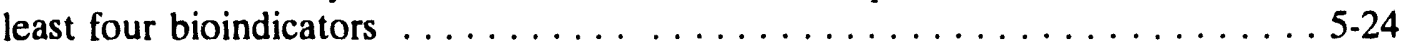

6.1 Mean number of Ephemeroptera, Plecoptera, and Trichoptera (EPT) taxa per sample in White Oak Creek watershed and Brushy Fork, May 1986 through April 1987

6.2 Relative production of Ephemeroptera, Plecoptera, Trichoptera (EPT), Mollusca, Chironomidae, and all other benthic macroinvertebrate taxa in White Oak Creek watershed and Brushy Fork $\ldots \ldots \ldots \ldots \ldots$. 6.8

6.3 Relative contribution of Ephemeroptera, Plecoptera, and Trichoptera (EPT) to total the total production of these three taxa in White Oak Creek watershed and Brushy Fork . . . . . . . . . . . . . . 6-9

8.1 Remobilization and Fate of Cesium and Cobalt. . . . . . . . . . . $8-3$

8.2 Contour map of the White Oak Creek Weir $\ldots \ldots \ldots \ldots \ldots \ldots$

8.3 Radionuclide concentrations in the macrophytes and sediments in the upstream, mid-section and downstream portions of White Oak Lake . . . . . . . 
8.4 Total number of waterfowl observed on White Oak Lake during weekly census from 1987 to 1989

8.5 Population trends of ring-necked ducks on Swan Pond in 1987-1988 and 1988-1989.

8.6 The total number of Canada Geese observed per observation at K-25 designated sites from October 1988 


\section{TABLES}

2.1 Number of days of zero discharge in upper Melton Branch at MEK $1.93 \ldots \ldots$ 2-4

2.2 Comparison of the variability in mean daily discharge and of mean discharge per unit area between streams with and without flow

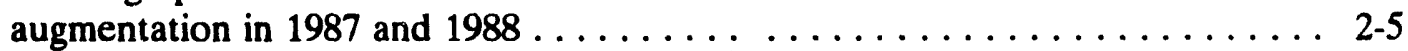

2.3 Description of the nine major effluents regulated under the Oak Ridge National Laboratory National Pollutant Discharge Elimination System permit issued on April 1, 1986 .

2.4 Number and location of category I, II, and III outfalls that discharge

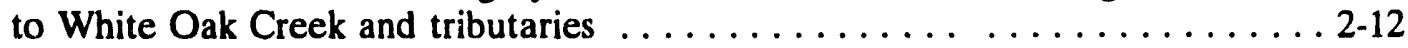

2.5 Median concentrations of 34 NPDES water quality parameters that are routinely monitored below ORNL in Melton Branch at NPDES site $\mathrm{X} 13$, in White Oak Creek at NPDES site X14, and at White Oak Dam at NPDES site X15, January-December 1988

2.6 Mean monthly water temperature $\left({ }^{\circ} \mathrm{C}\right)$ in White Oak Creek and tributaries, including First Creek, Fifth Creek, Melton Branch, and Northwest Tributary, January-December 1988

2.7 Water quality parameters determined for discrete samples collected monthly at ten sites in streams in the White Oak Creek watershed

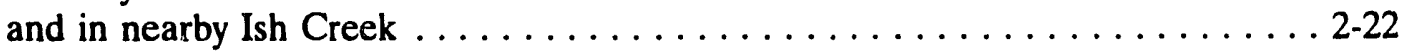

2.8 Water quality parameters based on samples collected monthly at the ten periphyton monitoring sites in the White Oak Creek watershed and at Ish Creek during 1987

2.9 Concentrations of dissolved elements at ten periphyton monitoring sites in White Oak Creek watershed and in Ish Creek. . . .

2.10 Substrate codes used in the physical habitat analysis of White Oak Creek watershed .......

2.11 Embeddedness rating for substrate material $\ldots \ldots \ldots \ldots \ldots \ldots \ldots \ldots$

2.12 Mean \pm 1 SD ratings for substrate and embeddedness, mean canopy percentage, and pool to riffle ratios for fish and benthos sampling sites on White Oak Creek, First Creek, Fifth Creek, Melton Branch, and Northwest Tributary for July-August $1988 \ldots \ldots \ldots \ldots \ldots \ldots \ldots . . \ldots \ldots 2$ 
2.13 Mean, standard deviation, minimum, and maximum current velocities and mean depth for each transect and for the entire reach/site at the fish and benthos sampling stations on White Oak Creek, First Creek, Fifth Creek, Melton Branch, and Northwest Tributary in May-June 1988 . . . 2 2-34

3.1 Summary of toxicity tests results for the Oak Ridge National Laboratory Process Waste Treatment Plant, Coal Yard Runoff Treatment

Facility, and Sewage Treatment Plant ................. 3-3

3.2 Summary of chemical analyses of effluent from the Oak Ridge National Laboratory Process Waste Treatment Plant, Coal Yard Runoff Treatment Facility, and Sewage Treatment Plant ............. 3-3

3.3 Chemical characteristics of water samples from Fifth Creek and selected outfalls to Fifth and White Oak Creeks . . . . . . . . . . . . 3-4

3.4 Survival and growth of fathead minnow larvae in 7-d tests on wastewater samples from Fifth Creek and selected outfalls . . . . . . . . . . . . 3-5

3.5 Concentrations of total residual chlorine in grab samples of water from outfalls on Fifth Creek and White Oak Creek, and 7-d toxicity test results for the samples after they had been dechlorinated with sodium

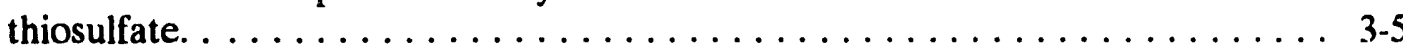

3.6 Results of Ceriodaphnia toxicity tests of water from National Pollutant Discharge Elimination System sites X13 and X14 on Melton Branch and White Oak Creek ..... . . . . . . . . . . . . . . . . . . . . . 3-7

3.7 Results of fathead minnow toxicity tests of water from National Pollutant Discharge Elimination System sites X13 and X14 on Melton Branch and White Oak Creek . . . . . . . . . . . . . . . . . .

3.8 Results of chemical analyses of (1) control water; (2) water from National Pollutant Discharge Elimination Systems sites X13 and X14 on Melton Branch and White Oak Creek; and (3) water from a noncontaminated reference site on upper WOC. . . . . . . . . . . . . . . . . . . .

3.9 Mean survival and fecundity of Ceriodaphnia in water from East Tributary and West Tributary, near Oak Ridge National Laboratory Solid

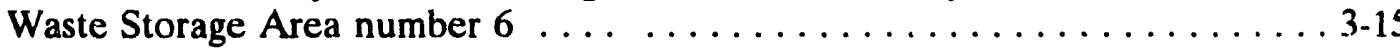

3.10 Fecal coliform bacteria in Sewage Treatment Plant effluent and at four sites on White Oak Creek . . . . . . . . . . . . . . . . . . . . 3-17 
3.11 Total residual chlorine in Sewage Treatment Plant effluent and at four sites on White Oak Creek ... . . . . . . . . . . . . . . . . 3-17

3.12 Fecal coliform bacteria in Sewage Treatment Plant effluent and at four sites on White Oak Creek .................. 3-18

3.13 Total residual chlorine concentrations in Sewage Treatment Plant effluent at four sites on White Oak Creek ............... 3-18

3.14 Fecal coliform bacteria in Sewage Treatment Plant effluent and in WOC at the USGS gaging station at WCK 3.41 after low-level feed rates of chlorine resumed on August $11 \ldots \ldots \ldots \ldots \ldots \ldots \ldots \ldots \ldots$

3.15 Total residual chlorine concentrations in Sewage Treatment Plant effluent, and in WOC at the USGS gaging station at WCK 3.41 after low-level feed rates of chlorine resumed on August $11 \ldots \ldots \ldots$. . . . . . . . 19

3.16 Mean percent survival and fecundity of Ceriodaphnia dubia in a life cycle test with various concentrations of calcium sulfate $\ldots \ldots \ldots \ldots \ldots . . \ldots 32$

3.17 Mean percent survival and fecundity of Ceriodaphnia dubia in a life cycle test with various concentrations of magnesium sulfate $\ldots \ldots \ldots \ldots \ldots$ 3-23

3.18 Integrated light at X-10 sampling sites on September $7,1988 \ldots \ldots \ldots \ldots$ 3:30

3.19 Characteristics of the periphyton brushed from rocks at ten sites in the White Oak Creek watershed, and a site in Ish Creek. . . . . . . . . 3-31

3.20 Periphyton algal assemblages, brushed from rocks. $\ldots \ldots \ldots \ldots \ldots \ldots \ldots$

3.21 Mean annual chlorophyll $a$ concentration for periphyton collected from sites with permanent and intermittent flow in 1988. . . . . . . 3-36

3.22 Mean annual primary production for periphyton collected from sites with permanent and intermittent flow in $1988 \ldots \ldots \ldots \ldots \ldots \ldots \ldots \ldots \ldots \ldots \ldots .37$

3.23 Chlorophyll-adjusted periphyton productivity in 1987 and 1988 at sites with permanent flow $\ldots \ldots \ldots \ldots \ldots \ldots \ldots \ldots \ldots \ldots \ldots \ldots \ldots$

3.24 Periphyton ATP and chlorophyll to ATP ratios for $1988 \ldots \ldots \ldots \ldots \ldots .42$

4.1 Mean metal concentrations in fish from White Oak Lake, White Oak

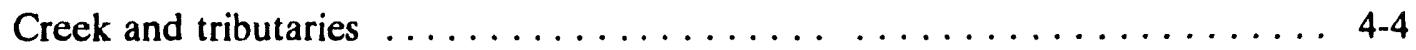


4.2 Concentrations of polychlorinated biphenyls and other organic priority pollutants in bluegill and redbreast sunfish (Lepomis macrochirus and $L$. auritus) from the Clinch River, White Oak Lake, White Oak Creek and tributaries, and Melton Hill Reservoir ............... 4-8

4.3 Concentrations of polychlorinated biphenyls and other organics in duplicate composite samples of caged clams (Corbicula fluminea) March 2-31, 1988 . . . . 4-9

4.4 Concentrations of polychlorinated biphenyls and ${ }^{90} \mathrm{Sr}$ in channel catfish (Ictalurus punctatus) from sites in the Clinch River arm of Watts Bar Reservoir in the vicinity of Department of Energy facilities, July/August . . . . . 4-16

4.5 Changes from 1986 to 1988 in mean concentrations of polychlorinated biphenyls, ${ }^{90} \mathrm{Sr}$, and fraction of fish exceeding the U.S. Food and Drug Administration limit for channel catfish from White Oak Creek embayment, the Clinch River, lower Poplar Creek and Melton Hill Reservoir . . . . . . . . 4-17

4.6 Concentrations of polychlorinated biphenyls and ${ }^{90} \mathrm{Sr}$ in gizzard shad (Dorosoma cepedianum) from White Oak Lake, lower White Oak Creek embayment, the Clinch River, lower Poplar Creek, and Melton Hill Reservoir .

4.7 Comparison of mean annual metal concentrations in water and mean metal concentrations in fish (Lepomis macrochirus and L. auritus)

from White Oak Creek, Melton Branch, White Oak Lake, Mitchell Branch, and East Fork Poplar Creek . . . . . . . . . . . . . . . 4-23

4.8 Mean annual concentrations of metals measured in receiving waters at National Pollutant Discharge Elimination System sites; ratio of mean metal concentrations in fish to Preliminary Guidance Values (PGVs); estimated minimum concentrations in receiving waters producing metals concentrations in fish equal to PGVs; and Environmental Protection Agency Water Quality Criteria for protection of human health from ingesting fish $\ldots \ldots \ldots \ldots \ldots$ 4-25

5.1 Temporal changes in bioindicator responses of redbreast sunfish over the period fall 1986-fall 1987 at two sites in the White Oak Creek watershed and Brushy Fork, the reference site $\ldots \ldots \ldots \ldots \ldots \ldots \ldots \ldots \ldots$

5.2 DNA integrity measured in sunfish from two reference sites $\ldots \ldots \ldots \ldots$. $\ldots . \ldots$

5.3 Comparison of DNA strand breaks in sunfish from sites in White Oak Creek watershed sampling sites and from Hinds Creek, a reference site . . . . 5-28

5.4 Mean metal-binding protein content in sunfish from White Oak Creek and two reference streams (Brushy Fork and Hinds Creek) . . . . . . . . 5-31 
6.1 Summary of field data collected during benthic macroinvertebrate sampling in the White Oak Creek watershed, May 1986 through April 1987

6.2 Comparisons of the mean EPT taxa richness for the benthic macroinvertebrate communities in White Oak Creek and Melton Branch . . . . 6-6

6.3 Estimated total community, Ephemeroptera, Plecoptera, and Trichoptera (EPT) and Mollusca production, and mean community production to biomass ( $\mathrm{P} / \mathrm{B})$ ratios of benthic macroinvertebrates in White Oak Lake, streams of White Oak Creek watershed, and Brushy Fork, May 1986 through April 1987 . . . . .

6.4 Comparisons of mean annual production to biomass ratios of the benthic macroinvertebrate communities in White Oak Creek and Melton Branch

6.5 Production estimates for benthic macroinvertebrate communities in Mitchell Branch above and below the Oak Ridge Gaseous Diffusion Plant

6.6 Published estimates of benthic invertebrate community production

6.7 Length, mean width, mean depth, and surface area of fish sampling sites in White Oak Creek, First Creek, Fifth Creek, Melton Branch, and Northwest Tributary, March-April and December, 1988

6.8 Fish species composition in White Oak Creek, First Creek, Fifth Creek, Melton Branch, and Northwest Tributary, March-April and December 1988

6.9 Total fish density, total biomass, and species richness for March-April and December 1988 in White Oak Creek, First Creek, Fifth Creek, Melton Branch, and Northwest Tributary

6.10 Index of Biotic Integrity values based on sampling conducted during March-April and December 1988 in White Oak Creek, First Creek, Fifth Creek, Melton Branch, and Northwest Tributary ..........

7.1 Mean percent volume of different food types in the GI tract of common snapping turtles (Chelydra serpentina) collected on the Oak Ridge Reservation ......................... $7-5$

7.2 Mean percent volume of different food types in the GI tract of yellow-bellied slider turtles (Pseudemys scripta) and common snapping turtles (Chelydra serpentina) from White Oak Lake . . . . . . . . . . 7-5

7.3 Cesium-137 and ${ }^{60} \mathrm{Co}$ in tissues of White Oak Lake yellow-bellied slider turtles (Pseudemys scripta) 
7.4 Cesium-137 in muscle tissues of yellow-bellied sliders (Pseudemys scripta) and common snapping turtles (Chelydra serpentina) collected from White Oak Lake ...................... 7.6

7.5 Strontium-90 in skeletal tissues of yellow-bellied slider (Pseudemys scripta) and common snapping turtles (Chelydra serpentina) collected from White Oak Lake

7.6 Total organic and inorganic Mercury in tissues of yellow-bellied slider (Pseudemys scripta) and common snapping turtles (Chelydra serpentina) collected from White Oak Lake . . . . . . . . . . . . . 7-9

7.7 Fraction of double-stranded DNA in liver samples of common snapping turtles (Chelydra serpentina) collected on the Oak Ridge Reservation. . . . . . 7-9

7.8 Fraction of double-stranded DNA in liver of yellow-bellied slider and common snapping turtles collected from White Oak Lake.

8.1 Estimated inventories of ${ }^{137} \mathrm{Cs},{ }^{60} \mathrm{Cs}$, and ${ }^{90} \mathrm{Sr}$ in the abiotic and biotic compartments of White Oak Lake

8.2 Mean radionuclide concentrations in the water column and sediments of

Melton Branch weir, White Oak Creek weir, and White Oak Lake . . . . . . . 8-8

8.3 Biomass and radionuclide concentration of Myriophyllum spicatum and associated epiphyton in White Oak Creek weir in 1988

8.4 Radionuclide concentrations in aquatic macrophytes collected in White Oak Creek weir in 1988 .

8.5 Radionuclide concentrations in aquatic macrophytes collected in Melton Branch weir in 1988

8.6 Results of transplant studies conducted at the White Oak Creek and Melton Branch weirs.

8.7 Species and locations of waterfowl observed at Oak Ridge National

8.8 Total number and location of waterfowl species observed during the weekly census at Oak Ridge National Laboratory ponds, October 1987-February 1989

8.9 Mean concentrations of ${ }^{137} \mathrm{Cs}$ and ${ }^{60} \mathrm{Co}$ in American coots collected from White Oak Lake 
8.10 Cesium-137 concentrations in tissues of Canada Geese collected near Pond $\mathbf{3 5 1 3}$ within the Oak Ridge National Laboratory complex.

8.11 Levels of ${ }^{137} \mathrm{Cs}$ in bluegill (Lepomis macrochirus) from the White Oak Creek system, December $1987 \ldots \ldots \ldots \ldots \ldots \ldots$. . . . . . . . . . . .

A.1 Analyses of reference tissues for metals $\ldots \ldots \ldots \ldots \ldots \ldots \ldots \ldots \ldots$

B.1 Metals in sunfish from White Oak Creek and tributaries, White Oak Lake, and the Clinch River . . . . . . . . . . . . . . . B-2

B.2 Organic contaminants in sunfish from White Oak Creek and tributaries and nearby reaches of the Clinch River and Melton Hill Reservoir . . . . . . B B-5

B.3 Detection limits of organic compounds $\ldots \ldots \ldots \ldots \ldots \ldots \ldots$

B.4 Concentrations of polychlorinated biphenyls and ${ }^{90} \mathrm{Sr}$ in channel catfish and gizzard shad from White Oak Creek embayment, lower Poplar Creek, the Clinch River, and Melton Hill Reservoir .............................

C.1 Annual production/biomass ratios and cohort production intervals used for annual production estimates for benthic macroinvertebrates from White Oak Creek watershed, May 1986 through April 1987 . . . . . . . . C-2

D.1 Index of Biotic Integrity metrics used to assess stream fish

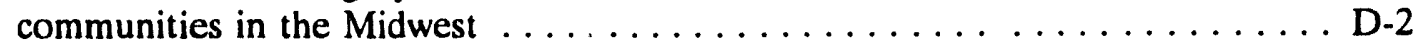

D.2 List of species found in small streams in the Clinch River drainage near Oak Ridge, Tennessee with information on trophic group, tolerance rankings, and reproductive guilds $\ldots \ldots \ldots \ldots \ldots \ldots \ldots \ldots$

D.3 IBI metrics used to assess stream fish communities in streams near Oak Ridge, Tennessee in the Clinch River system . . . . . . . . . . D-5

D.4 Index of Biotic Integrity metrics used to assess headwater stream fish communities in streams near Oak Ridge, Tennessee in the Clinch River system. . . . . . . . . . . . . . . . . . D -7

E.1 Fish densities for March-April 1988 in White Oak Creek, First Creek, Fifth Creek, Melton Branch, and Northwest Tributary . . . . . . . . . E-2

E.2 Fish biomass for March-April 1988 in White Oak Creek, First Creek, Fifth Creek, Melton Branch, and Northwest Tributary . . . . . . . . E E-3

E.3 Fish densities for December 1988 in White Oak Creek, First Creek, Fifth Creek, Melton Branch, and Northwest Tributary . . . . . . . . . E E-4 
E.4 Fish biomass for December 1988 in White Oak Creek, First Creek, Fifth Creek, Melton Branch, and Northwest Tributary ............. E-5

E.5 Comparison between sampling sites on White Oak Creek, First Creek, Fifth Creek, Melton Branch, and Northwest Tributary of mean condition factors of fish species collected in March-April and December $1988 \ldots \ldots \ldots \ldots \ldots \ldots \ldots \ldots \ldots \ldots \ldots \ldots \ldots$. E-6

F.1 Food habits of male snapping turtles (Chelydra serpentina) collected from White Oak Lake

F.2 Cesium-137 in muscle tissue of yellow-bellied sliders (Pseudemys scripta) collected from White Oak Lake $\ldots \ldots \ldots \ldots \ldots \ldots \ldots \ldots \ldots$ F-2

F.3 Cobalt-60 and ${ }^{137} \mathrm{Cs}$ in liver tissue of yellow-bellied sliders (Pseudemys scripta) collected from White Oak Lake $\ldots \ldots \ldots \ldots \ldots \ldots \ldots$ F-3

F.4 Cesium-137 in muscle tissue of male snapping turtles (Chelydra serpentina collected from White Oak Lake .................. F-3

F.5 Strontium-90 in bone and carapace of yellow-bellied sliders (Pseudemys scripta) collected from White Oak Lake .............. F-4

F.6 Strontium-90 in bone and carapace of yellow-bellied sliders (Pseudemys scripta) collected from Bearden Creek embayment . . . . . . . F F-4

F.7 Strontium-90 detected in the bone and carapace of male snapping turtles (Chelydra serpentina) collected in White Oak Lake ...............F-5

F.8 Strontium-90 detected in the bone and carapace of snapping turtles (Chelydra serpentina) collecl ' in Bearden Creek

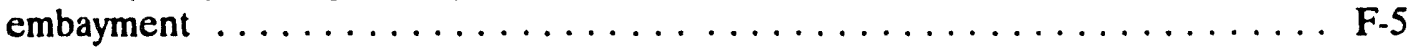

F.9 Total inorganic and organic mercury in tissues of common snapping turtles (Chelydra serpentina) collected from White Oak Lake . . . . . . . F F-6

F.10 Total inorganic and organic mercury in tissues of common snapping turtles (Chelydra serpentina) collected from Bearden Creek embayment

F.11 Fraction of double-stranded DNA in liver samples obtained from male snapping turtles (Chelydra serpentina) collected from White Oak Lake . . . . . F.7

F.12 Fraction of double-stranded DNA in liver samples obtained from snapping turtles (Chelydra serpentina) collected from Bearden Creek embayment 


\section{ACRONYMS}

ACD

ADI

AFDM

AI

ANCOVA

ANOVA

ARAP

ATDL

ATP

$\mathrm{B}[a] \mathrm{P}$

BFK

BMAP

BOD

CPI

CRK

CV

CYRTF

DEM

DEMC

DMSO

DNA

DOC

DTT

EDTA

EFK

EFPC

EMC

EPA

EROD

ESD

FC

FCB

FCK

FDA
Analytical Chemistry Division

allowable daily intake

ash-free dry matter

average intake

analysis of covariance

analysis of variance

Aquatic Resources Alteration Permit

Atmospheric Turbulence and Diffusion Laboratory

adenosine triphosphate

benzo[a]pyrene

Brushy Fork kilometer

Biological Monitoring and Abatement Program

biochemical oxygen demand

cohort production interval

Clinch River kilometer

coefficient of variation

Coal Yard Runoff Treatment Facility

Department of Environmental Management (name changed in 1987 to DEMC and revised in 1988 to EMC, see below)

Department of Environmental Monitoring and Compliance

dimethylsulfoxide

deoxyribonucleic acid

dissolved organic carbon

dithiothreitol

ethylenediamine tetracetic acid

East Fork Poplar Creek kilometer

East Fork Poplar Creek

Environmental Monitoring and Compliance Section

Environmental Protection Agency

7-Ethoxyresorufin O-deethylase

Environmental Sciences Division

free chlorine

fecal coliform bacteria

First Creek kilometer

U.S. Department of Agriculture Food and Drug Administration 
FFK Fifth Creek kilometer

$g$ acceleration due to gravity

GC/MS

gas chromatography/mass spectrometry

GC/ECD

gas chromatography/electron capture detector

GIS

GLM

Geographic Information System

HFIR

general linear models

HSRD

High Flux Isotope Reactor

HTML

Health and Safety Research Division

ICP

ISK

High Temperature Materials Laboratory

inductively-coupled plasma

IWC

Ish Creek

LDH

instream waste concentration

MEK

lactate dehydrogenase

MHR

Melton Branch kilometer

MIK

Melton Hill Reservoir

MPB

Mitchell Branch kilometer

MSL

metal-binding protein

MTL

mean sea level

NADH

Materials Testing Laboratory

NADPH

nicotinamide adenine dinucleotide, reduced form

NBS

Nicotinamide adenine dinucleotide phosphate, reduced form

National Bureau of Standards

NCRP

National Committee on Radiation Protection

NOAA

National Oceanic and Atmospheric Administration

NOEC

no-observed-effect concentration

NPDES

National Pollutant Discharge Elimination System

NRC

National Research Council

NRWTF

Nonradiological Wastewater Treatment Facility

NTK

Northwest Tributary kilometer

ORAU

Oak Ridge Associated Universities

ORGDP

Oak Ridge Gaseous Diffusion Plant

ORNL

Oak Ridge National Laboratory

ORR

Oak Ridge Reservation

PAH

polycyclic aromatic hydrocarbon

PAR

photosynthetic active radiation

PC

phosphatidylcholine

PCB

polychlorinated biphenyl 


\begin{tabular}{|c|c|}
\hline PCK & Poplar Creek kilometer \\
\hline PE & phosphatidylethanoamine \\
\hline PGV & preliminary guidance value \\
\hline PPM & parts per million $(=\mathrm{mg} / \mathrm{g})$ \\
\hline PWTP & Process Waste Treatment Plant \\
\hline RAP & Remedial Action Program \\
\hline RCRA & Resource Conservation and Recovery Act \\
\hline RNA & ribonucleic acid \\
\hline SAS & Statistical Analysis System \\
\hline SD & standard deviation \\
\hline SE & standard error \\
\hline SGOT & serum glutamate oxaloacetate transaminase \\
\hline SRP & soluble reactive phosphorus \\
\hline STP & Sewage Treatment Plant \\
\hline SWSA & solid waste storage area \\
\hline TCMP & Toxicity Control and Monitoring Program \\
\hline TDHE & Tennessee Department of Health and Environment \\
\hline TRC & total residual chlorine \\
\hline TSP & total suspended particle \\
\hline TSS & total suspended solids \\
\hline TVA & Tennessee Valley Authority \\
\hline USGS & U.S. Geological Survey \\
\hline WCK & White Oak Creek kilometer \\
\hline WOC & White Oak Creek \\
\hline WOD & White Oak Dam \\
\hline WOL & White Oak Lake \\
\hline WPCP & Water Pollution Control Program \\
\hline
\end{tabular}




\section{PREFACE}

On April 1, 1986, a National Pollutant Discharge Elimination System (NPDES) permit was issued for the Oak Ridge National Laboratory (ORNL) (EPA 1986a). As required in Part III: Special Conditions (item H) of the permit, a plan for biological monitoring of the Clinch River, White Oak Creek, Northwest Tributary of White Oak Creek, Melton Branch, Fifth Creek, and First Creek was prepared and submitted for approval in July 1986 to the U.S. Environmental Protection Agency (EPA) and the Tennessee Department of Health and Environmeni (Loar et al. 1991). The plan is referred to as the ORNL Biological Monitoring and Abatement Program (BMAP) and describes biomonitoring activities and characterization studies to be conducted for the 5-year duration of the permit.

This report is structured around the six major tasks that currently comprise the BMAP (see Table of Contents, Sects. 3.0-8.0). It is the third of a series of annual reports and presents the results of BMAP studies conducted in 1988. These reports also address any significant modifications in the scope of work outlined in Loar et al. (1991). 


\section{ACKNOWLEDGMENTS}

We thank all those individuals who assisted with the field sampling, including R. D. Bailey, P. W. Braden, D. K. Cox, G. J. Haynes, W. C. Kyker, C. M. Morrissey, L. M. Stubbs, and L. F. Wicker of the ORNL Environmental Sciences Division (ESD); H. Schöne (ORNL Physics Division); J. W. Evans, Tennessee Wildlife Resources Agency; W. M. Harris and E. M. Schilling (Automated Sciences Group, Inc.); B. C. Harvey (Weber State College); T. A. Anderson (University of Tennessee); M. S. Jen (California State University); and J. G. Stout (Denison University). Substantial support was provided by the staff of the toxicity testing laboratory, including L. A. Kszos, R. D. Bailey, P. W. Braden, L. S. Ewald, G. J. Haynes, G. P. Morris, J. Richmond, R. Thomas, and L. F. Wicker. We thank N. M. Ferguson, J. W. Wade, J. H. Stewart, and J. E. Caton of the ORNL Analytical Chemistry Division (ACD); and W. McDaniels, W. Loy, and T. Bennett of the EPA Environmental Services Laboratory, Athens, Georgia, for sample analyses. We thank I. L. Larsen and M. L. Frank of the ESD for guidance in gamma counting, and J. S. Eldridge and B. D. Keele of the ACD for assistance with Cerenkov counting. M. K. Gustin provided valuable discussions of the DNA alkaline unwinding assay. C. K. Valentine of the ORNL Environmental Monitoring and Compliance Section (EMC) and L. A. Kzsos (ESD) provided valuable assistance with the design of the special toxicity studies described in Sect. 3.1.3 of the report. We thank P. Buckley, K. Williams, and C. Pettway (Knoxville College) for conducting the periphyton special studies. We also thank K. Newman (Science Applications International Corporation) and L. D. Voorhees (ESD) for analyses of the NPDES data and K. L. Daniels (ORNL EMC) for providing the data. Statistical assistance was provided by J. J. Beauchamp (ORNL Computing and Telecommunications Division); A. W. Johnson (ESD); and B. C. Harvey. We thank T. W. Toole, K. Tennessen, L. Young, and J. Walden, and other staff of the Tennessee Valley Authority Aquatic Biology Laboratory in Muscle Shoals, Alabama, for taxonomic identification and enumeration of the benthic invertebrates. We also thank T. J. Williams for electronic publishing and E. B. Bryant for his editorial support. Finally, we are grateful to G. F. Cada, G. K. Eddlemon, and J. R. Trabalka in ESD and to C. K. Valentine who reviewed the draft report and provided many helpful comments and suggestions.

This work was jointly funded by the EMC Section of the ORNL Environmental and Health Protection Division and the ORNL Remedial Action Program. Some of the studies described in the report were conducted on the Oak Ridge National Environmental Research Park. 


\section{EXECUTIVE SUMMARY}

As a condition of the National Pollutant Discharge Elimination System (NPDES) permit issued to Oak Ridge National Laboratory (ORNL) on April 1, 1985, a Biological Monitoring and Abatement Program (BMAP) was developed for White Oak Creek (WOC); selected tributaries of WOC, including Fifth Creek, First Creek, Melton Branch, and Northwest Tributary; and the Clinch River. The BMAP currently consists of six major tasks that address both radiological and nonradiological contaminants in the aquatic and terrestrial environs at ORNL. These tasks are (1) toxicity monitoring, (2) bioaccumulation monitoring of nonradiological contaminants in aquatic biota, (3) biological indicator studies, (4) instream ecological monitoring, (5) assessment of contaminants in the terrestrial environment, and (6) radioecology of WOC and White Oak Lake (WOL). The investigation of contaminant transport, distribution, and fate in the WOC embaymentClinch River-Watts Bar Reservoir system was originally a task of the BMAP but, in 1988, was incorporated into the Resource Conservation and Recovery Act Facility Investigation for the Clinch River, a separate study to assess offsite contamination from all three Department of Energy facilities in Oak Ridge.

\section{Toxicity Testing and Community Studies (Tasks 1, 3, and 4)}

Toxicity testing was conducted on both wastewater effluents and receiving streams in 1988. Effluent toxicity was evaluated in three to five tests on each of three ORNL wastewater treatment facilities. Ambient (instream) toxicity was evaluated in five tests each on water from NPDES site X13 on lower Melton Branch at Melton Branch Kilometer (MEK) 0.16 and on water from NPDES site X14 on lower WOC at White Oak Creek Kilometer (WCK) 2.65. In addition, two small tributaries that drain the east and west portions of Solid Waste Storage Area (SWSA) 6 and enter WOL were tested in December 1988. All evaluations were based on 7-d static-renewal tests that utilized the survival and growth of fathead minnow (Pimephales promelas) larvae, and the survival and reproduction of a small crustacean (Ceriodaphnia dubia/affinis) as toxicity endpoints. Results indicated that the effluent from the Coal Yard Runoff Treatment Facility (CYRTF) was occasionally toxic to Ceriodaphnia, but no evidence of chronic toxicity was found in the ambient tests of water from WOC, Melton Branch, or the SWSA 6 streams.

Toxicity tests were also conducted to evaluate the toxicological significance of (1) total residual chlorine (TRC) in receiving streams and (2) neutral salts, such as calcium sulfate and sodium chloride, which are important constituents of some ORNL wastewaters. Chemical analyses showed that 8 of 13 outfalls to Fifth Creek and WOC (4 in each stream) contained moderate to high levels of TRC (400-1200 $\mu \mathrm{g} / \mathrm{L})$. Toxicity tests showed that water from at least one of these outfalls (No. 312, just downstream from the bridge at Building 5505) remained toxic even after uechlorination. Another special study indicated that it may be feasible to use a low, constant feed rate of chlorine at the Sewage Treatment Plant to effectively reduce the number of fecal coliform bacteria. Finally, Ceriodaphnia life-cycle tests $(35 \mathrm{~d})$ showed that virtually all of the toxicity of the CYRTF effluent could be due to calcium sulfate $\left(\mathrm{CaSO}_{4}\right)$. These tests were used to predict a toxic 
level for $\mathrm{CaSO}_{4}$ of about $15 \%$ full-strength effluent compared with a no-observed-effectsconcentration of $23 \%$ based on 11 Ceriodaphnia 7-day toxicity tests of the CYRTF effluent conducted between July 1986 and November 1988.

Surveys of the biological communities in streams near ORNL also demonstrated that the impacts of plant operation are greatest in Fifth Creek and the middle reaches of WOC (from the Building 5505 bridge near WCK 4.8 downstream to Melton Valley Drive at WCK 3.4). Sites in this reach of WOC had higher algal periphyton biomass and primary production rates than upstream reference sites due primarily to increased nutrient loading from ORNL effluents. Adverse impacts on algal periphyton seem restricted to areas near sampling sites WCK 3.9, WCK 3.4, and occasionally WCK 2.9. Chlorophyll-adjusted production rates, algal colonization rates, and species composition suggest that ecological conditions improved with distance downstream of ORNL discharges (e.g., WCK 2.3 and MEK 0.6).

The distribution and composition of the fish communities in WOC watershed were similar to those observed in previous years and substantially better in Melton Branch and at WCK 5.1 between the 6000 and 7000 areas. The 15 -fold increase in fish density from fall 1987 to fall 1988 returned the populations at WCK 5.1 to near the densities that existed prior to summer 1987. Such fluctuations in abundance are uncommon for most fish communities in streams on the Oak Ridge Reservation (ORR) and may be related to the severe and extended drought in 1987. Effects of the drought were not observed at a headwater site in upper WOC (WCK 6.8), where flows are relatively stable because of numerous springs, or at downstream sites where flow augmentation is significant (e.g., $>80 \%$ of the mean annual flow at WCK 3.9 was due to plant effluent in 1988). Mean annual flows were only 5\% lower in 1988 than in 1987 at USGS gaging stations on WOC (WCK 3.9 and WCK 3.41) but were 15 to $30 \%$ lower in 1988 for other streams on the ORR that have no flow augmentation.

Two indices of stream health were applied to WOC and tributaries to assess the current ecological status of the stream communities. The EPT richness index is based on the number of benthic invertebrate species in the orders Ephemeroptera, Plecoptera, and Tricoptera, which contain many pollution-intolerant species. On each tributary of WOC (First Creek, Fifth Creek, Melton Branch, and Northwest Tributary), the EPT index was significantly lower at the downstream site compared to the upstream reference site, and the index for lower WOC (WCK 2.3) was significantly lower than that for Brushy Fork, a reference stream located just north of Oak Ridge.

Estimates of the mean annual production:biomass (P:B) ratios for benthic invertebrates were significantly different between upstream and downstream sites on WOC and each of the four tributaries, suggesting that species with high turnover rates (e.g., many chironomids) inhabit those sites impacted by episodic discharges of residual chlorine (e.g., WCK 3.9, lower Fifth Creek).

The Index of Biotic Integrity (IBI) is a measure of the stream's capacity to support and maintain a "balanced, integrated, and adaptive community of organisms" similar in its structural and functional components to that of the natural habitat of the region. The index consists of 12 metrics that provide measures of species richness and composition, trophic composition, and fish abundance and condition. On a possible scale from 12 to 60 (equivalent to ratings of very poor to excellent, with a score of 60 being excellent), the WOC watershed sites ranged from 16 (WCK 3.9) to 44 (upper Fifth Creek). Lower First Creek was the only downstream site classified as fair; all other sites below ORNL facilities were either poor or very poor. The combination of intermittent discharges of chlorine and 
the restriction of fish movements by water control structures resulted in a poor or very poor rating for all sites on mainstem WOC except the upstream reference site (WCK 6.8 $=40$ or fair).

The health of individual fish populations in WOC watershed was also assessed. The overall health of redbreast and bluegill sunfish that were collected from Melton Branch, WOC (WCK 3.6 and WCK 3.2), WOL, and Brushy Fork was evaluated using a suite of biochemical and physiological parameters. These parameters included (1) indicators of carbohydrate-protein metabolism, lipid metabolism, organ dysfunction and DNA damage; (2) detoxification enzymes; (3) histopathological condition; and (4) condition indices. The redbreast sunfish population in WOC and WOL was generally in poorer overall health than that in Brushy Fork, whereas the bluegill population at WCK 3.2 and WOL was in better health than the population in Brushy Fork. The poorer health of bluegill in the reference stream may have been related to the drought and low stream flows, which reduced habitat and probably food availability as well. Because they are better adapted to lotic (i.e., flowing water) environments than are bluegill, redbreast sunfish may be better competitors for the limited resources, thus accounting for the differences in overall health of the two species in Brushy Fork. While the health of fish from the reference stream is related to nutritional stress, the health of fish from WOC may be related to toxicological exposure (as indicated, for example, by elevated levels of detoxification enzymes). Future studies will involve manipulative caging experiments to examine differences in bioindicator responses between caged (starved) and uncaged (well-fed) fish.

The significant ecological recovery of lower Melton Branch that was observed in 1987 following the shutdown of the High Flux Isotope Reactor (HFIR) in November 1986 continued in 1988. The periphyton production rate at MEK 0.6 remained high, and the dramatic increase in fish abundance in 1987 was sustained in 1988 at a level below that of the previous year but substantially higher than the 1985-86 levels. Fish abundance also increased noticeably at MEK 1.4 immediately below the confluence with a small, unnamed tributary that received discharges from the HFIR.

A detailed characterization of the abiotic environs at each of 16 sites on WOC and 4 tributaries was completed in 1988. During an extended low-flow period in early June, data were collected on channel morphometry, substrate composition, canopy cover (percentage), light availability, and riparian vegetation. These data will be used to assess the relative importance of natural factors as determinants of the structure and function of periphyton, benthic invertebrate, and fish communities.

In addition to continued routine monitoring to assess changes in ecological conditions, future studies will examine (1) conditions of microbial communities at sites where algal periphyton exhibit stress, (2) effects on Melton Branch when operation of the HFIR is resumed in spring 1989, and (3) further modification of the IBI for regional application and comparison with data from other BMAPs.

Bioaccumulation Studies (Tasks 2, 5, and 6)

Results from the monitoring of polychlorinated biphenyls (PCBs) in channel catfish in 1988 supported previous conclusions; that is, some channel catfish caught by anglers in the

*U.S. Department of Agriculture, Food and Drug Administration. 
Clinch River near WOC are likely to contain PCBs in excess of the FDA* limit of $2 \mu \mathrm{g} / \mathrm{g}$. Of 16 catfish collected from WOC embayment and the Clinch River just downstream of WOC, 3 (or 19\%) exceeded this limit, compared with $15 \%$ and $25 \%$ that exceeded the limit in 1986 and 1987 respectively. A significant fraction, although not necessarily most, of the PCB in catfish from the Clinch River near WOC originates in the WOC discharge and/or WOC embayment. The high levels of PCBs found in gizzard shad at localized sites of PCB contamination (e.g., WOL, WOC embayment, lower Poplar Creek), together with evidence from ${ }^{90} \mathrm{Sr}$ measurements indicating movement of several kilometers, supports the hypothesis that the movements of both species could act to distribute PCB contamination from localized sources throughout large reservoirs.

Semiannual monitoring of PCBs in bluegill sunfish in December 1987 at seven sites in WOC watershed showed levels similar to those found in 1986. These data and those obtained from 4-week exposure experiments with caged Asiatic clams suggest that PCBs in fish in WOC are the result of recent rather than historical exposure and that the source of PCB contamination is upstream of WCK 3.5 in the main plant area. No other organics were detected at significant concentrations in the clam samples.

Except for mercury, which was well below the FDA action limit of $1 \mu \mathrm{g} / \mathrm{g}$, metal concentrations in bluegill and redbreast sunfish from 7 sites in WOC watershed were similar to the concentrations found in fish at the uncontaminated reference site. To evaluate whether monitoring metal concentrations in water would provide adequate protection against their accumulation to hazardous levels in fish, a review was conducted of (1) NPDES data for metals in water and BMAP data for metals in fish at sites below ORNL, the Y-12 Plant, and the Oak Ridge Gaseous Diffusion Plant (K-25); (2) EPA water quality criteria for protection of human health from ingestion of contaminated fish; and (3) preliminary guidance values used in contaminant screening analyses. Results of this comparative evaluation showed that metal concentrations in both water and fish are not a public health problem with respect to the accumulation of metals (other than mercury) in fish below ORNL or any of the other DOE facilities in Oak Ridge.

The accumulation of contaminants by two turtle species in WOL was also examined in 1988. Analyses of radionuclides $\left({ }^{137} \mathrm{Cs},{ }^{60} \mathrm{Co}\right.$, and $\left.{ }^{90} \mathrm{Sr}\right)$ and mercury as well as DNAdamage assessment in the common snapping turtle were completed and compared with similar data reported in the previous annual report for yellow-bellied slider turtles. The mean mercury concentration in kidney and muscle of snappers was significantly higher than that found in sliders, probably reflecting trophic differences. (E.g., fish comprised $52 \%$ of the diet of snappers but only $3 \%$ of the diet of sliders.) The mean mercury concentration in muscle tissue of snapping turtles was similar to that of bluegill from WOL. Both turtle species from WOL had a significantly greater amount of DNA damage than the same species from Bearden Creek embayment (the reference site), indicating that turtles from WOL had a potentially greater exposure to nonspecific genotoxic agents. No significant difference in DNA damage was found between the two species from WOL. Future studies will include analyses of PCB residues in the two species.

Radioecological studies of WOL are being conducted to evaluate the significance of human exposure to contaminants in WOL and thus determine whether remedial actions are warranted under current conditions or under hypothetical loss of institutional control. Because they may remobilize radionuclides from lake sediments to the overlying water column, macrophyte populations in WOL, WOC, and Melton Branch were investigated with regard to their role in the transport and fate of radionuclides in the WOC system. 
The biomass per unit area and radionuclide concentration were determined for several macrophyte species in WOC and Melton Branch. Reciprocal transplant studies were conducted to determine the source (i.e., sediments vs water column) of radionuclides to the plants. Future studies will examine the fate of macrophyte-associated radionuclides in WOL and how macrophytes affect the accumulation, persistence, and transport of these contaminants within and out of WOL.

A weekly census of waterfowl populations on WOL and ten other radioactive waste ponds and contaminated areas near ORNL was conducted throughout 1988. The study was designed to evaluate the potential transport of radionuclides from these areas into the human food chain via ingestion of waterfowl. Based on the maximum ${ }^{137} \mathrm{Cs}$ concentration found in 3 American coot collected from WOL and 5 Canada geese from Pond 3513, the dose to an individual who consumed these waterfowl would be $0.002 \mathrm{mSv}(0.22 \mathrm{mrem})$ and $0.02 \mathrm{mSv}$ ( $2.3 \mathrm{mrem})$ respectively. Future studies will involve (1) contaminant uptake studies in domestic mallards released in WOL and (2) additional contaminant analyses (radionuclides, heavy metals, and PCBs) in transient and resident waterfowl.

\section{Abatement Program}

Abatement efforts at ORNL are directed toward providing both short-term and longterm management and technical solutions to water quality problems, including toxicity of some receiving streams. Abatement projects include chlorine reduction, substitution for ethylene glycol, tank diking, removal of leaking underground storage tanks, PCB and mercury monitoring, wastewater piping repair, construction of the Nonradiological Wastewater Treatment Project, and enhanced environmental surveillance of construction projects by staff of the ORNL Environmental Monitoring and Compliance Section. 


\title{
1. INTRODUCTION
}

\author{
J. M. Loar
}

In response to a condition of the National Pollutant Discharge Elimination System (NPDES) permit issued to Oak Ridge National Laboratory (ORNL) on April 1, 1986, a Biological Monitoring and Abatement Program (BMAP) was developed for White Oak Creek (WOC); selected tributaries of WOC, including Fifth Creek, First Creek, Melton Branch, and Northwest Tributary; and the Clinch River (Loar et al. 1991). The BMAP consists of seven major tasks that address both radiological and nonradiological contaminants in the aquatic and terrestrial environs onsite and the aquatic environs offsite. These tasks are (1) toxicity monitoring; (2) bioaccumulation monitoring of nonradiological contaminants in aquatic biota; (3) biological indicator studies; (4) instream ecological monitoring; (5) assessment of contaminants in the terrestrial environment; (6) radioecology of WOC and White Oak Lake (WOL); and (7) contaminant transport, distribution, and fate in the WOC embayment-Clinch RiverWatts Bar Reservoir system.

\subsection{OBJECTIVES}

The BMAP was developed to meet several objectives. First, studies (tasks) were designed to provide sufficient data to determine whether the effluent limits established for ORNL protect and maintain the classified uses of WOC, Melton Branch, Northwest Tributary, First Creek, and Fifth Creek. These streams have been classified by the Tennessee Department of Health and Environment (TDHE) for (1) growth and propagation of fish and aquatic life, (2) irrigation, and (3) livestock watering and wildlife.

Second, BMAP will provide ecological characterizations of WOC and tributaries and of WOL that can be used to (1) document ecological impacts of past and current operations and (2) identify contaminant sources that adversely affect stream biota. This ecological information will be important in the development of various Remedial Investigation/Feasibility Study plans and in the assessment of remedial action alternatives as part of the Resource Conservation and Recovery Act planning process within the ORNL Remedial Action Program (RAP).

Third, BMAP will document the effects on stream biota from implementation of the RAP and the Water Pollution Control Program (WPCP); these ORNL programs are described in detail in Bates et al. (1986) and are summarized in Berry et al. (1987). The major remedial action included in the latter program is completion of a new Nonradiological Wastewater Treatment Plant in 1989. The ecological characterization of WOC watershed will provide baseline data that can be used to document the ecological effects of the WPCP and the RAP and to determine the success of remedial actions implemented under these programs. The long-term nature of BMAP ensures that the effectiveness of remedial measures will be properly evaluated. 


\title{
2. DESCRIPTION OF WHITE OAK CREEK WATERSHED
}

\author{
R. D. Bailey, H. L. Boston, J. M. Loar, M. G. Ryon, and J. G. Smith
}

The WOC watershed is located near the southern boundary of the $150-\mathrm{km}^{2}$ DOE Oak Ridge Reservation (ORR). The watershed has a drainage area of $16.9 \mathrm{~km}^{2}$ at its mouth at Clinch River Kilometer (CRK) 33.5, and is similar in size to Bear Creek watershed $\left(20.1 \mathrm{~km}^{2}\right)$ near the Y-12 Plant (Evaldi 1986). (Note: CRK 0.0 is located at the confluence of the Clinch and Tennessee Rivers.) Parallel northeast-trending ridges constitute the northern and southern borders of the watershed, and a third ridge (Haw Ridge) bisects the basin and separates Bethel Valley to the north from Melton Valley to the south (Fig. 2.1). The WOC watershed is located near the southern boundary of the $150-\mathrm{km}^{2}$ DOE. Elevations in the watershed range from $226 \mathrm{~m}$ above mean sea level (MSL) at the mouth of WOC to $413 \mathrm{~m}$ MSL on Melton Hill at the crest of Copper Ridge, the highest point on the ORR (McMaster 1963, McMaster and Waller 1965).

Because of dam construction, three distinct environments can be identified within the WOC watershed: (1) White Oak Lake (WOL), (2) WOC embayment below the lake, and (3) WOC and tributaries above the lake. The lake was created in 1941 by construction of a small highway-fill dam approximately $1.0 \mathrm{~km}$ above the confluence of WOC and the Clinch River

(Fig. 2.1). It is a shallow impoundment that extends approximately $0.7 \mathrm{~km}$ upstream from the dam and has a surface area of about 8 ha at a lake elevation of $227.1 \mathrm{~km}$ MSL.

The water level in WOC embayment is controlled by the operation of Melton Hill Dam at CRK 37.2 and Watts Bar Dam, which is located at Tennessee River
Kilometer 852.6 , about $61 \mathrm{~km}$ below the confluence of the Clinch and Tennessee rivers. When Watts Bar Reservoir is maintained at or near full pool (approximately April to October) and discharges occur at Melton Hill Dam, the subsequent rise in water level in the Clinch River creates an embayment extending from the mouth of the creek to White Oak Dam. Because of this regulated condition, the WOC watershed is generally considered to be limited to the $15.5-\mathrm{km}^{2}$ area above the dam (Edgar 1978).

The region of the watershed above WOL is emphasized in the discussion that follows. Further descriptions of the WOL, WOC embayment, and Clinch River environments are provided in Loar et al. (1981), Boyle et al. (1982), Oakes et al. (1982), and Sherwood and Loar (1987) and in Sects. 4.0 and 7.0-9.0 of this report.

\subsection{GEOHYDROLOGY \\ J. M. Loar}

The headwaters of WOC originate on the southeast slope of Chestnut Ridge (Fig. 2.1). The belt of Knox Dolomite underlying the ridge is the principal water-bearing formation, and springs that occur along the base of Chestnut Ridge and in its valleys are the chief sources of base flow of upper WOC (McMaster and Waller 1965). The largest tributary of WOC is Melton Branch, which originates at the eastern end of Melton Valley and joins WOC at White Oak Creek Kilometer (WCK) 2.49 (Fig. 2.2), approximately 500 $\mathrm{m}$ above WOL (at a lake elevation of $227.1 \mathrm{~m}$ MSL). Most of the Melton Branch drainage basin is underlain by the Rome 


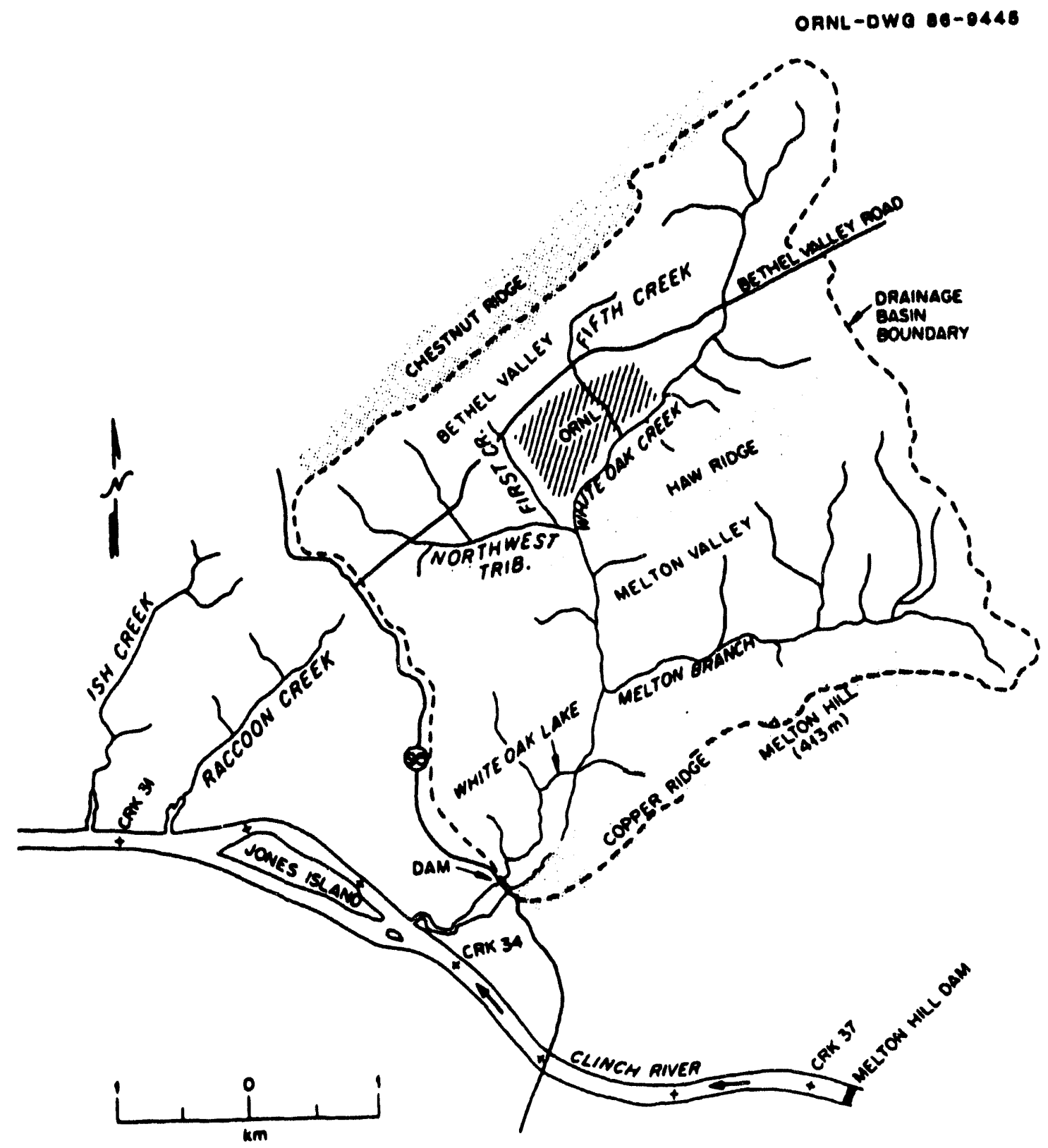

Fig. 2.1. Map of the White Oak Creck watershed above White Oak Dam. 


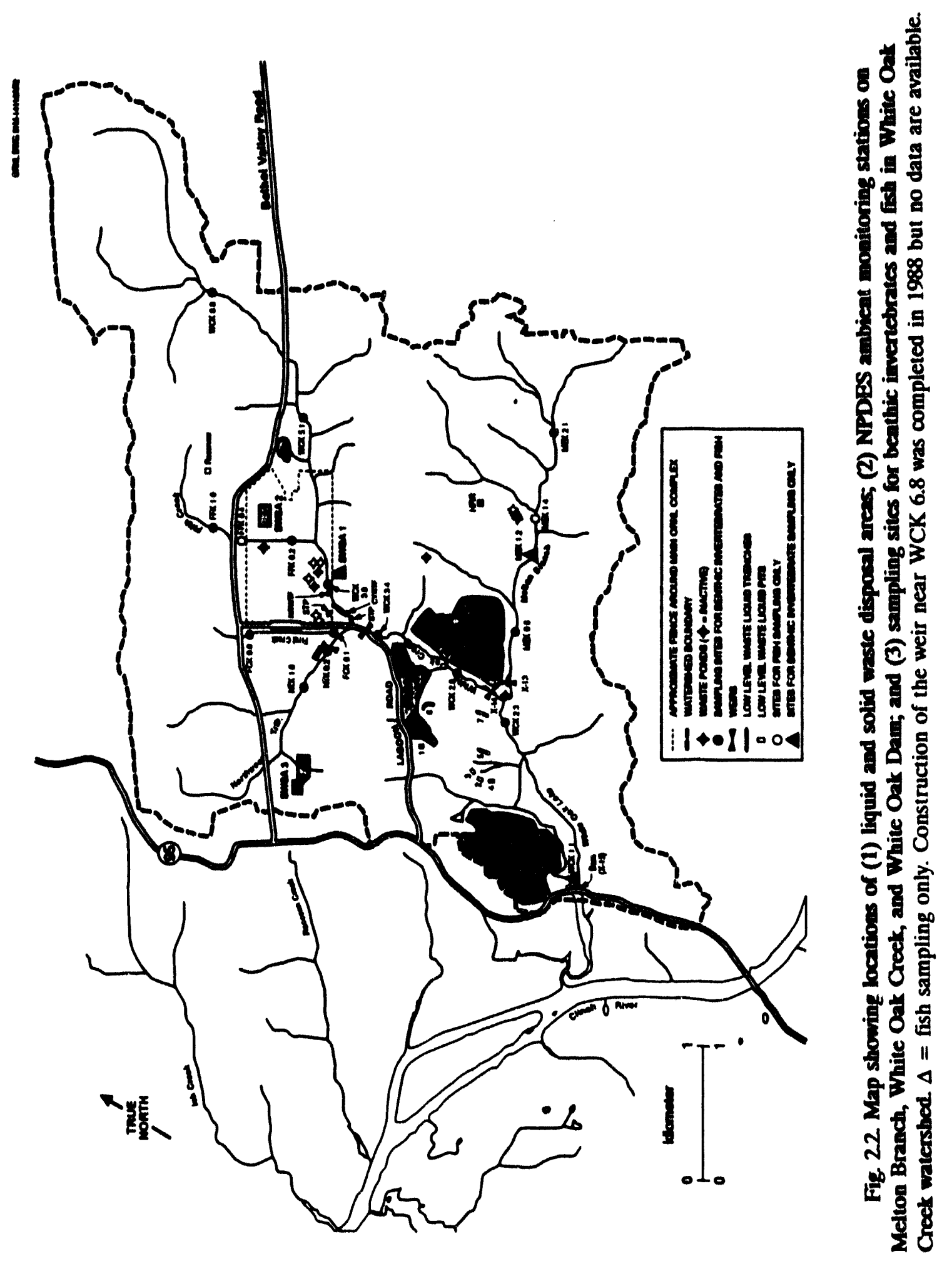


Formation (Haw Ridge), which is composed principally of siltstone and shale, and by the Conasauga Group (Melton Valley), a primarily calcareous shale interlayered with limestone and siltstone (McMaster 1963, McMaster 1967); both are poor water-bearing formations (McMaster and Waller 1965). Together, the two formations comprise $95 \%$ of the surface area of the Melton Branch watershed, whereas all of the upper WOC watershed north of Bethel Valley Road is underlain by Knox Dolomite (McMaster 1967, Table 10).

The hydrology of upper Melton Branch reflects the underlying geology of the watershed. Base-flow discharge is typically $\mathrm{K}, \mathrm{w}$ with periods of no flow at times (McMaster 1967). Precipitation was below normal in each of the past 4 years, and extended no-flow periods occurred in 1986-88 at the U.S. Geological Survey (USGS) gaging station on upper Melton Branch (MEK 1.93). More than $100 \mathrm{~d}$ of zero discharge occurred in each of the past 3 years (1986-88) (Table 2.1). Although the number of consecutive days of no flow in 1988 was substantially lower than the 155 days (July 13-December 14) in 1987, measurable flows occurred on only 16 days between June 1 and November 3, 1988. Zero discharge was also observed in each of the past 3 years in upper Northwest Tributary where a portion of the watershed drains the north slope of Haw Ridge.

Annual precipitation in 1988, as measured at the Atmospheric Turbulence and Diffusion Laboratory (ATDL) in Oak Ridge, was $124.3 \mathrm{~cm}$ (89\% of normal for the $1951-80$ record period), the highest since 1984 (143.6 cm or $103 \%$ of normal). Despite the higher rainfall, the average flow in most streams in 1988 was lower than in 1987 (Table 2.2). For example, at those USGS gaging stations located on streams that receive no effluents and have flow data for more than $85 \%$ of the year (i.e., all Bear Creek sites, North tributary 15, and MEK 1.93), the mean annual flow in 1988 was 15 to $34 \%$ lower than the mean flow in 1987. The higher annual precipitation in 1988 was due, in part, to high rainfall in July and September (150\% of normal in both months). Much of this precipitation probably never entered the streams via runoff because of the high rates of evapotranspiration during this time of year.

Stream flow in lower Melton Branch is augmented by periodic discharges of several process waste basins and cooling tower blowdown from the High Flux Isotope Reactor (HFIR) (see Sect. 2.2.1). The discharges, which enter the stream at

Table 2.1. Number of days of zero discharge (number of consecutive days in parentheses) in upper Melton Branch at MEK 1.93 (USGS gaging station 03537100)

\begin{tabular}{llllllllll}
\hline & May & June & July & August & September & October & November & December & Total \\
\hline 1985 & 0 & $4(2)$ & $8(6)$ & 0 & $2(2)$ & 0 & 0 & 0 & $14(6)$ \\
1986 & 0 & $10(10)$ & $15(15)$ & $31(31)$ & $27(24)$ & $20(12)$ & 0 & 0 & $103(47)$ \\
1987 & 0 & $11(8)$ & $21(19)$ & $31(31)$ & $30(30)$ & $31(31)$ & $30(30)$ & $18(14)$ & $172(155)$ \\
1988 & $2(2)$ & $30(30)$ & $21(12)$ & $30(26)$ & $25(11)$ & $31(31)$ & $3(3)$ & 0 & $142(145)$ \\
\hline
\end{tabular}

Source: J. F. Lowery et al. 1986, 1987. Water Resources Data for Tennessee, Water Year 1985. Report No. USGS/WRD/HD 86; and Water Resources Data for Tennessee, Water Year 1986, Report No. USGS/WRD/HD-87/225. U.S. Geological Survey, Nashville, Tenn., and USGS Provisional data (L. D. Voorhees, ORNL, unpublished data.) 
Table 2.2. Compariaon of the variability in mean daily diecharge (in liters per socond) and of mean dischinge per unit area (in liters per second per square idlometer) between streams with and without flow augmentation in 1987 and 1988 Coefficient of variation $(\mathrm{CV})=100 \mathrm{SD} / \mathrm{x}$

\begin{tabular}{|c|c|c|c|c|c|c|}
\hline \multirow{2}{*}{ Drainage/site• } & \multirow{2}{*}{$\begin{array}{l}\text { USGS } \\
\text { site ID }\end{array}$} & \multirow{2}{*}{$\begin{array}{l}\text { Drainage } \\
\text { area }\left(\mathrm{km}^{2}\right)\end{array}$} & \multicolumn{2}{|c|}{ Mean discharge (CY) } & \multicolumn{2}{|c|}{ Discharge per $\mathrm{km}^{2}$} \\
\hline & & & $1987^{\dagger}$ & $1988^{\circ}$ & 1987 & 1988 \\
\hline \multicolumn{7}{|l|}{ White Oak Croek } \\
\hline WCK 5.47 & 03536320 & 3.39 & $6.3(221.5)$ & $14.6(850.2)$ & 1.9 & 4.3 \\
\hline WCK 3.9 & 03536380 & 5.31 & $116.4(85.0)$ & $114.9(88.2)$ & 21.9 & 21.6 \\
\hline WCK 3.54 & 03536550 & 8.50 & $230.4(73.0)$ & $224.3(70.9)$ & 27.1 & 25.4 \\
\hline WCK $2.65^{\circ}$ & $\mathbf{X} 14$ & 9.53 & $227.7(64.2)$ & $226.4(76.9)$ & $23.9^{4}$ & $23.8^{4}$ \\
\hline \multicolumn{7}{|l|}{ Metton Branch } \\
\hline MEK $1.9 y$ & 03537100 & 1.35 & $10.1(398.5)$ & $9.1(469.3)$ & 7.5 & 6.7 \\
\hline MEK 0.16' & $\mathbf{x} 13^{\prime}$ & 3.83 & $54.0(237.7)$ & $35.1(334.6)$ & $14.1^{\alpha}$ & $9.2^{4}$ \\
\hline \multicolumn{7}{|c|}{ Melton Branch tributariesen" } \\
\hline MEK 2.25 & 3537300 & 0.62 & $0.1(491.1)$ & $3.0(449.7)$ & $0.2^{d}$ & 4.8 \\
\hline MEK 1.89 & 3537200 & 0.18 & $0.2(254.9)$ & $1.6(371.0)$ & $1.1^{\circ}$ & 8.9 \\
\hline MEK 1.59 & 3537050 & 0.39 & $0.1(382.7)$ & $4.6(389.9)$ & $0.3^{4}$ & 11.8 \\
\hline \multicolumn{7}{|l|}{ Frat Croek } \\
\hline FCK 0.2 & 03536450 & 0.85 & $15.2(105.4)$ & $16.2(109.8)$ & 17.9 & 19.1 \\
\hline \multicolumn{7}{|c|}{ Northweat Tributary } \\
\hline NTK 0.2 & 03536440 & 1.74 & $18.9(24.6)$ & $25.0(106.9)$ & 10.9 & 14.4 \\
\hline \multicolumn{7}{|c|}{ Bont Fort Poplar Creck } \\
\hline EFK 5.3 & 03538250 & 50.5 & $991.8(109.3)$ & $1099.7(147.7)$ & 19.6 & $21.8^{d}$ \\
\hline \multicolumn{7}{|l|}{ Bear Croek } \\
\hline BCK 6.24 & 035382673 & 8.29 & $63.8(300.2)$ & $58.8(356.7)$ & 7.7 & 7.1 \\
\hline BCK 4.55 & 03538270 & 11.03 & $110.6(209.1)$ & $91.9(238.9)$ & 10.0 & 8.3 \\
\hline BCK 3.88 & 03538273 & 12.95 & $119.3(292.6)$ & $101.4(297.5)$ & 9.2 & 7.8 \\
\hline
\end{tabular}


Table 2.2. (continued)

\begin{tabular}{|c|c|c|c|c|c|c|}
\hline \multirow{2}{*}{ Drainage/site“ } & \multirow{2}{*}{$\begin{array}{l}\text { USGS } \\
\text { site ID }\end{array}$} & \multirow{2}{*}{$\begin{array}{l}\text { Drainage } \\
\text { area }\left(\mathrm{km}^{\prime}\right)\end{array}$} & \multicolumn{2}{|c|}{ Mean discharge (CY) } & \multicolumn{2}{|c|}{ Discharge per $\mathrm{km}^{2}$} \\
\hline & & & $1987^{\circ}$ & $1988^{\circ}$ & 1987 & 1988 \\
\hline \multicolumn{7}{|c|}{ Bear Creek tributarienent } \\
\hline NT $14(B C K 6.24)$ & 035382672 & 0.78 & $5.3(368.0)$ & $4.8(425.4)$ & 6.8 & 6.2 \\
\hline NT 15(BCK 5.32) & 035382677 & 0.36 & $2.6(34.5 .3)$ & $2.3(417.0)$ & 7.2 & 6.4 \\
\hline ET 1(BCK 4.07) & 03538272 & 0.36 & $2.2(309.8)$ & $2.0(298.0)$ & 6.1 & 5.6 \\
\hline
\end{tabular}

Site decignations refer 10 the distance (in kilometers) above the mouth of the stream.

'Based on the following days of record in 1987: $128 \mathrm{~d}$ at MEK 2.25; $150 \mathrm{~d}$ at MEK 1.89 and MEK 1.59; $249 \mathrm{~d}$ al WCK 2.65 and MEK 0.16; $254 \mathrm{~d}$ at NTK 0.2; $268 \mathrm{~d}$ al WCK $5.47 ; 334 \mathrm{~d}$ at FCK 0.2; $364 \mathrm{~d}$ at NT 14; and $365 \mathrm{~d}$ at the remaining 9 siles.

Baced on the following days of record in 1988: 181 d at EFK 5.3 (atation was discontinued after June 30, 1988); $210 \mathrm{~d}$ at NT 14; $246 \mathrm{~d}$ at WCK 2.65; $249 \mathrm{~d}$ at MEK 0.16; $304 \mathrm{~d}$ at ET 1; $317 \mathrm{~d}$ at BCK 4.55 ; $322 \mathrm{~d}$ at MEK 1.89; $329 \mathrm{~d}$ at MEK 2.25; $338 \mathrm{~d}$ at MEK 1.59; $391 \mathrm{~d}$ at FCK 0.2; $353 \mathrm{~d}$ at WCK 3.54, NTK 0.2, BCK 6.24, and NT 15; $355 \mathrm{~d}$ at WCK 3.47 and WCK 3.9; 361 $\mathrm{d}$ at MEK 1.93; and $362 \mathrm{~d}$ at BCK 3.88.

Value is based on leas than $300 \mathrm{~d}$ of record (see footnotes $b$ and $c$ ).

Discharge data at this site are collected by the ORNL. Environmental Monitoring and Compliance Section.

Valuea are based on one discharge measurement each day, excluding weekends and holidays.

stream has no flow augmentation al this location.

Location of the confluence of the tributary with Melton Branch and Bear Creek (in parentheses) is given in kilometers. East Fork Poplar Creek and Bear Creek are located just north of Chesinut Ridge at the east and weat end, respectively, of the Oak Ridge Y-12 Plant.

Note: WCK = White Oak Creek kilometer; MEK = Melton Branch kilometer; FCK = First Creek kilometer; NTK = Northwest Tributary kilometer; EFK = East Fork Poplar Creek kilometer; and BCK = Bear Creek kilometer.

Melton Branch Kilometer (MEK) 1.59 via an unnamed tributary (Fig. 2.2), are a significant fraction of the flow in Melton Branch (Fig. 2.3). Extreme and possibly worst-case ambient conditions existed in lower Melton Branch in 1986 when upstream flows were at or near zero and dilution of plant discharges was minimal. Although upper Melton Branch was dry for even longer periods in 1987 and 1988, lack of dilution was less problematic because discharges from the HFIR were substantially reduced following shutdown of the reactor in November 1986.

The hydrology of the headwater region of WOC above ORNL could be expected to differ from that of upper Melton Branch due to differences in the geologies of the two areas. For example, drainage basins underlain by limestone and dolomite generally have higher unit-area low-flow discharges than those underlain by sandstone and shale (McMaster 1967). Although extended periods of zero discharge occurred in upper Melton Branch and Northwest Tributary, no periods of zero flow have been observed at sampling site WCK 6.8 north of Bethel Valley Road or at sites near the headwaters of other tributaries, such as First Creek and Fifth Creek, which also originate in the Knox Dolomite of Chestnut Ridge. The watershed area of upper WOC at WCK 6.8 is $2.07 \mathrm{~km}^{2}$ and is similar in size to that of upper Melton Branch at the USGS gaging station $\left(1.35 \mathrm{~km}^{2}\right)$. Several extended periods of no flow occurred during the summer of 1979 

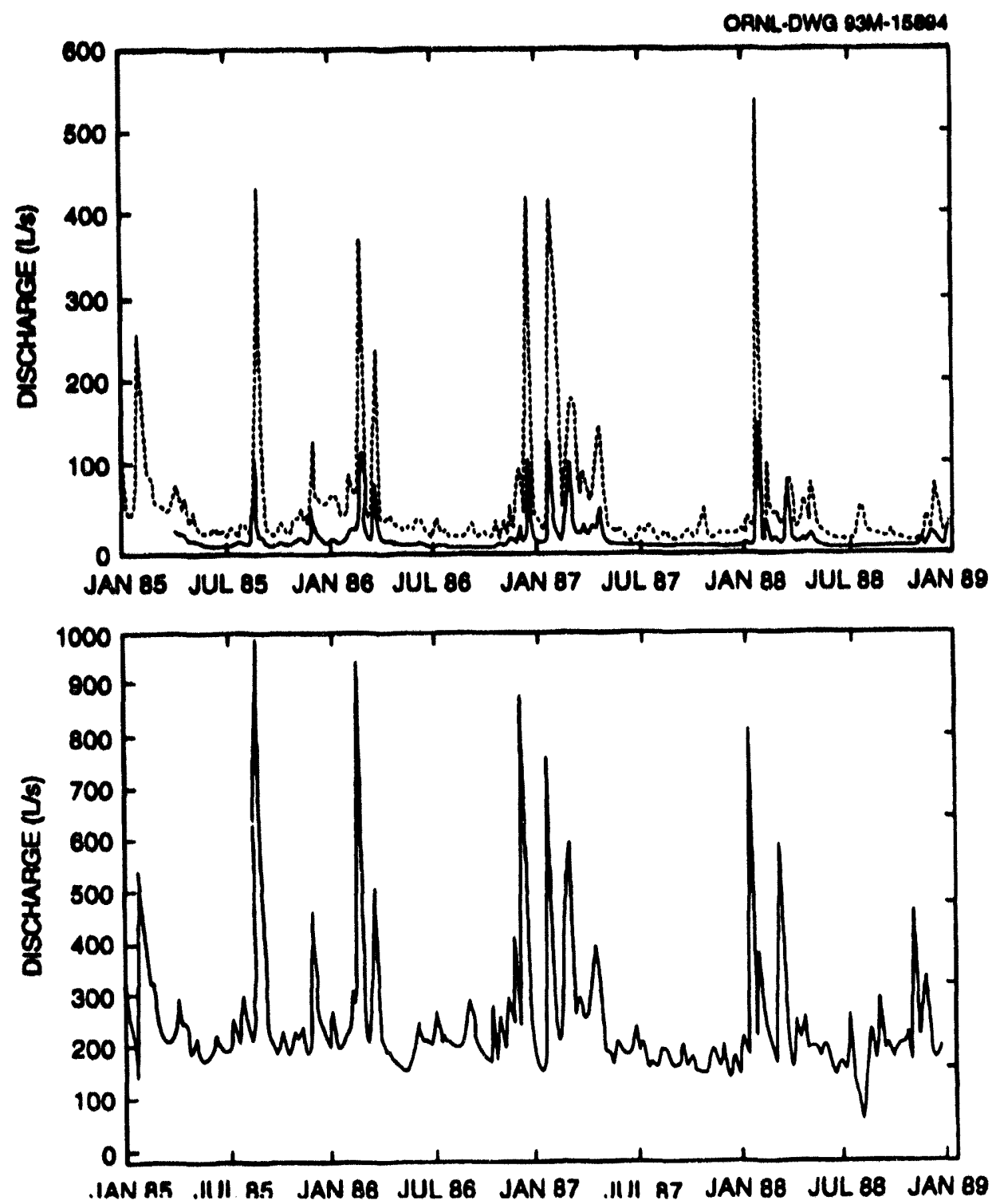

Fig. 23. Mean weekly stream flow in (1) Melton Branch at USGS gage 03537100 near Melton Branch kilometer (MEK) 1.9 and at NPDES station X13 near MEK 0.16 and (2) White Oak Creek at NPDES station X14 near White Oak Creek kilometer (WCK) 265. Discharge at the NPDES sites was measured once each day, excluding weekends and holidays. Sources: J. F. Lowery et al. 1986, 1987. Water Resources Data for Tennessee, Water Year 1985. Report No. USGS/WRD/HD 86; and Water Resources Data for Tennessee, Water Year 1986, Report No. USGS/WRD/HD-87/225. U.S. Geological Survey, Nashville, Tenn.; U.S.G.S. Provisional Data (L. D. Voorhees, ORNL, unpublished data); ORNL Environmental Monitoring and Compliance Section, unpublished data. 
in a reach of WOC just north of Bethel Valley Road near WCK 6.3 (Loar et al. 1981).

Like lower Melton Branch, stream flow in WOC below ORNL is augmented by discharges from various facilities (Sect. 2.2.1). Low-flow measurements have shown that approximately $90 \%$ of the dry-weather discharge of the creek originates as groundwater discharge from the Knox Dolomite of Chestnut Ridge, the Chickamauga Limestone of Bethel Valley, and from ORNL plant effluent (McMaster 1967). Plant effluent provides a substantial portion of the flow in WOC, accounting for more than $80 \%$ of the flow at WCK 3.9 (Table 2.2).

An indirect estimate of the relative importance of flow augmentation can be obtained from the coefficient of variation (CV) of stream discharge (Table 2.2). The $\mathrm{CV}$ is defined as the sample standard deviation (SD) expressed as a percentage of the sample mean (Steel and Torrie $1960)$ or $C V=\frac{100 S D}{\bar{x}}$. Because the temporal vasiability of effluent discharges is usually much lower than that of natural stream flows, streams with substantial flow augmentation exhibit a much lower $\mathrm{CV}$ (or higher flow constancy) than streams without flow augmentation. For example, in natural streams, such as Bear Creek and upper Melton Branch, the CV usually ranges from 200 to $400 \%$, but streams that receive plant discharges generally have a CV of $<200 \%$ and often $<100 \%$. For streams in WOC watershed, the CV ranged from $24 \%$ in Northwest Tributary in 1987, where most of the flow during summer and early fall was due to discharges from the 1500 area (Sect. 2.2.1), to $109 \%$ in First Creek in 1988 (Table 2.2).

Low flow upstream and flow augmentation downstream dominated the hydrographs for Melton Branch and WOC in 1985-88, and high flows occurred infrequently (Fig. 2.3). There were 13 major storms ( $>5 \mathrm{~cm}$ of precipitation in $24 \mathrm{~h}$ ) during this 4-year period (five occurred in 1988), but only two had a recurrence interval greater than 1.5 years. The maximum 24-h rainfall for the period 1985-88 occurred on August 16-17, 1985, when $10.9 \mathrm{~cm}$ of rain was recorded at the ATDL in Oak Ridge (NOAA 1985, 1986, 1987b, 1988). A storm of this magnitude has a recurrence interval of 3 years (Sheppard 1974). The other storm occurred on September 3-4, 1988 and had a recurrence interval of about 1.8 years based on $8.9 \mathrm{~cm}$ of rain during a $24-\mathrm{h}$ period.

\subsection{WATER QUALTTY J. M. Loar, H. L. Boston, and R. D. Bailey}

ORNL is centrally located in upper WOC watershed (Fig. 2.1). Although most of the ORNL complex is situated in Bethel Valley, some facilities are located in Melton Valley (Fig. 2.3). WOC and several tributaries (First Creek, Fifth Creek, and Northwest Tributary) are located within or adjacent to the main plant area and receive effluents from various ORNL operations.

\subsubsection{Description of ORNL Effluents}

Wastewater discharges at ORNL are generated by the operation of nuclear reactors, chemical pilot plants, research laboratories, radioisotope production laboratories, and various support facilities. Such discharges include sanitary wastewater, coal yard runoff and ash washwater, process wastewaters, cooling system wastewaters (once-through cooling water and cooling tower blowdown), and storm drainage (EPA 1986a). Approximately $30 \%$ and $36 \%$ of the estimated total effluent volume are contributed by the cooling and process 
systems, respectively; discharges from the sewage treatment plant, the steam plant, and leakage constitute the remainder of the discharges in approximately equal proportions (Kasten 1986, Table 5).

There are nine major effluent discharges that enter WOC either directly or indirectly via several tributaries (Table 2.3). Direct discharges to WOC, as listed in Table 2.3 and shown in Fig. 2.4, are largely restricted to a $1.5 \mathrm{~km}$ reach of the creek that flows west along the southern perimeter of ORNL (Fig. 2.2). Effluents are discharged to Melton Branch via a small tributary at $\mathrm{M} \backslash \mathrm{K} 1.59$, whereas discharges to Northwest Tributary from the 1500 area are located above Northwest Tributary Kilometer (NTK) 0.3 (Fig. 2.2).

In addition to these major waste streams, there are 127 outfalls that also discharge to streams in WOC watershed, including Fifth Creek, First Creek, Melton Branch, and WOC (Table 2.4). These include (1) 34 noncontaminated storm drains (identified as Category I outfalls in the NPDES permit); (2) 61 drains that have been contaminated by ORNL operations (Category II outfalls), including drains of roofs, parking lots, storage/spill areas, once-through cooling water, cooling tower blowdown and condensate; and (3) 32 untreated process drains (Category III outfalls) that are contaminated by pollutants because of inflow/ infiltration, cross-connections, or improper disposal of chemicals (DEM 1986, EPA 1986a).

Cooling system wastewater, a Category II outfall, is a major component, by volume, of the total effluent discharged by ORNL operations. Waste heat from reactors, particle accelerators, evaporators, environmental control systems, process systems, research laboratories, engineering-scale development facilities, and space-heating condensates is transferred to once-through cooling water or dissipated to the atmosphere via 26 wet-evaporative, mechanical draft cooling towers (Boyle et al. 1982, Kasten 1986). Seven mechanical-draft cooling towers discharge the principal heat burden generated by the operation of ORNL facilities, and an additional 19 smaller towers operate intermittently to meet lesser demands (Boyle et al. 1982). Total blowdown from all cooling towers is approximately $16.2 \mathrm{~L} / \mathrm{s}$ (Kasten 1986), of which an average of approximately $6.9 \mathrm{~L} / \mathrm{s}$ are discharged to Melton Branch from operation of the HFIR, $3.3 \mathrm{~L} / \mathrm{s}$ are discharged to Fifth Creek from operation of the Oak Ridge Reactor, and $3.8 \mathrm{~L} / \mathrm{s}$ are discharged to WOC from the Building 4500 cooling tower (Boyle et al. 1982, Table 2.12). Occasionally the blowdown may contain radionuclides, thus requiring diversion to the Process Waste Treatment Facility prior to discharge. Normally, however, cooling tower blowdown is discharged directly or indirectly via the storm sewer system to area streams.

\subsection{Wastewater Modifications for Pollution Abatement}

Several pollution abatement measures were implemented recently, and more are planned over the next several years as part of the ORNL Water Pollution Control Program (WPCP). The sewage treatment plant was upgraded in August 1985. A new coal yard runoff treatment facility became operational in early March 1986, and new demineralizer systems were installed at the HFIR and Oak Ridge Reactor in August 1986. One of the most significant components of the WPCP is construction of the Nonradiological Wastewater Treatment Facility (NRWTF). Scheduled for completion in 1989, the facility will treat effluents that currently are (1) untreated and discharged directly to area streams, (2) untreated but discharged to 
Table 23. Description of the nine major effluents regulated under the Oak Ridge National Laboratory National Pollutant Discharge Elimination System permit issued on April 1, 1986

\begin{tabular}{|c|c|c|c|}
\hline Receiving stream & Source of effluent & $\begin{array}{r}\text { NPDES } \\
\text { outfall }^{\circ}\end{array}$ & $\begin{array}{l}\text { Average flow } \\
\text { rate }(\mathrm{L} / \mathrm{s})^{b}\end{array}$ \\
\hline \multirow[t]{2}{*}{ Melton Branch } & TRU $U^{c}$ process waste basins & $\mathrm{X} 08$ & $2.2^{d}$ \\
\hline & HFIR' process waste basins $^{c}$ & $\mathrm{X} 09$ & $7.0^{d}$ \\
\hline Northwest Tributary & 1500 area & X03 & 0.3 \\
\hline \multirow[t]{6}{*}{ White Oak Creek } & Sewage Treatment Plant & X01 & $10.1^{\prime}$ \\
\hline & Coal Yard Runoff Treatment Facility & $\mathrm{X} 02$ & $1.0^{\circ}$ \\
\hline & 2000 area & X04 & 0.6 \\
\hline & 3539 and 3540 ponds & X06 & $5.9^{d}$ \\
\hline & 3544 Process Waste Treatment Plant & $\mathrm{X} 07$ & $7.9^{\circ}$ \\
\hline & 3518 Acid Neutralization Facility & $\mathrm{X} 11$ & $81.8^{d}$ \\
\hline
\end{tabular}

Source: Environmental Protection Agency (EPA). 1986. Authorization to Discharge Under the National Pollutant Discharge Elimination System, Permit No. TN0002941, Oak Ridge National Laboratory $(X-10)$ and Fact Sheet, April 1, 1986. U.S. Environmental Protection Agency, Region IV, Atlanta, Georgia.

No outfall X05 exists; outfall X10 to Fifth Creek from the Oak Ridge Reactor resin regeneration facility was eliminated in December 1986 (T. J. Blasing et al. 1989. Environmental Data Report for the Third Quarter of 1988. ORNL/TM-534. Environmental Monitoring and Compliance Section, Environmental and Health Protection Division, Oak Ridge National Laboratory, Oak Ridge, Tenn.); and outfall X12 is the planned discharge from the Nonradiological Wastewater Treatment Facility scheduled for compietion in 1989 (date for compliance is March 1990) and an estimated average flow rate of $22 \mathrm{~L} / \mathrm{s}$.

${ }^{6}$ For batch operations, average flow rate is based on days when waste is discharged.

TRU = Transuranium Processing Facility; HFIR = High Flux Isotope Reactor.

Batch discharge with frequencies of once every $5 \mathrm{~d}$ (X08), three times per month (X09), and 3 batches per $\mathrm{d}$ (X11); discharge $\mathrm{X06}$ is batch if radioactivity is below predetermined levels.

Maximum flow rates are $32.9 \mathrm{~L} / \mathrm{s}$ at X01, 9.6 L/s at X02, and $18.8 \mathrm{~L} / \mathrm{s}$ at X07.

process waste basins prior to release, and (3) treated by existing facilities. The NRWTF will collect and treat NPDES serial discharges $\mathrm{X} 03$ through $\mathrm{X} 10$; discharge $\mathrm{X} 11$ will be treated by either the NRWTF or the Coal Yard Runoff Treatment Facility (Table 2.3). Additional pollution abatement projects and programs are described in Sect. 9.

\subsubsection{NPDES Water Quality Monitoring Program}

Water quality in WOC and Melton Branch is influenced both by point-source discharges from ORNL facilities (Sect. 2.2.1) and by area-source discharges from waste disposal areas, such as the solid waste storage areas (SWSAs), former liquid 
Conl-owa and isens

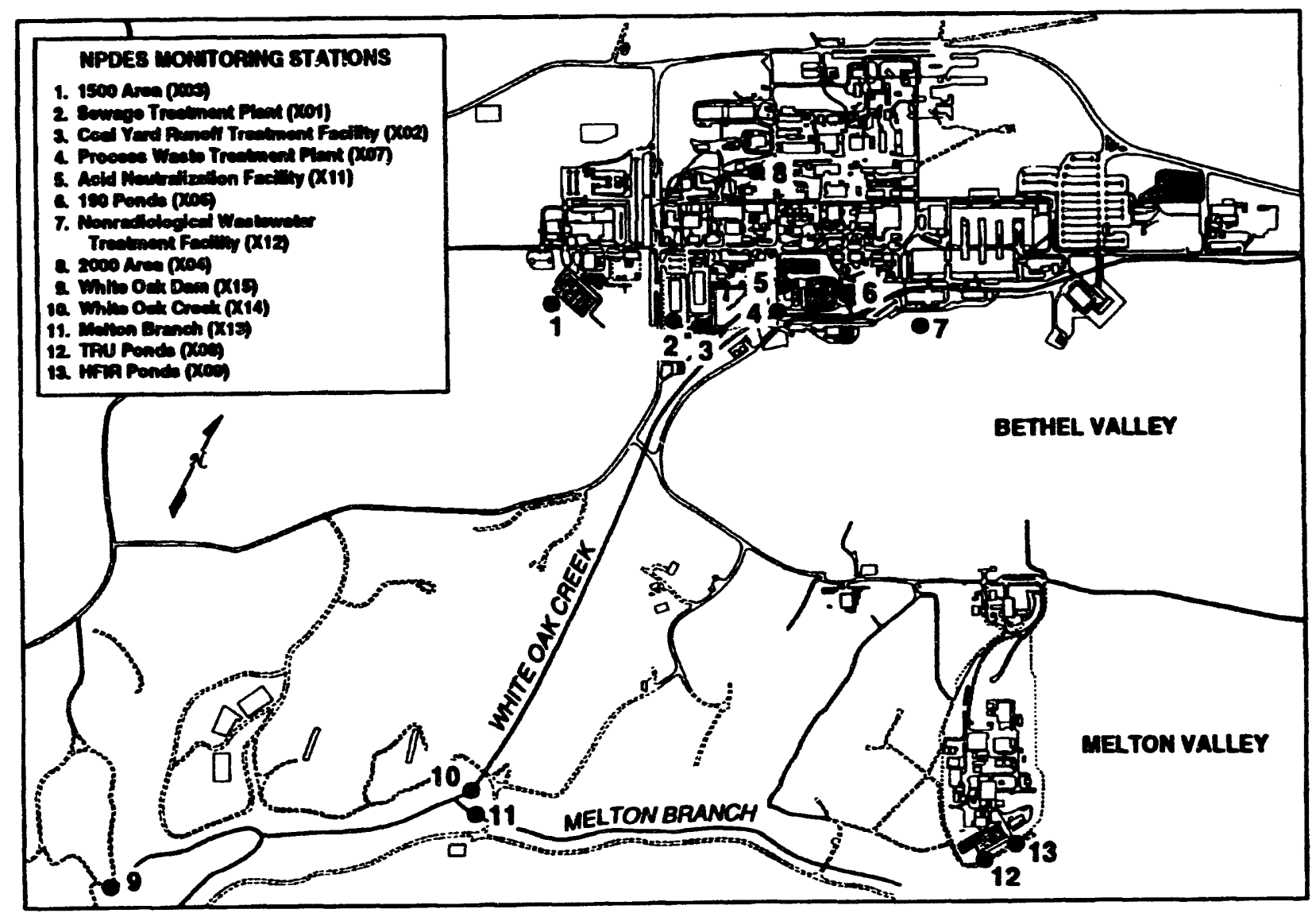

Fig. 24. Location of NPDES effluent (Sites 1-9 ard 12-14) and ambient (Sites 10-12) water quality monitoring stations. Station numbers on legend do not correspond to serial identification of the discharges in the NPDES permit. [Environmental Protection Agency (EPA). 1986. Authorization to Discharge Under the National Pollutant Discharge Elimination System, Permit No. TN0002941, Oak Ridge National Laboratory (X-10) and Fact Sheet, April 1, 1986. U.S. Environmental Protection Agency, Region IV, Atlanta, Georgia.] Source: T. J. Blasing et al. 1989. Environmental Data Report for the Third Quarter of 1988, Fig. 4. ORNL/TM-534. Environmental Monitoring and Compliance Section, Environmental and Health Protection Division, Oak Ridge National Laboratory, Oak Ridge, Tenn. 
Table 24. Number and location (receiving stream) of category I, II, and III outfalls that discharge to White Oak Creek and tributaries

\begin{tabular}{lccccc}
\multicolumn{1}{c}{ Type } & $\begin{array}{c}\text { White Oak } \\
\text { Creek }\end{array}$ & $\begin{array}{c}\text { Fifth } \\
\text { Creek }\end{array}$ & $\begin{array}{c}\text { First } \\
\text { Creek }\end{array}$ & $\begin{array}{c}\text { Melton } \\
\text { Branch }\end{array}$ & Total \\
\hline $\begin{array}{l}\text { Catcgory I } \\
\text { Storm drains }\end{array}$ & 16 & 13 & 4 & 1 & 34 \\
Category II & & & & & \\
$\quad$ Parking lot drains & 27 & 6 & 8 & 3 & 44 \\
Storage area drains & 0 & 0 & 2 & 0 & 2 \\
Spill area drains & 1 & 0 & 0 & 0 & 1 \\
Cooling tower blowdown & 2 & 3 & 0 & 1 & 6 \\
Condensate & 4 & 4 & 0 & 0 & 8 \\
Category III & & & & & 32 \\
\hline Process drains & 14 & 8 & 4 & 6 & \\
\hline
\end{tabular}

asettling ponds.

Source: Environmental Protection Agency (EPA). 1986. Authorization to Discharge Under the National Pollutant Discharge Elimination System, Permit No. TN0002941, Oak Ridge National Laboratory (X-10) and Fact Sheet, April 1, 1986. U.S. Environmental Protection Agency, Region IV, Atlanta, Georgia.

waste disposal areas (pits and trenches), and inactive process waste basins (Fig. 2.2). The discharge to area streams of leachates from waste disposal areas has been documented by Stueber et al. (1981) for Northwest Tributary (from SWSA 3) and by Cerling and Spalding (1982) for WOC (SWSA 4), Melton Branch (SWSA 5), and WOL (SWSA 6). A characterization of ambient water quality downstream of all point-source discharges and most major areasources is presented in Table 2.5. It is based on routine NPDES monitoring conducted in 1987 at sites MEK 0.16 and WCK 2.65 (NPDES sites X13 and X14, respectively), although data collected from sites on upper WOC and Melton Branch above ORNL and at White Oak Dam (WOD) are included for comparative purposes. Routine radiological monitoring is also conducted at the three NPDES ambient stations and other sites on Melton Branch just below HFIR, First Creek, Fifth Creek, Northwest Tributary, Raccoon Creek, and WOC at WCK 3.41 (Fig. 2.2). These data are collected either daily or weekly and are published quarterly by the ORNL Environmental Monitoring and Compliance Section.

Water quality in lower WOC, as characterized by the NPDES monitoring program (Table 2.5), consisted of (1) moderate levels of dissolved solids and turbidity, (2) elevated concentrations of most metals but very low concentrations of organics, (3) moderate phosphorus enrichment, and (4) high temperatures (Fig. 2.5). Nitrate enrichment also occurs in WOC below ORNL (Sect. 2.2.4) but was not observed in the NPDES 
Table 25. Median concentrations (range in parentheses) of 34 NPDES water quality parameters that are routinely monitored below ORNL in Melton Branch at NPDES site X13 (MEK 0.16), in White Oak Creek at NPDES site X14 (WCK 265), and at White Oak Dam (WOD) at NPDES site X15, January-December 1988

\begin{tabular}{|c|c|c|c|c|c|}
\hline \multirow{2}{*}{ Parameter } & \multicolumn{2}{|c|}{ Melton Branch } & \multicolumn{3}{|c|}{ White Oak Creek } \\
\hline & Above ORNL & MEK 0.16 & Above ORNL & WCK 2.65 & WOD \\
\hline \multicolumn{6}{|l|}{ Organics, $\mu g / L$} \\
\hline Chloroform & ND & $<5$ (all $<5$ ) & ND & $5(3-7)$ & $<5(1-<5)$ \\
\hline PCBs & $<0.5$ (all $<0.5$ ) & $<0.5$ (all $<0.5$ ) & $<0.5$ (all $<0.5$ ) & $<0.5$ (all $<0.5$ ) & $<0.5(<0.5-0.5)$ \\
\hline Phenols & ND & $<1(<1-1)$ & ND & $<1(<1-1)$ & ND \\
\hline Trichloroethylene & ND & $<5($ all $<5$ ) & ND & $<5$ (all $<5$ ) & $<5($ all $<5)$ \\
\hline \multicolumn{6}{|l|}{ Metak, $\mu \mathrm{g} / \mathrm{L}$} \\
\hline Al & $39^{b}$ & $420(150-1300)$ & ND & $360(240-1300)$ & $720(320-1900)$ \\
\hline As & ND & $<60(<18-<60)$ & ND & $<60(18-<60)$ & $<60(<18-<60)$ \\
\hline $\mathrm{Cd}$ & $0.05(0.01-0.59)$ & $<2($ all $<2)$ & $0.08(0.01-0.45)$ & $<2(<2-1)$ & $<2($ all $<2)$ \\
\hline $\mathrm{Cr}$ & $0.41(0.17-1.5)$ & $<6(<3.6-8.6)$ & $0.39(0.05-1.5)$ & $5(<3.6-7.9)$ & $14(<3.6-33)$ \\
\hline $\mathrm{Cu}$ & $0.82(0.30-2.1)$ & $<10(<6-<10)$ & $0.56(0.24-5.9)$ & $11(<6-15)$ & $6.7(<6-20)$ \\
\hline $\mathrm{Fe}$ & $97(47-578)$ & $260(140-1100)$ & $41(22-285)$ & $220(89-1300)$ & $600(290-1900)$ \\
\hline $\mathrm{Pb}$ & $0.70(0.2-5.7)$ & $<4($ all $<4)$ & $0.72(0.1-4.0)$ & $<4(<4-<30)$ & $<4(<4-4)$ \\
\hline Mn & $12^{b}$ & $100(68-191)$ & ND & $29(21-100)$ & $58(38-185)$ \\
\hline $\mathrm{Hg}$ & $0.003(<0.001-1.19)$ & $<0.05$ (all $<0.05$ ) & $0.002(<0.001-0.36)$ & $0.08(<0.05-0.10)$ & $<0.05(<0.05-0.10)$ \\
\hline $\mathrm{Ni}$ & $3.1(0.1-16)$ & $<5(<3.6-8.1)$ & $1.3(0.1-15)$ & $<6(<3.6-6.8)$ & $<5(<3.6-9.5)$ \\
\hline $\mathrm{Ag}$ & ND & $<5$ (all $<5$ ) & ND & $<5$ (all $<5$ ) & $<5$ (all $<5$ ) \\
\hline $\mathrm{Zn}$ & $0.52(0.19-56)$ & $15(<1.8-39)$ & $1.1(0.25-36)$ & $36(24-76)$ & $24(12-58)$ \\
\hline \multicolumn{6}{|c|}{ Conventional parameters, mg/L } \\
\hline Ammonia nitrogen & $<0.2($ all $<0.2)$ & $0.06(0.03-7.16)$ & $<0.2$ (all $<0.2$ ) & $0.07(0.02-0.17)$ & $0.08(0.02-0.18)$ \\
\hline BOD, 5-day & $<5($ all $<5)$ & $<5($ all $<5)$ & $<5$ (all $<5$ ) & $<5$ (all $<5)$ & $<5$ (all $<5$ ) \\
\hline Chlorine, total residual ${ }^{c}$ & $\sigma^{\infty}$ & $<0.01$ (all $<0.01)$ & $\sigma^{\alpha}$ & $<0.01(<0.01-0.12)$ & $<0.01(<0.01-0.10)$ \\
\hline Conductivity $(\mu \mathrm{S} / \mathrm{cm})^{e}$ & $231(118-262)$ & $365(250-800)$ & ND & $400(200-800)$ & $390(300-800)$ \\
\hline Dissolved oxygen ${ }^{c}$ & ND & $9.2(3.8-18.8)$ & ND & $9.0(5.1-13.2)$ & $9.5(4.0-16.2)$ \\
\hline
\end{tabular}


Table 25. (continued)

\begin{tabular}{|c|c|c|c|c|c|}
\hline \multirow{2}{*}{ Parameter } & \multicolumn{2}{|c|}{ Melton Branch } & \multicolumn{3}{|c|}{ White Oak Creek } \\
\hline & Above ORNL ${ }^{\circ}$ & MEK 0.16 & Above ORNLa & WCK 2.65 & WOD \\
\hline Dissolved solids & $158(118-266)$ & $186(144-288)$ & $95(68-239)$ & $236(117-317)$ & $226(136-279)$ \\
\hline Fluoride & $0.1(0.0-0.2)^{\gamma}$ & $1.0(<1.0-1.0)$ & ND & $1.0(<1.0-1.2)$ & $1.0(<1.0-1.1)$ \\
\hline Nitrate & $0.04(<0.005-1.10)$ & $<5($ all $<5)$ & $0.31(0.08-1.90)$ & $<5($ all $<5)$ & $<5($ all $<5)$ \\
\hline Oil and grease ${ }^{c}$ & $<2$ (all $<2$ ) & $<2(<2-9)$ & $<2($ all $<2)$ & $<2(<2-14)$ & $2(<2-38)$ \\
\hline Organic carbon, total & ND & $2.7(1.9-6.4)$ & ND & $2.4(2.0-4.0)$ & $3.4(2.2-4.2)$ \\
\hline $\mathrm{pH}^{e}$ & $7.9(7.5-8.1)^{\prime}$ & $8.0(6.7-8.9)$ & ND & $8.1(7.4-9.0)$ & $8.4(6.5-9.2)$ \\
\hline Phosphorus & $0.012(0.003-0.152)$ & $0.3(0.1-1.0)$ & $0.012(0.002-0.124)$ & $0.3(<0.1-1.7)$ & $0.2(0.2-1.1)$ \\
\hline Sulfate & $12.1(6.8-16.4)$ & $32(25-34)$ & $2.93(0.26-4.76)$ & $49(38-110)$ & $54(35-69)$ \\
\hline Suspended solids & $8(<5-159)$ & $7(<5-62)$ & $<5(<5-30)$ & $8(<5-17)$ & $12(<5-61)$ \\
\hline Temperature $\left({ }^{\circ} \mathrm{C}\right)^{s}$ & ND & $11.9(1.6-29.6)$ & $h$ & $16.4(8.3-29.0)$ & $15.5(1.6-31.8)$ \\
\hline Turbidity (NTU) & $6.4(2.5-32)$ & $20(0-240)$ & $3.7(1.4-30)$ & $14(0-140)$ & $28(8-78)$ \\
\hline
\end{tabular}

$\begin{array}{llll}\text { Turbidity (NTU) } & 6.4(2.5-32) & 20(0-240) & 3.7(1.4-30)\end{array}$

Values represent the median concentration (range in parentheses) of grab samples collected weekly between April 1979 . Environmental Analysis of the Operation upper Melton Branch near MEK 1.8 and in upper White Oak Creek near WCK 6.3 (J. W. Boyle el al. 1982. Environg, Tenn. Sect. 3.2.3.2 and Tables 4.15 uf the Oak Ridge National Laboratory (X-10 Site). ORNL-5870. Oak Ridge National Laboratory, Oak Ridge, Tenn. Sect. 3.2.3.2 and Tables 4.15 of the Oak Ridge National Laboratory (X-10 Sile). ORNL-s870.

and 4.16; ORNL Environmental Monitoring and Complance Section, ${ }^{b} N=1$; values for aluminum and manganese were obtained from W. M. McMaster 1967. Hydrologic Das

Geological Survey-Water Supply Paper

年

d. M. Loar et al. 1992. First Annual

Laboratory, Oak Ridge, Tenn. Fig. 3-6.

'Grab sample collected monthly.

Nalues

WCK 6.8 (McMaster 1967, Table 11).

(hrough July and weekly from August through December.

"See Table 2.6. 

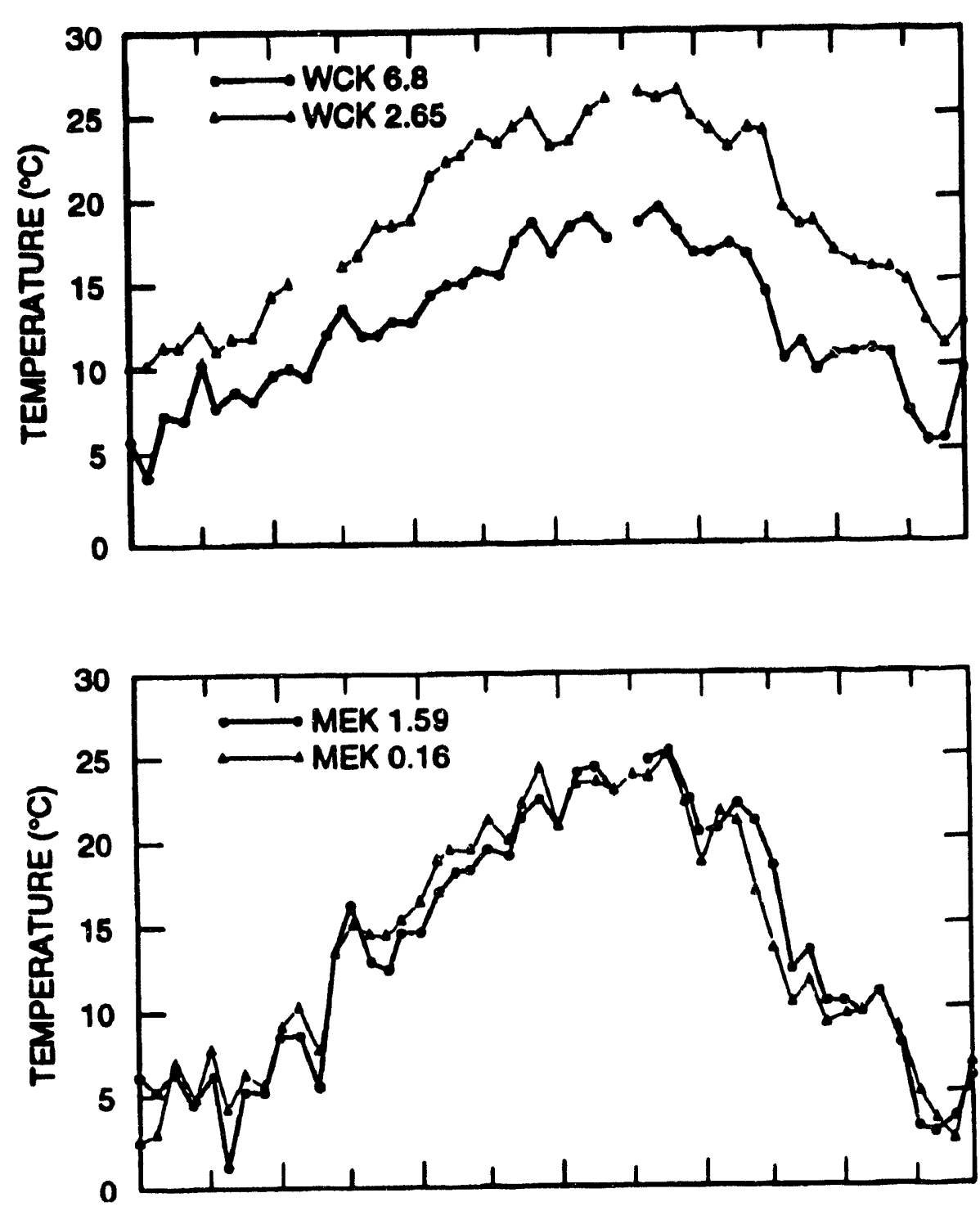

Fig. 2.5 Mean weekly temperatures in White Oak Creek at sites above and below ORNL (WCK 6.8 and WCK 265, respectively) and at two sites in Meltun Branch, January-December 1988. Temperature data at WCK 6.8 and MEK 1.59 were obtained hourly with a Ryan Tempmentor digital thermograph. At WCK 2.65 and MEK 0.16 (NPDES station X14 and X13 respectively), weekly values were based on average hourly temperatures computed from data collected at 10-min intervals with a real-time monitoring system (ORNL Environmental Monitoring and Compliance Section,

monitoring program due to the high analytical detection limit $(5 \mathrm{mg} / \mathrm{L})$. Of the conventional water quality parameters listed in Table 2.5, ammonia in 1 of the 12 samples from WCK 2.65 exceeded the EPA criteria for protection of freshwater aquatic organisms. The concentration of $7.16 \mathrm{mg} / \mathrm{L}$ ammonia nitrogen (total) that was measured in February 1988 exceeded the 1-h and 4-day average criteria of 6.16 and $1.18 \mathrm{mg} / \mathrm{L}$ respectively (EPA 1986b). These criteria apply to streams without 
salmonids and other sensitive coldwater species and are based on the actual temperature and $\mathrm{pH}$ of the water at the time the sample was collected for the ammonia analysis.

Although concentrations of trace elements in WOC below ORNL exceeded the levels observed in the unimpacted upper reaches of the stream, only mercury and iron clearly exceeded EPA water quality criteria for freshwater aquatic life (EPA 1976, 1980a, 1986b). The mean concentration of mercury in WOC exceeded the criterion of $0.012 \mu \mathrm{g} / \mathrm{L}$ (EPA 1986b), and concentrations of iron in 1 of 12 samples from WCK 2.65 and MEK 0.16 and 2 of 12 samples from WOD exceeded the criterion of $1000 \mu \mathrm{g} / \mathrm{L}$ (EPA 1976). If the total chromium measured in the NPDES ambient monitoring program were all $\mathrm{Cr}^{+6}$, then the average and maximum concentrations at WOD in 1988 exceeded the average and maximum criteria of 11 and $16 \mu \mathrm{g} / \mathrm{L}$ respectively (EPA 1986b). The detection limits for cadmium, mercury (Melton Branch and WOD only), and polychlorinated biphenyls (PCBs) exceeded the criteria either for average concentration or for protection of human health on most sampling dates. Based on the results of ambient toxicity testing (Sect. 3.1.2), however, it is unlikely that concentrations of these elements exceeded levels that would be toxic to biota.

In general, the water quality of WOC in 1988 was similar to that in the two previous years (Loar et al. 1992a; Loar 1992b). There were, however, a few exceptions. Average concentrations of both iron and aluminum were twice as high in 1988 compared to 1987 . Both are naturally occurring elements in area soils, and the increase between the two years may be due, in part, to limited sampling $(N=12$ samples per site) coincident with storms when transport of these particleassociated elements in streams is usually highest. The highest concentrations of aluminum and iron generally occurred on those sampling dates when high levels of either suspended solids or turbidity were observed. Although levels of suspended solids were relatively unchanged, there was a tenfold decrease in median turbidity in 1988 compared to 1987 which, in turn, was characterized by a tenfold increase over the previous year. Such fluctuations may be associated with shifts in construction activity associated with RAP projects or better control of soil erosion and runoff from construction sites. Minimum dissolved oxygen levels were also higher in 1988 compared with 1987; no measurements below $5.0 \mathrm{mg} / \mathrm{L}$ were recorded at WCK 2.65.

Temperatures in WOC below ORNL (WCK 2.65) are as much as 7 to $10^{\circ} \mathrm{C}$ higher than the temperatures in upper WOC north of Bethel Valley Road (Fig. 2.5). Although some increase in downstream temperatures would be expected due to the absence of a riparian canopy in the $1.5-\mathrm{km}$ reach of stream adjacent to the plant complex, plant operations probably account for much of the longitudinal gradient in water temperature (average of $2^{\circ} \mathrm{C} / \mathrm{km}$ ). Cooling tower blowdown and condensate are discharged to WOC and several tributaries (Table 2.4), and most of the streams show higher temperatures downstream of these outfalls (Fig. 2.6).

In Melton Branch, the significant improvement in water quality that occurred between 1986 and 1987 (Loar 1992b) was sustained in 1988. The concentrations of sulfates, phosphorus, and dissolved solids in both 1987 and 1988 were substantially lower than the concentrations observed at MEK 0.16 in 1986. Stream temperatures 

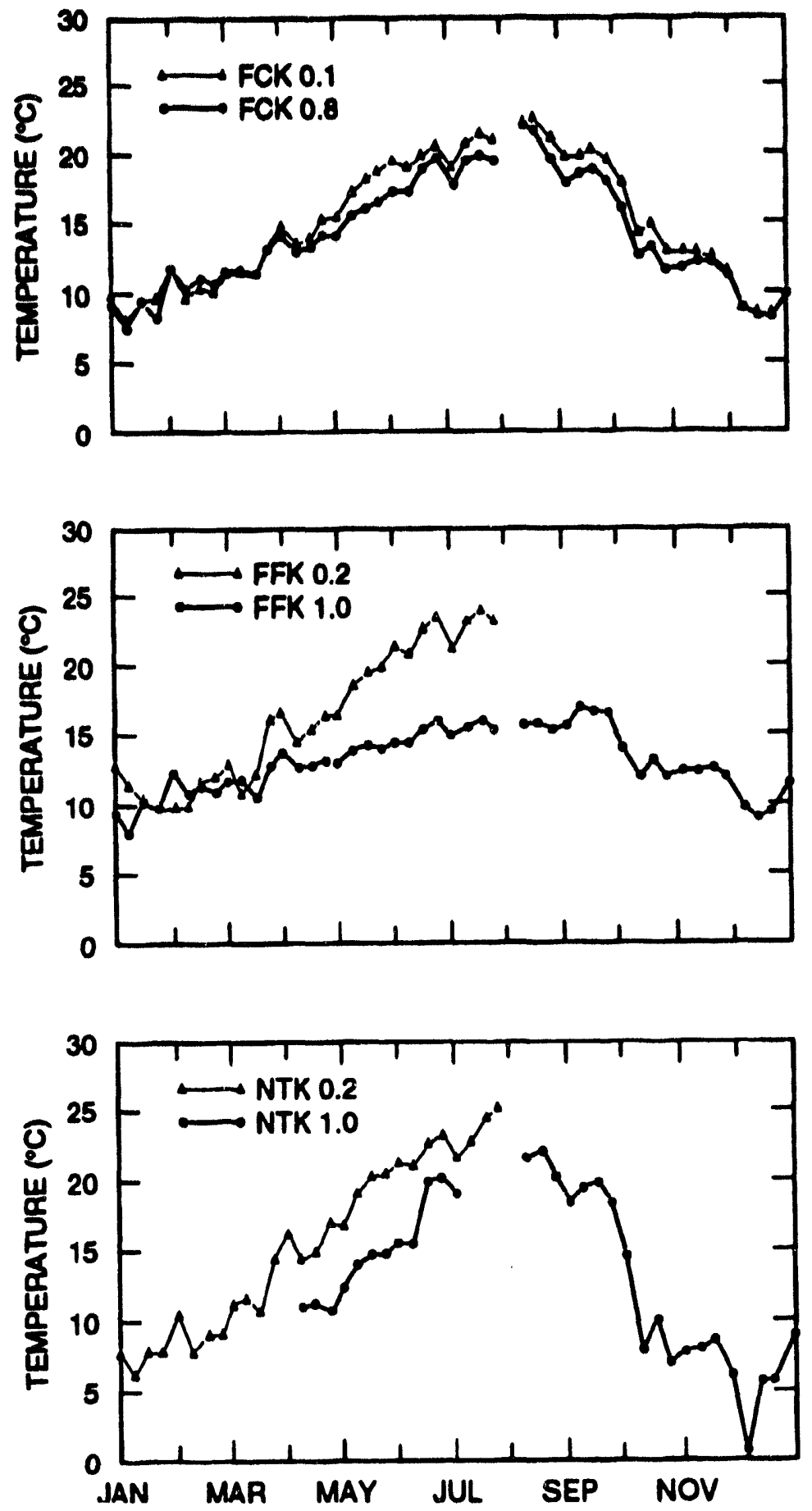

Fig. 2.6. Mean weekly temperatures in three tributaries of White Oak Creek, January-December. Mean values were calculated from data obtained at hourly intervals with a Ryan Tempmentor digital thermograph, except at NTK 1.0 where data for April-June were collected at 2-h intervals with a Ryan-Peabody thermograph (Model J90). FCK = First Creek; FFK = Fifth Creek; NTK = Northwest Tributary (see Fig. 2.2 of this document). 
were also much lower in the past 2 years. Although maximum temperatures at MEK0.16 approached $38^{\circ} \mathrm{C}$ in 1986 (Loar et al. 1992a, Fig. 2.6), they never exceeded $30^{\circ} \mathrm{C}$ in either 1987 or 1988 (Table 2.6). Temperatures in lower Melton Branch have been consistently lower than temperatures in WOC during the past 2 years (Fig. 2.7). The water quality of lower Melton Branch in 1988 was similar to that of the previous year, but there were some exceptions. Like WOC, median concentrations of both iron and aluminum in 1988 were approximately double the concentrations in 1987, and no dissolved oxygen concentrations below $5.0 \mathrm{mg} / \mathrm{L}$ were measured in 1988.

The improvement in water quality was associated with shutdown of the HFIR in November 1986 and a subsequent reduction in cooling tower blowdown and in discharges from the HFIR process ponds (Fig. 2.2). The HFIR is the largest of the five ORNL reactors. The volume of blowdown from its cooling towers is twice: that of any other reactor at ORNL.

Moreover, chemical usage exceeds that of all the cooling towers combined; the HFIR towers account for $77 \%$ of the sulfuric acid, $55 \%$ of the biocides, and $63 \%$ of the sodium phosphate used for the ORNL ccoling towers annually (Boyle et al. 1982, Table 2.2). Although the other four ORNL reactors were eventually shut down in March 1987, no measurable effects on WOC water quality were observed because the average flow in WOC is four times greater than the flow in Melton Branch (Table 2.2), and the volume of the blowdown from all the cooling towers at the main ORNL complex is less than that of the HFIR. Moreover, HFIR is the primary facility that discharges to Melton Branch, which was dry for much of 1986 above MEK 1.59 where HFIR discharges enter the stream. There are numerous facilities and substantially more discharges to WOC; thus dilution of the reactor discharges is considerably greater in WOC then in Melton Branch.

\subsubsection{BMAP Water Quality Sampling Program}

Water quality is an important component of the environment for aquatic organisms. Water quality parameters, such as $\mathrm{pH}$ and the concentrations of inorganic carbon, plant nutrients, and suspended solids, influence structural and functional aspects of attached algal and microbial communities (components of the "periphyton" on submersed surfaces). Potentially toxic metals and dissolved organic carbon (DOC) may also affect the periphyton and so influence other biotic communities via food web connections. Because such information is useful in evaluating the factors influencing biotic communities and for predicting the responses of these communities to remedial actions, a water quality monitoring program was initiated in mid1986 as part of the periphyton component of the in-stream monitoring studies. This program consisted of the monthly collection of water samples (grab samples) at the ten periphyton sampling sites in WOC watershed, and from nearby Ish Creek. This program is intended to augment the NPDES water quality monitoring program by providing data on (1) water quality at additional sites of interest and (2) parameters not included in the NPDES program. The monthly "snapshots" of water quality provided by these discrete samples have been useful for the interpretation of various parameters related to the structure and function of the periphyton communities at the study sites (see Sect. 3.2). 
Table 26. Mean ( 1 SD) monthly water temperature $\left({ }^{\circ} \mathrm{C}\right.$ ) in White Oak Creek and tributhies, indading Finst Croek, Fifth Creek, Melion Branch, and Northwest Tributary, Janany-December 1988

\begin{tabular}{|c|c|c|c|c|c|c|c|c|c|c|}
\hline & FCK 0.1 & FCK 0.8 & FFK 0.2 & FFK 1.0 & MEK $0.16^{\circ}$ & MEK $1.59^{\circ}$ & NTK 0.2 & NTK 1.0 & WCK $265^{\circ}$ & wCK 68 \\
\hline $\operatorname{Jan}^{2}$ & $\begin{array}{l}9.3 \pm 1.6 \\
(5.7-13.3)\end{array}$ & $\begin{array}{l}8.5 \pm 2.3 \\
(-1.8-16.8)\end{array}$ & $\begin{array}{l}11.0 \pm 2.8 \\
(-1.3-15.5)\end{array}$ & $\begin{array}{l}9.3 \pm 1.9 \\
(2.0-13.4)\end{array}$ & $\begin{array}{l}5.0 \pm 29 \\
(1.0-127)\end{array}$ & $\begin{array}{l}5.9 \pm 2.3 \\
(1.9-19.9)\end{array}$ & $\begin{array}{l}7.7 \pm 1.7 \\
(4.4-11.3)\end{array}$ & ND & $\begin{array}{l}11.2 \pm 1.3 \\
(8.8-14.1)\end{array}$ & $\begin{array}{l}6.2 \pm 2.0 \\
(1.2-13.1)\end{array}$ \\
\hline Feb & $\begin{array}{l}10.4 \pm 1.7 \\
(7.0-15.2)\end{array}$ & $\begin{array}{l}10.8 \pm 1.3 \\
(7.9-14.5)\end{array}$ & $\begin{array}{l}10.8 \pm 4.3 \\
(-8.3-16.8)\end{array}$ & $\begin{array}{l}11.4 \pm 1.0 \\
(9.5-14.0)\end{array}$ & $\begin{array}{l}6.6 \pm 2.5 \\
(2.5-12.8)\end{array}$ & $\begin{array}{l}4.7 \pm 4.9 \\
(-10.3-19.1)\end{array}$ & $\begin{array}{l}9.2 \pm 1.8 \\
(5.6-13.9)\end{array}$ & ND & $\begin{array}{l}122 \pm 1.4 \\
(9.8-15.7)\end{array}$ & $\begin{array}{l}89 \pm 20 \\
(48-143)\end{array}$ \\
\hline Mar & $\begin{array}{l}12.0 \pm 1.9 \\
(7.8-17.5)\end{array}$ & $\begin{array}{l}12.1 \pm 1.5 \\
(8.8-16.2)\end{array}$ & $\begin{array}{l}13.3 \pm 3.7 \\
(0.1-21.7)\end{array}$ & $\begin{array}{l}11.9 \pm 1.8 \\
(7.6-18.1)\end{array}$ & $\begin{array}{l}11.2 \pm 2.8 \\
(7.0-16.9)\end{array}$ & $\begin{array}{l}9.6 \pm 6.4 \\
(-4.3-36.7)\end{array}$ & $\begin{array}{l}12.3 \pm 2.3 \\
(7.8-18.3)\end{array}$ & ND & $\begin{array}{l}15.2 \pm 1.5 \\
(122-17.2)\end{array}$ & $\begin{array}{l}10.7 \pm 23 \\
(55-180)\end{array}$ \\
\hline Apr & $\begin{array}{l}14.5 \pm 1.9 \\
(10.9-19.7)\end{array}$ & $\begin{array}{l}13.7 \pm 1.5 \\
(10.8-18.6)\end{array}$ & $\begin{array}{l}15.8 \pm 2.8 \\
(3.6-28.1)\end{array}$ & $\begin{array}{l}13.1 \pm 1.7 \\
(9.8-18.5)\end{array}$ & $\begin{array}{l}15.8 \pm 1.8 \\
(121-20.3)\end{array}$ & $\begin{array}{l}14.4 \pm 5.5 \\
(-12.8-39.4)\end{array}$ & $\begin{array}{l}15.9 \pm 2.1 \\
(11.5-20.8)\end{array}$ & $\begin{array}{l}11.7 \pm 1.5 \\
(8.7-15.9)\end{array}$ & $\begin{array}{l}17.8 \pm 15 \\
(14.8-21.2)\end{array}$ & $\begin{array}{l}129 \pm 21 \\
(8.7-20.3)\end{array}$ \\
\hline May & $\begin{array}{l}17.7 \pm 2.3 \\
(12.3-23.2)\end{array}$ & $\begin{array}{l}15.8 \pm 20 \\
(11.7-21.4)\end{array}$ & $\begin{array}{l}22.2 \pm 20 \\
(18.3-25.5)\end{array}$ & $\begin{array}{l}13.8 \pm 1.3 \\
(10.6-16.8)\end{array}$ & $\begin{array}{l}18.9 \pm 1.8 \\
(15.6-21.9)\end{array}$ & $\begin{array}{l}17.3 \pm 2.6 \\
(10.1-23.7)\end{array}$ & $\begin{array}{l}19.6 \pm 20 \\
(14.1-24.4)\end{array}$ & $\begin{array}{l}14.2 \pm 1.7 \\
(9.2-17.9)\end{array}$ & $\begin{array}{l}21.7 \pm 1.8 \\
(18.8-24.9)\end{array}$ & $\begin{array}{l}145 \pm 24 \\
(9.5-21.0)\end{array}$ \\
\hline Jun & $\begin{array}{l}20.0 \pm 1.9 \\
(15.0-28.2)\end{array}$ & $\begin{array}{l}18.5 \pm 2.7 \\
(13.0-25.4)\end{array}$ & $\begin{array}{l}22.4 \pm 4.1 \\
(13.9-33.6)\end{array}$ & $\begin{array}{l}15.2 \pm 1.5 \\
(11.9-19.0)\end{array}$ & $\begin{array}{l}22.2 \pm 2.0 \\
(18.3-25.5)\end{array}$ & $\begin{array}{l}20.9 \pm 25 \\
(15.7-26.5)\end{array}$ & $\begin{array}{l}22.5 \pm 1.8 \\
(18.0-26.5)\end{array}$ & $\begin{array}{l}18.1 \pm 2.2 \\
(127-27.9)\end{array}$ & $\begin{array}{l}24.3 \pm 1.0 \\
(220-26.0)\end{array}$ & $\begin{array}{l}17.0 \pm 27 \\
(10.7-22.2)\end{array}$ \\
\hline JuY & $\begin{array}{l}20.7 \pm 1.8 \\
(15.8-28.3)\end{array}$ & $\begin{array}{l}19.4 \pm 2.1 \\
(14.1-28.5)\end{array}$ & $\begin{array}{l}23.1 \pm 3.5 \\
(14.7-38.3)\end{array}$ & $\begin{array}{l}15.6 \pm 1.0 \\
(12.7-20.2)\end{array}$ & $\begin{array}{l}22.7 \pm 1.9 \\
(18.4-25.4)\end{array}$ & $\begin{array}{l}23.2 \pm 21 \\
(16.2-30.1)\end{array}$ & $\begin{array}{l}23.5 \pm 1.6 \\
(19.3-27.4)\end{array}$ & ND & $\begin{array}{l}24.8 \pm 1.6 \\
(21.3-26.7)\end{array}$ & $\begin{array}{l}18.1 \pm 1.8 \\
(122-23.1)\end{array}$ \\
\hline Aug & $\begin{array}{l}22.2 \pm 1.6 \\
(18.5-27.3)\end{array}$ & $\begin{array}{l}21.3 \pm 3.3 \\
(15.4-29.2)\end{array}$ & ND & $\begin{array}{l}15.8 \pm 0.7 \\
(14.2-17.7)\end{array}$ & $\begin{array}{l}23.3 \pm 1.4 \\
(20.4-25.3)\end{array}$ & $\begin{array}{l}24.3 \pm 1.8 \\
(18.6-28.5)\end{array}$ & ND & $\begin{array}{l}21.7 \pm 1.7 \\
(16.8-25.3)\end{array}$ & $\begin{array}{l}25.8 \pm 0.9 \\
(23.8-27.0)\end{array}$ & $\begin{array}{l}18.7 \pm 1.5 \\
(15.0-23.5)\end{array}$ \\
\hline Sep & $\begin{array}{l}20.2 \pm 1.5 \\
(16.4-23.7)\end{array}$ & $\begin{array}{l}18.6 \pm 2.5 \\
(13.6-25.3)\end{array}$ & ND & $\begin{array}{l}16.6 \pm 1.8 \\
(12.1-23.8)\end{array}$ & $\begin{array}{l}19.8 \pm 3.3 \\
(17.4-22.8)\end{array}$ & $\begin{array}{l}21.2 \pm 24 \\
(12.2-26.9)\end{array}$ & ND & $\begin{array}{l}19.4 \pm 3.5 \\
(9.7-28.2)\end{array}$ & $\begin{array}{l}23.7 \pm 0.8 \\
(21.8-25.1)\end{array}$ & $\begin{array}{l}17.1 \pm 1.6 \\
(129-21.0)\end{array}$ \\
\hline
\end{tabular}


Table 26 (contineod)

\begin{tabular}{|c|c|c|c|c|c|c|c|c|c|c|}
\hline & FCK 0.1 & FCK 0.8 & FFK 0.2 & FFK 1.0 & MEK $0.16^{\circ}$ & MEK $1.59^{\circ}$ & NTK 0.2 & NTK 1.0 & waK 265" & WaK 6.8 \\
\hline Oct & $\begin{array}{l}15.0 \pm 2.8 \\
(9.1-22.6)\end{array}$ & $\begin{array}{l}13.4 \pm 3.1 \\
(7.3-24.0)\end{array}$ & ND & $\begin{array}{l}12.8 \pm 1.8 \\
(8.1-17.9)\end{array}$ & $\begin{array}{l}12.0 \pm 3.2 \\
(8.1-19.9)\end{array}$ & $\begin{array}{l}13.7 \pm 4.3 \\
(4.9-26.5)\end{array}$ & ND & $\begin{array}{l}9.9 \pm 5.5 \\
(-1.5-24.3)\end{array}$ & $\begin{array}{l}18.3 \pm 1.3 \\
(16.1-20.2)\end{array}$ & $\begin{array}{l}11.6 \pm 2.8 \\
(5.9-20.9)\end{array}$ \\
\hline Nov & $\begin{array}{l}12.6 \pm 2.0 \\
(7.9-18.2)\end{array}$ & $\begin{array}{l}12.1 \pm 2.4 \\
(6.9-28.5)\end{array}$ & ND & $\begin{array}{l}12.4 \pm 1.6 \\
(9.2-16.5)\end{array}$ & $\begin{array}{c}9.6 \pm 1.7 \\
(6.3-13.0)\end{array}$ & $\begin{array}{l}10.3 \pm 3.1 \\
(2.9-18.0)\end{array}$ & ND & $\begin{array}{l}7.8 \pm 5.4 \\
(-4.1-21.6)\end{array}$ & $\begin{array}{l}15.6 \pm 1.2 \\
(13.0-17.6)\end{array}$ & $\begin{array}{l}11.0 \pm 1.7 \\
(6.7-18.2)\end{array}$ \\
\hline Dec & $\begin{array}{l}9.2 \pm 2.2 \\
(4.6-14.1)\end{array}$ & $\begin{array}{c}9.1 \pm 2.5 \\
(4.0-21.4)\end{array}$ & ND & $\begin{array}{l}10.0 \pm 2.2 \\
(5.0-14.8)\end{array}$ & $\begin{array}{r}4.9 \pm 2.2 \\
(1.2-9.6)\end{array}$ & $\begin{array}{c}4.5 \pm 3.1 \\
(-1.1-11.3)\end{array}$ & ND & $\begin{array}{c}5.5 \pm 4.2 \\
(-6.4-13.0)\end{array}$ & $\begin{array}{l}123 \pm 1.0 \\
(10.5-14.1)\end{array}$ & $\begin{array}{c}7.5 \pm 28 \\
(0.9-123)\end{array}$ \\
\hline
\end{tabular}

'Days of record for incomplete months were: March (28 d), June (29 d), July (22 d), August and September (25 d), November (24 d), and December (27 d).

Site is located just betow the confluence of the HFIR tributary with Metton Branch. Temperatures were not measured at an upstream reference site due to zero discharge (see Table 21).

'Days of record for incomplete months were: March (14 d), April (22 d), May (27 d), July (21 d), August (29 d), September and October (26 d), and November (27 d).

$26 \mathrm{~d}$ of record at MEK 1.59 and WCK 6.8 .

-Data were recorded at 2 -h intervals with a Peabody-Ryan $\mathrm{J}-90$ thermograph.

$526 \mathrm{~d}$ of record except at MEK $1.59(27 \mathrm{~d})$ and NTK $0.2(28 \mathrm{~d})$.

$25 \mathrm{~d}$ of record except at FFK 1.0 and WCK $6.8(26 \mathrm{~d})$.

Note: Absolute maximum and minimum temperatures are given in parentheses. Data were obtained hourly using a Ryan Tempmentor digitat thermograph except sites MEK 0.16 and WCK 2.65, where tabular values are based on average hourty temperatures computed from data collected at 10-min intervals with a real-time monitoring system (ORNL Environmental Monitoring and Complianoe Section, unpublished data). ND = no data available; thermograph not deployed or lost before recovery. Minimum values below $0^{\circ} \mathrm{C}$ may have resulted from exposure of the thermograph to air due to ice formation or flooding. FCK = First Creek kilometer; FFK = Fifth Creek kilometer, MEK = Metton Branch kilometer, NTK = Northwest Tributary kilometer, WCK = White Oak Creek kilometer. 


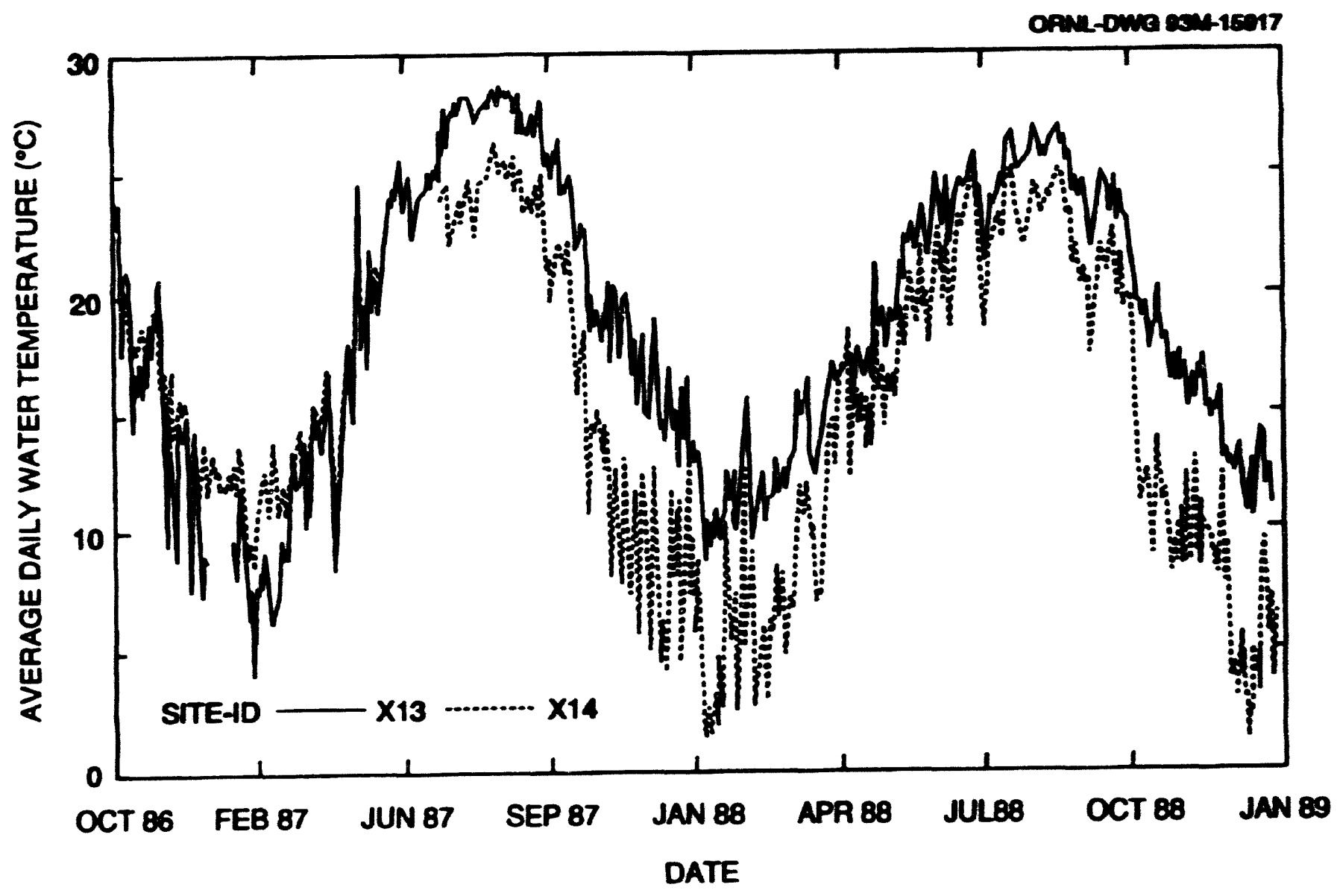

Fig 27. Water temperatures at NPDES monitoring stations X13 on lower Melkon Brasch (dashod line) and X14 on lower White Oak Creek (solid liec). Values represent a daily average computed from measurements taken at 10-min intervals with a real-time monitoring system. Source: ORNL Environmental Monitoring and Compliance Section, unpublished data. 


\subsection{Methods}

Two 1-L grab samples of stream water were collected from each of the 10 periphyton monitoring sites (Sect. 3.2) and from nearby Ish Creek at the time of collection of the monthly periphyton samples. The water samples were collected in acid-washed polyethylene bottles and taken to the laboratory within one hour of collection. Samples for the determination of DOC were collected in organic-free glass bottles with Teflon-sealed lids. The total amount of DOC was determined for samples collected each nonth. Quarterly, a subsample of this water was partitioned into hydrophilic and hydrophobic DOC fractions, which were again partitioned by molecular weight. A filtered water sample was analyzed quarterly for soluble metals by inductively-coupled plasma (ICP) spectroscopy. One sample was analyzed for each site for several basic water quality parameters $(\mathrm{pH}$, alkalinity, conductivity, hardness, and soluble metals). Analyses of the other parameters were performed on replicate samples. Analyses for $\mathrm{pH}$, alkalinity, hardness and conductivity were conducted within two hours of collection. Samples for other analyses were preserved and/or frozen according to approved methods (EPA 1979) until they could be analyzed. The methods for the parameters included in the BMAP water sampling program are listed in Table 2.7.

\subsubsection{Results}

Five sites were located upstream of ORNL operations and served as reference sites, including WCK 6.8, MEK 1.8, NTK 1.0, First Creek kilometer (FCK) 1.0, and Fifth Creek kilometer (FFK) 1.1, and five sites were downstream of ORNL discharges [White Oak Creek kilometer (WCK) 3.9, WCK 3.4, WCK 2.9, WCK 2.3, and MEK 0.6]. Periphyton and water

Table 27. Water quality parameters determined for discrete samples collected monthly at ten sites in streams in the White Oak Creek watershed and in nearby Ish Creek

\begin{tabular}{lll}
\hline \multicolumn{1}{c}{ Parameter } & \multicolumn{1}{c}{ Method } & Reference $^{a}$ \\
\hline ph & Glass electrode & APHA (1985) \\
Alkalinity & Acid tritration to $\sim \mathrm{pH} 4.7$ & APHA (1985) \\
Conductivity & Conductivity bridge & APHA (1985) \\
Hardness & EDT tritration & APHA (1985) \\
Phosphorus & Ascorbic acid method & APHA (1985) \\
\multicolumn{1}{c}{ Total P } & Persulfate digestion & APHA (1985) \\
\multicolumn{1}{c}{ Total soluble P } & Filter and digestion & \\
Nitrate and nitrite & Filter only & EPA (1979) \\
Ammonia (ammonium) & Cadmium reduction & EPA (1979) \\
Suspended solids & Phenate method & APHA (1985) \\
Particulate carbon and nitrogen & Total filterable (105 $\left.{ }^{\circ} \mathrm{C}\right)$ & \\
Dissolved metals & Elemental analzyer & APHA (1985) \\
Dissolved organic carbon & Filter and ICP emission spectroscopy & Dohrmann (1984) \\
\hline
\end{tabular}

${ }^{a}$ References cited here are listed in full in Sect. 10. 
quality samples were also collected from an additional reference site on nearby Ish Creek just above the weir (Fig. 2.1). Upstream (reference) sites MEK 1.8, NTK 1.0 and Ish Creek were dry for several months during the summer and fall of 1988 , but 12 months of data are available for the other sites. The water quality at all of the sites reflects the calcareous geology of this area, being moderately well-buffered and having slightly alkaline $\mathrm{pH}$ values (Table 2.8 ). The $\mathrm{pH}$, alkalinity, hardness, and conductivity were generally similar for all sites, except NTK 1.0 which had higher alkalinity, hardness, and conductivity than the other sites. In general, these parameters were more variable for reference sites than for downstream sites. Hardness and conductivity were somewhat higher during 1988 compared with 1987 at WCK 3.4 and WCK 2.9; both sites are downstream of the ORNL Sewage Treatment Plant (STP). Data for other sites were similar to those reported for 1987 (Loar 1992b).

Total suspended solids (TSS) concentrations were moderate but variable at most sites. The average concentration and the variance for TSS were low at WCK 6.8 and FFK 1.0 (both are headwater sites below springs), WCK 2.9 and WCK 3.4 (both are located below weirs), and at Ish Creek. Sites on Melton Branch and some on WOC (WCK 3.9 and WCK 2.3) had consistently high TSS concentrations that are likely important influences on the biotic communities at those sites.

Concentrations of DOC were higher at the downstream than the upstream sites (Table 2.8), and concentrations at upstream sites seemed to reflect watershed area; in other words, concentrations were lowest at sites with small drainage areas (e.g., spring-fed sites) because most DOC is of recent terrestrial origin.

Concentrations of DOC in 1988 were similar to those observed in 1987 (Loar 1992b).

Soluble reactive phosphorus (SRP) concentrations were typically about 6 to $11 \mathrm{mg}$ of phosphorus per liter for the upstream sites, with occasional peaks of 13 to $20 \mathrm{mg}$ of phosphorus per liter (Table 2.8). The low average SRP concentrations suggest that phosphorus availability may limit primary production during certain times of the year at upstream sites. (The influences of light and grazing are discussed in Sect. 3.2.) Sites receiving discharges from ORNL operations typically had concentrations of SRP in excess of 50 $\mu \mathrm{g}$ of phosphorus per liter. These sites typically had high algal biomass and growth rates compared with most upstream sites (Sect. 3.2).

Although discharges in the HFIRTRU area have been reduced since November 1986, high concentrations of SRP persist at MEK 0.6. Concentrations of SRP were on the order of $200 \mathrm{mg}$ of phosphorus per liter at MEK 0.6 during the summer of 1988 . These concentrations were lower than those found during the summer of 1987 (up to $1700 \mathrm{mg}$ of phosphorus per liter). The cause for elevated concentrations of phosphorus at that site remain unresolved; however, the high concentrations of SRP likely have a stimulatory influence on biotic activity at that site.

High concentrations of SRP were found at MEK 1.8 during July $(1030 \mu \mathrm{g} / \mathrm{L})$ and December $(70 \mu \mathrm{g} / \mathrm{L})$ in 1987. In 1988, MEK 1.8 was dry during much of July (Table 2.1), and the maximum SRP concentration was about $19 \mu \mathrm{g} / \mathrm{L}$ in December. When water was flowing at 
Table 28. Water quality parameters basisd on samples collected monthly at the ten periphyton monitoring sites

in White Oak Oreek watershed and in Ish Creek during 1988

$N=12$ for all sites except MEK $1.8(N=6)$, NTK $1.0(N=7)$

\begin{tabular}{|c|c|c|c|c|c|c|c|c|c|c|c|}
\hline & WCK 6.8 & WCK 3.9 & WCK 3.4 & WCK 2.9 & WCK 2.3 & MEK 1.8 & MEK 0.6 & NTK 1.0 & ISK & FCK 1.0 & FFK 1.1 \\
\hline \multicolumn{12}{|l|}{ pH } \\
\hline Mean & 7.92 & 8.01 & 7.95 & 7.98 & 7.99 & 7.84 & 8.00 & 7.91 & 7.94 & 8.00 & 7.68 \\
\hline SD & 0.20 & 0.14 & 0.15 & 0.12 & 0.15 & 0.12 & 0.14 & 0.13 & 0.11 & 0.25 & 0.24 \\
\hline Range & $7.55-8.24$ & $7.77-8.28$ & $7.68-8.19$ & $7.72-8.16$ & $7.75-8.17$ & $7.60-7.95$ & $7.82-8.25$ & $7.68-8.02$ & $7.68-8.08$ & $7.41-8.21$ & $7.22-8.14$ \\
\hline \multicolumn{12}{|c|}{ Altalinity (mog/L) } \\
\hline Mean & 2.42 & 2.33 & 2.24 & 2.26 & 2.28 & 2.15 & 2.44 & 3.66 & 2.40 & 2.70 & 2.47 \\
\hline SD & 0.57 & 0.19 & 0.15 & 0.17 & 0.16 & 0.32 & 0.37 & 0.93 & 0.75 & 0.50 & 0.35 \\
\hline Range & $1.44-3.18$ & $1.86-2.62$ & $1.89-2.54$ & $1.86-2.58$ & $1.88-2.48$ & $1.61-2.48$ & $1.78-3.00$ & $1.57-4.52$ & $1.30-3.97$ & $1.78-3.38$ & $1.72-296$ \\
\hline \multicolumn{12}{|c|}{ Hardnesx (mg/L a $\mathrm{CaCO}_{3}$ ) } \\
\hline Mean & 132 & 151 & 169 & 174 & 162 & 128 & 158 & 232 & 124 & 142 & 132 \\
\hline SD & 26 & 8.7 & 29 & 27 & 11 & 19 & 18 & 16 & 31 & 25 & 18 \\
\hline Range & $98-168$ & $128-162$ & $130-224$ & $140-230$ & $146-180$ & $102-156$ & $130-188$ & $216-246$ & $86-170$ & $108-170$ & $106-156$ \\
\hline \multicolumn{12}{|c|}{ Conductivity (uS/cm) } \\
\hline Mean & 234 & 313 & 392 & 411 & 376 & 270 & 327 & 442 & 222 & 249 & 239 \\
\hline$S D$ & 45 & 18 & 68 & 68 & 29 & 28 & 33 & 34 & 48 & 54 & 47 \\
\hline Range & $152-282$ & $260-344$ & $329-530$ & $332-541$ & $333-430$ & 223-305 & $248-373$ & $376-497$ & $149-280$ & $124-302$ & $120-283$ \\
\hline \multicolumn{12}{|c|}{ Total P (us PR) } \\
\hline Mean & 10 & 278 & 429 & 407 & 371 & 16 & 310 & 13 & 13 & 16 & 15 \\
\hline SD & 5 & 73 & 88 & 99 & 103 & 8 & 278 & 5 & 5 & 7 & 6 \\
\hline Range & $2-18$ & $155-375$ & $210-584$ & $108-595$ & $141-587$ & $7-29$ & $56-937$ & 4-22 & 4-18 & 6-29 & $6-27$ \\
\hline \multicolumn{12}{|c|}{ Total soluble P (ug PR) } \\
\hline Mean & 9 & 205 & 365 & 351 & 315 & 13 & 270 & 8 & 11 & 14 & 15 \\
\hline SD & 6 & 79 & 76 & 96 & 82 & 8 & 250 & 4 & 6 & 7 & 6 \\
\hline Range & $0-21$ & $38-343$ & $162-474$ & $134-524$ & $106-446$ & $0-22$ & $34-820$ & $0-14$ & $0-23$ & $0-24$ & $0-26$ \\
\hline
\end{tabular}


Table 28 (continued)

\begin{tabular}{|c|c|c|c|c|c|c|c|c|c|c|c|}
\hline & WCK 6.8 & WCK 3.9 & WCK 3.4 & WCK 2.9 & WCK 2.3 & MEK 1.8 & MEK 0.6 & NTK 1.0 & ISK & FCK 1.0 & FFK 1.1 \\
\hline \multicolumn{12}{|c|}{ Soluble ractive P (ug PR) } \\
\hline Mean & 6 & 51 & 238 & 232 & 229 & 7 & 144 & 7 & 6 & 8 & 11 \\
\hline SD & 5 & 24 & 64 & 57 & 74 & 6 & 91 & 4 & 4 & 3 & 4 \\
\hline Range & $1-16$ & $21-113$ & $174-348$ & $105-359$ & 92-409 & $1-19$ & $39-314$ & $0-13$ & $0-16$ & 3-13 & $2-16$ \\
\hline \multicolumn{12}{|c|}{$\mathrm{NO}_{2}+\mathrm{NO}_{3}(\mathrm{Mg} \mathrm{N} / \mathrm{L})$} \\
\hline Mean & 131 & 288 & 1400 & 1220 & 923 & 17 & 165 & 148 & 27 & 163 & 159 \\
\hline SD & 199 & 146 & 930 & 830 & 540 & 21 & 140 & 312 & 26 & 252 & 27 \\
\hline Range & $0-115$ & $30-265$ & $100-4010$ & $100-1640$ & $90-1600$ & $0-60$ & $10-420$ & $0-910$ & $\mathbf{0}$ & $0-720$ & $100-190$ \\
\hline \multicolumn{12}{|c|}{$\mathrm{NH}_{4}+($ (ng N/L) } \\
\hline Mean & 9 & 21 & 21 & 17 & 18 & 6 & 11 & 10 & 5 & 8 & 4 \\
\hline $\mathrm{SD}$ & 8 & 15 & 10 & 10 & 10 & 5 & 9 & 7 & 4 & 9 & 4 \\
\hline Range & $0-24$ & $0-44$ & $9-43$ & 4-35 & 3-31 & $1-16$ & 0-28 & $0-20$ & $0-12$ & $\mathbf{0 - 3 0}$ & $0-13$ \\
\hline \multicolumn{12}{|c|}{ Diseolved organic carbon (me Cll) } \\
\hline Mean & 1.6 & 2.8 & 2.5 & 2.4 & 2.5 & 2.3 & 2.9 & 2.4 & 2.2 & 1.2 & 0.9 \\
\hline SD & 0.5 & 0.9 & 0.6 & 0.5 & 0.5 & 1.0 & 0.8 & 0.8 & 1.0 & 0.3 & 0.2 \\
\hline Range & $1-2.6$ & $1.9-4.8$ & $1.8-3.6$ & $1.9-3.6$ & $2.0-3.3$ & $1.3-4.3$ & $1.9-4.2$ & $1.7-4.2$ & $1.1-4.5$ & $0.6-1.9$ & $0.6-1.2$ \\
\hline \multicolumn{12}{|c|}{ Direolvad inorganic carbon (mg Cll) } \\
\hline Mean & 30 & 29 & 28 & 28 & 29 & 26 & 30 & 46 & 27 & 32 & 30 \\
\hline SD & 7.1 & 3.2 & 3.0 & 3.4 & 2.3 & 4.9 & 5.1 & 6.1 & 7.8 & 6.6 & 4.8 \\
\hline Range & $20-38$ & 21-34 & $21-34$ & $22-36$ & $24-33$ & $19-33$ & 23-35 & $40-56$ & $17-37$ & 23-35 & 23-35 \\
\hline \multicolumn{12}{|c|}{ Total suppondad solids (mg dy wh) } \\
\hline Mean & 3.5 & 5.7 & 3.1 & 3.6 & 5.7 & 7.2 & 5.9 & 4.6 & 2.4 & 4.6 & 26 \\
\hline SD & 1.7 & 5.2 & 1.0 & 1.6 & 4.4 & 8.8 & 4.5 & 2.9 & 1.7 & 4.3 & 2.2 \\
\hline Range & $0.8-6.7$ & $1.0-20$ & $2.1-3.6$ & $2.2-6.4$ & $1.9-15$ & $1.6-26$ & $1.3-14$ & $1.9-11$ & $0.3-4.5$ & $1.7-18$ & $0.21-5.3$ \\
\hline
\end{tabular}

kilometer, FFK = Fifth Creek kilometer. 
MEK 1.8 (i.e., January through May), concentrations of SRP were similar between the 2 years.

Ammonia concentrations were low at all sites, averaging less than $25 \mathrm{mg}$ of nitrogen per liter (Table 2.8). Concentrations of $\mathrm{NO}_{2}^{-}+\mathrm{NO}_{3}^{-}$nitrogen were also low to moderate $(<0.3 \mu \mathrm{g} \mathrm{N} / \mathrm{L})$ at most sites. Nitrate was enriched below the STP (WCK 3.4) and remained elevated downstream (WCK 2.3). In general, data from 1988 were similar to those collected for the same period in 1987 (Loar et al. 1992a, Loar 1992b).

Quarterly sampling for dissolved constituents. Quarterly analyses of stream water for dissolved elements generally found only $\mathrm{Al}, \mathrm{Ba}, \mathrm{Be}, \mathrm{Ca}, \mathrm{Mg}, \mathrm{Mn}, \mathrm{Na}, \mathrm{Si}$, and $\mathrm{Sr}$ at concentrations above the ICP detection limits (Table 2.9). Concentrations of $\mathrm{Fe}, \mathrm{P}$, and $\mathrm{Zn}$ were occasionally above the detection limits for some sites. Because the detection limits of the ICP are relatively high in relation to biologically significant concentration of some elements (e.g., $\mathrm{Cd}, \mathrm{Cu}$, and $\mathrm{Ni}$ ), these data provide only a screening for excessive concentrations of potentially toxic elements and a general characterization of the concentrations of the major cations (excluding potassium) at each site. Trends in the general ionic composition of the water among and between reference and downstream sites are discussed in Loar (1993).

Data for most dissolved metals during 1988 were similar to data from 1987 (Table 2.9; Loar 1992b). Several metals were found in slightly higher concentrations at most sites during 1988 than in 1987 (e.g., $\mathrm{Ba}, \mathrm{Be}, \mathrm{Mg}$, and $\mathrm{Na}$ ). Concentrations of calcium seemed slightly higher at all downstream sites and MEK 1.8 during 1988 , and manganese was higher at WCK 3.4, WCK 2.9 and WCK 2.3 in 1988 than in 1987. For some metals (e.g., strontium) data were insufficient to compare between years.

For all of these metals, only limited comparisons are possible based on four quarterly grab samples. However, data collected during 1988 were generally similar to those obtained in 1987. The observed trend towards slightly higher concentrations of some metals may reflect drier conditions during 1988 than in 1987. For those elements detectable by ICP, no evidence was found of continuous excessive inputs of potentially toxic materials.

\subsubsection{Summary}

Water samples collected monthly in conjunction with the periphyton component of the instream monitoring program provide useful snapshots of water quality at ten locations in the WOC drainage and at the weir on nearby Ish Creek which augment the NPDES monitoring program. Data for the parameters reported here were similar to data collected during 1987. Although operations at the HFIR-TRU facility have been slowed down since November 1986, concentrations of SRP remain high at MEK 0.6 , and are likely stimulating biotic activity at that site.

\subsection{SUBSTRATE AND COVER M. G. Ryon and J. G. Smith}

\subsubsection{Introduction}

A component of the BMAP involved analysis of the fish and benthic invertebrate communities at selected study sites distributed throughout the WOC watershed. These sites were selected to evaluate point-source and area-source discharges, while attempting to minimize community differences resulting from 
Table 29. Concentrations of dissohed clements (epresed in milligrams per liter) at ten periphyton monitoring sites in White Ook Creek watershed and in Ish Creek

\begin{tabular}{|c|c|c|c|c|c|c|c|c|c|c|c|}
\hline & WCK 6.8 & WCK 3.9 & WCK 3.4 & WCK 2.9 & WCK 2.3 & MEK 1.8 & MEK 0.6 & NTK 1.0 & ISK & FCK 1.0 & FFK 1.1 \\
\hline \multicolumn{12}{|l|}{$\mathbf{A}$} \\
\hline Mean & 0.13 & 0.29 & 021 & 0.21 & 0.22 & & 0.25 & 0.27 & 0.21 & 0.19 & 0.18 \\
\hline SD & 0.079 & 0.04 & 0.08 & 0.07 & 0.08 & & 0.11 & 0.13 & 0.04 & 0.02 & 0.01 \\
\hline Range & & & & & & $0.074-0.3$ & & & & & \\
\hline \multicolumn{12}{|l|}{ Ba } \\
\hline Mean & 0.07 & 0.056 & 0.047 & 0.050 & 0.047 & & 0.058 & 0.052 & 0.084 & 0.061 & 0.074 \\
\hline SD & 0.03 & 0.006 & 0.004 & 0.004 & 0.005 & & 0.003 & 0.009 & 0.024 & 0.028 & 0.010 \\
\hline Range & & & & & & $0.05-0.055$ & & & & & \\
\hline \multicolumn{12}{|l|}{ Be } \\
\hline Mean & 0.0036 & 0.0015 & 0.0016 & 0.0016 & 0.0016 & & 0.0015 & 0.0013 & 0.0012 & 0.0013 & 0.0010 \\
\hline SD & 0.0034 & 0.0008 & 0.0007 & 0.0007 & 0.0008 & & 0.0007 & 0.0005 & 0.0007 & 0.0007 & 0.0005 \\
\hline Range & & & & & & $0.0005-0.0014$ & & & & & \\
\hline \multicolumn{12}{|l|}{ Ca } \\
\hline Mean & 28 & 47 & 51 & 52 & 51 & & 50 & 65 & 28 & 34 & 32 \\
\hline SD & 6.3 & 3.8 & 11 & 10 & 9 & & 5.3 & 42 & 6.6 & 5.6 & 3.9 \\
\hline Range & & & & & & $47-50$ & & & & & \\
\hline \multicolumn{12}{|l|}{ Co } \\
\hline $2 / 88$ & 0.012 & 7.019 & 0.017 & 0.018 & 0.015 & 0.013 & 0.015 & 0.015 & 0.014 & $<0.010$ & $<0.010$ \\
\hline $8 / 88$ & & & 0.011 & 0.014 & 0.013 & & & & & & \\
\hline \multicolumn{12}{|l|}{ Fe } \\
\hline Mean & 0.036 & 0.026 & 0.026 & 0.018 & 0.037 & & 0.061 & 0.049 & 0.048 & $<0.020$ & $<0.020$ \\
\hline SD & 0.006 & 0.006 & 0.003 & 0.004 & 0.012 & & 0.030 & 0.039 & 0.020 & & \\
\hline Range & & & & & & $0.039-0.073$ & & & & & \\
\hline
\end{tabular}


Table 29. (continued)

\begin{tabular}{|c|c|c|c|c|c|c|c|c|c|c|c|}
\hline & WCK 6.8 & wCK 3.9 & WCK 3.4 & WCK 2.9 & wCK 2.3 & MEK 1.8 & MEK 0.6 & NTK 1.0 & ISK & FCK 1.0 & FFK 1.1 \\
\hline \multicolumn{12}{|l|}{ Mg } \\
\hline Mean & 14 & 10 & 9.7 & 10 & 9.4 & & 7.9 & 5.9 & 12 & 14 & 14 \\
\hline SD & 5 & 0.5 & 0.3 & 0.6 & 0.3 & & 1.6 & 0.2 & 4.1 & 3.8 & 3.1 \\
\hline Range & & & & & & $4.3-5.8$ & & & & & \\
\hline SD & 0.005 & 0.001 & 0.004 & 0.009 & 0.012 & & 0.011 & 0.064 & 0.007 & 0.0017 & 0.0017 \\
\hline Range & & & & & & $0.008-0.026$ & & & & & \\
\hline $\begin{array}{l}\text { Mean } \\
\text { SD }\end{array}$ & $\begin{array}{l}0.52 \\
0.07\end{array}$ & 1.3 & 3.9 & 3.8 & 4.0 & & 1.9 & 0.7 & 0.31 & 0.18 & 0.45 \\
\hline Range & & & & & & $4.3-8.1$ & & & & & \\
\hline \multicolumn{12}{|l|}{ Si } \\
\hline Mean & 3.6 & 2.1 & 2.0 & 2.0 & 2.1 & & 2.8 & 3.0 & 3.4 & 3.6 & 3.4 \\
\hline SD & 0.3 & 0.6 & 0.6 & 0.6 & 0.6 & & 0.5 & 0.4 & 0.4 & 0.5 & 0.1 \\
\hline Range & & & & & & $2.8-3.5$ & & & & & \\
\hline \multicolumn{12}{|r|}{0.034} \\
\hline $2 / 88$ & 0.028 & 0.12 & 0.14 & 0.14 & 0.14 & 0.86 & 0.01 & 0.15 & 0.031 & 0.036 & 0.034 \\
\hline $11 / 88$ & 0.023 & 0.10 & 0.11 & 0.12 & 0.11 & & 0.08 & 0.12 & 0.024 & 0.027 & 0.033 \\
\hline \multicolumn{12}{|c|}{ ICP metals that were below detoction limits (mg/) } \\
\hline $\begin{array}{l}\mathrm{Ag} \\
<0.005\end{array}$ & $\begin{array}{l}\text { As } \\
<0.060\end{array}$ & $\begin{array}{l}\mathrm{B} \\
<0.080\end{array}$ & $\begin{array}{l}\mathrm{Be} \\
<0.00030\end{array}$ & $\begin{array}{l}\mathrm{Cd} \\
<0.0020\end{array}$ & $\begin{array}{l}\text { Co } \\
<0.0030\end{array}$ & $\begin{array}{l}\mathrm{Cr} \\
<0.0050\end{array}$ & $\begin{array}{l}\mathrm{Cu} \\
<0.010\end{array}$ & $\begin{array}{l}\mathrm{Ga} \\
<0.030\end{array}$ & $\begin{array}{l}\mathrm{Li} \\
<0.20\end{array}$ & $\begin{array}{l}\text { Mo } \\
<0.040\end{array}$ & $r$ \\
\hline $\begin{array}{l}\mathrm{Ni} \\
<0.0050\end{array}$ & $\begin{array}{l}\mathrm{Pb} \\
<0.050\end{array}$ & $\begin{array}{l}\mathrm{Sb} \\
<0.030\end{array}$ & $\begin{array}{l}\mathrm{Se} \\
<0.060\end{array}$ & $\begin{array}{l}\mathrm{Sn} \\
<0.050\end{array}$ & $\begin{array}{l}\mathrm{Ti} \\
<0.020\end{array}$ & $\begin{array}{l}\mathrm{Zn} \\
<0.0080\end{array}$ & $\begin{array}{l}\mathrm{Zr} \\
<0.020\end{array}$ & & & & \\
\hline
\end{tabular}

Note: WCK $=$ White Oak Creek kilometer, MEK = Melton Branch kilometer, NTK = Northwest Tributary kilometer, ISK = Ish Creek kilometer, FCK $=$ First Creek kilometer, FFK = Fifth Creek kilometer. Values are based on ICP analyses of discrete water samples collected quart

of concentrations is provided for MEK 1.8 because data were available for two dates only. $N=3$ for $N$ such or were assumed to be that concentration in the detection limits on two date

calculation of the mean. 
differences in habitat. An analysis of the assumption that habitat differences were minimal was initiated in the summer of 1988, focusing on current velocity, substrate, bank cover and canopy, and the pool:riffle ratio. These data describe the habitat conditions in WOC watershed during low-flow periods and will be followed by future surveys during other times of the year.

\subsubsection{Methods}

The analytical techniques used for the habitat survey were based on methods described in Platts et al. (1983). The surveys involved comprehensive estimates of several habitat characteristics and were conducted using a nonrandom transect system. Transect intervals ranged from 5 to $15 \mathrm{~m}$ (depending on length of site and substrate heterogeneity), and samples were taken at 3 to 5 positions on each transect. Some clustering of transects was added to the system to ensure that all habitat types were adequately covered. Such an approach to transect selection is acceptable when preexisting knowledge of site conditions is high (Platts et al. 1983).

Current velocity was recorded with a Marsh-McBirney Model 210D portable electronic water current meter; readings were taken at the bank, midside, and midstream positions on every transect. Depths and stream width were also recorded and used to calculate stream discharge. Measurements were taken between May 21 and June 1, 1988; no significant rainfall events (i.e., more than $2.5 \mathrm{~cm}$ in $48 \mathrm{~h}$ ) occurred during this period (NOAA 1988).

Substrate analysis was conducted from July 28 to August 2 and included a description of principal cover size, degree of embeddedness, and associated aquatic plants. The substrate was described within a 0.5 - to $1-\mathrm{m}$ zone of the stream bottom at the midside and/or midstream positions (depending on stream width) on the transect. A weighted rope painted at $10-\mathrm{cm}$ intervals with alternating colors provided zones for identifying the dominant substrate type (Bain et al. 1985). A rating system based on codes for certain rock/debris types and size (Table 2.10) was used to classify the dominant substrate type in each zone. The codes reflected a general trend toward increasing substrate coarseness and complexity with increasing number. By using the zones, five to ten codes were generated for each transect position. The mean and standard deviation (SD) of the codes provided information on coarseness and degree of uniformity of the substrate (Bain et al. 1985). A similar approach was used to grade the embeddedness or degree to which the dominant particles were covered by fine sediments in each zone (Table 2.11).

Aquatic plants were also identified, and the percentage of their cover for the entire transect was estimated visually.

The stream bank cover was described for each transect based on three zones: (1) vegetation overhanging the stream; (2) herbaceous cover on the bank slope; and (3) the general forest type within $10 \mathrm{~m}$ of the stream bank. This qualitative description is only briefly discussed in the following section. Also, a measure of the riparian canopy was made at the mid-point of each transect by obtaining a percentage reading from a convex mirror with a $10 \times$ $10 \mathrm{~cm}^{2}$ engraved grid. The canopy percentage represented the number of grids covered by the overhanging vegetation and was used as a comparative measure of available sunlight (modified from Platts et al. 1987).

\subsubsection{Results}

The primary purpose of the habitat characterization was to provide data that 
Table 2.10. Substrate codes used in the physical habitat analysis of White Oak Creek watershed NA $=$ Not applicable

\begin{tabular}{clc}
\hline Code & \multicolumn{1}{c}{ Substrate index } & $\begin{array}{c}\text { Particle size range } \\
(\mathrm{mm})\end{array}$ \\
\hline 1 & Bedrock, smooth & $\mathrm{NA}$ \\
2 & Clay & $<0.004$ \\
3 & Silt & $<0.004-0.062$ \\
4 & Sand/Fine sediment & $0.062-2.0$ \\
5 & Gravel & $2.0-64.0$ \\
6 & Cobble/Rubble & $64.0-250.0$ \\
7 & Small boulder & $250.0-610.0$ \\
8 & Large boulder & $610.0-2000.0$ \\
9 & Bedrock, rough & $>2000.0$ \\
10 & Plant detritus & $\mathrm{NA}$ \\
11 & Woody debris & $\mathrm{NA}$ \\
12 & Root wads & $\mathrm{NA}$ \\
13 & Trash, human origin & $\mathrm{NA}$ \\
\hline
\end{tabular}

${ }^{a}$ Although particle size is not applicable, smooth bedrock represents a flat surface and thus is placed at the smaller end of the particle size range.

Source: Adapted from M. B. Bain, J. T. Finn, and H. E. Booke, 1985, Quantifying Stream Substrate for Habitat Analysis Studies. N. Amer. J. Fish. Manag. 5:499-500; and W. S. Platts et al. 1983. Methods for Evaluating Stream, Riparian, and Biotic Conditions. General Technical Report INT-138. U.S. Forest Service, Intermountain Forest and Range Experimental Station, Ogden, Utah.

Table 2.11. Embeddedness rating for substrate material

\begin{tabular}{cl}
\hline Rating & \multicolumn{1}{c}{ Rating description } \\
\hline 5 & $\begin{array}{l}\text { Predoininant particles have }<5 \% \text { of their surface } \\
\text { covered by fine sediment } \\
4\end{array}$ \\
3 & $\begin{array}{l}\text { Predominant particles have } 5-25 \% \text { of their surface } \\
\text { covered by fine sediment } \\
\text { Predominant particles have } 25-50 \% \text { of their surface } \\
\text { covered by fine sediment }\end{array}$ \\
& $\begin{array}{l}\text { Predominant particles have } 50-75 \% \text { of their surface } \\
\text { covered by fine sediment } \\
\text { Predominant particles have }>75 \% \text { of their surface } \\
\text { covered by fine sediment }\end{array}$ \\
\hline
\end{tabular}

Source: W. S. Platts et al. 1983. Methods for Evaluating Stream, Riparian, and Biotic Conditions. General Technical Report INT-138. U.S. Forest Service, Intermountain Forest and Range Experimental Station, Ogden, Utah. 
could be used in the fish and benthic invertebrate community analysis; therefore, the study site descriptions are separated in that manner. Because most of the benthos sites are included within or adjacent to the fish sites, the following information represents the general site conditions. Any differences or conditions especially applicable to the benthos are discussed in Sect. 2.3.3.2.

\subsubsection{Fish study sites}

The locations of the 16 fish study sites in WOC watershed are shown in Fig. 2.2. The length, average depth, and average width of the sites were measured on each fish population sampling date, and the data are presented in Sect. 6.2.

The uppermost site on WOC (WCK 6.8 ) is a second-order stream with a watershed area of $2.2 \mathrm{~km}^{2}$. The site consisted of a reach that was $56 \mathrm{~m}$ long, $2.3 \mathrm{~m}$ wide, and $7 \mathrm{~cm}$ deep with a pool:riffle ratio of 1.68 (Table 2.12 ). The substrate is predominantly a mixture of gravel, cobble, rubble, and bedrock with an embeddedness of between 5 and $25 \%$. The high standard deviation of the mean substrate codes indicates a heterogenous mixture of smooth (bedrock) and rough (gravel) substrata. Abundant aquatic vegetation, including watercress (Nasturtium officinale) and peppermint (Mentha peperata), covered up to $60 \%$ of a transect. The mean current velocity was $0.03 \mathrm{~m} / \mathrm{s}$ and ranged from 0 to $0.34 \mathrm{~m} / \mathrm{s}$; mean depths ranged from 1.2 to $4.8 \mathrm{~cm}$ (Table 2.13). The surrounding cover was a disturbed, young-to-mature forest on one bank with greater disturbance, including a road cut, on the other. The forest included sycamore (Platanus occidentalis), walnut (Juglans nigra), pine (Pinus spp.), slippery elm (Ulmus rubra), oaks (Quercus spp.), tulip poplar (Liriodendron tulipifera), and red cedar (Juniperus virginiana). The bank cover consisted of honeysuckle (Lonicera japonica), Virginia creeper (Parthenocissus quinquefolia), poison ivy (Taxicodendron radicans), grape (Vitis sp.), phlox (Phlox $s p$.$) , cardinal flower (Lobelia cardinalis),$ and some grasses (Poa sp.). Overhanging vegetation included the larger tree cover, as well as the smaller dogwood (Cornus spp.), box elder (Acer negundo), winged sumac ( $R$ hus copallina), multiflora rose (Rosa multiflora), and redbud (Cercis canadensis). The resulting canopy covered $65 \%$ of the stream with most transects showing similar coverage (Table 2.12).

The next downstream site, WCK 5.1, was a shorter $(48 \mathrm{~m})$, narrower $(1.5 \mathrm{~m})$, and slightly deeper $(9.0 \mathrm{~cm})$ second-order reach with a lower pool to riffle ratio (0.88). Current velocities were very low (mean velocity was $0.01 \mathrm{~m} / \mathrm{s}$ with a range of 0 to $0.14 \mathrm{~m} / \mathrm{s}$ ), and the mean depth was $5.5 \mathrm{~cm}$. When velocity data were recorded, the site was severely affected by drought conditions; riffle areas were very shallow, and one large pool provided most of the depth measurements. The substrate consists of gravel, cobble, boulders, and root wads with a nigh standard deviation, indicating a heterogenous substrate. The embeddedness was moderate, ranging from 5 to $25 \%$. The surrounding cover consisted of a high rip-rap bank and open grassy field with scattered cedars. Canopy included black willow (Salix nigra), sycamore, ash (Fraxinus americana), dogwood, and red cedar, with a mean percent canopy of 53.8 and high variability. The bank cover was dominated by grasses, grape vines, touch-me-not (Impatiens capensis), and poison ivy. Aquatic vegetation was minimal but included willow roots and several large bulrush (Scirpus cyperinus). The vegetation in the area is influenced by periodic mowing.

WCK 3.9 is a long (170-m), secondorder section totally within the fenced boundaries of ORNL. It is wider $(3 \mathrm{~m})$ and deeper $(18 \mathrm{~cm})$ than the two upstream 
Table 2.12. Mean ( \pm 1 SD) ratings for substrate and embeddednces, mean canopy percentage, and pool to rifie $(\mathrm{p} / \mathrm{r})$ ratios for fish and benthos sampling sites on White Oak Creek, First Creek, Fifh Creek, Melton Branch, and Northwest Tribukary, July-August 1988 NA $=$ Not applicable

\begin{tabular}{|c|c|c|c|c|}
\hline Site/Type & Substrate & Embeddedness & $\begin{array}{c}\text { Canopy } \\
\text { percentage }\end{array}$ & P/R Ratio \\
\hline \multicolumn{5}{|l|}{ FCK 0.1} \\
\hline Fish & $4.97 \pm 0.82$ & $3.49 \pm 1.46$ & $6.5 \pm 26.4$ & 2.40 \\
\hline Benthos & $5.0^{\circ}$ & $3.40 \pm 0.84$ & 90.0 & \\
\hline \multicolumn{5}{|l|}{ FCK 0.8} \\
\hline Fish & $4.75 \pm 1.10$ & $3.75 \pm 1.66$ & $5.0 \pm 10.10$ & 1.19 \\
\hline Benthos & $5.60 \pm 0.52$ & $5.0^{\circ}$ & 25.0 & \\
\hline \multicolumn{5}{|l|}{ FFK 0.2} \\
\hline Fish & $5.58 \pm 3.29$ & $3.27 \pm 1.29$ & $44.6 \pm 22.4$ & 0.86 \\
\hline Benthos & $5.40 \pm 2.51$ & $5.0^{\circ}$ & 30.0 & \\
\hline \multicolumn{5}{|l|}{ FFK 0.4} \\
\hline Fish & $5.42 \pm 0.92$ & $4.69 \pm 0.66$ & $19.0 \pm 34.6$ & 0.50 \\
\hline \multicolumn{5}{|l|}{ FFK 1.0} \\
\hline Fish & $5.56 \pm 1.42$ & $3.80 \pm 1.71$ & $77.8 \pm 19.1$ & 0.88 \\
\hline Benthos & $5.40 \pm 0.52$ & $5.0^{\circ}$ & 83.0 & \\
\hline \multicolumn{5}{|l|}{ MEK 0.6} \\
\hline Fish & $6.20 \pm 2.10$ & $1.99 \pm 1.41$ & $77.7 \pm 6.2$ & 5.11 \\
\hline Benthos & $5.43 \pm 0.50$ & $2.75 \pm 1.52$ & $71.5 \pm 7.7$ & \\
\hline \multicolumn{5}{|l|}{ MEK 1.2} \\
\hline Benthos & $5.0^{\circ}$ & $2.70 \pm 0.82$ & 90.0 & NA \\
\hline \multicolumn{5}{|l|}{ MEK 1.4} \\
\hline Fish & $4.98 \pm 3.32$ & $2.10 \pm 1.45$ & $82.0 \pm 11.8$ & 2.05 \\
\hline \multicolumn{5}{|l|}{ NTK 0.2} \\
\hline Benthos & $5.55 \pm 0.51$ & $5.0^{\circ}$ & 70.0 & NA \\
\hline \multicolumn{5}{|l|}{ NTK 0.3} \\
\hline Fish & $5.46 \pm 1.48$ & $4.64 \pm 0.85$ & $79.9 \pm 11.2$ & 0.51 \\
\hline
\end{tabular}


Table 2.12 (continued)

\begin{tabular}{|c|c|c|c|c|}
\hline Site/Type & Substrate & Embeddedness & $\begin{array}{c}\text { Canopy } \\
\text { percentage }\end{array}$ & P/R Ratio \\
\hline \multicolumn{5}{|l|}{ NTR 1.0} \\
\hline Fish & $6.03 \pm 1.81$ & $3.45 \pm 1.79$ & $76.8 \pm 15.9$ & 2.64 \\
\hline Benthos & $5.83 \pm 0.41$ & $4.00 \pm 0.63$ & 65.0 & \\
\hline \multicolumn{5}{|l|}{ WCx 23} \\
\hline Fish & $5.03 \pm 1.40$ & $2.66 \pm 1.60$ & $88.1 \pm 6.0$ & 4.87 \\
\hline Benthos & $5.0^{\circ}$ & $4.13 \pm 0.63$ & 94.0 & \\
\hline \multicolumn{5}{|l|}{ WCK 29} \\
\hline Fish & $5.42 \pm 2.46$ & $2.02 \pm 1.59$ & $87.2 \pm 4.3$ & 4.87 \\
\hline Benthos & $5.05 \pm 0.22$ & $5.0^{\circ}$ & 85.0 & \\
\hline \multicolumn{5}{|l|}{ wCK 3.4} \\
\hline Fish & $5.44 \pm 2.18$ & $3.78 \pm 1.57$ & $65.8 \pm 17.8$ & 1.55 \\
\hline Benthos & $5.53 \pm 0.89$ & $4.83 \pm 0.38$ & $79.5 \pm 5.6$ & \\
\hline \multicolumn{5}{|l|}{ WCX 3.9} \\
\hline Fish & $4.89 \pm 1.89$ & $4.51 \pm 0.90$ & $\sigma$ & 1.94 \\
\hline Benthos & 5.0 & $4.60 \pm 0.51$ & $\mathbf{0}$ & \\
\hline \multicolumn{5}{|l|}{ WCK 5.1} \\
\hline Fish & $7.07 \pm 2.54$ & $4.42 \pm 0.99$ & $53.8 \pm 29.3$ & 0.88 \\
\hline Benthos & $6.20 \pm 0.63$ & $4.80 \pm 0.42$ & 80.0 & \\
\hline \multicolumn{5}{|l|}{ WCK 6.8} \\
\hline Fish & $4.14 \pm 2.31$ & $4.47 \pm 1.30$ & $65.7 \pm 12.1$ & 1.68 \\
\hline Benthos & $5.93 \pm 0.25$ & $4.93 \pm 0.37$ & $66.0 \pm 4.1$ & \\
\hline
\end{tabular}


Table 2.13. Mean, standard deviation (SD), minimum, and maximum current velocities and mean depth for each transect and for the entire reach/site (all transects) at the fish and benthos sampling stations on White Oak Creek, First Creek, Finth Creek, Melton Branch, and Northwest Tributary in May-June 1988

\begin{tabular}{|c|c|c|c|c|c|}
\hline $\begin{array}{c}\text { Site/ } \\
\text { Transecte }\end{array}$ & $\begin{array}{l}\text { Mean velocily } \\
(\mathrm{m} / \mathrm{s})\end{array}$ & $\begin{array}{l}\text { SD } \\
(\mathrm{m} / \mathrm{s})\end{array}$ & $\begin{array}{l}\text { Minimum } \\
\text { velocity } \\
\text { (m/s) }\end{array}$ & $\begin{array}{l}\text { Maximum } \\
\text { velocity } \\
(\mathrm{m} / \mathrm{s})\end{array}$ & $\begin{array}{l}\text { Mean depth } \\
(\mathrm{cm})\end{array}$ \\
\hline \multicolumn{6}{|l|}{ FCK 0.1} \\
\hline SR & 0.15 & 0.13 & 0.01 & 0.30 & 11.2 \\
\hline T1 & 0.04 & 0.04 & 0 & 0.10 & 6.8 \\
\hline T2 & 0.08 & 0.10 & 0 & 0.25 & 12.4 \\
\hline T3 & 0.10 & 0.12 & 0 & 0.28 & 4.4 \\
\hline$T 4$ & 0.08 & 0.15 & $\mathbf{0}$ & 0.35 & 8.4 \\
\hline T6 & 0.199 & 0.07 & 0 & 0.18 & 11.4 \\
\hline$T 7$ & 0.08 & 0.14 & 0 & 0.33 & 5.4 \\
\hline All transects & 0.09 & 0.11 & 0 & 0.35 & 8.6 \\
\hline \multicolumn{6}{|l|}{ FCK 0.8} \\
\hline SR & 0.04 & 0.05 & 0 & 0.12 & 4.4 \\
\hline $\mathrm{T} 1$ & 0.02 & 0.01 & 0 & 0.03 & 14.8 \\
\hline $\mathrm{T} 2$ & 0.16 & 0.30 & 0 & 0.71 & 5.0 \\
\hline T3 & 0.01 & 0.01 & 0 & 0.02 & 15.4 \\
\hline T4 & 0.06 & 0.11 & 0 & 0.25 & 4.4 \\
\hline All transects & 0.06 & 0.15 & 0 & 0.71 & 8.8 \\
\hline \multicolumn{6}{|l|}{ FFK 0.2} \\
\hline SR & 0.13 & 0.13 & 0 & 0.39 & 9.9 \\
\hline $\mathrm{T} 1$ & 0.12 & 0.08 & 0.03 & 0.18 & 12.8 \\
\hline $\mathrm{T} 2$ & 0.13 & 0.10 & 0 & 0.23 & 6.4 \\
\hline T3 & 0.06 & 0.10 & 0 & 0.23 & 11.8 \\
\hline$T 4$ & 0.08 & 0.07 & 0 & 0.16 & 7.4 \\
\hline T5 & 0.07 & 0.09 & 0 & 0.20 & 9.2 \\
\hline$T 8$ & 0.01 & 0.02 & -0.01 & 0.04 & 23.0 \\
\hline All transects & 0.09 & 0.10 & -0.01 & 0.39 & 11.3 \\
\hline \multicolumn{6}{|l|}{ FFK 0.4} \\
\hline $\mathrm{T} 1$ & 0.01 & 0.02 & 0 & 0.03 & 3.6 \\
\hline $\mathrm{T} 2$ & 0.01 & 0.01 & 0 & 0.03 & 14.8 \\
\hline T3 & 0.05 & 0.04 & 0 & 0.10 & 4.8 \\
\hline T4 & 0.02 & 0.02 & 0 & 0.05 & 9.0 \\
\hline T5 & 0.02 & 0.02 & 0 & 0.05 & 5.4 \\
\hline T6 & 0.01 & 0.02 & -0.01 & 0.63 & 31.2 \\
\hline All transects & 0.02 & 0.02 & -0.01 & 0.10 & 11.4 \\
\hline \multicolumn{6}{|l|}{ FFK 1.0} \\
\hline SR & 0.05 & 0.10 & 0 & 0.23 & 2.2 \\
\hline T2 & $<0.01$ & $<0.01$ & 0 & 0.01 & 3.0 \\
\hline$T 3$ & 0.05 & 0.06 & 0 & 0.13 & 3.4 \\
\hline$T 4$ & 0.04 & 0.01 & 0.02 & 0.05 & 14.4 \\
\hline
\end{tabular}


Tuble 2.13. (continued)

\begin{tabular}{|c|c|c|c|c|c|}
\hline $\begin{array}{c}\text { Site/ } \\
\text { Transect }\end{array}$ & $\begin{array}{l}\text { Mean velocity } \\
(\mathrm{m} / \mathrm{s})\end{array}$ & $\underset{(m / s)}{S D}$ & $\begin{array}{l}\text { Minimum } \\
\text { velocity" } \\
\text { (m/s) }\end{array}$ & $\begin{array}{l}\text { Maximum } \\
\text { velocity } \\
\text { (m/s) }\end{array}$ & $\begin{array}{l}\text { Mean depth } \\
(\mathrm{cm})\end{array}$ \\
\hline $\begin{array}{l}\text { T5 } \\
\text { T6 }\end{array}$ & $\begin{array}{l}0.07 \\
0.03\end{array}$ & $\begin{array}{l}0.09 \\
0.03\end{array}$ & $\begin{array}{l}0 \\
0\end{array}$ & $\begin{array}{l}0.2 \\
0.08\end{array}$ & $\begin{array}{l}22.0 \\
6.0\end{array}$ \\
\hline All transects & 0.04 & 0.06 & 0 & 0.23 & 5.2 \\
\hline \multicolumn{6}{|l|}{ MEK 0.6} \\
\hline $\mathbf{S R}$ & 0.05 & 0.09 & 0 & 0.27 & 4.2 \\
\hline T1 & 0.11 & 0.08 & 0 & 0.22 & 3.2 \\
\hline $\mathbf{T} 2$ & $<0.01$ & $<0.01$ & 0 & 0.01 & 20.0 \\
\hline T3 & 0 & 0 & 0 & 0 & 14.8 \\
\hline$T 4$ & $<0.01$ & $<0.01$ & 0 & 0.01 & 12.2 \\
\hline All transects & 0.03 & 0.07 & 0 & 0.27 & 9.8 \\
\hline \multicolumn{6}{|l|}{ MEK 1.2} \\
\hline $\begin{array}{l}\text { SR } \\
\text { MEK } 1.4\end{array}$ & 0.10 & 0.11 & 0 & 0.25 & 2.6 \\
\hline $\mathbf{T}$ & 0.06 & 0.08 & 0 & 0.17 & 2.0 \\
\hline T3 & 0 & 0 & $\mathbf{0}$ & 0 & 18.4 \\
\hline T4 & 0.01 & 0.01 & 0 & 0.03 & 7.6 \\
\hline T5 & 0.02 & 0.03 & 0 & 0.07 & 8.0 \\
\hline T6 & 0.12 & 0.16 & 0 & 0.3 & 22.4 \\
\hline $\mathrm{T} 7$ & 0.01 & 0.01 & 0 & 0.02 & 5.0 \\
\hline T8 & 0.01 & 0.02 & 0 & 0.04 & 5.4 \\
\hline All transects & 0.03 & 0.07 & 0 & 0.32 & 6.8 \\
\hline \multicolumn{6}{|l|}{ NIK 0.3} \\
\hline SR & 0.06 & 0.08 & 0 & 0.16 & 2.6 \\
\hline T1 & 0.22 & 0.21 & 0 & 0.50 & 3.0 \\
\hline $\mathbf{T} 2$ & 0.04 & 0.05 & 0 & 0.11 & 4.2 \\
\hline T4 & 0.05 & 0.07 & 0 & 0.18 & 3.4 \\
\hline T5 & 0.06 & 0.11 & 0 & 0.25 & 4.6 \\
\hline T6 & 0.03 & 0.04 & o & 0.09 & 5.8 \\
\hline$T 7$ & 0.03 & 0.06 & 0 & 0.14 & 3.4 \\
\hline All transects & 0.07 & 0.11 & 0 & 0.50 & 3.9 \\
\hline \multicolumn{6}{|l|}{ NTK 1.0} \\
\hline SR & $\mathrm{DS}^{c}$ & DS & DS & DS & DS \\
\hline $\mathrm{T} 1$ & 0.01 & 0.01 & 0 & 0.03 & 1.8 \\
\hline T2 & 0 & 0 & 0 & 0 & 3.2 \\
\hline $\mathbf{T 3}$ & 0 & 0 & 0 & $\mathbf{0}$ & 6.8 \\
\hline $\mathrm{T} 4$ & 0 & 0 & 0 & 0 & 5.6 \\
\hline T5 & 0 & 0 & 0 & 0 & 12.2 \\
\hline All transects & $<0.01$ & 0.01 & 0 & 0.03 & 4.2 \\
\hline \multicolumn{6}{|l|}{ WCK 23} \\
\hline SR & 0.11 & 0.10 & 0 & 0.19 & 9.6 \\
\hline
\end{tabular}


Table 213. (continued)

\begin{tabular}{|c|c|c|c|c|c|}
\hline $\begin{array}{c}\text { Site/ } \\
\text { Transecte }\end{array}$ & $\begin{array}{l}\text { Mean velocity } \\
(\mathrm{m} / \mathrm{s})\end{array}$ & $\begin{array}{l}\text { SD } \\
(\mathrm{m} / \mathrm{s})\end{array}$ & $\begin{array}{l}\text { Minimum } \\
\text { velocity" } \\
(\mathrm{m} / \mathrm{s})\end{array}$ & $\begin{array}{l}\text { Maximum } \\
\text { velocity } \\
(\mathrm{m} / \mathrm{s})\end{array}$ & $\begin{array}{l}\text { Mean depth } \\
(\mathrm{cm})\end{array}$ \\
\hline$T 1$ & 0.06 & 0.06 & 0 & 0.14 & 23.6 \\
\hline$T 2$ & 0.09 & 0.15 & 0 & 0.35 & 23.2 \\
\hline T3 & 0.14 & 0.13 & 0 & 0.25 & 19.4 \\
\hline$T_{4}$ & 0.06 & 0.06 & 0 & 0.11 & 25.0 \\
\hline T5 & 0.05 & 0.05 & 0 & 0.09 & 26.6 \\
\hline T6 & 0.04 & 0.05 & 0 & 0.10 & 42.6 \\
\hline $\mathrm{T} 7$ & 0.04 & 0.06 & 0 & 0.12 & 28.0 \\
\hline T8 & 0.05 & 0.05 & 0 & 0.12 & 24.8 \\
\hline T9 & 0.09 & 0.06 & 0 & 0.15 & 13.8 \\
\hline All transects & 0.07 & 0.08 & 0 & 0.35 & 23.7 \\
\hline \multicolumn{6}{|l|}{ WCK 29} \\
\hline SR & 0.34 & 0.31 & 0 & 0.5 & 96.4 \\
\hline $\mathrm{T} 1$ & 0.03 & 0.03 & 0 & 0.07 & 55.6 \\
\hline $\mathrm{T} 2$ & 0.08 & 0.06 & 0 & 0.14 & 17.6 \\
\hline T3 & 0.04 & 0.03 & 0 & 0.09 & 67.2 \\
\hline$T 4$ & 0.04 & 0.04 & 0 & 0.10 & 34.6 \\
\hline T5 & 0.06 & 0.09 & -0.02 & 0.16 & 28.0 \\
\hline T6 & 0.05 & 0.05 & 0 & 0.10 & 42.0 \\
\hline$T 7$ & 0.13 & 0.07 & -0.03 & 0.15 & 26.8 \\
\hline$T 8$ & 0.07 & 0.16 & -0.01 & 0.36 & 16.8 \\
\hline T9 & 0.11 & 0.09 & 0 & 0.20 & 23.2 \\
\hline All transects & 0.08 & 0.14 & -0.03 & 0.59 & 31.8 \\
\hline \multicolumn{6}{|l|}{ WCK 3.4} \\
\hline SR & 0.30 & 0.28 & $\mathbf{0}$ & 0.63 & 9.6 \\
\hline $\mathrm{T} 1$ & 0.14 & 0.15 & 0 & 0.37 & 14.2 \\
\hline $\mathrm{T} 2$ & 0.34 & 0.37 & 0 & 0.78 & 19.6 \\
\hline $\mathbf{T}$ & 0.17 & 0.06 & 0.10 & 0.22 & 48.8 \\
\hline T4 & 0.13 & 0.10 & 0 & 0.24 & 36.8 \\
\hline T5 & 0.12 & 0.12 & -0.02 & 0.26 & 47.2 \\
\hline T6 & 0.36 & 0.34 & 0 & 0.92 & 17.4 \\
\hline$T 7$ & 0.05 & 0.10 & -0.08 & 0.18 & 17.6 \\
\hline All transects & 0.20 & 0.23 & -0.08 & 0.92 & 26.4 \\
\hline \multicolumn{6}{|l|}{ WCX 3.9} \\
\hline SR & 0.11 & 0.13 & 0 & 0.30 & 12.2 \\
\hline$T 2$ & 0.27 & 0.34 & 0 & 0.87 & 8.6 \\
\hline T3 & 0.07 & 0.07 & 0 & 0.15 & 18.6 \\
\hline T4 & 0.06 & 0.06 & 0 & 0.15 & 19.8 \\
\hline T5 & 0.13 & 0.13 & 0 & 0.27 & 12.0 \\
\hline T6 & 0.12 & 0.08 & 0 & 0.20 & 17.6 \\
\hline $\mathrm{T} 7$ & 0.15 & 0.19 & 0 & 0.48 & 10.8 \\
\hline $\mathbf{T 8}$ & 0.14 & 0.15 & 0 & 0.32 & 9.8 \\
\hline
\end{tabular}


Table 2.13. (continued)

\begin{tabular}{lccccc}
\hline $\begin{array}{c}\text { Site/ } \\
\text { Transect }\end{array}$ & $\begin{array}{c}\text { Mean velocity } \\
(\mathrm{m} / \mathrm{s})\end{array}$ & $\begin{array}{c}\text { SD } \\
(\mathrm{m} / \mathrm{s})\end{array}$ & $\begin{array}{c}\text { Minimum } \\
\text { velocity } \\
(\mathrm{m} / \mathrm{s})\end{array}$ & $\begin{array}{c}\text { Maximum } \\
\text { velocity } \\
(\mathrm{m} / \mathrm{s})\end{array}$ & $\begin{array}{c}\text { Mean depth } \\
(\mathrm{cm})\end{array}$ \\
\hline T9 & 0.18 & 0.17 & 0 & 0.35 & 11.8 \\
T10 & 0.33 & 0.30 & 0 & 0.60 & 9.4 \\
T11 & 0.07 & 0.07 & 0 & 0.16 & 15.6 \\
All transects & 0.15 & 0.18 & 0 & 0.87 & 13.3 \\
WCK 5.1 & & & & & \\
SR & & & & & \\
T1 & 0.01 & 0.02 & 0 & 0.06 & 1.5 \\
T2 & 0.01 & 0.02 & 0 & 0.04 & 4.4 \\
T3 & 0.01 & 0.01 & 0 & 0.02 & 8.8 \\
T4 & 0.01 & 0.02 & 0 & 0.04 & 13.4 \\
All transects & 0.04 & 0.06 & 0 & 0.14 & 3.2 \\
& 0.01 & 0.03 & 0 & 0.14 & 5.5 \\
WCK 6.8 & & & & & \\
SR & & & & & \\
T1 & 0.03 & 0.04 & 0 & 0.09 & 2.6 \\
T2 & 0.09 & 0.15 & 0 & 0.34 & 1.2 \\
T3 & 0.01 & 0.01 & 0 & 0.02 & 3.2 \\
T4 & 0.01 & 0.01 & 0 & 0.03 & 4.8 \\
T5 & 0.01 & 0.02 & 0 & 0.03 & 2.4 \\
All transects & 0.02 & 0.03 & 0 & 0.05 & 2.4 \\
\hline SR & 0.03 & 0.06 & 0 & 0.34 & 2.7 \\
\hline
\end{tabular}

SR = benthic invertebrate sampling sites.

Negative values indicate upstream flow typical of eddy movements in pools.

DS = transect was dry during sampling.

Note: FCK $=$ First Creek kilometer; FFK $=$ Fifth Creek kilometer; MEK $=$ Melton Branch kilometer; NTK = Northwest Tributary kilometer; $\mathbf{W C K}=$ White Oak Creek kilometer.

WOC sites and has a pool:riffle ratio of 1.94. A large pool occurred at the top of this site below a discharge monitoring flume. The substrate is a heterogenous mixture of sand/fine sediment, gravel, and smooth and rough bedrock. Embeddedness is low (between 5 and 25\%) with low variability. Aquatic vegetation was limited to green algae and some watercress at 1 to $25 \%$ coverage. Velocities ranged from 0 to $0.87 \mathrm{~m} / \mathrm{s}$; the mean velocity and depth were $0.15 \mathrm{~m} / \mathrm{s}$ and $13.3 \mathrm{~cm}$, respectively. The surrounding vegetation was highly disturbed; there are no large trees and only a few shrubs and small willows. The banks are steep with mowed grasses (Poa sp.,
Festuca pratensis, and Leersia oryzoides), curly dock (Rumex crispus), and touch-menot. No overhanging vegetation was available to provide cover (the mean canopy was $0 \%$ ).

The next mainstream site, WCK 3.4 , is located downstream of a small weir impoundment, has steep clay-rock banks, and is a third-order reach that is $60 \mathrm{~m}$ in length and $3 \mathrm{~m}$ wide. The site is dominated by a deep pool at the upper end of the reach with a narrow swift run area leading into a series of small pools. It is deeper than upstream sites (mean depth of $30 \mathrm{~cm}$ ) and has a pool to riffle ratio of 1.55 . The substrate is highly variable with gravel, 
cobble, rough bedrock, and clay dominating (Table 2.12). Embeddedness is moderate (5 to $50 \%$ ) and highly variable. The mean current velocity was $0.20 \mathrm{~m} / \mathrm{s}$ and ranged from -0.08 to $0.92 \mathrm{~m} / \mathrm{s}$ (negative values represent back flow in eddies). The mean depth was $26.4 \mathrm{~cm}$. The surrounding area consists of a sparsely vegetated, gravel bank and a steep bedrock slope with trees growing at the top. The mostly young trees include blue beech (Carpinus caroliniana), white oak (Quercus alba), ash, box elder, sycamore, and willow. The bank vegetation, which was very sparse with areas devoid of cover, was dominated by honeysuckle; although grasses, such as clearweed (Pilea pumila), false nettle (Boehmeria cylindrica), and blackberry (Rubus allegheniensis) were also present. The overhanging vegetation provided a canopy of $65.8 \%$.

WCK 2.9 is an $85-\mathrm{m}$, third-order reach of WOC that is deeper $(38 \mathrm{~cm})$ and wider $(5 \mathrm{~m})$ than the upstream sites and is dominated by pools (pool:riffle ratio of 4.87). Mean velocity was $0.08 \mathrm{~m} / \mathrm{s}$ and ranged from -0.03 to $0.59 \mathrm{~m} / \mathrm{s}$. The mean depth was $31.8 \mathrm{~cm}$. The substrate is a heterogenous mixture dominated by gravel with considerable sand and/or fine sediments, clay, and root wads (Table 2.12). The embeddedness of almost $75 \%$ reflects the large pools with depositional areas for silt. Surrounding vegetation was a young forest (secondary growth) with red mulberry (Morus rubra), slippery elm, sycamore, redbud, ash, and walnut. The bank vegetation included honeysuckle, poison ivy, clearweed, smartweed (Polygonum sp.), white avens (Geum canadense), and short grasses. Overhanging vegetation was thick (canopy of $87.2 \%$ ) and consisted of spicebush (Lindera benzoin) and hackbery (Celtis sp.) in addition to secondary forest species.

Site WCK 2.3 is the most downstream site on WOC. Although it is a fourth-order stream and is somewhat shallower than WCK $2.9(30 \mathrm{~cm})$, it is very similar to
WCK 2.9 in terms of reach length and width, and pool to riffle ratio (Table 2.12; Sect. 6.2). The mean velocity was $0.07 \mathrm{~m} / \mathrm{s}$ and ranged from 0 to $0.35 \mathrm{~m} / \mathrm{s}$; the mean depth was $23.7 \mathrm{~cm}$. The substrate is a uniform mixture of gravel with some sand/fine sediment, clay and woody debris. The embeddedness is between 25 and $75 \%$, again demonstrating the amount of pool depositional area. The surrounding vegetation was characterized by a young, lowland woods with some disturbed areas. Overhanging trees included box elder, sycamore, ash, and spicebush; and the bank vegetation included clearweed, smartweed, honeysuckle, poison ivy, false nettle, and grasses. This site had the highest canopy cover in the survey $(88.1 \%)$.

In addition to the sites on mainstem WOC, fish and benthos sampling sites are also located on four tributaries of WOC (Fig. 2.2). Fifth Creek is a first-order stream with a watershed area of $1.0 \mathrm{~km}^{2}$; it enters WOC above site WCK 3.9. Another first-order stream, First Creek, has a watershed area of $0.9 \mathrm{~km}^{2}$ and joins another tributary, Northwest Tributary, before entering WOC above site WCK 3.4. Northwest Tributary has a watershed area of $2.0 \mathrm{~km}^{2}$, and the two sampling sites are both located on a second-order section of the stream. Melton Branch is the largest tributary (watershed area $4.2 \mathrm{~km}^{2}$ ) and enters WOC at WCK 2.49. One sampling site is located in the upper, second-order section and two sites are located downstream in a third-order section.

The uppermost site on Fifth Creek, FFK 1.0, is a short $(27-\mathrm{m})$, narrow $(1.0-\mathrm{m})$, shallow $(8.5-\mathrm{cm})$ site with a pool:riffle ratio of 0.88 . The substrate is a coarse mixture of gravel, cobble/rubble, and plant detritus with a moderate degree of embeddedness (Table 2.12). Velocities ranged from 0 to $0.23 \mathrm{~m} / \mathrm{s}$ with a mean of $0.04 \mathrm{~m} / \mathrm{s}$ and a mean depth of $5.2 \mathrm{~cm}$. Surrounding vegetation reflected an upland forest on one bank and a mowed field with a strip of 
young trees and shrubs on the other bank. Typical overhanging cover included slippery elm, tulip poplar, walnut, spicebush, and redbud with a canopy of $77.8 \%$. Bank cover reflected the meadow influences, consisting of grasses, fescue, honeysuckle, poison ivy, and Virginia creeper.

The two lower sites on Fifth Creek, FFK 0.4 and FFK 0.2, are within the ORNL boundary and, as such, have a very disturbed vegetative cover. Both sites are adjacent to mowed areas and weedy plants, such as pokeweed (Phytolacca americana), fescue, and touch-me-not. A few large willows, mimosa (Albizia julibrissin), and small shrubs [e.g., smooth sumac (Rhus glabra) and multiflora rose] provide the only overhanging vegetation. The canopy is $19.0 \%$ at FFK 0.4 and $44.6 \%$ at FFK 0.2 . Watercress occurs at both sites, but is more abundant at FFK 0.4. That site has other emergent vegetation, including water horehound (Lycopus rubellus) and path rush (Juncus tenuis). FFK 0.4 is a short reach $(26 \mathrm{~m})$ with a large pool at the upper end immediately below a culvert (which acts as an effective barrier) and a long reach of riffle (pool to riffle ratio of 0.5 ). The principal substrate is a relatively homogeneous mixture of gravel, rubble, and cobble with only 5-25\% embeddedness. The mean current velocity was $0.02 \mathrm{~m} / \mathrm{s}$ and the mean depth was 11.4 cm. FFK 0.2 is structurally similar to FFK 0.4 but has a pool to riffle ratio of 0.86 . The substrate is an extremely heterogeneous mixture of gravel, bedrock, root wads, and small boulders with a moderate amount of embeddedness. The mean current velocity was $0.09 \mathrm{~m} / \mathrm{s}$ and the mean depth was $11.3 \mathrm{~cm}$.

First Creek is another tributary adjacent to large mowed fields. The upper site (FCK 0.8 ) is bordered by grasses, primarily fescue, with one large post oak (Quercus stellata) near the stream; the mean canopy cover is only $5.0 \%$ Aquatic vegetation includes Elodea (Elodea $s p$.), watercress, and peppermint covering 5 to 95\% of the stream. The site is $30 \mathrm{~m}$ long, $1.5 \mathrm{~m}$ wide, and in May-June had a mean velocity of $0.06 \mathrm{~m} / \mathrm{s}$ and a mean depth of $8.8 \mathrm{~cm}$. The substrate is a homogeneous mixture of gravel and fine sediment/sand with an embeddedness of 5 to $50 \%$. The lower site, FCK 0.1, is surrounded by mowed fields with a strip of pole-sized trees and small shrubs adjacent to the banks. Slippery elm, walnut, dogwood, willow, and multiflora rose are the primary canopy vegetation and provide a canopy cover of $65 \%$. Bank vegetation includes touch-me-not, wild rye (Elymus vinginicus), poison ivy, fescue, bulrush, horse-nettle (Solanum carolinense), and clearweed. Aquatic vegetation was limited to algae at 25 to $90 \%$ of each transect. The substrate is similar to FCK 0.8, consisting of a homogeneous mixture of gravel and fine sediments with a moderate degree of embeddedness. The mean velocity was 0.09 $\mathrm{m} / \mathrm{s}$ and the mean depth was $8.6 \mathrm{~cm}$.

Northwest Tributary is located along the base of a wooded ridge (Haw Ridge) with mowed fields, experimental ponds, and parking lots bordering the opposite bank. Canopy vegetation includes sycamore, blue beech, tulip poplar, white oak, and dogwood. Bank cover is less abundant on the forested ridge. Typical cover included false nettle, bedstraw (Galium sp.), cutgrass (Leersia oryzoides), poison ivy, monkey flower (Mimulus alatus), clearweed, and panic grass (Panicum sp.). Canopy values for the upper and lower sampling sites were similar (76.8 and $79.9 \%$ respectively). The lower site, NTK 0.3 , is long $(66 \mathrm{~m})$, wide $(2.7 \mathrm{~m})$, and shallow $(6.5 \mathrm{~cm})$. The substrate is a mixture of gravel, cobble, and rubble with a embeddedness of between 5 and $25 \%$. The mean current velocity was $0.07 \mathrm{~m} / \mathrm{s}$ and the mean depth was $3.9 \mathrm{~cm}$. At the upper site, NTK 1.0, length, width, and depth values were slightly below those of NTK 0.3 . 
Also, the substrate at NTK 1.0 has more cobble and rubble and a higher degree of embeddedness (5 to 50\%) than the substrate at NTK 0.3. Stream flow in May-June was minimal, with a mean velocity of $<0.01 \mathrm{~m} / \mathrm{s}$.

The three sites on Melton Branch are all about $50 \mathrm{~m}$ in length and become progressively narrower (from 3.0 to $1.5 \mathrm{~m}$ ) and shallower (from 17 to $4.7 \mathrm{~cm}$ ) from the lower to the upper site (Sect. 6.2). The surrounding vegetation at the three sites is primarily a young forest and progresses from a mesic, lowland character to a drier, more upland nature. Canopy vegetation includes sweet gum (Liquidambar styraciflua), sugar maple (Acer saccharum), buckeye (Aesculus sp.), tulip poplar, slippery elm, sycamore, blue beech, red cedar, dogwood, and several oaks. At the lower sites, bank cover includes mesic species, such as green dragon (Arisaema dracontium), jack-in-the-pulpit (Arisaema quinatum), and sedge (Carex crinita). The green dragon is designated as rare on the ORR and is only locally abundant in Tennessee (Kitchings and Mann 1976). Other bank species include grasses, poison ivy, honeysuckle, virginia creeper, wood sorrel (Oxalis sp.), clearweed, catbriar (Smilax sp.), raspberry (Rubus occidentalis), and Christmas fern (Polystichum acrostichoides). The canopy cover ranged from 77.7 to $82.0 \%$ at MEK 0.6 and MEK 1.4, respectively. The substrate at MEK 0.6 is a coarse mixture of gravel, cobble, rubble, and rough bedrock with a high degree of embeddedness (50 to 100\%). Velocity ranged from 0 to $0.27 \mathrm{~m} / \mathrm{s}$ with a mean of $0.03 \mathrm{~m} / \mathrm{s}$. The substrate at MEK 1.4 is a very heterogenous mix of gravel, smooth bedrock, sand/fine sediment, plant detritus, and root wads. Although embeddedness was slightly less than at MEK 0.6, it was still in the range of 50 to 75\%. Velocities at MEK 1.4 ranged from 0 to $0.32 \mathrm{~m} / \mathrm{s}$ with a mean of $0.03 \mathrm{~m} / \mathrm{s}$. The benthos site at MEK 1.2 is described in the next section.

\subsubsection{Benthic macroinvertebrate study sites}

The location of the benthic macroinvertebrate study sites in WOC watershed is shown in Fig. 2.2. The vegetation and general forest type of all sites except MEK 1.2 were described in the discussion of fish study sites (Sect. 2.3.3.1); the benthos site at NTK 0.2 is at the lower end of the fish site at NTK 0.3 , thus descriptions of these sites are equivalent. Habitat descriptions are not yet available for the reference site on Brushy Fork, and habitat descriptions of WOL were not made.

The benthos site at MEK 1.2 is at the edge of a transmission line right-of-way; the lower end of the site is located in a weedy portion of this clearing, and the remainder is located within a thin stand of young trees covered with abundant vine growth. Some relatively mature trees also occurred along the stream bank and within the floodplain of the right bank, providing a considerable canopy cover (90.0\%) (Table 2.12). Common trees providing cover include tulip poplar, sweet gum, pine, walnut, and white ash. Common ground cover vegetation includes grape vines, poison ivy, clearweed, and wild rye.

Both mean velocity and depth of the benthos sampling sites generally increased with distance downstream (Table 2.13). Mean current velocities ranged from 0.01 to $0.34 \mathrm{~m} / \mathrm{s}$, and mean depths ranged from 1.2 to $12.2 \mathrm{~cm}$. Considerable differences in canopy cover occurred between sites ( 0 to $94 \%$ ), although coverage was $65 \%$ or greater at all but three sites (Table 2.12). The substrate at most of the sites consists of a heterogeneous mixture of gravel and rubble, but at FCK 0.1, MEK 1.2, 
WCK 2.3, WCK 2.9, and WCK 3.9, the substrate consists primarily of gravel (Table 2.12). In general, embeddedness ranged from $<5$ to $25 \%$, but at FCK 0.1, MEK 0.6 , and MEK 1.2, embeddedness was greater, ranging from 25 to $50 \%$ at FCK 0.1 and from 50 to $75 \%$ at MEK 0.6 and MEK 1.2 (Table 2.12).

\subsubsection{Discussion}

The initial habitat characterization of WOC provided data on substrate and cover for low-flow periods during summer. In this regard, the comparisons are limited and some conclusions concerning the role of habitat differences between sites may change under higher flow conditions.

The relationship between fish populations and available habitat has been examined from many perspectives. Gorman and Karr (1978) helped establish the relationship between fish community complexity and physical habitat variables, such as stream depth, bottom type, and current velocity. Angermeier and Karr (1984) compared the abundance of fish populations with the abundance of woody debris in streams. The role of large substrate, undercut banks, and aquatic vegetation in determining population characteristics of smallmouth bass and rock bass was examined by McClendon and Rabeni (1987). Other environmental variables, such as temperature (Baltz et al. 1987) and regulated stream flows (Bain et al. 1988), have been found to significantly influence microhabitat preferences and fish community structure. Thus, any study that examines the ecological effects of remedial actions must address the importance of differences in fish community structure.

There are considerable differences in habitat structure between the fish sampling sites. The initial selection of sites focused on obtaining an equal representation of pools and riffles at all sites. Data from this survey show considerable variety in pool:riffle ratios at low flows, with higher ratios at the downstream sites, particularly in mainstem WOC. The degree of embeddedness also increased in a downstream direction. However, substrate composition did not appear to be substantially different between upper and lower sites. Mean velocities in May showed a trend toward higher velocities at the lower sites, as might be expected during a low-flow period. All sites showed evidence of recent vegetational disturbance, with Fifth Creek, First Creek, and the middle section of WOC affected the most.

In analyzing data on embeddedness, substrate composition, and pool to riffle ratio in the tributaries, no obvious, consistent patterns were evident. For example, an increase in the pool to riffle ratio did not always result in an increased degree of embeddedness. However, a habitat pattern was evident in WOC. The lower sites (WCK 2.3 and WCK 2.9) had high pool to riffle ratios, a high degree of embeddedness, similar substrate, and a closed canopy. Riparian cover was also less disturbed and more characteristic of lowland habitats. The middle section of WOC (WCK 3.4 to WCK 5.1) had more variable substrate, lower embeddedness, fewer pools, and a highly disturbed vegetative cover. The upper site (WCK 6.8 ) had a more stable riparian vegetation, a more typical upstream pool to riffle ratio, and very low embeddedness.

Despite efforts to minimize habitat variability among sites, the preliminary characterization of physical habitat at the fish and benthic macroinvertebrate sites showed that differences in habitat could account for some of the observed differences in the fish and benthic communities between sites. Many of these differences are due not only to natural expected spatial differences but also to past and current operations and activities at ORNL, including flow augmentation, 
streambed modifications (e.g., channel rerouting, installation of bridges and culverts, channelization), and land use practices (e.g., clear cutting). Thus, many of the differences observed in the biotic communities between sites reflect true differences which have resulted from both current and past operations at ORNL and from agricultural uses prior to the establishment of ORNL. As remedial actions improve the water quality of WOC, assessing the importance of habitat as a factor influencing the composition of the fish and benthic invertebrate communities will become more important. 


\section{TOXICITY MONITORING}

Toxicity monitoring studies detailed in the first annual report (Loar et al. 1992a) were largely descriptive; tests with two species (larvae of the fathead minnow, Pimephales promelas, and neonates of the daphnid microcrustacean, Ceriodaphnia dubia) were used to describe the general spatial and temporal patterns of ambient toxicity at ORNL.

Toxicity monitoring studies during the second year were used to identify specific linkages between ambient toxicity and chemical conditions within the streams. In that report (Loar 1992b), (1) episodic releases of oxidants titrating as total residual chlorine (TRC) were implicated as controlling the overall patterns in ambient toxicity (Stewart et al. 1990), (2) chlorinated tapwater (which is used widely at ORNL as once-through coolant) was identified as the major source of TRC in the streams, (3) Ceriodaphnia was shown to be more sensitive than the minnows to TRC, and (4) a statistical relationship between Ceriodaphnia fecundity and neutral salts that contributed to hardness was identified. Studies conducted during the second year suggested that relationships between conservative water quality factors (e.g., the ratio of alkalinity to hardness) could be used to track releases of treated and nontreated wastewaters.

The results of toxicity tests performed during the third year of the BMAP (February 1988-February 1989) are summarized in this report. As a logical extension of the earlier studies, the toxicity tests conducted during 1988-89 had two principal objectives: (1) to provide additional insight into the sources and toxicological significance of TRC in ORNL streams, and (2) to evaluate the toxicological significance of neutral salts, such as calcium sulfate and sodium chloride, which are important constituents of some ORNL wastewaters [e.g., effluent from the Coal Yard Runoff Treatment Facility (CYRTF)].

Toxicity of effiuents produced by wastewater treatment operations at ORNL is routinely assessed and reported on a case-by-case basis under the Toxicity Control and Monitoring Program (TCMP) section of the ORNL NPDES permit (EPA 1986a, Part V). These effluents enter WOC as point-source discharges and could contribute to ambient toxicity. The NPDES permit also requires the monitoring of toxicity at two ambient sites (X13 on lower Melton Branch at MEK 0.16 and X14 on lower WOC at WCK 2.65). To provide a more comprehensive review of toxicity in ORNL streams, the results of both point- and area-source toxicity tests are summarized in this report.

\subsection{POINT-SOURCE AND AREA- SOURCE CONTRIBUTIONS TO AMBIENT TOXICITY}

\section{A. J. Stewart}

Point- and area-source contributions to ambient toxicity in streams in the WOC watershed were evaluated with 7-d staticrenewal tests based on the survival and growth of fathead minnow (Pimephales promelas) larvae and the survival and reproduction of the daphnid Ceriodaphnia dubia. These standard, EPA-approved tests are described in Mount and Norberg (1984), Horning and Weber (1985), and Norberg and Mount (1985). Each fathead minnow test used four replicates, with ten 
larvae per replicate. Each Ceriodaphnia test used ten replicates, with one neonate per replicate. The no-observed-effect concentration (NOEC) for effluents from the Sewage Treatment Plant (STP), Process Waste Treatment Plant (PWTP), and the CYRTF were calculated using one-way analysis of variance and Dunnett's test, as described by Horning and Weber (1985). On each day of each toxicity test, subsamples of the water or effluent being tested for toxicity were also analyzed for conductivity, $\mathrm{pH}$, alkalinity and hardness. Most samples collected for toxicity tests were also analyzed for free and total residual chlorine by amperometric titrations with phenylarsene oxide. The temperature of the water sample at each site was recorded when the sample was collected. Statistical computations were made using SAS (Statistical Analysis System; SAS 1985a,1985b) procedures with PC-SAS (Software Release 6.03) on an IBM AT computer. Survival values for the minnows and the Ceriodaphnia were transformed (arcsin square root; Steel and Torrie 1960) before analysis.

\subsubsection{Point-Source Contributions to Toxicity}

Point-source discharges that were routinely tested for toxicity under the TCMP included those from the STP, PWTP, and CYRTF (Fig. 2.4). The results of the toxicity tests of effluents from these three facilities are summarized in Table 3.1. The results of chemical analyses conducted in conjunction with these effluent toxicity assessments are given in Table 3.2.

In November 1988, samples from selected ambient sites and outfalls were evaluated to identify possible point-source contributions to toxicity in Fifth Creek and
WOC. Water from 24 sites was analyzed for TRC, hardness, conductivity, $\mathrm{pH}$, soluble reactive phosphorus, and nitrate nitrogen $\left(\mathrm{NO}_{3}-\mathrm{N}\right)$. Samples from four of the Fifth Creek outfalls were dechlorinated with sodium sulfite and then tested for toxicity with fathead minnow larvae to determine if toxicants other than chlorine were present. The results of the chemical analyses of the 24 samples are shown in Table 3.3; the results of the toxicity tests of the dechlorinated samples are given in Table 3.4.

In December 1988, grab samples of water from one stream site (Fifth Creek just upstream from cooling tower 3103) and from four outfalls (three to WOC, one to Fifth Creek) were analyzed for TRC before being dechlorinated and tested for toxicity. The results of the December tests showed that water from WOC outfall \#312, which is just downstream from the bridge to the Transuranic Laboratory, was clearly toxic to both species even after it had been dechlorinated. Dechlorinated water samples from outfall \#368 (to Fifth Creek) and from \#226 and \#227 (to WOC) reduced fecundity of Ceriodaphnia but did not reduce fish growth or survival (Table 3.5).

The results of the chemical analyses conducted during November and December showed that wastewaters from at least four outfalls to Fifth Creek (\#368, \#363, \#265 and \#367) and three outfalls to WOC (\#219, \#227, and \#312) contain moderate to high levels of chlorine.

Toxicity tests showed that water from at least two of these outfalls (\#368 to Fifth Creek and \#312 to WOC) remained toxic even after dechlorination. Because TRC is extremely toxic to aquatic biota, the criterion for chronic exposure to chlorine is only $11 \mu \mathrm{g} / \mathrm{L}$ (EPA 1985). Thus, water released to WOC via just two outfalls (\#12 and \#227 near the Transuranic 
Table 3.1. Summary of toxicity teat results for the Oak Ridge National Laboratory Process Waste Treatment Plant (PWTP), Coal Yard Runoff Treatment Facility (CYRTF), and Sewage Treatment Plant (STP)

\begin{tabular}{cccc}
\hline ORNL Facility & Test Date & $\begin{array}{c}\text { Fathead Minnow } \\
\text { NOEC }(\%)\end{array}$ & $\begin{array}{c}\text { Ceriodaphnia } \\
\text { NOEC (\%) }\end{array}$ \\
\hline PWTP & Jan. 1988 & 80 & 80 \\
PWTP & Mar. 1988 & 80 & 80 \\
PWTP & Jun. 1988 & 80 & 80 \\
PWTP & Oct. 1988 & 80 & UT \\
CYRTF & Jan. 1988 & 80 & 25 \\
CYRTF & Mar. 1988 & 100 & $\geq 60$ \\
CYRTF & Jul. 1988 & 60 & 15 \\
CYRTF & Sep. 1988 & 100 & UT \\
CYRTF & Nov. 1988 & 100 & $<40$ \\
STP & Feb. 1988 & $<75$ & $<75$ \\
STP & Jun. 1988 & 100 & 100 \\
STP & Dec. 1988 & $<80$ & $<80$ \\
\hline
\end{tabular}

Based on survival only. Fecundity comparisons could not be made due to the high proportion of males in the test.

Note: NOEC $=$ No-observed-effect concentration, or highest tested concentration (percentage) causing no statistically significant reduction $(p<0.05)$ in survival or growth of fathead minnow larvae, or survival or reproduction of Ceriodaphnia. UT = Unacceptable test due to low fecundity of animals in the control.

Table 3.2. Summary of chemical analyses of effluent from the Oak Ridge National Laboratory Process Waste Treatment Plant (PWTP), Coal Yard Runoff Treatment Facility (CYRTF), and Sewage Treatment Plant (STP)

Values are means for each test $(N=7)$

\begin{tabular}{lllccr}
\hline $\begin{array}{l}\text { ORNL } \\
\text { Facility }\end{array}$ & Test Date & pH & $\begin{array}{c}\text { Conductivity } \\
(\mu \mathrm{S} / \mathrm{cm})\end{array}$ & $\begin{array}{c}\text { Alkalinity } \\
(\mathrm{mg} / \mathrm{L})\end{array}$ & $\begin{array}{c}\text { Hardness } \\
(\mathrm{mg} / \mathrm{L})\end{array}$ \\
\hline PWTP & Jan. 1988 & 7.40 & 665 & 40.4 & 3.7 \\
PWTP & Mar. 1988 & 7.76 & 663 & 59.3 & 4.2 \\
PWTP & Jun. 1988 & 7.64 & 840 & 54.4 & 0.6 \\
PWTP & Oct. 1988 & 7.90 & 681 & 60.6 & 0.1 \\
CYRTF & Jan. 1988 & 6.84 & 1703 & 5.9 & 1005.7 \\
CYRTF & Mar. 1988 & 7.17 & 1812 & 9.3 & 957.1 \\
CYRTF & Jul. 1988 & 7.58 & 2478 & 20.7 & 2013.3 \\
CYRTF & Sep. 1988 & 7.27 & 2550 & 12.6 & 1465.4 \\
CYRTF & Nov. 1988 & 6.84 & 27800 & 1.0 & 2040.0 \\
STP & Feb. 1988 & 7.66 & 483 & 88.3 & 169.4 \\
STP & Jun. 1988 & 7.82 & 447 & 82.0 & 158.9 \\
STP & Oct. 1988 & 7.81 & 459 & 104.3 & 179.7 \\
\hline
\end{tabular}

${ }^{a}$ Results of the November 1988 test are based on a single grab sample collected on November 15 . All other tests used samples that were collected fresh each day during the 7-d test period. 
Table 3.3. Chemical charecteristics of water enmples from Fifth Creek and selected outfills to Fith and White Oak creels

\begin{tabular}{|c|c|c|c|c|c|c|c|}
\hline $\begin{array}{l}\text { Site } \\
\text { Code }\end{array}$ & Site Deacription & pH & $\begin{array}{l}\text { Conductivity } \\
(\mu \mathrm{S} / \mathrm{cm})\end{array}$ & $\begin{array}{l}\text { Hardness } \\
(\mathbf{m} \Omega /)\end{array}$ & $\begin{array}{c}\text { TRC } \\
(\mu / L)\end{array}$ & $\underset{(\mu \rho /)}{\operatorname{SRP}}$ & $\begin{array}{l}N \mathrm{O}_{-}-\mathrm{N} \\
(\mu \rho / L)\end{array}$ \\
\hline 1 & $\begin{array}{l}\text { Fifth Creek, juwt upetream } \\
\text { from cooling tower } 3103\end{array}$ & 8.03 & 285 & 164 & $\mathbf{0}$ & 72 & 194 \\
\hline 2 & $\begin{array}{l}\text { Fifth Creek, } 5 \mathrm{~m} \text { downatream } \\
\text { from outfall } \$ 171\end{array}$ & 8.07 & 288 & 166 & $\mathbf{0}$ & 76 & 173 \\
\hline 3 & $\begin{array}{l}\text { Fith Creek, culven } 5 \mathrm{~m} \text { upatream } \\
\text { from outfall } \$ 170\end{array}$ & 8.09 & 288 & 152 & 0 & 73 & 191 \\
\hline 4 & Outfall $\# 267$, on Fifth Creek & 8.01 & 331 & 178 & 100 & 71 & 293 \\
\hline 5 & $\begin{array}{l}\text { Fifth Creek, } 1 \text { m upstream } \\
\text { from outfall } \# 368\end{array}$ & 8.01 & 311 & 174 & 20 & 75 & 219 \\
\hline 6 & Outfall $\# 368$, on Fifth Creek & 8.01 & 301 & 156 & 650 & 107 & 389 \\
\hline 7 & $\begin{array}{l}\text { Fifth Creek, } 1 \text { m upstream } \\
\text { from outfall } \# 266\end{array}$ & 8.10 & 310 & 154 & 80 & 82 & 258 \\
\hline 8 & $\begin{array}{l}\text { Fifth Creek, } 1 \mathrm{~m} \text { downstream } \\
\text { from outfall } \# 166\end{array}$ & 8.11 & 314 & 158 & so & 81 & 252 \\
\hline 9 & $\begin{array}{l}\text { Fifth Creek, } 2 \mathrm{~m} \text { upstream } \\
\text { from outfall } \# 367\end{array}$ & 8.16 & 317 & 178 & 30 & 86 & 290 \\
\hline 10 & Outfall $\# 367$, on Fifth Creek & 8.10 & 302 & 158 & 1010 & 76 & 451 \\
\hline 11 & Outfall \#265, on Fifth Creek & 8.35 & 284 & 166 & 650 & 175 & 376 \\
\hline 12 & Outfall $\# 365$, on Fifth Creek & 7.97 & 698 & 358 & $\mathbf{0}$ & 39 & 39. \\
\hline 13 & $\begin{array}{l}\text { Fifth Creek, } 10 \mathrm{~m} \text { downstream } \\
\text { from outfall } \# 263\end{array}$ & 8.20 & 319 & 154 & so & 94 & 303 \\
\hline 14 & Outfall $\# 363$, on Fifth Creek & 8.22 & 322 & 168 & 400 & 153 & 358 \\
\hline 15 & $\begin{array}{l}\text { Fifth Creek, } 1 \mathrm{~m} \text { upstream } \\
\text { from outfall } \# 363\end{array}$ & 8.22 & 318 & 164 & 40 & 91 & 292 \\
\hline 16 & $\begin{array}{l}\text { Fifth Creek, } 1 \mathrm{~m} \text { downstream } \\
\text { from outfall } \# 161\end{array}$ & 8.14 & 289 & 172 & 10 & 94 & 311 \\
\hline 17 & $\begin{array}{l}\text { Fifth Creek, at its confluence } \\
\text { with White Oak Creek }\end{array}$ & 8.25 & 315 & 158 & 50 & 95 & 296 \\
\hline 18 & White Oak Creek, outfall \#217 & 7.98 & 227 & 108 & 400 & 46 & 293 \\
\hline 19 & White Oak Creek, outfall \#311 & 6.39 & 35 & 4 & $\mathbf{0}$ & 3 & 1 \\
\hline 20 & White Oak Creek, outfall \#218 & 8.24 & 304 & 148 & $\mathbf{0}$ & 106 & 267 \\
\hline 21 & White Oak Creek, outfall $\# 219$ & 8.03 & 292 & 144 & 1200 & 52 & 279 \\
\hline 22 & White Oak Creek, outfall \#227 & 8.21 & 311 & 156 & 1100 & 57 & 431 \\
\hline 23 & White Oak Creek, outfall \#312 & 8.31 & 260 & 136 & 830 & 45 & 314 \\
\hline 24 & White Oak Creek, outfall \#226 & 7.81 & 350 & 188 & 110 & 120 & 356 \\
\hline
\end{tabular}


Table 3.4. Survival and growth (mean \pm 1 SD) of suthead minnow brvec in 7d tests on watewnter anmples from Finh Creek and elected outhills

\begin{tabular}{lcc}
\hline \multicolumn{1}{c}{ Sample/Site } & $\begin{array}{c}\text { Survival } \\
(\%)\end{array}$ & $\begin{array}{c}\text { Orowth } \\
(\mathrm{m} / \text { /fish })\end{array}$ \\
\hline Control ${ }^{4}+\mathrm{Na}_{2} \mathrm{SO}_{3}$ & 92.5 & $0.49 \pm 0.02$ \\
Control $\left(\mathrm{no} \mathrm{Na}_{2} \mathrm{SO}_{3}\right)$ & 95.0 & $0.51 \pm 0.03$ \\
Site 1 & 70.0 & $0.47 \pm 0.14$ \\
Site 4 & 93.3 & $0.54 \pm 0.05$ \\
Site 6 & 90.0 & $0.30 \pm 0.01$ \\
Site 17 & 93.3 & $0.54 \pm 0.09$ \\
\hline
\end{tabular}

"Control water was diluted mineral water (1:9, v:v, Perrier water and deionized distilled water).

Note: A grab sample from each site was collected on November 16, 1988 and dechlorinated with sodium sulfite $\left(\mathrm{Na}_{2} \mathrm{SO}_{3}\right)$ before being tested for toxicity. Site numbers correspond to those described in Table 3.3 of this document.

Table 3.5. Concentrations of total residual chlorine (TRC) in grab samples of water from outfalls on Fifth Creek and White Oak Creek, and 7-d toxicity test results (mean \pm 1 SD) for the samples after they had been dechlorinated with sodium thiosulfate

\begin{tabular}{|c|c|c|c|c|c|}
\hline \multirow[b]{2}{*}{ Site/outfall } & \multirow{2}{*}{$\begin{array}{c}\text { TRC } \\
(\mu g / L)\end{array}$} & \multicolumn{2}{|c|}{ Fathead Minnows } & \multicolumn{2}{|c|}{ Ceriodaphnia } \\
\hline & & $\begin{array}{c}\text { Survival } \\
(\%)\end{array}$ & $\begin{array}{c}\text { Growth } \\
\text { (mg/fish) }\end{array}$ & $\begin{array}{c}\text { Survival } \\
(\%)\end{array}$ & $\begin{array}{c}\text { Fecundity } \\
\text { (offspring/female) }\end{array}$ \\
\hline FIF $\# 368$ & 950 & 90.0 & $0.42 \pm 0.06$ & 100 & $2.6 \pm 3.0$ \\
\hline WOC \#227 & 1150 & 90.0 & $0.42 \pm 0.08$ & 90 & $6.7 \pm 7.3$ \\
\hline WOC $\# 312$ & 850 & 67.5 & $0.29 \pm 0.05$ & 0 & .. \\
\hline WOC \#226 & 140 & 92.5 & $0.46 \pm 0.02$ & 100 & $7.7 \pm 6.2$ \\
\hline Controla & 0 & 87.5 & $0.44 \pm 0.05$ & 100 & $19.6 \pm 1.5$ \\
\hline
\end{tabular}

${ }^{a}$ Control water was diluted mineral water (1:9, v:v, Perrier water and deionized distilled water) treated with enough sodium thiosulfate to neutralize $1150 \mu \mathrm{g}$ TRC/L.

Laboratory), for example, would have to be diluted 75 - to 100 -fold in order to lower TRC levels to environmentally acceptable levels. A visual estimate of the flow rates of outfalls \#312 and \#227, relative to thatof WOC at the point of discharge suggested that dilution was probably less than 10 times. Hence, these outfalls are almost certainly important point-source contributors to toxicity in WOC.

\subsubsection{Area-Source Contributions to Ambient Toxicity}

\subsubsection{NPDES Permit sites X13 and X14}

Water from NPDES site X13 on Melton Branch at MEK 0.16 and X14 on WOC at WCK 2.65 was tested for chronic and acute toxicity with fathead minnow larvae and Ceriodaphnia five times during 
1988. The samples from each site were collected as daily grabs for each 7-d test. The $\mathrm{pH}$, conductivity, alkalinity, and hardness of each sample was measured within $2 \mathrm{~h}$ after the sample had been delivered to the laboratory.

The results of the Ceriodaphnia and fathead minnow tests are shown in Tables 3.6 and 3.7 respectively. Fecundity of Ceriodaphnia reared in water from $\mathrm{X} 13$ and X14 was higher than that of animals in the control in every test, and all Ceriodaphnia tests had acceptable controls. Growth of the minnow larvae in water from sites X13 and X14 also differed little from growth of minnow larvae in the controls. Additionally, there was no evidence for acute toxicity at either site. Survival of the test animals in water from the two sites was generally high (>75\%). An exception was noted in the test that was initiated on February 25, 1988. In this test, survival of the minnows in water from $\mathrm{X} 13$ was only $67.5 \%$. However, variability in fish survival among replicates for this sample was exceptionally high $(40 \%, 50 \%$, $80 \%$ and $100 \%$ for the four replicates). High variability in fish survival among replicates is fairly common but typically occurs only in tests of water from relatively pristine streams (A. J. Stewart, ORNL/ESD, personal observation). The variability in the February 1988 tests appeared to be associated with the presence of pathogenic fungi such as Saprolegnia. Thus, the results of the February test for X13 may actually reflect water quality improvements associated with changes in discharge patterns to that stream: pollution-sensitive fungi, such as Saprolegnia, are now detectable at this site using the fish toxicity tests.

The results of the chemical analyses conducted in association with the toxicity tests are summarized in Table 3.8. Based on measurements of conductivity (Fig. 3.1), conditions at X13 in Melton Branch appeared to be slightly better than those at X14 in lower WOC. On most sampling dates, for example, the conductivity at X14 was slightly higher than at X13, indicating that the concentrations of dissolved salts in WOC were somewhat higher than those in Melton Branch. The ratio of alkalinity to hardness (A:H) can also be used as a simple index of chemical perturbation because alkalinity provides an estimate of buffering capacity (due largely to the presence of bicarbonate and carbonate salts), while hardness provides a measure of divalent cations (e.g., $\mathrm{Ca}^{++}+\mathrm{Mg}^{++}$) (Loar 1992b). The values of A:H at X14 in WOC tended to be slightly lower than those at X13 in Melton Branch (Fig. 3.2), which lends further credence to the notion that water quality at Melton Branch was slightly better than that at X14 in WOC. At both sites, however, A:H values fluctuated between about 0.6 and 0.8 , while A:H values for noncontaminated pristine streams on the ORR were closer to unity (i.e., 0.92-0.94; Loar 1992b). Thus, based on these salt-related water quality parameters,water at X13 and X14 differed only slightly, and both showed evidence of degradation relative to pristine systems.

\subsubsection{Streams near Solid Waste Storage Area (SWSA) 6}

On December 8, 1988, water samples were collected from two small streams near Solid Waste Storage Area (SWSA) 6. Both streams flow southward into White Oak Lake; one (East Tributary) flows near the east boundary of SWSA 6 and the other flows near the west boundary (Figs. 2.1 and 2.2). Water from East Tributary was collected as a single grab sample at the weir. Water from West Tributary was collected as a single grab sample on the south side of the road just outside the SWSA 6 fence. Water from each site was 
Table 3.6. Results of Ceriodaphnia todeity teats of water from National Pollutunt Discharge Eliminntion System sites X13 and X14 on Melton Branch and White Oat Crook, respoctively

\begin{tabular}{|c|c|c|c|}
\hline Test date & Site & $\begin{array}{c}\text { Survival } \\
(\%)\end{array}$ & $\begin{array}{c}\text { Fecundity } \\
\text { (oftupring/female) }\end{array}$ \\
\hline \multirow[t]{3}{*}{ Jan. 14, 1988} & Controp & 100 & $27.4 \pm 2.3(10)$ \\
\hline & $\mathrm{MBr} \cdot \mathrm{X} 13$ & 100 & $27.8 \pm 1.9(10)$ \\
\hline & WOC-X14 & 90 & $28.2 \pm 2.6(9)$ \\
\hline \multirow[t]{4}{*}{ Feb. 25, 1988} & Controp & 90 & $19.7 \pm 7.5$ (7) \\
\hline & WCK 6.8 & 80 & $20.1 \pm 2.0$ \\
\hline & $\mathrm{MBr} \cdot \mathrm{X} 13$ & 90 & $22.8 \pm 2.2$ \\
\hline & WOC-X14 & 100 & $23.3 \pm 3.5(10)$ \\
\hline \multirow[t]{3}{*}{ Apr. 21, 1988} & Controp & 80 & $26.5 \pm 3.8$ \\
\hline & $\mathrm{MBr}-\mathrm{X} 13$ & 100 & $31.2 \pm 2.0(10)$ \\
\hline & WOC-X14 & 90 & $29.1 \pm 4.4$ \\
\hline \multirow[t]{3}{*}{ Jun. 9, 1988} & Controp & 87 & $17.5 \pm 2.0(13)$ \\
\hline & $\mathrm{MBr} \cdot \mathrm{X} 13$ & 100 & $21.8 \pm 5.6(15)$ \\
\hline & WOC.X14 & 87 & $20.5 \pm 2.5(13)$ \\
\hline \multirow[t]{3}{*}{ Aug. 25, 1988} & Control & 100 & $18.6 \pm 4.6(10)$ \\
\hline & $\mathrm{MBr} \cdot \mathrm{X} 13$ & 90 & $23.7 \pm 7.0$ \\
\hline & WOC-X14 & 100 & $21.3 \pm 3.8(10)$ \\
\hline
\end{tabular}

Control water was well/spring water.

'Control water was diluted mineral water.

Note: Mean survival is based on 10 animals in most tests (one neonate in each of 10 replicates); the test conducted in June used 15 replicates. Mean fecundity ( $\pm 1 \mathrm{SD}$ ) is computed using all surviving females in each test. The number of females used to calculate fecundity is given in parentheses. Results of tests of water from a reference site on upper WOC (W'hite Oak Creek 6.8) are given for comparison. Test date indicates the first day of the 7-d test. In the February test, discrepancies between the number of animals used to calculate percentage survival vs the number of animals used to calculate fecundity are due to the presence of males. $\mathrm{MBr}=$ Mitchell Branch; WOC $=$ White Oak Creek; $\mathbf{W C K}=$ White Oak Creek kilometer. 
Table 3.7. Results of ththead minnow toricity teats of water from National Pollutant Diechare Blimination System sites X13 and X14 on Melton Brench and White Ont Creck, reapectively

\begin{tabular}{|c|c|c|c|}
\hline Teat date & Site & $\begin{array}{c}\text { Survival } \\
(\%)\end{array}$ & $\begin{array}{c}\text { Growth } \\
\text { (me/tish) }\end{array}$ \\
\hline \multirow[t]{3}{*}{ Jan. 14, 1988} & Contror & 97.5 & $0.94 \pm 0.07$ \\
\hline & $\mathrm{MBr}-\mathrm{X} 13$ & 82.5 & $0.88 \pm 0.05$ \\
\hline & WOC.X14 & 95.0 & $0.78 \pm 0.07$ \\
\hline \multirow[t]{4}{*}{ Feb. 25, 1988} & Controp & 95.0 & $0.42 \pm 0.01$ \\
\hline & wCK 6.8 & 95.0 & $0.52 \pm 0.07$ \\
\hline & MBr-X13 & 67.5 & $0.56 \pm 0.02$ \\
\hline & WOC-X14 & 90.0 & $0.62 \pm 0.02$ \\
\hline \multirow[t]{3}{*}{ Apr. 21, 1988} & Control" & 100.0 & $0.49 \pm 0.03$ \\
\hline & $\mathrm{MBr} \cdot \mathrm{X} 13$ & 77.5 & $0.63 \pm 0.08$ \\
\hline & WOC.X14 & 80.0 & $0.68 \pm 0.04$ \\
\hline \multirow[t]{4}{*}{ June 9, 1988} & Controt & 100.0 & $0.39 \pm 0.02$ \\
\hline & WCK 6.8 & 77.5 & $0.41 \pm 0.08$ \\
\hline & $\mathrm{MBr} \cdot \mathrm{X} 13$ & 90.0 & $0.45 \pm 0.01$ \\
\hline & WOC.X14 & 87.5 & $0.43 \pm 0.05$ \\
\hline \multirow[t]{3}{*}{ Aug. 25, 1988} & Control ${ }^{b}$ & 97.5 & $0.55 \pm 0.05$ \\
\hline & $\mathrm{MBr}-\mathrm{X} 13$ & 87.5 & $0.51 \pm 0.04$ \\
\hline & WOC-X14 & 97.5 & $0.53 \pm 0.05$ \\
\hline
\end{tabular}

Control water was dechlorinated tap water.

'Control water was diluted mineral water.

'Based on two replicates.

Note: Mean survival is based on 40 larvac in each test (10 larvac in each of 4 replicates). Mean growth $( \pm 1 \mathrm{SD}$ ) of the fish in each test is corrected for weight of larvae at the start of the test. Results of tests of water from a reference site on upper WOC (White Oak Creek kilometer 6.8) are given for comparison. Test date indicates the first day of the 7-d test. $\mathrm{MBr}=$ Mitchell Branch; WOC = White Oak Creek; WCK = White Oak Creek kilometer. 
Table 3.8. Results of chemical anabyes of (1) control water; (2) wator from National Pollutant Diecharge Ellmination Syatem sites X13 and X14 on Molton Branch and White Oak Croek (WOC) respectively; and (3) water from a noncontaminated reference site on upper WOC

\begin{tabular}{|c|c|c|c|c|c|}
\hline Date & Site & pH & $\begin{array}{l}\text { Conductivity } \\
(\mu \mathrm{S} / \mathrm{cm})\end{array}$ & $\begin{array}{c}\text { Alkalinity } \\
\text { (mgll as } \mathrm{CaCO}_{3} \text { ) }\end{array}$ & $\begin{array}{c}\text { Hardness } \\
\left.\text { (mg/L as } \mathrm{CaCO}_{3}\right)\end{array}$ \\
\hline $01 / 14 / 88$ & Control & 8.26 & 270 & 102 & 130 \\
\hline $01 / 15 / 88$ & Control & 7.91 & 278 & 102 & 138 \\
\hline $01 / 16 / 88$ & Control & 7.82 & 277 & 91 & 132 \\
\hline $01 / 17 / 88$ & Control & 7.91 & 282 & 97 & 124 \\
\hline 01/18/88 & Control & 7.64 & 280 & 105 & 124 \\
\hline $01 / 19 / 88$ & Control & 7.66 & 241 & 99 & 118 \\
\hline $01 / 20 / 88$ & Control & 7.64 & 280 & 99 & 124 \\
\hline $01 / 14 / 88$ & $\mathrm{MBr}-\mathrm{X} 13$ & 8.10 & 428 & 112 & 182 \\
\hline $01 / 15 / 88$ & $\mathrm{MBr}-\mathrm{X} 13$ & 8.07 & 378 & 116 & 174 \\
\hline $01 / 16 / 88$ & $\mathrm{MBr} \cdot \mathrm{X} 13$ & 8.17 & 370 & 123 & 172 \\
\hline $01 / 17 / 88$ & $\mathrm{MBr}-\mathrm{X} 13$ & 8.25 & 349 & 110 & 154 \\
\hline $01 / 18 / 88$ & $\mathrm{MBr} \cdot \mathrm{X} 13$ & 7.74 & 267 & 118 & 190 \\
\hline $01 / 19 / 88$ & $\mathrm{MBr} \cdot \mathrm{X} 13$ & 7.82 & 248 & 69 & 104 \\
\hline $01 / 20 / 88$ & $\mathrm{MBr} \cdot \mathrm{X} 13$ & 7.53 & 222 & 37 & 60 \\
\hline $01 / 14 / 88$ & woc.X14 & 8.13 & 477 & 116 & 186 \\
\hline $01 / 15 / 88$ & WOC-X14 & 8.21 & 292 & 157 & 168 \\
\hline $01 / 16 / 88$ & WOC-X14 & 8.17 & 491 & 112 & 206 \\
\hline $01 / 17 / 88$ & wOC-X14 & 8.10 & 509 & 108 & 200 \\
\hline $01 / 18 / 88$ & wOC-X14 & 7.94 & 414 & 111 & 144 \\
\hline $01 / 19 / 88$ & WOC-X14 & 8.05 & 454 & 118 & 176 \\
\hline $01 / 20 / 88$ & WOC-X14 & 7.84 & 223 & 74 & 108 \\
\hline $02 / 25 / 88$ & Control & 7.78 & 101 & 29 & 36 \\
\hline $02 / 26 / 88$ & Control & $\cdots$ & $\cdots$ & $\cdots$ & $\cdots$ \\
\hline $02 / 27 / 88$ & Control & $\cdots$ & $\cdots$ & $\cdots$ & $\cdots$ \\
\hline $02 / 28 / 88$ & Control & $\cdots$ & $\cdots$ & $\cdots$ & $\cdots$ \\
\hline $02 / 29 / 88$ & Control & $\cdots$ & $\cdots$ & $\cdots$ & $\cdots$ \\
\hline $03 / 01 / 88$ & Control & $\cdots$ & $\cdots$ & $\cdots$ & $\cdots$ \\
\hline $03 / 02 / 88$ & Control & 7.77 & 99 & 33 & 40 \\
\hline
\end{tabular}


Table 3.8 (continued)

\begin{tabular}{|c|c|c|c|c|c|}
\hline Date & Site & pH & $\begin{array}{c}\text { Conductivity } \\
(\mu \mathrm{S} / \mathrm{cm})\end{array}$ & $\begin{array}{c}\text { Alkalinity } \\
\left(\mathrm{mg} / \mathrm{L} \text { as } \mathrm{CaCO}_{3}\right)\end{array}$ & $\begin{array}{c}\text { Hardness } \\
\left(\mathrm{mg} / \mathrm{L} \text { as } \mathrm{CaCO}_{3}\right)\end{array}$ \\
\hline $02 / 25 / 88$ & WCK 6.8 & 8.01 & 197 & 87 & 138 \\
\hline $02 / 26 / 88$ & WCK 6.8 & 8.06 & 223 & 89 & 102 \\
\hline $02 / 27 / 88$ & WCK 6.8 & 8.12 & 205 & 92 & 130 \\
\hline $02 / 28 / 88$ & WCK 6.8 & 7.98 & 200 & 92 & 96 \\
\hline $02 / 29 / 88$ & WCK 6.8 & 8.06 & 206 & 96 & 122 \\
\hline $03 / 01 / 88$ & WCK 6.8 & 8.01 & 184 & 99 & 110 \\
\hline $03 / 02 / 88$ & WCK 6.8 & 8.02 & 214 & 104 & 112 \\
\hline $02 / 25 / 88$ & $\mathrm{MBr}-\mathrm{X} 13$ & 8.01 & 319 & 104 & 142 \\
\hline 02/26/88 & $\mathrm{MBr}-\mathrm{X} 13$ & 8.02 & 328 & 105 & 146 \\
\hline $02 / 27 / 88$ & $\mathrm{MBr}-\mathrm{X} 13$ & 8.11 & 329 & 109 & 144 \\
\hline $02 / 28 / 88$ & $\mathrm{MBr}-\mathrm{X} 13$ & 7.92 & 323 & 109 & 142 \\
\hline 02/29/88 & $\mathrm{MBr}-\mathrm{X} 13$ & 7.97 & 288 & 112 & 164 \\
\hline 03/01/88 & $\mathrm{MBr}-\mathrm{X} 13$ & 8.01 & 328 & 111 & 146 \\
\hline $03 / 02 / 88$ & $\mathrm{MBr}-\mathrm{X} 13$ & 7.99 & 330 & 117 & 158 \\
\hline $02 / 25 / 88$ & WOC-X14 & 8.10 & 424 & 101 & 172 \\
\hline $02 / 26 / 88$ & WOC-X14 & 8.12 & 369 & 109 & 142 \\
\hline $02 / 27 / 88$ & WOC-X14 & 8.18 & 458 & 113 & 192 \\
\hline $02 / 28 / 88$ & wOC-X14 & 8.05 & 394 & 109 & 160 \\
\hline $02 / 29 / 88$ & WOC-X14 & 8.10 & 344 & 109 & 156 \\
\hline 03/01/88 & WOC-X14 & 8.03 & 390 & 108 & 138 \\
\hline $03 / 02 / 88$ & WOC-X14 & 8.03 & 522 & 108 & 210 \\
\hline $04 / 21 / 88$ & Control & 8.02 & 84 & 34 & 60 \\
\hline $04 / 22 / 88$ & Control & 8.35 & 84 & 33 & 36 \\
\hline $04 / 23 / 88$ & Control & 8.05 & 83 & 30 & 38 \\
\hline $04 / 24 / 88$ & Control & 7.93 & 82 & 28 & 40 \\
\hline $04 / 25 / 88$ & Control & 7.93 & 81 & 29 & 45 \\
\hline $04 / 26 / 88$ & Control & 7.55 & 81 & 34 & 44 \\
\hline $04 / 27 / 88$ & Control & 8.14 & 78 & 27 & 40 \\
\hline $04 / 21 / 88$ & $\mathrm{MBr}-\mathrm{X} 13$ & 7.92 & 267 & 105 & 116 \\
\hline $04 / 22 / 88$ & $\mathrm{MBr}-\mathrm{X} 13$ & 7.98 & 308 & 118 & 158 \\
\hline $04 / 23 / 88$ & $\mathrm{MBr}-\mathrm{X} 13$ & 8.09 & 345 & 129 & 152 \\
\hline $04 / 24 / 88$ & $\mathrm{MBr}-\mathrm{X} 13$ & 8.16 & 322 & 127 & 156 \\
\hline $04 / 25 / 88$ & $\mathrm{MBr} \cdot \mathrm{X} 13$ & 8.13 & 315 & 131 & 164 \\
\hline
\end{tabular}


Table 3.8 (continued)

\begin{tabular}{|c|c|c|c|c|c|}
\hline Date & Site & pH & $\begin{array}{c}\text { Conductivity } \\
(\mu \mathrm{S} / \mathrm{cm})\end{array}$ & $\begin{array}{c}\text { Alkalinity } \\
\left.\text { (mg/L as } \mathrm{CaCO}_{3}\right)\end{array}$ & $\begin{array}{c}\text { Hardness } \\
\left(\mathrm{mg} / \mathrm{L} \text { as } \mathrm{CaCO}_{3}\right)\end{array}$ \\
\hline $04 / 26 / 88$ & $\mathrm{MBr}-\mathrm{X} 13$ & 8.12 & 326 & 135 & 166 \\
\hline $04 / 27 / 88$ & $\mathrm{MBr}-\mathrm{X} 13$ & 8.09 & 372 & 140 & 176 \\
\hline $04 / 21 / 88$ & WOC-X14 & 7.98 & 347 & 118 & 128 \\
\hline $04 / 22 / 88$ & wOC-X14 & 8.05 & 339 & 123 & 152 \\
\hline $04 / 23 / 88$ & WOC-X14 & 8.07 & 370 & 116 & 152 \\
\hline $04 / 24 / 88$ & WOC-X14 & 8.13 & 343 & 127 & 150 \\
\hline $04 / 25 / 88$ & WOC-X14 & 8.05 & 291 & 116 & 154 \\
\hline $04 / 26 / 88$ & WOC-X14 & 8.06 & 330 & 109 & 144 \\
\hline $04 / 27 / 88$ & WOC-X14 & 8.08 & 378 & 116 & 166 \\
\hline 06/09/88 & Control & 8.26 & 80 & 28 & 40 \\
\hline $06 / 10 / 88$ & Control & 7.79 & 84 & 36 & 42 \\
\hline $06 / 11 / 88$ & Control & 8.38 & 83 & 38 & 40 \\
\hline $06 / 12 / 88$ & Control & 8.38 & 83 & 35 & 42 \\
\hline $06 / 13 / 88$ & Control & 8.08 & 84 & 33 & 46 \\
\hline $06 / 14 / 88$ & Control & 8.00 & 85 & 35 & 40 \\
\hline $06 / 15 / 88$ & Control & 8.16 & 83 & 31 & 46 \\
\hline 06/09/88 & WCK 6.8 & 8.23 & 278 & 139 & 148 \\
\hline 06/10/88 & WCK 6.8 & 8.25 & 278 & 149 & 158 \\
\hline $06 / 11 / 88$ & WCK 6.8 & 8.29 & 276 & 149 & 152 \\
\hline $06 / 12 / 88$ & WCK 6.8 & 8.30 & 275 & 151 & 154 \\
\hline $06 / 13 / 88$ & WCK 6.8 & 8.27 & 244 & 148 & 150 \\
\hline $06 / 14 / 88$ & WCK 6.8 & 8.31 & 278 & 146 & 152 \\
\hline $06 / 15 / 88$ & WCK 6.8 & 8.27 & 273 & 151 & 150 \\
\hline 06/09/88 & $\mathrm{MBr}-\mathrm{X} 13$ & 7.93 & 370 & 138 & 156 \\
\hline $06 / 10 / 88$ & $\mathrm{MBr}-\mathrm{X} 13$ & 8.00 & 340 & 130 & 170 \\
\hline $06 / 11 / 88$ & $\mathrm{MBr}-\mathrm{X} 13$ & 7.95 & 372 & 149 & 176 \\
\hline $06 / 12 / 88$ & $\mathrm{MBr}-\mathrm{X} 13$ & 7.97 & 380 & 145 & 196 \\
\hline $06 / 13 / 88$ & $\mathrm{MBr}-\mathrm{X} 13$ & 7.95 & 371 & 142 & 174 \\
\hline $06 / 14 / 88$ & $\mathrm{MBr}-\mathrm{X} 13$ & 8.08 & 352 & 110 & 170 \\
\hline $06 / 15 / 88$ & $\mathrm{MBr}-\mathrm{X} 13$ & 7.97 & 352 & 134 & 170 \\
\hline 06/09/88 & WOC-X14 & 8.06 & 419 & 99 & 136 \\
\hline $06 / 10 / 88$ & WOC-X14 & 8.21 & 352 & 115 & 152 \\
\hline
\end{tabular}


Table 3.8 (continued)

\begin{tabular}{|c|c|c|c|c|c|}
\hline Date & Site & $\mathrm{pH}$ & $\begin{array}{l}\text { Conductivity } \\
(\mu \mathrm{S} / \mathrm{cm})\end{array}$ & $\begin{array}{c}\text { Alkalinity } \\
\left.(\mathrm{mg} / \mathrm{L} \text { as } \mathrm{CaCO})_{3}\right)\end{array}$ & $\begin{array}{c}\text { Hardness } \\
\left(\mathrm{mg} / \mathrm{L} \text { as } \mathrm{CaCO}_{3}\right)\end{array}$ \\
\hline $06 / 11 / 88$ & WOC-X14 & 8.11 & 361 & 110 & 154 \\
\hline $06 / 12 / 88$ & woc-X14 & 8.07 & 391 & 112 & 174 \\
\hline $06 / 13 / 88$ & woc-X14 & 8.0 .2 & 455 & 107 & 164 \\
\hline $06 / 14 / 88$ & WOC-X14 & 8.07 & 362 & 135 & 168 \\
\hline $06 / 15 / 88$ & WOC-X14 & 8.07 & 470 & 105 & 204 \\
\hline 08/25/88 & Control & 7.82 & 81 & 34 & 40 \\
\hline $08 / 26 / 88$ & Control & 7.85 & 79 & 32 & 42 \\
\hline $08 / 27 / 88$ & Control & 8.05 & 82 & 33 & 42 \\
\hline 08/28/88 & Control & 8.14 & 83 & 32 & 38 \\
\hline $08 / 29 / 88$ & Control & 8.19 & 83 & 34 & 38 \\
\hline $08 / 30 / 88$ & Control & 7.94 & 73 & 32 & 42 \\
\hline $08 / 31 / 88$ & Control & 7.95 & 83 & 35 & 40 \\
\hline $08 / 25 / 88$ & $\mathrm{MBr}-\mathrm{X} 13$ & 7.96 & 335 & 122 & 156 \\
\hline $08 / 26 / 88$ & $\mathrm{MBr}-\mathrm{X} 13$ & 7.94 & 322 & 130 & 152 \\
\hline $08 / 27 / 88$ & $\mathrm{MBr}-\mathrm{X} 13$ & 8.09 & 349 & 130 & 184 \\
\hline $08 / 28 / 88$ & $\mathrm{MBr}-\mathrm{X} 13$ & 8.12 & 350 & 130 & 164 \\
\hline $08 / 29 / 88$ & $\mathrm{MBr}-\mathrm{X} 13$ & 8.08 & 324 & 119 & 158 \\
\hline 08/30/88 & $\mathrm{MBr}-\mathrm{X} 13$ & 7.99 & 320 & 124 & 164 \\
\hline $08 / 31 / 88$ & $\mathrm{MBr}-\mathrm{X} 13$ & 8.03 & 349 & 130 & 158 \\
\hline $08 / 25 / 88$ & WOC-X14 & 8.01 & 493 & 107 & 204 \\
\hline $08 / 26 / 88$ & WOC-X14 & 7.98 & 336 & 110 & 136 \\
\hline $08 / 27 / 88$ & WOC-X14 & 8.07 & 394 & 112 & 176 \\
\hline 08/28/88 & WOC-X14 & 8.14 & 355 & 106 & 150 \\
\hline $08 / 29 / 88$ & WOC-X14 & 8.21 & 405 & 119 & 170 \\
\hline $08 / 30 / 88$ & WOC-X14 & 8.13 & 374 & 123 & 204 \\
\hline 08/31/88 & WOC.X14 & 8.08 & 373 & 116 & 156 \\
\hline
\end{tabular}

${ }^{\mathrm{a}} \mathrm{MBr}=$ Melton Branch; WOC = White Oak Creek; WCK = White Oak Creek kilometer.

Note: Data are shown for grab samples collected daity during each toxicity test period. In the January test, controls consisted of dechlorinated tap water; in all other tests, controls used diluted mineral water. 


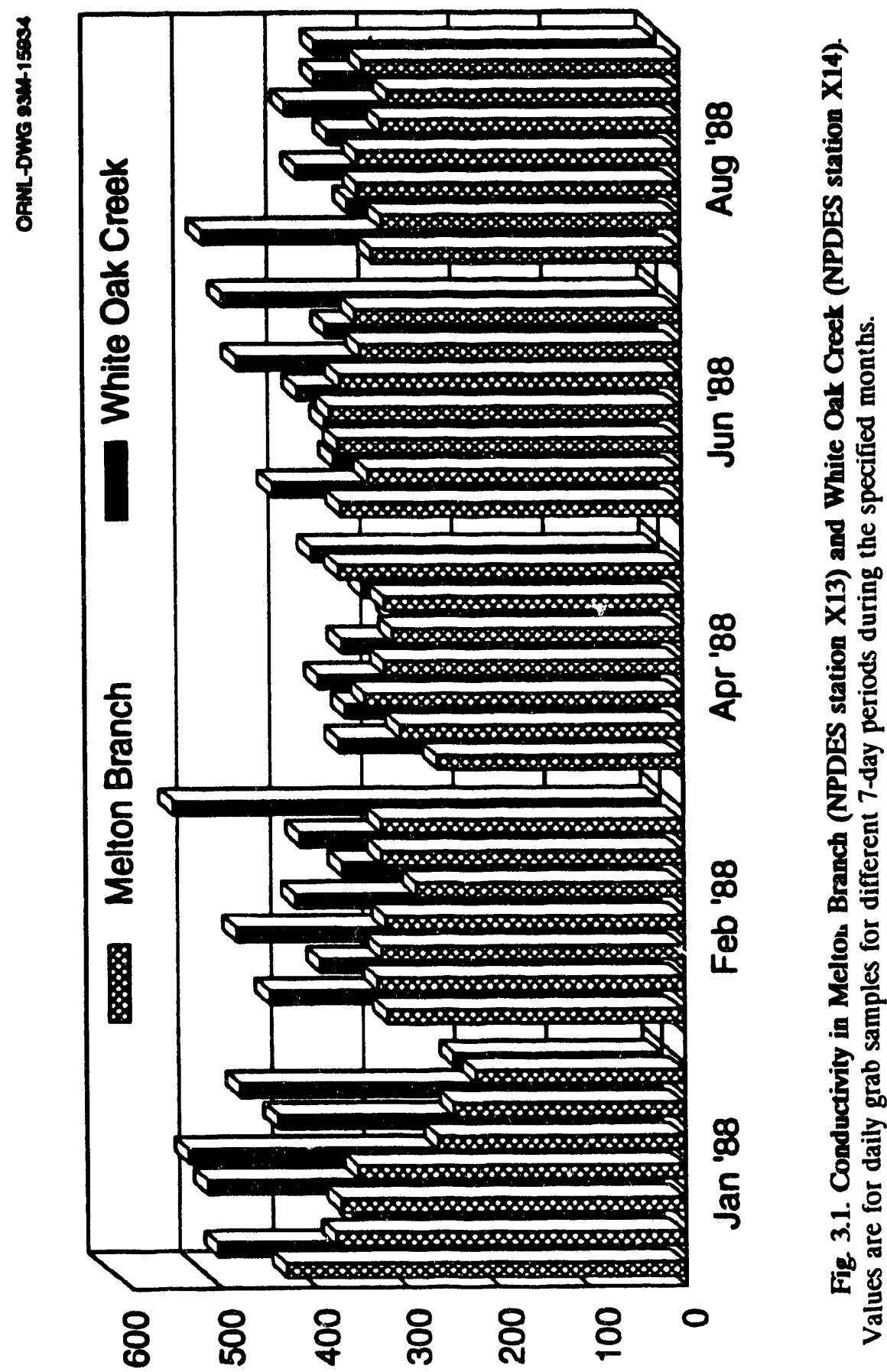




\section{ALKALINITY TO HARUNESS RATIOS}

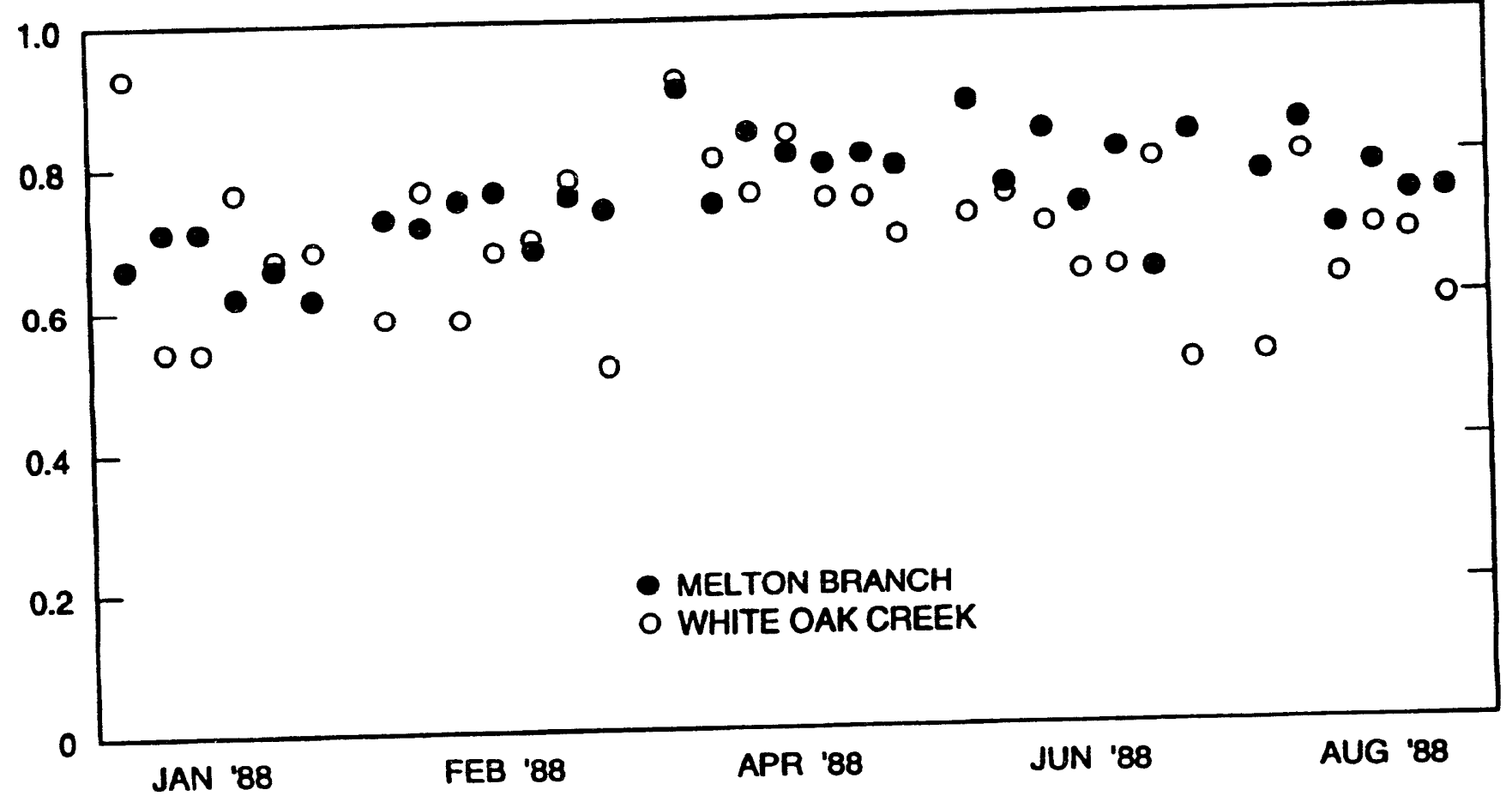

Fig. 3.2 Alkalinity to hardness ratios for water samples from Melton Branch (NPDES station X13 and White Oak Creek (NPDES station X14). Values are for daily grab samples for different 7-day periods d:ring the specified months (specific dates are given in Table 3.8 of this document. 
then tested for acute and chronic toxicity to Ceriodaphnia. The samples collected on the first day of the test were used throughout the 7-d static-renewal test. Survival of Ceriodaphnia was $100 \%$ in the controls and in each concentration of water from both tributaries. Using all 10 replicates, average fecundity of Ceriodaphnia tested in water from each of the sites was high ( $>16$ offspring per female) relative to the controls (14.9 offspring per female), and fecundity of Ceriodaphnia tested in water from East Tributary was about $25 \%$ higher than that of Ceriodaphnia tested in water from West Tributary. However, within-treatment variation in fecundity tended to be higher than usual in the controls and in fullstrength water from West Tributary. When only the seven most fecund animals in each sample were compared, the number of offspring per female in water from West Tributary was virtually identical to that in the control, while the fecundity of Ceriodaphnia in water from East Tributary exceeded that in the controls by about $18 \%$ ("able 3.9). Hence, there wa: proba $y$ a real difference in the biological quality of water in the two streams, but no evidence for acute or chronic toxicity was found for either stream.

\subsubsection{Special Studies}

Two special studies addressing different aspects of point-source contributions to ambient toxicity in WOC were completed during 1988. The first study was designed by $\mathrm{C}$. $\mathrm{K}$. Valentine of the ORNL Environmental and Health Protection Division (EHPD) and A. J. Stewart and L. A. Kszos (ORNL/ESD) and focused on problems associated with the use of chlorine to control fecal coliform bacteria at the ORNL STP. Although this study was funded by the ORNL Plant and Equipment Division (PED), it is included here because the information is relevant to other ambient toxicity studies.

The second study was designed by $\mathrm{L}$. A. Kszos and focused on the chronic toxicity of salts that are commonly present in various treated wastewaters. More specifically, this study evaluated chronic toxicity of low concentrations of two salts $\left(\mathrm{NaC1}\right.$ and $\left.\mathrm{CaSO}_{4}\right)$ to Ceriodaphnia in full life-cycle tests. The study was conducted to

Table 3.9. Mean survival and fecundity ( \pm 1 SD) of Ceriodaphnia in water from East Tributary and West Tributary near Oak Ridge National Laboratory Solid Waste Storage Area 6

\begin{tabular}{llll}
\hline & & \multicolumn{2}{c}{ Fecundity (offspring/female) } \\
\cline { 3 - 4 } Sample/concentration & Survival $(\%)$ & All replicates & 7 best replicates \\
\hline Control & 100 & $14.9 \pm 9.6$ & $20.6 \pm 3.6$ \\
East Tributary, 100\% & 100 & $21.8 \pm 4.7$ & $24.3 \pm 2.9$ \\
East Tributary, 50\% & 100 & $21.5 \pm 5.0$ & $24.3 \pm 2.4$ \\
West Tributary, 100\% & 100 & $16.2 \pm 8.3$ & $20.4 \pm 4.4$ \\
West Tributary, 50\% & 100 & $17.1 \pm 5.0$ & $18.9 \pm 5.0$ \\
\hline
\end{tabular}

Note: Controis consisted of animals reared in diluted mineral water. The test was conducted during December 8-15, 1988. 
improve our understanding of relationships between "chronic" toxicity, as measured in 7-d tests, and "chronic" toxicity caused by longer exposure regimes. The experiments used calcium sulfate as a model salt because it is a primary constituent of the effluent from the CYRTF. This salt is formed from the neutralization of the acidic coal wastes by addition of lime and is a major constituent of many wastewater treatment systems.

\subsubsection{Sewage treatment plant-chlorine- use reduction experiment}

Chlorine is normally added to the STP effluent to reduce the number of fecal coliform bacteria (FCB) that are discharged to WOC. However, the STP sometimes incurred TRC noncompliances when too much chlorine was added and FCB noncompliances when too little chlorine was added (W. K. Simon, ORNL/PED, and C. K. Valentine, ORNL/EHPD, personal communication). Greater amounts of chlorine also increased the toxicity of the STP effluent to Ceriodaphnia and fish. Consequently, an experiment was conducted to evaluate the feasibility of reducing the use of chlorine at the STP.

The three-part study, which was approved by the TDHE, was conducted during August 1-15, 1988. During August $1-5$, the STP was operated normally so baseline data could be collected on FCB and TRC concentrations in the STP effluent and in WOC upstream and downstream from the STP outfall (Tables 3.10 and 3.11). During August 8-10, no chlorine was added to the STP effluent. Samples of effluent and of water from WOC downstream of the STP outfall were collected to determine the maximum likely FCB loading to WOC (Tables 3.12 and 3.13). Finally, during August 11-15, chlorine was added to the STP ef ?iseist but at a low, constant feed rate. Effluent and water samples from WOC at the USGS gaging station near WCK 3.41, approximately $100 \mathrm{~m}$ below the STP outfall, were collected to determine whether the lower-than-normal chlorine feed rates could produce an effluent with a satisfactorily low number of FCB (Tables 3.14 and 3.15).

The results of the STP chlorination study can be summarized as follows:

1. Analyses of samples from WOC just above the STP, at WCK 2.65, and at White Oak Dam indicated that FCB were already present in low numbers ( $<1$ to 290 colonies per $100 \mathrm{~mL}$ ) throughout much of lower WOC. This level of FCB "contamination" is typical of. streams that serve as wildlife habitat.

2. Normal chlorine feed rates (i.e., the rate based on flow in order to maintain a positive residual) and low, constant feed rates markedly lowered the number of FCB in the STP effluent (Tables 3.10 and 3.15).

3. When chlorine was not added to the effluent, the number of FCB in WOC downstream from the STP outfall did not increase greatly (Table 3.12). Two reasons could account for this finding. First, FCB are rapidly deactivated and killed by exposure to sunlight and by the lower concentrations of nutrients and suitable organic substrates. Second, chlorine concentrations in WOC near the STP outfall are already elevated (Tables 3.11 and 3.13) and may be high enough to deactivate or kill living FCB released to the receiving stream.

Adding chlorine to the STP waste stream substantially reduces the number of FCB discharged to WOC but may be more detrimental than advantageous environmentally. Disadvantages of chlorination include (1) greater risk of effluent toxicity violations; (2) production 
Table 3.10. Fecal coliform bacteria (colonies per $100 \mathrm{~mL}$ ) in Sewage Treatment Plant (STP) effluent and at four sites on White Oak Creek

\begin{tabular}{|c|c|c|c|c|c|c|c|}
\hline \multirow{2}{*}{ Sampling Site } & \multicolumn{2}{|c|}{ Aug. 1} & \multicolumn{2}{|c|}{ Aug. 3} & \multicolumn{2}{|c|}{ Aug. 5} & \multirow{2}{*}{ Mean } \\
\hline & A.M. & P.M. & A.M. & P.M. & A.M. & P.M. & \\
\hline STP $^{a}$, pre-chlor. & 56 & $>600$ & 400 & 700 & 330 & 300 & $>398$ \\
\hline STP, post-chlor. & $<1$ & $<1$ & $<2$ & $<1$ & $<1$ & $<1$ & $<1$ \\
\hline WOC above STPb & $<1$ & 10 & $<1$ & 14 & 120 & 20 & $<28$ \\
\hline WCK $3.41^{\circ}$ & 30 & 30 & 4 & $>60$ & 50 & 70 & $>40$ \\
\hline WCK $2.65^{d}$ & 100 & 30 & 60 & 53 & 290 & 130 & 110 \\
\hline WCK $1.0^{\circ}$ & 8 & 10 & 20 & 4 & 20 & 130 & 32 \\
\hline
\end{tabular}

aSewage Treatment Plant, pre- and post-chlorination sites.

${ }^{b}$ White Oak Creek, $10 \mathrm{~m}$ above the STP outfall.

'White Oak Creek (WOC) at White Oak Creek kilometer (WCK) 3.41 (USGS gaging station

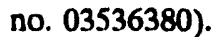

WOC at WCK 2.65 (NPDES site X-14).

'WOC at WCK 1.0 (NPDES site X-15).

Note: Morning and afternoon samples from the six sites were collected on August 1, 3, and 5, 1988 to establish baseline numbers of bacteria under normal operating conditions (i.e., before the feed-rate of chlorine at the STP was reduced).

Table 3.11. Total residual chlorine in Sewage Treatment Plant (STP) effluent and at four sites on White Oak Creek (WOC)

\begin{tabular}{|c|c|c|c|c|c|c|c|}
\hline \multirow{2}{*}{ Sampling Site } & \multicolumn{2}{|c|}{ Aug. 1} & \multicolumn{2}{|c|}{ Aug. 3} & \multicolumn{2}{|c|}{ Aug. 5} & \multirow{2}{*}{ Mean } \\
\hline & A.M. & P.M. & A.M. & P.M. & A.M. & P.M. & \\
\hline STP, pre-chlor. & 0 & $\mathbf{0}$ & 0 & 0 & $\mathbf{0}$ & 0 & 0 \\
\hline STP, post-chlor. ${ }^{b}$ & 0.09 & 0.02 & 0.10 & 0.04 & 0.18 & 0.07 & 0.08 \\
\hline WOC above STPc & 0.11 & 0.05 & 0.13 & 0.06 & 0.06 & 0.04 & 0.08 \\
\hline WCK $3.41^{d}$ & 0.04 & $\mathbf{0}$ & 0.05 & 0 & 0.02 & 0.04 & 0.03 \\
\hline WCK $2.65^{\circ}$ & 0 & $\mathbf{0}$ & 0 & 0 & 0 & 0 & 0 \\
\hline WCK 1.0 & 0 & 0 & 0 & 0 & 0 & 0 & 0 \\
\hline
\end{tabular}

${ }^{a}$ Expressed in milligrams per liter.

'Pre-chlorination and post-chlorination sites relative to the STP.

'White Oak Creek (WOC) at a puint $10 \mathrm{~m}$ above the STP outfall.

WOC at the USGS gaging station (03536380) at White Oak Creek kilometer (WCK) 3.41.

WOC at NPDES site X-14 (WCK 2.65).

WOC at NPDES site X-15 (WCK 1.0) (outfall of White Oak Lake).

Note: Morning and afternoon samples from the six sites were collected on August 1, 3, and 5, 1988 to establish baseline TRC concentrations under normal operating conditions (i.e., before the feed-rate of chlorine at the STP was reduced). 
Table 3.12 Fecal coliform becteria (colonies per $100 \mathrm{~mL}$ ) in Sewage Treatment Plant (STP) effluent and at four sites on White Oak Creek (WOC)

NS $=$ Not sampled

\begin{tabular}{|c|c|c|c|c|c|c|c|c|c|}
\hline \multirow{2}{*}{ Sampling Site } & \multicolumn{3}{|c|}{ Aug. 8} & \multicolumn{3}{|c|}{ Aug. 9} & \multicolumn{3}{|c|}{ Aug. 10} \\
\hline & A.M. & Noon & P.M. & A.M. & Noon & P.M. & A.M. & Noon & P.M. \\
\hline STP effluent & NS & $>600$ & $>6000$ & 3100 & 3000 & 5600 & 1600 & 1100 & 3400 \\
\hline WOC above STP & NS & $<1$ & 20 & $<1$ & $<1$ & 10 & $<1$ & $<1$ & 10 \\
\hline WCK $3.41^{b}$ & NS & 50 & 32 & $<1$ & 40 & 200 & 44 & 500 & 56 \\
\hline WCK $2.65^{c}$ & NS & 80 & 150 & 40 & 52 & 10 & 80 & 30 & 10 \\
\hline WCK $1.0^{d}$ & NS & 10 & 1 & 10 & 5 & $<1$ & $<1$ & 20 & $<1$ \\
\hline
\end{tabular}

Sample taken at a point $10 \mathrm{~m}$ above the STP outfall.

'Sample taken at the USGS gaging station (03536380) at White Oak Creek kilometer (WCK) 3.41.

'Sample taken at NPDES site X14 (WCK 2.65).

'Sample taken at NPDES site X15 at the outfall of White Oak Lake (WCK 1.0) after chlorine additions ceased.

Table 3.13. Tota iesidual chlorine concentrations (in milligrams per liter) in Sewage Treatment Plant (STP) effluent and at four sites on White Oak Creek (WOC)

NS $=$ Not sampled

\begin{tabular}{|c|c|c|c|c|c|c|c|c|c|}
\hline \multirow{2}{*}{ Sampling Site } & \multicolumn{3}{|c|}{ Aug. 8} & \multicolumn{3}{|c|}{ Aug. 9} & \multicolumn{3}{|c|}{ Aug. 10} \\
\hline & A.M. & Noon & P.M. & A.M. & Noon & P.M. & A.M. & Noon & P.M. \\
\hline sTP effluent & NS & 0.00 & 0.00 & 0.00 & 0.00 & 0.00 & 0.00 & 0.00 & 0.00 \\
\hline WOC above STPa & NS & 0.10 & 0.08 & 0.28 & 0.21 & 0.10 & 0.11 & 0.18 & 0.10 \\
\hline WCK $3.41^{\circ}$ & NS & 0.08 & 0.04 & 0.09 & 0.05 & 0.01 & 0.04 & 0.09 & 0.03 \\
\hline WCK $2.65^{\circ}$ & NS & 0.00 & 0.00 & 0.00 & 0.00 & 0.00 & 0.01 & 0.00 & 0.00 \\
\hline WCK $1.0^{d}$ & NS & 0.00 & 0.00 & 0.00 & 0.00 & 0.00 & 0.00 & 0.00 & 0.00 \\
\hline
\end{tabular}

"Sample taken at a point $10 \mathrm{~m}$ above the STP outfall.

'Sample taken at the USGS gaging station (03536380) at White Oak Creek kilometer (WCK) 3.41 .

'Sample taken at NPDES site X14 (WCK 2.65).

'Sample taken at NPDES site X15 at the outfall of White Oak Lake (WCK 1.0) after chlorine additions ceased. 
Table 3.14. Fecal wo lform bacteria (colonies per $100 \mathrm{~mL}$ ) in Sewage Treatment Plant (STP) efiluent (pre- and post-chlorination sites) and in White Oak Creek at the USG:, gaging station (03536380) at WCK 3.41 after low-level feed rates of chlorine resumed on August 11

NS $=$ Not sampled

\begin{tabular}{|c|c|c|c|c|c|c|c|c|c|}
\hline \multirow{2}{*}{ Sampling Site } & \multicolumn{3}{|c|}{ Aug. 11} & \multicolumn{3}{|c|}{ Aug. 12} & \multicolumn{3}{|c|}{ Aug. 15} \\
\hline & A.M. & Noon & P.M. & A.M. & Noon & P.M. & A.M. & Noon & P.M. \\
\hline STP, pre-chlor. & NS & 800 & 2800 & 280 & 303 & 1220 & 44 & 1200 & NS \\
\hline STP, post-chlor. & NS & $<1$ & $<1$ & 20 & $<5$ & $<5$ & $<1$ & $<1$ & NS \\
\hline WCK 3.41 & NS & 22 & 31 & $<5$ & 20 & 39 & 60 & 60 & NS \\
\hline
\end{tabular}

Note: WCK $=$ White Oak Creek kilometer.

Table 3.15. Total residual chlorine concentrations (in milligrams per liter) in Sewage Treatment Plant (STP) effluent (pre- and post-chlorination sites) and in White Oak Creek at the USGS gaging station (03536380) at WCK 3.41 after low-level feed rates of chlorine resumed on August 11 NS $=$ Not sampled

\begin{tabular}{|c|c|c|c|c|c|c|c|c|c|}
\hline \multirow{2}{*}{ Sampling Site } & \multicolumn{3}{|c|}{ Aug. 11} & \multicolumn{3}{|c|}{ Aug. 12} & \multicolumn{3}{|c|}{ Aug. 15} \\
\hline & A.M. & Noon & P.M. & A.M. & Noon & P.M. & A.M. & Noon & P.M. \\
\hline STP, pre-chlor. & NS & 0.00 & 0.00 & 0.00 & 0.00 & 0.00 & 0.00 & 0.00 & NS \\
\hline STP, post-chlor. & NS & $0.25^{a}$ & 0.03 & 0.03 & 0.02 & 0.03 & 0.06 & 0.10 & NS \\
\hline WCK 3.41 & NS & 0.00 & 0.03 & 0.03 & 0.06 & 0.01 & 0.02 & 0.05 & NS \\
\hline
\end{tabular}

aAt $\sim 1005 \mathrm{~h}$, the chlorine feed rate was erroneously adjusted to provide an effluent residual concentration of $0.25 \mathrm{mg} / \mathrm{L}$ rather than a contact concentration of $0.25 \mathrm{mg} / \mathrm{L}$; the feed-rate was adjusted to the correct level later that afternoon. WCK $=$ White Oak Creek kilometer.

of mutagenic and/or carcinogenic chlorination products (Ward 1974, Marouka and Jamanaka 1980; GuttmanBass et al. 1987); (3) augmentation of chlorine concentrations in WOC where concentrations are already high enough to be of environmental concern; (4) possibility of accruing violations in permitted levels of chlorine in the STP effluent while trying to maintain a low but positive TRC level in the effluent; and (5) increased risk of a major chlorine release to WOC through inadvertent failure at the chlorine contact unit of the STP. Although the discharge of nonchlorinated STP effluent appears environmentally sound based on data reported here, this may be because chlorine levels in a mid-reach segment of WOC are already high enough to be efforts are currently underway to reduce inputs of chlorinated once-through cooling water to WOC, it may not be advisable to depend on instream chlorine levels to reduce the number of FCB that could be discharged from the STP.

The STP has an average discharge rate of about $10 \mathrm{~L} / \mathrm{s}$ (Table 2..3) compared to an average daily flow in WDC of about $114 \mathrm{~L} / \mathrm{s}$ at WCK 3.9 above the STP. Thus, during normal flow conditions, the STP 
effluent is diluted to about $8 \%$ of fullstrength after complete mixing in the receiving stream. A limit for $\mathrm{FCB}$ of 200 colonies per $100 \mathrm{~mL}$ has been recommended as an upper limit for recreational waters (EPA 1976). Based on dilution only, concentrations of FCB in the STP effluent would have to exceed 1500 colonies per $100 \mathrm{~mL}$ to yield an instantaneous instream concentration that could exceed this upper limit. Because the numbers of FCB in the STP effluent just upstream from the chlorine contact unit are sometimes higher and sometimes lower than this 1500 -per-100 $\mathrm{mL}$ threshold, some method of reducing the number of FCB in the STP effluent before it is discharged to WOC would be advantageous.

Adding chlorine to the STP effluent at a low, constant feed rate (about 0.25 $\mathrm{mg} / \mathrm{L}$ in the chlorine contact chamber yields a chlorine residual in the effluent of $0.02-0.06 \mathrm{mg} / \mathrm{L}$ ) is sufficient to reduce the number of FCB in the STP effluent. The use of a low, constant feed rate of chlorine is also advantageous because it is easily maintained and produces an effluent that is unlikely to contain chlorine at a concentration high enough to cause either TRC or toxicity noncompliances.

\subsubsection{Toxicity of $\mathrm{CaSO}_{4}$ and $\mathrm{MgSO}_{4}$ in Ceriodaphnia life-cycle test}

Effluent toxicity tests can provide information that can be used by (1) regulatory agencies to establish effluent discharge limits suitable for protecting biota in receiving waters, and (2) wastewater treatment operators to improve biological quality of a wastewater treatment facility's effluent. Regulatory decisions regarding the suitability of a wastewater for discharge should consider the following factors:

1. the effluent release pattern (e.g., batch vs continuous),
2. the amount of dilution available in the receiving stream,

3. the nature of the materials contributing to an effluent's toxicity

(e.g., persistent vs temporary compounds and the potential for bioaccumulation), and

4. features unique to the receiving stream that could affect its capacity to assimilate the toxicants without serious adverse effects (e.g., presence of rare or endangered species, inputs of other wastewaters, or unusual physicochemical conditions, such as temperature, hardness, alkalinity, or $\mathrm{pH})$.

It is also important to consider the sensitivity of the toxicity test system relative to the degree of protection that is desired for a particular receiving stream.

Various kinds of extrapolations, each with an attendant degree of uncertainty, are usually needed to estimate the overall environmental risk. The types of extrapolation may include (1) estimates of chronic toxicity from the results of acute toxicity tests, (2) estimates of life-cycle effects from the results of short-term (e.g., 7-d) chronic toxicity tests, and (3) estimates of ecological effects from tested to untested species groupings (cf. Suter et al. 1983, 1987, Barnthouse and Suter 1986). The reliability of the individual extrapolations obviously should be verified whenever possible in order to reduce the overall error associated with estimates of risk made from toxicity test results.

Effluent toxicity reduction evaluations conducted under the Y-12 Plant TCMP and toxicity tests of pure salts sponsored by the Y-12 Plant Development Division have shown that compounds such as sodium sulfate, sodium bicarbonate, and sodium and calcium chloride are toxic to Ceriodaphnia at low to moderate concentrations (Taylor et al. 1988). Such salts are major constituents of many 
wastewaters, including those released by the CYRTF at OHNL. The 7-d (or 3brood) Ceriodaphnia test is rapidly gaining acceptance as a reliable, sensitive procedure for estimating chronic toxicity of effluents. However, little information is yet available as to the reliability of extrapolating effects from 7-d Ceriodaphnia tests to life-cycle tests, simply because few Ceriodaphnia full life-cycle tests have been conducted.

Full life-cycle tests have been done with Daphnia pulex, a cladoceran microcrustacean that is similar to Ceriodaphnia but slightly larger (Daniels and Allan 1981). When D. pulex was exposed to sublethal concentrations of dieldrin (a pesticide), the total number of offspring produced during its lifetime declined, but the reduction was due more to reduced survival than to reduced fecundity. The mean number of offspring per brood, for example, was nearly constant (10.7 to 12.0 offspring per brood), but mean longevity declined by nearly $90 \%$ (from 37.5 to $3.4 \mathrm{~d}$ ) as the concentration of dieldrin increased to $200 \mu \mathrm{g} / \mathrm{L}$ (Daniels and Allan 1981). In contrast, demographic studies of Ceriodaphnia in the absence of toxicants have shown that mean brood size increases with age of the mother (at least up to and including the seventh brood)(Cowgill et al. 1985). Finally, a chemical perturbation that temporarily delayed production of first broods could markedly influence interpretation of a test whose endpoint is the number of offspring produced in just $7 \mathrm{~d}$, even though a 1-day delay in brood production could be biologically trivial or statistically indetectable in the context of a full lifecycle test.

Life-cycle tests of Ceriodaphnia dubia exposed to various concentrations of calcium sulfate and magnesium sulfate were used to address several of the considerations above. Pure calcium sulfate $\left(\mathrm{CaSO}_{4}\right)$ was tested at $10.3,308,615$, and $1230 \mathrm{mg} / \mathrm{L}$, and pure magnesium sulfate was tested at 425,850 , and $1700 \mathrm{mg} / \mathrm{L}$. A control (pure well/spring water) was included with each test. Each $\mathrm{CaSO}_{4}$ or $\mathrm{MgSO}_{4}$ corcentration was tested with 50 animals; each animal served as an independent replicate. The tests used procedure: identical to those used in a standard 7-d test (e.g., the test solutions were rencwed daily; each animal was fed daily; and daily observations were made to determine survival and the number of offspring produced). Results of the $\mathrm{CaSO}_{4}$ test, which are directly pertinent to CYRTF operations, are summarized in Table 3.16, and results of the $\mathrm{MgSO}_{4}$ test are summarized in Table 3.17.

Fundamental differences in response patterns of Ceriodaphnia to the two neutral salts were evident (cf. Table 3.16 vs Table 3.17) but are not discussed here because $\mathrm{MgSO}_{4}$-rich wastewaters are not discharged to WOC or its tributaries.

Based on $95 \%$ confidence intervals for fecundity of the controls, the $\mathrm{CaSO}_{4}$ "detection limit" for Ceriodaphnia dubia did not vary much with test duration. For successive 7-d periods, for example, the interpolated "detection limit" (NOEC) in the life-cycle test was $345,418,315,147$, and 208 milligrams of $\mathrm{CaSO}_{4}$ per liter. The mean $( \pm 1 \mathrm{SD})$ interpolated fecunditybased "detection limit" was $287 \pm$ $109 \mathrm{mg}$ of $\mathrm{CaSO}_{4}$ per liter. The mean interpolated concentration of $\mathrm{CaSO}_{4}$ needed to reduce fecundity by $50 \%$ (based on multiple 7-d periods) was $433 \pm 87$ milligrams of $\mathrm{CaSO}_{4}$ per liter. Thus, a $\mathrm{CaSO}_{4}$ concentration of about $300 \mathrm{mg} / \mathrm{L}$ can be detected fairly consistently using the Ceriodaphnia test. Moreover, these findings indicate that the effects of $\mathrm{CaSO}_{4}$ at concentrations that exceed about $300 \mathrm{mg} / \mathrm{L}$ are both statistically significant and 
Table 3.16. Mean percent survival (S) and fecundity $(F=$ the number of oftapring per surviving females mean \pm 1 SD) of Ceriodaphria dubia in a life cycle test with varioes concentrations of calcium sulfote

Fifty neona'es were used to test each concentration of CaSO,

\begin{tabular}{|c|c|c|c|c|c|c|c|c|c|c|}
\hline \multirow{2}{*}{$\begin{array}{l}\text { Cind } \\
\text { concentration } \\
(\mathrm{mg} / \mathrm{L})\end{array}$} & \multicolumn{2}{|r|}{$7 d$} & \multicolumn{2}{|r|}{$14 d$} & \multicolumn{2}{|r|}{$21 \mathrm{~d}$} & \multicolumn{2}{|r|}{$28 \mathrm{~d}$} & \multicolumn{2}{|r|}{$35 \mathrm{~d}$} \\
\hline & $\mathbf{S}$ & $\mathbf{F}$ & $\mathbf{S}$ & $\mathbf{F}$ & $\mathbf{S}$ & $\mathbf{F}$ & $\mathbf{S}$ & $\mathbf{F}$ & $\mathbf{S}$ & $\mathbf{F}$ \\
\hline$\sigma^{\infty}$ & 90 & $16.6 \pm 3.1$ & 84 & $48.2 \pm 10.6$ & 72 & $74.1 \pm 15.8$ & 26 & $98.6 \pm 18.3$ & 22 & $1263 \pm 195$ \\
\hline 10.3 & 86 & $15.4 \pm 3.9$ & 80 & $43.3 \pm 10.4$ & 60 & $64.5 \pm 17.6$ & $\mathbf{2 8}$ & $72.9 \pm 24.9$ & 18 & $813 \pm 35.4$ \\
\hline 308 & 94 & $10.8 \pm 3.8$ & 76 & $31.4 \pm 8.4$ & 54 & $42.9 \pm 127$ & 40 & $49.2 \pm 14.8$ & 36 & $68.5 \pm 21.6$ \\
\hline 615 & 86 & $7.1 \pm 1.7$ & 78 & $19.7 \pm 7.2$ & 58 & $32.5 \pm 15.3$ & 44 & $37.4 \pm 16.9$ & 22 & $46.0 \pm 16.6$ \\
\hline 1230 & 56 & $24 \pm 1.7$ & 34 & $7.6 \pm 5.1$ & 20 & $18.6 \pm 13.0$ & 12 & $18.7 \pm 26$ & 6 & $24.7 \pm 1.2$ \\
\hline
\end{tabular}

Well/spring water had a hardness of $182 \pm 13 \mathrm{mg} \mathrm{CaCO} / \mathrm{L}$ (mean $\pm 1 \mathrm{SD} ; n=31$ ). A single ICP scan of wellspring water showed a calcium concentration of $52 \mathrm{mg} / \mathrm{L}$ and a magnesium concentration of $17 \mathrm{mg} / \mathrm{L}$. 
Table 3.17. Mean percent survival (S) and fecundity (F a the number of oftipring per surviving female; mean \pm 1 SD) of Ceriodaphria dubia in a life-cycle test with various concentrations of magesesium sulfite

\begin{tabular}{|c|c|c|c|c|c|c|}
\hline \multirow{2}{*}{$\begin{array}{l}\mathrm{MgSO}_{4} \\
\text { concentration } \\
(\mathrm{mg} / \mathrm{L})\end{array}$} & \multicolumn{2}{|r|}{$7 d$} & \multicolumn{2}{|r|}{$14 d$} & \multicolumn{2}{|r|}{$21 d$} \\
\hline & $\mathbf{s}$ & $\mathbf{F}$ & $\mathbf{S}$ & $\mathbf{F}$ & $\mathbf{S}$ & $\mathbf{F}$ \\
\hline $0^{n}$ & 72 & $17.6 \pm 5.3$ & 46 & $78.1 \pm 16.0$ & 30 & $129.1 \pm 25.2$ \\
\hline 425 & 96 & $16.2 \pm 5.6$ & 80 & $59.4 \pm 19.6$ & 38 & $102.4 \pm 41.5$ \\
\hline 850 & 90 & $11.1 \pm 6.1$ & 76 & $49.8 \pm 22.9$ & 32 & $88.3 \pm 38.6$ \\
\hline 1700 & 34 & $3.4 \pm 3.5$ & 16 & $28.8 \pm 22.3$ & $2^{b}$ & 59.0 \\
\hline
\end{tabular}

biologically meaningful. They also show that the results of a 7-d Ceriodaphnia test can (at least for $\mathrm{CaSO}_{4}$ ) be used to reliably extrapolate to effects of the salt measured for a full life-cycle test.

Fifteen 7-d toxicity tests were conducted from July 1986 through January 1988 , and the overall mean hardness of the CYRTF effluent was $1495 \mathrm{mg}$ of $\mathrm{CaCO}_{3}$ per liter (computed using 7-d means for each toxicity test period). This amount of hardness could be accounted for by $2033 \mathrm{mg}$ of $\mathrm{CaSO}_{4}$ per liter. Over about the same time period, the mean concentration of sulfate in the CYRTF effluent was $1463 \mathrm{mg} / \mathrm{L}$ (Rogers et al. 1988b). This amount of sulfate, if associated with only calcium, could account for $2074 \mathrm{mg}$ of $\mathrm{CaSO}_{4}$ per liter.

Additionally, a solution made by dissolving $100 \mathrm{mg}$ of pure $\mathrm{CaSO}_{4}$ into one liter of pure water has a conductivity of about $170 \mu \mathrm{S} / \mathrm{cm}$. The estimated average effluent (about $2050 \mathrm{mg} / \mathrm{L}$ ) is sufficient to account for all of the effluent's conductivity (mean of $2136 \mu \mathrm{S} / \mathrm{cm}$, based on the 7-d means for 14 toxicity test periods).

The striking similarity in the two independent estimates of the $\mathrm{CaSO}_{4}$ concentration of the CYRTF effluent (one based on hardness measurements and the other on sulfate measurements) and the fact that the effluent's conductivity is less than that predicted from the amount of $\mathrm{CaSO}_{4}$ present suggests that virtually all of the effluent's toxicity to Ceriodaphnia could be due to $\mathrm{CaSO}_{4}$. The fecundity reductions in Ceriodaphnia life-cycle tests with pure $\mathrm{CaSO}_{4}$ indicate that, on average, this effluent would be toxic at a concentration of about 15\% ("detection limit" of $300 \mathrm{mg} / \mathrm{L}$ vs mean concentration of $2050 \mathrm{mg}$ of $\mathrm{CaSO}_{4}$ per liter). Based on 11 Ceriodaphnia toxicity tests (Loar 1992b, Table 3.1; Table 3.1 this report), CYRTF effluent had an average NOEC of $23 \%$. Hence, predicted toxicity based on the $\mathrm{CaSO}_{4}$ content of the effluent closely approximates the effluent's measured toxicity. Thus, the toxicity of the CYRTF effluent can probably be attributed almost exclusively to $\mathrm{CaSO}_{4}$.

The average discharge of the CYRTF is $1.0 \mathrm{~L} / \mathrm{s}$ (Table 2.3 ), and the average discharge of the receiving stream (WOC) near the CYRTF outfall is about $114 \mathrm{~L} / \mathrm{s}$ (at WCK 3.9; see Table 2.2). Thus, the average instream waste concentratic $a$ of 


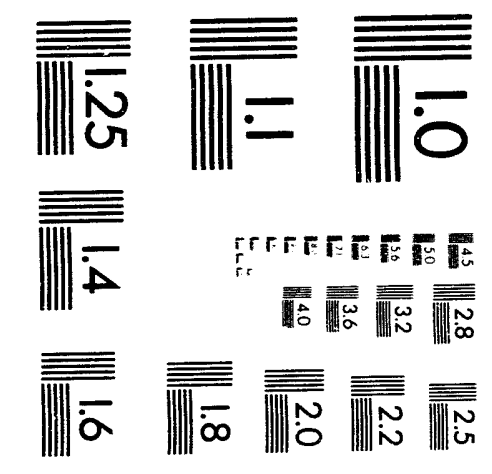



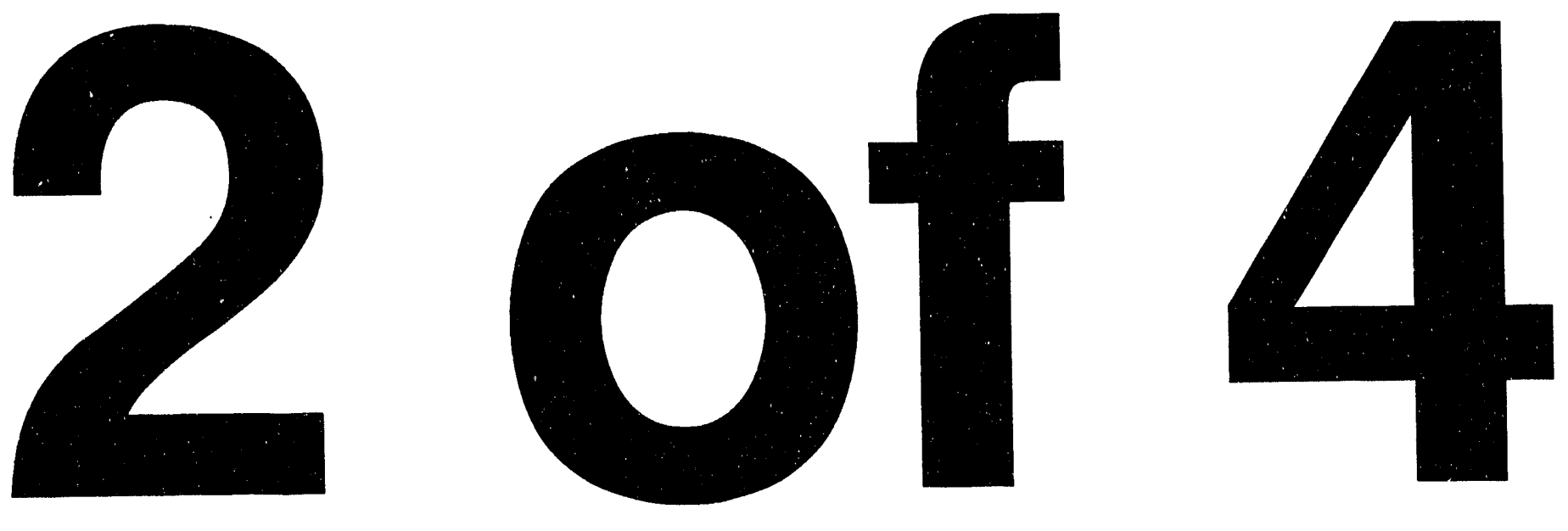
the CYRTF is only $0.9 \%$, which suggests a safety factor as high as $16-20 \times$. However, the flow at WCK 3.9 is variable

$(\mathrm{CV}=86 \%$, Table 2.2$)$, as is the discharge of effluent from the CYRTF. [E.g., maximum discharge is $9.6 \mathrm{~L} / \mathrm{s}$ (Table 2.3).] With an average flow at WCK 3.9 and higher discharge rates at the CYRTF, the safety factor could be reduced to less than two. Additionally, wastes from the Acid Neutralization Facility (X11; average flow of $1.8 \mathrm{~L} / \mathrm{s}$ ) may ultimately be treated and released by the CYRTF (Sect. 2.2.2).

The low safety factor between present discharge patterns and possible impacts on instream communities (based on results of the Ceriodaphnia effluent tests and full life-cycle tests with calcium sulfate) indicate that effluent from the CYRTF could be at least intermittently problematic. Operations at this facility should be evaluated carefully before a decision is made to treat wastewaters from outfall X11 at the CYRTF.

Instream conductivity measurements made in conjunction with exceedancefrequency analyses could be used to more accurately predict the probability of instream toxicity for different waste treatment scenarios. The major difficulty with this approach is the uncertainty associated with extrapolating from the effects of the effluent on Ceriodaphnia in laboratory tests to its effects on biota in the receiving stream. However, temporal variability in chemical composition of the CYRTF effluent is relatively low, and the effluent's toxicity appears to be dominated by a single compound $\left(\mathrm{CaSO}_{4}\right)$ that is both persistent yet only moderately toxic. Therefore, the experiments needed to definitively establish the reliability of extrapolations from Ceriodaphnia test results to effects on stream communities would be relatively simple. Because neutral salts, such as $\mathrm{CaSO}_{4}$, are present at moderate to high concentrations in various wastewaters at all three DOE Oak Ridge facilities, such studies might be beneficial.

\subsubsection{Future Studies}

Water from the 15 sites used to evaluate spatiotemporal patterns in ambient toxicity at ORNL will be tested quarterly (in May, August, and November 1989, and in February 1990) with Ceriodaphnia and fathead minnow larvae, as stipulated in the ORNL BMAP (Loar et al. 1991). This relatively low level of monitoring is believed to be sufficient because little overall improvement in ambient conditions is likely until inputs of TRC to Fifth Creek, First Creek, and WOC are controlled.

Toxicity tests and chemical analyses showed that water quality in Melton Branch improved markedly after the HFIR was shut down in November 1986 (Loar $1992 \mathrm{~b})$. When the reactor is restarted, monitoring efforts at NPDES sites X13 (Melton Branch) and X14 (WOC) will be increased to adequately document changes in stream water quality attributable either to the restart of HFIR or to changes in the effluent discharged to Melton Branch as wastewaters from the HFIR-TRU process waste basins (outfall X09) are diverted to the Nonradiological Wastewater Treatment Facility (NRWTF). The NRWTF is not expected to go on line until March 1990. As an interim measure, however, wastewaters that later will be treated at the NRWTF may be diverted to WOC.

Short-term experiments will be used to evaluate persistence of TRC in water from various sites in WOC. Data obtained from these studies should be useful operationally and may provide insight into 
how TRC concentrations should be interpreted toxicologically. It remains unclear, for example, why TRC at a concentration of 0.10 to $0.15 \mathrm{mg} / \mathrm{L}$ is toxic in some water samples but not in others. Differences in the rate at which TRC is reduced may account for the differences in TRC toxicity that are measured using static-renewal test procedures.

The BMAP outlines studies to evaluate sediment toxicity at 20-25 sites using growth of Elodea (Loar et al. 1991, pp. 54-55). Toxicity data obtained during the first three years of biological monitoring, however, suggest that testing ORNL stream sediments for toxicity would not be informative. If sediments are toxic, for example, the greatest levels of toxicity should occur in depositional areas (e.g., in ponded areas behind the weirs at NPDES sites X13 and X14 and at WCK 3.4). At each of these sites, growth of submersed aquatic plants is high $(\mathrm{H}$. L. Boston, ORNL/ESD, personal communication and Sect. 8.2 of this report). Preliminary tests have also shown that shoot and root growth of Elodea is extremely variable among replicates. The Elodea test (or any other plant-growth test) is, therefore, unlikely to provide meaningful information. Because the sediments in the depositional areas are also contaminated with radionuclides (e.g., ${ }^{137} \mathrm{Cs},{ }^{60} \mathrm{Co}$, and ${ }^{90} \mathrm{Sr}$ ), they are less satisfactory to work with for reasons of human health. Accordingly, sediment tests will not be conducted and are deferred indefinitely.

\subsection{IN-STREAM MONITORING OF THE PERIPHYTON COMMUNITY}

\section{H. L. Boston and W. R. Hill}

Periphyton is a complex matrix of algae and heterotrophic microbes attached to submersed surfaces that serves as a major food source for many stream invertebrates (Minshall 1978) andherbivorous fishes (Power et al. 1985). The biotic activity and organic content of the periphyton can result in concentration of certain contaminants (e.g., $\mathrm{Hg}$ and $\mathrm{Cd}$ ) within the periphyton matrix (Huckabee and Blaylock 1973, Selby et al. 1985). Thus, periphyton becomes important to both the natural functioning of aquatic systems and to the food chain transfer of contaminants entering these systems. Turnover rates on the order of days for the biotic components of the periphyton make this community especially useful for detecting short-term environmental changes (e.g., infrequent pulses of toxicants that might not be detectable when considering organisms with longer life spans).

Periphyton, therefore, can be used to (1) characterize biological communities, (2) evaluate contaminant transport and food chain accumulation, (3) identify sources and frequencies of toxicant entry into the system, and (4) predict and evaluate biotic responses to remedial action measures.

To date, efforts have largely addressed the algal component of the periphyton, measuring biomass and primary production (as short-term photosynthetic rates) of algae on rock surfaces in riffles. Temporal and spatial patterns in algal biomass and production provide information on (1) the biotic community at each site, (2) the health or condition of these communities, and (3) the structure and dynamics of the stream system for the various reaches. Data on biomass and production were used to develop analytical techniques for evaluating the physiological state or "health" of the algal periphyton. To describe two potentially important environmental regulators of periphyton, discrete water quality samples were collected in conjunction with the monthly collection of periphyton (Sect. 2.2.4), and light 
availability was measured at each site. The taxonomic composition of the algal assemblages was also determined.

\subsubsection{Methods}

To monitor algal periphyton biomass and photosynthetic rates, small rocks with their associated periphyton were collected monthly from ten sites in WOC watershed and from nearby Ish Creek (Fig. 3.3). The periphyton sampling sites largely coincided with the fish and invertebrate sampling stations (cf. Figs. 2.2 and 2.3). Five sites receive drainage or are downstream from ORNL effluent discharges (WCK 3.9, WCK 3.4, WCK 2.9, WCK 2.3, and MEK 0.6). The other five sites are all located above ORNL [WCK 6.8, MEK 1.8, NTK 1.0 (Northwest Tributary), FCK 1.0 (First Creek), and FFK 1.1 (Fifth Creek)] and, along with Ish Creek, are used as reference sites.

\subsubsection{Periphyton characterization}

Three or four small rocks were collected from riffles in each study area on four dates. The rocks were taken to the laboratory where the periphyton was removed by brushing, using a tooth brush. A subsample of the periphyton removed from the rocks was filtered (Whatman GF$F$, glass fiber filter), and then the filter was divided for determination of Chlorophyll $a$ (Chl $a$ ), adenosine triphosphate (ATP), dry weight $\left(48 \mathrm{~h}\right.$ at $\left.70^{\circ} \mathrm{C}\right)$, and ash-free dry matter (AFDM, as determined after dry ashing for $3 \mathrm{~h}$ at $500^{\circ} \mathrm{C}$. Methods for Chl $a$ and ATP analyses are presented below. Data were expressed per unit rock upper surface area (see below). A subsample of the periphyton was preserved in Lugol's solution for later determination of algal taxonomic composition.

\subsubsection{Periphyton chlorophyll and carbon incorporation}

To determine algal periphyton biomass and production, four small (10- to $60-\mathrm{cm}^{2}$ ) relatively flat rocks were collected monthly from shallow ( $<25-\mathrm{cm}$ deep) riffle areas at each site. The rocks were taken to the laboratory in water from the collection site. In the laboratory, rocks from each site were incubated for $2 \mathrm{~h}$ in water from the collection site containing $10 \mu \mathrm{Ci}$ $\mathrm{NaH}^{14} \mathrm{CO}_{3}$. During the incubation, the water temperature was maintained within $2^{\circ} \mathrm{C}$ of ambient stream temperature. Approximately $400 \mu \mathrm{mol} \mathrm{m}^{-2} \mathrm{~s}^{-1}$ of photosynthetically active radiation or PAR ( $\sim 16 \%$ full sun) was provided by a 1000 W metal halide lamp, and the water in the incubation chambers was circulated by submersible pumps to simulate natural conditions. After incubation, the rocks were rinsed twice in distilled water to remove residual inorganic ${ }^{14} \mathrm{C}$ and then placed in $30 \mathrm{ml}$ of dimethylsulfoxide (DMSO) and kept in darkness for $24 \mathrm{~h}$ to extract soluble organic compounds and chlorophyll (Shoaf and Lium 1976, Palumbo et al. 1987). Five $\mathrm{mL}$ of extract was diluted 1:1 with $90 \%$ acetone, and the $\mathrm{Chl} a$ content was determined spectrophotometrically using the equations of Jeffrey and Humphrey (1975).

Corrections were made for phaeopigments Strickland and Parsons 1972). A 500- $\mu \mathrm{L}$ aliquot of the extract was added to $10 \mathrm{~mL}$ of Aquasol (scintillation cocktail), and the ${ }^{14} \mathrm{C}$ in the aliquot was determined by liquid scintillation spectrometry.

The surface area of each rock was determined by covering the upper surface 


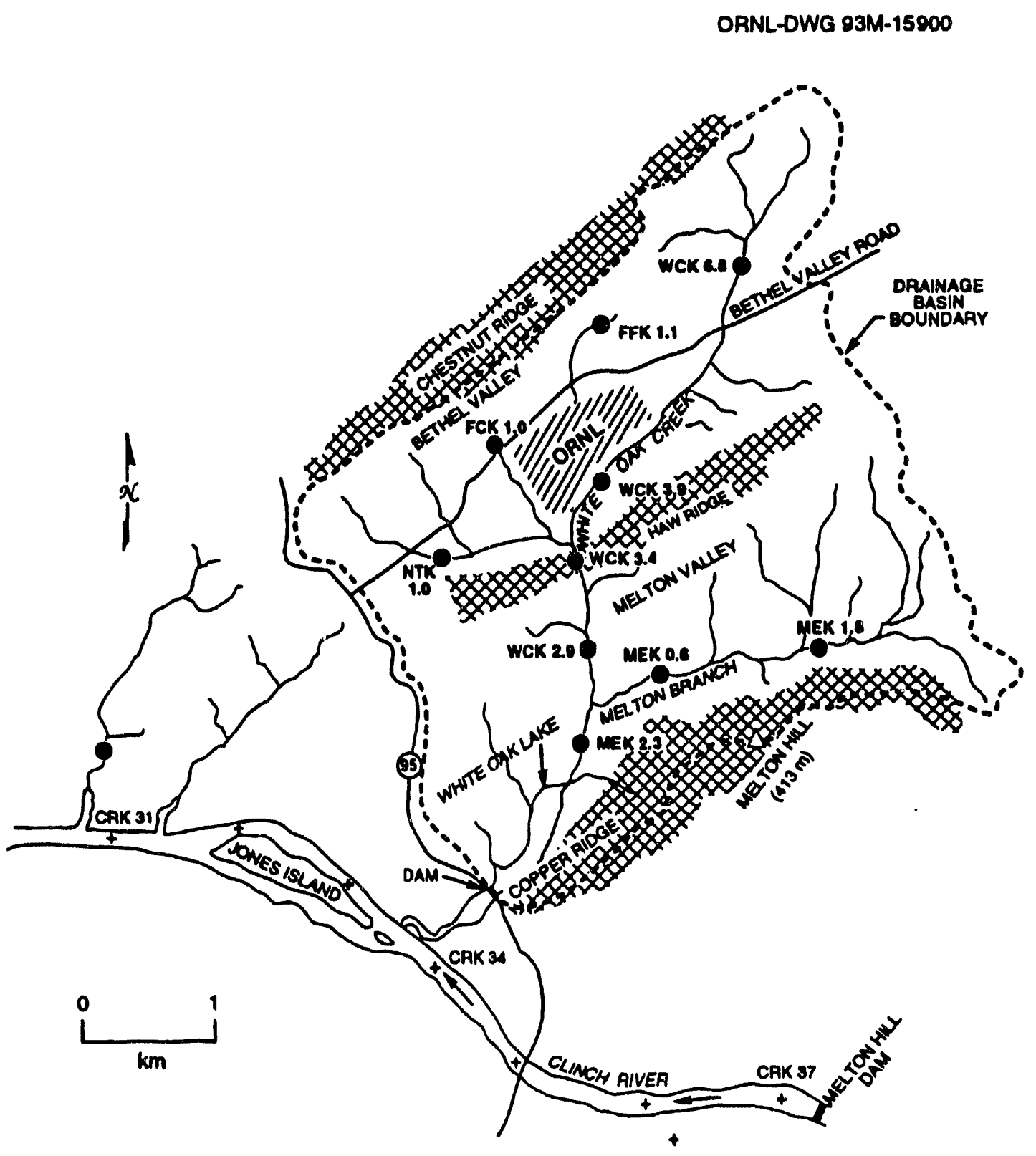

Fig. 3.3. Periphyton monitoring sites in the White Oak Creek watershed. 
with aluminum foil, determining the weight of the foil, and converting to surface area based on a known weight per unit area of foil. This procedure was repeated twice for each rock. Chl $a$, the rate of carbon incorporation, and ATP were then expressed on a surface area basis.

\subsubsection{Periphyton ATP}

ATP was determined by assaying an aliquot of DMSO extract (Shoaf and Lium 1976) using Lumac reagents and a Lumac Biocounter integrating photometer. Phosphate was added to the DMSO to obtain a final concentration of about 20 $\mathrm{mM} / \mathrm{L}$ prior to extraction in order to prevent loss of ATP to phosphatase activity (Palumbo et al. 1987).

\subsubsection{Special Studies}

\section{Periphyton colonization/development study}

Ceramic tiles attached to bricks were placed at several sites to determine the rate of periphyton accumulation (colonization and growth). Four bricks with 24 unglazed $5.3-\mathrm{cm}^{2}$ ceramic tiles were placed at FCK 1.0, FFK 1.1, WCK 6.8, WCK 3.9, WCK 3.4, WCK 2.3, and MEK 0.6 on June 22, 1988. Beginning 3 weeks after placement and continuing weekly thereafter for 6 weeks, 1 tile was randomly selected from each brick and placed in DMSO to extract Chl $a$ and thus provide an estimate of algal biomass (as described for the monthly sampling program). On each date, a fifth tile was selected from each site, and the periphyton was brushed from the surface and preserved in Lugol's solution for the later examination of algal taxonomic composition.

\section{Algal colonization and accumulation at a chlorine-impacted site}

Ceramic tiles were placed at WCK 6.8 and WCK 3.4 for an initial "conditioning" (i.e., colonization by algae and microbes). These tiles, along with new tiles, were then placed at WCK 3.9, and the accumulation of $\mathrm{Chl} a$ on the tiles was determined after 12 and $20 \mathrm{~d}$, as described previously.

As a second component of this experiment, 26 small flat rocks (10- to $50-\mathrm{cm}^{2}$ upper surface area) were collected from a shallow riffle at WCK 3.9. Much of the periphyton was removed from 13 of these rocks by brushing with a tooth brush. The remaining 13 rocks were placed in a $2.5 \%$ hypochlorite solution (50\% commercial bleach) overnight to sterilize the rocks. Four rocks from each group were selected for initial measurement of $\mathrm{Chl} a$ per unit surface area as described previously. The remaining rocks were put into a wire screen basket (open at the top) and placed in a riffle at WCK 3.9. Four rocks from each group were collected on 12 and $20 \mathrm{~d}$ after placement, and the Chl $a$ per unit area was measured.

\section{Evaluation of controls on algal growth}

Porous, artificial substrates (clay pots) were used to evaluate the influence of nutrient enrichment; grazer exclusion; and their combination on algal colonization, accumulation, and primary production at several sites in the WOC watershed. Four sets of small clay pots (3-in diam flower pot bases) filled with (1) agar only; (2) agar amended with nutrients $(0.5 \mathrm{M}$ $\mathrm{KH}_{2} \mathrm{PO}_{4}$ and $0.5 \mathrm{M} \mathrm{NaNO}$ ); (3) agar amended with insecticide $(0.26 \%$ concentrated commercial grade Malathion); and (4) agar amended with both nutrients and insecticide were placed at WCK 6.8, 
WCK 3.4, and FFK 1.1. An additional set of agar-only and nutrient-amended pots were elevated above the substratum at WCK 6.8 to exclude snails, as a mechanical rather than chemical grazer-exclusion experiment. Snails were removed by hand from the elevated pots at least once a day, and the total number of snails present on all pots was recorded each day. Sets of pots with a lower $(0.026 \%)$ and higher $(2.6 \%)$ concentration of the insecticide were also placed at WCK 6.8. At all sites one pot from each treatment group, including agaronly pots, was randomly placed within one of four blocks. After $34 \mathrm{~d}$ in the field, the pots were retrieved, and $\mathrm{Chl} a$ per unit surface area and photosynthetic carbon uptake were measured, as described for rocks collected monthly from these sites.

\subsubsection{Results and Discussion}

\subsubsection{Site characterization}

Ozalid paper light meters (Friend 1961) were used at all sites (except Northwest Tributary) to obtain an integrated measure of light over a 24-h period on September 7, 1988. Large differences in the amount of light available for periphyton photosynthesis were quantified by these meters (Table 3.18). Canopy cover at most sites reduced PAR to $10 \%$ or less of full sunlight, suggesting that limited light may be a major factor at these sites. Light was abundant at WCK 3.9, however, where the absence of riparian vegetation allowed large amounts of light to reach the stream surface. Data on other physical habitat variables (e.g., current velocity and mean depth) are presented in Sect. 2.3 for the fish and benthic invertebrate sampling sites, which coincide with most of the periphyton sampling sites.

\subsubsection{Periphyton characterization}

Concentrations of Chl $a$ and ATP in the periphyton brushed from rock surfaces were generally higher at the downstream sites than the upstream sites (Table 3.19), reflecting increased biological activity. However, substantial periphyton biomass accumulated at FFK 1.1, as evidenced by the data for Chl $a$, ATP, and AFDM.

Periphyton dry weight reflected the contributions of organisms, detritus, and inorganic material on rock surfaces. It was low at reference sites WCK 6.8 and FCK 1.0 , where grazing and low nutrients kept biomass low, and little inorganic material accumulated. Inorganic material (silt) contributed substantially to periphyton biomass at MEK 1.8, NTK 1.0, WCK 2.3, and MEK 0.6.

Data on percentage of organic content (or the AFDM as a percentage of dry weight) are useful for grouping sites. Because sites WCK 3.9, WCK 3.4, and WCK 2.9 tended to have high biomass (Chl $a$ and ATP) and little silt accumulation, the periphyton matrix had a high percentage of organic content (typically $>60 \%$ ). Sites far downstream (WCK 2.3 and MEK 0.6) had a low percentage organic content (typically 20 to $30 \%$ ) -as a result of substantial siltation-and a large fraction of diatoms $(\mathrm{AFDM}=25-60 \% \mathrm{Si})$ among the periphyton. In general, reference sites also had a low organic fraction, due to either an abundance of diatoms (FFK 1.1) or siltation (MEK 1.8 and NTK 1.0). At WCK 6.8 and FCK 1.0, intense grazing pressure on the periphyton selected for green algae, which have a higher organic content than diatoms, and resulted in an intermediate percentage of organic content for the periphyton at those sites.

The DMSO extraction procedure is more effective than brushing for removing 
Table 3.18. Integrated $(24 \mathrm{~h})$ light at periphyton sampling sites on September 7, 1988

\begin{tabular}{lc}
\hline Site & $\begin{array}{c}\text { PAR } \\
E \cdot m^{-2} \mathbf{d}^{-1}\end{array}$ \\
\hline Ish Creek & 1.7 \\
FCK 1.0 & 1.0 \\
FFK 1.1 & 2.4 \\
WCK 6.8 & 3.8 \\
WCK 3.9 & 21.2 \\
WCK 3.4 & 2.1 \\
WCK 2.9 & 2.2 \\
WCK 2.3 & 1.0 \\
MEK 0.6 & 3.0 \\
Full Sun (Bldg. 1504) & 31.2 \\
\hline Note: PAR = photosynthetic active radiation, 400-700 nm; E = Einsteins, \\
FCK = First Creek kilometer; FFK = Fifth Creek kilometer; WCK = White \\
Oak Creek kilometer; MEK = Melton Branch kilometer.
\end{tabular}

ATP and Chl $a$ from the rock surfaces when little periphyton is present and organisms are closely appressed to the rock surfaces. Consequently, the data for $\mathrm{Chl} a$ and ATP obtained by DMSO extraction were used to compare periphyton among the study sites.

Distinct differences in taxonomic structure of algal assemblages existed between reference and impacted sites (Table 3.20). Algal assemblages at reference sites were dominated by diatoms and prostrate Stigeoclonium cells and filaments. The relative abundance of diatoms also increased in WOC with increasing distance downstream from ORNL, as shown at sites WCK 2.9 and WCK 2.3. A peculiar and characteristic unicellular, prostrate green alga dominated the periphyton in the toxic zone of WOC at WCK 3.9, where fish are absent and the benthos community consists of only a few pollution-tolerant taxa (see Sects. 6.1 and
6.2). This alga is also dominant in upper East Fork Poplar Creek (EFPC) within the Y-12 Plant where conditions (e.g., high light and high levels of chlorine and nutrients) are similar to those at WCK 3.9 (Loar 1992c). The alga persists to some degree downstream at WCK 3.4 but is diluted by prostrate cells/filaments of Stigeoclonium and some diatoms. Algal assemblages in First Creek consist primarily of stalked or filamentous diatoms that are not closely appressed to the substrate, possibly as a result of the absence of the grazing snail, Elimia, at this site.

\subsubsection{Monthly determination of algal periphyton biomass and productivity}

Periphyton Chl $a$ per unit area of rock surface provided a measure of algal biomass at each of the monitoring sites. 
Table 3.19. Characteristics of the periphyton brushed from rocks at ten sites in the White Oak Creek watershed and a site in Ish Creek

\begin{tabular}{|c|c|c|c|c|c|c|c|c|c|c|c|}
\hline & $\begin{array}{c}\text { WCK }^{\mathrm{R}} \\
6.8\end{array}$ & $\begin{array}{c}\text { FCK }^{R} \\
1.0\end{array}$ & $\begin{array}{c}\text { FFK }^{n} \\
1.1\end{array}$ & $\begin{array}{c}\text { MEK }^{\AA} \\
1.8\end{array}$ & $\begin{array}{c}\text { NTK }^{R} \\
1.0\end{array}$ & $\begin{array}{c}\text { Isk } \\
\text { Creek }\end{array}$ & $\begin{array}{c}\text { WCK } \\
3.9\end{array}$ & $\begin{array}{c}\text { WCK } \\
3.4\end{array}$ & $\begin{array}{c}\text { WCK } \\
2.9\end{array}$ & $\begin{array}{c}\text { WCK } \\
2.3\end{array}$ & MEK 0.6 \\
\hline \multicolumn{12}{|c|}{ Dry waight (mg/cm²) } \\
\hline Jan. & 0.95 & 0.18 & 3.8 & 1.2 & 1.6 & - & 1.5 & 1.2 & 0.95 & 6.2 & 2.8 \\
\hline Mar. & 0.79 & 0.34 & 3.5 & 2.5 & 0.77 & 0.26 & 4 & 1.5 & 2.9 & 2.9 & 1.8 \\
\hline May & 0.49 & 0.21 & 3.1 & 1.4 & - & 1.9 & 1.8 & 0.72 & 1.3 & 1.4 & 3.2 \\
\hline Mean & 0.74 & 0.24 & 3.5 & 1.7 & 1.2 & 1.1 & 2.4 & 1.1 & 1.7 & 3.5 & 2.6 \\
\hline \multicolumn{12}{|c|}{ Chloroplyyll a (ug/cmin) } \\
\hline Jan. & 1.2 & 0.4 & 13.7 & 1.8 & 0.9 & - & 20 & 19 & 8.7 & 13 & 5.3 \\
\hline Mar. & 0.48 & 0.48 & 3.1 & 5.8 & 0.71 & 0.16 & 35 & 9 & 10 & 24 & 3.4 \\
\hline May & - & 0.78 & 2.1 & - & - & 0.65 & 11 & 3.7 & 8.3 & 2.5 & 7.8 \\
\hline Mean & 0.84 & 0.55 & 6.3 & 3.8 & 0.81 & 0.41 & 22 & 10 & 9 & 13 & 5.5 \\
\hline \multicolumn{12}{|c|}{ ATP $\left(\mathrm{ng} / \mathrm{cm}^{2}\right)$} \\
\hline Jan. & 25 & 7.6 & 975 & 55 & 30 & - & 2239 & 1344 & 621 & 499 & 203 \\
\hline Mar. & 9 & 7.1 & 702 & 428 & 19 & $s$ & 1914 & 424 & 687 & 2336 & 363 \\
\hline May & 384 & 251 & 2495 & 461 & - & 245 & 14762 & 3101 & 9790 & 1603 & 42914 \\
\hline Mean & 139 & 88 & 1390 & 315 & 24 & 125 & 6305 & 1623 & 3699 & 1479 & 14493 \\
\hline \multicolumn{12}{|c|}{ AFDM (mg/cm²) } \\
\hline Jan. & 0.3 & 0.07 & 1.37 & 0.44 & 0.34 & - & 1.0 & 0.92 & 0.54 & 1.0 & 0.64 \\
\hline Mar. & 0.13 & 0.13 & 0.97 & 0.76 & 0.22 & 0.06 & 2.6 & 0.9 & 0.92 & 1.5 & 0.46 \\
\hline May & 0.31 & 0.09 & 0.76 & 0.32 & - & 0.33 & 1.5 & 0.45 & 0.87 & 0.34 & 0.72 \\
\hline Mean & 0.25 & 0.10 & 1.0 & 0.51 & 0.28 & 0.20 & 1.7 & 0.76 & 0.78 & 0.96 & 0.61 \\
\hline \multicolumn{12}{|c|}{ \% Organic content } \\
\hline Jan. & 26 & 38 & 36 & 36 & 23 & & 69 & 71 & 56 & 24 & 23 \\
\hline Mar. & 26 & 42 & 33 & 30 & 28 & 26 & 66 & 61 & 36 & 51 & 26 \\
\hline May & 56 & 42 & 24 & 21 & - & 22 & 78 & 63 & 65 & 26 & 21 \\
\hline Mean & 36 & 41 & 31 & 29 & 26 & 24 & 71 & 65 & 52 & 34 & 23 \\
\hline
\end{tabular}

Note: WCK $=$ White Oak Creek kilometer, FCK = First Creek kilometer; FFK = Fifth Creek kilometer; MEK = Melton Branch kilometer, NTK = Northwest Tributary kilometer. Samples were collected in January, March, and May 1988. $\mathrm{AFDM}=$ ash free dry matter. For all values, $n=3, \mathrm{R}=$ reference site. 
Table 3.20. Periphyton algal assemblages brushed from rocks Taxa listed in order of dominance

\begin{tabular}{|c|c|c|}
\hline Site & March 1, 1988 & May 31,1988 \\
\hline FCK 1.0 & $\begin{array}{l}\text { Stigeoclonium (prostrate) } \\
\text { Thin cyanophyte filament }\end{array}$ & Stigeoclonium (erect) \\
\hline FFK 1.1 & $\begin{array}{l}\text { Diatoms (mostly Gomphonema and } \\
\text { Meridion; some Achnanthes, Melosira, } \\
\text { and Fragilaria) }\end{array}$ & $\begin{array}{l}\text { Diatoms (Fragilaris, Synedra, } \\
\text { Gomphonema, Achnanthes) }\end{array}$ \\
\hline Ish Creek & $\begin{array}{l}\text { Diatoms (Cymbella, Gomphonema, } \\
\text { Meridion) }\end{array}$ & NS \\
\hline WCK 6.8 & $\begin{array}{l}\text { Mostly diatoms (Gomphonema and } \\
\text { Achnanthes) and Stigeoclonium } \\
\text { Some thin cyanophyte filaments }\end{array}$ & $\begin{array}{l}\text { Stigeoclonium filaments } \\
\text { Thin cyanophyte } \\
\text { Diatoms (Gomphonema) }\end{array}$ \\
\hline WCK 3.9 & $\begin{array}{l}\text { Small }(<5 \mu \mathrm{m}) \text { green unicells } \\
\text { A few diatoms (Achnanthes) }\end{array}$ & $\begin{array}{l}\text { Mostly small green unicells } \\
\text { Some Achnanthes } \\
\text { Few thin cyanophyte filaments } \\
\text { Few Stigeoclonium }\end{array}$ \\
\hline WCK 3.4 & $\begin{array}{l}\text { Stigeoclonium (prostrate) } \\
\text { Irregular round green cells } \\
\text { (Stigeoclonium basal cells?) }\end{array}$ & $\begin{array}{l}\text { Small green or blue-green } \\
\text { unicells } \\
\text { Stigeoclonium } \\
\text { A few diatoms }\end{array}$ \\
\hline WCK 2.9 & $\begin{array}{l}\text { Diatoms (mostly Achnanthes and } \\
\text { Minutissima; some Surirella and } \\
\text { Navicula) }\end{array}$ & $\begin{array}{l}\text { Diatoms }(<5 \mu \mathrm{m}) \text { (Achnanthes ?) } \\
\text { Small green or blue-green cells } \\
\text { Thin cyanophyte filament } \\
\text { Stigeoclonium }\end{array}$ \\
\hline WCK 2.3 & $\begin{array}{l}\text { Small diatoms }(<7 \mu \mathrm{m}) \text { (Achnanthes, } \\
\text { Surirella, Navicula) } \\
\text { Thin cyanophyte filament }\end{array}$ & $\begin{array}{l}\text { Diatoms (Cocconeis, Nitzschia, } \\
\text { Navicula, Melosira, Achnanthes) } \\
\text { Prostrate green (Stigeoclonium) }\end{array}$ \\
\hline MEK 0.6 & $\begin{array}{l}\text { Diatoms (Synedra, small Surirella, } \\
\text { Meridion) }\end{array}$ & $\begin{array}{l}\text { Diatoms (Synedra, Navicula, } \\
\text { Rhoicosphenia, Achnanthes, } \\
\text { Cocconeis, Surirella) }\end{array}$ \\
\hline
\end{tabular}

Note: NS = Not sampled. FCK = First Creek kilometer; FFK = Fifth Creek kilometer; WCK = White Oak Creek kilometer; MEK = Melton Branch kilometer.

The periphyton distribution was very patchy at WCK 3.9; it was not uncommon to find single rocks with thick periphyton coverings, while surrounding rocks were barren. To avoid both excessive variance and the analysis of many barren rocks, only rocks with some visible periphyton cover were collected. The data for WCK 3.9 represent average biomass and production on noticeably colonized rocks; as few as $1 \%$ of the rocks might have had obvious periphyton growth in a given month. These data are useful for evaluating the physiological condition of the algal periphyton at WCK 3.9 , but overestimate average biomass and production and underestimate variance.

Monthly mean $\mathrm{Chl} a$ and primary production at two sites (WCK 6.8 and WCK 2.3) are illustrated in Figs. 3.4 and 3.5 respectively. The annual pattern at these sites was generally representative of 

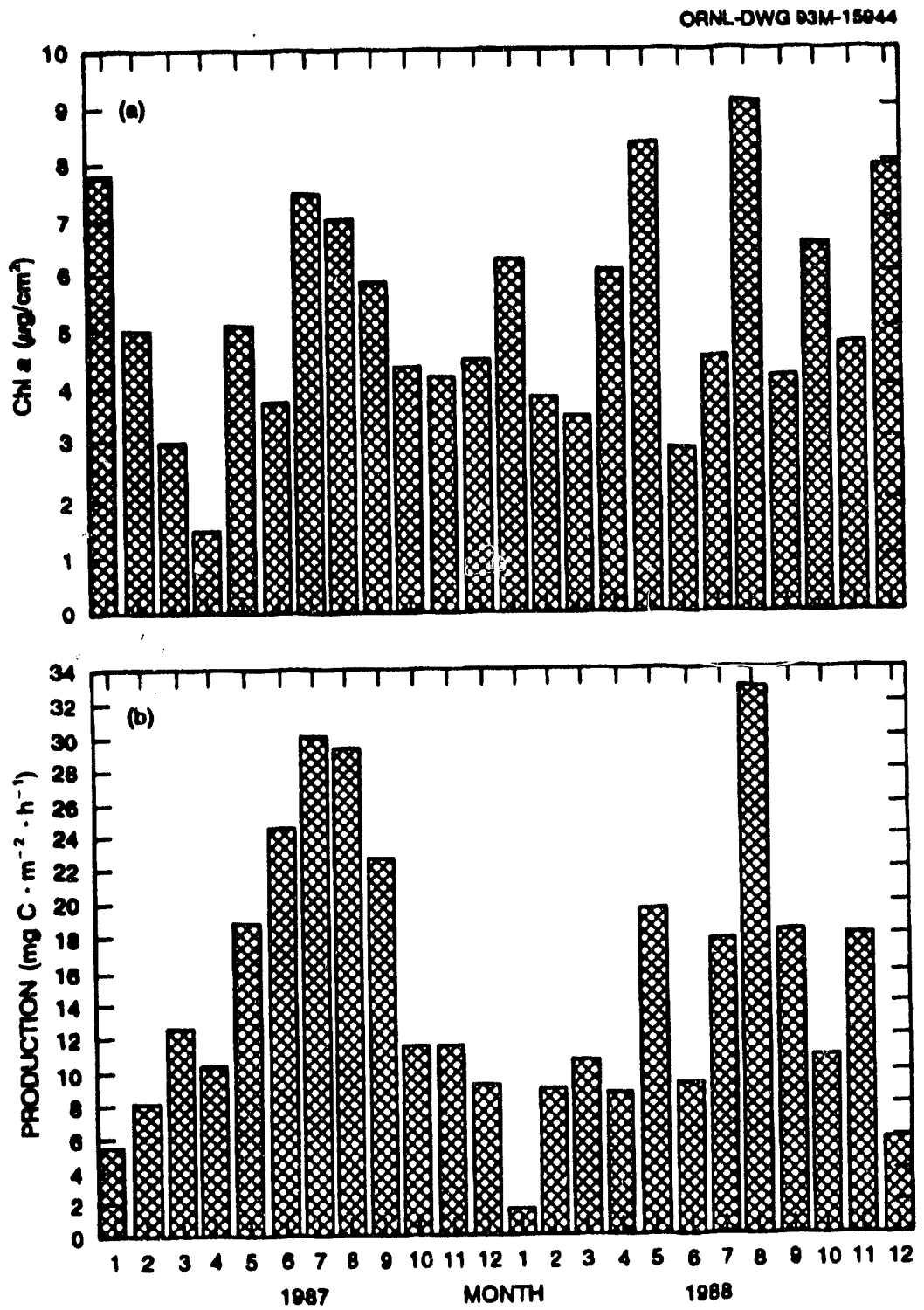

Fig. 3.4. (a) Periphyton chlorophyll a and (b) periphyton primary production, on small flat rocks in shallow riffle areas at reference site WCK 6.8 during 1987 and 1988. Values are means $\pm 1 S D, n=4$. 

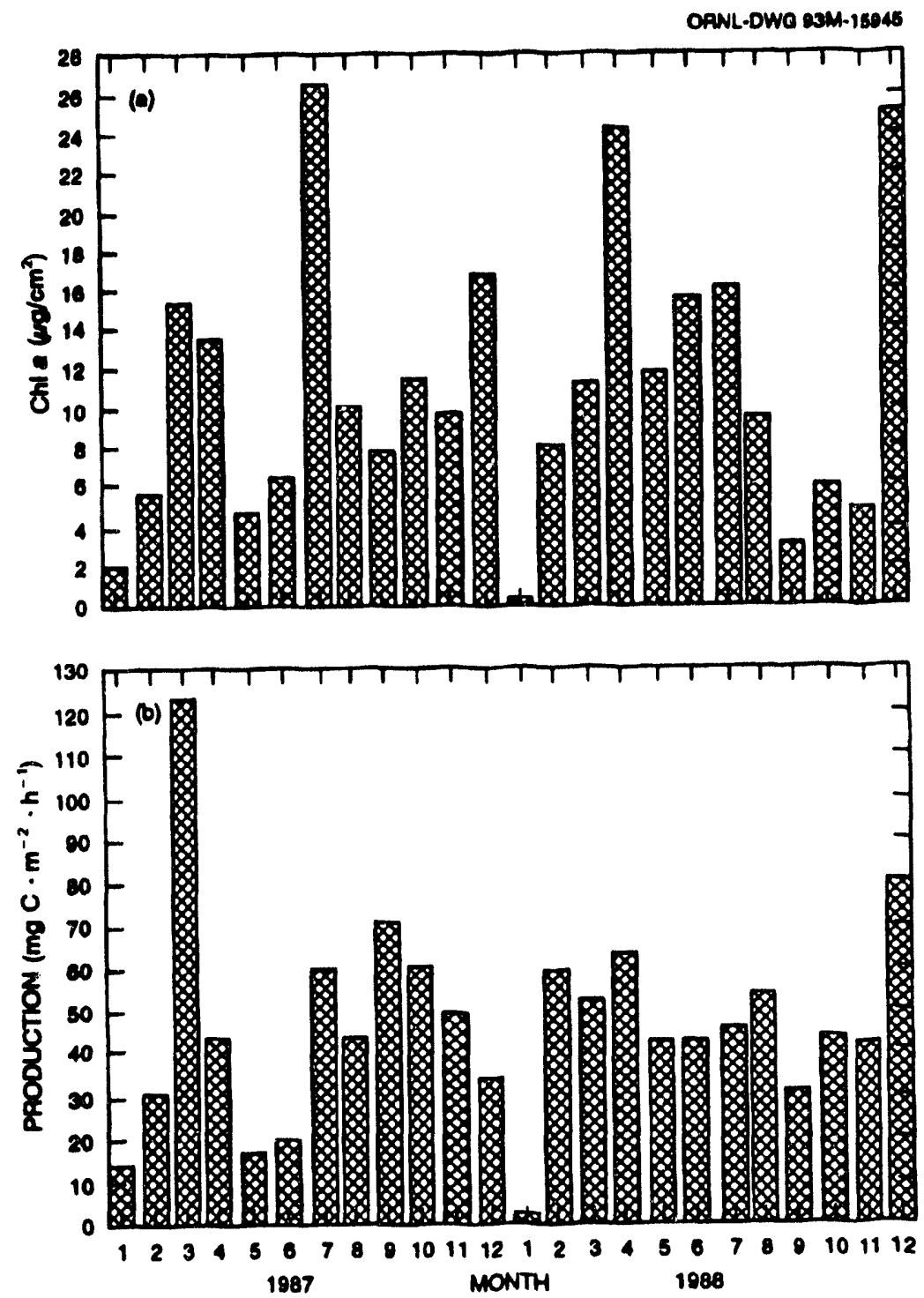

Fig. 3.5. (a) Periphyton chlorophyll a and (b) periphyton primary production, on small flat rocks in shallow riffle areas at downstream site WCK 23 during 1987 and 1988. Values are means $\pm 1 S D, n=4$. 
the patterns at other sites; in other words, there was substantial monthly variation in both parameters with a slight tendency toward higher production during the summer at WCK 6.8. Much of this variation was the result of floods. Flood effects tend to be site-specific, with downstream sites experiencing proportionately higher flows during floods than upstream sites. For example, severe rainstorms in January 1988 scoured periphytun biomass (as measured by $\mathrm{Chl} a$ ) to extremely low levels at the downstream site on WOC (WCK 2.3) but had little effect on biomass at the uppermost site (WCK 6.8). Interestingly, primary production at WCK 6.8 was very low in January 1988 despite normal biomass.

The average annual periphyton $\mathrm{Chl} a$ concentration in 1988 was generally similar to that in 1987 at all sites (Table 3.21).

The highest $\mathrm{Chl} a$ concentration was found at WCK 3.9, reflecting, in part, the selective sampling of rocks with high biomass. However, the highest individual values of chlorophyll also occurred at WCK 3.9, indicating that conditions were very favorable for the accrual of biomass on some rocks despite occasional chlorine toxicity. Site WCK 3.9 is characterized by high light levels, moderate to high nutrient levels, and no macroinvertebrate grazers. The site with the next highest mean annual Chl $a$ concentration was WCK 3.4, where light levels are moderate, nutrient levels are high, grazing macroinvertebrate abundance is low, and toxic conditions occur less frequently than at WCK 3.9. Downstream sites WCK 2.9 and WCK 2.3 had lower mean annual Chl $a$ concentrations despite high nutrients and limited grazing. These sites are heavily shaded by a well-developed canopy (Table 2.12), so the algae at these sites may be severely light-limited.

With the exception of FFK 1.1, the reference sites displayed low mean annual $\mathrm{Chl} a$ values. These sites are characterized by relatively low light levels, low nutrient concentrations, and, except for FFK 1.1, very high densities of grazing snails. The relatively high chlorophyll concentration at FFK 1.1 may testify to the importance of grazing snails in regulating algal biomass in streams on the ORR. Reference sites NTK 1.0 and MEK 1.8 were dry during summer. When water was flowing at these sites, however, chlorophyll values were typical of other shaded, low-nutrient sites.

Mean periphyton carbon incorporation rates generally followed the same pattern exhibited for algal periphyton biornass and sc were typically higher at the downstream sites (Table 3.22). Mean annual periphyton carbon incorporation rates in 1988 were similar to those in 1987 (Table 3.22). The sites tend to be grouped by water-column nutrient concentrations; that is, the downstream sites with higher nutrient levels had higher rates of primary production. Upstream site FFK 1.1 was an apparent exception to this pattern, having fairly high rates of carbon incorporation but nutrient concentrations that were only slightly higher than other reference sites. The higher-than-expected rates of primary production at FFK 1.1 may be related to the proximity of its groundwater source; groundwater provided elevated levels of carbon dioxide compared to other reference sites. Mean annual carbon incorporation rates at FFK 1.1 were similar to several downstream sites due, in part, to its relatively high $\mathrm{Chl} a$ per unit area.

The periphyton at WCK 3.4 had a lower rate of primary production than would be expected based on water chemistry and $\mathrm{Chl} a$ concentration. This observation suggests the presence of unfavorable conditions, perhaps related to operation of the STP. The rate of periphyton primary production at WCK 3.9 was also lower than would be expected based on biomass or water chemistry. As noted previously (Loar 1992b), the absence of invertebrates and patchy distribution of 
Table 3.21. Mean annual Chlorophyll a concentration for periphyton collected from sites with permanent and intermittent flow in 1988

\begin{tabular}{|c|c|c|c|c|}
\hline Site & $\begin{array}{c}1988 \text { Chlorophyll a } \\
\left(\mu \mathrm{g} / \mathrm{cm}^{2}\right)\end{array}$ & SE & Tukey & $\begin{array}{c}1987 \\
\text { Chlorophyll } a \\
\left(\mu \mathrm{g} / \mathrm{cm}^{2}\right)\end{array}$ \\
\hline \multicolumn{5}{|c|}{ Permaneat sites } \\
\hline Ish Creek ${ }^{R}$ & 4.1 & 0.5 & & - \\
\hline FCK $1.0^{R}$ & 6.2 & 0.7 & C & 6.2 \\
\hline FFK $1.1^{R}$ & 14.3 & 1.2 & A & 9.8 \\
\hline WCK $6.8^{R}$ & 5.4 & 0.6 & C & 5.0 \\
\hline WCK 3.9 & 32.8 & 4.0 & & 28.8 \\
\hline WCK 3.4 & 20.0 & 2.0 & A & 15.0 \\
\hline WCK 2.9 & 11.7 & 1.3 & B & 16.4 \\
\hline WCK 2.3 & 12.2 & 1.6 & B & 11.5 \\
\hline MEK 0.6 & 7.2 & 1.3 & C & 7.9 \\
\hline \multicolumn{5}{|c|}{ Intermittent sites } \\
\hline NTK $1.0^{R}$ & 4.5 & 0.6 & & 5.1 \\
\hline MEK $1.8^{R}$ & 2.8 & 0.5 & & 2.0 \\
\hline
\end{tabular}

'Not included in Tukey multiple comparison procedure.

Note: $N=48$. Means with same letter in the Tukey column are not significantly different from each other (Tukey multiple comparison procedure, $p>0.05$. $\mathrm{SE}=$ standard error; $\mathrm{R}=$ reference site. FCK = First Creek kilometer; FFK = Fifth Creek kilometer; $W C K=$ White Oak Creek kilometer; MEK $=$ Melton Branch kilometer; NTK $=$ Northwest Tributary kilometer.

the periphyton at WCK 3.9 (some rocks have thick coatings, while other rocks nearby are barren) suggest frequent episodes of exposure to transient toxicants, such as chlorine. Among the downstream sites, WCK 2.3 was the one most similar to the upstream reference sites. (See Table 3.20.) Data on the benthic invertebrate and fish communities (Sects. 6.1 and 6.2, respectively) also suggest that environmental quality at this downstream site had recovered somewhat compared to other sites in the main plant area.

The rate of photosynthesis per unit algal biomass provides a convenient means for comparing sites with different periphyton biomass. Chlorophyll (biomass) and the rate of carbon incorporation are positively, but not linearly, related. Selfshading limits the amount of light available to algal cells in the lower layers of the periphyton matrix, and thickening of the matrix slows rates of diffusion of inorganic carbon and nutrients to algal cells in lower layers. These limitations cause carbon incorporation to increase more slowly than chlorophyll as biomass accumulates and additional cells are added to the periphyton matrix. The rate of primary production (carbon incorporation) per unit b ttom 
Table 3.22. Mean annual primary production (in milligrams of carbon per square meter per hour) for periphyton collected from sites with permanent and intermittent flow in 1988

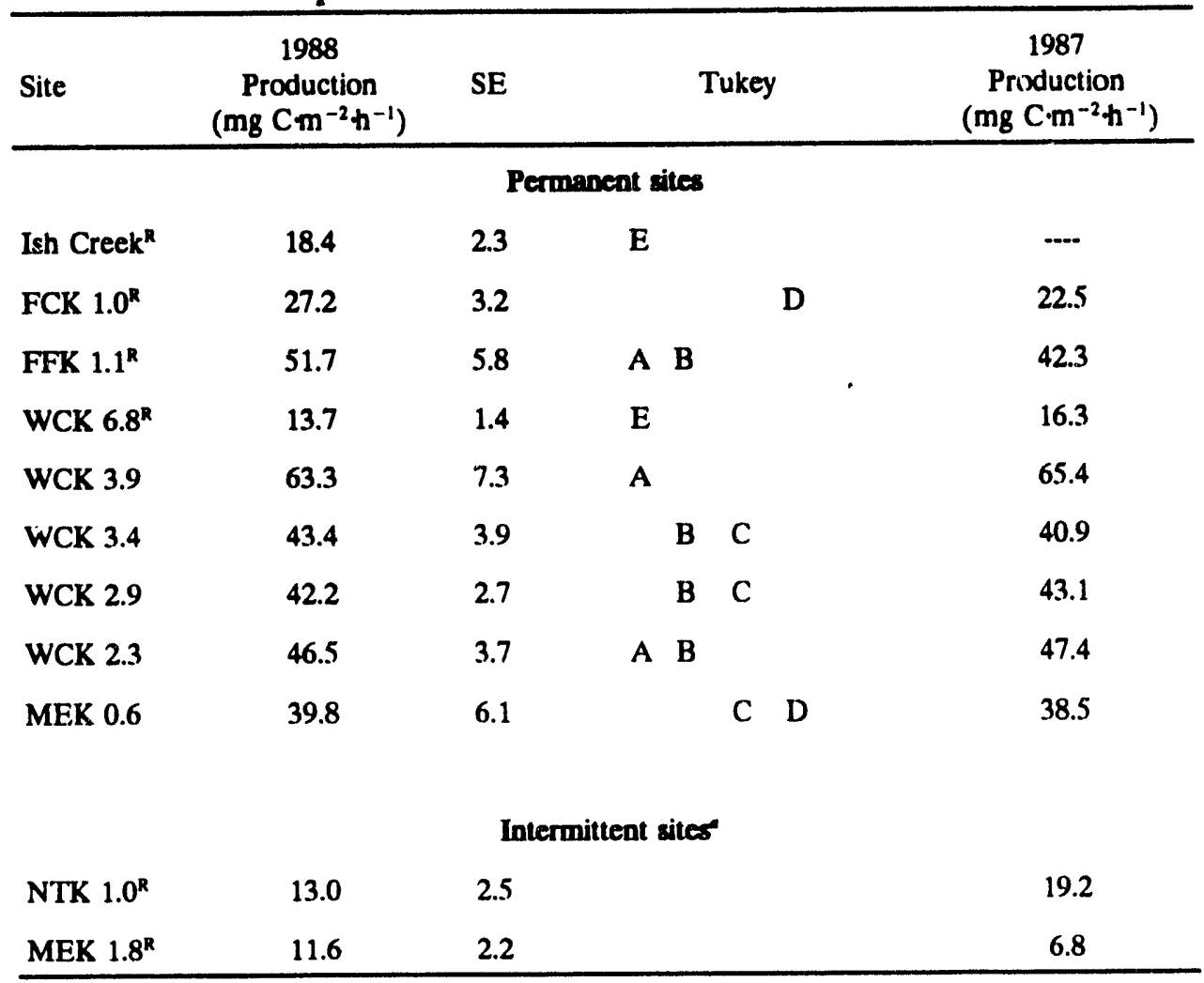

"Not included in Tukey multiple comparison procedure.

Note: $N=48$. Means with the same letter in the Tukey column are not significantly different from each other (Tukey multiple comparison procedure, $p>0.05$ ). $\mathrm{SE}=$ standard error; $\mathbf{R}=$ reference site; FCK $=$ First Creek kilometer; FFK $=$ Fifth Creek kilometer; WCK $=$ White Oak Creek kilometer; MEK $=$ Melton Branch kilometer.

surface area may eventually reach a point beyond which the addition of biomass no longer increases the rate of production. In the resulting relationship, chlorophyllspecific production (carbon uptake per unit chlorophyll per unit time) decreases with increasing chlorophyll as soon as enough cells are present to influence the rate of resource delivery to the cells below them in the matrix.

Because the relationship between chlorophyll (biomass) and production is nonlinear, production rates at sites that differ substantially in periphyton biomass are difficult to compare. To parcel out the effect that biomass has on decreasing biomass-specific production, an analysis of covariance (ANCOVA) was performed on the production rates for the different sites and months, using chlorophyll as the covariate. Production and chlorophyll were log-transformed to generate an approximately linear relationship between the two variables. The ANCOVA model was as follows: $\log$ production $=$ site + month + site $\times$ month + log chlorophyll. All four factors were highly significant; chlorophyll effects were most important, followed by site, month, and the site-month interaction. 
The mean annual values for production in 1987, when adjusted to equivalent densities of Chl $a$ (LSMEANS in PROC GLM, SAS 1985b), were highest for FFK 1.1, WCK 3.9, and WCK 2.3 (Table 3.23). These sites represent three very different habitats: unpolluted reference areas, highly impacted sites, and recovery areas. It is somewhat difficult, therefore, to account for their relatively high photosynthetic performances in the context of ORNL discharges or any other single factor. Because of low grazing pressure, periphyton at FFK 1.1 may be able to attain vertical structure conducive to efficient photosynthesis. As mentioned previously, FFK 1.1 is also located near its groundwater source and may benefit from elevated carbon dioxide and stable nutrient concentrations in comparison with other reference sites. The high productivity at WCK 3.9 may result from the combination of higher levels of available light and nutrients despite episodes of toxicity. The relatively high production at WCK 2.3 is difficult to explain, considering the limited light availability at that site. However, similar sites in other local streams (e.g., lower EFPC) also have relatively high production (Loar 1992c).

The significantly lower chlorophylladjusted production at WCK 6.8 is also difficult to explain. Although nutrient concentrations and shade are similar to other reference sites, it is possible that the high grazing pressure at WCK 6.8 and FCK 1.0 selects for an alga (Stigeoclonium) that has inherently low biomass-specific production.

In 1988, mean annual production, when adjusted to equivalent densities of Chl $a$, was highest at WCK 2.3, MEK 0.6, WCK 2.9, and FFK 1.1 (Table 3.23). Annual production was lowest at WCK 6.8, while reference sites FCK 1.0 and ISK and WOC sites WCK 3.9 and WCK 3.4 were intermediate. The intermediate position of the two WOC sites, which are obviously impacted by ORNL operations, is interesting. While chlorine or other toxic

Table 3.23. Chlorophyll-adjusted periphyton productivity

[log (milligrams of carbon per square meter per hour)] in 1987 and 1988 at sites with permanent flow

\begin{tabular}{|c|c|c|c|c|}
\hline Site & 1987 & PDIFF & 1988 & PDIFF \\
\hline Ish Creek ${ }^{R}$ & - & & 3.05 & C \\
\hline FCK $1.0^{R}$ & 3.11 & $D$ & 3.16 & $\mathrm{C}$ \\
\hline FFK $1.1^{R}$ & 3.72 & A & 3.39 & A B \\
\hline WCK $6.8^{R}$ & 2.81 & & 2.67 & \\
\hline WCK 3.9 & $3.5 ?$ & A B & 3.26 & B C \\
\hline WCK 3.4 & 3.35 & $C D$ & 3.20 & C \\
\hline WCK 2.9 & 3.49 & B C & 3.48 & A \\
\hline WCK 2.3 & 3.58 & A B & 3.50 & A \\
\hline MEK 0.6 & 3.23 & $C D$ & 3.50 & A \\
\hline
\end{tabular}

Note: Tabular values with the same letter are not significantly different from each other (SAS GLM PDIFF procedure, $\mathrm{p}>0.05$ ). $\mathrm{R}=$ reference site; $\mathrm{FCK}=$ First Creek kilometer; FFK $=$ Fifth Creek kilometer; WCK $=$ White Oak Creek kilometer; $M E K=$ Melton Branch kilometer. 
substances probably depress the photosynthetic performance of the periphyton at these sites, the additional light and/or nutrients present may compensate for any toxic effects. Monthly means of chlorophylladjusted production for 1987 and 1988 are plotted in Figs. 3.6 and 3.7, respectively. In both years there was an obvious seasonal trend, with higher production during the summer. Such a pattern probably reflects a response to higher temperatures rather than a response to light, as canopy cover decreases the light available to periphyton at most sites during spring and summer. Similar to the differences observed in mean annual values between sites, monthly chlorophyll-adjusted production was consistently low at WCK 6.8 but was quite variable over the year at the other sites. For example, chlorophyll-adjusted production at FFK 1.1 was higher than any other site in January 1988 but lower than any site the following month. The extremely low value at MEK 0.6 in October 1987 may have resulted from the inadvertent selection of rocks that had recently been overturned in a flood.

\subsubsection{Periphyton ATP}

ATP is present in all living cells. When considered together with the data for chlorophyll, periphyton ATP per unit area can sometimes be used to evaluate the extent of heterotrophic activity and the condition of stream periphyton (Bothwell 1985). The ATP data were characterized by high variability among sites and seasons (Table 3.24). Analysis of variance showed statistically significant differences by season, site, and site $x$ season interaction. In general, those sites with higher chlorophyll (WCK 3.9, WCK 3.4 and FFK 1.1) had higher ATP values, suggesting either that the majority of the ATP measured was derived from algae or that microscopic heterotrophs were strongly associated with algae. Consistently high ATP values were observed at WCK 3.9, a site that also had the highest chlorophyll. Seasonally, ATP appeared to be highest in May, but it is not known whether such a result reflects seasonal factors or just month-to-month variation.

Periphyton chlorophyll to ATP ratios were also quite variable (Table 3.24). Periphyton Chl a/ATP values tended to be highest in September, but strong site $\times$ season interactions $(p<0.0001)$ obscured almost all differences between sites. For example, site WCK 2.9 had a relatively high Chl a/ATP ratio in May but fairly low ratios in February and September. The only consistent difference between sites over all three months was between WCK 2.9 and MEK 0.6 (Tukey comparison, $p<0.05$ ). Chlorophyll/ATP ratios are difficult to interpret because changes in the algal component alone (due to physiological/taxonomic reasons) can alter Chl a/ATP ratios in periphyton without any influence from heterotrophic microbes (Healey and Hendzel 1980, Bothwell, 1985).

\subsubsection{Periphyton colonization}

Ceramic tiles were first retrieved three weeks after deployment (Fig. 3.8). Algal biomass on rocks collected from the riffles containing the tiles is shown as " $R$ " in Fig. 3.8. By week 3, substantial biomass (as $\mathrm{Chl} a$ ) was present on tiles at WCK 3.4, WCK 2.3, and MEK 0.6. At those sites, periphyton accumulated 
LN CARBON UPTAKE

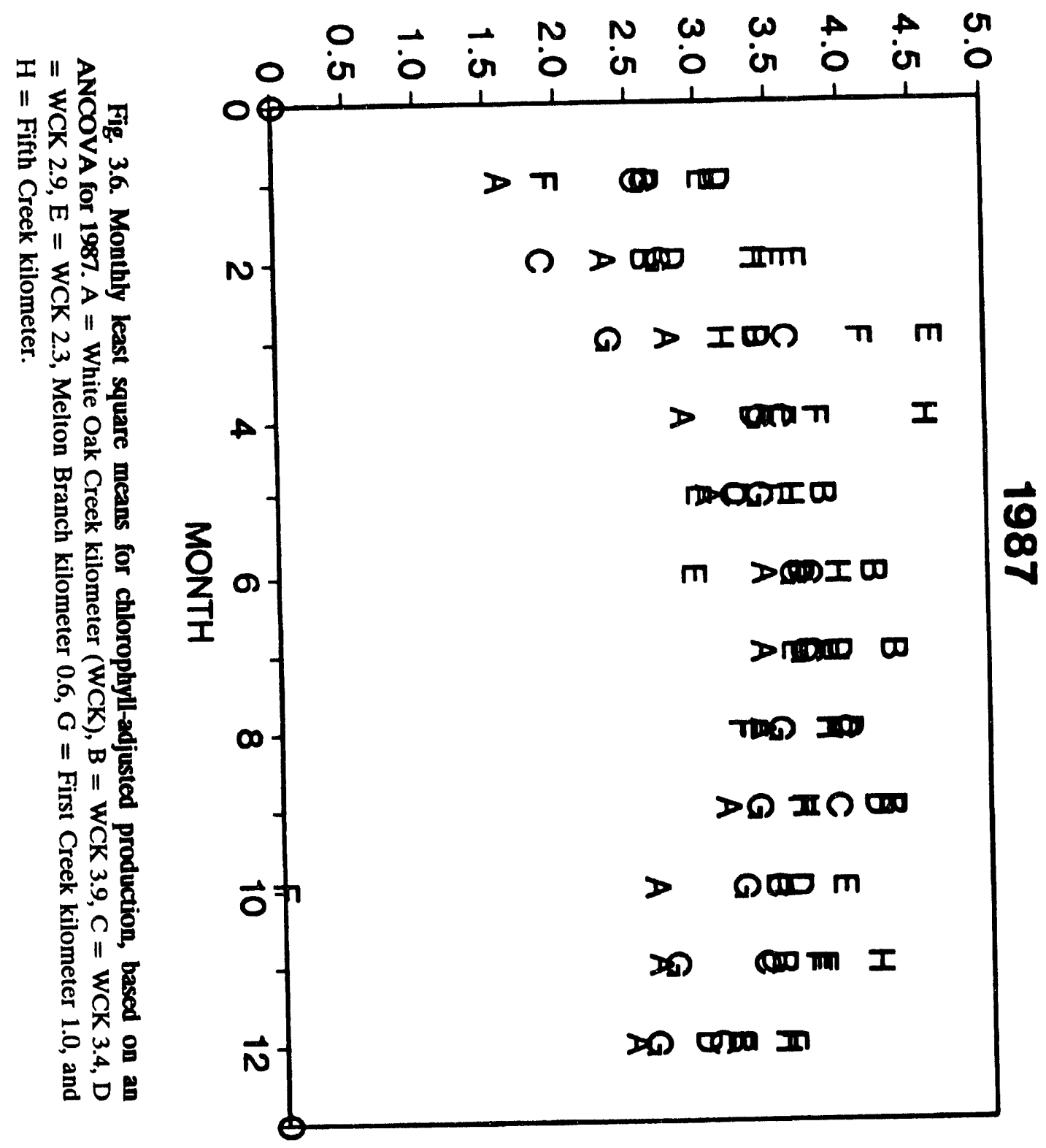




\section{LN CARBON UPTAKE}

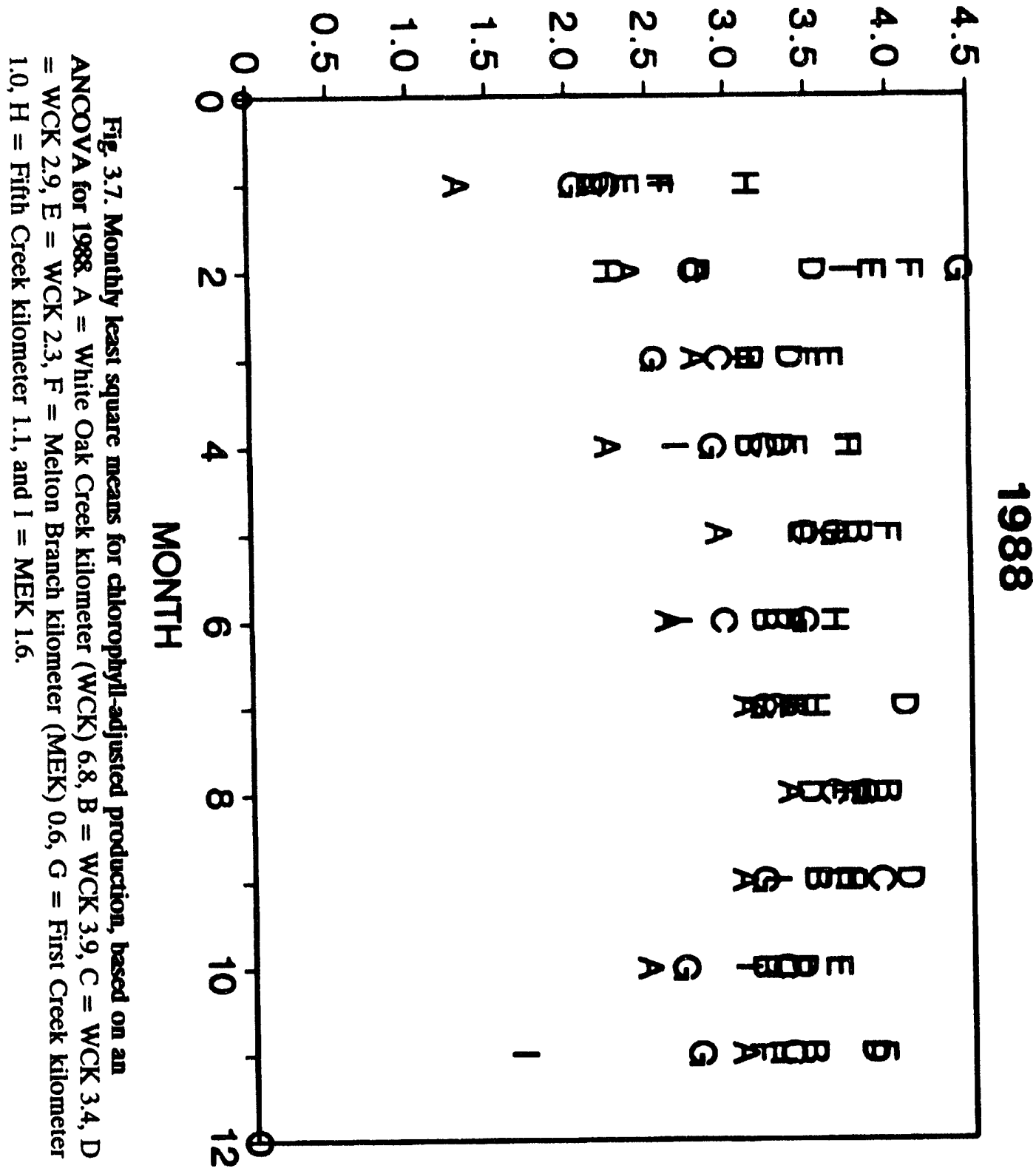


Table 3.24. Periphyton ATP and chlorophyll to ATP ratios, 1988 Each value represents the mean of four samples

\begin{tabular}{lccc}
\hline Site & February & May & September \\
\hline & ATP $\left(\mu \mathrm{g} / \mathrm{cm}^{2}\right)$ & & \\
NTK $1.0^{\mathrm{R}}$ & 0.35 & 0.54 & - \\
Ish Creek & 0.22 & 0.20 & 0.11 \\
FCK $1.0^{\mathrm{R}}$ & 0.19 & 0.30 & 0.10 \\
FFK 1.1 & 2.55 & 1.14 & 0.78 \\
WCK 6.8 & 0.28 & 1.14 & 0.78 \\
WCK 3.9 & 1.46 & 4.58 & 1.31 \\
WCK 3.4 & 0.73 & 4.51 & 0.31 \\
WCK 2.9 & 1.32 & 0.28 & 0.22 \\
WCK 2.3 & 1.32 & 0.91 & 0.56 \\
MEK 1.8 & 0.17 & 0.13 & - \\
MEK 0.6 & 1.03 & 1.40 & -
\end{tabular}

\section{Chlorophyll to ATP $(\mu \mathrm{g} / \mu \mathrm{g})$}

\begin{tabular}{lccc} 
NTK $1.0^{R}$ & 16.4 & 14.9 & - \\
Ish Creek $^{R}$ & 5.4 & 18.9 & 35.2 \\
FCK $1.0^{R}$ & 16.9 & 23.6 & 46.6 \\
FFK $1.1^{R}$ & 5.2 & 19.5 & 25.9 \\
WCK 6.8 & 13.4 & 8.2 & 61.6 \\
WCK 3.9 & 13.2 & 7.4 & 29.4 \\
WCK 3.4 & 24.0 & 14.3 & 27.4 \\
WCK 2.9 & 11.2 & 82.6 & 11.7 \\
WCK 2.3 & 6.3 & 34.6 & 7.0 \\
MEK 1.8 & 14.0 & 43.6 & - \\
MEK 0.6 & 4.1 & 14.4 & - \\
\hline
\end{tabular}
First Creek kilometer; FFK = Fifth Creek kilometer; WCK $=$ White Oak Creek kilometer; $\mathrm{MEK}=$ Melton Branch kilometer; $\mathrm{R}=$ reference site. 


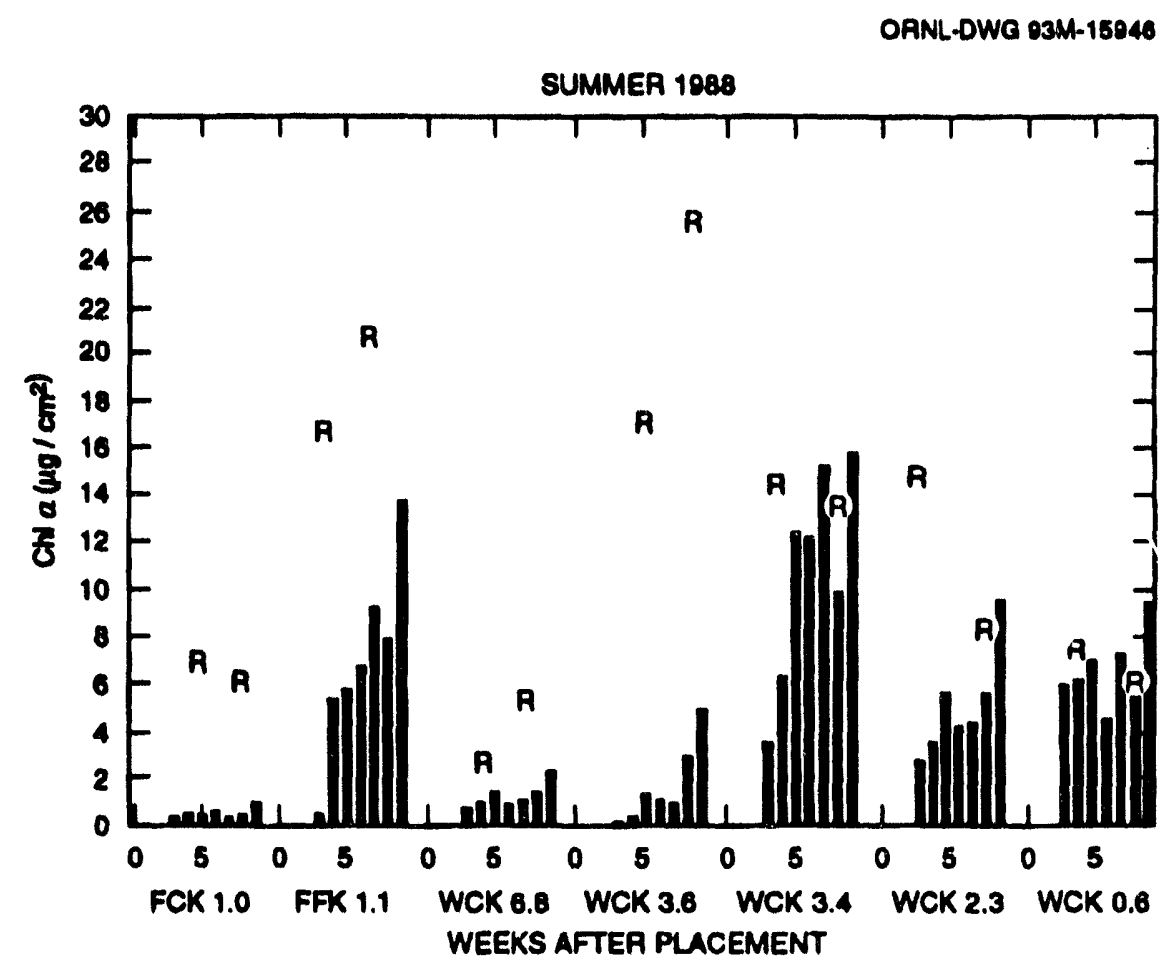

Fig. 3.8. Periphyton colonization or accumulation (as microgram chlorophyll a per square centimeter on ceramic tiles placed at seven sites in the White Oak Creek watershed. Data are means of four replicate tiles. $R$ denotes chlorophyll on rocks adjacent to the tiles.

rapidly, and by week 9 the concentration of Chl $a$ was similar for tiles and the adjacent rocks.

At reference sites FCK 1.0, FFK 1.1 and WCK 6.8, Chl $a$ per unit tile surface never reached densities comparable to those on adjacent rocks during the 9 week experiment. However, at FFK 1.1, biomass accumulation was rapid, and substantial biomass did develop during the experiment. At FCK 1.0, WCK 6.8, and reference sites in other systems where substantial snail populations occur, the slow and low biomass accumulation (compared with rocks) suggests that the irregular surface of stream rocks provides protection from invertebrate grazers (mostly snails) that may efficiently remove algal biomass from tiles. At several of these reference sites, biomass on the tiles increased during the experiment, suggesting that in lownutrient and low-light habitats, a community eventually develops that is apparently more resistant to grazing.

At FFK 1.1, lower apparent grazing pressure (few snails observed) allowed the development of substantial algal biomass despite relatively low nutrient levels. Although biomass was increasing throughout the experiment, the reason for the lower biomass on tiles compared with rocks is not known.

Through week 6, there was very little algal periphyton present on the tiles at WCK 3.9 (Fig. 3.8). By week 8, 
periphyton biomass had increased; however, the surrounding rocks always had much greater biomass. Similarly slow colonization was found in upper EFPC inside the Y-12 Plant boundary where the stream also receives cooling tower blowdown and experiences occasional chlorine toxicity (H. L. Boston, ORNL/ESD, unpublished data).

\subsubsection{Algal colonization and} accumulation at a chlorineimpacted site

Tiles placed at WCK 6.8 and WCK 3.4 for "conditioning" had $<0.1$ and
$0.6 \mu \mathrm{g} \mathrm{Chl} a$ per square centirneter, respectively, at the time they were transferred to WCK 3.9. Twelve days after placement at WCK 3.9, the unconditioned tiles and those preconditioned at WCK 6.8 had a similar algal biomass ( $<0.1 \mu \mathrm{g} \mathrm{Chl} a$ per square centimeter). Tiles preconditioned at WCK 3.4 had an average of about $0.2 \mu \mathrm{g}$ Chl $a$ per square centimeter, a density not substantially different from that at the time of placement (Fig. 3.9). On day 20 , unconditioned tiles had about $0.1 \mu \mathrm{g}$ $\mathrm{Chl}$ a per square centimeter, tiles conditioned at WCK 6.8 had about $1 \mu \mathrm{g}$ $\mathrm{Chl} a$ per square centimeter, and tiles preconditioned at WCK 3.4 had about

ORNL-DWG 93M-15926

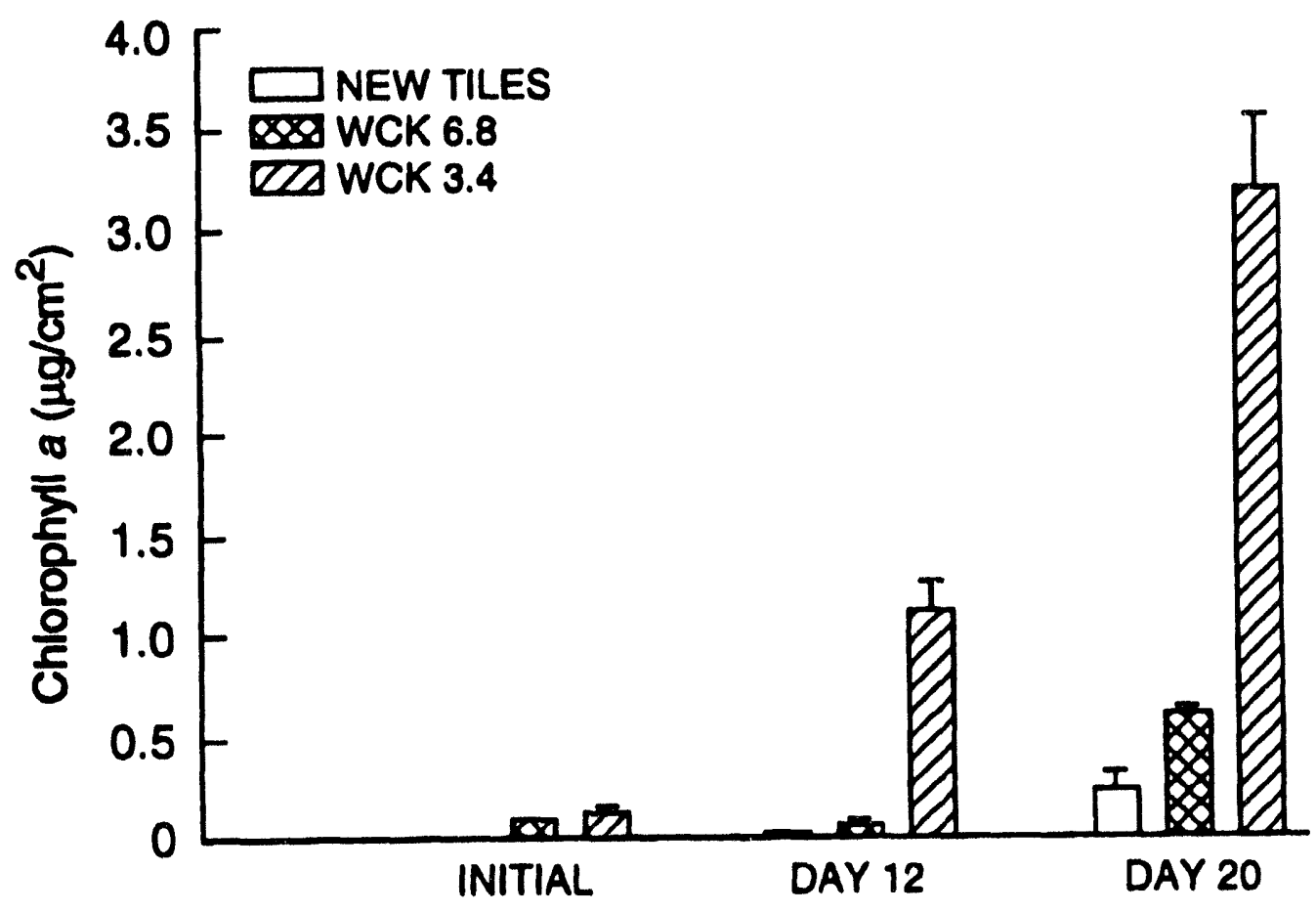

Fig. 3.9. Chlorophyll $a$ on new tiles and tiles preconditioned by placement at WCK 6.8 or WCK 3.4 for one week prior to placement at WCK 3.9, initially, and after 12 and 20 days. Values are means $( \pm 1$ SD) of six replicate tiles. 
$3.2 \mu \mathrm{g} \mathrm{Chl} a$ per square centimeter. Even though after $20 \mathrm{~d}$ relatively little biomass had accumulated (compared to rocks at that site that had about $30 \mu \mathrm{g} \mathrm{Chl} a$ per square centimeter), the effects of preconditioning on algal biomass were significant. Further, 1-week preconditioning at WCK 3.4 resulted in greater algal biomass accumulation than preconditioning at WCK 6.8, possibly as a result of the quantity and/or quality of biomass initially present.

Rocks collected from WCK 3.9 averaged about 1 and $5 \mu \mathrm{g}$ of $\mathrm{Chl} a$ per square centimeter immediately after treatment by bleaching or brushing respectively. After $12 \mathrm{~d}$ at WCK 3.9, no Chl $a$ was detected on bleached rocks, but brushed rocks had an average of about $25 \mu \mathrm{g} \mathrm{Chl} a$ per square centimeter, consisting of new growth of the unicellular sessile green alga that dominates the periphyton at WCK 3.9 (Fig 3.10). After $20 \mathrm{~d}$ at WCK 3.9, bleached rocks averaged about $2 \mu \mathrm{g}$ Chl $a$ per square centimeter, and brushed rocks averaged about $35 \mu \mathrm{g} \mathrm{Chl} a$ per square centimeter, which was similar to the $\mathrm{Chl} a$ concentration on rocks native to that site.

Treating rocks from WCK 3.9 with bleach effectively sterilized them. Any chlorophyll present following treatment was residual and lost shortly after the rocks were placed at WCK 3.9. Like the tile experiment, recolonization of sterilized rocks was extremely slow, despite high algal biomass on surrounding rocks. Brushing removed most of the algal biomass from rocks collected at WCK 3.9; however, biomass had largely recovered after only $12 \mathrm{~d}$ at

ORNL-DWG 93M-15927

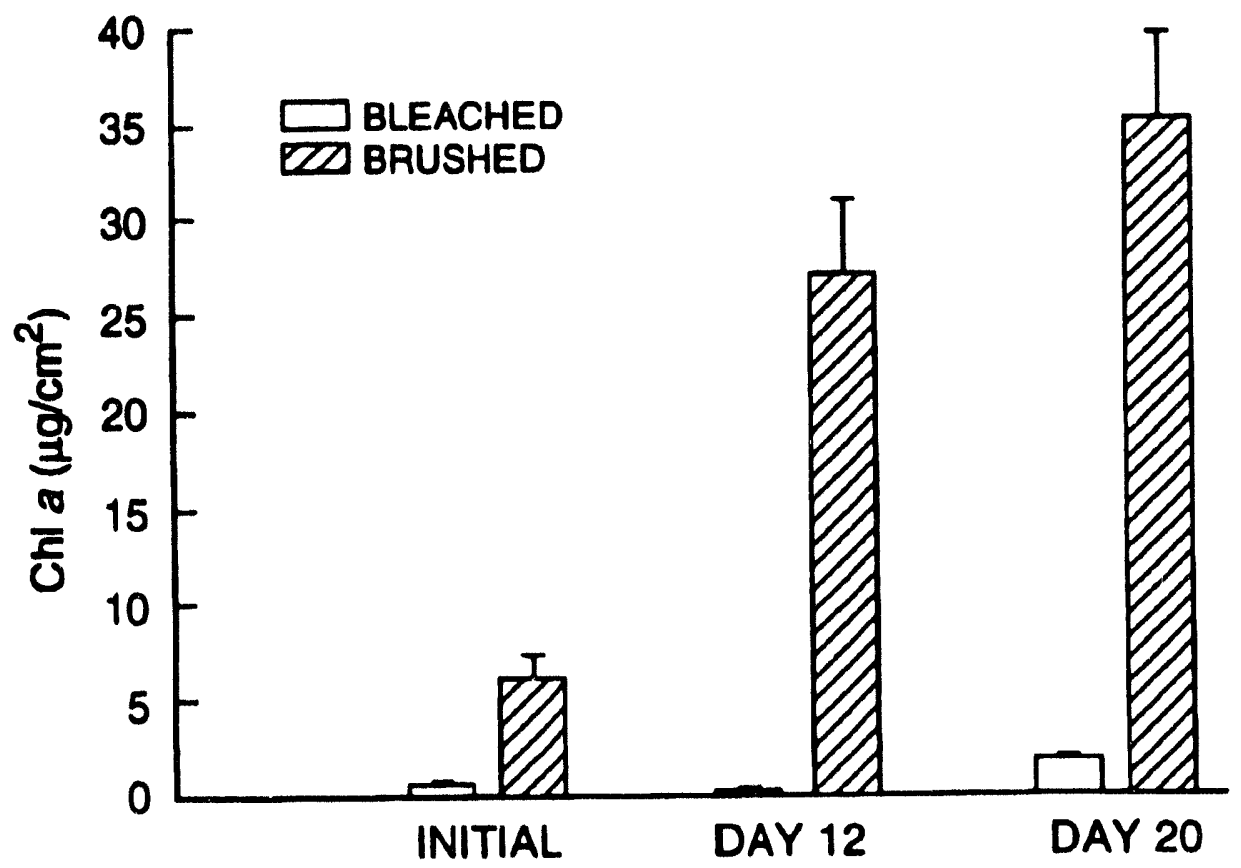

Fig. 3.10. Chlorophyll $a$ on rocks placed at WCK 3.9 following either brushing or sterilization by bleaching. Values are means $( \pm 1 \mathrm{SD})$ for four rocks. 
WCK 3.9, suggesting that regrowth is rapid at that site. Rapid regrowth at WCK 3.9 was expected, given the high rates of photosynthesis by periphyton at that site. As observed in the experiment with preconditioned tiles, the presence of living organisms on a surface increases the rate of algal colonization at WCK 3.9.

It was noted previously that some rocks at WCK 3.9 and in upper EFPC at site EFK 24.4 have very high algal biomass, while nearby rocks are bare. The intermittent exposure to chlorine at those sites may remove much of the algal biomass on the rocks and have a similar effect on heterotroph biomass. The algal assemblages at WCK 3.9 and EFK 24.4 are dominated by the same sessile unicellular green alga. Although this organism apparently has a high growth rate and can reestablish itself rapidly following biomass reduction, it is a poor colonizer of barren substrata. Following episodes of chlorine toxicity, therefore, regrowth is rapid on rocks where some live biomass remains, but recolonization is slow on rocks where all the biomass has been removed. These characteristics explain the patchy distribution of biomass and may also account for the observation that large rocks, and exposed sections of bedrock, are usually well colonized, while smaller rocks are frequently barren.

(Large rocks with more surface area and refugia have a higher probability of having some cells survive a toxic episode and, thus, experience rapid regrowth of the periphyton.)

\subsubsection{Evaluating controls on algal growth}

The insecticide (Malathion) treatment was not effective in reducing macroinvertebrate grazers, as similar numbers of snails (at WCK 6.8), chironomids (WCK 3.4), and other grazers (FFK 1.1) were observed on insecticide-treated pots and control (agar-only) pots. The mechanical grazerexclusion method of elevating the pots at WCK 6.8 was similarly ineffectual. Although snails were removed daily from the elevated pots, the number of snails per pot was only slightly lower than that for pots which were neither elevated nor had snails removed.

After $34 \mathrm{~d}$ at WCK 6.8, Chl $a$ and primary production on the control pots (C) was greater than or equal to that on pots from all other treatments except the elevated, grazer-excluded, nutrientamended (NG) pots (Fig. 3.11). Chl $a$ and primary production on the pots amended with the medium and high concentration of insecticide (Fig. 3.11, $I_{2}$ and $\mathrm{I}_{3}$ ) were lower than the control pots, suggesting an inhibitory effect of the insecticide at high concentrations.

Nutrient addition seemed to ameliorate the adverse effect on algal biomass and primary production of the moderate insecticide treatment (Fig. 3.11; compare $\mathrm{NI}_{2}$ with $\mathrm{I}_{2}$ ).

Although the average number of snails on the grazer-excluded pots was about $40 \%$ lower than on the $C$ pots, this level of grazer reduction was apparently not sufficient to result in a significant effect on algal biomass or primary production. (Compare treatments $\mathrm{C}$ and $\mathrm{G}$ in Fig. 3.11.) Elevated pots amended with nutrients (NG) had greater algal biomass than $\mathrm{C}$ pots or elevated, unamended pots (GT); although the number of snails on the two sets of elevated pots was similar. Examining the data for snail numbers, biomass, and primary production for individual pots showed a strong influence of snail numbers on biomass and primary production for the NG pots. At low snail numbers, there was a substantial increase in both biomass and primary production 
ORNL-DWG 93M-15928

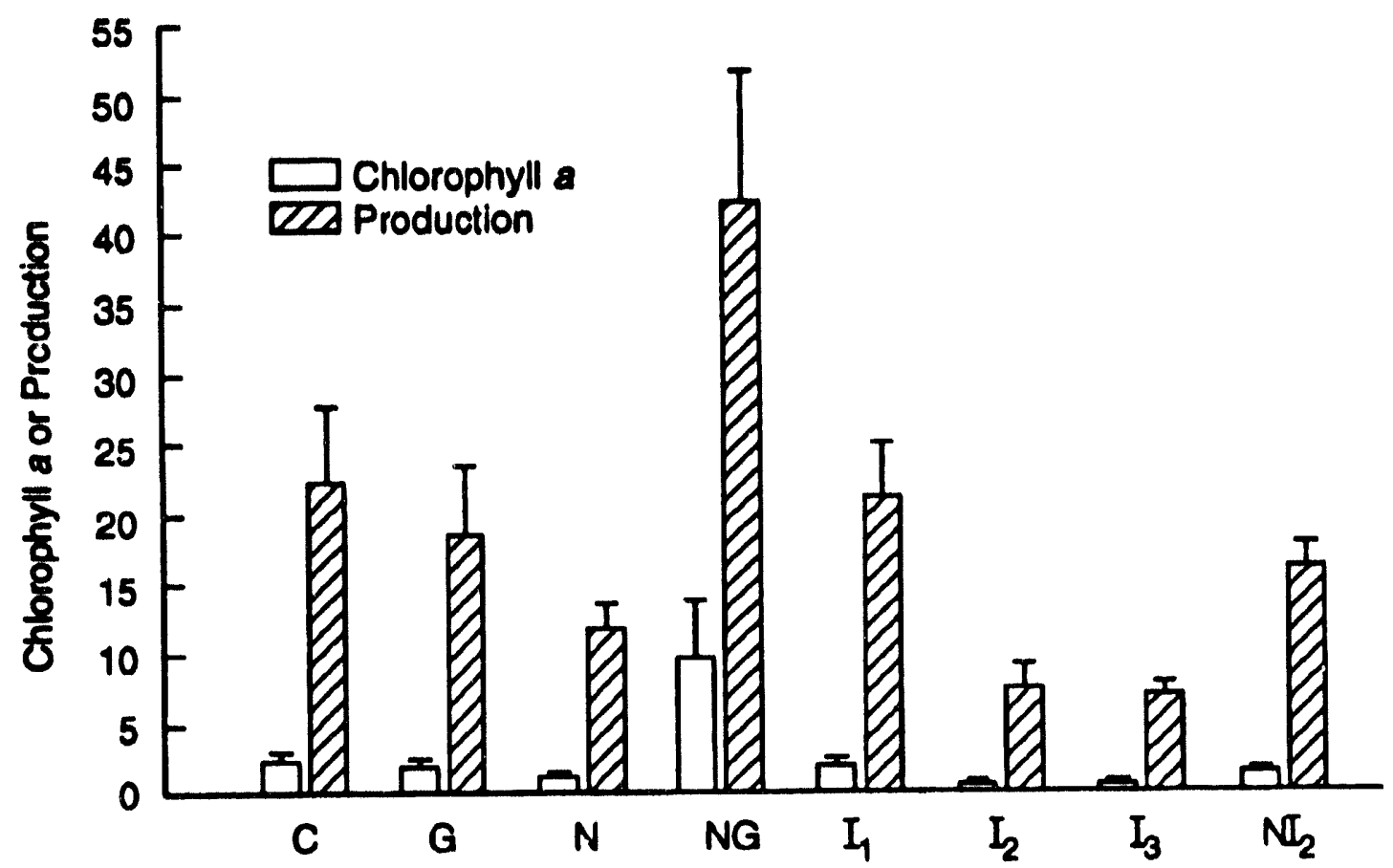

Fig. 3.11. Chlorophyll $a$ and primary production on clay pots with agar only (C), pots elevated to exclude grazers (G), pots with agar amended with $\mathbf{N}$ and $P(N)$, pots elevated with nutrient-enriched agar (NG), pots amended with three concentrations of malathion $\left(I_{1}, I_{2}, I_{3}\right)$, and pots with malathion and nutrients $\left(\mathrm{NI}_{2}\right)$. Chlorophyll and production were measured after 34 d at White Oak Creek kilometr 6.8. Values are means $\pm 1 \mathrm{SE}, N=4$.

for the NG treatment compared with the C or $\mathbf{G}$ treatments.

At WCK 6.8, reducing the grazing pressure and increasing the nutrient supply resulted in an increase in algal biomass and production; separate treatments, however, had no significant effect. These results suggest that algal biomass is tightly constrained by a low supply of nutrients and intense grazing pressure. Shading by riparian vegetation likely adds an additional constraint on periphyton biomass and primary production at this site.

At FFK 1.1 control pots and pots amended with nutrients, insecticide $\left(I_{2}\right)$, or both $\left(\mathrm{NI}_{2}\right)$ had similar algal biomass after $34 \mathrm{~d}$ in the field. Primary production was similar for all except the $\mathrm{I}_{2}$ pots which were lower. Biomass averaged about $12 \mu \mathrm{g} \mathrm{Chl} a$ per square centimeter and primary production averaged about $130 \mathrm{mg}$ carbon per square meter per hour on control pots, and both values were substantially higher than for the control pots at WCK 6.8 (Fig. 3.11). These results suggest that either nutrient availability was not limiting algal biomass and production or that low grazing pressure similarly constrained the algae on $\mathrm{C}$ and $\mathrm{N}$ pots at FFK 1.1. The differences in algal biomass 
and production between WCK 6.8 and FFK 1.1 implicate grazing as a major controlling factor because nutrients (Table 2.8) and light (Tables 2.12 and 318) are similar for these sites.

At WCK 3.4 biomass did not differ among treatments (Fig. 3.12). An orthogonal analysis revealed that primary production was greater on nutrientamended pots ( $\mathrm{N}$ and $\mathrm{NI}_{2}$ ) compared with other pots $\left(\mathrm{C}\right.$ and $\left.\mathrm{I}_{2}\right)$. The observation of a significant effect from nutrient addition at WCK 3.4 was not surprising because water-column nutrients ( $\mathrm{N}$ and $\mathrm{P}$ ) are abundant (Table 2.8). Perhaps nutrient availability decreases with depth in thick periphyton matrices (such as at WCK 3.4) in a manner that stimulates production by additional nutrients supplied from below the matrix.

\subsubsection{Summary}

Efforts to date have focused on characterizing primary production rates and algal periphyton biomass at ten study sites in WOC watershed and a site in nearby Ish Creek. These studies have (1) documented the current condition of the periphyton communities in selected stream reaches; (2) identified some of the effects of ORNL discharges on this important component of the stream ecosystem; (3) demonstrated responses of periphyton to changes in effluent discharges (e.g., continued high production at MEK 0.6 following the

OANL-DWG 93M-15929

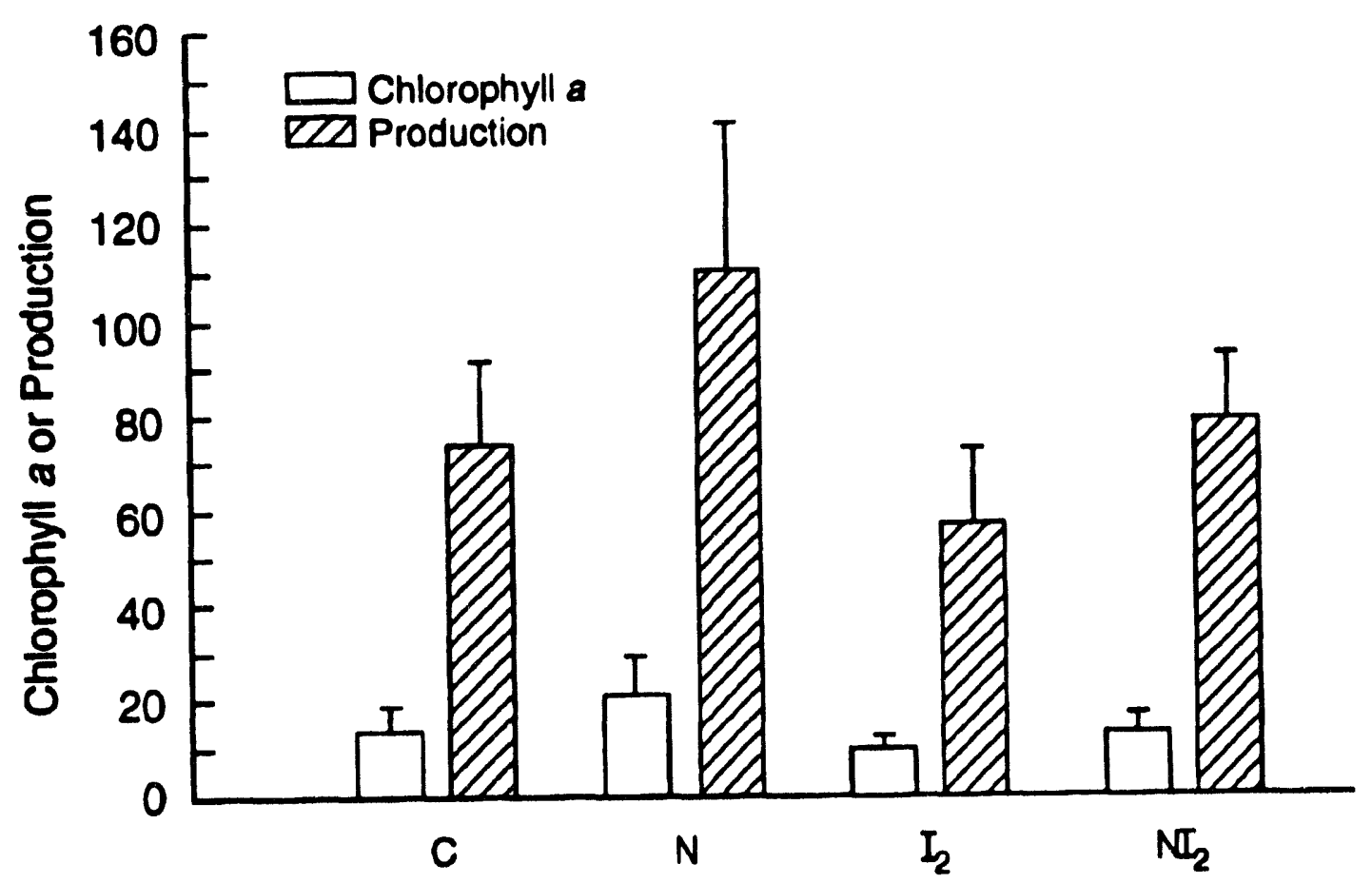

Fig. 3.12. Chlorophyll $a$ and primary production on clay pots with agar only (C) with agar amended with $N$ and $P(N)$, with agar amended with malathion $\left(I_{2}\right)$, and with agar amended with malathion and nutrients $\left(\mathrm{NI}_{2}\right)$. Chlorophyll and production were measured after $34 \mathrm{~d}$ at White Oak Creek kilometer 3.4. Values are means $\pm 1 \mathrm{SE} ; n=4$. 
slowdown of operations at the HFIRTRU facility); and (4) corroborated results of studies of other stream communities.

Previous studies of the periphyton communities in ORNL streams showed that differences in periphyton production among sites could not be explained by differences in water quality, based on short-term exposure, but may be the result of intermittent toxic exposures. Physical factors or biotic interactions not examined thus far (e.g., grazing and siltation, which appeared to be important influences on poriphyton biomass and performance at several sites) could also be important. Increased concentrations of several metals (e.g., $\mathrm{Cr}, \mathrm{Cu}, \mathrm{Hg}, \mathrm{Pb}, \mathrm{Zn}$ ) in periphyton at the downstream sites reflected ORNL operations. However, none of these were present in excessive or physiologically damaging concentrations (Loar 1992b).

Several other conclusions are evident at this stage of the program. For example, sites downstream of ORNL facilities had higher algal periphyton biomass and primary production rates compared with upstream reference sites, possibly due to nutrient loading. Also, algal biomass on rocks at reference sites was fairly typical of natural woodland streams. Reference site FFK 1.1 was an exception, having high algal biomass and production due to low grazing pressure, availability of nutrients, or other factors not yet identified.

Because the rate of carbon incorporation is not linearly related to biomass, an ANCOVA was performed, and chlorophyll-adjusted production was used to compare the photosynthetic rates among sites that differed in biomass. This evaluation showed that the periphyton at WCK 2.3 and FFK 1.1 had the highest rates of chlorophyll-adjusted production (i.e., were in the best "condition"), although periphyton at WCK 3.9, MEK 0.6 , and WCK 2.9 also had high rates of chlorophyll-adjusted production. The lowest rate of chlorophyll-adjusted production occurred at WCK 6.8 upstream of ORNL; periphyton at WCK 3.4 and two reference sites (FCK 1.0 and Ish Creek) were intermediate. The chlorophyll-adjusted production or condition of the periphyton seemed related to both natural and anthropogenic factors. In addition, chlorophyll-adjusted production rates, together with data on algal colonization rates and species composition, suggest that conditions improve with distance downstream of ORNL operations (e.g., WCK 2.3 and MEK 0.6).

Although chlorophyll-adjusted production was usually high at WCK 3.9, algal colonization was extremely slow. Intermittent chlorine toxicity and, perhaps, a persistent low level of toxicity restricts algal diversity to a single species that is a very poor colonizer of new surfaces. Its inability to recolonize rock surfaces may explain the patchy distribution of periphyton on the rocks at WCK 3.9. Algal colonization is rapid at WCK 3.4, WCK 2.3, MEK 0.6 and FFK 1.1. At most reference sites (e.g., WCK 6.8 and FCK 1.0), shade, grazing pressure, and low nutrient levels likely combined to limit biomass accumulation. Studies at WCK 6.8 using nutrientdiffusing substrata and grazer exclusions suggested that both low nutrient availability and grazing by snails limit algal periphyton biomass and production at most reference sites.

Finally, the adverse impacts of ORNL effluents on algal periphyton may be restricted to those reaches of WOC near WCK 3.9, WCK 3.4 and occasionally WCK 2.9. Impacts of toxic 
releases on the microbial component of the periphyton may contribute to the slow colonization at WCK 3.9 and overall performance at WCK 3.4; this hypothesis will be examined in the future studies described in the following section.

\subsection{FUTURE STUDIES}

Efforts to date have identified reaches of WOC below the Bldg. 4500 complex and below the outfall of the STP as areas where the algal periphyton community is impacted by ORNL discharges. During 1989, these impacted reaches will be evaluated to determine the patterns and downstream extent of the impact (stress) and to obtain information that can be used to predict the possible responses to remedial actions.
Monitoring has demonstrated an improvement in the physiological condition and primary production of the periphyton at MEK 0.6 , following the slowdown of HFIR-TRU operations. Because HFIR is scheduled to resume operations in 1989, continued monitoring will document changes in the periphyton community and provide information on the downstream extent of effects.

Substantial information has been obtained on the current condition and characteristics of the algal periphyton. During 1989, the number of periphyton monitoring sites will be reduced, and studies will be initiated to characterize the heterotrophic (microbial) component of the periphyton. The assessment of the condition of the microbial communities will focus initially on those stream reaches where the algal periphyton are stressed. 


\title{
4. BIOACCUMULATION STUDIES
}

\author{
M. J. Peterson and G. R. Southworth
}

The bioaccumulation monitoring task of the ORNL BMAP (Loar et al. 1991)

has five subtasks with the following objectives:

1. To determine what materials present in the WOC system accumulate to unacceptable levels in aquatic biota (Subtask 2a),

2. To identify specific sources of any observed contamination (Subtask 2b),

3. To calibrate water quality monitoring data against contaminant levels in biota (Subtask 2c),

4. To determine the source and scope of PCB contamination of channel catfish in WOC embayment and the Clinch River (Subtask 2d), and

5. To develop the capability to forecast future levels to biotic contamination under various remedial action alternatives (Subtask 2e).

Results of studies relating to Subtasks $2 a, 2 b$, and $2 c$ are reported in Sect. 4.1 of this report; results relating to Subtasks $2 b$ and $2 \mathrm{~d}$ are reported in Sect. 4.2, and Subtask $2 c$ is reported in Sect. 4.3. Data from all five subtasks will be applicable to Subtask 2e.

\subsection{IDENTIFICATION OF CONTAMINANTS THAT ACCUMULATE IN AQUATIC BIOTA}

\subsubsection{Introduction}

Results reported in the second annual report (Loar 1992b, Sect. 4.0) indicated that the ORNL complex was an apparent source of mercury and polychlorinated biphenyl (PCB) contamination to fish in WOC. No other organic contaminants, including polycyclic aromatic hydrocarbons (PAHs), pesticides, and acid/base neutral semivolatiles were detected in fish from WOC. Despite evidence of past (Loar 1992b, Sect. 4.1.1) and current discharges of copper and zinc (Loar 1992b, Table 3.17) to WOC, concentrations of metals (other than mercury) in fish from WOC, White Oak Lake (WOL), and Melton Branch were similar to concentrations in fish from an uncontaminated reference stream.

The contaminant monitoring program initiated in 1986 was continued in 1987-88 with little change in order to provide an additional year of data on concentrations of metals and organics in WOC. biota. Because the 1986-87 sampling indicated the presence of $\mathrm{PCBs}$ at significant concentrations in sunfish in WOC, semiannual PCB monitoring of sunfish was initiated in 1988 at two sites (WCK 2.9 and WOL) to provide a better baseline for evaluating future changes in PCB body burdens. Efforts to use caged clams to locate sources of contamination and to detect the presence of hydrophobic organics that are readily metabolized (and therefore not accumulated) by fish were also continued.

\subsubsection{Methods}

Fish were collected by electrofishing at three sites on WOC and single sites on WOL, WOC embayment, Northwest Tributary, and Melton Branch in winter 1987-88. Sites on WOC, Melton Branch, and Northwest Tributary corresponded 
closely to the benthos and fish community sampling sites (Fig. 2.2). Twelve fish were collected at each site to provide samples for analysis of metals, organics, and archival storage. Samples were taken from eight fish for analysis of mercury and PCBs, six fish for analysis of metals, and four fish for analysis of organics (except at MEK 0.2 where fish numbers were inadequate). Bluegill (Lepomis

macrochirus) were collected at all sites; however, redbreast sunfish ( $L$. auritus) were also collected at WCK 2.9 because bluegill abundance was low at this site and redbreast sunfish could be collected from a more restricted reach of stream downstream of the weir at WCK 3.41 (Fig. 2.2). Eight redbreast sunfish and eight bluegill were also collected at WCK 2.9 and WOL, respectively, in July 1988 to initiate the semiannual monitoring of $P C B$ contamination in WOC. Although an attempt was made to restrict the collections to individuals of a size likely to be taken by sport fishermen, it was impossible to meet this requirement at all sites. Fish were collected from Hinds Creek (Anderson County, Tennessee) to estimate background levels of contaminants and to provide analytical controls.

Fish collected at each site were placed on ice in a labeled ice chest and returned to the laboratory for processing. Upon return to the laboratory, fish were tagged with a unique four-digit tag wired to the lower jaw. Each fish was then weighed, measured, and scales were taken for age determination. The fish was fileted, and the skin was removed from the filet. A 1- to 2-g sample of the anterior dorsal portion of the axial muscle filet was excised for the determination of mercury; the remainder of the filet was retained for analysis of other metals and radionuclides. Samples to be analyzed for metals were freeze-dried, wrapped in aluminum foil, and stored in a locked freezer until analyzed. The remaining filet was either used for a duplicate sample, archived, or analyzed for organic contaminants. Samples to be analyzed for organics or maintained in archival storage were wrapped in heavy-duty aluminum foil, labeled, and stored at $-20^{\circ} \mathrm{C}$ in a locked freezer in Building 1504 until delivered to the ORNL Analytical Chemistry Division (ACD) for analysis.

Asiatic clams (Corbicula fluminea) were placed in the streams to monitor for PCBs and organic contaminants. Clams were obtained in March 1988 from upper Bull Run near Maynardville in Union County, Tennessee. After the clams were held for $24 \mathrm{~h}$ in clean-flowing water, they were put into polypropylene cages and placed in various sites in WOC and tributaries, WOL and WOC embayment at WCK 0.1. One set of clams collected from Bull Run was frozen immediately for analysis as a control. Each cage held approximately 50 clams, which contained between 0.5 and $2 \mathrm{~g}$ (wet wt) of soft tissue each. The clams were suspended in the stream for 4 weeks, at which time they were removed and processed prior to delivery to the ACD laboratory at ORNL. After freezing the clams, the shells were removed, and the frozen soft tissue was placed in a $20-\mathrm{ml}$ glass vial. Two composite samples weighing approximately 5 and $10 \mathrm{~g}$ were taken for PCB analysis from all sites and for gas chromatographic/mass spectrometric (GC/MS) analysis from WCK 3.5, MEK 0.2, WOL, and WCK 0.1.

Mercury determinations were conducted using a modification of the procedure described in EPA (1979). Samples were digested in a mixture of nitric acid, perchloric acid, and potassium dichromate, after which the mercury was reduced with stannous chloride and determined by cold vapor atomic adsorption spectrophotometry. Other metals were determined using graphite furnace atomic absorption spectrophotometry, following digestion with 
concentrated nitric acid (EPA 1980b). Organic priority pollutants were analyzed by procedure PPB 12/83 (EPA 1984) in which the homogenized sample is extracted in methylene chloride, cleaned up using column chromatography, and analyzed by GC/MS or by gas chromatography with electron capture detectors (GC/ECD) and high performance liquid chromatography (HPLC) with fluorimetric detection.

Quality assurance was maintained using a combination of blind duplicate analyses; split sample analyses between the EPA Environmental Services Laboratory in Athens, Georgia, and ORNL; and the analysis of biological reference standards and uncontaminated fish. Recoveries of representative organics were verified by spiking uncontaminated fish or clam samples with known amounts of PCBs and analyzing them. Details and results of these procedures are summarized in Appendix A.

\subsubsection{Results}

\subsubsection{Metals}

Mercury contamination in fish from the WOC system (WOC, Northwest Tributary, Melton Branch, WOL, and WOC embayment) has been described in previous annual reports (Loar et al. 1992a; Loar 1992b). In this most recent sampling, concentrations remained elevated above those found in fish from Hinds Creek, a reference stream, but they were well below the FDA tolerance level $(1 \mu \mathrm{g} / \mathrm{g})$ in all fish (Table 4.1). Mercury contamination was not evident in fish downstream from WOL (WCK 0.9) or in fish from Melton Branch (MEK 0.2).

Bluegill were also captured in Melton Hill Reservoir (MHR) and the Clinch River upstream (CRK 35.2) and downstream (CRK 31.5) from the mouth of WOC and analyzed for mercury in order to identify any impact of ORNL discharges to WOC in terms of mercury concentrations in fish in the Clinch River. Mercury concentrations in fish at these sites were quite low, indicating that mercury in the WOC discharge was having no effect on ordinary levels in fish in the Clinch River. While mercury contamination in fish in WOC is clear, the efficiency of WOL in trapping mercury, coupled with the dilution of the WOC discharge in WOC embayment and the Clinch River, act to confine elevated mercury concentrations in fish to the WOC drainage proper.

As was the case in 1986 and 1987, fish collected from the WOC system contained all other metals at concentrations similar to those found in fish from the reference stream (Table 4.1; Appendix B, Table B.1). Improved analytical detection limits made it possible to discern an apparent slight difference in mean copper concentrations between reference stream fish and WOC fish; however, the difference was only statistically significant (paired t-tests, $p$ $<0.05$ ) at WCK 0.9 . The concentrations of metals (except for mercury) in fish from the WOC system also were quite similar to those reported by the Tennessee Valley Authority (TVA) for MHR (Table 4.1; TVA 1985, 1986) and to the geometric mean concentrations of metals ( $\mathrm{Pb}, \mathrm{Cd}, \mathrm{As}$, $\mathrm{Se}, \mathrm{Cu}, \mathrm{Zn}$ ) observed in fish in the National Contaminant Biomonitoring Program (Table 4.1; Lowe et al. 1985). A comparison of the levels of metals in fish from the WOC system with Preliminary Guidance Values (PGVs) [derived to screen for levels of contamination that potentially threaten human health (Hoffman et al. 1984, Travis et al. 1986)] indicates that only arsenic, beryllium, and mercury may approach this threshold (Table 4.1). Neither arsenic nor beryllium were elevated in WOC fish; however, the $P G V$ is set at a level below background due to the carcinogenicity of these two metals. The PGV screening approach is 
Table 4.1. Mean metal concentrations in fish (measured in micrograms per gram, wet $w$ ) from White Oak Lake (WOL), White Oak Creek and tributaries

\begin{tabular}{|c|c|c|c|c|c|c|c|c|c|c|c|}
\hline \multirow{2}{*}{ Metal } & \multicolumn{11}{|c|}{ Site } \\
\hline & NTK 0.2 & WCK 3.5 & WCK $29^{\circ}$ & WCK 2.3 & MEK 0.2 & WOL & WCK 0.9 & Hinds $\mathrm{Cr}^{b}$ & $T^{T} A^{c}$ & USFWS & PGV \\
\hline Sb & $<0.12$ & $<0.12$ & $<0.12$ & $<0.12$ & $<0.12$ & $<0.12$ & $<0.12$ & $<0.3$ & - & - & 5.2 \\
\hline As & $<0.06$ & $<0.06$ & $<0.06$ & $<0.06$ & $<0.06$ & $<0.06$ & $<0.06$ & $<0.06$ & $<0.03$ & 0.16 & 0.0007 \\
\hline $\mathrm{Be}$ & $<0.04$ & $<0.04$ & $<0.04$ & $<0.04$ & $<0.04$ & $<0.04$ & $<0.04$ & $<0.05$ & $<1$ & - & 0.004 \\
\hline $\mathrm{Cd}$ & $\begin{array}{c}0.005 \\
(0.004)\end{array}$ & $\begin{array}{c}0.005 \\
(0.004)\end{array}$ & $\begin{array}{c}0.008 \\
(0.004)\end{array}$ & $\begin{array}{c}0.003 \\
(0.002)\end{array}$ & $\begin{array}{c}0.006 \\
(0.005)\end{array}$ & $\begin{array}{c}0.007 \\
(0.007)\end{array}$ & $\begin{array}{c}0.003 \\
(0.002)\end{array}$ & $\begin{array}{c}0.007 \\
(0.005)\end{array}$ & $\begin{array}{c}0.007 \\
(0.003)\end{array}$ & 0.04 & 1.0 \\
\hline $\mathrm{Cr}$ & $<0.1$ & $<0.1$ & $<0.1$ & $<0.1$ & $<0.1$ & $<0.1$ & $<0.1$ & $<0.1$ & 0.06 & - & 1.8 \\
\hline $\mathrm{Cu}$ & $\begin{array}{c}0.15 \\
(0.17)\end{array}$ & $\begin{array}{c}0.23 \\
(0.14)\end{array}$ & $\begin{array}{c}0.27 \\
(0.18)\end{array}$ & $\begin{array}{c}0.16 \\
(0.14)\end{array}$ & $\begin{array}{c}0.15 \\
(0.18)\end{array}$ & $\begin{array}{c}0.18 \\
(0.16)\end{array}$ & $\begin{array}{c}0.69 \\
(0.64)\end{array}$ & $\begin{array}{c}0.08 \\
(0.05)\end{array}$ & $\begin{array}{c}0.4 \\
(0.3)\end{array}$ & 0.86 & 36 \\
\hline $\mathbf{P b}$ & $<0.02$ & $\begin{array}{l}<0.02^{\prime} \\
(0.04)\end{array}$ & $0.03^{\prime}$ & $<0.02$ & $<0.02$ & $0.02^{\prime}$ & 0.02 & $<0.02$ & $\begin{array}{c}0.21 \\
(0.33)\end{array}$ & 0.19 & 1.8 \\
\hline $\mathbf{L i}$ & $<0.4$ & $<0.4$ & $<0.4$ & $<0.4$ & $<0.4$ & $<0.4$ & $<0.4$ & $<0.05$ & - & - & - \\
\hline $\mathbf{H g}$ & $\begin{array}{c}0.25 \\
(0.10)\end{array}$ & $\begin{array}{c}0.30 \\
(0.07)\end{array}$ & $\begin{array}{c}0.38^{8} \\
(0.11)\end{array}$ & $\begin{array}{c}0.18 \\
(0.07)\end{array}$ & $\begin{array}{c}0.06 \\
(0.02)\end{array}$ & $\begin{array}{c}0.26 \\
(0.12)\end{array}$ & $\begin{array}{c}0.06 \\
(0.01)\end{array}$ & $\begin{array}{c}0.09^{4} \\
(0.03)\end{array}$ & $<0.1$ & 0.11 & 0.42 \\
\hline $\mathrm{Ni}$ & $<0.6$ & $<0.6$ & $<0.6$ & $<0.6$ & $<0.6$ & $<0.6$ & $<0.6$ & $<1.0$ & $<1.0$ & - & 5.2 \\
\hline Se & $\begin{array}{c}0.42 \\
(0.13)\end{array}$ & $\begin{array}{c}0.33 \\
(0.15)\end{array}$ & $\begin{array}{c}0.40 \\
(0.10)\end{array}$ & $\begin{array}{c}0.35 \\
(0.16)\end{array}$ & $\begin{array}{c}0.23 \\
(0.07)\end{array}$ & $\begin{array}{c}0.24 \\
(0.05)\end{array}$ & $\begin{array}{c}0.29 \\
(0.07)\end{array}$ & $\begin{array}{c}0.30 \\
(0.15)\end{array}$ & $\begin{array}{c}0.7 \\
(0.2)\end{array}$ & 0.46 & 12 \\
\hline Ag & $<0.06$ & $<0.06$ & $<0.06$ & $<0.06$ & $<0.06$ & $<0.06$ & $<0.06$ & $<0.10$ & $<0.3$ & - & 0.29 \\
\hline
\end{tabular}


Table 4.1. (contineed)

\begin{tabular}{|c|c|c|c|c|c|c|c|c|c|c|c|}
\hline \multirow{2}{*}{ Metal } & \multicolumn{11}{|c|}{ Site } \\
\hline & NTK 0.2 & WCK 3.5 & WCK $29^{\circ}$ & WCK 23 & MEK 0.2 & WOL & WCK 0.9 & Hinds $\mathrm{Cr}$ & TVA $^{c}$ & USFWS & PGVe \\
\hline $\mathrm{T}$ & $<0.2$ & $<0.2$ & $<0.2$ & $<0.2$ & $<0.2$ & $<0.2$ & $<0.2$ & $<0.2$ & $<1$ & - & 0.66 \\
\hline $\mathrm{Zn}$ & $\begin{array}{c}6.0 \\
(3.0)\end{array}$ & $\begin{array}{c}4.8 \\
(1.2)\end{array}$ & $\begin{array}{c}6.9 \\
(1.6)\end{array}$ & $\begin{array}{c}6.5 \\
(2.1)\end{array}$ & $\begin{array}{c}6.8 \\
(1.5)\end{array}$ & $\begin{array}{c}9.5 \\
(3.2)\end{array}$ & $\begin{array}{c}6.3 \\
(1.7)\end{array}$ & $\begin{array}{c}6.1 \\
(0.5)\end{array}$ & $\begin{array}{c}8.4 \\
(2.6)\end{array}$ & 25.6 & 180 \\
\hline
\end{tabular}

$n=6$ bluegill, 7 redbreast sunfish.

${ }^{6}$ Reference stream located in Anderson County, Tennessee.

Tennessee Valley Authority (TVA) 1985. Instream Contaminant Study, Task 4: Fish sampling and analysis. Report to U.S.

Department of Energy, Oak Ridge Operations Office. Tennessee Valley Authority, Office of Natural Resources and Economic Development, Knoxville, Tennessee.

T. P. Lowe et al. 1985. National Contaminant Biomonitoring Program: Concentrations of seven elements in freshwater fish, 1978-1981. Arch. Environ. Contam. Toxicol. 14:363-388.

-Preliminary Guidance Values (from Hoffman, F. O. et al. 1984. Preliminary Screening of Contaminants in Sediments. ORNLTM 9370. Oak Ridge National Laboratory, Oak Ridge, Tennessee; and Travis, C. C. et al. 1986. Preliminary Review of TVA Fish Sampling and Analysis Report. Report

of Task Group Five to Oak Ridge Task Force. Mimeo)

Only one sample exceeded detection limit.

$s_{n}=15$.

$n=16$.

Note: NTK = Northwest Tributary kilometer, WCK = White Oak Creek kilometer; MEK = Melton Branch kilometer, WOL = White Oak Lake; Hinds $\mathrm{Cr}=$ Hinds Creek; TVA = Tennessee Valley Authority; USFWS = U.S. Fish and Wildlife Service. Fish are bluegill (Lepomis

macrochinus) and redbreast sunfish (Lepomis aurinus) collected in winter 1987/1988; $n=6$ except where noted; \pm 1 SD in parentheses. 
very conservative and designed to eliminate from concern any substances not exceeding a specific PGV (Hoffman et al. 1984).

\subsubsection{Organics}

In organic screening analyses, fish collected in WOC and Melton Branch in 1986 were found to be contaminated with PCBs (Loar 1992b). In 1987, fish were therefore collected at all sites and analyzed for PCBs using packed column gas chromatography, which provides greater sensitivity than the capillary column system used in screening analyses and is used in this program for quantitative PCB studies. Semiannual sampling was initiated at two sites (WOL and WCK 2.9) to establish a better baseline for evaluating future changes. Results of the 1987-1988 monitoring confirmed the general conclusion of Loar (1992b) that there is a source of PCB contamination in the WOC drainage upstream from WCK 3.5 (Table 4.2; Appendix B, Table B.5; Fig. 4.1). PCBs were found in sunfish at all sites in WOC, with the highest mean concentration occurring in bluegill at WCK 2.9. Statistical comparisons conducted using an analysis of variance (ANOVA) and paired t-tests on $\log _{e}$ - transformed data $(p<0.05)$ indicated that PCB concentrations at most sites in WOC were similar. The mean concentration of PCBs in bluegill from WOC embayment (WCK 0.9) was significantly lower than the concentrations at all sites in WOC except WCK 2.3 and WCK 3.5, and the mean concentration of PCBs in bluegill from WCK 2.9 was significantly higher than that at WCK 2.3. Comparisons among other combinations of sites in WOC did not differ. The mean PCB concentrations in bluegill from Melton Branch (MEK 0.2) and Northwest Tributary (NTK 0.2) were significantly different, and each was significantly lower than the concentration at all sites in WOC. Mean PCB concentrations at all sites exceeded the concentrations in reference stream fish; however, the mean concentration in fish from Melton Branch was not atypical of results observed previously at the reference site. The occurrence of very low PCB concentrations in sunfish from Melton Branch was a change from the previous year, when results of caged clam studies indicated no PCB contamination in this stream but fish collected from Melton Branch contained significant concentrations of PCBs.

PCBs were found in some fish collected in Northwest Tributary but not in others, a trend similar to that observed previously. As was discussed in the first annual report (Loar et al. 1992a), fish are able to move back and forth between NTK 0.2 and WCK 3.5. The dichotomous pattern of contamination observed for PCBs, mercury, and ${ }^{137} \mathrm{Cs}$ all suggest that NTK 0.2 is not contaminated with these materials. Instead, some fish from contaminated reaches of WOC move into Northwest Tributary and are captured.

The distribution of mean PCB concentrations in bluegill in the WOC drainage in winter $1987-88$ is depicted in Fig. 4.1. This figure includes data on PCB concentrations in fish collected in MHR and the Clinch River upstream from ORNL discharges, as well as the Clinch River downstream from the mouth of WOC. Elevated concentrations of PCBs were not observed in bluegill collected at any sites in the Clinch River system in the vicinity of ORNL, despite the fact that channel catfish and gizzard shad from these sites did contain elevated concentrations of PCBs (Sect. 4.2; Loar 1992b).

The PCB mixtures found in fish from WOC and tributaries most closely resembled commercial mixtures Arochlor 
OFin-DWG asen-15007

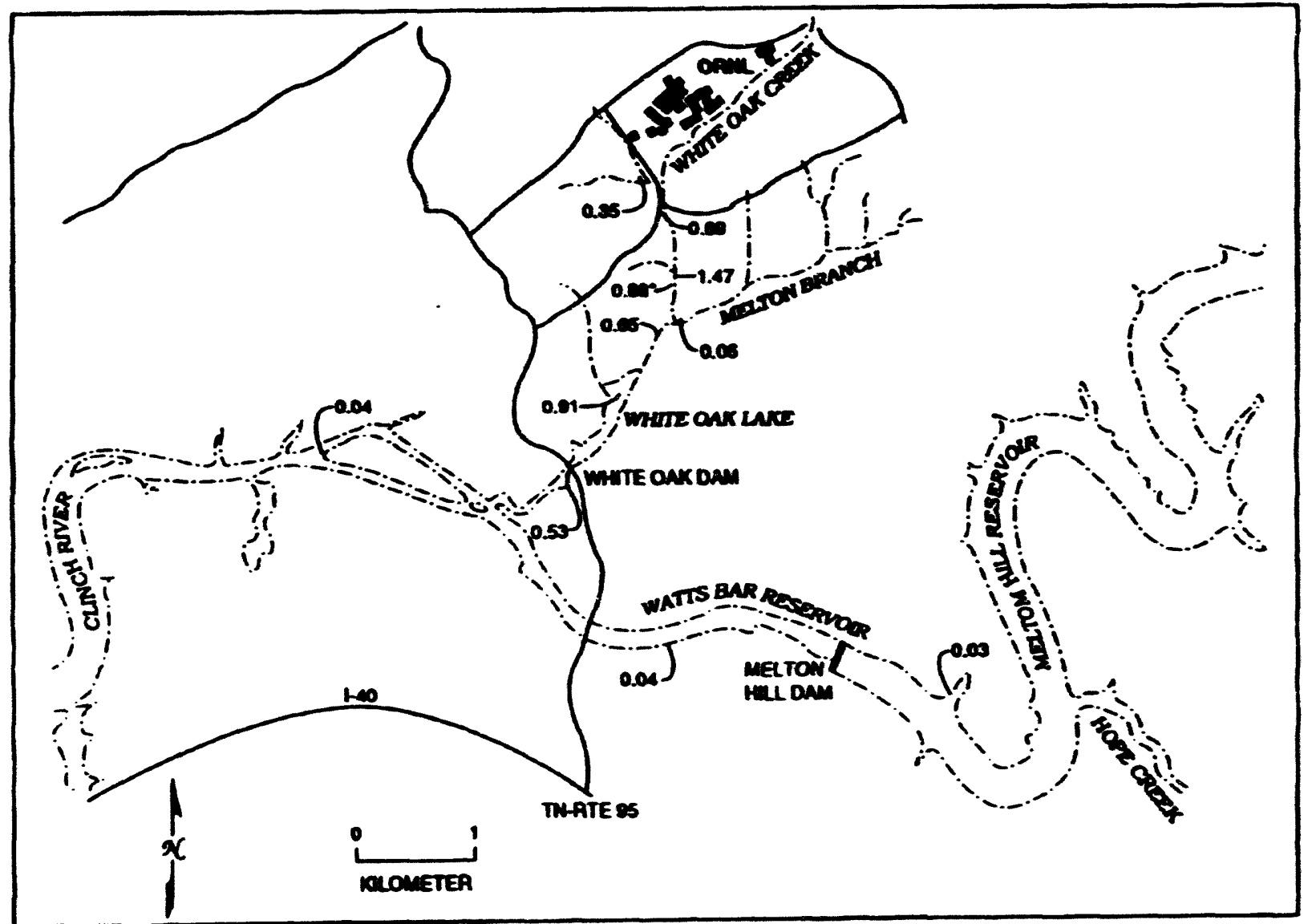

Fig. 4.1. Mean concentrations of polychlorinated biphenyts in blucgill (Lepamis macochines) collected at sites in the White Oak Creek drainge and nearby reaches of the Clinch River, Nov $\Omega$ Dec 1987. "Redbreast sunfish, $L$. Aurizus. 
1254 and 1260 (referred to as PCB-1254 and PCB-1260 because the composition of PCBs extracted from fish differs substantially from that of commercial mixtures). PCB-1254 generally predominated in samples taken from WOC, but the proportion of PCB-1260 was higher in fish from WOL.

No other organic contaminants were detected in fish from WOC, except for trace levels of PAHs and di- $N$-butylphthalate, which were also present in laboratory blanks (Table 4.2).

The results of PCB analysis of caged clams held in WOC and tributaries are given in Table 4.3. An expanded number of sites were evaluated in 1988 in an effort to locate the area of the PCB source in the WOC system. Elevated concentrations of PCBs were clearly evident only at sites in WOL and WOC embayment. Clams from WCK 3.5 did not indicate the presence of

Table 4.2 Concentrations of polychlorinated biphenyls (PCBs) and other organic priority pollutants (in micrograms per gram, wet weight) in bluegill and redbreast sunfish

(Lepomis macrochirus and $L$ auritus) from the Clinch River, White Oak Lake, White Oak Creek and tributaries, and Melton Hill Reservoir

\begin{tabular}{lllllll}
\hline Site & Season & Species & $\begin{array}{c}\text { PCB } \\
\text { Mean } \pm \text { SD }\end{array}$ & Range & Exceedencese & $\begin{array}{c}\text { Other } \\
\text { organics }\end{array}$ \\
\hline WCK 3.5 & Dec. 1987 & Bluegill & $0.69 \pm 0.36$ & $0.34-1.19$ & $0 / 8$ & BLD \\
WCK 2.9 & Dec. 1987 & Bluegill & $1.47 \pm 1.25$ & $0.50-4.2$ & $1 / 7$ & BLD \\
& Dec. 1987 & Redbreast & $0.88 \pm 0.31$ & $0.47-1.34$ & $0 / 8$ & \\
& July 1987 & Redbreast & $0.89 \pm 0.90$ & $0.13-2.7$ & $1 / 8$ & \\
WCK 2.3 & Dec. 1987 & Bluegill & $0.65 \pm 0.41$ & $0.31-1.6$ & $0 / 8$ & BLD \\
WOL & Dec. 1987 & Bluegill & $0.91 \pm 0.70$ & $0.30-2.25$ & $1 / 8$ & BLD \\
& July 1987 & Bluegill & $1.17 \pm 0.68$ & $0.35-2.4$ & $1 / 8$ & BL.D \\
WCK 0.9 & Dec. 1987 & Bluegill & $0.53 \pm 0.62$ & $0.09-2.0$ & $1 / 8$ & \\
MEK 0.2 & Dec. 1987 & Bluegill & $0.06 \pm 0.01$ & $0.05-0.08$ & $0 / 8$ & \\
NTK 0.2 & Dec. 1987 & Bluegill & $0.35 \pm 0.45$ & $0.03-1.29$ & $0 / 8$ & BLD \\
CRK 31.5 & Dec. 1987 & Bluegill & $0.04 \pm 0.02$ & $0.02-0.08$ & $0 / 8$ & \\
CRK 35.2 & Dec. 1987 & Bluegill & $0.04 \pm 0.02$ & $0.01-0.08$ & $0 / 8$ & \\
MHR & Dec. 1987 & Bluegill & $0.03 \pm 0.01$ & $0.02-0.06$ & $0 / 8$ & \\
\hline
\end{tabular}

Number of samples exceeding the FDA limit for PCBs of $2 \mu \mathrm{g} / \mathrm{g}$ [U.S. Department of Agriculture Food and Drug Administration (FDA). 1984. Polychlorinated Biphenyls in Fish and Shelljish:

Reduction of Tolerances, Final Decision. Fed. Regist. 49:21514-21520.]

$n=4$.

${ }^{\prime} B L D=$ Below limit of detection. Low concentrations of benzo[a]pyrene $(<0.04 \mu g / g) ;$ benzo[b]fluoranthene $(<0.25 \mu \mathrm{g} / \mathrm{g})$; benzo[k]fluoranthene $(<0.09 \mu \mathrm{g} / \mathrm{g})$; and dibenz $[a, h]$ anthracene $(<0.36 \mu \mathrm{g} / \mathrm{g})$ were reported in HPLC analysis of most samples. Benzo[ghi]perylene and indenopyrene were reported in HPLC analysis of most samples and laboratory blank.

Note: WCK $=$ White Oak Creek kilometer; WOL $=$ White Oak Lake; MEK $=$ Melton Branch kilometer; NTK $=$ Northwest Tributary kilometer; CRK $=$ Clinch River kilometer; MHR $=$ Melton Hill Reservoir. 
Table 43. Concentrations of polychlorinated bipheayls (PCBs) and other organios in duplicate composite samples of caged clams (Corbicula fuminea) March 2-31, 1988

\begin{tabular}{|c|c|c|c|}
\hline \multirow{2}{*}{ Site } & \multicolumn{2}{|c|}{ Total PCBo ( $u$ :/8 wet wt) } & \multirow{2}{*}{$\begin{array}{l}\text { Other organics } \\
\text { ( } \mu \mathrm{g} / \mathrm{g} \text { wet } w t)\end{array}$} \\
\hline & Mean & Range & \\
\hline WCK 6.9 & 0.07 & $0.07-0.07$ & NA \\
\hline WCK 5.4 & • & $\bullet$ & $\bullet$ \\
\hline WCK 4.7 & 0.08 & $0.08-0.08$ & NA \\
\hline WCK 3.8 & 0.08 & $0.04-0.12$ & NA \\
\hline WCK 3.5 & 0.06 & $0.06-0.06$ & BLD' \\
\hline WCK 2.6 & व & 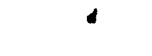 & \\
\hline WOL & 0.82 & $0.77-0.87$ & BLD' \\
\hline WCK 0.1 & 0.37 & $0.36-0.37$ & BLD' \\
\hline NTK 0.2 & 0.05 & $0.04-0.05$ & \\
\hline MEK 0.2 & 0.04 & $0.03-0.05$ & BLD' \\
\hline East Tributary & 0.03 & 0.03 & \\
\hline SWSA 4 Tributary & 0.05 & $0.04-0.05$ & \\
\hline Bull Run & 0.04 & $0.03-0.04$ & BLD' \\
\hline
\end{tabular}

PCB-1254 + PCB-1260. PCB-1260 was $\leq 0.01 \mu \mathrm{g} / \mathrm{g}$ in all samples except WOL ( $0.06 \mu \mathrm{g} / \mathrm{g}$ in each) and WCK 0.1 (0.04 $\mu \mathrm{g} / \mathrm{g}$ in each).

Interference prevented detection of PCBs. GC/MS analysis of samples identified interference as chlordane (estimated concentrations of 18.6 and $19.4 \mu \mathrm{g} / \mathrm{g}$ in duplicate samples).

-All clams (including reference site) contained similar concentrations of benzo[a]pyrene, $(0.033-0.086 \mu \mathrm{g} / \mathrm{g})$, dibenz $[\mathrm{a}, \mathrm{h}$ ]anthracene, $(0.012-0.030 \mu \mathrm{g} / \mathrm{g})$ and pyrene $(0.024-0.040 \mu \mathrm{g} / \mathrm{g})$. Benzo[ghi]perylene and indenopyrene were present in all samples and most laboratory blanks. Other results exceeding detection limits in individual samples were $0.29 \mu \mathrm{g} / \mathrm{g}$ naphthalene and $0.04 \mu \mathrm{g} / \mathrm{g}$ phenanthrene at WOL, $0.04 \mu \mathrm{g} / \mathrm{g}$ anthracene at WCK 3.5, and $0.015 \mu \mathrm{g} / \mathrm{g}$ at WOK 0.9 .

'Cage lost in high water.

small tributary on east side of White Oak Creek at WCK 3.4.

'Only a single sample was available for analysis at this site; thus, there is only one value.

'Small tributary draining SWSA 4.

"Background concentrations in clams before placement in stream.

Nore: $\mathrm{NA}=$ Not analyzed; $\mathrm{BLD}=$ Below detection limit. $\mathrm{WCK}=$ White Oak Creek kilometer; WOL $=$ White Oak Lake; NTK $=$ Northwest Tributary kilometer; MEK = Melton Hill kilometer; SWSA $=$ Solid Radioactive Waste Storage and Disposal Area.

PCB contamination, despite the fact that fish from this site were clearly PCB contaminated. In 1987, the PCB concentration in clams from WCK 2.6 was much higher than that in clams from WCK 3.5 (Loar 1992b). In 1988, the WCK 2.6 samples were lost in high water; however, PCBs in clams placed in WOC tributaries between WCK 3.5 and WCK 2.6 did not accumulate PCBs. No PCBs were detected in clams from Melton Branch in 1988, a result consistent with the 1987 findings and the 1988 sunfish results.

Chlordane was found at very high concentrations $(19 \mu \mathrm{g} / \mathrm{g}$ wet $w t)$ in duplicate samples at a single site (WCK 
5.4) upstream from most ORNL facilities, but downstream from the 7000 area. However, chlordane was not found in clams at sites farther downstream.

Chlordane was not detected in sunfish collected at various sites in the WOC drainage downstream from WCK 5.4 in 1987. Clam exposures were repeated in late summer/fall 1988 to specifically investigate the possibility of chlordane contamination in WOC. Preliminary results of these studies indicated that chlordane was present in clams, with the highest concentration occurring at WCK 5.4 . Confirmation of the presence of chlordane by $\mathrm{GC} / \mathrm{MS}$ is pending. No other organic contaminants were found at significant concentrations in the clam samples. Very low concentrations of several PAHs were reported in clams from both WOC and the reference site (Table 4.3), using the highly sensitive HPLC/ fluorescence method.

Although this method is sensitive, it is nonconfirmatory and susce $\mu$ tible to interferences. It is unlikely that the trace levels of PAHs found in the clams reflect hydrocarbon contamination of the WOC system.

\subsubsection{Discussion}

\subsubsection{Metals}

The 1987-88 monitoring confirmed the conclusion of the previous year's results: that the bioaccumulation of metals other than mercury is not a problem anywhere in the WOC drainage. The concentrations of trace metals in fish were typical of those found in fish from a reference stream and were similar to concentrations found in 1986 and in previous surveys of WOC (Loar et al. 1981, TVA 1985, Loar 1992b). Moreover, no cause for concern was indicated by the comparison of concentrations of metals in
WOC fish with concentrations assumed for screening purposes to represent a potential health hazard to humans who ingest fish on a regular basis.

Results of mercury analyses in fish again indicated the presence of a source of biologically available mercury upstream from WCK 3.5. Preliminary results of the NPDES mercury monitoring program implemented by the ORNL EMC suggests multiple sources to WOC and Fifth Creek in the vicinity of lower Fifth Creek (F.G. Taylor, ORNL/EMC, personal communication). Biological monitoring of mercury in fish closer to the source is impossible due to the absence of resident populations in this reach (Sect. 6.2); however, populations of species consumed by humans would be very limited in this reach, even if it were nontoxic, due to the scarcity of suitable habitat for such fishes.

\subsubsection{Organics}

The accumulation of PCBs in fish from the WOC system was again evident in 1987-88. Two pieces of evidence suggest that PCBs in fish in WOC are the result of recent, rather than historical, exposure:

(1) concentrations in sunfish were similar to those observed in 1986, and (2) clams placed in WOC for 4 weeks accumulated PCBs. If PCB concentrations in sunfish in 1986 resulted from prior, episodic exposure, the levels in fish in 1987 would have decreased due to depuration and mortality/replacement of contaminated fish. The 1987-88 results provided additional evidence that the source of PCB contamination in the WOC system is upstream from WCK 3.5 and that Melton Branch is not a PCB source. Results of analyses of PCBs in sediments conducted as part of the NPDES PCB Monitoring Program were consistent with the distribution of PCBs in fish; the highest 
PCB concentrations occurred in the sediments at WCK 3.5 (Blasing et al. 1989).

Monitoring with caged clams did not detect PCB contamination at WCK 3.5 in 1987 or at sites on WOC upstream from the Bldg. 4500 complex. These results suggest either that much of the PCB accumulation in stream biota results from episodic exposures or that residual chlorine in WOC above WCK 3.5 may prevent clams from effectively accumulating PCBs. (I.e., filtering rates are reduced to avoid exposure to toxic chlorine concentrations, resulting in less feeding and PCB uptake and the consumption of lipid reserves that would accumulate PCBs).

\subsubsection{Conclusions}

The bioaccumulation of $\mathrm{PCBs}$ remains the most significant problem in the WOC system related to the accumulation of metals and organics in biota. Biotic contamination reflects recent accumulation rather than historical residues from past exposures, and the source of ongoing PCB inputs to stream waters is either sediments or discharges upstream from WCK 3.5 (and probably downstream from WCK 4.7). The WOC drainage continues to act as a source of PCB contamination to upper Watts Bar Reservoir; however, PCB inputs to that system do not have a perceptible impact on PCB concentrations in sunfish and, presumably, other species with similar food habits, intramuscular lipid content, and lifespan. The accumulation of PCBs by fat-rich forage fish, such as gizzard shad, and the subsequent transfer to predator fishes provides a mechanism by which PCB discharges from WOC can impact PCB concentrations in some fishes (e.g., channel catfish) in the Clinch River while producing no discernable increase in PCBs in sunfish (See Sect. 4.2 for additional discussion)
Mercury concentrations in WOC fish were well below the FDA action level throughout the drainage, and WOL appears to be an effective trap that prevents elevated mercury concentrations in fish below the lake. Efforts by EMC personnel to locate sources have been successful, but the nature of such sources and their amenability to remedial measures remains unknown.

\subsection{EVALUATION OF PCB CONTAMINATION IN WHITE OAK CREEK EMBAYMENT AND THE CLINCH RIVER}

\subsubsection{Introduction}

Monitoring conducted in 1986 and 1987 (Loar et al. 1992a; Loar 1992b) established that the WOC discharge is a source of PCB contamination to WOC embayment and the Clinch River.

Approximately $25 \%$ of the channel catfish (Ictalurus punctatus) captured in WOC embayment and nearby reaches of the Clinch River in both 1986 and 1987 contained PCB concentrations in excess of the $2 \mu \mathrm{g} / \mathrm{g}$ FDA limit (FDA 1984b). Results of the 1987 survey suggested that channel catfish ranges were greater than indicated in 1986, thus increasing the likelihood that fish contaminated during a period of residence in WOC embayment would at some time be vulnerable to capture by anglers in waters open to the public. The 1986 and 1987 studies also indicated that other sources were significant contributors to PCB levels in catfish near ORNL. In particular, MHR upstream from the confluence of WOC with the Clinch River appeared to contribute approximately $50 \%$ of the PCB burden of catfish in the upper Clinch River.

The objectives of this task of the ORNL BMAP in 1988 were to continue 
(1) routine monitoring of $\mathrm{PCBs}$ in channel catfish in WOC embayment and nearby reaches of the Clinch River to ensure that PCB contamination from this source does not increase, and (2) assessment of the extent to which ORNL is the source of PCB contamination in channel catfish in public waters downstream. In an effort to compare the impact of ORNL (as a PCB source to Clinch River catfish) with that of the EFPC/Poplar Creek system, which is also known to be a major contributor of PCBs (Loar et al. 1992c), the study was expanded in 1988 to include sites in lower Poplar Creek (within the K-25 site) and the Clinch River several kilometers downstream from the mouth of Poplar Creek. Measuring ${ }^{90} \mathrm{Sr}$ in catfish vertebrae was continued in 1988 as a means of identifying fish with substantial exposure to the WOC discharge, which is the only significant input of ${ }^{90} \mathrm{Sr}$ to the upper Clinch River. Because ${ }^{90} \mathrm{Sr}$ is readily accumulated in fish bone and retained due to its long biological half-time, it acts as a measure of cumulative exposure to the WOC discharge. Both PCBs and ${ }^{90} \mathrm{Sr}$ were also measured in gizzard shad collected at the catfish sampling sites to further evaluate the possible role of this species as a vector for PCB dispersal and accumulation by catfish.

\subsubsection{Methods}

Results of monitoring conducted in 1986 and 1987 indicated that channel catfish collected from sites near the mouth of WOC contained PCB concentrations similar to those in fish collected in WOC embayment. The 1988 collections near ORNL, therefore, were restricted to (1) WOC embayment (WCK 0.3 ), to measure the maximum impact of the WOC/WOC embayment source on PCB concentrations in this species; (2) a single site in the Clinch River $1.3 \mathrm{~km}$ downstream from the mouth of WOC (CRK 32.2), to measure the maximum impact of the WOC source on PCB levels in channel catfish populations in the Clinch River; and (3) MHR, to identify that component of the PCB burden in Clinch River fish associated with sources upstream from WOC. To evaluate the relative significance of WOC and Poplar Creek as sources of PCB contamination in Clinch River catfish, collections were also made in lower Poplar Creek (PCK 6.9) and in the Clinch River about $4 \mathrm{~km}$ below the mouth of Poplar Creek (CRK 15.0). Catfish were collected in July/August 1988 by trotline and gill net at the five sites noted in Fig. 4.2. The sampling program attempted to capture eight channel catfish (Ictalurus punctatus) weighing $440 \mathrm{~g}$ or more at each site. Uncontaminated catfish purchased from a local commercial fish farm in 1987 were used again in 1988 as analytical controls.

Fish collected at each site were placed on ice in a labeled ice chest and returned to the laboratory for processing. Individual ice chests were used to contain fish from each site when more than one station was sampled on a given date. Upon return to the laboratory, fish were tagged with a unique four-digit tag wired to the lower jaw. Each fish was then weighed, measured, and the dorsal fin removed for possible age determination. The fish was fileted, and the skin was removed from the filet. Filets were rinsed in running water, and one filet was wrapped in heavy duty aluminum foil and stored in a locked freezer at $-20^{\circ} \mathrm{C}$ for archival purposes. The remaining filet was frozen and then ground three times in a hand meat grinder. A 10 - to $20-\mathrm{g}$ sample of ground fish was wrapped in heavy duty aluminum foil, labeled by writing directly on the aluminum foil with a permanent marker, and stored in a locked freezer until submitted to the ORNL/ACD laboratory for analysis.

Gizzard shad were collected from the five sites in Fig. 4.2 by electrofishing and 


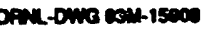

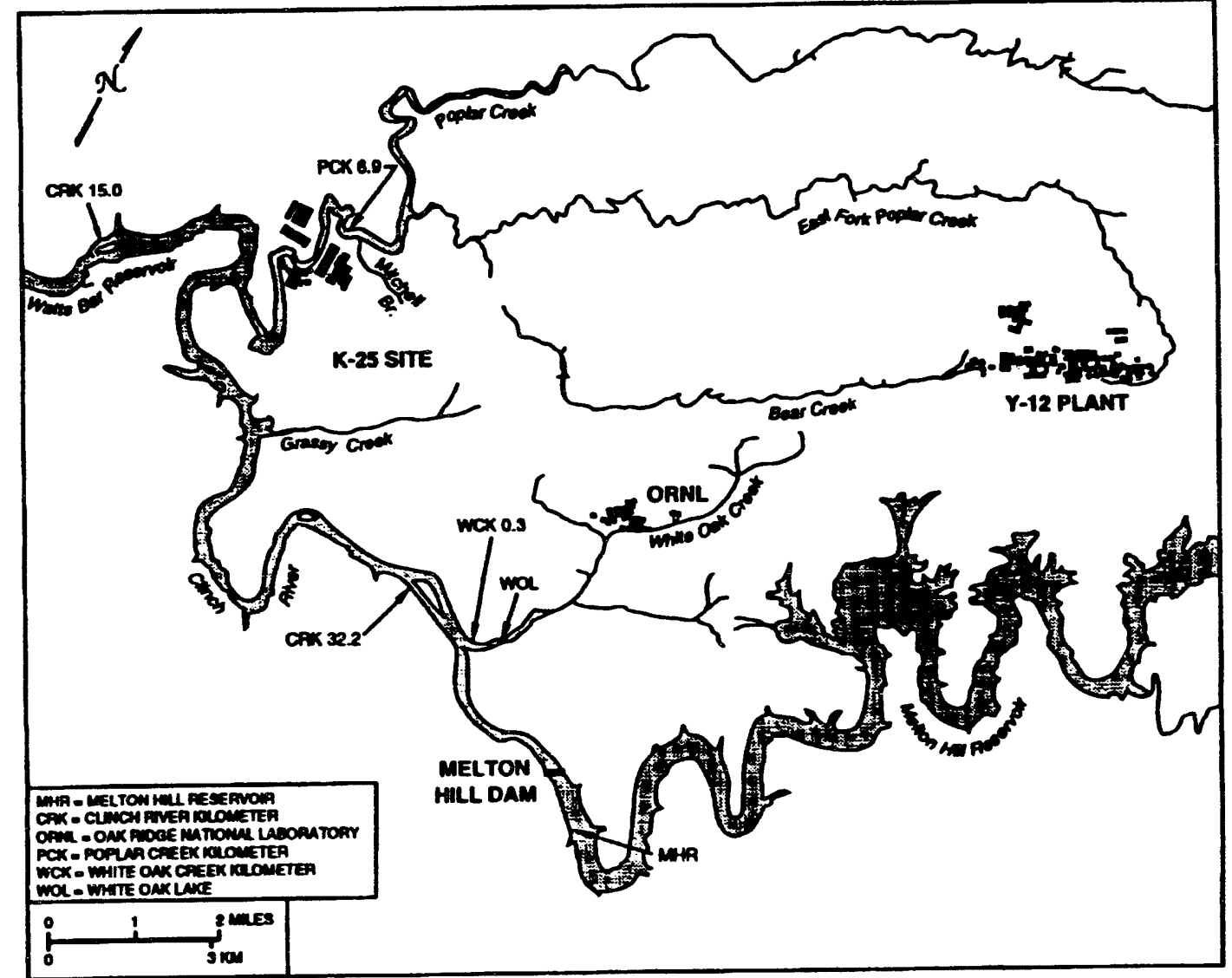

Fig. 4.2 Location of sites on the Oak Ridge Reservation where channel catfish and givard shad were collected for polychlorinated biphenyl analysis in July/August 1988. Numerical designations indicated distance in kilometers above the mouth of the stream (i.e., Clinch River kilometer (CRK) 15.0 is a site in the Clinch River $15 \mathrm{~km}$ upstream from its mouth). 
analyzed for PCBs in order to estimate levels in a likely food of channel catfish. Three composite samples of five fish each (22-29 cm total length) were taken from each site. After removing the viscera, the fish were ground whole, frozen, and submitted for analysis.

A 4- to 5-cm portion of the vertebral column was removed from the tail of each catfish, air dried, wrapped and labeled, and sent to the $A C D$ for ${ }^{90} \mathrm{Sr}$ analysis. For gizzard shad, portions of the backbone of each fish were removed and submitted as composite samples (from the same five fish) for ${ }^{90} \mathrm{Sr}$ analysis.

Fish were analyzed for PCBs using procedure EPA 600/4-81-055 (EPA 1980b). This procedure utilizes extraction with methylene chloride followed by adsorption column cleanup, solvent exchange, and evaporative concentration prior to analysis by packed column GC/ECD. Strontium-90 was determined by beta counting using a low background proportional counter. Prior to counting, the fish vertebrae were ashed, dissolved in nitric acid, and subjected to a chemical purification procedure in which a strontium oxalate precipitate is ultimately isolated for counting (Volchok and Planque 1982).

Statistical evaluations of the data were made using SAS procedures and software (SAS 1985b) for ANOVA, paired t-tests, linear regression analysis, and calculation of the mean, standard deviation, standard error, and coefficient of variation.

Quality assurance was maintained using a combination of blind duplicate analyses; split sample analyses between the EPA Environmental Services Laboratory, in Athens, Georgia and the ORNL/ACD laboratory; and the analysis of fish reference standards and uncontaminated fish spiked with PCBs. Details and results of these procedures are summarized in Appendix A.

\subsubsection{Results}

\subsubsection{PCBs in catfish from WOC Embayment/Clinch River}

PCB contamination was evident in channel catfish from WOC ambayment, the Clinch River near ORNL, ana the Clinch River and Poplar Creek near the K-25 site (Table 4.4 and Appendix B, Table B.4). As was the case in 1986 and 1987 (Loar et al. 1992a; Loar 1992b), channel catfish collected from MHR (upstream from any possible inputs from WOC) also contained significant concentrations of PCBs. The PCB mixtures recovered from fish contained predominantly penta- and hexachlorobiphenyl congeners characteristic of Arochlor 1254 and 1260 commercial mixtures. PCB-1260 predominated in fish from MHR and sites near the K-25 site; however, PCB 1254 and 1260 were present in roughly equal concentrations in fish collected near ORNL. Total PCBs in individual fish ranged from a high of $2.4 \mu \mathrm{g} / \mathrm{g}$ at CRK 32.2 (near ORNL) to a low of $0.07 \mu \mathrm{g} / \mathrm{g}$ in a fish from MHR. Catfish obtained in 1987 from a commercial catfish farm were re-analyzed in 1988 and again were found to contain very low concentrations of PCBs, averaging $0.03 \mu \mathrm{g} / \mathrm{g}$. The minimum PCB concentration found in Clinch River/WOC embayment fish from the ORNL vicinity was $0.15 \mu \mathrm{g} / \mathrm{g}$. In 1988 , the fraction of fish near ORNL (sites WCK 0.3 and CRK 32.2) that contained PCB concentrations in excess of the FDA tolerance limit of $2 \mu \mathrm{g} / \mathrm{g}(3 / 16)$ was similar to that observed in $1986(3 / 20)$ and 1987 (4/16) (Table 4.5). No fish exceeded the FDA limit at any of the other sites. Contaminants with long biological half-lives tend to accumulate in a fish to ever higher levels throughout much of its lifespan. Thus, larger, older fish may 
contain higher contaminant levels than smaller, younger fish. The effects of such a bias can be significant if fish collected from some sites are predominantly small while those from other sites are predominantly large. Such effects can often be avoided by collecting adult fish of similar size. Therefore, channel catfish weighing less than $440 \mathrm{~g}$ were not included in this study if adequate numbers of larger fish were collected at a site. Mean weights of fish comprising the collections varied somewhat among sites (659 to $1773 \mathrm{~g}$ ). In general, mean fish size in 1988 more closely resembled that of the 1986 collection than the 1987 one, if two very large fish (6118 and $4850 \mathrm{~g}$ ) collected in MHR are excluded. The fish were retained and analyzed in an effort to gain further understanding of PCB contamination at that site. These two samples were included in the overall analysis because no statistically significant relationship between PCB concentration and fish weight was found at this site, even when data from 1986,1987 , and 1988 were pooled.

Regressions of ${ }^{90} \mathrm{Sr}$, total PCB, PCB-1254, and PCB-1260 vs fish weight at each site showed no significant relationship (slope not different from zero, $p>0.05$ ) in 17 of 20 possible comparisons. Therefore, comparisons of mean contaminant levels among sites were made without normalizing for variations in fish weight.

The highest mean concentration of PCBs in catfish collected in 1988 was 0.91 $\mu \mathrm{g} / \mathrm{g}$ in fish from WOC embayment (Table 4.4). The mean PCB concentration in fish at this site was also highest in 1986 (Loar et al. 1992a) and differed only slightly from the maximum in 1987 (Loar 1992b). The mean PCB concentrations in fish from the two Clinch River sites $(0.58$ and $0.50 \mu \mathrm{g} / \mathrm{g}$ at CRK 32.2 and CRK 15.0, respectively) were virtually the same as the concentration in fish from MHR
$(0.51 \mu \mathrm{g} / \mathrm{g})$. Statistical comparisons of $\log _{e}-$ transformed and untransformed data (ANOVA and pairwise t-tests, $p>0.05$ ) indicated that there were no significant differences in mean total PCB concentrations among the five sites. Although mean concentrations of PCB-1260 also were not significantly different among sites, PCB-1254 concentrations did differ significantly. Concentrations of PCB-1254 in fish from WOC embayment and a nearby site on the Clinch River (CRK 32.2) were significantly higher than in fish from the lower Clinch River site (CRK 15.0) and MHR. (This comparison was based on $\log _{e}$-transformed values to adjust for unequal variances.) Finally the mean PCB-1254 concentration in fish from Poplar Creek was significantly lower than that in fish from WCK 0.3.

Results of the analyses of ${ }^{90} \mathrm{Sr}$ in catfish vertebrae in 1988 were similar to previous results in that ${ }^{90} \mathrm{Sr}$ concentrations varied much more among sampling sites than did PCBs. The highest mean concentration of ${ }^{90} \mathrm{Sr}(732 \mathrm{~Bq} / \mathrm{kg})$ was not found in fish from WOC embayment, but rather in fish from a nearby reach of the Clinch River (CRK 32.2). As was the case in $1987,{ }^{90} \mathrm{Sr}$ concentrations in fish bone did not differ significantly between the two sites (paired $t$-tests on $\log _{\mathrm{e}}$-transformed data due to unequal variances); however, ${ }^{90} \mathrm{Sr}$ was significantly higher at these two sites than at the two sites not in the Clinch River (MHR and PCK 6.9). Fish from the lower Clinch River site contained significantly higher levels of ${ }^{90} \mathrm{Sr}$ than fish from MHR, which has no major ${ }^{90} \mathrm{Sr}$ source, and significantly lower levels of ${ }^{90} \mathrm{Sr}$ than fish from WCK 0.3. Some fish collected at all three Clinch River/WOC sites contained levels of ${ }^{90} \mathrm{Sr}$ consistent with exposure to a relatively undiluted WOC discharge, with maximum concentrations of 2100,3200 , and 1200 
Table 4.4. Concentrations of polychlorinated biphenyls (PCBs) and "Sr in channel cattish (Ictaburus punctatus) from sites in the Clinch River arm of Watts Bar Reservoir in the vicinity of Department of Energy facilities, July/August

\begin{tabular}{lcccc}
\hline Location $^{a}$ & $\begin{array}{c}\text { PCB-Total } \\
(\mu \mathrm{g} / \mathrm{g} \text { wet wt })\end{array}$ & $\begin{array}{c}\text { PCB-1254 } \\
(\mu \mathrm{g} / \mathrm{g} \text { wet wt })\end{array}$ & $\begin{array}{c}\text { PCB-1260 } \\
(\mu \mathrm{g} / \mathrm{g} \text { wet wt })\end{array}$ & $\begin{array}{c}{ }^{90} \mathrm{Sr} \\
(\mathrm{Bq} / \mathrm{kg} \text { dry wt bone })\end{array}$ \\
\hline WCK 0.3 & $0.96 \pm 0.80$ & $0.45 \pm 0.45$ & $0.51 \pm 0.38$ & $600 \pm 677$ \\
& $0.15-2.27$ & $0.08-1.30$ & $0.07-1.00$ & $405-1425$
\end{tabular}

(8)

(8)

(8)

(8)

\begin{tabular}{lcccc} 
CRK 32.2 & $0.58 \pm 0.75$ & $0.27 \pm 0.42$ & $0.31 \pm 0.33$ & $732 \pm 1125$ \\
& $0.20-2.40$ & $0.06-1.30$ & $0.11-1.10$ & $14-3200$ \\
& $(8)$ & $(8)$ & $(8)$ & $(8)$ \\
PCK 6.9 & $0.71 \pm 0.37$ & $0.10 \pm 0.09$ & $0.61 \pm 0.39$ & $33 \pm 35$ \\
& $0.28-1.31$ & $0.01-0.28$ & $0.21-1.30$ & $3-110$ \\
& $(8)$ & $(8)$ & $(8)$ & $(8)$ \\
CRK 15.0 & $0.50 \pm 0.21$ & $0.08 \pm 0.08$ & $0.42 \pm 0.17$ & $217 \pm 399$ \\
& $0.15-0.90$ & $<0.01-0.23$ & $0.12-0.67$ & $19-1200$ \\
& $(9)$ & $(9)$ & $(9)$ & $(9)$ \\
MHR & & & & $58 \pm 95$ \\
& $0.52 \pm 0.49$ & $0.04 \pm 0.08$ & $0.48 \pm 0.47$ & $0-250$ \\
& $0.07-1.61$ & $<0.01-0.27$ & $0.05-1.60$ & $(10)$ \\
\hline
\end{tabular}

${ }^{\text {"WCK }}=$ White Oak Creek kilometer; CRK = Clinch River kilometer; PCK = Poplar Creek kilometer; $\mathrm{MHR}=$ Melton Hill Reservoir.

Note: Sampling sites were located in lower White Oak Creek embayment, the Clinch River, lower Poplar Creek, and Melton Hill Reservoir. Values are mean \pm 1 SD, range, and number of samples (in parentheses).

$\mathrm{Bq} / \mathrm{kg}$ at WCK 0.3, CRK 32.2, and CRK 15.0 , respectively.

\subsubsection{Strontium-90 vs PCB}

No close correspondence between mean $\mathrm{PCB}$ and ${ }^{90} \mathrm{Sr}$ concentrations in fish was apparent in fish from the 1988 collection (Table 4.4). The slopes of linear regressions of PCB vs ${ }^{90} \mathrm{Sr}, \mathrm{PCB}$ vs $\mathrm{l}_{\mathrm{n}}\left({ }^{90} \mathrm{Sr}\right)$, and $I_{n}(P C B)$ vs $I_{n}\left({ }^{90} \mathrm{Sr}\right)$ were not significantly different from zero $(p>0.05)$ when fish from WOC embayment, CRK
32.2, and MHR were combined. The same treatment of the data on individual Arochlor mixtures gave similar results, with the exception of $\mathrm{l}_{\mathrm{a}}(\mathrm{PCB}-1254)$ vs $\mathrm{l}_{\mathrm{a}}\left({ }^{90} \mathrm{Sr}\right)$. When fish from all sites were combined, no significant relationship was noted for total PCBs or PCB-1260, but $l_{n}$ (PCB-1254) vs $\left.\mathrm{I}_{\mathrm{a}}{ }^{90} \mathrm{Sr}\right)$ was again statistically significant. Thus, the results were similar to those observed in 1986 and 1987; that is, there was no discernable relationship between ${ }^{90} \mathrm{Sr}$ and total PCBs or PCB-1260 but a significant, though weak, relationship between ${ }^{90} \mathrm{Sr}$ and PCB-1254. 


\subsubsection{Temporal changes in PCB concentrations in catfish}

Concentrations of PCBs in fish collected from WOC embayment and the Clinch River (CRK 32.2) in 1988 were somewhat lower than the concentrations found in fish from the same sites in 1987 and 1986 (Table 4.5). A statistical comparison (ANOVA and paired t-tests, $p>0.05$ ) indicated that the differences between years were not statistically significant at WCK 0.3. At CRK 32.2, the 1988 levels were significantly lower than those in 1987 and 1986 for the comparison based on $\log _{e}$-transformed data but not for that based on untransformed data. Year-toyear variation in PCBs in MHR was not statistically significant. When fish from the WOC embayment and Clinch River sites that were sampled in all 3 years were pooled and compared, the mean PCB concentration in 1988 was significantly lower than that in 1987. However, it should be noted that the mean weight of fish in the 1987 collection was higher and a significant relationship was observed between weight and PCB content (Loar 1992b).

The mean concentration of ${ }^{90} \mathrm{Sr}$ observed in fish from WOC embayment in 1988 was similar to that found in 1986 and somewhat higher than the mean concentration in 1987 (Table 4.5). At CRK 32.2 , the presence of several fish with high concentrations of ${ }^{90} \mathrm{Sr}$ produced a mean concentration that was much higher than the mean in 1986 or 1987 , but the difference was not statistically significant. Similarly, differences between years at WCK 0.3 and MHR were not significant.

In 1988, the fraction of fish from CRK 32.2 with a ${ }^{90} \mathrm{Sr}$ concentration that was typical of exposure within WOC embayment was higher than in previous years. For example, the maximum ${ }^{90} \mathrm{Sr}$ concentrations at this site in 1986 and 1987 were 120 and $800 \mathrm{~Bq} / \mathrm{kg}$, respectively, while 3 of 8 fish from this reach of the Clinch River contained $1100 \mathrm{~Bq} / \mathrm{kg}$ or more in

Table 4.5. Changes from 1986 to 1988 in mean concentrations of polychlorinated biphenyls and

"Sr, and the fraction of fish exceeding the U.S. Food and Drug Administration limit for channel catfish from lower White Oak Creek embayment, the Clinch River, lower Poplar Creek and Melton Hill Reservoir

\begin{tabular}{|c|c|c|c|c|c|c|c|c|c|}
\hline \multirow[t]{2}{*}{ Site } & \multicolumn{3}{|c|}{$\begin{array}{c}\text { PCB } \\
(\mu \mathrm{g} / \mathrm{g} \text { wet } w t)\end{array}$} & \multicolumn{3}{|c|}{$\begin{array}{c}{ }^{90} \mathrm{Sr} \\
\text { (Bq/kg dry wt bone) }\end{array}$} & \multicolumn{3}{|c|}{ Number over FDA limit ${ }^{b}$} \\
\hline & 1986 & 1987 & 1988 & 1986 & 1987 & 1988 & 1986 & 1987 & 1988 \\
\hline MHR & 0.46 & 0.81 & 0.52 & 14 & 11 & 58 & $0 / 6$ & $1 / 7$ & $0 / 10$ \\
\hline WCK $0.3^{a}$ & 1.30 & 1.59 & 0.96 & 741 & 351 & 600 & $3 / 12$ & $2 / 8$ & $2 / 8$ \\
\hline CRK 32.2 & 1.01 & 1.61 & 0.58 & 57 & 158 & 732 & $0 / 8$ & $2 / 8$ & $1 / 8$ \\
\hline PCK 6.9 & & & 0.71 & & & 33 & & & $0 / 8$ \\
\hline CRK 15.0 & & & 0.50 & & & 217 & & & $0 / 9$ \\
\hline
\end{tabular}

Two fish from WCK 0.9 in upper WOC embayment were included in the 1986 sample.

bNumber of samples that exceeded the FDA limit/total number of samples.

Note $:$ MHR = Melton Hill Reservoir; WCK $=$ White Oak Creek kilometer; CRK $=$ Clinch River kilometer; PCK = Poplar Creek kilometer; CRK $=$ Clinch River kilometer. 
1988. Two fish collected $17 \mathrm{~km}$ downstream contained 500 and $1200 \mathrm{~Bq} / \mathrm{kg}$ of ${ }^{90} \mathrm{Sr}$, indicating a much wider movement of fish exposed to WOC embayment than was observed in the 1986 and 1987 studies.

The proportion of fish exceeding the

FDA limit for PCBs in 1988 was similar to that observed in 1986 and 1987, with 25\% of the fish at WCK 0.3 containing more than $2 \mu \mathrm{g} / \mathrm{g}$ PCBs in all 3 years (Table 4.5). In 1988, 1 of 8 fish from CRK 32.2 exceeded the FDA limit, compared to 0 and 2 of 8 fish in 1986 and 1987 respectively.

\subsubsection{PCBs in gizzard shad}

Gizzard shad, an important forage fish in most reservoirs in East Tennessee, were sampled and analyzed for PCBs again in 1988 to further assess the significance of PCB accumulation in channel catfish via the food chain and to evaluate the role of forage fish as a possible mechanism for PCB dispersal.

PCB contamination was evident in gizzard shad at all six sampling sites in 1988. The highest concentrations were found in WOL, averaging $6.03 \mu \mathrm{g} / \mathrm{g}$ (Table 4.6). Shad from WOC embayment (WCK 0.3) and lower Poplar Creek (PCK 6.9) also contained high concentrations of PCBs, averaging $2.98 \mu \mathrm{g} / \mathrm{g}$ at each site. Concentrations of PCBs in fish from the Clinch River were strikingly lower, averaging 0.98 and $0.82 \mu \mathrm{g} / \mathrm{g}$ at CRK 32.2 and CRK 15.0, respectively. PCB contamination was also evident in MHR fish, which averaged $0.40 \mu \mathrm{g} / \mathrm{g}$. PCB-1260 was the predominant mixture in fish from MHR and locations near the K-25 site (PCK 6.9 and CRK 15.0), but PCB-1254 was relatively higher in fish collected near ORNL (WCK 0.3 and CRK 32.2). The lower proportion of PCB-1254 in fish from WOL is seemingly inconsistent with the higher proportion of PCB-1254 in fish collected in WOC embayment and the Clinch River near ORNL. Results of ANOVA and paired t-test comparisons $(p<0.05)$ showed that $(1)$ the mean PCB concentration in fish from WOL was significantly higher than the concentration at the other sites and (2) concentrations at WCK 0.3 and PCK 6.9 significantly exceeded those at CRK 15.0 and MHR. Other comparisons between sites were not significantly different. Similar results were obtained when the same comparisons were made using $\log _{e}$-transformed data; WOL, PCK 6.9, and WCK 0.3 each were significantly higher than the other three sites, and the concentration in fish from WOL significantly exceeded that in fish from WCK 0.3.

There was little difference in mean PCB concentrations in shad between 1987 and 1988. Fish from WCK 0.3 averaged 3.0 $\mu \mathrm{g} / \mathrm{g}$ and $2.98 \mu \mathrm{g} / \mathrm{g}$ in 1987 and 1988 respectively. Corresponding comparisons at CRK 32.2 and MHR for the 2 years were 0.65 vs 0.98 and 0.44 vs $0.40 \mu \mathrm{g} / \mathrm{g}$, respectively.

Gizzard shad from WOL contained high concentrations of ${ }^{90} \mathrm{Sr}$, while fish from WOC embayment had substantially lower concentrations (Table 4.6), reflecting dilution of the WOC discharge in the embayment. Fish collected in the Clinch River contained elevated concentrations of ${ }^{90} \mathrm{Sr}$, although levels were substantially lower than in WOC embayment. The occurrence of a high concentration of ${ }^{90} \mathrm{Sr}$ $(380 \mathrm{~Bq} / \mathrm{kg})$ in one composite from CRK 15.0 , as well as the wide range of concentrations at WCK 0.3 , suggest substantial movement of schools of gizzard shad between sampling locations. Statistical comparison of ${ }^{90} \mathrm{Sr}$ vs site indicated that levels in shad at all sites except lower Poplar Creek significantly exceeded the concentration in MHR fish, but differences between fish from WCK 0.3 and each of the two Clinch River sites could not be distinguished. Mean ${ }^{90} \mathrm{Sr}$ concentrations in 
Table 4.6. Concentrations of polychlorinated biphenyls and $\mathrm{Mr}$ in givard shad (Dorasoma cepedianum) from White Oak Lake, lower White Oak Creek embayment, the Clinch River, lower Poplar Creek, and Melton Hill Reservoir

\begin{tabular}{lcccc}
\hline Site & $\begin{array}{c}\text { PCB-total } \\
(\mu \mathrm{g} / \mathrm{g} \text { wet wt })\end{array}$ & $\begin{array}{c}\text { PCB-1254 } \\
(\mu \mathrm{g} / \mathrm{g} \text { wet wt) }\end{array}$ & $\begin{array}{c}\text { PCB-1260 } \\
(\mu \mathrm{g} / \mathrm{g} \text { wet wt })\end{array}$ & $\begin{array}{c}\text { NSr } \\
(\mathrm{Bg} / \mathrm{kg} \text { dry wt bone })\end{array}$ \\
\hline WOL & $6.03 \pm 0.55$ & $1.73 \pm 1.65$ & $4.30 \pm 1.60$ & $2967 \pm 833$ \\
& $5.40-6.39$ & $0.49-3.60$ & $2.70-5.90$ & $2300-3900$ \\
WCK 0.3 & $2.98 \pm 2.33$ & $1.38 \pm 1.26$ & $1.60 \pm 1.10$ & $718 \pm 561$ \\
& $0.91-5.50$ & $0.41-2.80$ & $0.50-2.70$ & $74-1100$ \\
CRK 32.2 & $0.98 \pm 0.66$ & $0.40 \pm 0.37$ & $0.58 \pm 0.29$ & $106 \pm 60$ \\
& $0.58-1.74$ & $0.17-0.83$ & $0.38-0.91$ & $37-150$ \\
CRK 15.0 & $0.82 \pm 0.21$ & $0.24 \pm 0.05$ & $0.58 \pm 0.18$ & $149 \pm 201$ \\
& $0.58-0.94$ & $0.21-0.30$ & $0.37-0.7$ & $218-380$ \\
PCK 6.9 & $2.98 \pm 1.31$ & $0.61 \pm 0.47$ & $2.37 \pm 1.61$ & $18 \pm 18$ \\
& $1.76-4.37$ & $0.17-1.10$ & $1.20-4.20$ & $0-35$ \\
MHR & $0.40 \pm 0.05$ & $0.13 \pm 0.04$ & $0.27 \pm 0.06$ & $8 \pm 6$ \\
& $0.35-0.44$ & $0.08-0.16$ & $0.21-0.33$ & $0.7-13$ \\
\hline
\end{tabular}

${ }^{a}$ WOL $=$ White Oak Lake; WCK $=$ White Oak Creek kilometer; CRK = Clinch River kilometer; PCK $=$ Poplar Creek kilometer; MHR = Melton Hill Reservoir.

shad vertebrae in 1988 were similar to those observed in 1987 (Loar 1992b), with only WCK 0.3 differing by more than $20 \%$ between the 2 years (397 vs $718 \mathrm{~Bq} / \mathrm{kg}$ in 1987 and 1988 respectively).

There was a reasonably strong relationship between $\mathrm{PCB}$ concentrations in gizzard shad and the ${ }^{90} \mathrm{Sr}$ concentration in shad vertebrae, even though the sample size was relatively small. Among the WOL, WCK 0.3, CRK 32.2, and MHR samples (PCK 6.9 and CRK 15.0 were not included because they were taken downstream from other known PCB sources), linear regression of $\mathrm{PCB}$ vs ${ }^{90} \mathrm{Sr}$ yielded the expression:

$$
[\mathrm{PCB}]=0.0017\left[{ }^{90} \mathrm{Sr}\right]+1.03, \mathrm{r}^{2}=0.74
$$

When WOL was eliminated from the analysis because sediments in WOC embayment may be the primary source of PCBs at that site, the following expression was obtained:

$$
[\mathrm{PCB}]=0.0032\left[{ }^{90} \mathrm{Sr}\right]+0.57, \mathrm{r}^{2}=0.68
$$

Including only WCK 0.3 and CRK 32.2 in the analysis shows whether or not PCB and ${ }^{90} \mathrm{Sr}$ are related in fish that are able to enter and leave the ${ }^{90} \mathrm{Sr}$-tagged effluent. (Fish at WOL are confined to and those in MHR are excluded from the ${ }^{90} \mathrm{Sr}$ source.) Unfortunately, this severely restricts the sample size, making it difficult to discern a relationship. The observed relationship between PCBs and ${ }^{N} \mathrm{Sr}$ at these two sites was thus significant only at $0.1>p>0.05$ in 1988; however, when 1987 and 1988 data were combined, the following expression was statistically significant:

$\left.[\mathrm{PCB}]=0.00311^{90} \mathrm{Sr}\right]+0.89, \mathrm{r}^{2}=0.46$.

These results indicate that the concentration of ${ }^{90} \mathrm{Sr}$ in shad vertebrae is a predictor of PCB content of the fish in the reach of the Clinch River near ORNL. Such a finding is consistent with WOC 
embayment/WOL being the source of a substantial fraction of the PCB burden in gizzard shad in this reach.

\subsubsection{Discussion}

\subsubsection{PCBs in Clinch River catfish}

Concentrations of PCBs in catfish in WOC embayment and nearby reaches of the Clinch River continued to remain stable between 1986 and 1988, following the large decrease between 1984 and 1986 (Loar et al. 1992a). As in 1986 and 1987, a substantial fraction (19\%) of channel catfish collected in 1988 from WOC embayment and nearby reaches of the Clinch River open to public fishing contained PCBs in excess of the 2 ppm FDA limit. Thus, the characterization of PCB contamination in channel catfish near ORNL remained unchanged from the previous two years.

Concentrations of PCBs in channel catfish from the Clinch River (CRK 15.0) downstream of other known sources of PCBs in the Poplar Creek drainage differed relatively little from levels at upstream sites. It was particularly surprising to observe little increase in PCB concentrations in catfish from Poplar Creek embayment, because the PCB contribution of EFPC to this system has been well documented (Loar 1992c), and the high concentrations from PCBs in gizzard shad at this site indicate the presence of significant contamination.

Several lines of evidence suggest that channel catfish may have larger ranges than was initially believed on the basis of the 1986 and 1987 studies. Thus, their contaminant burdens may not be as closely related to the site of capture as suggested by these previous data. Both the presence of high levels of ${ }^{90} \mathrm{Sr}$ in vertebrae of catfish collected at CRK 15.0-far from the source at WOC-and the high concentrations of
${ }^{90} \mathrm{Sr}$ in 3 of 8 fish taken at CRK 32.2 demonstrate greater movement than was found in 1986 or 1987. Concentrations of PCBs in gizzard shad appeared to correspond well to local sites of PCB contamination despite evidence from the ${ }^{90} \mathrm{Sr}$ analyses that shad range between sampling sites as far apart as ORNL and the ORGDP. Concentrations of PCBs in catfish, however, did not exhibit this pattern. The most straightforward explanation for how catfish living in a site of localized PCB contamination (of both food and water) would not accumulate corresponding PCB residues is that the catfish obtained much of their food by foraging outside the contaminated area. For example, catfish in WOC embayment may forage extensively outside the embayment in the Clinch River. Although speculative, such an explanation would also result in a poor correlation between ${ }^{90} \mathrm{Sr}$ and PCB concentrations. The 1988 data do further support the conclusion of the previous monitoring reports (Loar et al. 1992a; Loar 1992b) that catfish which accumulate contaminants in WOC embayment are likely to move into areas of the Clinch River open to public fishing.

\subsubsection{WOC as a source of PCBs}

Results reported in Sect. 4.1 of this report and in the previous report (Loar 1992b) clearly documented that WOC upstream from WOL contained a source of biologically available PCBs. The high levels of PCBs in gizzard shad from WOL and WCK 0.3 indicated that the WOL discharge was a likely source of PCBs to WOC embayment. However, PCB ccncentrations in both channel catfish and gizzard shad from MHR suggest that, even if no additional PCB sources were present at ORNL, catfish in the Clinch River near WOC would contain levels at least as high as those in MHR, or approximately 0.6 
$\mu \mathrm{g} / \mathrm{g}$ (mean PCB concentration in MHR, 1986-88). Disregarding the lack of a strong relationship between ${ }^{90} \mathrm{Sr}$ and PCBs, a maximum estimate of the impact of the ORNL discharge on PCB concentrations in Clinch River catfish would be to assume that all PCBs in excess of $0.6 \mu \mathrm{g} / \mathrm{g}$ come from the WOC discharge. Using this assumption, ORNL could have contributed approximately $40 \%$ of the PCB burden of channel catfish collected in WOC embayment in 1988, but its contribution was not detectable in fish collected in the Clinch River. It is likely that this contribution from WOC is important in causing a substantial fraction of catfish to exceed the FDA limit near ORNL.

Two other methods can be used to estimate the importance of the WOC discharge as a PCB source. The first assumes that all PCBs in gizzard shad in excess of the mean concentration in MHR shad $(0.4 \mu \mathrm{g} / \mathrm{g})$ are derived from WOC/WOC embayment. This approach estimates that $87 \%$ of the PCBs in gizzard shad in WOC embayment are from that source, and $58 \%$ of the PCB burden of shad in the Clinch River (CRK 32.2) is due to the WOC discharge. A second method uses the relationship between PCBs and ${ }^{90} \mathrm{Sr}$ in gizzard shad to estimate the impact of the WOL/WOC embayment discharge on PCB concentrations in shad near ORNL. If mean concentrations of ${ }^{90} \mathrm{Sr}$ in MHR, WCK 0.3, and CRK 32.2 are used to estimate mean concentrations of PCBs in shad at these sites, equation (1) in Sect. 4.2.3.4 estimates that 54 and $15 \%$ of the PCB burden of shad at WCK 0.3 and CRK 32.2 , respectively, comes from WOC/WOC embayment. Equation (2) in Sect. 4.2.3.4 may be a better choice of predictive expressions, because the differing ratios of PCB-1254/1260 between shad collected in WOL vs WCK 0.3 suggest that contaminated sediments in the embayment may be a PCB source in addition to the WOL discharge. The use of this expression estimates that WOL/WOC embayment contributes 80 and $37 \%$, respectively, of the PCBs found in shad in the embayment and in the Clinch River at CRK 32.2.

The high levels of PCBs accumulated by gizzard shad in WOC embayment, coupled with the evidence of movement of several kilometers based on ${ }^{90} \mathrm{Sr}$ concentrations in fish well downstream from the source, supports the hypothesis that this species could act to distribute PCB contamination from localized sources throughout large reservoirs.

\subsubsection{Conclusions}

The results of the 1988 PCB monitoring of channel catfish are consistent with the conclusions of the previous two years (Loar et al. 1992a; Loar 1992b): (1) some channel catfish caught by anglers in the Clinch River in the vicinity of WOC are likely to contain PCBs in excess of the $2 \mu \mathrm{g} / \mathrm{g}$ FDA limit, and (2) a significant fraction, although not necessarily most, of the PCB content of those fish originates in the WOC discharge and/or WOC embayment. The highest mean PCB concentrations in channel catfish were again found in fish from WOC embayment, and PCB concentrations in gizzard shad from WOL and WOC embayment indicated the role of WOL discharge as a source.

Additional evidence on the movement of channel catlish and gizzard shad was obtained in 1988. These data, together with the high levels of PCB contamination found in gizzard shad at localized sites of PCB contamination (i.e., WOL, WOC embayment, and lower Poplar Creek), 
suggest that the movements of both species may provide a mechanism whereby localized PCB sources can result in more widespread contamination of channel catfish within a reservoir.

\subsection{INTEGRATION OF WATER QUALITY AND BIOACCUMULATION DATA}

Concentrations of various metals are routinely measured in surface waters at the Y-12 Plant, $\mathrm{K}-25$ site, and ORNL as part of routine NPDES monitoring. Concentrations of metals in sediments and periphyton clearly indicate that fish at several of these sites are likely to be exposed to higher than normal concentrations of metals. (Ashwood et al. 1986; Loar 1992b, Sect. 3.2.2; Weston, Inc. 1988). Fish at these sites have been analjzed for trace metal content as part of the BMAPs at the three DOE facilities in Oak Ricige (Loar 1992b, 1992c; Smith et al. 1993a). The objective of this task is to investigate the relationship between the concentration of metals measured in water and in fish at NPDES monitoring sites in order to "calibrate" NPDES

aqueous-phase monitoring so it can be used to predict metal concentrations in fish. If the water quality characteristics of specific sites could be used to determine whether hazardous concentrations of metals could occur in fish, it would eliminate the need for monitoring a broad spectrum of metals in fish.

Work on this task follows two lines of investigation. An empirical comparison will be made of the NPDES data on metals in water and fish in receiving waters below discharges from DOE facilities. Also, published studies and reviews of the bioaccumulation of metals in fish will be used to evaluate whether the concentrations of metals in water at those sites could produce hazardous levels of metals in fish.

Mean concentrations of metals in water and fish at NPDES sites in WOC, WOL, Melton Branch, Mitchell Branch, and EFPC are presented in Table 4.7. No metals occurred at consistently higher concentrations in water at some sites than at others, except mercury. Mean concentrations generally varied by less than a factor of five among all sites, and much of that difference appeared to result from a few high values or differences in detection limits among laboratories at the three facilities. The pattern of low variation in metal concentrations among sites was repeated in the fish data; again only mercury differed substantially among sites. Metal concentrations in fish at all sites were similar to concentrations in fish at the uncontaminated reference site (Sect. 4.1; Loar 1992b, 1992c; Smith et al. 1993a). No bioaccumulation of metals in fish was evident, even though metals are presumed to be elevated in plant effluents. Because no substantial variation in metal concentrations in water and fish exists among the five sites and because metal concentrations in fish are similar to background levels at all sites, the calibration of NPDES water monitoring data against BMAP fish data is not a meaningful exercise, and other approaches must be taken to evaluate such data.

Concentrations of mercury in fish and water did differ among sites. The highest mean mercury concentration in fish $(1.23 \mu \mathrm{g} / \mathrm{g}$ in EFPC) corresponded to the highest mean concentration in water $(2.8$ $\mu \mathrm{g} / \mathrm{L})$. However, mercury-contaminated fish were also found in WOC and WOL (0.38 and $0.26 \mu \mathrm{g} / \mathrm{g}$ ), where aqueous mercury concentrations were far lower $(0.08 \mu \mathrm{g} / \mathrm{L})$. Fish from Melton Branch contained mercury at levels $(0.06 \mu \mathrm{g} / \mathrm{g})$ typical of uncontaminated sites, but the mean aqueous mercury concentration $(0.05 \mu \mathrm{g} / \mathrm{L})$ 


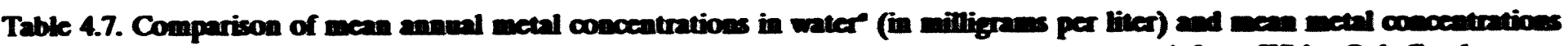

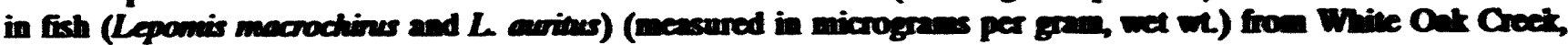
Melton Branch, White Oak Lake, Mitchell Branch, and East Fort Poplar Creek

\begin{tabular}{|c|c|c|c|c|c|c|c|c|c|c|}
\hline \multirow{3}{*}{ Metal } & \multicolumn{10}{|c|}{ Sise } \\
\hline & \multicolumn{2}{|c|}{ WCK 29} & \multicolumn{2}{|c|}{ MEK 0.2} & \multicolumn{2}{|l|}{ WOL } & \multicolumn{2}{|c|}{ Mivelell Branel } & \multicolumn{2}{|c|}{ EFK 234 } \\
\hline & Waver & Fiste & waver & Fish & Waver & Fich & Waver & Fin & Where & Find \\
\hline$A_{\mathbf{B}}$ & $<0.005$ & $<0.04$ & $<0.005$ & $<0.04$ & $<0.005$ & $<0.00$ & $<001$ & 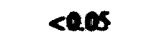 & ND & $<a 1$ \\
\hline As & $<0.06$ & $<0.06$ & $<0.06$ & $<0.06$ & $<0.06$ & $<0.06$ & ND & $<0.1$ & ND & cess \\
\hline Be & ND & $<0.02$ & ND & $<0.02$ & ND & $<0.02$ & <ocon & cees & $\begin{array}{c}\text { 2ecen } \\
\text { (<0.0001-0.0003) }\end{array}$ & $<0 e s$ \\
\hline Cd & $<0.002$ & $0.006 \pm 0.001$ & $<0.002$ & $0.006 \pm 0.002$ & $<0.005$ & $0.007 \pm 0.003$ & $\begin{array}{c}0.0022 \\
(<0.002-0.012)\end{array}$ & $2.05 \pm 0.01$ & $<0.003$ & $0.011 \pm 0.005$ \\
\hline $\mathrm{Cr}$ & $\begin{array}{c}0.062 \\
(<0.024-0.48)\end{array}$ & $<0.1$ & $<0.024$ & $<0.1$ & $\begin{array}{c}0.034 \\
(<0.024-0.093)\end{array}$ & $<0.1$ & $\begin{array}{c}0.011 \\
(<0.01-0.023)\end{array}$ & $<0.1$ & $\frac{0.036}{(<0.006-0.011)}$ & $<0.1$ \\
\hline Cw & $\begin{array}{c}0.012 \\
(<0.012-0.014)\end{array}$ & $0.27 \pm 0.05$ & $\begin{array}{c}0.012 \\
(<0.012-0.017)\end{array}$ & $0.15 \pm 0.05$ & 0.015 & $0.18 \pm 0.06$ & ND & $0.68 \pm 0.14$ & $\frac{0.007}{(2003-0.025)}$ & $0.37 \pm$ a.4 \\
\hline $\mathrm{H}_{6}$ & $\begin{array}{c}0.00008 \\
(<0.00005-0.00011)\end{array}$ & $0.38 \pm 0.29$ & $\begin{array}{c}0.000005 \\
(<0.00005-0.00010)\end{array}$ & $0.006 \pm 0.01$ & $\begin{array}{c}0.00005 \\
(<0.00005-0.00020)\end{array}$ & $0.26 \pm 0.044$ & $\begin{array}{c}0.0003 \\
(<0.0002-0.00006)\end{array}$ & $0.17 \pm 0.068$ & $\begin{array}{c}0.002 \\
\text { (<0.002-0.037) }\end{array}$ & $1.23 \pm 0.31$ \\
\hline Li & ND & $<0.4$ & ND & $<0.4$ & ND & $<0.4$ & ND & $<0.5$ & $\begin{array}{c}0.023 \\
(0.002-0.318)\end{array}$ & $<05$ \\
\hline $\mathrm{Ni}$ & $\begin{array}{c}0.047 \\
(<0.036-0.17)\end{array}$ & $<0.6$ & $<0.036$ & $<0.6$ & $<0.036$ & $<0.6$ & ND & $<1$ & $\frac{0.009}{(<0.007-0.204)}$ & $<1$ \\
\hline $\mathbf{P b}$ & $\begin{array}{c}0.0047 \\
(<0.004-0.012)\end{array}$ & $<0.06$ & $<0.004$ & $<0.02$ & $\begin{array}{c}0.0065 \\
(<0.004-0.019)\end{array}$ & $<0.03^{\circ}$ & $\begin{array}{c}0.009 \\
(<0.004-0.036)\end{array}$ & $0.05 \pm 0.05$ & $<0.02$ & $\alpha .3 \pm 2003$ \\
\hline Se & ND & $0.40 \pm 0.03$ & ND & $0.23 \pm 0.03$ & ND & $0.24 \pm 0.02$ & $<0.005$ & $0.50 \pm 0.10$ & ND & $2.45 \pm 0.4$ \\
\hline $\mathbf{Z n}$ & $\begin{array}{c}0.035 \\
(0.022-0.072)\end{array}$ & $6.5 \pm 0.5$ & $\begin{array}{c}0.030 \\
(<0.012-0.099)\end{array}$ & $6.8 \pm 0.6$ & $\begin{array}{c}0.042 \\
(<0.012-0.18)\end{array}$ & $9.5 \pm 1.3$ & $\begin{array}{c}0.036 \\
(<0.02-0.32)\end{array}$ & $5.5 \pm 0.3$ & $\begin{array}{c}0.053 \\
(0.19-0.151)\end{array}$ & $6.6 \pm 0.6$ \\
\hline
\end{tabular}

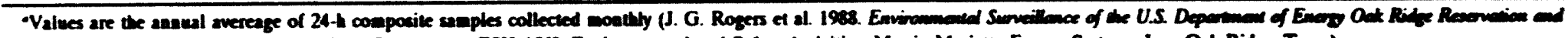

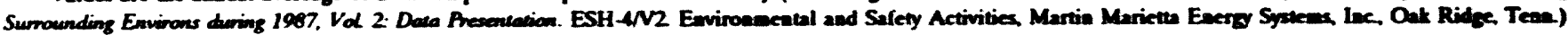

$P_{n}=13$.

$m=12$

Mean $H_{B}$ values calculated using $n=15$ for WCK 29. $n=8$ for MEK 0.2 and WOL, and $n=16$ for EFS 23.4 .

Only one of six samples coceeded delection timit

Eight values betow detection limit of 0.2 were included as 0.2 in calculatiog mean $(n=12)$.

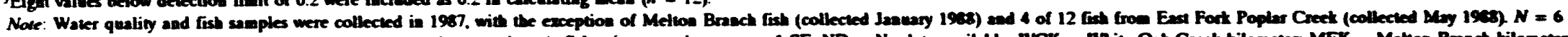

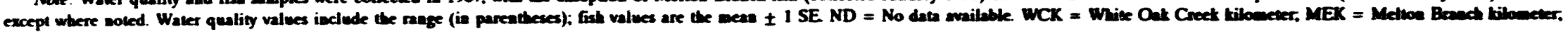
WOL = Whike Oak Lake; EFK = East Fort Poplar Creet kilometer. 
was similar to that in WOC/WOL. It does not appear, therefore, that aqueous mercury monitoring provides a useful tool for predicting mercury in fish at different sites. Elevated mercury in fish can occur where aqueous mercury barely exceeds the extremely low detection limit used at ORNL $(<0.05 \mu \mathrm{g} / \mathrm{L})$, while total mercury concentrations that are 50 times higher in EFPC are associated with mercury concentrations in fish that are only 4 times higher than those in WOC/WOL. Another approach to evaluating whether monitoring metal concentrations in water can protect against the accumulation of hazardous levels in fish is to compare measured aqueous concentrations with metal concentrations that would result in accumulation to hazardous levels in fish. The latter concentrations were obtained in two ways. Water quality criteria published by EPA (EPA 1986b) present aqueous phase concentrations of metals derived to protect human health from the ingestion of contaminated fish. Site-specific estimations of such criteria were obtained by comparing the mean concentrations of metals found in fish at these sites with the concentrations judged to be hazardous to consumers (PGVs) that were used in screening analyses (Hoffman et al. 1984, Travis et al. 1986). The second method involved calculation of the concentrations of specific metals in water that would result in metal concentrations in fish equal to the PGV. In this calculation, the mean annual concentration in water was divided by the ratio of the metal concentration in fish to the PGV. Such an analysis assumes that any increase in mean metal concentration in water would result in a proportional increase in metal concentration in fish. This assumption is unlikely to be valid due, in part, to homeostatic regulation of internal electrolyte composition in fish. However, it should provide a maximum estimate of any increases in metals in fish resulting from increases in aqueous-phase metal concentrations. The results of this analysis are shown in Table 4.8.

Metal concentrations measured in fish were well below levels judged to be hazardous, with the ratio of concentration in fish to PGV generally less than 0.05 when detectable concentrations were measured. Only arsenic and beryllium could not be judged not to exceed the PGVs; while both were below the analytical limits of detection, the levels judged to be hazardous are extremely low (below background levels in many foods). Mean annual concentrations or detection limits of all metals in water, except arsenic (and beryllium at the K-25 site), were well below EPA water quality criteria for protection of human health. Similarly, the site-specific criteria developed by the first method are well above concentrations detected in receiving waters. Thus, metal concentrations in both fish and water indicate that no public health problem exists with respect to metals accumulation (other than mercury) in fish at DOE facilities in Oak Ridge. Any increase to receiving streams of metal concentrations that are large enough to result in hazardous accumulations in fish could be readily detected by the present NPDES monitoring program, providing those metals were analyzed in water samples at all facilities and their detection limits were equal to the lowest currently reported by any of the three DOE plants. Implications of the results of this task will be considered in evaluating the future need for monitoring these metals in fish.

\subsection{FUTURE STUDIES}

Both the presence of significant PCB contamination in biota in WOC and evidence that PCBs from the WOC drainage are detectable in channel catfish 
Table 4.8. Mean annual concentrations of metals measured in receiving waters at National

Pollutant Discharge Elimination System sites; ratio of mean metal concentrations in fish

to Preliminary Ouidance Values (FISH/POV); estimated minimum concentrations in recelving waters producing metal concentrations in fish equal to PGVs (Water, Fish =PGV; and Environmental Protection Agency Water Quality Criteria (WQC) for protection of human health from ingesting fish

\begin{tabular}{|c|c|c|c|c|}
\hline \multirow[t]{2}{*}{ Metal } & \multirow[t]{2}{*}{$\begin{array}{l}\text { Water } \\
(\mu g / L)\end{array}$} & \multirow[t]{2}{*}{ Fish/PGV• } & $\begin{array}{c}\text { Fish, water } \\
\text { concentrations equal to } \\
\text { PGVs' }\end{array}$ & \multirow[t]{2}{*}{$\begin{array}{c}\text { WOC } \\
(\mu \mathrm{g} / \mathrm{L})\end{array}$} \\
\hline & & & $(\mu \mathrm{g} / \mathrm{L})$ & \\
\hline Ag & $<0.005$ & $<0.14$ & & $0.05^{c}$ \\
\hline As & $<0.06$ & $<86$ & & 0.00002 \\
\hline $\mathrm{Be}$ & $<0.001$ & $<5$ & & 0.0006 \\
\hline $\mathrm{Cd}$ & $<0.002$ & 0.02 & $<0.1$ & $0.01^{c}$ \\
\hline $\mathrm{Cr}$ & 0.01 & $<0.06$ & 0.2 & $0.05^{c}$ \\
\hline $\mathrm{Cu}$ & 0.008 & 0.01 & 0.8 & 3.4 \\
\hline $\mathbf{L i}$ & 0.02 & & & \\
\hline $\mathrm{Ni}$ & $<0.04$ & $<0.12$ & & 0.1 \\
\hline $\mathbf{P b}$ & 0.009 & 0.04 & 0.1 & $0.05^{c}$ \\
\hline Se & $<0.005$ & 0.03 & $<0.2$ & $0.01^{\mathrm{c}}$ \\
\hline $\mathrm{Zn}$ & 0.04 & 0.04 & 1.0 & $5^{e}$ \\
\hline
\end{tabular}

Preliminary guidance values (from Hoffman, F. O. et al. 1984. Preliminary Screening of Contaminants in Sediments. ORNL/TM-9370. Oak Ridge National Laboratory, Oak Ridge, Tenn.; and Travis, C. C. et al. 1986. Preliminary Review of TVA Fish Sampling and Anabysis Report. Report of Task Group Five to Oak Ridge Task Force. Mimeo.

The concentration in water producing a concentration in fish equal to the PGV; calculated by dividing measured concentrations in water (column 1) by Fish/PGV (column 2). This calculation assumes that any increase in metal concentration in water produces a proportional increase in metal concentration in fish. Such an assumption maximizes the impact of increased metal concentrations for screening purposes; it is unlikely to be correct.

'Criteria were calculated for ingestion of fish and water.

and gizzard shad in nearby reaches of the Clinch River demonstrate the need for continued routine monitoring of $\mathrm{PCB}$ concentrations in fish in the WOC drainage and Clinch River. Such monitoring will ensure protection of the public and establish a baseline against which to evaluate the effectiveness of any remedial actions. Annual monitoring of PCBs in sunfish at all sites in the WOC drainage and semiannual monitoring of PCBs in fish at WCK 2.9 and WOL will continue. Annual monitoring of PCBs in channel catfish in WOC embayment and a nearby reach of the Clinch River will also continue in conjunction with PCB monitoring at sites near the $\mathrm{K}-25$ site and funded by the K-25 site and Y-12 Plant BMAPs.

A one-time study comparing PCB concentrations in bluegill, largemouth bass, and carp in WOL will be conducted. Measurements of PCB concentrations in different species from the same small, closed system will provide a stronger basis for using measured concentrations in one species (especially bluegill) to predict concentrations in another at that site. This 
will enhance the ability to compare the severity of PCB contamination among sites where the same fish species is not abundant at all sites.

Analyses will be conducted for various trace metals in fish collected in 1988-89, after which a decision will be made regarding the value of continuing such measurements. Preliminary conclusions of Subtask 2C of the BMAP (Loar et al. 1991), as discussed in Sect. 4.3 of this report, suggest that continued monitoring of metals other than mercury in edible tissues of fish in WOC is not needed. A similar evaluation will be made for the monitoring of a broad spectrum of organic contaminants in biota after the 1988-89 data have been evaluated. 


\title{
5. BIOLOGICAL INDICATORS OF CONTAMINANT-RELATED STRESS
}

\author{
S. M. Adams, B. D. Jimenez, K. L. Shepard, and L. R. Shugart
}

\subsection{INTRODUCTION}

A principal advantage of using bioindicators in a biomonitoring program is that it permits simultaneous investigation of a spectrum of biological sensitivities to stress and specificities of effects. This approach not only maximizes predictive capabilities and increases understanding of causal mechanisms responsible for any stress effects observed in organisms, but also minimizes the cost and time involved in biomonitoring programs (Adams, 1990).

The bioindicator task was been designed to address three major issues related to the principal objectives of the BMAP. These issues include (1) evaluation to determine whether the effluent limits established for ORNL protect and maintain the classified uses of the streams in WOC watershed, (2) assessment of the effectiveness of remedial actions, and (3) identification of causative agents or mechanisms (such as contaminant stress) responsible for any effects observed on the fish communities. The first two BMAP annual reports (Loar et al. 1992a; Loar 1992b) presented the results of the initial bioindicator studies conducted during fall 1986 and spring 1987 respectively. Although this report presents results of studies conducted during fall 1987 , it also includes an integrated analysis of all the bioindicator data collected through fall 1987.

This integrated assessment addressed these three issues by utilizing two approaches: (1) analysis of functional response groups and (2) analysis of integrative bioindicator groups. The functional group approach involved analysis of each of the five major groups of biotic responses that were measured in fish (carbohydrate-protein metabolism, lipid metabolism, histology, condition indices, and detoxification enzymes) to determine if differences in fish health existed between sites and if changes in fish health had occurred over time. The integrative bioindicator approach used all the bioindicators together within a multivariate context to investigate holistic responses of fish to stress and to identify the causative agents or mechanisms most responsible for observed effects on organisms. In addition to addressing spatial and temporal trends and identifying causative mechanisms, this task also included a study of biomolecular indicators of stress.

\subsection{METHODS}

\subsubsection{Sampling Procedures}

During fall 1987, sampling was conducted at four sites in WOC watershed: (1) Melton Branch near the weir at MEK 0.16, (2) WOC near WCK 3.6 (above the weir at WCK 3.41 but below the ORNL STP), (3) WOC between WCK 2.9 and 3.4, and (4) White Oak Lake (WOL). Fish were also collected from a reference stream (Brushy Fork) located north of Oak Ridge near Marlowe. For the integrated analysis of the data collected between fall 1986 and fall 1987, the sampling sites were the same as above with 
two exceptions: MEK 0.16 was not sampled in fall 1986 and WCK 3.6 was not sampled in fall 1986 or spring 1987.

At each of these sites, 10-15 adult redbreast and bluegill sunfish were collected by electroshocking. Only redbreast sunfish were collected during the initial sampling in fall 1986, whereas both species were collected in spring and fall 1987. Blood samples were taken from each fish within 2 min after collection by puncturing the caudal blood vessels with a 20-gauge needle. Samples of approximately $0.7 \mathrm{~mL}$ were obtained from all fish using unheparinized 3-mL vacutainers (Becton, Dickson, \& Co.). Each tube was labeled with a fish identification number and placed in ice for transport to the laboratory.

\subsubsection{Analytical Procedures}

Total lengths and weights were recorded for fish transported from the field, and observations were made on the general condition of the fish, such as presence or absence of fin disease, body and/or mouth sores, external parasites, and general starvation status. Following sacrifice, the liver and spleen were removed from each fish for further analysis. A 100-mg section of liver for histopathological analysis was placed in a $20-\mathrm{mL}$ scintillation vial with $5 \mathrm{~mL}$ of Bouin's fixative. A 300-mg sample of liver was placed in a small plastic bag and immediately frozen in liquid nitrogen for subsequent ribonucleic acid and deoxyribonucleic acid (RNA and DNA) analysis. The spleen was also removed from the body cavity and weighed to the nearest milligram, and a section was placed in Bouin's fixative for subsequent histopathological analysis. The ovary was removed from females, weighed to the nearest $\mathrm{mg}$, and placed in a separate vial with $10 \mathrm{~mL}$ of Bouin's fixative for future enumeration of egg numbers and size. The viscera were excised from the body cavity and the total weight recorded after all food material was removed from the stomach and intestine. Liver- and visceral-somatic indices were calculated as the weights of these respective organs divided by total body weight. Condition factor was calculated as $K=10^{5} W / L^{3}$, where $W$ is body weight (in grams) and $\mathrm{L}$ is total length (in centimeters).

\subsubsection{Lipid analysis}

Following dissection and removal of the critical organs, four individuals of each sex from each site were chosen for lipid analysis. These fish were frozen at $-120^{\circ} \mathrm{C}$ until shipment to the subcontractor. Lipid biochemical analysis was performed according to a modification of the Bligh and Dyer (1959) method and using the Iatroscan Analyzer System (Harvey and Patton 1981) for lipid class quantification. The Iatroscan system for lipid analysis combines the resolution capabilities of thin layer chromatography with the quantitative sensitivity of a flame ionization detector. Lipid analysis for each fish included total lipids (percent of body weight);

triglycerides (percentage of total lipids); sterols, including cholesterol and/or sterol esters; phospholipids; and the two major fractions of phospholipids, phosphatidylcholine (PC) and phosphatidylethanolamine (PE).

\subsubsection{Serum chemical analysis}

Blood collected in the unheparinized tubes was allowed to clot, transferred with Pasteur pipettes to $1.5-\mathrm{mL}$ conical microcentrifuge tubes labeled with the fish identification number, and centrifuged for $3 \mathrm{~min}$ in a Beckman Microfuge. The clear supernatant (serum) was drawn off with 
clean pipettes and transferred to labeled 1$\mathrm{mL}$ conical plastic tubes. Serum glucose, serum glutamate oxyaloacetate transaminase (SGOT), bilirubin, cholesterol, and triglycerides were analyzed by the ORNL Health Division and the ORNL Chemical Technology Division, using a Rotochem IIa 36-cuvette centrifugal analyzer (Burtis et al. 1973). Glucose analysis was performed according to the method of Peterson and Young (1968); SGOT was analyzed following the procedures of the Scandinavian Committee on Enzymes (1974); cholesterol was analyzed by the method of Allain et al. (1974); triglycerides were analyzed by the procedure of Bucolo and David (1973); and bilirubin was determined by the method of Tietz (1986). All of these methods are enzymatic assays and the reagents for each assay were obtained from Smith Kline Beckman Instruments. Calibrations for all enzymatic assays are traceable to the National Bureau of Standards (NBS) reference materials. In addition, each batch of samples was run with quality control materials.

Total serum proteins were measured by the Biuret method (NCCLS 1979). The procedures for the assay are described in the Roche Diagnostic Systems (1986) information package. Assays were performed on an automated Centrifugal Fast Analyzer System (Cobas-Fara, Roche Inc.). Calibrations were performed using the Roche serum calibrator as the standard and monitrol Level 1 and 2 (American Dade, Miami, Florida) as internal controls.

\subsubsection{RNA/DNA analysis}

A 50- to $100-\mathrm{mg}$ section of liver was homogenized in approximately $1 \mathrm{~mL}$ of distilled water for $1 \mathrm{~min}$ using a Teflon homogenizer while keeping the sample cold. After the homogenate was brought to a final volume of $1.5 \mathrm{~mL}$ with distilled water, it was transferred to $1.5-\mathrm{mL}$ microcentrifuge tubes and centrifuged for $2 \mathrm{~min}$ in a Beckman microfuge. The RNA content of each sample was analyzed in triplicate by adding to each of three $1.5-\mathrm{mL}$ centrifuge tubes $200 \mu \mathrm{l}$ of supernatant from the liver homogenate, $1.2 \mathrm{~mL}$ of $95 \%$ ethanol, $0.035 \mathrm{~mL}$ of $2 M$ sodium acetate, and $0.015 \mathrm{~mL}$ of $1 M$ magnesium acetate. Samples were cooled for $20 \mathrm{~min}$ in a refrigerator before centrifuging for $2 \mathrm{~min}$. After the supernatant was decanted, $1 \mathrm{~mL}$ of $0.3 \mathrm{M}$ $\mathrm{KOH}$ was added to the tubes with the precipitate and incubated at $37^{\circ} \mathrm{C}$ in a constant water bath until the pellet dissolved. Each tube then received $0.5 \mathrm{~mL}$ of $1.4 \mathrm{~N}$ perchloric acid before it was cooled for an additional $20 \mathrm{~min}$ in the refrigerator. The mixture was centrifuged for $2 \mathrm{~min}$ and the supernatant was recovered in $20-\mathrm{mL}$ scintillation vials. The precipitate was washed once with $1 \mathrm{~mL}$ of $0.2 \mathrm{~N}$ perchloric acid, centrifuged again, and the supernatant was combined with the previous supernatant. Standards were prepared using $1100 \mu \mathrm{g}$ of RNA processed in exactly the same manner as the liver samples. Absorbance of the samples and standards was measured at $260 \mathrm{~nm}$ using a Gilford Response Spectrophotometer and a distilled water blank as a reference. Results were expressed as micrograms of RNA per milligram wet weight of liver tissue. For DNA analysis, duplicate samples were prepared by adding $3 \mathrm{~mL}$ of $0.2 \mathrm{M}$ phosphate buffer at pH 7.0 to $100 \mu \mathrm{L}$ of the original liver homogenate supernatant. Standards were prepared with $4.6 \mu \mathrm{g}$ of salmon sperm DNA. The fluorescence was measured using an excitation wavelength of $360 \mathrm{~nm}$ and an emission wavelength of $450 \mathrm{~nm}$ with a Beckman LS-5 spectrofluorometer. Results were expressed as micrograms of RNA per milligram wet weight liver tissue. 


\subsubsection{Histopathological analysis}

The following histopathological analyses were performed by the subcontractor at the School of Medicine, University of California, Davis: (1) percentage of tissue occupied by parasites, (2) percentage of liver composed of necrotic parenchyma, (3) percentage of tissue composed of macrophage aggregates, and 4) percentage of liver occupied by functional parenchyma. These analyses were performed according to the methods of Hinton and Couch (1984).

\subsubsection{Detoxification enzymes}

\section{Microsome isolation}

Fish hepatic microsomes were prepared by differential centrifugation (Mckee et al. 1983) using several modifications. Fish were killed by severing the spinal cord and the livers were immediately removed and blotted dry. Each liver sample was placed in a chilled buffer (0.25 mmol sucrose, $0.1 M$ Tris, $\mathrm{pH}$ 7.4). The minced tissues were homogenized in 5 volumes of buffer using 10 complete strokes of a motor-driven Potter-Elvehjem glass and Teflon homogenizer. The homogenates were centrifuged at $3,000 \mathrm{~g}$ * for $10 \mathrm{~min}$ and at $10,000 \mathrm{~g}^{*}$ for $20 \mathrm{~min}$, using a J-21B Beckman centrifuge. The resulting supernatants were centrifuged at $105,000 \mathrm{~g}^{*}$ for $60 \mathrm{~min}$ in a Beckman L3-50 ultracentrifuge. Microsomal pellets were resuspended in Tris buffer $(0.1 \mathrm{M}$ Tris, 1.0 mmol EDTA, and $20 \%$ glycerol at $\mathrm{pH}$

7.4) by sonication with a Braun Sonic 1510 at 50 watts for $10-15 \mathrm{~s}$. All operations were performed at 0 to $4^{\circ} \mathrm{C}$, and microsomes were frozen with liquid nitrogen and stored at $-120^{\circ} \mathrm{C}$. No significant change in 7-ethoxyresorufin O-deethylase (EROD) activity was detected after 6 months of storage at this temperature. The activity of fish microsomes stored under these conditions has been reported to be stable for 1 year (Forlin and Anderson 1985).

\section{Enzyme assays}

The activity of EROD was measured fluorimetrically at $30^{\circ} \mathrm{C}$ (Burke and Mayer 1974) and expressed as picomoles of resorufin $\mathrm{min}^{-1} \cdot \mathrm{mg}^{-1}$ of microsomal protein. The final reaction buffer contained HEPES buffer (pH 7.8), $80 \mathrm{mmol}$; magnesium acetate, $5 \mathrm{mmol}$; 7 ethoxyresorufin, $1.0 \mu \mathrm{mol}$; NADPH, $250 \mu \mathrm{mol}$; and EDTA, $100 \mu \mathrm{mol}$. The concentration of total protein used in the enzyme assay ranged from 0.2 to $1 \mathrm{mg} / \mathrm{mL}$, depending on the activity of the sample. Proteins were measured by the Bio-Rad (Richmond, California) reagent method (Bradford 1976) on the Cobas Fara (Hoffman La Roche Instruments) using bovine serum albumin as a standard. Cytochrome P-450 and cytochrome $b_{5}$ content were each measured by their characteristic oxidized and reduced spectra. Cytochrome P-450 samples were oxidized with carbon monoxide and reduced with sodium dithionite (Johannesen and DePierre 1978). Cytochrome $b_{5}$ was reduced with NADII (Stegeman et al. 1979). Assays of cytochrome $b_{5}$ were conducted prior to cytochrome P-450 analysis.

NADPH-cytochrome $c$ reductase was assayed spectrophotometrically by the 
reduction of the electron acceptor cytochrome $c$ with an extinction coefficient of $21.1 \mathrm{~cm} / \mathrm{mmol}$. The reaction mixture contained $1.1 \mathrm{mg} / \mathrm{mL}$ horse heart cytochrome $\mathrm{c}$ in $0.2 \mathrm{M}$ phosphate buffer with 2-10 $\mu \mathrm{g}$ of microsomal protein.

\subsection{DNA integrity}

\section{Measurement of strand breaks in DNA.}

Alkaline unwinding is a sensitive analytical technique which has previously been used in cells in culture to detect and quantify DNA strand breaks induced by physical and chemical carcinogens (Ahnstrom and Erixon 1980; Kanter and Schwartz 1979, 1982; Daniel et al. 1985). To assess the level of strand breaks of DNA in aquatic species, existing methods were modified to allow (1) isolation of intact, highly polymerized DNA from livers of aquatic organisms; and (2) estimation of the number of strand breaks in the isolated DNA by allowing strand separation under carefully controlled experimental conditions.

The isolation of DNA was accomplished by homogenizing the intact fish liver in $1 \mathrm{~N} \mathrm{NH}_{4} \mathrm{OH} / 0.2 \%$ Triton X100. The DNA is further purified by differential extraction with chloroform/isoamyl alcohol/phenol $[24 / 1 / 25(v / v)]$ and passage through a molecular sieve column (Sephadex G50). DNA strand breaks were measured in the isolated DNA by an alkaline unwinding assay (Kanter and Schwartz 1982; Shugart 1988a, 1988b). The technique is based on the time-dependent partial alkaline unwinding of DNA followed by determination of the duplex:total DNA ratio ( $\underline{F}$ value). Because DNA unwinding takes place at single-strand breaks within the molecule, the amount of doublestranded DNA remaining after a given period of alkaline unwinding will be inversely proportional to the number of strand breaks present at the initiation of the alkaline exposure, provided renaturation is prevented. The amounts of these two types of DNA (i.e., singlestranded and double-stranded) are quantified by measuring the fluorescence that results with bisbenzimidazole Hoechst dye \#33258 (Kanter and Schwartz 1982; Shugart 1988a, 1988b).

\section{Data Analysis}

Rydberg (1975) has established the theoretical background for estimating strand breaks in DNA by alkaline unwinding, which is summarized by the equation:

$$
\ln \underline{F}=-(\mathrm{K} / \mathrm{M})\left(\mathrm{t}^{\mathrm{b}}\right)
$$

where $K$ is a constant, $t$ is time, $M$ is the number-averaged molecular weight between two breaks, and $b$ is a constant less than 1 which is influenced by the conditions for alkaline unwinding.

The relative number of strand breaks ( $\underline{N}$ value) in DNA of sunfish from sampled sites compared with those from reference sites can be calculated as follows (Kanter and Schwartz 1982; Shugart 1988b):

$$
\underline{N}=\left(\ln \underline{F}_{s} / \ln \underline{F}_{r}\right)-1 ;
$$

where $E$ and $E_{r}$ are the mean $\underline{F}$ values of DNA from the WOC watershed sites and reference sites, respectively. Values of $\underline{\mathrm{N}}>$ zero indicate that DNA from the sampled sites has more strand breaks than DNA from the reference site; an $\underline{N}$ value of 5 , for example, indicates 5 times more strand breakage. Statistical analyses were performed on the $\ln \mathrm{F}$ data because the observed values of $\ln \mathrm{F}$ are independent, and hypotheses about values of $\underline{N}$ being significantly different (positive or negative) can be translated into equivalent 
hypotheses about differences in the mean $\ln \underline{\mathbf{E}}$ and mean $\ln \mathbf{E}$ values. Thus, an $\underline{\mathbf{N}}$ value reported to be significantly different from zero indicates that the mean $\ln \mathrm{F}$ at the WOC sampled site was significantly different from the mean $\ln F$ at the reference site, using appropriate statistical tests [Dunnett's test for comparing the mean responses (In F) of the two sites].

\subsubsection{Metal-binding proteins}

Metal-binding protein (MBP) content of sunfish was measured by the Chelex-100 assay (Sloop, unpublished data). This assay involves (1) preparation of a homogenate containing the soluble protein fraction of liver tissue; (2) acid displacement and subsequent removal of protein-bound endogenous cadmium and zinc and their replacement with ${ }^{109} \mathrm{Cd}$; (3) removal of large, non-metallothionein MBPs via isoelectric precipitation; (4) adsorption of free or weakly bound ${ }^{109} \mathrm{Cd}$ from the assay solution to Chelex-100; and (5) quantification of metallothionein by scintillation counting of the fraction not adsorbed to Chelex-100. Quantifying a $\gamma$ emitting isotope $\left({ }^{109} \mathrm{Cd}\right)$ with a $\beta$-detecting instrument is unusual. It is possible with ${ }^{109} \mathrm{Cd}$ because its decay product, ${ }^{109} \mathrm{Ag}$, when filling an inner shell electron vacancy, coincidentally emits an Auger electron that has an energy level comparable to the average $\beta$-particle of ${ }^{14} \mathrm{C}$. By setting the scintillation counter for ${ }^{14} \mathrm{C},{ }^{109} \mathrm{Cd}$ can be accurately quantified.

\subsubsection{Statistical Procedures}

ANOVA procedures were used to test for differences in individual bioindicators among sites, between sexes, and between seasons. Interaction effects between site, sex, and seasons were also included in the ANOVA model. If the ANOVA procedure rejected a multisample (site, sex, or season) null hypothesis of equal means, then the Tukey multiple range test was used to identify significant differences among pairs of variables (e.g., sites). The Tukey test was selected because it is fairly robust with respect to departures of the data from normality and homogeneity of variance and also because it is the most widely accepted and commonly used multiple comparison test (Zar 1984).

To determine the integrated response of fish to the environmental conditions at each sampling site, all the bioindicator variables were considered jointly within a multivariate context by using canonical discriminant analysis available on SAS (PROC CANDISC, SAS 1985b). This method provides a graphical representation of the positions and orientations of the various integrated site responses relative to each other. In addition, this method derives linear combinations of all variables and has the potential to indicate statistical differences among treatment means even if the single variables do not indicate such differences. The technique of Klecka (1980) for variable selection through discriminant analysis was used to identify the variables which contributed most to the discrimination of integrated site responses. This variable selection procedure considered all possible combinations of the observed values and, for any specified subset size, selected those variables having the greatest power for discrimination.

Tests for homogeneity of variance of individual response variables between sites were conducted using Levenes test, an Fdistribution test that compares ihe ratios of the variances from two independent sample populations (Sokal and Rohlf 1981).

\subsection{RESULTS AND DISCUSSION}

Three types of analyses were conducted to address each of the major 
BMAP objectives described in Sect. 5.1. A spatial effects analysis was conducted to evaluate differences between sites in order to determine the effectiveness of the ORNL NPDES effluent limits in protecting the classified uses of streams in WOC watershed. An analysis of temporal changes in the overall health of the sunfish populations in WOC watershed was performed to assess the effects of remedial actions. Finally, the relative importance of direct and indirect stresses was evaluated as an initial step in identifying cause-effect relationships.

\subsubsection{Analysis of Spatial Effects}

To assess spatial effects or differences among sites in fish responses to stress, the parameters measured in this task were grouped into six functional categories. The groups represented indicators of (1) carbohydrate-protein metabolism, (2) organ dysfunction, (3) detoxification enzyme induction, (4) lipid metabolism, (5) histopathology, and (6) overall fish health or condition. These responses or functional groups reflect gradients of both ecological relevance and time course of the response to a stress such as a contaminant. Those variables in groups (1)-(3) are short-term response indicators and have relatively low ecological relevance, whereas indicators included in groups $(\hat{i})-(6)$ are longer-term response variables and are characterized by low toxicological but high ecological relevance.

\subsubsection{General site patterns}

The relative difference in the response of each group of bioindicators between each WOC site and the reference site is shown in Figs. 5.1 to $\mathbf{5 . 6}$ for all seasons combined. In each figure, values above the zero line indicate that the response in fish at a WOC site was greater than that in fish from the reference site. Values below the zero line indicate that the response in WOC fish was less than that in reference fish.

\section{Carbohydrate-Protein metabolism}

In bluegill, the indicators of carbohydrate-protein metabolism demonstrated a varied response among sites. Compared to reference fish, blood glucose, which is a generalized stress response to a broad spectrum of environmental perturbations (Silbergeld 1974), was higher in Melton Branch and WOL fish but lower in bluegill from WCK 3.2 and WCK 3.6 (Fig. 5.1). Fish in all four WOC watershed sites had slightly higher serum protein values than did the reference fish, possibly indicating that fish in Brushy Fork were experiencing some level of nutritional stress over this period because of their low protein levels. Lockhart and Metner (1984) reported depressed serum protein levels in the white sucker (Catostomus commersoni) under conditions of low food availability.

Plasma albumin plays a major role in the binding and transport of insoluble or sparingly soluble compounds, such as fatty acids, bilirubin, and hormones. Other functions of this protein include maintenance of osmotic regulation and utilization as a reserve source of protein and amino acids. Albumin levels were depressed in Melton Branch, WCK 3.2, and WCK 3.6 but slightly elevated in WOL fish (Fig. 5.1). Depressed levels of this protein indicate liver or kidney disease and/or protein starvation (Tietz 1986). 

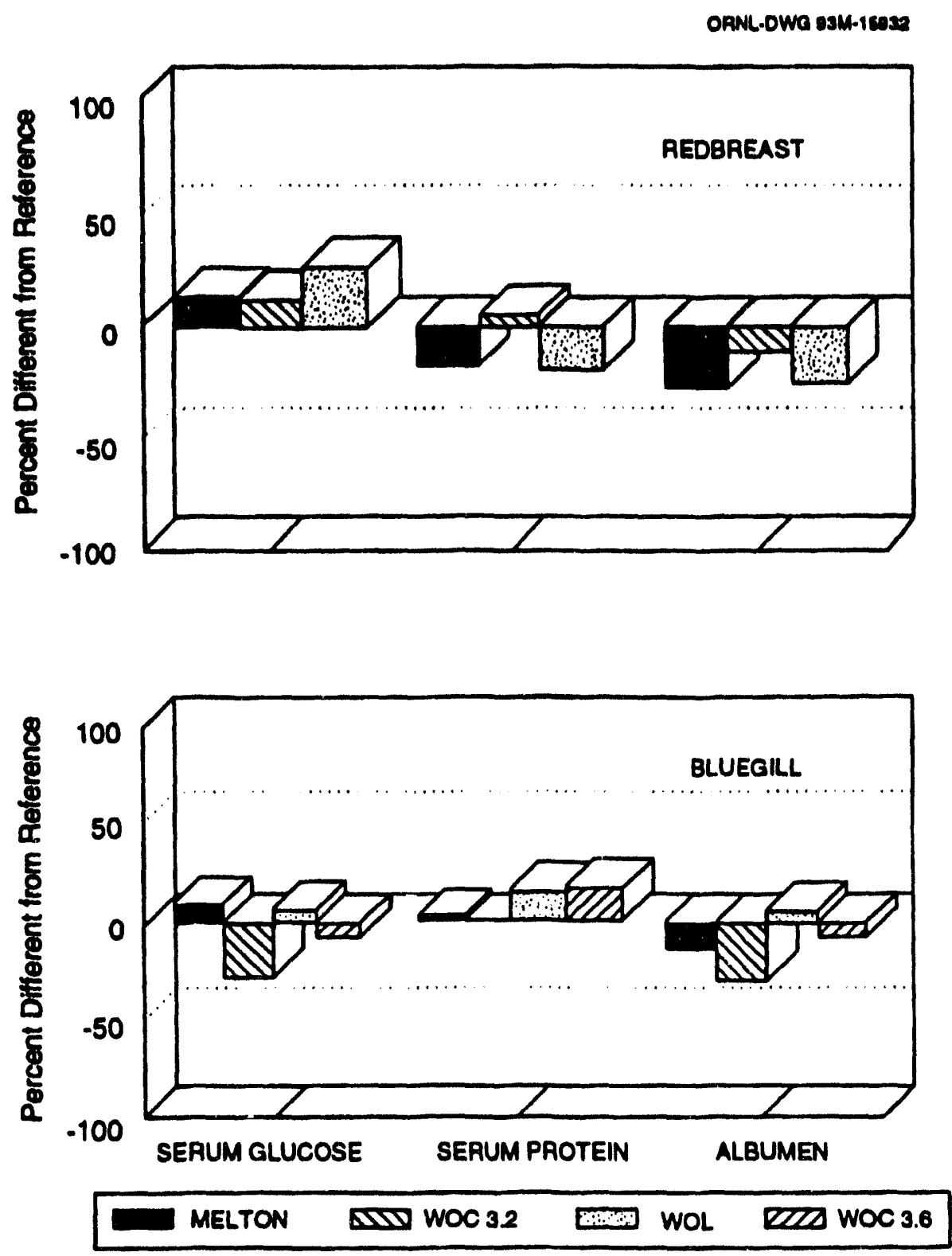

Fig. 5.1. Relative differences in the response of the carbohydrate-protein for redbreast and bluegill sunfish at each of the White Oak Creck System sites compared with the reference site, Brushy Fork. Values above or below the zero line indicate that the response for fish at any particular WOC site was higher or lower, respectively, than the response at the reference site. 
Interestingly, albumin was lowest, relative to the reference stream, at the two flowing-water sites (lotic environments), while higher values were observed in fish that inhabited standing-water (lentic) environments (WCK 3.6 and WOL).

In redbreast sunfish, glucose was also high at all sites (Fig. 5.1). Serum protein was low, however, in Melton Branch and WOL, suggesting nutritional deficiencies in these fish. The depressed levels of albumin at all sites may be indicative of some level of protein starvation or deficiency in this species.

\section{Organ dysfunction}

Bilirubin is a metabolite of the heme portion of hemoglobin; elevated levels of this compound in the blood typically indicate liver cell damage or bile duct obstruction due to parasitic infestation. Concentrations of bilirubin in the blood of bluegill were slightly depressed in Melton Branch and WCK 3.2; however, levels in WCK 3.6 and WOL fish were similar to the reference fish (Fig. 5.2).

Elevated creatinine levels are typically used as an indicator of kidney damage or malfunction (Tietz 1986). Levels in bluegill were higher than the reference site only at WCK 3.2 (by $\sim 40 \%$ ) (Fig. 5.2). The transaminase enzyme, SGOT, is an indicator of tissue damage or impaired organ function, particularly in the liver (Rhodes et al. 1985). Only Melton Branch fish exhibited elevated levels of this enzyme, suggesting that liver function in bluegill from the remaining WOC sites had not been affected.

The enzyme lactate dehydrogenase ( $\mathrm{LDH})$ is widely distributed in tissue, especially in the liver, kidney, muscle, and heart. Elevated levels of LDH can be indicative of a variety of tissue/organ disorders, including abnormal liver and kidney function (Henry 1979). Only bluegill from Melton Branch had LDH levels that were higher than the reference fish. Indicators of organ dysfunction in redbreast sunfish exhibited a spatial pattern similar to that of bluegill, especially for bilirubin, SGOT, and LDH. Redbreast sunfish had elevated levels of creatinine at both WCK 3.2 and WOL, possible indicating some kidney impairment for fish at these sites (Fig. 5.2).

\section{Detoxification enzymes}

The activity or level of liver detoxification enzymes is used to indicate exposure to and possible effects of various xenobiotics, such as PAHs, PCBs, and pesticides (Payne and Penrose 1975, Lindmann et al. 1976). Many of these compounds commonly occur in industrial and municipal effluents and are accumulated within living tissues (Ahokas et al. 1976, Neff 1978, Brown et al. 1986). Although all four enzymes were elevated in bluegill at WCK 3.2, cytochrome P-450 and $\mathrm{NADPH}^{*}$ cytochrome $\mathrm{c}$ reductase levels were only slightly higher than the levels found in reference fish (Fig. 5.3). Levels of NADPH reductase were lower at three of the WOC watershed sites as compared with the reference site, but the remaining three enzymes were elevated at all sites.

Similar enzyme patterns across sites were found for redbreast sunfish. The cytochrome P-450 and $b_{s}$ enzymes in this species were elevated at all sites, with EROD activity at WCK 3.2 and WOL exceeding that in Brushy Fork (Fig. 5.3). NADPH cytochrome $c$ reductase levels

* Nicotinamide adenine dinucleotide phosphate, reduced form. 
OANL-OWO $03 M \cdot 15033$
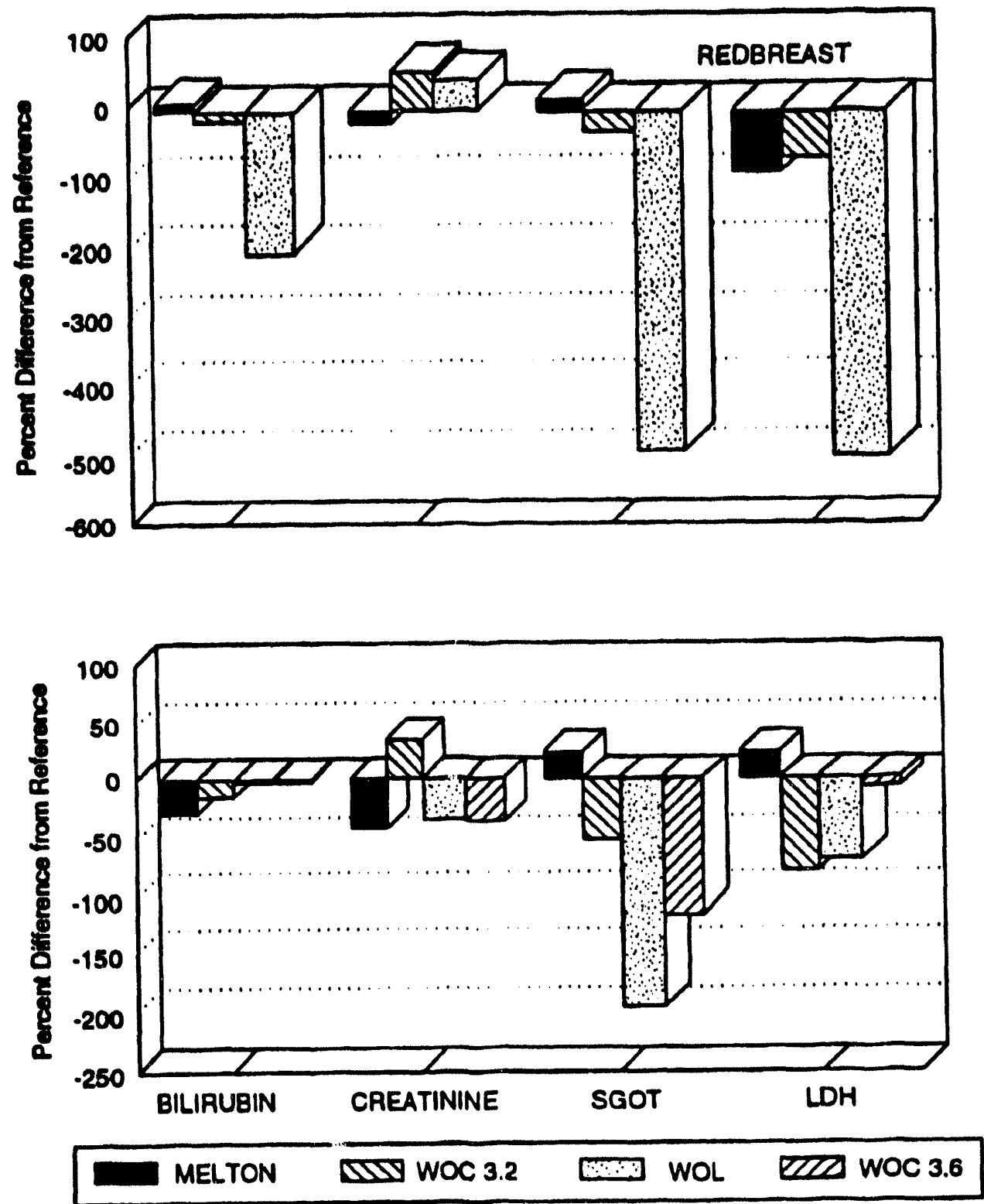

Fig. 5.2. Relative differences in the response of the organ dysfunction indicators for redbreast and bluegill sunfish at each of the White Oak Creck System sites compared with the reference site, Brushy Fork. Values above or below the zero line indicate that the response for fish at any particular WOC site was higher or lower, respectively, than the response at the reference site. SGOT $=$ serum glutamate oxyaloacetate transaminase. 

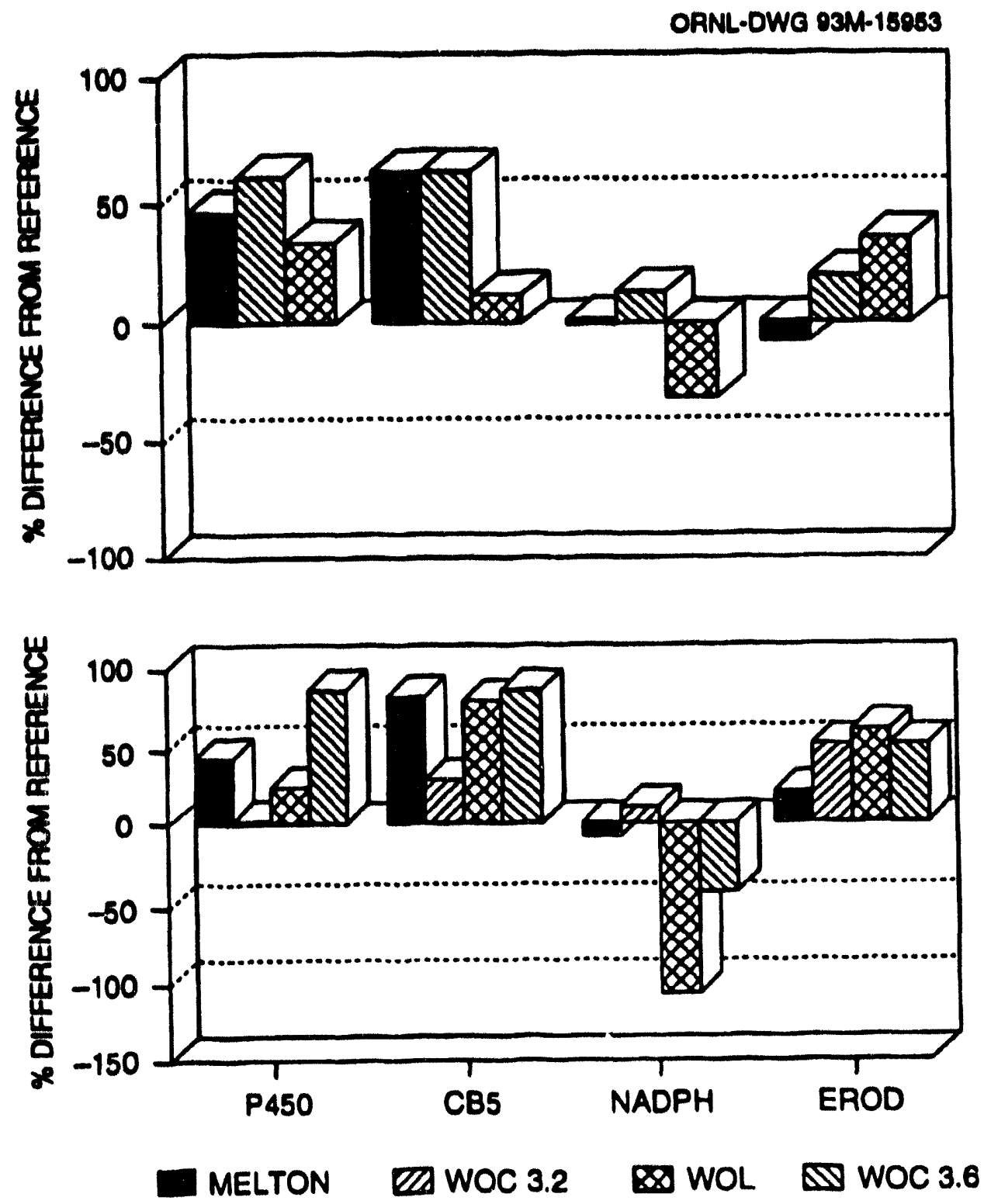

Fig 5.3. Relative difierences in the response of the detoxification enzymes for redbreast and bluegill sunfish at each of the White Oak Crcek System sites compared with the reference site, Brushy Fork. Values above or below the zero line indicate that the response for fish at any particular WOC site was higher or lower, respectively, than the response at the reference site. 
were elevated only at WCK 3.2 and were lower than the reference site in Melton Branch and WOL.

\section{Lipid metabolism}

Indicators of lipid metabolism can reflect both the nutritional status and level of metabolic stress in fish. The condition or status of the lipid pool is important because the vulnerability of an organism to stress depends, in part, on the level of lipid reserves (Shul'man 1974, Glebe and Leggett 1981). Plasma triglyceride levels in bluegill were higher than those found in reference fish at all sites except WOL. Serum cholesterol is an indicator of both nutrition and steroid metabolism in fish and was slightly depressed at WCK 3.6 (Fig. 5.4).

Total body triglycerides reflect the energy available to an organism for mediating the effects of stress (Lee et al. 1983) and for performing critical physiological functions, such as growth and gonadal development. Triglycerides also act as energy buffers in periods of food shortages (Adams et al. 1985). Bluegill energy reserves were lower at the reference site than at all WOC watershed sites except WCK 3.6 (Fig. 5.4). Elevated levels of body fat in these fish could be attributed to their residency in a large pool behind the USGS gaging station weir at WCK 3.41. Both primary and secondary production are probably high in this environment due to high nutrient loading (Table 2.8), which provides large amounts of food for fish inhabiting this pool, resulting in high lipid levels.

Compared with the reference site, phospholipids, the nonphysiologically useful energy components of lipids, were slightly elevated at all sites except WCK 3.6. Such a pattern was not surprising because phospholipid levels generally show an inverse relationship to triglyceride levels.
The ratio of the two major phospholipids that constitute the cell wall, PE and PC, can reflect cell wall membrane integrity. Membrane lipid structure can influence membrane fluidity, enzyme kinetics, and electrical properties (Friedman et al. 1986). The PC/PE ratio was elevated slightly in bluegill from WCK 3.6 and WOL but depressed in fish from WCK 3.2 and Melton Branch (Fig. 5.4). This pattern could possibly be due to differences in temperature or water chemistry (e.g., dissolved solids) between these sites, which can effect the ratio of these two components of cell walls (Roche et al. 1983). The rat:o was lower for bluegill from the lotic sites compared with those from the lentic sites.

In contrast to the short-term response indicators (i.e., carbohydrate-protein metabolism, organ dysfunction, and detoxification enzymes), there were major differences between the two sunfish species in the lipid metabolism parameters, which are long-term response indicators. Serum triglycerides, serum cholesterol, and body triglycerides were all lower in redbreast sunfish in WOC watershed as compared with the reference site (Fig. 5.4). In addition, the PC/PE ratio was higher in redbreast sunfish than in bluegill at the two lentic sites (WCK 3.6 and WOL).

\section{Histopathological condition}

Indicators of the histopathological condition of WOC fish were distinctly different from those of reference fish (Fig. 5.5). Except for WCK 3.2, the percentage of liver composed of parasites was $100-500 \%$ lower in fish from WOC watershed as compared with those in Brushy Fork.

An informative indicator of tissue disease or pathology is the occurrence of macrophage aggregates in the liver. These are localized centers of phagocytes (white 

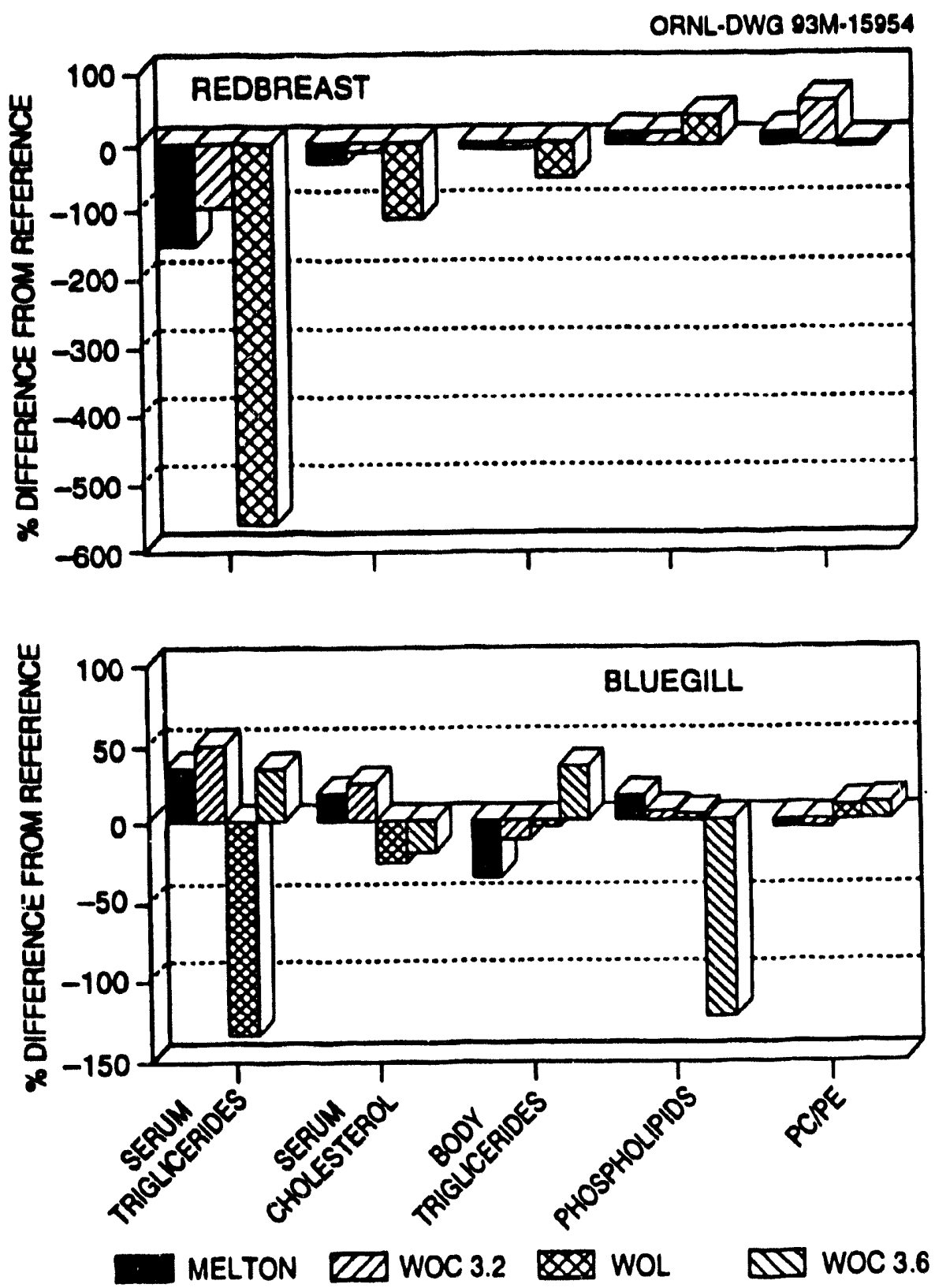

Fig. 5.4. Relative differences in the response of the lipid metabolism parameters for redbreast and bluegill sunfish at each of the White Oak Creek System sites compared with the reference site, Brushy Fork. Values above or below the zero line indicate that the response for fish at any particular WOC site was higher or lower, respectively, than the response at the reference site, Brushy Fork. PC=phosphatidylcholine, $\mathrm{PE}=$ phosphatidylethanolamine. 

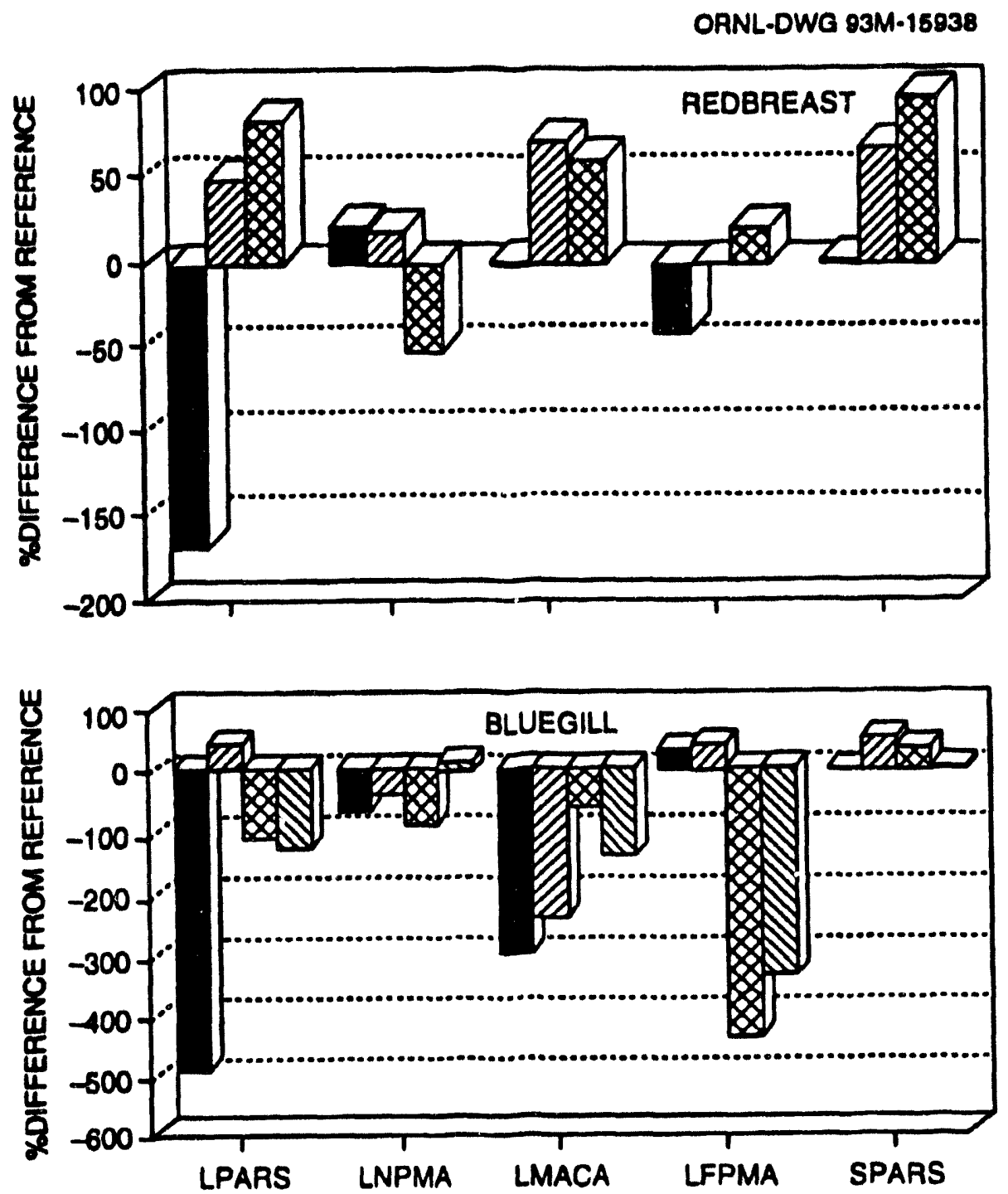

MELTON WOC $3.2 W$ WOL WOC 3.6

Fig. 5.5. Relative differences in histological condition for redbreast and bluegill sunfish at each of the White Oak Creek System sites compared with the reference site, Brushy Fork. Values above or below the zero line indicate that the response for fish at any particular WOC site was higher or lower, respectively, than the response at the reference site. LPARS =liver parasites, LNPMA = necrotic liver parenchyma, LMACA = macrophage aggregates in liver, LFPMA = functional parenchyma in liver, SPARS $=$ spleen parasites. 
blood cells) that invade an area that is diseased or damaged. Macrophage aggregates in the livers of bluegill from the WOC sites were $75-300 \%$ lower than in bluegill from the reference site, but the opposite was true for redbreast sunfish.

The percentage of liver actually occupied by functional parenchyzma was much higher for bluegill from the two lotic sites than those from the lentic sites. Reduced functional parenchyma in bluegill from Melton Branch and WCK 3.2 could indicate that fish with this condition have a reduced capacity to (1) produce enzymes for detoxifying contaminants, (2) store important glycogen and lipid energy reserves, (3) manufacture vitellogenin necessary for normal egg development, and (4) convert and process protein and lipid compounds into physiologically useful energy.

Histological examination of the spleen indicated that the parasite load of redbreast sunfish and, to a lesser extent, of bluegill from WCK 3.2 and WOL was about $50 \%$ higher than that of fish from the reference stream. The other two sites exhibited spleen parasite loads similar to those in Brushy Fork fish. Because the spleen is a hemopoietic organ, injury from parasitic infestations could reduce production of both red and white blood cells, possibly resulting in anemia and increased vulnerability to disease (Anderson, 1990).

As with lipid metabolism, indicators of histopathological condition were dramatically different between the two species at each of the WOC sites. In general, the level of liver and spleen parasites, necrotic liver parenchyma, and macrophage aggregates were all higher in redbreast than bluegill sunfish in WOC watershed. In addition, bisegill at all sites in WOC watershed had lower levels of all indicators except spleen parasites than bluegill in Brushy Fork.

\section{Condition indices}

Five condition indices were used to describe the general health of fish. The condition factor $(K)$ is a generalized indicator of overall health or "plumpness" and can reflect the integrated effect of both nutritional level and metabolic costs caused by stress. Possibly because the condition factor is relatively insensitive to changes in lipid stores (Adams and McLean 1985), values of this index were similar in bluegill from all sites (Fig. 5.6).

Total body lipid is used to indicate overall fat storage and general nutritional status of fish. Compared with those in fish in the reference stream, lipid levels were slightly lower in bluegill from Melton Branch and WOL but higher at WCK 3.2 and WCK 3.6 (Fig. 5.6). Highly elevated lipid levels at WCK 3.6 are not surprising in view of the high nutrient and probable high primary productivity levels in that reach of WOC.

The liver-somatic index (LSI) reflects both short-term nutritional status and metabolic energy demands (Heidinger and Crawford 1977, Adams and McLean 1985). In addition, the LSI is sensitive to toxicant stress, and liver enlargement due to hyperplasia (increase in cell number) and hypertrophy (increase in cell size) has been reported in fish exposed to toxic compounds (Fletcher et al. 1982, Addison 1984, Heath 1987). This may be the case for bluegill in WOC watershed; the LSI is higher at all sites compared to Brushy Fork (Fig. 5.6).

The visceral-somatic index (VSI) reflects energy stored as lipids in the mesenteries of the viscera. These lipids are important for long-term energy uses and for gonad maturation (Adams and McLean 1985). The VSI was depressed in bluegill at all sites except WCK 3.6, where food production and fish feeding rates were probably high. 

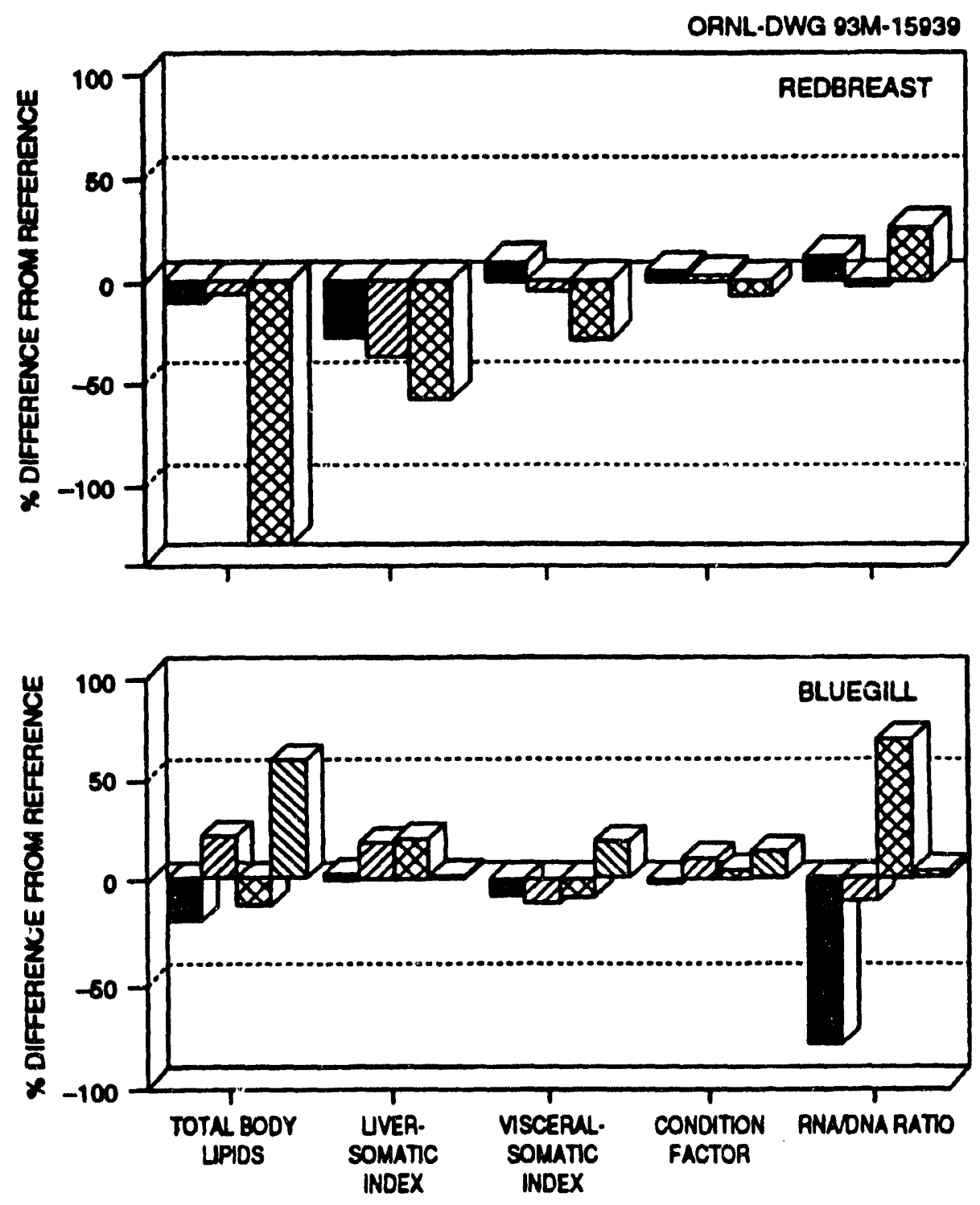

\section{MELTON EA WOC $3.2 \quad B 8$ WOL $\triangle 18$ WOC 3.6}

Fig. 5.6. Relative differences in the condition indices of redbreast and bluegill sunfish at each of the White Oak Creek System sites compared with the reference site, Brushy Fork. Values above or below the zero line indicate that the response for fish at any particular WOC site was higher or lower, respectively, than the response at the reference site. 
The RNA/DNA ratio is used as an indicator of immediate or short-term growth in fish (Bulow 1970, Haines 1973) as well as an indicator of exposure to sublethal concentrations of toxicants (Barron and Adelman 1984). Growth is one of the ultimate indicators of fish health because it integrates all the biotic and abiotic variables acting on an organism and reflects secondary impacts of chronic stress (Waters 1977, Larkin 1978). The growth of bluegill, as reflected by this ratio, was severely depressed in Melton Branch and was about $10 \%$ lower than the reference stream at WCK 3.2 (Fig. 5.6). Both lentic sites, but particularly WOL, displayed higher growth than the reference site.

In addition to the substantial differences noted (between bluegill and redbreast sunfish) in the lipid metabolism and histopathological indicators, equally dramatic differences were observed in the condition indices for the two species. Total lipids and LSI in redbreast sunfish were lower than in bluegill at all three sampling sites. Like bluegill, the VSI and condition factor for redbreast sunfish appear to be fairly insensitive to changes in other body condition indices. How/ever, growth of this species, as reflected by the RNA/DNA ratio, was high in Melton Branch and WOL.

\section{Conclusions and synthesis}

As evidenced by the response of the carbuhydrate-protein, organ dysfunction, and detoxification enzyme indicators, both bluegill and redbreast sunfish in the WOC system appear to be experiencing some degree of physiological or related shortterm stress. Detoxification enzymes were elevated in both species, indicating exposure to contaminants. On a short-term basis, the effects of this contaminant exposure could appear as kidney dysfunction in both species from WCK 3.2 and as liver damage in fish from all sites, but particularly those in Melton Branch.

Even though both bluegill and redbreast sunfish in WOC watershed may be experiencing short-term physiological stress, the longer-term expression of this stress is dramatically different between the two species, as shown by differences in lipid metabolism, histopathology, and condition indices. Differences between species in the expression of these longerterm stress indicators could be due to biotic modifying factors which influence both the degree and mechanism of longterm responses in an organism. Several investigators have emphasized the effect of biotic modifying factors on the expression of stress responses in fish, including Hazel and Prosser (1974), Sastry and Miller (1981), Larsson et al. (1985), and Munkittrick and Dixon (1988). For example, indirect effects, such as contaminant-induced differences in feeding behavior, competitive abilities, and predation relationships, could all influence the way short-term physiological stress ultimately becomes long-term stress. Because redbreast sunfish are better adapted ecologically to lotic environments than are bluegill (Robinson and Buchanan 1945), they may compete with bluegill for preferred food and habitat in these streams. For example, Pflieger (1975) reported that growth of bluegill is highest in ponds and new reservoirs and lowest in streams. In fact, differences in the condition of bluegill between lotic and lentic habitat types is evident within the WOC system itself. Bluegill collected from lentic habitats (WCK 3.6 and WOL) are generally in better health and condition than bluegill from lotic habitats (WCK 3.2 and Melton Branch) (Fig. 5.6b). The additional stresses on an organism from competition for food and space, for example, could act synergistically or cumulatively with contaminant-related 
stresses and elicit the types of long-term differential stress responses that were observed between the two species in this study.

\subsubsection{Seasonal-site comparisons}

Not only can environmental and biotic factors influence the response of an organism to stress (Cairns and van de Schalie 1980, Larsson et al. 1985), but variables such as sampling location (site effect) and sampling period (seasonal effect) can also influence the interpretation of a particular stress response. With several different sampling-related variables, including seasons (2-3), sampling sites (4), and response variables (24) involved in this study, it becomes necessary to integrate the data in a manner that will facilitate the evaluation of relationships between site, season, and response.

Seasonal-response comparisons between sites are summarized in Fig. 5.7, where significant differences in bioindicators

OANL-DWG 89M-1690R

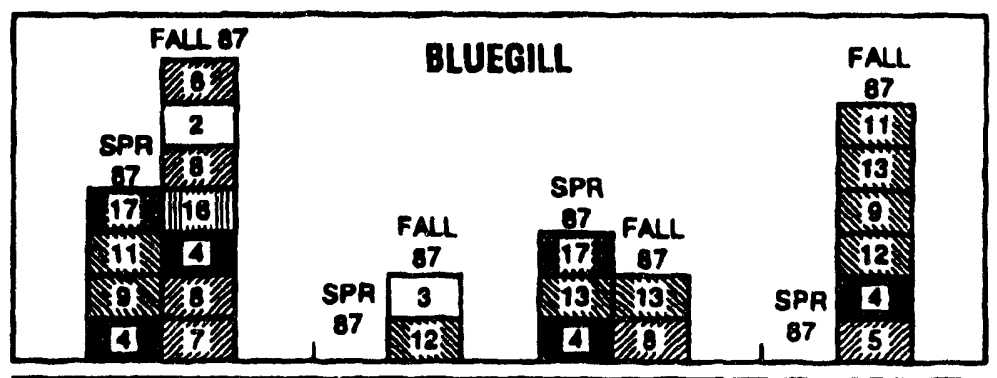

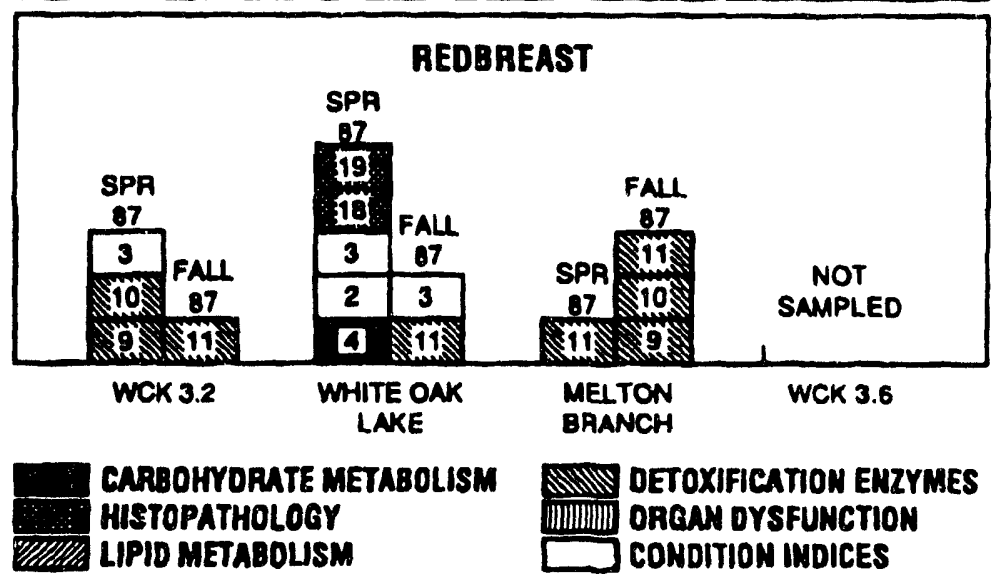

Fig. 5.7. Seasonal differences in bioindicator responses between each of the White Oak Creek System sites compared with the reference site, Brushy Fork. Numbers inside each histogram represent those specific indicators that are significantly different $(p<0.05)$ from the reference site. $1=$ total body lipid, $2=$ visceral-somatic index, $3=$ RNADNA ratio, $4=$ serum glucose, $5=$ serem triglyceride, $6=$ serum cholesterol, $7=$ body triglycerides, $8=$ phospholipids, $9=$ cytochrome $\mathrm{P}-450,10=\mathrm{NADPH}$, $11=$ microsomal protein, 12=EROD, 13=cytochrome $b_{5}, 14=$ bilirubin, $15=$ creatinine, $16=$ albumin, $17=$ macrophage aggregates, $18=$ liver parasites, $19=$ functional liver parenchyma. 
between all WOC sites and the reference site are shown. The numbers inside each histogram represent those indicators that were significantly different between that WOC site and the reference site during that particular season. For example, in spring 1987, variable 3 (RNA/DNA ratio) and variable 12 (EROD) were significantly different between redbreast sunfish from WOL and the reference stream.

The most obvious feature of the comparisons in Fig. 5.7 is that bluegill from WCK 3.2 had the highest number of indicators that were significantly different from the reference fish during a given season. White Oak Lake had the fewest number of indicators that were significantly different from the reference site, and WOL bluegill appeared most similar to the reference fish in both seasons. Fig. 5.7 also shows the relative importance of the various functional groups in characterizing the overall condition of bluegill among sites. For example, detoxification enzymes were important as diagnostic indicators of stress at all four sites. At least one indicator from each functional group (condition indices, carbohydrate-protein metabolism, lipid metabolism, histopathology, organ dysfunction indicators, and detoxification enzymes) was important in characterizing fish condition at WCK 3.2 relative to the reference site.

The pattern of site responses was dramatically different, however, for redbreast sunfish (Fig. 5.7). In contrast to bluegill, redbreast sunfish from WOL had the highest number of indicators that were significantly different from the fish at the reference site. Condition indices and histopathological parameters were the primary distinguishing variables at WOL, and the detoxification enzymes were the most important group of variables at WCK 3.2 and Melton Branch.

\section{Summary}

The seasonal-site comparisons revealed two important aspects of the response of WOC watershed fish relative to that of reference stream fish: (1) bluegill from WOL were most similar and redbreast sunfish from WOL were most dissimilar to fish from the reference site; (2) for both species, detoxification enzymes are the most important indicators for distinguishing between responses at sites in WOC watershed and those at the reference site; and (3) the relative importance of each functional group in distinguishing differences between the WOC watershed and reference fish varies with site.

\subsubsection{Integrated site analysis}

An informative approach for determining the overall response of fish to stress is canonical discriminant analysis.

This method includes all the bioindicators within a multivariate context and provides a graphical representation of the positions and orientations of the site responses relative to each other. Because this method is sensitive to sample sizes, the analysis was performed only on bluegill because a large data set was available. The Melton Branch site was also excluded from this analysis because of insufficient sample sizes.

Two obvious features of the integrated site responses shown in Fig. 5.8 are evident. First, the integrated response for fish sampled at the reference site was distinct from that for fish at each of the WOC sites, and second, the integrated response of bluegill from WCK 3.6 and WOL was not significantly different. As indicated by the differences in the linear distances between the centers of the site 
ORNL-DWO 93M-15057

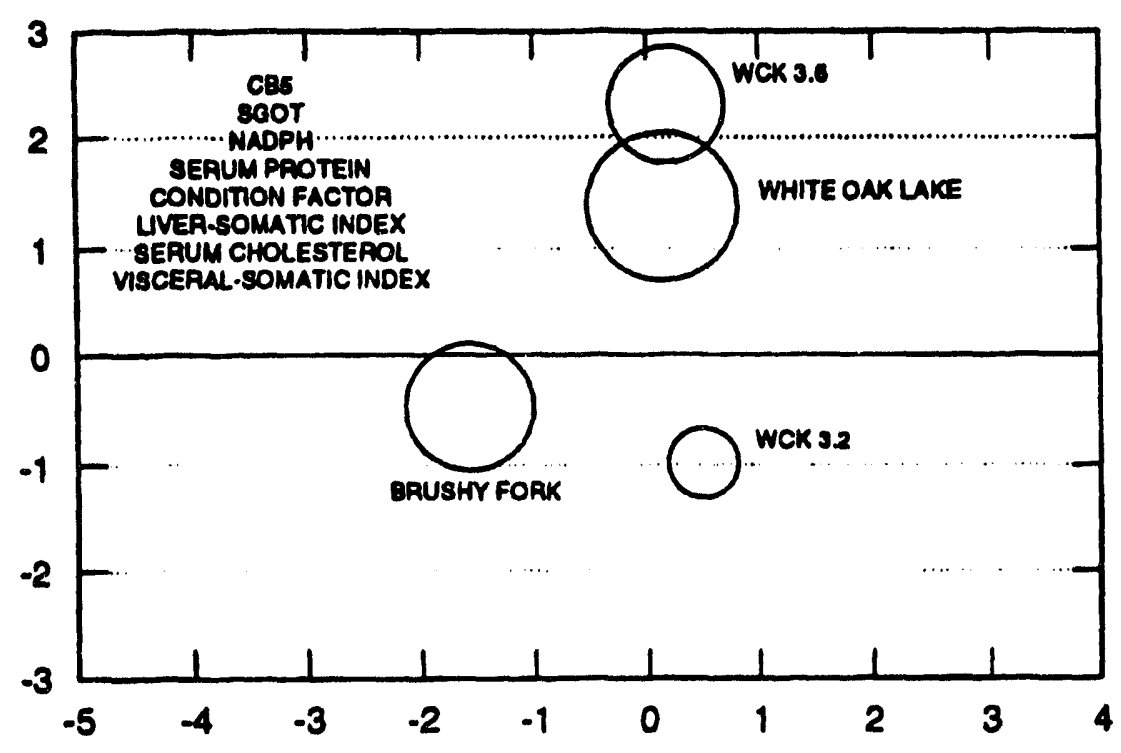

Fig. 5.8. Segregation of integrated health responses for bluegill sunfish at three sites in the White Oak Creek System and Brushy Fork using bioindicators measured from fall 1987 and spring 1987. Circles represent the site mean and the $95 \%$ confidence radii of the site mean. The variables used for discriminating among these sites are also shown.

means, bluegill at WCK 3.2 were most similar, and those at WCK 3.6 were least similar, to bluegill in Brushy Fork. Because the $95 \%$ confidence radii of fish from WCK 3.6 and WOL overlap, there is no significant difference between these two lentic sites. Because of their standing-water characteristics, environmental and biotic modifying factors at these two sites should be similar. Therefore, it is reasonable to expect that the expression of the integrated stress response of fish from these two sites would also be similar.

The variables that are most significant in discriminating among sites are also indicated on Fig. 5.8. These eight variables consist of representative indicators from five of the functional groups (see Sect. 5.3.1), including two detoxification enzymes, three condition indices, and one indicator each from the lipid metabolism, carbohydrate-protein metabolism, and organ dysfunction groups. It is important, therefore, to include indicators at several levels of biological organization when evaluating responses of fish to stress.

\subsubsection{Temporal analysis}

The purpose of the temporal analysis was to determine if any changes had occurred in fish health since BMAP was implemented in 1986. Temporal changes in each indicator/site combination were determined by the significance of the slope of the regression line of all redbreast sunfish values at each site measured between fall 1986 and fall 1987. A significant positive (or negative) regression slope indicated that a variable increased (or decreased) significantly over this 
period. If the slope was not significantly different from zero, then no significant temporal change was indicated. The analysis was limited to redbreast sunfish because a complete year of data was not available for bluegill. For redbreast sunfish in Brushy Fork, temporal changes in responses primarily involved indicators of lipid metabolism and liver condition (Table 5.1). Both plasma triglycerides and cholesterol decreased significantly over this period, as did the LSI. All of these responses are indicators of reduced levels of feeding or nutritional state of fish. Triglyceride and cholesterol levels in the blood reflect the short-term (hours or days) nutritional state of the organism, while the LSI is an indicator of longerterm (days or weeks) energy availability (Adams and McLean 1985). If feeding levels of fish are low and nutritional deficits are indicated (i.e., low plasma

Table 5.1. Temporal changes in bioindicator responses of redbreast sunfish over the period fall 1986-fall 1987 at two sites in White Oak Creck watershed and Brushy Fork, the reference site

\begin{tabular}{lccc}
\hline Response variable & White Oak Lake & WCK 3.2 & Brushy Fork \\
\hline Total body lipid & 0 & 0 & 0 \\
Liver-somatic index & + & 0 & - \\
Visceral-somatic index & 0 & 0 & 0 \\
Condition factor & 0 & 0 & 0 \\
RNADNA & + & + & 0 \\
SGOT & 0 & 0 & 0 \\
Serum glucose & 0 & 0 & + \\
Serum triglycerides & 0 & 0 & - \\
Serum cholesterol & 0 & - & - \\
Body triglycerides & 0 & 0 & 0 \\
PC/PE & 0 & 0 & 0 \\
Cytochrome P-4.50 & 0 & - & 0 \\
Cytochrome $b$ s & 0 & - & 0 \\
NADPH & 0 & - & 0 \\
Liver parasites & 0 & 0 & 0 \\
Function liver & 0 & - & - \\
parenchyma & 0 & 0 & 0 \\
Creatinine & 0 & 0 & 0 \\
\hline
\end{tabular}

${ }^{a}$ RNA/DNA = Ribonucleic acid/deoxyribonucleic acid; SGOT = Serum glutamate oxaloacetate transaminose; $\mathrm{PC} / \mathrm{PE}=$ phosphatidylcholine/phosphatidylethanoamine; $\mathrm{NADPH}=$ Nicotinamide adenine dinucleotide phosphate, reduced form; $W C K=$ White Oak Creek kilometer.

Note: A significant increase in a response over this period is indicated by a plus $(+)$, a significant decrease by a minus $(-)$, and no significant change by a zero $(0), p<0.05$. 
triglycerides and LSI), then the observed increase in glucose levels may indicate that amino acids are being catabolized to plasma glucose by the process of gluconeogenesis (Nakano and Tomlinson 1967). Significant reductions in the functional liver parenchyma of redbreast sunfish in Brushy Fork may also be related to starvation and nutritional deficiencies.

Decreases in nutrition-related parameters in Brushy Fork over this period are not surprising because of the severe drought conditions during 1987 that extended well into the fall (Table 2.1). Low stream flows result in reduced availability of benthic invertebrates for consumption by fish (Larimore et al. 1959) and, therefore, less available energy for critical physiological processes, such as growth. In contrast to temporal changes in nutrition-related parameters at the reference site, significant temporal changes at WCK 3.2 were due primarily to the detoxification enzymes (Table 5.1). Three enzymes (NADPH and cytochromes $P_{450}$ and $b_{5}$ ) showed significant decreases in activity from 1986 to 1987 , suggesting that fish at this site may have been exposed to reduced levels of organic contaminants over this period. Reduced contaminant exposure could not be corroborated on the basis of reduced concentrations in water. Comparisons of a..ıbient NPDES data showed no substantial differences between years for the period from 1986 to 1988 (Loar et al. 1992a; Loar 1992b). Finally, the significant increase in the RNA/DNA ratio over this period may indicate that an increased amount of physiologically useful energy was being channeled into growth instead of stress-related metabolic demands.

Redbreast sunfish in WOL showed significant increases in two important condition indicators, the LSI and the RNA/DNA ratio. Improvement in the condition of WOL fish may not be directly related to changes in levels of contaminant exposure (e.g., because enzyme levels did not change) but to an increase in the eutrophic state of the lake, food availability, feeding intensity, or other ecologically-related variables, such as changes in competition, predation, behavior, or predator/prey abundance.

\section{Conciusions}

Redbreast sunfish in WOC appeared to have experienced reduced levels of toxicant exposure from 1986 to 1987. Such reductions may have decreased metabolic demands on these fish, ultimately resulting in more physiologically available energy being channeled into growth and maintenance of overall condition. Decreases in nutrition-related indicators in fish from Brushy Fork were probably associated with drought conditions, which reduced water levels and presumably decreased food availability. Because of substantial flow augmentation due to discharges of ORNL effluents to WOC (Table 2.2), reductions in stream flow in WOC, as a percentage of the mean annual flow, were considerably less than in Brushy Fork.

\subsubsection{Causative Mechanisms}

The purpose of this analysis was to identify potential causal mechanisms that may be responsible for the observed differences in the health of fish among the various sites. Two basic mechanisms exist by which stress can aifect an organism. Stress can either act directly through metabolic and/or toxicological influences or indirectly through the food chain (Fig. 5.9). To aid in the identification of chese mechanisms, the relative importance of direct vs indirect effects was evaluated using two independent approaches: assessment of fish health by a variable 


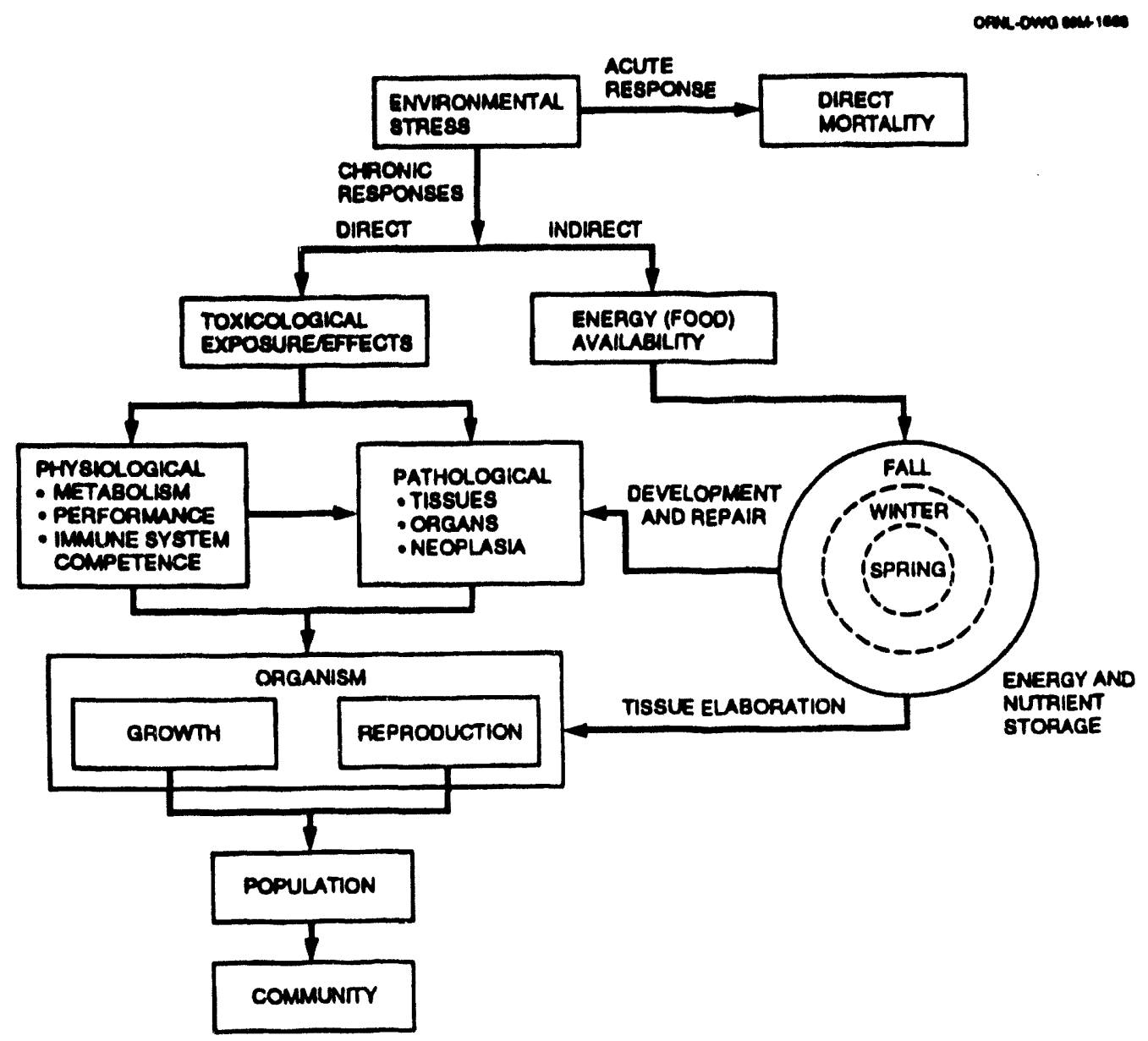

Fig. 5.9. Chronic-level responses of fish to sublethal contaminant stress, emphasizing the relative importance of the direct and indirect pathways and the status of the lipid pool in influencing responses at the organism, population, and community levels.

ranking procedure, and multivariate selection based on discriminant analysis.

\subsubsection{Health status ranking}

To assess the relative health of the sunfish population in WOC watershed and Brushy Fork, all fish were segregated into one of four quartile ranks for each response variable. For example, if a fish from WCK 3.2 had an NADPH value that fell within the highest $25 \%$ of all NADPH values (i.e., all fish at all sites), then it was placed in the lowest quartile for that indicator because high NADPH values are indicative of toxicant exposure or high stress. Conversely, if a fish from Brushy Fork had an NADPH value within the lowest $25 \%$ of all measured values, then it was placed in the highest quartile for that parameter. For each bioindicator parameter, fish were segregated into quartiles, by site, and the total number of bioindicators for which a fish ranked in the lowest quartile was tabulated. Based on 
this approach, the subjective criterion for fish health was the percentage of fish at each site that appeared in the lowest quartile for at least four of the indicators.

This analysis showed that bluegill in Brushy Fork, Melton Branch, and WOC at WCK 3.6 were in the poorest health (Fig. 5.10). However, when only the longer-term indicators were considered (lipid metabolism, histopathology, and condition indices), bluegill from the three lotic sites (Brushy Fork, Melton Branch, WCK 3.2) were in the poorest health (Fig. 5.10). For redbreast sunfish, Brushy Fork had the healthiest population, with only $30 \%$ of the fish in the lowest quartile as compared with $55-70 \%$ of the fish from the other sites. When the longer-term indicators were considered alone, fish in WOL were in the poorest condition, and the health

ORWL-OWE O3M-15050
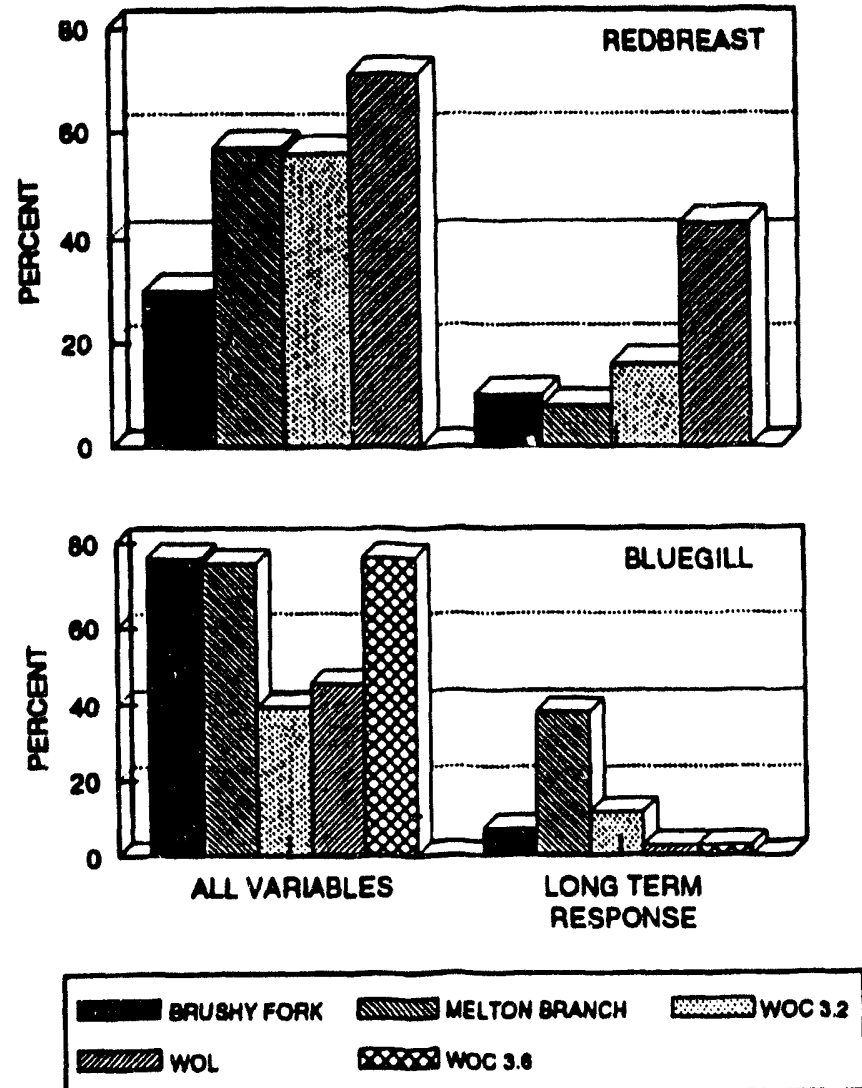

Fig. 5.10. Health status of percentage of redbreast and bluegill sunfish at all White Oak Creek System sites ranked in the lowest quartile for at least four bioindicators. Fish ranked in the lowest quartile represent those individuals that are in poorest health relative to all fish at all sites. 
status of the other populations was similar and more than $50 \%$ "better" than the status of the WOL population.

The bioindicator functional groups that were responsible for the health status ranking varied among sites. It is on the basis of differences in these groups of distinguishing variables that the mechanisms or agents ultimately responsible for the effects on fish can be evaluated. To identify these variables, the percentage of fish included in the lowest quartile of each variable was calculated. The variables associated with the poor health of bluegill from the reference stream were primarily indicators of organ dysfunction and condition indices. Indicators of poor health in bluegill from WOC watershed were almost exclusively detoxification enzymes, lipid metabolism, and carbohydrate-protein metabolism parameters. The identifying health indicators for redbreast sunfish from the reference site were lipid metabolism and organ dysfunction, while the health status of the same species from the WOC system was determined by detoxification enzymes and condition indices.

Because elevated detoxification enzymes are indicators of toxicant exposure, the effects observed in redbreast and bluegill sunfish in WOC were probably due to contaminant loading. Effects of this contaminant exposure on bluegill are expressed mainly as impaired lipid and protein metabolism with little effect on overall body condition. In redbreast sunfish, however, effects of toxicant exposure are manifested primarily as changes in body condition and growth, especially at WCK 3.2 and in WOL.

Both species in the reference stream showed no indication of toxicological exposure, as evidenced by the baseline levels of detoxification enzymes. The health indicators at this site are those that primarily reflect inadequate food availability and, therefore, reduced nutrition or energy intake. Drought conditions in Brushy Fork during the past several years could be responsible for reduced levels of food available to the resident fish populations, particularly in the fall. Low stream flows result in the reduced availability of benthic macroinvertebrates for consumption by fish (Larimore et al. 1959). Therefore, less energy is available for growth and for maintaining body condition.

By comparison, some of the observed effects on fish in the WOC system related to alterations in lipid metabolism, pathological condition, and overall condition that could be related to reduced food availability. In this case, however, availability would not be related to adverse natural conditions, such as low stream flow, but more likely to the indirect effect of toxicological exposure being manifested through the food chain (Fig. 5.10). Future studies will attempt to further quantify the relative importance of indirect effects of toxicological exposure on the stress responses of WOC fish populations.

\subsubsection{Multivariate selection}

A multivariate selection procedure was used to identify those variables that best discriminate between the health status of fish at the various sites. Because only fish in WOC experience toxicant exposure (Sect. 5.3.1.2), the variables that discriminate between fish at the reference site and those at each of the WOC sites should reflect this exposure. For each comparison between reference and WOC system fish, a detoxification enzyme (NADPH, cytochromes $b_{5}$ or $\mathrm{P}_{450} \mathrm{C}$ ) was the single most important variable for distinguishing between sites. Like the health status evaluation based on the variable ranking procedure, indicators of lipid and carbohydrate-protein metabolism were also important in site segregation. 
The LSI was considered in this multivariate analysis because, under toxicant stress, the liver increases in size (Klaunig et al. 1976), resulting in elevated LSI values. In addition to the detoxification enzymes, selection of the LSI as an important discriminating site variable provides additional evidence that fish in WOC could be subjected to toxicant-related stress.

\subsubsection{Summary}

Two independent analyses have demonstrated that the poor health of the sunfish populations in the WOC system is due primarily to contaminant exposure, and the effects of this exposure are manifested mainly as impaired lipid and carbohydrateprotein metabolism. Evidence for toxicological exposure include elevated levels of detoxification enzymes and a high LSI, particularly in fish at WCK 3.2 and 3.6. As evidenced by the impaired lipid and carbohydrate-protein metabolism in WOC bluegill, metabolic-related stress due to direct toxicant exposure can reduce the quantity and quality of energy available for maintaining immune system competence and adequate rates of growth. Further, reduced energy availability could affect reproductive competence and reduce repair rates of damaged tissues. The effects of direct toxicant stress on chemical and biological processes in organisms as they relate to immune and reproductive competence is unknown but will be addressed in future s'udies. The indirect effects of exposure on food availability will also be investigated.

The poor health of the bluegill population in the reference stream is probably a direct result of the drought, which reduced stream flow and probably food availability for fish, thereby adversely affecting the overall condition of the fish. While the health status of fish in the WOC system might also have been influenced by food or energy availability, in this case, availability would probably have been related to the indirect effects of toxicants on the food chain.

The effects of stress or toxicant loading on the behavior of fish is also unknown. Periodic pulses of contaminants, such as chlorine, heavy metals, PAHs, eic., could alter feeding behavior, reproductive behavior, or predator-prey and/or competition relationships. All these modifications in behavior could ultimately be manifested in fish populations as reduced growth and reproduction.

\subsubsection{Indicators of Contaminant Exposure}

\subsubsection{DNA Integrity}

\section{Background}

DNA damage has been proposed as a useful biological parameter for assessing the genotoxic properties of environmental pollutants (Kohn 1983). The theoretical basis of this usage is derived from studies on the mode of action of chemicals known to be carcinogenic and mutagenic (Harvey 1982). Analytical techniques that detect and quantify DNA damage have been developed at ORNL to facilitate studies on the relation between exposure, metabolism, and subsequent biological effects of genotoxic chemicals in the environment. These include methods that (1) quantify the formation of stable adducts between genotoxic chemicals and DNA (Shugart et al. 1983, Shugart et al. 1987), (2) detect excess strand breakage within the DNA polymer which may be chemically-induced (Shugart 1988a, 1988b), and (3) measure the aberrant nucleotide composition of DNA (Shugart unpublished data). Application of these techniques to aquatic organisms exposed experimentally to known genotoxic agents demonstrates that the integrity of the organism's DNA is 
affected and how it can be detected and quantified.

Early in 1987, detection of strand breaks in the DNA of bluegill sunfish was implemented as a biological monitor for environmental genotoxicity as part of the ORNL BMAP (Loar et al. 1991). Analysis for DNA strand breakage is easy to perform and cost effective, and the assay detects a general type of DNA damage that could result from any one of a wide range of genotoxic agents with the potential to cause transient DNA strand breakage. For example, some chemicals, such as certain PAHs, are known to be mutagenic and carcinogenic. They cause direct DNA damage as a result of their metabolism in the exposed organism (Shugart et al. 1987; Shugart 1988a, 1988b). Other chemicals, such as mercury, when present at noncytotoxic levels, can potentiate DNA damage in organisms exposed to complex mixtures of chemicals because of their capacity to interfere with normal DNA repair processes (Williams et al. 1986). Thus, the detection and quantitation of transient strand breaks in DNA can provide useful information about the status (integrity) of DNA and whether that organism is responding to genotoxic agents in its environment.

It should be noted that DNA damage unrelated to genotoxic compounds can also occur. The most frequent lesion that occurs in cellular DNA is depurination and is the result of random thermal collisions. The rate has been estimated at thousands per day per genome. However, these lesions and most other types of DNA damage are rapidly eliminated by the normal process of DNA repair. The fidelity with which DNA is maintained in higher eucaryotes is reflected in the observed low mutational rate of ahout one mutation per average gene per 200,000 years (Alberts et al. 1983). The alkaline unwinding assay used to detect strand breaks in DNA accounts for background levels of damage due to the random process described above by referencing strand breaks in animals from affected sites to those present in the same species from a relatively unpolluted reference site; in other words, data are reported as number of breaks above the random background level.

\section{Results and Discussion}

Reference site. The selection of a suitable reference site is of great importance to the interpretation of the data on DNA strand breaks in fish from WOC watershed. Ideally the alkaline unwinding assay should indicate little DNA damage at the reference site. Data were obtained on strand breaks in fish from two streams off the ORR to determine their suitability as appropriate reference sites (Table 5.2). These streams were Hinds

Table 5.2. DNA integrity measured in sunfish from two reference sites Values are $\ln \mathbf{F} \pm \mathrm{SD} ; \mathrm{NS}=$ Not sampled

\begin{tabular}{lcc}
\hline \multicolumn{1}{c}{ Sampling date } & Brushy Fork & Hinds Creek \\
\hline May 1987 & $-0.65352 \pm 0.15182$ & NS \\
June 1987 & NS & $-0.21078 \pm 0.07150$ \\
Nov 1987 & $-0.29060 \pm 0.14055$ & NS \\
May 1988 & NS & $-0.09710 \pm 0.05170$ \\
Aug 1988 & $-0.40170 \pm 19998$ & $-0.10718 \pm 0.13494$ \\
\hline
\end{tabular}


Creek, in Anderson County north of Clinton, and Brushy Fork, which is also located in Anderson County north of Oak Ridge. Statistical analyses of the data from Hinds Creek indicated that the mean $\ln \mathrm{E}$ values obtained on 3 different sampling dates were not significantly different $(p>0.3)$. Analyses of the Brushy Fork data showed a significant difference between the $\ln \mathrm{E}$ values for May 1987 and November $1987(p<0.001)$ but not between the values for November 1987 and August 1988. However, a comparison of the mean In $\mathrm{E}$ values between Hinds Creek and Brushy Fork for August 1988 irdicated that the 2 sites were significantly different $(p<0.001)$.

Therefore, Hinds Creek appears to be a better reference stream than Brushy Fork for comparison with data on DNA integrity from fish in the WOC system. Although PCBs in Brushy Fork sunfish have been found at levels similar to those found in EFPC sunfish (Loar 1992c), other data indicate that the biotic communities in
Brushy Fork are diverse and consist of many pollution-intolerant species. (See comparison of benthos communities in Brushy Fork and WOC in Sect. 6.1.) Fish from the Hinds Creek site appear to beunder less genotoxic stress, as indicated by the minimal fluctuation in $\ln \mathrm{E}$ values over a period of 14 months (Table 5.2). The small negative in $\mathrm{E}$ value (average for all dates is $-0.11909 \pm 0.11264$ ) in the alkaline unwinding assay is indicative of highly polymerized, double-stranded DNA with few endogenous breaks (Rydberg 1975, Ahnstrom and Erixon 1980) and is similar to data obtained from sunfish maintained under laboratory conditions without genotoxic stress (Shugart 1988a, 1988b).

WOC sites. Results of the analysis of DNA strand breaks in sunfish collected at sites in the WOC watershed in May 1987, November 1988, and September 1988 are shown in Table 5.3. The average $\ln \mathrm{F}$ value for all Hinds Creek data was used to

Table 5.3. Comparison of DNA strand breaks in sunfish from sites in White Oak Creek watershed and from Hinds Creek, a reference site

\begin{tabular}{lcccc}
\hline \multirow{2}{*}{ Sampling site } & \multicolumn{5}{c}{ Sampling date } \\
\cline { 2 - 5 } & May 1987 & Nov 1987 & Aug 1988 & Sep 1988 \\
\hline Brushy Fork & $4.49^{\circ}$ & $1.44^{\circ}$ & $2.37^{\circ}$ & NS \\
WCK 3.6 & NA & $2.78^{\circ}$ & NS & $4.79^{\circ}$ \\
WCK 3.2 & $15.34^{\circ}$ & NS & NS & $5.61^{\circ}$ \\
WCK 3.0 & $5.35^{\circ}$ & 0.01 & NS & $7.28^{\circ}$ \\
White Oak Lake & $4.52^{\circ}$ & $1.77^{\circ}$ & NS & $9.32^{\circ}$ \\
Melton Branch & $1.85^{\circ}$ & 0.11 & NS & NS \\
\hline
\end{tabular}

Significantly different from reference stream $(p<0.001)$.

Significantly different from reference stream $(p<0.05)$.

Note: Tabular values represent $\underline{N}$, which is the relative number of strand breaks in fish from the site indicated compared with the reference site. $N S=$ Not sampled. $W C K=$ White Oak Creek kilometer. 
compute the $\underline{N}$ value (Sect. 5.2.2.6) at the other sampling sites. Such data can be examined for the occurrence of genotoxic stress in the WOC sunfish population with respect to the reference population.

The data in Table 5.3 show that the DNA isolated from sunfish at all sampling sites in the WOC system for May 1987 and September 1988 had significantly $(p<0.001)$ more strand breakage than the DNA from the same species at the reference site. Relative to the other sampling dates, values of $\underline{\mathbf{N}}$ for November 1987 were lower and, in some cases, not significantly different from the reference site.

\section{Summary}

The results of the DNA integrity study indicate that fish in the WOC system were experiencing genotoxic stress during this investigation. The stress is neither uniform nor declining but appears to be fluctuating, as noted by (1) low $\underline{N}$ values at all sampling sites in the fall 1987 as compared with other sampling times, and (2) the occurrence of significantly greater strand breakage $(p<0.001)$ in the DNA of fish in WOC (WCK 3.2) relative to the fish in WOL at the beginning of the study (May 1987), while just the opposite was found (WCK 3.6 vs WOL) in the latter part of the study (September 1988).

These results could reflect responses of fish to periodic releases of contaminants to WOC below ORNL. Correlation of documented occurrences of contaminants in WOC with increased levels of strand breakage are needed to validate this interpretation. The biological ramifications of the level of DNA strand breakage found in fish in the WOC system are unknown at present. However, the $\underline{N}$ values reported here are equal to or greater than those found in sunfish exposed experimentally to the carcinogen, benzo[ $a$ ]pyrene (Shugart 1988b).

The determination of other end points of DNA damage on the continuum from exposure to effect would help substantiate the interpretation of results from future studies. In this regard, an analytical method for the detection of aberrant nucleotide composition of DNA has been developed (Shugart, unpublished data), while the use of a flow cytometric technique for quantifying unequal distribution of DNA in cells due to chromosomal aberrations (McBee and Bickham 1988) is being studied. Effective remedial actions that prevent releases of pollutants should result in the diminution of DNA damage in exposed animal populations.

\subsubsection{Metal-binding proteins}

\section{Background}

MBPs are a ubiquitous class of proteins that play a variety of roles within an organism. Although their principal biological function has not been elucidated, it appears that their major role is the homeostasis of essential bivalent metal ions, especially zinc and copper, within the cell (Brady 1982, Webb and Cain 1982, Hamer 1986, Bremner 1987, Thomas et al. 1987). The chief MBP, and the one most thoroughly studied, is metallothionein. It also has numerous secondary roles, both proven and postulated, including heavy metal detoxification; sulfur metabolism; maintenance of intracellur redox potential; activated oxygen detoxification; as a component of the defense mechanism against physical and inflammatory stress, starvation and infection; and as a general detoxification agent against certain chemical compounds (Hamer 1986, Brady et al. 1987, Abe et al. 1987, Dunn et al. 1987). The important secondary role of 
metallothionein in the detoxification of heavy metals permits it to serve as a measure of the biological response of an organism to the presence of elevated levels of heavy metals and as a monitor of the exposure to these metals (Simkiss and Taylor 1981). In particular, the measurement of this important class of MBPs can be a tool for predicting the intoxication state of metal compounds (Winge et al. 1974) and serve as a biomarker for metal pollution, a concept supported by a number of recent studies relating metallothionein to the presence of toxic metals (Brown et al. 1977, 1986, Chang et al. 1980, Roch et al. 1982, 1985, Hening 1986). MBPs have been demonstrated in a variety of fish (Bouquegnea et al. 1975; Bouquegneau 1979; Kito et al. 1982a, 1982b, 1982c; Thomas et al. 1983), and a recent reviev has underscored the importance of using metallothionein in fish for assessing stress from metal contaminants (Hamilton and Mehrle 1986).

\section{Results and Discussion}

Metal-binding proteins were assayed in bluegill sunfish from four sites in WOC in September 1986, May 1987, and September 1988 and from two reference streams (Brushy Fork and Hinds Creek) during the same periods and in August 1988. A total of 119 fish were analyzed and the data obtained are presented in Table 5.4 .

Except for the high value in Brushy Fork in May 1987, the MBP content of sunfish from the two reference streams was not significantly different over the 2-year period. Values were similar to those found in sunfish maintained unde $r$ laboratory conditions where exposure to heavy metal jons is restricted (Sloop, unpublished data). High levels of MBP, such as those observed in September 1986 (Table 5.4), suggest that the fish were responding to metal contamination. Levels of MBP were significantly higher than the reference stream (Brushy Fork) at all sampling sites in September 1986. In September 1988, however, only one site (WCK 3.2) was significantly higher than the reference stream (Hinds Creek). Also, MBP content of fish from WOL was significantly lower $(p<0.001)$ in this sampling period as compared with levels observed 15 months earlier.

\section{Summary}

Levels of MBPs in fish from WOC were higher than those in fish from the reference stream in at least one of the four sampling sites on WOC on all three sampling dates. Assuming both streams are subjected to the same or similar influencing environmental factors (Wang 1987), then the higher levels of MBPs suggest that the fish in the WOC system are responding biochemically to some degree of metal toxicity.

The levels of MBP in WOL fish did not change significantly between September 1986 and May 1987; however, by the final samp! :ng period (September 1988), MBP content had significantly decreased to a level similar to that found in the reference stream (Hinds Creek). These data may indicate that stresses from metal pollutants, as measured by the production of MBPs in the fish from WOL, are decreasing with time. However, it should be noted that levels at one sampling site (WCK 3.2) have remained significantly higher than the reference streams.

\subsubsection{Summary and Synthesis}

A comprehensive analysis of the data was conducted on a suite of bioindicators 
Table 5.4. Mean ( \pm 1 SD) metal-binding protein content (nanograms of ${ }^{10} \mathrm{Cd}$ bound per gram of soluble liver protein) in sunfish from White Oak Creek and two reference streams (Brushy Fork and Hinds Creek)

Number of fish analyzed in parentheses; NS = Not sampled

\begin{tabular}{|c|c|c|c|c|}
\hline \multirow{2}{*}{ Sampling site } & \multicolumn{4}{|c|}{ Sampling date } \\
\hline & Sept. 1986 & May 1987 & Aug. 1988 & Sept. 1988 \\
\hline Brushy Fork & $\begin{array}{l}551 \pm 109 \\
(9)\end{array}$ & $\begin{array}{l}1678 \pm 117 \\
(3)\end{array}$ & $\begin{array}{l}532 \pm 322 \\
(14)\end{array}$ & NS \\
\hline Hinds Creek & NS & NS & $\begin{array}{l}418 \pm 157 \\
(17)\end{array}$ & $\begin{array}{l}523 \pm 255 \\
(10)\end{array}$ \\
\hline WCK 3.6 & NS & NS & NS & $\begin{array}{l}175 \pm 75 \\
(8)\end{array}$ \\
\hline WCK 3.2 & $\begin{array}{l}1299 \pm 929^{\circ} \\
(9)\end{array}$ & NS & NS & $\begin{array}{l}111 \pm 659^{a} \\
(9)\end{array}$ \\
\hline WCK 3.0 & $\begin{array}{l}1558 \pm 595^{b} \\
(6)\end{array}$ & $\begin{array}{l}231 \\
(3)\end{array}$ & NS & $\begin{array}{l}644 \pm 259 \\
(12)\end{array}$ \\
\hline White Oak Lake & $\begin{array}{l}1338 \pm 971^{a} \\
\text { (3) }\end{array}$ & $\begin{array}{l}1703 \pm 1045 \\
(4)\end{array}$ & NS & $\begin{array}{l}579 \pm 346 \\
(12)\end{array}$ \\
\hline
\end{tabular}

Significantly different from reference stream $(p<0.05)$.

Significantly different from reference stream $(p<0.001)$.

Note: WCK $=$ White Oak Creek kilometer.

measured in sunfish collected from fall 1986 through fall 1987 in WOC watershed and reference streams. Several significant conclusions resulted from this review. Significant differences were observed in fish health between the WOC sites and the reference site (Brushy Fork). Redbreast sunfish at each of the WOC sites were in poorer health than fish from the reference stream, while bluegill at the two lotic sites in WOC watershed (Melton Branch and WCK 3.2) were in poorer health than bluegill from Brushy Fork. Two independent analyses demonstrated that the health status of fish in the WOC system was due primarily to toxicological exposure, and the effects of this exposure were manifested mainly as impaired lipid and carbohydrate-protein metabolism.

Other important trends were also evident. Even though both species in the WOC system were probably experiencing some degree of short-term, physiological stress, the longer-term expression of this stress was dramatically different between the two sunfishes. These interspecific differences may be due to biotic and environmental modifying factors such as habitat and food availability, competition, and behavior. For example, natural environmental stressors that are incurred by an organism as a result of competition for food or space could act in a synergistic or cumulative fashion, together with 
contaminant-related stresses, and produce the types of stress responses observed between the two species in this study.

Evidence for toxicological exposure of fish in the WOC system included elevated detoxification enzymes, DNA damage, and MBPs. Metabolic stress due to toxicant exposure probably reduces the amount of energy available for growth, gonad maturation, and repair of damaged tissues, and compromises the integrity of the reproductive and immune systems.

Monitoring to date has demonstrated the need to incorporate bioindicators representative of several levels of biological organization in monitoring programs in order to effectively evaluate the effects of contaminant-related stress on fish.

\subsection{FUTURE STUDIES}

The annual monitoring of bioindicators in fish will continue at four sites in WOC watershed and a reference stream. The bioindicators to be measured will be those that have provided the most cost-effective information relative to addressing the principal objectives of the BMAP. Hinds Creek will replace Brushy Fork as the primary reference site in future biomonitoring studies because, as demonstrated in this report, the condition of fish in Brushy Fork has apparently been adversely affected by drought. Fish in Hinds Creek, however, seemed less affected by the drought, possibly because it is a larger stream and critical resources, such as food and habitat availability, may not be as limiting there as in Brushy Fork. In addition a more ecologically appropriate reference system for the two lentic sites on WOC (WOL and WCK 3.6) will be chosen, possibly in Watts Bar or Melton Hill reservoirs.

\subsubsection{New Initiatives}

\subsubsection{Manipulative caging experiments}

These experiments will be conducted during the spring and summer of 1989 to evaluate the effects of stress on fish under semicontrolled conditions. Uncontaminated fish will be placed in large cages located in WOC and in reference streams. The response of these fish to environmental conditions in WOC will be determined by examining a selected suite of indicators that have been shown in the present study to provide the most cost-effective information for assessing the effects of chronic stress on fish.

\subsubsection{Reproductive studies}

Preliminary studies have been initiated on the reproductive biology of redbreast sunfish in both reference streams as part of the Y-12 Plant BMAP (Loar 1992c). Based on these investigations, efforts will be initiated in 1989 to assess the effects of contaminant stress on reproductive success. Reproductive competence will be evaluated through studies of gonad condition (e.g., quality and quantity of eggs), sizes and timing of clutches, hormone leveis, and gonad histology.

\subsubsection{Identification of causal mechanisms}

Both laboratory and field studies will be conducted to further evaluate the relative importance of direct (water-borne) vs indirect (food-chain) effects of chronic stress on fish in the WOC system. With the manipulative caging experiments, differences in responses between caged (nutritionally deficient) and uncaged (wellfed) fish should provide information on the 
relative importance of direct vs indirect pathways in influencing fish health. Laboratory experiments will also be conducted; for example, the amount of food and level of direct metabolic stress can be varied to assess the relative importance of these variables on selected bioindicator responses. Results of these experiments can be used to evaluate the causal mechanisms responsible for the overall condition of fish in the WOC system. 


\title{
6. INSTREAM ECOLOGICAL MONITORING
}

\author{
M. A. Huston, M. G. Ryon, J. G. Smith
}

The objectives of the instream ecological monitoring task (Task 4 of the BMAP) are (1) to characterize spatial and temporal patterns in the distribution and abundance of the benthos and fish populations in WOC watershed; (2) to identify contaminant sources that adversely affect stream biota, including differentiation between point sources and nonpoint (or area) sources, wherever possible; and (3) to monitor these populations and evaluate the future effects on community structure and function from the operation of new wastewater treatment facilities, from improvements in waste management operations, and from implementation of remedial actions directed at area-source control. This task consists of three components: (1) benthic invertebrate studies (Subtask 6a), (2) fish population studies (Subtask $6 \mathrm{~b}$ ) and

(3) evaluation of biotic changes (Subtask

$6 c)$; results to date are presented in Sects.

6.1-6.3, respectively.

\subsection{BENTHIC MACROINVERTEBRATES J. G. Smith}

\subsubsection{Introduction}

Benthic macroinvertebrates are those organisms which are large enough to be seen without the aid of magnification and which live on or in the substrate of flowing and nonflowing bodies of water. Their limited mobility and relatively long life spars (a few weeks to more than a year) make them ideal for use in evaluating the ecological effects of effluents on streams (Platts et al. 1983). The composition and structure of the benthic community reflects the relatively recent past and can be considerably more informative than monitoring methods that rely solely on water quality analyses and often fail to detect episodic releases of toxicants.

Prior to initiating processing of the samples collected from May 1987 through April 1988, a reduction-in-force was implemented in September 1988 within TVA, the primary processing subcontractor. This action resulted in the loss of all personnel associated with the processing of benthic invertebrate samples. Because processing of the samples collected during the second year was not initiated, no new data were available for this report. Therefore, additional analyses were performed only on data collected during the first year of the BMAP (i.e., May 1986-April 1987). This analysis provided further clarification of the trends originally observed, as well as additional characterizations of the study sites. All samples were returned to ORNL where processing will be completed in the future.

\subsubsection{Materials and Methods}

Benthic macroinvertebrates were sampled at approximately monthly intervals from May 1987 through April 1988, from 15 stream sites in the WOC watershed (Fig. 2.2); two transects were sampled in WOL at approximately bimonthly intervals. The uppermost site of each stream served as a reference site. Additionally, a single site on Brushy Fork (BFK 7.6), a primary reference site for the Y-12 Plant BMAP (Loar 1992b, 1992c), was also used as a reference site for WCK 2.3. This site is 
located just north of Oak Ridge near the Marlowe community.

Three randomly selected benthic macroinvertebrate samples were collected from riffles at each stream site in the WOC watershed with a Surber bottom sampler $\left(0.09 \mathrm{~m}^{2}\right.$ or $1 \mathrm{ft}^{2}, 363-\mu \mathrm{m}$-mesh net). In WOL, five samples were collected at approximately $10-\mathrm{m}$ intervals across each transect with a hand-operated Ponar dredge $(15 \times 15 \times 15 \mathrm{~cm})$. Five randomly selected samples were collected from a riffle in Brushy Fork with a modified Hess sampler $\left(0.1 \mathrm{~m}^{2}, 363-\mu \mathrm{m}\right.$-mesh net). Qualitative samples were collected from all stream sites and from WOL in March/April 1988 with a D-frame aquatic dip net (mesh of $800 \times 900 \mu \mathrm{m}$ ). Qualitative samples were collected from riffle and nonriffle habitats (e.g., pools, leaf packs, detritus, snags) at the stream sites and from all identifiable habitats (e.g., emergent vegetation, leaf packs, snags, riprap) in WOL. Qualitative samples were washed in the field in a $363-\mu \mathrm{m}$-mesh net and a white pan to concentrate the organisms. Both quantitative and qualitative samples were placed in prelabeled glass jars and preserved in $80 \%$ ethanol; the ethanol was replaced with fresh ethanol within 1 week. The laboratory procedures used to process these samples are described in detail in Loar (1992b).

Various supplemental information was also obtained at the time of sample collection. Water temperature and specific conductance were measured with a ColeParmer Model R-1491-20 LCD temperature/conductivity meter at each stream site. Water depth, location within the riffle area (distance from permanent headstakes on the stream bank), relative current velocity (very slow, slow, moderate, or fast), and substrate type [using a modified Wentworth particle-size scale
(Table 2.10)], were recorded for each sample. In WOL a single measurement of water temperature and specific conductance was obtained at the surface, and water depth and substrate type were recorded for each sample.

All data were managed and analyzed on computer, with the Statistical Analysis System (SAS 1985a, 1985b). The mean number of Ephemeroptera (mayflies), Plecoptera (Plecoptera), and Trichoptera (caddisflies) taxa per sample (EPT richness) were calculated for each site. The basis for using EPT richness as an index of the "health" of a stream is that, although some pollution-tolerant taxa do exist within each of the three taxonomic groups, greater richness of these groups is usually associated with good water quality (e.g., Lenat 1988). Prior to statistical comparison, the data were transformed $\left[\log _{10}(x+1)\right.$, where $x=$ total number of EPT taxa in the sample] (Elliott 1977). Values for EPT richness were compared with a two-way analysis of variance (ANOVA) with site and date as the main effects. When significant site differences were detected, they were separated with a Tukey's studentized range test (HSD), accepting $p<0.05$. The number of samples varied among sites because some upstream reference sites were partially dry or, in the case of FCK 0.8, were initially sampled at a different frequency (see Loar et al. 1992a, Table 6.1 and Loar 1992b, Sect. 6.1).

Consequently, statistical analyses involving these sites were limited to only those months in which samples were collected from both the reference stream and its downstream sites.

Annual production of the benthic macroinvertebrates at each site was estimated indirectly by multiplying the mean annual biomass of each taxon by an estimated production to biomass ( $\mathrm{P}: \mathrm{B})$ 
ratio for that taxon. Values for individual taxa were then totaled to get an estimate of community production. P:B ratios were based on (1) values published for specific taxa in the upper Southeast region of the United States, or (2) a theoretical cohort $\mathrm{P}: \mathrm{B}$ of 5.0 and then corrected for the cohort production interval $(C P I=$ the length of aquatic life during which a taxon is present and growing) (Waters 1977, Benke 1979, Waters 1979). The CPIs were obtained from (1) published values,

(2) published life history information, or

(3) unpublished data of the authors. It is assumed for this report that water quality is not significantly affecting $P: B$ ratios of the individual taxa. Thus, the same P:B ratios are being used for all sites. The $P: B$ ratios used in this report are listed in Appendix C, Table C.1.

Following the same strategy as that used for comparisons of EPT richness, mean values (untransformed) for $\mathrm{P}: \mathrm{B}$ ratios were compared with a two-way ANOVA, with site and date as the main effects. Considerable heterogeneity existed in the variance of the means; however, a log transformation of the data resulted in no notable improvement. Thus, statistical analysis of these data with an ANOVA results in conservative comparisons. Where possible, significant site differences $(p<0.05)$ were separated with Tukey's studentized range test (HSD).

\subsubsection{Results}

\subsubsection{White Oak Creek and tributaries}

\section{Field Data}

A summary of pertinent field data collected from May 1986 through April 1987 is provided in Table 6.1; field data collected from May 1987 through April 1988 will be presented concurrently with the benthos data covering the same time period in a future report. Temperature readings obtained along with benthos samples are not included because temperature is monitored continuously at several sites within the WOC watershed; temperature data obtained from these continuous monitors are presented in Sect. 2.2.3.

Except in Northwest Tributary, conductivity in each stream tended to increase with increasing distance downstream. The most notable site differences in conductivity were exhibited in Melton Branch, where values at the downstream sites were about 2.5 times greater than at the upstream reference site.

Estimates of current velocity, depth, and substrate obtained concurrently with benthos samples were very similar to those obtained in the habitat characterization study conducted during summer 1988 (see Sect. 2.3). Not unexpectedly, current velocity and water depth increased with increasing distance downstream. The substrate at the reference sites tended to be dominated by rubble-sized rocks (size range of 64 to $250 \mathrm{~mm}$ ). The substrate of many of the downstream sites was generally dominated by rubble, but the substrate at some sites also contained much gravel (size range of 2 to $64 \mathrm{~mm}$ ) (e.g., MEK 1.2, WCK 2.3, and WCK 2.9). White Oak Lake (WCK 1.1) was dominated by a mixture of clay and silt. Embeddedness of substrate particles was generally similar among sites within each stream. However, larger particles at most downstream sites tended to be covered more with a fine layer of silt (J. G. Smith, Environmental Sciences Division, ORNL, personal observation).

Benthic macroinvertebrate data

EPT richness. Clear trends were observed in EPT richness in WOC 
Table 6.1. Summary of field data collected during benthic macroinvertebrate sampling in the White Oak Creek watershed, May 1986 through April 1987

Values are means $\pm 1 \mathrm{SD}$ (in parentheses)

\begin{tabular}{|c|c|c|c|c|c|}
\hline Site & $\begin{array}{l}\text { Depth } \\
(\mathrm{cm})\end{array}$ & $\begin{array}{l}\text { Dominant } \\
\text { substrate }\end{array}$ & $\begin{array}{c}\% \\
\text { Embeddedness }\end{array}$ & $\begin{array}{l}\text { Current } \\
\text { velocity" }\end{array}$ & $\begin{array}{l}\text { Conductivity } \\
(\mu \mathrm{S} / \mathrm{cm})\end{array}$ \\
\hline \multicolumn{6}{|l|}{ Firet Creet } \\
\hline FCK 0.1 & $\begin{array}{c}9.1 \\
(2.9)\end{array}$ & $\begin{array}{c}5.9 \\
(0.3)\end{array}$ & $\begin{array}{l}41.4 \\
(8.7)\end{array}$ & $\begin{array}{l}3.1 \\
(1.0)\end{array}$ & $\begin{array}{l}278.8 \\
89.2)\end{array}$ \\
\hline FCK 0.8 & $\begin{array}{c}7.5 \\
(3.3)\end{array}$ & $\begin{array}{c}6.2 \\
(0.5)\end{array}$ & $\begin{array}{l}38.4 \\
(8.1)\end{array}$ & $\begin{array}{c}2.8 \\
(0.9)\end{array}$ & $\begin{array}{l}221.0 \\
(76.0)\end{array}$ \\
\hline \multicolumn{6}{|l|}{ Fith Creek } \\
\hline FFK 0.2 & $\begin{array}{l}23.6 \\
(5.6)\end{array}$ & $\begin{array}{c}6.1 \\
(1.1)\end{array}$ & $\begin{array}{c}25.0 \\
(15.2)\end{array}$ & $\begin{array}{c}3.7 \\
(0.7)\end{array}$ & $\begin{array}{l}287.4 \\
(87.8)\end{array}$ \\
\hline FFK 1.0 & $\begin{array}{c}5.9 \\
(2.5)\end{array}$ & $\begin{array}{c}6.2 \\
(0.4)\end{array}$ & $\begin{array}{l}41.7 \\
(7.7)\end{array}$ & $\begin{array}{c}3.0 \\
(0.8)\end{array}$ & $\begin{array}{l}204.5 \\
(64.6)\end{array}$ \\
\hline \multicolumn{6}{|c|}{ Melton Branch } \\
\hline MEK 0.6 & $\begin{array}{l}12.2 \\
(6.3)\end{array}$ & $\begin{array}{c}6.5 \\
(1.2)\end{array}$ & $\begin{array}{c}29.4 \\
(22.3)\end{array}$ & $\begin{array}{c}2.8 \\
(1.0)\end{array}$ & $\begin{array}{c}553.2 \\
(329.9)\end{array}$ \\
\hline MEK 1.2 & $\begin{array}{l}10.1 \\
(6.2)\end{array}$ & $\begin{array}{l}5.1 \\
(0.7)\end{array}$ & $\begin{array}{c}43.3 \\
(19.4)\end{array}$ & $\begin{array}{c}2.6 \\
(0.8)\end{array}$ & $\begin{array}{c}656.2 \\
(418.5)\end{array}$ \\
\hline MEK 2.1 & $\begin{array}{c}6.2 \\
(2.9)\end{array}$ & $\begin{array}{c}6.3 \\
(0.8)\end{array}$ & $\begin{array}{c}34.2 \\
(16.1)\end{array}$ & $\begin{array}{c}2.1 \\
(0.9)\end{array}$ & $\begin{array}{l}229.1 \\
(95.4)\end{array}$ \\
\hline \multicolumn{6}{|c|}{ Northwest Tributary } \\
\hline NTK 0.2 & $\begin{array}{c}6.4 \\
(1.9)\end{array}$ & $\begin{array}{c}5.9 \\
(0.5)\end{array}$ & $\begin{array}{c}40.0 \\
(11.7)\end{array}$ & $\begin{array}{c}2.7 \\
(0.6)\end{array}$ & $\begin{array}{l}280.5 \\
(77.2)\end{array}$ \\
\hline NTK 1.0 & $\begin{array}{c}5.4 \\
(3.8)\end{array}$ & $\begin{array}{c}6.0 \\
(0.0)\end{array}$ & $\begin{array}{c}39.7 \\
(10.0)\end{array}$ & $\begin{array}{l}3.1 \\
(1.0)\end{array}$ & $\begin{array}{c}347.6 \\
(109.5)\end{array}$ \\
\hline \multicolumn{6}{|c|}{ White Oak Creek } \\
\hline WCK 2.3 & $\begin{array}{l}13.9 \\
(7.8)\end{array}$ & $\begin{array}{c}5.6 \\
(0.5)\end{array}$ & $\begin{array}{l}46.9 \\
(8.2)\end{array}$ & $\begin{array}{c}3.4 \\
(1.0)\end{array}$ & $\begin{array}{c}355.8 \\
(101.1)\end{array}$ \\
\hline WCK 2.9 & $\begin{array}{c}17.7 \\
(11.6)\end{array}$ & $\begin{array}{c}5.6 \\
(0.5)\end{array}$ & $\begin{array}{c}45.1 \\
(11.4)\end{array}$ & $\begin{array}{c}3.2 \\
(1.1)\end{array}$ & $\begin{array}{l}331.7 \\
(76.1)\end{array}$ \\
\hline WCK 3.4 & $\begin{array}{l}16.5 \\
(7.0)\end{array}$ & $\begin{array}{c}6.2 \\
(1.0)\end{array}$ & $\begin{array}{c}44.2 \\
(11.8)\end{array}$ & $\begin{array}{c}3.4 \\
(1.1)\end{array}$ & $\begin{array}{c}346.1 \\
(130.9)\end{array}$ \\
\hline WCK 3.9 & $\begin{array}{l}13.5 \\
(3.7)\end{array}$ & $\begin{array}{c}6.0 \\
(0.0)\end{array}$ & $\begin{array}{c}41.4 \\
(10.7)\end{array}$ & $\begin{array}{l}3.5 \\
(1.1)\end{array}$ & $\begin{array}{c}312.4 \\
(173.3)\end{array}$ \\
\hline WCK 5.1 & $\begin{array}{c}9.2 \\
(3.8)\end{array}$ & $\begin{array}{c}6.4 \\
(0.5)\end{array}$ & $\begin{array}{c}43.6 \\
(12.2)\end{array}$ & $\begin{array}{c}2.7 \\
(0.9)\end{array}$ & $\begin{array}{c}299.7 \\
(103.1)\end{array}$ \\
\hline WCK 6.8 & $\begin{array}{c}7.2 \\
(2.6)\end{array}$ & $\begin{array}{c}6.1 \\
(0.3)\end{array}$ & $\begin{array}{c}39.7 \\
(10.0)\end{array}$ & $\begin{array}{l}3.0 \\
(0.9)\end{array}$ & $\begin{array}{l}194.9 \\
(77.4)\end{array}$ \\
\hline \multicolumn{6}{|c|}{ White Oak Lake } \\
\hline WCK 1.1 & $\begin{array}{c}1.0 \\
(0.0)\end{array}$ & $\begin{array}{c}2.2 \\
(0.4)\end{array}$ & $\mathrm{ND}^{d}$ & ND & $\begin{array}{l}3.53 .7 \\
(97.6)\end{array}$ \\
\hline
\end{tabular}

This value is a mean of the substrate code for the most dominant substrate type only.

'Percent dominant substrate types covered in silt and sand.

'Based on visual estimates, so values are unitless. Current velocity for each sample was estimated as fast $(=4)$, moderate $(3)$, slow (2), or very slow(1).

Not determined.

Note FCK = First Creek kilometer; FFK = Fifth Creek kilometer; MEK = Melton Branch kilometer; NTK = Northwest Tributary kilometer; WCK = White Oak Creek kilometer. 
watershed, where upi tream reference sites averaged 4.8 to $8.0 \mathrm{I}$.PT taxa/sample, and downstream sites an $/ 1$ WOL averaged 0.03 to $2.1 \mathrm{EPT}$ taxa/sample (Fig. 6.1). EPT richness values at the reference sites in First Creek, Fifth Creek, and Northwest Tributary were significantly (ANOVA, $p<0.0001)$ greater than the values at the respective downstream sites. Highly significant (ANOVA, $p<0.0001$ ) trends were also observed in EPT richness among Melton Branch sites and WOC sites. Identification of significant differences with a Tukey's test showed that EPT richness in the reference site of each stream was significantly greater than all other sitcs on that stream. Maximum reduction in richness occurred in the midreach sites of each of these latter two streams followed by some improvement at the downstream sites (Table 6.2). Additionally, EPT richness in Brushy Fork was significantly greater (ANOVA, $p<0.0001$ ) than that in WCK 2.3.

Secondary production. Estimates of secondary production of benthic macroinvertebrates in WOL, all stream sites in the WOC watershed, and Brushy Fork are presented in Table 6.3. Invertebrate production was 19.90 and $624.98 \mathrm{~g}$ wet $\mathrm{wt} \cdot \mathrm{m}^{-2}$ year $^{-1}$ in WOL and Brushy Fork, respectively, and in the stream sites of WOC watershed, production ranged from 7.08 (FFK 0.2 ) to 188.72 (NTK 0.2) g wet wt $\mathrm{m}^{-2}$ year'. Estimates of production tended to be highest at the reference sites, although Melton Branch and Northwest Tributary were exceptions. In WOC, production was lowest at WCK 5.1, then gradually increased with increasing distance from the ORNL complex.

Several general trends were evident in the distribution of production among major groups at each site (Table 6.3 and Fig. 6.2).
The proportion of total production attributable to chironomids was typically highest at the nonreference sites; this trend was most notable in WOC and lower First Creek. Production of mollusks was generally greatest at reference sites, although their contribution to production at FFK 1.0 and MEK 2.1 was minimal, where taxa within these groups generally occur in low numbers. At those reference sites where mollusks were major contributors to total production, most of the production of this group was by a single species of snail, Elimia, although in Brushy Fork this taxon as well as one additional snail, Pleurocera, and three genera of mussels (Corbicula, Sphaerium, and Villosa) contributed substantially to production. At NTK 0.2, almost all mollusk production was attributable to a single species of clam, Corbicula fluminea.

The combined contribution of Ephemeroptera (mayflies), Plecoptera (stoneflies), and Trichoptera (caddisflies) (i.e., EPT) to total community production was considerable at several sites (Table 6.3 and Fig. 6.2). Total production of these three groups was lowest at FFK 0.2 and WCK 3.9, while the highest combined production of these groups occurred at FFK 1.0, WCK 2.3, and WCK 2.9. There were no consistent trends among streams in the differences in total EPT production between the reference site and the corresponding downstream site, but a very distinct trend existed in the relative contribution of each individual group to total EPT production (Fig. 6.3). In WOC watershed Ephemeroptera and Plecoptera contributed substantially to the total EPT production at all reference sites except FFK 1.0; while, at the nonreference sites, very little or none of the production was attributable to these two groups. Furthermore, most of the Trichoptera production at the nonreference sites was 
ORNL-DWG O3M-15050

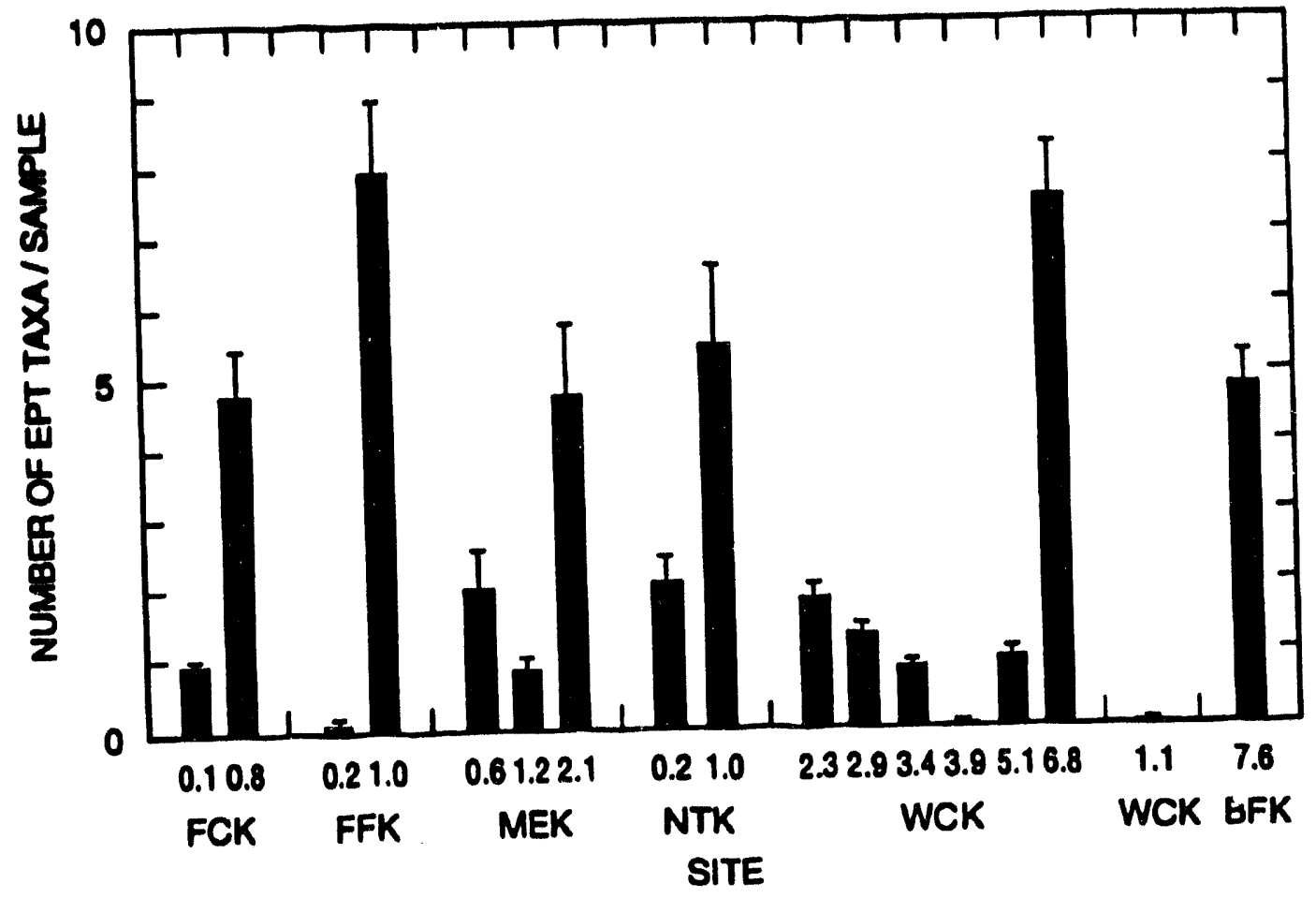

Fig. 6.1. Mean number of Ephemeroptera, Plecoptera, and Trichloptera (EPT) taxa per sample in White Oak Creek watershed and Brushy Fork, May 1986 though April 1987. FCK = First Creek kilometer; FFK = Fifth Creek kilometer; MEK = Melton Branch kilometer; NTK = Northwest Tributary kilometer; WCK = White Oak Creek kilometer; $\mathrm{BFK}=$ Brushy Fork kilometer. Vertical bars are $\pm 1 \mathrm{SE}$.

Table 6.2. Comparisons of the mean EPT tara richness (number of EPT taxa/sample) for the benthic macroinvertebrate communities in White Oak Creek and Melton Branch

Site

\begin{tabular}{|c|c|c|c|c|c|}
\hline \multicolumn{6}{|c|}{ Melton Branch } \\
\hline & MEK 2.1 & \multicolumn{2}{|c|}{ MEK 0.6} & \multicolumn{2}{|c|}{ MEK 1.2} \\
\hline \multicolumn{6}{|c|}{ White Oak Creek } \\
\hline WCK 6.8 & WCK 2.3 & WCK 2.9 & WCK 5.1 & WCK 3.4 & WCK 3.9 \\
\hline
\end{tabular}

EPT = Ephemeroptera, Plecoptera, and Trichoptera.

Note: Comparisons are based on 36 samples for White Oak Creek and 23 to 24 samples for Melton Branch. Sites not connected by the same line are significantly different $(p<0.05)$, based on Tukey's studentized range test (HSD). Sites are arranged in order of highest to lowest values from left to right. 
Table 6.3. Estimated total community, Ephemeroptere, Plecopter, and Trichoptera (EPT), and $K_{2}$ sllusca production, and mean community production to blomess (P/B) ratios ( $\pm 1 \mathrm{SE}$ ) of benthic macroinvertebrates in White Ouk Lake, streams of White Oak Creek watershed, and Brushy Fork, May 1986 through April 1987

\begin{tabular}{|c|c|c|c|c|}
\hline \multirow{2}{*}{ Site } & \multicolumn{3}{|c|}{ Production (g wet wt $\cdot \mathrm{m}^{-2} \cdot$ year $^{-1}$ ) } & \multirow{2}{*}{ P/B } \\
\hline & Total & EPT & Mollusca & \\
\hline \multicolumn{5}{|l|}{ Fint Creek } \\
\hline FCK 0.1 & 21.6 & 2.3 & 0.3 & $15.0 \pm 0.77$ \\
\hline FCK 0.8 & 87.9 & 3.8 & 67.8 & $6.3 \pm 0.21$ \\
\hline \multicolumn{5}{|l|}{ Fifth Creek } \\
\hline FFK 0.2 & 7.1 & $<0.1$ & 0.1 & $12.2 \pm 0.90$ \\
\hline FFK 1.0 & 50.1 & 19.4 & 0.3 & $9.9 \pm 0.31$ \\
\hline \multicolumn{5}{|c|}{ Metton Branch } \\
\hline MEK 0.6 & 19.2 & 7.4 & 0.5 & $16.1 \pm 0.59$ \\
\hline MEK 1.2 & 16.4 & 8.1 & $<0.1$ & $14.6 \pm 0.80$ \\
\hline MEK 2.1 & 12.9 & 3.1 & 0.1 & $10.3 \pm 0.95$ \\
\hline \multicolumn{5}{|c|}{ Nortbweat Tributary } \\
\hline NTK 0.2 & 188.7 & 9.1 & 163.5 & $11.5 \pm 0.53$ \\
\hline NTK 1.0 & 24.3 & 5.7 & $<0.1$ & $9.4 \pm 0.40$ \\
\hline \multicolumn{5}{|c|}{ White Oak Creek } \\
\hline WCK 2.3 & 51.4 & 35.8 & 0.3 & $15.1 \pm 0.83$ \\
\hline WCK 2.9 & 35.3 & 14.2 & 0.6 & $17.0 \pm 0.75$ \\
\hline WCK 3.4 & 34.9 & 6.6 & 0.2 & $22.4 \pm 0.26$ \\
\hline WCK 3.9 & 20.5 & $<0.1$ & 0.1 & $20.3 \pm 0.65$ \\
\hline WCK 5.1 & 15.8 & 2.4 & $<0.1$ & $19.4 \pm 0.64$ \\
\hline WCK 6.8 & 96.8 & 7.2 & 73.2 & $8.4 \pm 0.42$ \\
\hline \multicolumn{5}{|c|}{ White Oak Lake } \\
\hline WCK 1.1 & 19.9 & 0.4 & 0.2 & $14.2 \pm 0.35$ \\
\hline \multicolumn{5}{|c|}{ Brusby Fork } \\
\hline BFK 7.6 & 625.0 & 8.2 & 604.2 & $6.1 \pm 0.32$ \\
\hline
\end{tabular}

Note: FCK $=$ First Creek kilometer; FFK $=$ Fifth Creek kilometer; MEK $=$ Melton Branch kilometer; NTK $=$ Northwest Tributary kilometer; $\mathrm{WCK}=$ White Oak Creek kilometer; $\mathrm{BFK}=$ Brushy Fork kilometer. 


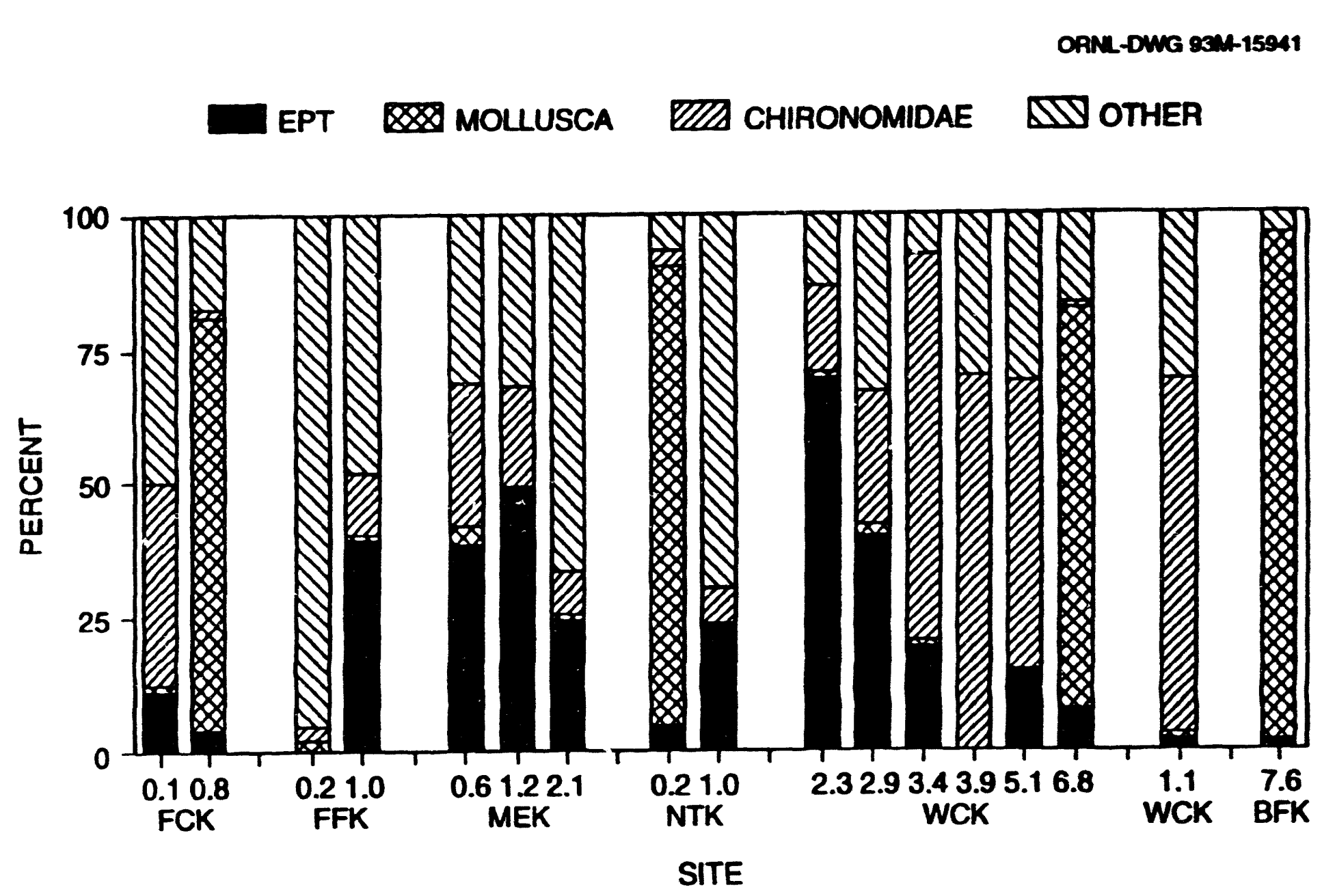

Fig. 6.2 Relative production of Ephemeroptera, Plecoptera, Trichoptera (EPT), Mollusca, Chironomidae, and all other benthic macroinvertebrate tax in White Oak Creek watershed and Brushy Fork FCK = First Creek kilometer; FFK $=$ Fifth Creek kilometer; MEK $=$ Melton Branch kilometer; NTK $=$ Northwest Tributary kilometer, WCK $=$ White Oak Creek kilometer; BFK = Brushy Fork kilometer. 


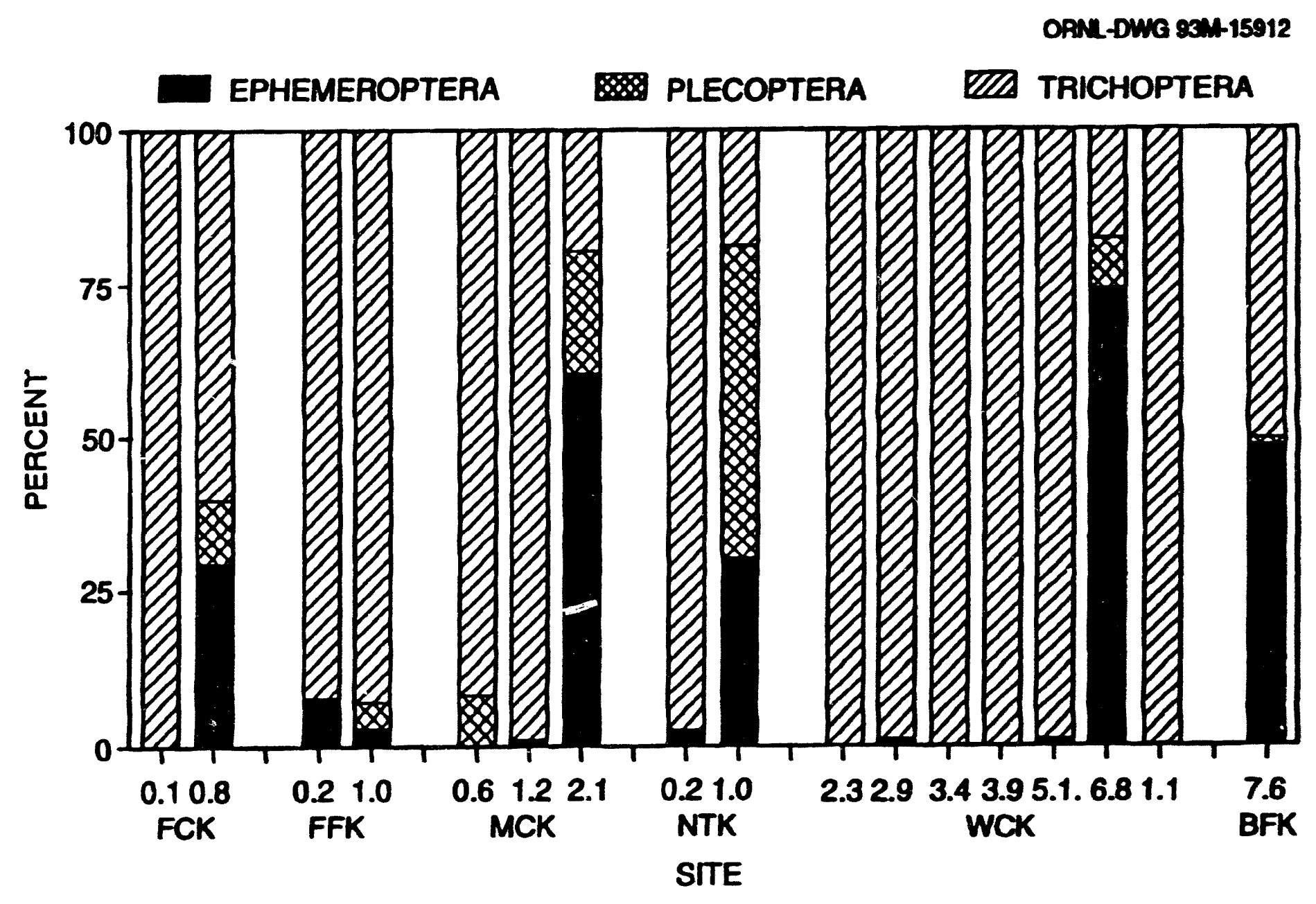

Fig. 63. Relative contribution of Ephemeroptera, Plocoptera, and Trichoptera (EPT) to total the total production of these three tam in White Oak Creek watershed and Brushy Fork FCK = First Creek kilometer, FFK = Fifth Creek kilometer; MEK = Melton Branch kilometer, NTK = Northwest Tributary kilometer, WCK $=$ White Oak Creek kilometer; BFK = Brushy Fork kilometer. 


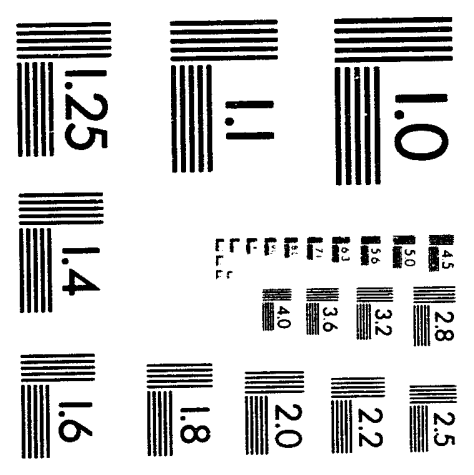



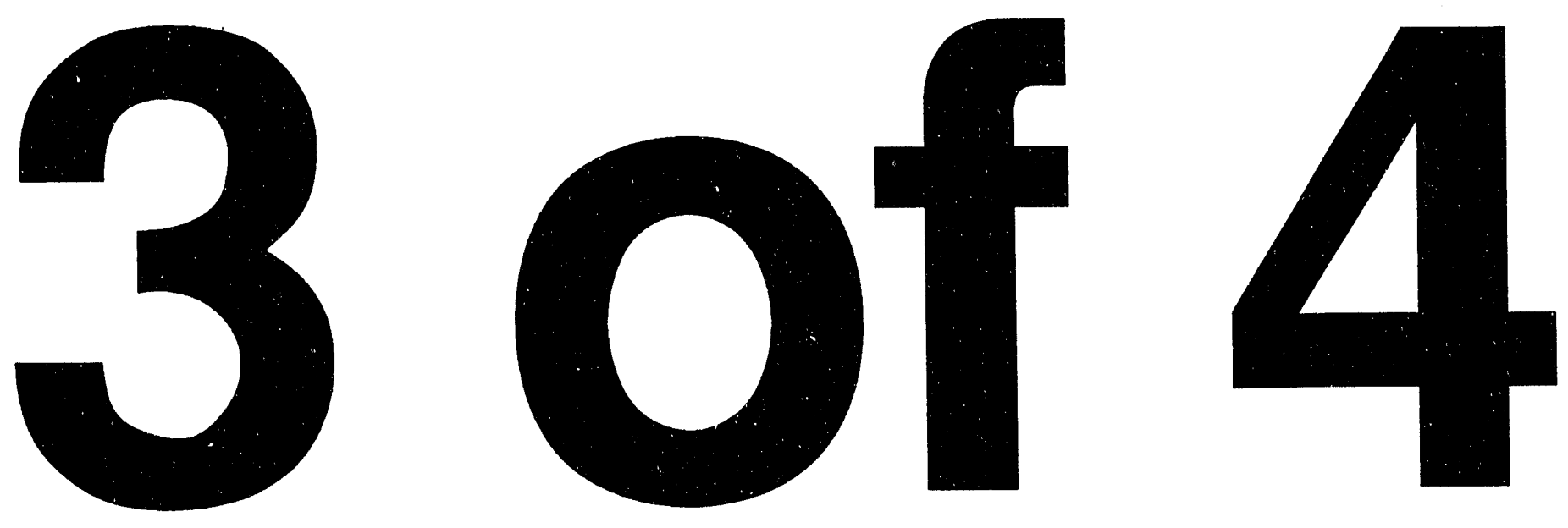
due to one or two taxa, while Trichoptera production at the reference sites, particularly at FFK 1.0, was attributable to several taxa. In Brushy Fork, very little of the EPT production was attributable to Plecoptera, while Ephemeroptera and Trichoptera each contributed almost half of the production.

Considerable differences were found among stream sites in mean annual $\mathrm{P}: \mathrm{B}$ ratios (Table 6.3). The lowest mean $\mathrm{P}: \mathrm{B}$ ratios were obtained from the reference sites, with their values being significantly less at the reference sites in First Creek (ANOVA, $p<0.0001$ ), Fifth Creek (ANOVA, $p<0.001$ ), and Northwest Tributary (ANOVA, $p<0.0001$ ). P:B ratios at BFK 7.6 were also significantly less at BFK 7.6 than at WCK 2.3 (ANOVA, $p<0.0001$ ). Highly significant (ANOVA, $p<0.0001$ ) trends were also observed in Melton Branch and WOC. Significant differences among sites were identified with a Tukey's test; this analysis showed that the $P: B$ ratios were significantly lower at the reference sites than at their respective downstream sites in both streams (Table 6.4). The highest P:B ratios in WOC occurred at WCK 3.4 and WCK 3.9 and then decreased at the two lowermost sites.

\subsubsection{Discussion}

Further analyses of the first year of benthic macroinvertebrate data for WOC watershed both confirmed and clarified the findings presented by Smith (1993) in the second annual report. Analysis of EPT richness in the WOC watershed showed conclusively that the nonreference sites of each stream are impacted relative to their upstream reference sites, including NTK 0.2 and MEK 0.6. Previous analyses of Northwest Trïutary and Melton Branch did not conclusively demonstrate that NTK 0.2 and MEK 0.6 were significantly impacted relative to their reference sites (Loar 1992b). Clear trends were also found which demonstrated that some improvement occurs in the benthic

Table 6.4. Comparisons of the mean annual production to biomass $(\mathrm{P} / \mathrm{B})$ ratios of the benthic macroinvertebrate communities in White Oak Creek and Melton Branch

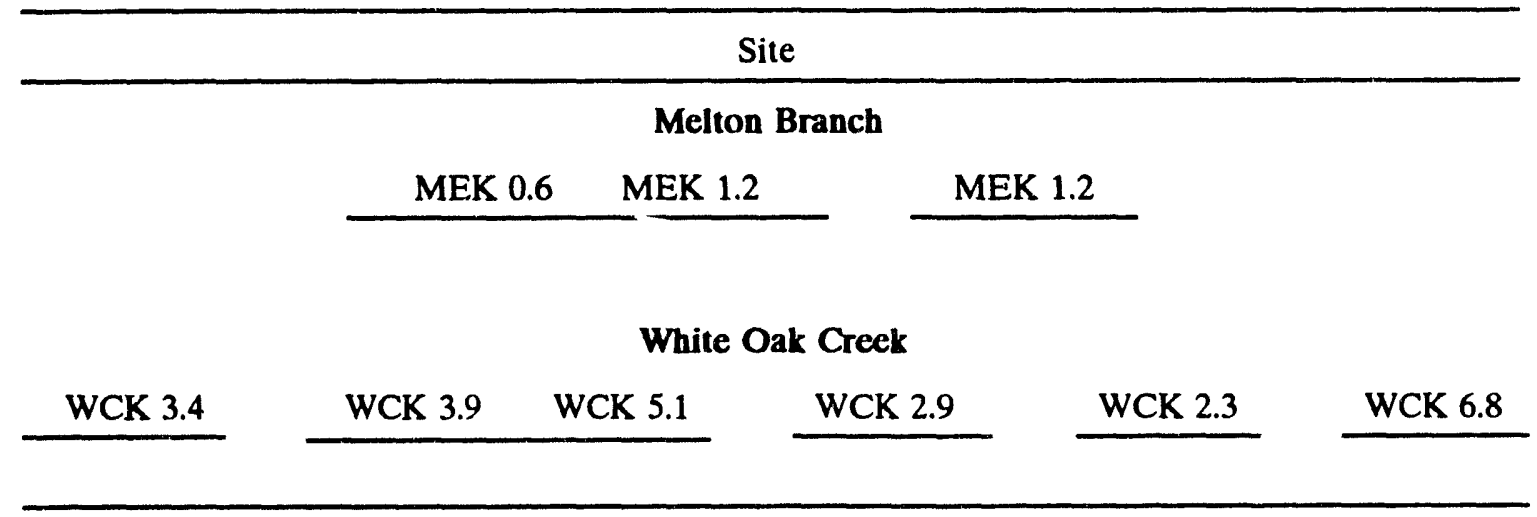

Note: Sites not connected by the same line are significantly different $(p<0.05)$, based on Tukey's Studentized range test (HSD). Sites are arranged in order of highest to lowest values from left to right. $n$ $=36$ for WOC; $n=23$ or 24 for Melton Branch. MEK = Melton Branch kilometer; WCK = White Oak Creek kilometer. 
communities of WOC and Melton Branch with increasing distance from the major source(s) of perturbation.

The accuracy of secondary production estimates for benthic invertebrate communities depends upon a number of factors, including the procedures and equipment used in collecting samples, efficiency in processing the samples, and the method(s) used for calculating production (Waters 1979, Benke 1984). Direct methods for calculating secondary production are the most accurate (Benke 1984) but require considerably more effort, which may not be feasible in studies such as a large-scale BMAP. Although methods that use $P: B$ ratios are less accurate than direct methods, they still provide a better estimate of the food potentially available to higher trophic levels than biomass alone. In addition their accuracy can be enhanced when corrected for the cohort production interval (CPI) (Waters 1979). Such estimates also provide another means of comparing the "health" of benthic communities among sites and between years.

Production of benthic invertebrates is controlled by factors such as food quality and quantity, temperature, habitat, and biological complexity (Benke 1984). The relative importance of these factors can vary among streams and among sites within a stream. Thus, not unexpectedly, considerable differences in production occurred among sites in the WOC watershed.

No consistent spatial trends in total production were observed in the WOC watershed (Fig. 6.2). High values in the reference sites were usually associated with mollusk production, although mollusks contributed little to total production at FFK 1.0 and MEK 2.1. High production at the nonreference sites was generally associated with high trichopteran (caddisfly) production, although most of the production at NTK 0.2 was attributable to a single invasive species of clam (i.e., Corbicula fluminea).

Some striking spatial trerids were found, however, in the distribution of relative production among the EPT taxa (Fig. 6.3). With the exception of FFK 1.0, each group contributed substantially to the total EPT production at the reference sites, while only Trichoptera made substantial contributions at the nonreference sites. Although Trichoptera accounted for over $80 \%$ of the EPT production at FFK 1.0, several other taxa also contributed to the production, while at the nonreference sites, most of the Trichoptera production was due to only one or two taxa. Some Trichoptera, such as the filter-feeding Hydropsychidae found at many of these sites, are tolerant of conditions associated with moderate pollution (e.g., high concentrations of organic matter) where they can be found in relatively high densities (e.g., Schuster and Etnier 1978). The combination of an enriched food supply, relatively short generation times (approximately 6 months) (J. G. Smith, ORNL/Health and Safety Research Division, unpublished data), and high biomass contributes to their high levels of production at some of the moderately impacted sites in the WOC watershed.

Currently, the only stream in the Oak Ridge area for which benthic macroinvertebrate production estimates are available is Mitchell Branch near the K-25 Site (Smith 1993b). Consequently, only a minimal database exists to assess the normal range of benthic invertebrate production in the Oak Ridge area. However, published estimates exist which provide additional information on the potential variability and magnitude of benthic invertebrate production in small, relatively undisturbed or minimally disturbed (e.g., runoff from livestock pastures) streams outside the Oak Ridge area. Estimates of secondary production 
Table 6.6. Published estimates of benthic invertebrate community production Values represent total community estimates from riffle habitat only

\begin{tabular}{|c|c|c|}
\hline Stream & $\begin{array}{c}\text { Production } \\
\left(\mathrm{g} \text { wet } \mathrm{wt} \cdot \mathrm{m}^{-2} \cdot \text { year }^{-1}\right)\end{array}$ & Reference $^{a}$ \\
\hline Bear Brook & 28.1 & Fisher and Likens 1973 \\
\hline Caribou River & 32.7 & Kruger and Waters 1983 \\
\hline Blackhoof River & 43.4 & Kruger and Waters 1983 \\
\hline Ball Creek ${ }^{b}$ & 47.3 & Huryn and Wallace 1987 \\
\hline $\begin{array}{l}\text { Hinau Stream } \\
\text { S. Branch }\end{array}$ & 50.4 & Hopkins 1976 \\
\hline Rold Kilde $^{b}$ & 62.3 & Iversen 1988 \\
\hline North Branch Creek & 132.4 & Kruger and Waters 1983 \\
\hline $\begin{array}{l}\text { Horokiwi Stream } \\
\text { Bush }\end{array}$ & 147.8 & Hopkins 1976 \\
\hline Bisballe Bæk & 150.0 & Mortensen and Simonsen 1983 \\
\hline $\begin{array}{l}\text { Hinau Stream } \\
\text { N. Branch }\end{array}$ & 195.2 & Hopkins 1976 \\
\hline $\begin{array}{l}\text { Horokiwi Stream } \\
\text { Gyton }\end{array}$ & 338.7 & Hopkins 1976 \\
\hline
\end{tabular}

(= voltinism) (Waters 1979). For example, as voltinism increases and/or the CPI decreases, the P:B ratio increases. The higher $P: B$ ratios at the nonreference sites show that they are dominated by macroinvertebrates that have shorter generation times and/or are capable of producing several generations per year. Thus, in the event of the release of a toxicant, the probability is high that less susceptible stages (i.e., eggs and/or adults) would be available to increase chances for rapid recolonization. This provides further support for the hypothesis presented in the second annual report that episodic releases of toxicants may be one of the primary factors controlling the structure and composition of the benthic invertebrate community at some sites (Smith 1993).

The "episodic release" hypothesis, however, does not preclude the possible associated impacts from other chronic anthropogenic stresses (e.g., siltation, elevated temperatures, flow augmentation, nutrient enrichment) which were discussed by Smith (1993). For example, invertebrate production at the nonreference sites in both Melton Branch and Northwest Tributary was higher than their respective reference sites. This could possibly be due 
to a combination of an altered thermal regime (e.g., nonlethal increases in temperature could decrease generation time and/or increase the growing season), flow augmentation (both reference sites were periodically dry while the downstream sites were never dry); and enrichment through either the release of nutrients, or as in the case of NTK 0.2 , the possible release of high quality planktonic food from pond discharges. Continued monitoring of the benthic invertebrate communities in combination with studies designed to address some of the most likely sources of impact (episodic toxic events, siltation, elevated temperatures) should help identify those factors most likely responsible for the altered benthic communities.

\subsubsection{Future Studies}

The sampling frequency for benthic macroinvertebrates in streams was continued in a monthly schedule during the second year but will be reduced to quarterly in succeeding years. Similarly, sampling in WOL using a Ponar dredge remained at a bimonthly frequency during the second year but will be reduced to quarterly in succeeding years. During the spring of 1987, the bimonthly collection of invertebrates with artificial substrates (Hester Dendy Multiplate Samplers) was initiated to supplement the data obtained from Ponar samples. Collection of invertebrate samples with artificial substrate will continue through March 1989 and will then be terminated. Artificial substrate samples will be processed only if a strong need for the data arises in the future. Qualitative samples will continue to be collected from all sites each spring.

Characterization of physical habitat at each sampling site will also continue in order to provide information on temporal trends. In situ and laboratory studies will be pursued to try to identify the factors impacting the benthic invertebrates. Finally, additional parameters (e.g., similarity indices), will be considered in the analysis of data in future reports and less sensitive parameters indices will be replaced by more sensitive parameters (e.g., EPT richness).

\subsection{FISHES \\ M. G. Ryon}

\subsubsection{Introduction}

Fish population and community studies can be used to assess the ecological effects of water quality and habitat degradation. These studies offer several advantages over other indicators of environmental quality (see Karr et al. 1986, Karr 1987) and are especially relevant to assessment of the biotic integrity of WOC. For example, fish communities include several trophic levels, and species that comprise the potential sport fishery in WOC [e.g., bluegill (Lepomis macrochirus), redbreast sunfish (L. auritus), and largemouth bass (Micropterus salmoides)] are at or near the end of food chains. Consequently, they potentially integrate the direct effects of water quality and habitat changes on primary producers (periphyton) and consumers (benthic invertebrates) that are utilized for food. Because of these trophic interrelationships, the well-being of fish populations has often been used as an index of water quality (e.g., Weber 1973, Greeson et al. 1977, Karr et al. 1986). Moreover, statements about the condition of the fish community are better understood by the general public (Karr 1981).

The initial objectives of the instream fish monitoring task (Subtask $4 \mathrm{~b}$ of the BMAP, as described in Loar et al. 1991) were (1) to characterize spatial and temporal patterns in the distribution and 
abundance of fishes in WOC and (2) to document any effects on fish community structure and function resulting from implementation of the ORNL Water Pollution Control Program and Remedial Action Program.

\subsubsection{Methods}

Quantitative sampling of the fish populations at 16 sites in WOC watershed (Fig. 2.2) was conducted by electrofishing in March-April and December 1988. The resulting data were used to (1) determine species richness, (2) estimate population size (numbers and biomass pe: unit area), (3) determine age structure and growth rates, and (4) calculate IBI values. The length of the sampling reaches ranged from 25 to $77 \mathrm{~m}$ at the tributary sites and from 47 to $202 \mathrm{~m}$ at the WOC sites (Table 6.7). Fish sampling sites either overlapped or were within $100 \mathrm{~m}$ of the sites included in the instream benthic invertebrate monitoring task (Sect. 6.1), except for FFK 0.4 (where benthos were not sampled) and MEK 1.4 (benthos were sampled at MEK 1.2). Lengths of the sampling reaches were similar (greatest difference was 20\%) to those used in 1985-1987 (Loar et al. 1992a, Loar 1992b).

Table 6.7. Length, mean width, mean depth, and surface area of fish sampling sites in White Oak Creek, First Creek, Fifth Creek, Melton Branch, and Northwest Tributary, March-April and December 1988

\begin{tabular}{|c|c|c|c|c|c|c|c|c|}
\hline \multirow{2}{*}{ Site $^{a}$} & \multicolumn{2}{|c|}{$\begin{array}{l}\text { Length } \\
\text { (m) }\end{array}$} & \multicolumn{2}{|c|}{$\begin{array}{l}\text { Mean width } \\
\text { (m) }\end{array}$} & \multicolumn{2}{|c|}{$\begin{array}{l}\text { Area } \\
\left(\mathrm{m}^{2}\right)\end{array}$} & \multicolumn{2}{|c|}{$\begin{array}{l}\text { Mean depth } \\
\quad(\mathrm{cm})\end{array}$} \\
\hline & Spring & Fall & Spring & Fall & Spring & Fall & Spring & Fall \\
\hline FCK 0.1 & 61 & 63 & 1.3 & 1.2 & 79 & 76 & 10.5 & 8.7 \\
\hline FCK 0.8 & 25 & 38 & 1.8 & 1.2 & 45 & 46 & 11.1 & 7.0 \\
\hline FFK 0.2 & 75 & 70 & 1.0 & 1.1 & 75 & 77 & 11.7 & 10.4 \\
\hline FFK 0.4 & 26 & 27 & 1.9 & 1.5 & 49 & 41 & 14.1 & 13.2 \\
\hline FFK 1.0 & 29 & 25 & 1.3 & 0.8 & 38 & 20 & 7.0 & 10.0 \\
\hline MEK 0.6 & 51 & 50 & 3.0 & 2.9 & 153 & 145 & 18.3 & 15.8 \\
\hline MEK 1.4 & 52 & 51 & 2.2 & 2.0 & 114 & 102 & 8.1 & 8.1 \\
\hline MEK 2.1 & 45 & 48 & 1.4 & 1.7 & 63 & 82 & 4.9 & 4.5 \\
\hline NTK 0.3 & 65 & 67 & 2.7 & 2.7 & 176 & 181 & 7.3 & 6.0 \\
\hline NTK 1.0 & 40 & 39 & 2.2 & 1.8 & 88 & 70 & 6.3 & 7.5 \\
\hline WCK 2.3 & 84 & 88 & 5.5 & 5.7 & 462 & 502 & 30.6 & 29.6 \\
\hline WCK 2.9 & 83 & 87 & 5.0 & 5.1 & 415 & 444 & 37.0 & 38.0 \\
\hline WCK 3.4 & 60 & 61 & 2.7 & 3.1 & 162 & 189 & 31.8 & 27.4 \\
\hline WCK 3.9 & 145 & 148 & 3.1 & 2.8 & 450 & 414 & 16.1 & 19.2 \\
\hline WCK 5.1 & 47 & 48 & 1.4 & 1.6 & 66 & 77 & 9.5 & 8.9 \\
\hline WCK 6.8 & 55 & 57 & 2.3 & 2.4 & 126 & 137 & 7.7 & 6.2 \\
\hline
\end{tabular}




\subsubsection{Field sampling procedures}

All stream sampling was conducted using one or two Smith-Root Model 15A backpack electrofishers, depending on strea.n size. Each unit has a self-contained, gasoline-powered generator capable of delivering up to $1200 \mathrm{~V}$ of pulsed direct current. A pulse frequency of 90 to $120 \mathrm{~Hz}$ was used, and the output voltage was adjusted to the optimal value (generally $300-500 \mathrm{~V}$ ) based on the specific conductance of the water. The circular (ring) electrode at the end of the fiberglass anode pole was fitted with a nylon net (0.64-cm mesh) to allow the electrofisher operator to collect stunned fish.

After a 0.64-cm-mesh seine was placed across the upper and lower boundaries of the fish sampling site to restrict fish movement, a two- to five-person sampling team electrofished the site in an upstream direction on three consecutive passes. If fish numbers captured during the first pass were extremely low or zero, then only one pass was made. Depending upon the turbidity of the water, the consecutive passes could not always be made immediately. Rather, fish were processed after each pass to allow sufficient time for the water to clear before another pass was initiated. Stunned fish were collected and stored, by pass, in wire mesh cages $(0.64-\mathrm{cm}$ diam) or in buckets with small holes during further sampling.

Following electrofishing, fish were anesthetized with MS-222 (tricaine methanesulfonate), identified, measured to the nearest $0.1 \mathrm{~cm}$ (total length), and weighed on Pesola spring scales to the nearest $0.1 \mathrm{~g}$ (for fish $<100 \mathrm{~g}$ ) or gram (for fish > than $100 \mathrm{~g}$ ). At sites with high fish densities, individuals were recorded by $1-\mathrm{cm}$ size classes and species. After 25 individuals of a species-size class were measured and weighed, additional members of that size class were only measured. Later, length-weight regressions (SAS 1985b) were determined from Railsback et al. (1989) to estimate weights of unweighed fish. Other data recorded (if possible to determine) included sex, reproductive state, disposition (i.e., dead or kept for laboratory identification and reference collection), whether scales were taken for age and growth studies, and presence of any abnormalities (e.g., external parasites, skeletal deformities).

After processing fish from all passes, the fish were allowed to fully recover from the anesthesia and were returned to the stream. Any additional mortality that occurred as a result of processing was noted at that time. In addition to data on individual fish, selected physical and chemical parameters were measured, and sampling effort was recorded. A Horiba Model U-7 battery-powered field sampler was used to measure conductivity, $\mathrm{pH}$, water temperature, and dissolved oxygen content. An HF Instruments Model DRT15 turbidimeter was used to measure turbidity. The duration of the electrofishing effort was recorded and a visual estimate was made of percentage of cloud cover. Following completion of fish sampling, the length, width, and depth of the sampling reach were measured at each site.

\subsubsection{Data analysis}

\section{Population size}

Species population estimates were obtained using the three-pass removal method of Carle and Strub (1978). Biomass was estimated by multiplying the population estimate by the mean weight per individual. To calculate density and biomass per unit area, total numbers and biomass were divided by the surface area (in square meters) of the study reach. For each sampling date, surface area was estimated by multiplying the length of the sampling reach by t!.e mean width based 
on measurements taken at 5-m intervals (Table 6.7). These data were compiled and analyzed by a comprehensive Fortran 77 program developed by Railsback et al. (1989).

\section{Growth and condition factor}

Scale samples were taken from redbreast and bluegill sunfish at WCK 2.3, WCK 2.9 and WCK 3.4 in December 1988 for analysis of age and growth parameters. In 1986 and 1987, similar samples were used to age fish and calculate population growth rates. Also in 1987, an instantaneous rate of increase, or true growth, was calculated. Because the period between sample collection and report preparation was too short to complete the analysis of all the scales, the assessment of age and growth will be included in 1988 in the fourth annual report (Loar et al. unpublished data).

Condition factors $(\mathrm{K})$ were

calculated for individual fish by site and species using the formula:

$$
K=100\left(\text { weight//ength }{ }^{3}\right),
$$

with weight in grams and total length in centimeters (Hile 1936). Fish without measured weights were not used in calculations of condition factors. Comparisons of condition factors between sites and between sampling periods were made using an ANOVA procedure (PROC GLM) on untransformed data (SAS 1985b) because the condition factors exhibited homogeneity of variance as estimated with the UNIVARIATE procedure (SAS 1985a). If the GLM procedure indicated significant differences in condition factors between groups, the Tukey test was performed to identify those groups that were significantly different $(p<0.05)$.

\section{Index of biotic integrity}

The fish population data at each site were analyzed using the Index of Biotic Integrity (IBI), a fish community assessment technique which includes measures of species richness and composition, trophic composition, and fish abundance and condition (Karr 1981; Karr et al. 1986). As suggested by Karr and others (Karr et al. 1986; Ohio EPA 1988), modifications were made to the basic IBI metrics to reflect differences between midwestern streams, on which the IBI was originally based, and streams in the Clinch River drainage in the Oak Ridge area, which includes WOC. In addition to this modified IBI, another IBI developed by the Ohio EPA $(1987,1988)$ for use in headwater streams (drainage area less than $52 \mathrm{~km}^{2}$ ) was applied to the WOC data. A detailed discussion of the IBI and the various modifications that were made to it are given in Appendix D.

\subsubsection{Results and Discussion}

\subsubsection{Species richness and composition}

A total of 15 species were collected in quantitative surveys of WOC in 1988 (Table 6.8). At the lowermost site on WOC (WCK 2.3), 12 species were found, of which 5 were centrarchids and 4 were cyprinids. Intermediate sites on WOC (WCK 2.9 to WCK 5.1) had two to seven species, while the uppermost reference site (WCK 6.8) had three species. The number of species in the tributaries of WOC ranged from two to six. No fish were collected in lower Fifth Creek (FFK 0.2) or upper Melton Branch (MEK 2.1).

The patterns observed in species richness during 1988 were very similar to those found in 1985-1987 (Loar et al. 1992a, 1992b). Generally, species richness 
Table 6.8. Fish species composition in White Oak Creek, First Creek, Fifth Creek, Melton Branch,

and Northwest Tributary, March-April and December 1988

\begin{tabular}{|c|c|c|c|c|c|c|c|c|c|c|c|c|c|c|c|c|}
\hline Species & $\begin{array}{c}\text { FCK } \\
0.1\end{array}$ & $\begin{array}{c}\text { FCK } \\
0.8\end{array}$ & $\begin{array}{c}\text { FFK } \\
0.2\end{array}$ & $\begin{array}{c}\text { FFK } \\
0.4\end{array}$ & $\begin{array}{c}\text { FFK } \\
1.0\end{array}$ & $\begin{array}{c}\text { MEK } \\
0.6\end{array}$ & $\begin{array}{c}\text { MEK } \\
1.4\end{array}$ & $\begin{array}{c}\text { MEK } \\
2.1\end{array}$ & $\begin{array}{c}\text { NTK } \\
0.3\end{array}$ & $\begin{array}{c}\text { NTK } \\
1.0\end{array}$ & $\begin{array}{l}\text { WCK } \\
2.3\end{array}$ & $\begin{array}{c}\text { WCK } \\
2.9\end{array}$ & $\begin{array}{c}\text { WCK } \\
3.4\end{array}$ & $\begin{array}{c}\text { WCK } \\
3.9\end{array}$ & $\begin{array}{c}\text { WCK } \\
5.1\end{array}$ & $\begin{array}{c}\text { wCK } \\
6.8\end{array}$ \\
\hline \multicolumn{17}{|l|}{ Centrarchidac } \\
\hline $\begin{array}{l}\text { Bluegill } \\
\text { (Lepomis macrochinus) }\end{array}$ & 2 & - & $\mathbf{N F}$ & - & - & - & - & $\mathrm{NF}$ & 1 & - & 2 & - & 2 & - & - & - \\
\hline $\begin{array}{l}\text { Redbreast sunfish } \\
\text { ( } L \text { aurious) }\end{array}$ & - & - & $\cdot-$ & - & - & 2 & - & - & - & - & 2 & 2 & 2 & - & - & - \\
\hline $\begin{array}{l}\text { Largemouth Bass } \\
\text { (Micropterus salmoides) }\end{array}$ & - & 1 & - & - & - & - & - & - & - & - & 2 & 1 & 1 & - & - & - \\
\hline $\begin{array}{l}\text { Warmouth } \\
\text { ( } L \text { gulosus) }\end{array}$ & - & - & - & - & - & - & - & - & - & - & 2 & - & - & - & - & - \\
\hline $\begin{array}{l}\text { Rock bass } \\
\text { (Ambloplities nupestris) }\end{array}$ & - & - & - & - & - & - & - & - & - & - & 1 & - & - & - & - & - \\
\hline \multicolumn{17}{|l|}{ Cupeidae } \\
\hline $\begin{array}{l}\text { Gizzard shad } \\
\text { (Dorosoma cepedianum) }\end{array}$ & - & - & - & - & - & - & - & - & - & - & 1 & - & - & - & - & - \\
\hline \multicolumn{17}{|l|}{ Cotlidae } \\
\hline $\begin{array}{l}\text { Banded sculpin } \\
\text { (Cotrus carolinae) }\end{array}$ & - & - & - & 2 & 2 & - & - & - & - & - & - & - & - & - & - & 2 \\
\hline \multicolumn{17}{|l|}{ Cyprinidare } \\
\hline $\begin{array}{l}\text { Carp } \\
\text { (Cyprinus carpio) }\end{array}$ & - & - & - & - & - & - & - & - & - & - & 1 & - & - & - & - & - \\
\hline $\begin{array}{l}\text { Blacknose dace } \\
\text { (Rhinichthys atratulus) }\end{array}$ & 2 & 2 & - & 2 & 2 & 2 & 2 & - & 2 & 2 & 1 & 1 & 2 & - & 2 & 2 \\
\hline
\end{tabular}


Table 68 (continued)

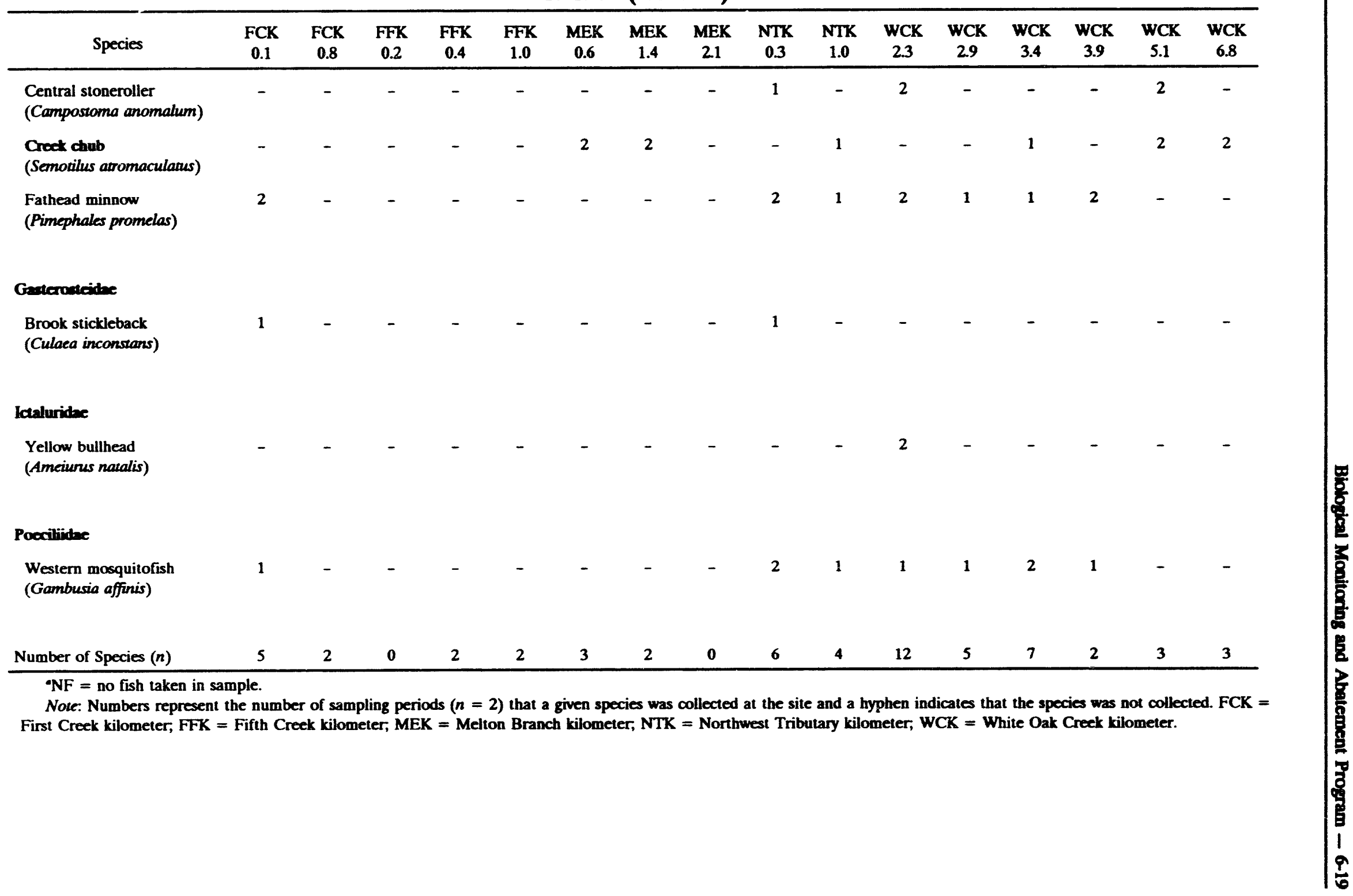


increased with stream size but abrupt changes in the number of species were evident as a result of isolating barriers. These structures (e.g., weirs) act as barriers to upstream movement and tend to isolate the fish populations at some sites. The WOC watershed remained depauperate in comparison with other area watersheds (Ryon and Loar 1988). The higher richness at WCK 2.3 was a result of its proximity to WOL and the transient movement of WOL species into lower WOC to spawn or forage. No new species were found in the WOC watershed in 1988.

Distribution patterns of individual species in 1988 again showed little change from earlier years. The blacknose dace (Rhinichthys atratulus) was collected from 13 of the 16 sites, followed by the fathead minnow (Pimephales promelas) and western mosquitofish (Gambusia affinis) at 7 sites and the creek chub (Semotilus atromaculatus) at 6 sites. In 1988, the creek chub was found at only $50 \%$ of the 1987 sites; it was not collected at 2 mainstem WOC sites (WCK 3.9 and WCK 2.9) or in First Creek. Bluegill were also absent at these two WOC sites in 1988. Although absent from WCK 2.3 in 1988, the brook stickleback (Culaea inconstans) showed a possible expansion of its range to lower First Creek and lower Northwest Tributary. Both sites are near the established population in the ESD ponds south of the 1500 area (Figs. 2.2 and 2.4).

\subsubsection{Density and biomass}

Population surveys of WOC were conducted twice in 1988 (spring and late fall), and the data were used to determine species biomass and density for each period. The total biomass and density at each site for each sampling period are presented in Table 6.9. Values for individual species are given in Appendix E, Tables E.1 through E.4.

During 1985-86, fish densities

decreased downstream, while biomass increased with increasing stream size. In 1987, the downstream (nonreference) sites often had higher densities, particularly in the tributaries; and, again, fish biomass generally increased downstream. The trend (within tributaries) of higher densities and biomass at the lower vs upper sites continued in 1988. In mainstem WOC, however, abundance fluctuated, with densities generally higher at upstream sites and biomass increasing downstream. Unlike the pattern in 1987, biomass and densities were higher in the fall compared with levels in the spring.

Fish density and biomass in lower Melton Branch (MEK 0.6) increased substantially in 1987 in response to shutdown of the HFIR in November 1986 and the subsequent improvement in the adverse stream conditions, such as high temperatures, which existed in 1985-1986 (Loar et al. 1992a, Loar 1992b). This high abundance was sustained in 1988 as the HFIR remained shut down. Although densities declined to about half the December 1987 level, biomass in the 2 years remained comparable. These data suggest that the fish community in lower Melton Branch had reached an equilibrium density that was still substantially higher than that observed when HFIR was operational. Further evidence of the ecological recovery in Melton Branch was the increasing fish abundance at MEK 1.4 just below the confluence with the small tributary that received discharges from the HFIR. Densities in April and December 1988 were three and ten times higher, respectively, than the December 1987 density. Mean annual biomass (based on estimates in spring and fall of each year) increased from $0.07 \mathrm{~g} / \mathrm{m}^{2}$ in 1987 to $2.35 \mathrm{~g} / \mathrm{m}^{2}$ in 1988 . Stream flow at MEK 1.4 
Table 6.9. Total fish density (individuals per square meter), total biomass (in grams per square meter), and species richness for March-April and December 1988 in White Oak Creek, First Croek, Fifth Creek, Melton Branch, and Northwest Tributary $\mathrm{NF}=$ No fish collected in sample

\begin{tabular}{|c|c|c|c|c|c|c|c|c|c|c|c|c|c|c|c|c|}
\hline $\begin{array}{l}\text { Parameters per } \\
\text { sampling periods }\end{array}$ & $\begin{array}{c}\text { FCK } \\
0.1\end{array}$ & $\begin{array}{c}\text { FCK } \\
0.8\end{array}$ & $\begin{array}{c}\text { FFK } \\
0.2\end{array}$ & $\begin{array}{c}\text { FFK } \\
0.4\end{array}$ & $\begin{array}{c}\text { FFK } \\
1.0\end{array}$ & $\begin{array}{c}\text { MEK } \\
0.6\end{array}$ & $\begin{array}{c}\text { MEK } \\
1.4\end{array}$ & $\begin{array}{c}\text { MEK } \\
2.1\end{array}$ & $\begin{array}{c}\text { NTK } \\
0.3\end{array}$ & $\begin{array}{c}\text { NTK } \\
1.0\end{array}$ & $\begin{array}{c}\text { WCK } \\
2.3\end{array}$ & $\begin{array}{c}\text { WCK } \\
2.9\end{array}$ & $\begin{array}{c}\text { WCK } \\
3.4\end{array}$ & $\begin{array}{c}\text { WCK } \\
3.9\end{array}$ & $\begin{array}{c}\text { WCK } \\
5.1\end{array}$ & $\begin{array}{c}\text { WCK } \\
6.8\end{array}$ \\
\hline \multicolumn{17}{|l|}{ March-April } \\
\hline Total density & 0.89 & 0.84 & NF & 6.25 & 2.21 & 1.87 & 0.55 & NF & 0.14 & 0.12 & 0.65 & 0.31 & 0.90 & $<0.01$ & 0.53 & 0.80 \\
\hline Total biomass & 4.31 & 4.10 & NF & 18.80 & 9.68 & 4.09 & 2.32 & NF & 0.38 & 0.21 & 13.83 & 7.16 & 21.96 & $<0.01$ & 7.21 & 1.05 \\
\hline Species richness & 4 & 2 & NF & 2 & 2 & 3 & 2 & NF & 5 & 3 & 9 & 3 & 7 & 1 & 3 & 3 \\
\hline \multicolumn{17}{|l|}{ December } \\
\hline Total density & 3.72 & 2.39 & NF & 16.17 & 3.95 & 1.64 & 1.94 & NF & 1.12 & 0.13 & 0.61 & 0.25 & 0.68 & 0.12 & 8.47 & 2.04 \\
\hline Total biomass & 2.97 & 2.57 & NF & 18.62 & 10.59 & 4.13 & 2.35 & $\mathrm{NF}$ & 0.80 & 0.26 & 7.92 & 4.82 & 3.49 & $<0.06$ & 10.61 & 2.21 \\
\hline Species richness & 4 & 1 & NF & 2 & 2 & 3 & 2 & NF & 4 & 2 & 10 & 3 & 4 & 2 & 3 & 3 \\
\hline
\end{tabular}

Note: FCK = First Creek kilometer, FFK = Fifth Creek kilometer, MEK = Melton Branch kilometer; NTK = Northwest Tributary kilometer, WCK = White Oak Creek kilometer. 
was augmented by unheated discharges from HFIR-TRU ponds in 1987 and 1988. The recovering fish community at MEK 1.4 contrasts with the upper site (MEK 2.1) which did not support a fish community due to the prolonged drought in $\mathbf{1 9 8 8}$ (Table 2.1).

The effects of the drought were also evident at NTK 1.0, where density and biomass were only half the 1987 levels. Other sites located below springs, such as WCK 6.8 and FFK 1.0, have more stable flow regimes and did not exhibit lower fish abundance due to the drought.

Fish populations at WCK 5.1 entered 1988 having suffered a major decline in abundance in December 1987 (Loar 1992b). Although this trend in low abundance continued in April 1988, the community had rebounded dramatically by December 1988 with a 15-fold increase in density and a 2 -fold increase in biomass. Apparently the unknown impact that occurred in the summer of 1987 produced no permanent change in total community density or biomass, although richness was still lower by two species (fathead minnow and banded sculpin, Cottus carolinae) in 1988.

Total fish densities were highest at FFK 0.4 and WCK 5.1 (16.17 and 8.47 individuals $/ \mathrm{m}^{2}$, respectively) and similar to the densities observed at these sites in 1986 and 1987 (Loar et al. 1992a; Loar 1992b). As was the case in 1986 and 1987. density was lowest at WCK 3.9 ( $<0.01$ and 0.12 individuals $/ \mathrm{m}^{2}$ in April and December respectively). In 1988, maximum biomass values of 21.96 and $18.80 \mathrm{~g} / \mathrm{m}^{2}$ were observed at WCK 3.4 and FFK 0.4, respectively, and were very similar to the 1987 values for these sites. The lowest biomass values in 1988 occurred at WCK 3.9 $\left(<0.01 \mathrm{~g} / \mathrm{m}^{2}\right)$, as was observed in 1986 and 1987.

Contributions of individual species to total community density and biomass were similar to $1985-1987$ patterns. The blacknose dace was the dominant species in terms of density and biomass in 13 and 10 , respectively, of 25 possible sampling date-site combinations. Other dominant species included redbreast sunfish (dominant at three sites based on density and five sites based on biomass), and creek chub (two sites based on density and four sites based on biomass).

In summary, the most significant improvements in fish abundance occurred in WOC at WCK 5.1 and in Melton Branch. Site WCK 5.1 was an area of extremely high fish density and biomass in 1985-1986. After a precipitous decline in fall 1987, the fish community recovered to near previous levels in late 1988. It is uncertain whether the drought or some other stress (perhaps an undetected spill) caused the decline in 1987. For example, the mean annual discharge of streams with no flow augmentation, such as WCK 5.1 which receives only minimal discharges from the 7000 area, was actually 15 to $30 \%$ lower in 1988 as compared with 1987 (Sect. 2.1). However, the drought extended well into the fall in 1987 (Table 2.1), and this low-flow period coincided with the fish population surveys.

Similarly, MEK 0.6 had below-average biomass and density from 1985 to early 1987 , but a dramatic increase in both parameters occurred in late 1987 . Sampling in 1988 indicated that the recovery was still continuing at that site. Also, MEK 1.4 showed a substantial increase in density and biomass in 1988 as compared with the previous year. The shutdown of HFIR in November 1986 resulted in successful reproduction and recovery of the three species that inhabit Melton Branch. In 1985-1986, biomass and density at WCK 2.9 were below the values at sites just upstream and downstream (WCK 3.4 and WCK 2.3, respectively). During 1987 , values at WCK 2.9 were higher than or similar to those of adjacent sites. In 1988, the fish populations at WCK 2.9 again 
were below those of adjacent sites. Sites shown to be significantly impacted by plant operations in the 1985-1987 surveys (FFK 0.2 and WCK 3.9) continued to have very low densities or no fish in 1988 and showed no evidence of recovery.

\subsubsection{Condition factors}

Condition of fish in WOC watershed was evaluated by calculating condition factors $(K)$ for all species and by making statistical comparisons to evaluate differences between sites and between sampling periods. Comparisons between sampling periods showed that the condition factors for the March-April sampling period were significantly greater than the December period. Of 22 comparisons where a significant difference was indicated, 21 had higher condition factors in the spring. This trend was also observed in 1985-1987 (Loar et al. 1992a; Loar 1992b) and indicated the expected preparation for spawning. Several situations existed that deviated from the expected spring increase in condition factor prior to spawning. In 5 of 14 comparisons where no significant difference between spring and fall condition factors was observed, the species involved (fathead minnow and western mosquitofish) were known to spawn over an extended period (well into late fall). Another three of the comparisons involved immature specimens at nursery sites. An interesting pattern occurred for adults of some species (e.g, sculpin and blacknose dace) at headwater sites, including NTK 1.0, FFK 1.0, and WCK 6.8. In five of these cases, a significant difference in condition was not evident between spring and fall, perhaps due to their spawning in late winter. Comparisons of condition factors between sites within a sampling period generally showed no pattern of significant differences (Appendix E, Table E.5). Sites that had been identified as being impacted based on fish biomass, density, or species richness (WCK 3.9 and WCK 2.9) did not have significantly lower condition factors than upstream reference sites for any species.

\subsubsection{Index of Biotic Integrity}

The modified IBI developed for the Clinch River area (Table D.3) was applied to both spring and fall population data for 1988. The results indicated that the entire WOC system had been severely impacted by ORNL operations; values ranged from 12 to 36 during both sampling periods (Table 6.10). Using the guidelines given by Karr et al. (1986), all sites ranked as either poor or very poor.

The major deficiency identified by the IBI was the reduced species richness and composition component. Only two sites, WCK 2.3 and WCK 3.4, had anything higher than the lowest possible rating for the first five metrics. No darter or sucker species and few pollution-intolerant species were found in WOC, and only WCK 2.3 had a total number of species that exceeded the minimum value. In trophic composition, the lack of cyprinids and percids again resulted in low values for the insectivore metric. A few additional sites had above-minimum ratings for the piscivore component. The reduced fauna did result in some higher ratings because few tolerant species or omnivores were present. As discussed in Loar et al. (1992a), the lower species richness was a result of barriers to fish movement within the WOC watershed. Although the barriers (White Oak Dam and WOC weirs) that separated the WOC watershed from the remainder of the Clinch River system 
Table 6.10. Index of Biotic Integrity (IBI) values based on sampling conducted during March-April and December 1988 in White Oak Creek, First Creek, Fifth Creek, Melton Branch, and Northwest Tributary

\begin{tabular}{|c|c|c|c|c|c|c|c|c|c|c|c|c|c|c|c|c|}
\hline Sampling periods & $\begin{array}{c}\text { FCK } \\
0.1\end{array}$ & $\begin{array}{c}\text { FCK } \\
0.8\end{array}$ & $\begin{array}{c}\text { FFK } \\
0.2\end{array}$ & $\begin{array}{c}\text { FFK } \\
0.4\end{array}$ & $\begin{array}{c}\text { FFK } \\
1.0\end{array}$ & $\begin{array}{c}\text { MEK } \\
0.6\end{array}$ & $\begin{array}{c}\text { MEK } \\
1.4\end{array}$ & $\begin{array}{c}\text { MEK } \\
2.1\end{array}$ & $\begin{array}{c}\text { NTK } \\
0.3\end{array}$ & $\begin{array}{c}\text { NTK } \\
1.0\end{array}$ & $\begin{array}{c}\text { WCK } \\
2.3\end{array}$ & $\begin{array}{c}\text { WCK } \\
2.9\end{array}$ & $\begin{array}{c}\text { WCK } \\
3.4\end{array}$ & $\begin{array}{c}\text { WCK } \\
3.9\end{array}$ & $\begin{array}{c}\text { WCK } \\
5.1\end{array}$ & $\begin{array}{c}\text { WCK } \\
6.8\end{array}$ \\
\hline \multicolumn{17}{|l|}{ March-April } \\
\hline CR IBI value & $\begin{array}{c}34 \\
P\end{array}$ & $\begin{array}{c}32 \\
P\end{array}$ & $\mathrm{NF}^{*}$ & $\begin{array}{c}36 \\
P\end{array}$ & $\begin{array}{c}32 \\
P\end{array}$ & $\begin{array}{c}26 \\
P\end{array}$ & $\begin{array}{c}24 \\
\text { VP }\end{array}$ & NF & $\begin{array}{c}26 \\
P\end{array}$ & $\begin{array}{l}20 \\
\text { VP }\end{array}$ & $\begin{array}{l}24 \\
\text { VP }\end{array}$ & $\begin{array}{l}24 \\
\text { VP }\end{array}$ & $\begin{array}{l}24 \\
\text { VP }\end{array}$ & $\begin{array}{l}12 \\
\text { VP }\end{array}$ & $\begin{array}{l}22 \\
\text { VP }\end{array}$ & $\begin{array}{l}30 \\
\mathbf{P}\end{array}$ \\
\hline HW IBI value & $\begin{array}{c}34 \\
P\end{array}$ & $\begin{array}{c}28 \\
P\end{array}$ & & $\begin{array}{c}40 \\
F\end{array}$ & $\begin{array}{c}42 \\
F\end{array}$ & $\begin{array}{c}29 \\
P\end{array}$ & $\begin{array}{l}22 \\
\text { VP }\end{array}$ & & $\begin{array}{c}36 \\
P\end{array}$ & $\begin{array}{c}24 \\
\text { VP }\end{array}$ & $\begin{array}{c}32 \\
P\end{array}$ & $\begin{array}{l}26 \\
\text { VP }\end{array}$ & $\begin{array}{c}30 \\
\mathbf{P}\end{array}$ & $\begin{array}{l}12 \\
\text { VP }\end{array}$ & $\begin{array}{c}28 \\
P\end{array}$ & $\begin{array}{c}40 \\
F\end{array}$ \\
\hline \multicolumn{17}{|l|}{ December } \\
\hline HW IBI value & $\begin{array}{c}40 \\
F\end{array}$ & $\begin{array}{c}32 \\
\mathbf{P}\end{array}$ & & $\begin{array}{c}40 \\
F\end{array}$ & $\begin{array}{c}44 \\
F\end{array}$ & $\begin{array}{c}30 \\
\mathbf{P}\end{array}$ & $\begin{array}{c}32 \\
\mathbf{P}\end{array}$ & & $\begin{array}{c}36 \\
P\end{array}$ & $\begin{array}{c}32 \\
P\end{array}$ & $\begin{array}{c}36 \\
P\end{array}$ & $\begin{array}{c}28 \\
\mathrm{P}\end{array}$ & $\begin{array}{c}28 \\
P\end{array}$ & $\begin{array}{l}16 \\
\text { VP }\end{array}$ & $\begin{array}{c}32 \\
\mathbf{P}\end{array}$ & $\begin{array}{c}40 \\
F\end{array}$ \\
\hline
\end{tabular}

Note: Values are based on methodologies developed for the Clinch River (CR) and for headwater (HW) streams (Ohio Environmental Protection Agency [EPA], 1987. Biological Criteria for the Protection of Aquatic Life, Vol. III: Standardized Biological Field Sampling and Laboratory Methods (1988]: Users Manual for Biological Field Assessment of Ohio Surface Streams, Ohio for Assessing Fish and Macroinvertebrate Communities; Vol. II (1988]. Users Manual for Biological Field Assessmen Environmental Protection Agency, Division of Water Quali Morthest Tributary kilometer; WCK = White Oak Creek kilometer.

Creek kilometer; MEK = Melton Branch kilometer; NTK = Northwest Tributary kilom 
complicated the application of the IBI, they can also be considered as a component of the ORNL impact.

In comparison, the IBI for headwater systems designed by the Ohio EPA $(1987,1988)$ rated most of the sites (19 of 28) higher than the IBI developed for the Clinch River area (Table 6.10). This numerical increase resulted in 12 changes in the descriptive rating, with 7 sites receiving a fair rating (increased from a rating of poor) and 5 sites receiving a poor rating (increased from a rating of very poor). Fifth Creek received the most consistent increase with all four sample/site combinations rated as fair. Much of the higher rating can be attributed to the larger baseline data set of the Ohio headwater IBI (Ohio EPA 1987, 1988) in comparison with that for the Clinch River IBI. The larger data set allowed metric values to be adjusted with drainage area in a more sensitive fashion and resulted in better resolution for changes at sites with smaller drainage areas (e.g., Fifth Creek). However, other adjusted metric values reduced the sensitivity in some areas (e.g., removing the creek chub as an insectivore because it was a generalized feeder but including the bluegill). The overall conclusion for WOC watershed was the same with both modifications of the IBI; namely, it has been significantly impacted by ORNL operations.

The Clinch River IBI descriptive ratings clearly showed several sites as being highly disturbed. WCK 3.9 had the lowest rating, followed by WCK 2.9 (fall), WCK 5.1 (spring), MEK 1.4 (spring), WCK 2.9 (spring), and WCK 2.3 (spring). The Ohio headwater IBI also suggested that WCK 3.9, MEK 1.4 (spring), NTK 1.0 (spring), and WCK 2.9 (spring) were more affected than the remainder of WOC or its tributaries.

\subsubsection{Fish Kills}

During 1988, two fish kills in WOC were discovered by ESD personnel during routine sampling. Neither kill was judged to be insignificant at the time of detection, and they were considered similar because they occurred in the same general area of WOC and involved the same species.

The first incident occurred during March 1988, and consisted of a slow die-off of fathead minnows in WOC within the plant boundaries. When the kill was detected on March 2, 1988, ESD personnel initiated systematic surveys of a $1.7-\mathrm{km}$ reach of stream, from the Melton Valley Drive bridge just above sampling site WCK 3.4 to the 6000 area just below sampling site WCK 5.1. This section included the fish sampling site at WCK 3.9. Initially, surveys were made twice daily and were gradually reduced in frequency as the number of dead fish declined. After four consecutive surveys of finding no dead fish, the surveys were terminated on March 17, 1988. A total of 40 dead or dying fathead minnows were collected (mean of 2.3 fish per sampling day). Additional mortality included western mosquitofish (1 individual), crayfish (13), frog (1), and dusky salamanders (2). The cause of the kill was not identified.

A second fish kill was observed in the same area on December 2, 1988 during the routine fish population survey at WCK 3.9. Systematic surveys were conducted daily beginning December 9, 1988. As the number of dead fish declined, survey frequency was reduced to twice weekly on January 4, 1989 and to weekly on January 20, 1989. The surveys continued until May 1989 (J. M. Loar, unpublished data).

For the period that included the daily and twice weekly surveys, a total of 94 fathead minnows were recovered (mean 
of 5.5 fish per sampling day). Additional mortality included western mosquitofish (1), blacknose dace (3), crayfish (5), and water snake (1). Unlike the first kill, water quality data indicated that residual chlorine might be responsible for the kill. Data collected by the ORNL Environmental Monitoring and Compliance Section on December 12 identified three outfalls (no. 217, no. 211, and no. 218) as sources of high levels of chlorine (1.30-1.69 mg/L). Ambient levels within WOC were also elevated $(0.0-0.70 \mathrm{mg} / \mathrm{L}$, mean $=0.41$ $\mathrm{mg} / \mathrm{L}$ ) in the approximate section where most of the dead fish were located (WCK 3.9 to WCK 4.1). During the period of chlorine monitoring (December 12-20), 74 dead fish were recovered (mean of $\mathbf{1 0 . 6}$ fish per sampling date). Following this period, increased dilution from abovenormal precipitation and high runoff may have reduced the levels of chlorine to less toxic levels, and the total number of dead fish declined to 20 between December 21, 1988 and April 19, 1989 (<1 fish per sampling date). The weekly monitoring continued in 1989 as long as dead fish were encountered in order to provide a baseline for future analyses of the impact of low-level, chronic mortality on the fish community in this reach of WOC.

\subsubsection{Conclusions}

This report presents the results from the third year of studies designed to characterize the fish populations of the WOC watershed. In general, the data gathered in 1988 supported trends observed in 1985-1987 (Loar et al. 1992a, Loar 1992b). Continued drought conditions during much of 1987 and 1988 influenced the data collected in 1988. Average daily flow in 1988 was below that of 1987 in streams without flow augmentation, and several upstream sites were very shallow and occasionally dry. These conditions, in turn, affected fish distributions and may have increased densities.

Data on species richness in WOC watershed indicated little change during 1988. The total number of species within WOC proper in 1988 (15) was identical to the number in 1987 and appeared to be relatively stable.

Population density and biomass values for 1988 supported some of the trends observed in 1985-1986. Data at FFK 0.2 and WCK 3.9, for example, showed evidence of significant impacts, thus reinforcing trends observed during the first two years of characterization. Data associated with the two fish kills in a reach of WOC near WCK 3.9 provided an explanation of the low species numbers in that area. Episodic discharges of residual chlorine, especially during cold or low-flow periods, resulted in intermittent mortality from December 1988 through April 1989 near WCK 3.9. Until these chlorine discharges are controlled, fish communities in this section of WOC will continue to be adversely affected.

The areas of highest biomass and density in 1985-1987 (FFK 0.4 and WCK 5.1) were again the highest in 1988. Biomass and density at these two sites were as much as four times higher than they were at other area streams, and may be related to nutrient enrichment (see Sect. 2.2.4). Density and biomass at WCK 5.1 showed a substantial recovery from the depressed levels noted in fall 1987 and spring 1988. The trend of increasing fish abundance in lower Melton Branch observed in 1987 continued, and a relatively stable abundance was noted in both sampling periods in 1988 . Following the dramatic increase observed at MEK 0.6 in the fall 1987, abundance was maintained at about half of this maximum in 1988 but was still substantially higher than that observed in 1985-1986. This stable population reflected successful spawning 
seasons during the summers of 1987 and 1988. The recovery represented by this spawning corresponded closely with the shutdown of the HFIR facility in November 1986, and suggested that, with normal flow, recovery might extend to all of Melton Branch. The expected recovery was noted at MEK 1.4 in 1988; steady improvement cumulated in the fall with 10 fold and twofold increases in density and biomass, respectively.

Another site exhibiting a change from 1985-1986 conditions was WCK 2.9. Initially, this was a site of fluctuating density and biomass, but a more stable community was evident in 1987 . Density values were more consistent, and biomass was three to ten times higher in 1987 than in 1986 due, in large part, to the establishment of a resident, breeding population of fathead minnow and larger adult centrarchids. Had this trend been sustained, genuine improvement would be indicated, although significant improvement at this site might require the expansion of other species (e.g., largemouth bass) into this area. Data in 1988 failed to confirm the improvement suggested in 1987; species richness and density declined and the IBI rating for WCK 2.9 was poor. The decline of fathead minnow populations and the absence of bluegill in this section during 1988 have no obvious explanation.

The abundance of individual species remained similar to that observed in the first 2 years of sampling. Blacknose dace was the dominant species, although redbreast sunfish and bluegill, as well as creek chub, were also significant.

Evaluations of growth and condition also supported the findings of 1985-1987. Condition factors of all species in 1988 again were significantly higher in the spring sampling period, representing spawning preparation as well as winter mortality of some young-of-the-year. Little more could be ascertained from the condition factors, even in the larger centrarchid species.
Between-site comparisons did not show a pattern among impacted sites that paralleled the biomass, density and richness data.

The IBI methodologies adapted for the Clinch River area and for headwater systems (Ohio EPA 1987, 1988) supported the conclusions based on density, richness, and biomass data. WCK 3.9 was the most impacted site, while other sites showing adverse eifects included WCK 2.9 and the spring samples at NTK 1.0, WCK 5.1, WCK 2.3, and MEK 1.4. The improvement in IBI scores for WCK 5.1 and MEK 1.4 from very poor to poor paralleled the improvement suggested by the population data. For the WOC system the IBI reflected the significant adverse effect of ORNL operations. The combination of intermittent releases of pollutants (e.g., chlorine to WOC) and isolation by water control structures resulted in a poor rating for WOC. The consideration of trophic composition; tolerance ratings; and more detailed examination of species richness, composition, and abundance included in the 12 metrics of the IBI provided further measures of stream "health" beyond that provided by the richness, biomass, and density data alone. Thus, the agreement between the individual population measures and a more comprehensive analysis (the IBI) makes the observed trends much more likely to be of biological significance.

\subsubsection{Future Studies}

A variety of approaches and shortterm experimental studies will be considered for implementation in 1989-1990 to assess the impacts of ORNL activities on the fish populations of WOC watershed and to identify specific sources/areas of impact. As a first step, routine, quantitative monitoring of fish density, biomass, and richness at sites in 
WOC watershed will be conducted twice annually (spring and fall). Age determination and growth rate computation will be based on scales collected in the fall.

To further evaluate the role of habitat differences in explaining differences in community composition between sites, the habitat at each site may be characterized during the high-flow (winter) period using the same procedure as that described in Sect. 2.3 for the low-flow characterization. Additional analytical techniques for interpreting existing data will also be refined or employed. The IBI will be further modified for regional application to better evaluate the impacts on fish communities at different sites. Comparisons with other streams included in the K-25 Site and Y-12 Plant BMAPs will also be possible using the IBI methodology. Production will be estimated using the procedure of Garman and Waters (1983), and a statistical evaluation of fish growth rate data will be conducted. As part of the growth evaluation, a validation program will be developed for the age determinations from scale analyses. This will involve analyzing otoliths and scales from sunfish collected in the bioaccumulation and the bioindicator monitoring programs (Sects. 4.0 and 5.0, respectively) and determining the degree of correspondence. The failure of condition factors to show site differences will be examined.

Examination of the WCK 3.9 and FFK 0.2 sites for additional evidence of a relationship between chlorine levels and fish kills or low population levels will also continue. Periodic surveys and more frequent chlorine monitoring may be used to address this problem.
Another longer-term study is planned to address the isolation of WOC watershed from the rest of the Clinch River system. The barriers to fish recolonization may be sidestepped by reintroducing selected species and monitoring their population dynamics. Being able to monitor species that occurred in the system historically and that have been reintroduced would provide better documentation of the ecological recovery process.

\subsection{INTERPRETATION OF BIOTIC CHANGES \\ M. A. Huston}

The work outlined in the second annual report (Loar 1992b) is still underway. The primary tasks are to expand the database to include more small watersheds and to prepare a peer-reviewed publication based on the results of the progress was made on both of these tasks in 1988. The final report will integrate the results of basic stream research that was conducted by ESD, underwritten by the National Science Foundation, with the results obtained in the BMAP studies of streams on the ORR. The theoretical framework being used in the integration, the "dynamic equilibrium hypothesis" (Huston 1979), was identified in a major review of the role of disturbance in stream ecology (Resh et al. 1988) as the most generally applicable of the hypotheses that have been proposed to explain stream community structure. The results of the analyses being conducted as part of the BMAP are expected to be a major contribution to the understanding of stream responses to and recovery from natural and manmade disturbances. 


\title{
7. ASSESSMENT OF CONTAMINANTS IN THE TERRESTRIAL ENVIRONMENT
}

\author{
L. J. Meyers-Schone and B. T. Walton
}

This study was undertaken as a scoping activity (1) to determine what contaminants are present in the terrestrial environment at ORNL, (2) to examine the mobility of these contaminants and their availability to terrestrial biota, and (3) to select appropriate organisms and monitoring approaches in the event that more detailed biological monitoring is needed. In addition, studies of turtles, which utilize both aquatic and terrestrial habitats, were included in this task to further consider the importance of species-specific characteristics in monitoring contaminants in biota.

\subsection{REVIEW OF PREVIOUS STUDIES}

\section{B. T. Walton}

The biological monitoring plan for the terrestrial environment of the WOC watershed (Loar et al. 1991) included a number of specific projects, many of which have been completed or are near completion. A survey of tritium concentrations in shallow well water, surface water, and atmospheric moisture was completed and published as an ORNL technical memorandum (Amano, et al. 1987). These studies identified an area of tritium migration from SWSA-5 that appears to have increased in the last 10 years.
Major findings from biological monitoring using small mammals were reported in the 1988 Annual Report (Talmage et al. 1988). Subsequent analyses of small mammals during the past year (Talmage 1989) did not change the preliminary conclusions of the study. In brief, mercury accumulation in kidney tissue and ${ }^{90} \mathrm{Sr}$ in bone were related to the extent of environmental contamination as well as to the trophic level of the species analyzed. Neither $\mathrm{B}[a] \mathrm{P}$ nor PCBs were elevated in small mammals from the ORNL reservation. The data from these studies have been reported in full by Talmage (1989). In addition, a comparative evaluation was made of small mammals as monitors of environmental contamination based on both the monitoring study at ORNL and an extensive review of the literature (Talmage and Walton 1989).

Exploratory studies to relate radiation exposure to DNA damage were undertaken using liver tissues from woodchucks (Marmota monax) receiving high levels of radiation exposure, livetrapped at a settling pond for liquid radioactive waste at ORNL (Pond 3524). Results of the analyses were equivocal (Shugart, unpublished data), and the study of woodchucks could not be continued due to the eradication of this unique population. The techniques used for DNA analysis have since been refined and have been applied to the study of 
turtle populations reported in the following section (Sect. 7.2). In addition, the merit of the technique as a general indicator of environmental exposure of natural populations to genotoxic agents is under further investigation as part of the bioindicator studies of sunfish populations in WOC (Sect. 5.0).

\subsection{FRESHWATER TURTLES AS MONITORS OF RADIONUCLIDE AND HEAVY METAL CONTAMINANTS \\ L. J. Meyers-Schone and \\ B. T. Walton}

\subsubsection{Introduction}

Subtask 5a of the BMAP is designed to examine the usefulness of freshwater turtles as monitors of contaminants in WOL. A variety of contaminants have been reported in turtles (e.g., Olafsson et al. 1983, Albers et al. 1986, Scott et al. 1986); however, the importance of species selection in the monitoring of specific contaminants has not been addressed. Hence, the purpose of this study is twofold: (1) to compare tissue concentrations of selected contaminants in two turtle species inhabiting WOL, and (2) to evaluate the usefulness of these species as indicators of chemical contaminants in aquatic ecosystems.

Two species of turtles common to the southeast and central United States were selected for study. Because these species occupy different ecological niches, the influence of food habits and habitat preference on exposure to and uptake of sediment-associated contaminants can be evaluated. The yellow-bellied slider (Pseudemys scripta), a pond turtle that feeds primarily on vegetation as an adult, was compared with the common snapping turtle (Chelydra serpentina), a carnivorous species more closely associated with sediment. These species were examined for tissue residues of selected contaminants and for DNA damage, a nonspecific indicator of exposure to genotoxic agents. In addition, gut analyses were performed on both species to establish dietary sources of contamination and to confirm ihat any intra- or interspecific differen'es in tissue residues between sites were nct due to differences in diet. The contaminants analyzed were ${ }^{90} \mathrm{Sr},{ }^{137} \mathrm{Cs}$, ${ }^{60} \mathrm{Co}$. and mercury. PCBs are also of interest and will be addressed in future studies. In the preceding annual report, $P$. scripta was shown to be herbivorous and very mobile (Meyers et al. 1993). In addition, exposure to contaminants in WOL was evidenced by residue and biochemical analyses of turtle tissues. In this report additional data are presented on radionuclide concentrations in $P$. scripta, along with data on $C$. serpentina collected during the 1988 field season. These data will be used to make both between-site comparisons for a given species and between-species comparisons for the contaminated site.

\subsubsection{Study Sites}

Bearden Creek embayment and WOL were used as study sites in the evaluation of freshwater turtles as monitors of contaminated aquatic sites. Major contaminants in WOL that have been reported in the lake biota include ${ }^{90} \mathrm{Sr},{ }^{137} \mathrm{Cs}$, ${ }^{60} \mathrm{Co}$ (e.g., Oakes et al. 1982 , Blaylock and Mohrbacher 1988), mercury and PCBs (Southworth 1992a, 1992b). Bearden Creek embayment is located approximately $5 \mathrm{~km}$ from WOL and 
served as the reference site (Meyers et al. 1993).

\subsection{Materials and Methods}

\subsubsection{Field tochniques and animal dissection}

Pseudemys scripta was trapped from WOL and Bearden Creek embayment from July 23 through September 18, 1987. A description of field techniques and procedures for animal dissection were presented in Meyers et al. (1993).

Common snapping turtles (Chelydra serpentina) were trapped from WOL from April 20 through May 15, 1988, and from Bearden Creek embayment from April 29 through July 12, 1988. Hoop nets baited with wire packets containing rainbow trout and beef were placed in water approximately $80 \mathrm{~cm}$ deep. Traps were set and checked daily.

The original plan was to capture six male and six female $C$. serpentina from each site. However, trapping success was less than expected, with 12 males captured from WOL and 6 males and 3 females trapped in Bearden Creek embayment. Captured turtles were either decapitated or shot in the head. Turtles were immediately dissected in the field, and a section of liver was removed and placed on ice for DNA analysis. Samples of bone and carapace were retained for ${ }^{90} \mathrm{Sr}$ determinations. Kidney and muscle samples were removed for mercury analysis, and sections of muscle and liver were retained for ${ }^{137} \mathrm{Cs}$ and ${ }^{60} \mathrm{Co}$ determinations. In addition, the gastrointestinal (GI) tract contents of the turtles were saved for analysis in order to verify the food habits of $C$. serpentina.

\subsubsection{Tissue analysis}

Cesium-137 and ${ }^{60} \mathrm{Co}$ were measured in frozen muscle and liver samples using a GeLi crystal scintillation spectrometer. Muscle samples from $P$. scripta that were previously counted on an $\mathrm{NaI}$ detector were recounted using a $\mathrm{GeLi}$ detector. The GeLi detector was used because of its higher resolution capabilities, permitting better detection of very low gamma radiation activity. Bone and carapace samples were analyzed for ${ }^{90} \mathrm{Sr}$ by Cerenkov counting following acid digestion of ashed samples (Meyers et al. 1993).

Total inorganic and organic mercury concentrations were measured in muscle and kidney tissue by atomic absorption spectrophotometry (Meyers et al. 1993). Mercury analysis was performed by the ACD/ORNL Laboratory.

DNA damage was used as a biochemical indicator of exposure to genotoxic agents in the environment. DNA isolated from turtle liver samples was examined for breakage using a three-part sub-assay developed by Kanter and Schwartz (1982) and modified by Shugart (1988b). The assay used is nonspecific, and although it does not identify the source of the genetic insult, it does serve as a method for identifying contaminant-induced stress on an organism. Therefore, this assay was used to evaluate the integrity of DNA in turtles exposed to contaminants in WOL (Meyers et al. 1993). See Sect. 5.2.2.6 for a discussion of this technique.

The single-stranded to doublestranded DNA ratio determined by this assay is both organ and species specific. Because this ratio differed in $C$. serpentina (and in $P$. scripta) between 
sites, the possibility exists that a contaminant may have bound to the DNA of the turtles from WOL, thus altering the experimentally determined ratio. This problem was corrected for mathematically using a rnethod described by Kanter and Schwartz (1982). The corrected values were used in the calculation of the fraction of doublestranded DNA in WOL turtles.

\subsubsection{Results and Discussion}

\subsubsection{Food habits}

Examination of the GI tract contents confirmed that $C$. serpentina is omnivorous at both WOL and Bearden Creek embayment, but the relative contribution of plants and animals to the diet differed among sites (Table 7.1). The percentage of fish and of vegetation present in the GI tracts of the turtles differed significantly between the two sites (Student's t-test, $p<0.05$ and $p<0.02$ respectively). A greater percentage of vegetation was ingested by C. serpentina at WOL than at the reference site. The vegetation present in C. serpentina from WOL was almost exclusively algae, while that from Bearden Creek embayment was largely water milfoil (Myriophyllum sp.), a submergent aquatic macrophyte. Field observations indicated that algae was considerably more abundant in WOL than in Bearden Creek embayment. Although water milfoil was present at both sites, it was more abundant at the reference site. It is possible that C. serpentina fed preferentially on algae when it was available.

A comparison of the food habits of $P$. scripta and $C$. serpentina showed the former species to be more herbivorous (Table 7.2). P. scripta from WOL consumed approximately $87 \%$ vegetation and $3 \%$ fish, whereas $C$. serpentina from the same site ingested more fish (52\%) than vegetation (48\%). Because the diet of $C$. serpentina consists of a high proportion of animal than plant matter, this species is likely to be a better monitor than $P$. scripta for contaminants that are biomagnified through food chains.

\subsubsection{Radionuclide concentrations}

Cesium-137 and ${ }^{60} \mathrm{Co}$ concentrations were greater in $P$. scripta from WOL than in those from Bearden Creek embayment. A two-way ANOVA of these data did not reveal significant differences in concentrations between males and females within a given site, so the sexes were pooled for subsequent analyses. Statistically significant differences between the two sites were found in the concentrations of ${ }^{137} \mathrm{Cs}$ (Student's t-test on log-transformed data using minimum detectable activity values for Bearden Creek embayment samples, $p<0.001$ for both liver and muscle tissues) and ${ }^{60} \mathrm{Co}$ (Student's t-test on non-transformed data using minimum detectable activity values for Bearden Creek embayment samples, $p<0.01$ for liver tissue).

The mean concentration of ${ }^{137} \mathrm{Cs}$ in muscle tissue of $P$. scripta from WOL was $44.9 \pm 144 \mathrm{~Bq} / \mathrm{g}$, wet wt (Table 7.3). Only 1 of the $12 P$. scripta from the Bearden Creek embayment had a concentration of ${ }^{137} \mathrm{Cs}$ in muscle that exceeded the detection limit of $3.7 \times$ $10^{-3} \mathrm{~Bq} / \mathrm{g}$. This single turtle contained $1.44 \times 10^{-2} \mathrm{~Bq} / \mathrm{g}$ (wet wt) ${ }^{137} \mathrm{Cs}$ in muscle. Cobalt-60 was not detected in the muscle of turtles from either site. Both ${ }^{137} \mathrm{Cs}$ and ${ }^{60} \mathrm{Co}$ were detected in liver samples of $P$. scripta from WOL (Table 7.3). Mean concentrations of the two radionuclides were $5.84 \pm 19.0 \mathrm{~Bq} / \mathrm{g}$ 
Table 7.1. Mean percent volume of different food types in the GI tract of common smapping turtles (Chebydra sespentina) collected on the Oak Ridge Reservation $N=$ Number of turtles analyzed

\begin{tabular}{lccccc}
\hline & \multicolumn{5}{c}{ Diet composition (\% volume) } \\
\cline { 2 - 6 } Collection site & $N$ & Fish & Vegetation & Clams & $\begin{array}{c}\text { Rocks and } \\
\text { mud }\end{array}$ \\
\hline White Oak Lake & 12 & $51.7^{a}$ & $47.9^{\circ}$ & 0 & 0.4 \\
Bearden Creek & 9 & $85.1^{\circ}$ & $12.6^{\circ}$ & 0.2 & 2.1 \\
\hline
\end{tabular}

Mean percentage of fish was significantly different between sites, $p<0.05$ (Student's t-test). 'Mean percentage of vegetation was significantly different between sites, $p<0.02$ (Student's t-test).

Table 7.2. Mean percent volume of different food types in the GI tract of yellow-bellied slider (Pseudemys scripta) and common snapping turtles (Cheigdra serpentina) from White Oak Lake $N=12$ for each species

\begin{tabular}{lcccc}
\hline \multirow{2}{*}{ Species } & \multicolumn{4}{c}{ Diet composition (\% Volume) } \\
\cline { 2 - 5 } & Vegetatio: & Fish & Insects & $\begin{array}{r}\text { Rocks, mud } \\
\text { and detritus }\end{array}$ \\
\hline Pseudemys scripta & 86.5 & 3.0 & 8.5 & 2.0 \\
Chelydra serpentina & 47.9 & 51.7 & 0 & 0.4 \\
\hline
\end{tabular}

Table 7.3. Cesium-137 and ${ }^{\infty} \mathrm{Co}$ in tissues of yellow-bellied slider turtles (Pseudenys scripta) from White Oak Lake

Values are the mean \pm 1 SD; $n=$ Number of turtles analyzed

\begin{tabular}{llllll}
\hline & \multicolumn{2}{c}{${ }^{137} \mathrm{Cs}(\mathrm{Bg} / \mathrm{g}$, wet wt) } & & \multicolumn{2}{c}{${ }^{80} \mathrm{Co}(\mathrm{Bq} / \mathrm{g}$, wet wt) } \\
\cline { 1 - 2 } \cline { 5 - 6 } Sex & Muscle & Liver & & Muscle & Liver \\
\hline $\begin{array}{l}\text { Male } \\
(n=6)\end{array}$ & $89.6 \pm 20.2$ & $11.6 \pm 26.7$ & & $<3.7 \times 10^{-3}$ & $7.65 \times 10^{-2}$ \\
& & & & $8.20 \times 10^{-2}$ \\
$\begin{array}{l}\text { Female } \\
(n=6)\end{array}$ & $27.3 \times 10^{-2}$ & $7.49 \times 10^{-2}$ & & $<3.7 \times 10^{-3}$ & $4.42 \times 10^{-2}$ \\
& $10.8 \times 10^{-2}$ & $2.5 \times 10^{-2}$ & & & $2.55 \times 10^{-2}$ \\
Both & $44.9 \pm 144$ & $5.84 \pm 19.0$ & & $<3.7 \times 10^{-3}$ & $6.03 \times 10^{-2}$ \\
$(n=12)$ & & & & $6.03 \times 10^{-2}$ \\
\hline
\end{tabular}


and $6.03 \times 10^{-2} \pm 6.03 \times 10^{-2} \mathrm{~Bq} / \mathrm{g}$ (wet $w t)$, respectively. Neither radionuclide was detected $\left(<3.7 \times 10^{-3} \mathrm{~Bq} / \mathrm{g}\right)$ in the liver samples of Bearden Creek embayment turtles.

Muscle samples from $C$. serpentina collected from WOL contained abovebackground concentrations of ${ }^{137} \mathrm{Cs}$. A significant difference in the mean ${ }^{137} \mathrm{Cs}$ concentration was detected between the two populations (Student's t-test on non-transformed data, $p<0.01$ ). The radionuclide was present in all WOL muscle samples (mean of $39.6 \times 10^{-2} \pm$ $31.3 \times 10^{-2} \mathrm{~Bq} / \mathrm{g}$, wet wt) but was not detected $\left(<3.7 \times 10^{-3} \mathrm{~Bq} / \mathrm{g}\right)$ in muscle samples from the Bearden Creek turtles. Cobalt-60 was not detected in any of the muscle samples.

Concentrations of ${ }^{137} \mathrm{Cs}$ in muscle tissues of $C$. serpentina and $P$. scripta from WOL were not significantly different (Student's t-test and Mann-Whitney U-test on nontransformed and log-transformed data from both species, $p>0.05$ ) (Table 7.4). Of the $12 P$. scripta, 2 contained concentrations of ${ }^{137} \mathrm{Cs}$ that were 2 to 3 orders of magnitude higher than the mean concentration detected in the remaining 10 turtles $\left(32.9 \times 10^{-2} \pm 12.3\right.$ $\times 10^{-2} \mathrm{~Bq} / \mathrm{g}$, wet wt). As discussed in Meyers et al. (1993), these two turtles are believed to have immigrated to WOL from other contaminated sites on the reservation.

Two lines of evidence point to $C$. serpentina as better monitors of ${ }^{137} \mathrm{Cs}$ in WOL. Less variability was detected in the $C$. serpentina data than in the $P$. scripta data, suggesting that the former species has greater uniformity in exposure to radionuclides. Secondly, radionuclide spectral analysis provided evidence for the movement of one $P$. scripta from the Old Hydrofracture Pond about $0.25 \mathrm{~km}$ from WOL (Meyers et al. 1993), indicating that $P$. scripta may be highly mobile. Because of the lower variability in the $C$. serpentina data set and because it is less mobile than $P$. scripta, $C$. serpentina appears to be a better monitor of ${ }^{137} \mathrm{Cs}$ in WOL than P. scripta.

Elevated levels of ${ }^{90} \mathrm{Sr}$ were found in calcified tissues of $P$. scripta from WOL. Strontium-90 concentrations in the bone and carapace of $P$. scripta from this site ranged from 2.31 to $4.83 \times 10^{3} \mathrm{~Bq} / \mathrm{g}$ (wet wt) with a mean of $4.26 \times 10^{2} \pm$ $1.39 \times 10^{3} \mathrm{~Bq} / \mathrm{g}$ and from 1.65 to $4.07 \times$ $10^{3} \mathrm{~Bq} / \mathrm{g}$ (wet wt) with a mean of $3.66 \times$ $10^{2} \pm 1.17 \times 10^{3} \mathrm{~Bq} / \mathrm{g}$, respectively. As with the ${ }^{137} \mathrm{Cs}$ data, a two-way ANOVA did not indicate a significant difference in the mean concentration for males and

Table 7.4. Cesium-137 in muscle tissue of yellow-bellied slider (Pseudemys scripta) and common snapping turtles (Chelydra serpentina) collected from White Oak Lake $N=12$ for each species

\begin{tabular}{llc}
\hline \multirow{2}{*}{ Species } & \multicolumn{2}{c}{${ }^{137} \mathrm{Cs}(\mathrm{Bq} / \mathrm{g}$ wet wt) } \\
\cline { 2 - 3 } & $44.9 \pm 144^{a}$ & $12.4 \times 10^{-2}$ to 502 \\
\hline Pseudemys scripta & $39.6 \times 10^{-2} \pm 31.3 \times 10^{-2 a}$ & $20.3 \times 10^{-2}$ to 1.37 \\
\hline
\end{tabular}

${ }^{a}$ Means not significantly different (Student's t-test, $p>0.05$ ) 
females within a given site (Student's ttest, $p>0.05$ ). The radionuclide was detected in several turtles from Bearden Creek embayment; bone concentrations in these turtles ranged from nondetectable levels $\left(<3.7 \times 10^{-2} \mathrm{Bg} / \mathrm{g}\right)$ to $1.04 \mathrm{~Bq} / \mathrm{g}$ wet wt. Concentrations in the carapace were similar, ranging from nondetectable levels to $1.18 \mathrm{~Bq} / \mathrm{g}$, wet wt. In both tissues a statistically significant difference was found between the ${ }^{90} \mathrm{Sr}$ concentrations of the two populations (Mann-Whitney U-test, $p \leq 0.05$ ).

Strontium-90 concentrations in the bone of $C$. serpentina collected from the two sites differed by several orders of magnitude. Concentrations in the bone of $C$. serpentina from WOL ranged from 1.70 to $47.2 \mathrm{Bg} / \mathrm{g}$ with a mean ( $\pm 1 \mathrm{SD}$ ) of $18.0 \pm 13.0 \mathrm{~Bq} / \mathrm{g}$ (wet wt). Only three
The concentrations in C. serpentina from WOL ranged from 1.32 to $46 \mathrm{~Bq} / \mathrm{g}$ (wet wt) with a mean of $18.3 \pm 11.1 \mathrm{~Bq} / \mathrm{g}$ (wet wt). Strontium-90 concentrations in the carapace of Bearden Creek $C$. serpentina ranged from nondetectable $\left(<3.7 \times 10^{-2} \mathrm{~Bq} / \mathrm{g}\right.$ ) to $20.6 \times 10^{-2} \mathrm{~Bq} / \mathrm{g}$ (wet wt).

No species difference was found between the ${ }^{90} \mathrm{Sr}$ concentrations of $P$. scripta and $C$. serpentina from WOL (Student's t-test on nontransformed and log-transformed data, $p>0.05$ ). This finding was true for the concentrations in both bone and carapace (Table 7.5). The close association of $C$. serpentina to sediment did not result in a higher ${ }^{90} \mathrm{Sr}$ concentration than that detected in $P$. scripta, a more pelagic species. It may be that the sample sizes were too small to

Table 7.5. Strontium-90 in skeletal tissues of yellow-bellied slider (Pseudemys scripta) and common snapping turtles (Chelydra serpentina) collected from White Oak Lake Values are mean $\pm 1 \mathrm{SD} ; n=12$ for each species

\begin{tabular}{lll}
\hline \multirow{2}{*}{ Species } & \multicolumn{2}{c}{${ }^{90} \mathrm{Sr}(\mathrm{Bg} / \mathrm{g}$, wet wt) } \\
\cline { 2 - 3 } & \multicolumn{1}{c}{ Bone } & \multicolumn{1}{c}{ Carapace } \\
\hline Pseudemys scripta & $4.26 \times 10^{2} \pm 1.39 \times 10^{39}$ & $3.66 \times 10^{2} \pm 1.17 \times 10^{3}$ \\
Chelydra serpentina & $18.0 \times 13.0^{\circ}$ & $18.3 \times 11.1$ \\
\hline
\end{tabular}

${ }^{a}$ Means not significantly different (Student's t-test, $p>0.05$ )

of the nine snapping turtles collected from Bearden Creek embayment contained detectable concentrations of ${ }^{90} \mathrm{Sr}\left(>3.7 \times 10^{-2} \mathrm{~Bq} / \mathrm{g}\right)$. These three turtles averaged $20 \times 10^{-2} \pm 24 \times$ $10^{-3} \mathrm{~Bq} / \mathrm{g}$ of ${ }^{90} \mathrm{Sr}$ in bone. The mean concentration at the two sites was tes statistically using a Mann-Whitney U-test and found to be significant $(p \leq 0.05)$.

The mean ${ }^{90} \mathrm{Sr}$ concentration in the carapace of $C$. serpentina was also significantly different between the two sites (Mann-Whitney U-test, $p \leq 0.05$ ). thoroughly evaluate the hypothesis or that differences in habitat preference between the species play only a minor role in exposure of these species to ${ }^{90} \mathrm{Sr}$ in WOL. As with the ${ }^{137} \mathrm{Cs}$ data, greater variability characterized the $P$. scripta data set for ${ }^{90} \mathrm{Sr}$ compared with that of C. serpentina (Table 7.5). Given that no significant differences in ${ }^{90} \mathrm{Sr}$ concentrations were found, $C$. serpentina appears to be a better monitor than $P$. scripta based on the reduced variability in the data. 


\subsubsection{Mercury}

Total organic and inorganic mercury concentrations in kidney tissues were significantly higher in $C$. serpentina from WOL than in those from Bearden Creek embayment (Student's t-test, $p<0.025$ ).

Mercury concentrations in $C$. serpentina from Bearden Creek embayment ranged from 0.16 to $1.07 \mu \mathrm{g} / \mathrm{g}$ (wet wt) with a mean \pm 1 SD of $0.34 \pm 0.28 \mu \mathrm{g} / \mathrm{g}$ (wet wt). No significant difference was detected between the concentrations of mercury in male vs female turtles from Bearden Creek embayment (Student's t-test, $p>0.05$ ). Total mercury concentrations in the kidney of turtles from WOL ranged from 0.32 to $4.38 \mu \mathrm{g} / \mathrm{g}$ (wet wt) with a mean of $1.30 \pm 1.16 \mu \mathrm{g} / \mathrm{g}$ (wet $w t$ ).

Residue analyses of muscle tissue aiso showed snapping turtles from WOL to contain significantly higher concentrations of mercury than were found in muscle of $C$. serpentina from Bearden Creek embayment (Student's ttest, $p<0.01$ ). The mean concentration of mercury in muscle of Bearden Creek turtles was $0.10 \pm 0.13 \mu \mathrm{g} / \mathrm{g}$ (wet wt) compared with a mean concentration of $0.17 \pm 0.07 \mu \mathrm{g} / \mathrm{g}$ (wet wt) in muscle of $C$. serpentina from WOL. Both sets of data reveal that mercury in WOL is either present in higher concentrations or is more bioavailable than that in Bearden Creek embayment.

Higher mercury concentrations were found in $C$. serpentina kidney tissue than that of $P$. scripta (Student's t-test on logtranstormed data, $p<0.01$, Table 7.6). If the two $P$. scripta that were believed to have immigrated to WOL from other, more highly contaminated sites are removed from the data set, the statistical significance of the difference between the two species increases $(p<0.02$ for nontransformed data and $p<0.001$ for log-transformed data). The mean mercury concentration in muscle was also significantly different between the two species (Student's t-test on nontransformed data, $p<0.01$ ). The species difference may be due to differences in the food habits of the animals. Because $C$. serpentina is more carnivorous than $P$. scripta, the elevated concentrations of mercury in the former may be due to biomagnification.

\subsubsection{DNA damage assessment}

A double-stranded DNA alkaline unwinding assay was conducted on liver samples from $C$. serpentina collected from the two sites. The mean fraction of double-stranded DNA (ds-DNA) detected under the conditions of the assay was 0.61 and 0.89 for the WOL and Bearden Creek embayment turtles (Table 7.7) respectively. The difference in the fraction of ds-DNA between the two populations was significant (Student's ttest, $p<0.001$ ); the DNA from the WOL turtles contained 3.7 times more breaks than were detected in the DNA of Bearden Creek $C$. serpentina. The smaller fraction of ds-DNA in the WOL turtles suggests that they may be exposed to higher levels of genotoxic agents than are the turtles in Bearden Creek embayment.

A comparison of the relative number of breaks per alkaline unwinding unit for $C$. serpentina and $P$. scripta from WOL indicated a similar level of DNA damage in the two populations (Table 7.8). No statistically significant difference (Student's t-test, $p \geq 0.05$ ) was detected between the two populations, indicating 
Table 7.6. Total organic and inorganic mercury in tissues of yellow-bellied slider (Pseudemys scripta) and common snapping turtles (Chelydra serpentina) collected from White Oak Lake Values are mean $\pm 1 \mathrm{SD} ; n=12$ for each species

\begin{tabular}{lcc}
\hline \multirow{2}{*}{ Species } & \multicolumn{2}{c}{ Mercury concentration $(\mu \mathrm{g} / \mathrm{g}$, wet wt) } \\
\cline { 2 - 3 } & Kidney & Muscle \\
\hline Pseudemys scripta & $0.64 \pm 1.12^{\circ}$ & $0.10 \pm 0.13^{\circ}$ \\
Chelydra serpentina & $1.30 \pm 1.16^{\circ}$ & $0.17 \pm 0.07^{\circ}$ \\
\hline
\end{tabular}

Means significantly different, $p<0.01$ (Student's t-test).

'Means significantly different, $p<0.05$ (Student's t-test).

Table 7.7. Fraction of double-stranded $\left(F_{\mathrm{d}}\right)$ DNA in liver samples of common snapping turtles (Chelyctra serpentina) collected on the Oak Ridge Reservation $\mathrm{SD}=$ one standard deviation of the mean; $n=$ Number of turtles analyzed

\begin{tabular}{|c|c|c|c|c|}
\hline \multirow{2}{*}{ Collection site } & \multicolumn{3}{|c|}{ DNA (fraction ds) } & \multirow{2}{*}{$\begin{array}{c}\text { Relative number breaks per } \\
\text { alkaline } \\
\text { unwinding unit }\end{array}$} \\
\hline & Mean & SD & $n$ & \\
\hline White Oak Lake (WOL) & $0.61^{b}$ & 0.11 & 12 & 3.66 \\
\hline Bearden Creek embayment & $0.89^{b}$ & 0.06 & 9 & 1.0 \\
\hline
\end{tabular}

In $F_{d s}$ (WOL)

In $F_{\mathrm{ds}}$ (reference site) - 1 (see Sect. 5.2.2.6)

Means significantly different (Student's t-test, $p<0.001$ ).

Table 7.8. Fraction of double-stranded $\left(F_{\alpha}\right)$ DNA in liver of yellow-bellied slider (Pseudemys scripta) and common snapping turtles (Chelydra serpentina) collected from White Oak Lake (WOL) $\mathrm{SD}=$ one standard deviation of the mean; $n=$ Number of turtles analyzed

\begin{tabular}{|c|c|c|c|c|}
\hline \multirow{2}{*}{ Species } & \multicolumn{3}{|c|}{ DNA (fraction ds) } & \multirow{2}{*}{$\begin{array}{c}\text { Relative number breaks } \\
\text { per alkaline } \\
\text { unwinding unit }{ }^{a}\end{array}$} \\
\hline & Mean & SD & $N$ & \\
\hline Pseudemys scripta & $0.49^{b}$ & 0.42 & 12 & 4.42 \\
\hline Chelydra serpentina & $0.61^{b}$ & 0.11 & 12 & 3.66 \\
\hline
\end{tabular}

In $F_{d s}$ (WOL)

In $F_{d s}$ (reference site) - 1 (see Sect. 5.2.2.6)

'Means not significantly different (Student's t-test, $p<0.05$ ). 
that exposure to genotoxic agents in WOL is nearly equal between $C$. serpentina and $P$. scripta.

\subsection{Conclusions}

From the data presented here and in the preceding annual report (Meyers et al. 1993), it is evident that both $P$. scripta and $C$. serpentina are able to accumulate ${ }^{137} \mathrm{Cs},{ }^{60} \mathrm{Co},{ }^{90} \mathrm{Sr}$, and mercury from WOL. Higher concentrations of the radionuclides were detected in the turtles from WOL than in turtles from Bearden Creek embayment, a reference site. Mercury in $C$. serpentina from WOL also exceeded that detected in the same species from the reference site. Both species served as useful biomonitors in revealing the presence of abovebackground concentrations of contaminants in WOL but not in Bearden Creek embayment.

A more thorough comparison of contaminant concentrations between the species indicated both similarities and differences. Differences in ${ }^{137} \mathrm{Cs}$ and ${ }^{90} \mathrm{Sr}$ concentrations were not statistically significant between the two species in WOL. However, lower variability was evident in the $C$. serpentina data than in the $P$. scripta data. Less variability in the data and evidence of movement of two $P$. scripta from contaminated sites outside of WOL (Meyers et al. 1993) indicate that $C$. serpentina had a more uniform exposure to radionuclides in WOL. Consequently, $C$. serpentina may serve as a more useful biological monitor of ${ }^{137} \mathrm{Cs}$ and ${ }^{90} \mathrm{Sr}$ than P. scripta.

Mercury concentrations were significantly higher in $C$. serpentina than in $P$. scripta from WOL, a difference that could be explained on the basis of differences in the food habits of the two species. $C$. serpentina is primarily a carnivore, whereas $P$. scripta is a herbivore. (C. serpentina ingested an average of $52 \%$ fish and $48 \%$ vegetation compared to an average of $3 \%$ fish and $87 \%$ vegetation in $P$. scripta.) Because methylmercury can be biomagnified through the food chain, a carnivore would be expected to have higher concentrations of the metal than an herbivore. Although mercury concentrations in WOL $C$. serpentina exceeded those detected in the same species from the reference site, the average mercury concentration of $0.17 \pm 0.07 \mu \mathrm{g} / \mathrm{g}$ (wet wt) in muscle of WOL turtles is less than the $1.0 \mu \mathrm{g} / \mathrm{g}$ FDA action limit (FDA 1984a). Concentrations of mercury in WOL sediment were reported to range from 3 to $5 \mu \mathrm{g} / \mathrm{g}$ (Hoffman et al. 1984). This metal is present in WOL at above background concentrations $(>1.0 \mu \mathrm{g} / \mathrm{g}$ ) but appears to be in a form that is not readily taken up by biota.

Results of the alkaline unwinding assay indicate that both $P$. scripta and $C$. serpentina have a higher frequency of DNA breaks than do the same species from Bearden Creek embayment. No statistically significant difference was found between the levels of DNA damage in the two species from WOL. Although the assay provides evidence of exposure to genotoxic agents in WOL, the specific causative agent cannot be established from this assay. The finding of elevated DNA damage in WOL turtles does, however, suggest that biota in the lake are exposed to above-background concentrations of genot(jxicants.

Of the two species of freshwater turtles examined, $C$. serpentina appears to be a better monitor of the contaminants measured in this study. Data obtained for this species were compared with BMAP data on fish from WOL. The concentration of ${ }^{137} \mathrm{Cs}$ in the muscle of C. serpentina averaged $39.6 \times 10^{-2} \mathrm{~Bq} / \mathrm{g}$ (wet wt) and was within the range 
reported in WOL fish. Concentrations of ${ }^{137} \mathrm{Cs}$ in filets of seven species of fish from WOL ranged from $21.9 \times 10^{-2}$ (carp, Cyprinus carpio) to $96.0 \times$ $10^{-2} \mathrm{Bg} / \mathrm{g}$ wet wt (largemouth bass, Micropterus salmoides) (Loar 1992b, Table 8.1). If $C$. serpentina were exclusively piscivorous, the concentration of ${ }^{137} \mathrm{Cs}$ in the turtles would be expected to be higher than that reported here due to biomagnification through the food chain.

In WOL, ${ }^{90} \mathrm{Sr}$ concentrations in $C$. serpentina appear greater than those in fish. The mean concentration of $18 \mathrm{~Bq} / \mathrm{g}$ (wet wt) in $C$. serpentina bone was greater than the $4.8 \mathrm{~Bq} / \mathrm{g}$ (air-dried wt) measured in channel catfish (Ictalurus punctatus) bone (Southworth 1992b) as well as the $1.35 \mathrm{~Bq} / \mathrm{g}$ (wet wt) detected in bone from carp (B. G. Blaylock, ORNL/ESD, unpublished data). Differences in the mode of uptake may account for these differences.

However, the concentrations of mercury in $C$. serpentina and fish from WOL were similar. Chelydra serpentina contained $0.17 \mu \mathrm{g} / \mathrm{g}$ (wet wt) of mercury in muscle, whereas redbreast (Lepomis auritus) and bluegill sunfish ( $L$. macrochinus) contained $0.16 \mu \mathrm{g} / \mathrm{g}$ (wet wt) of mercury in muscle (Southworth 1992b). Both concentrations were below the FDA action limit of $1 \mu \mathrm{g} / \mathrm{g}$. The low concentrations of mercury detected in both fish and turtles from WOL support the hypothesis that mercury in the lake sediment may be, to a large extent, biologically unavailable.

The data obtained on turtles from WOL served as a useful supplement to that recorded for fish from the same site. The concentration of ${ }^{137} \mathrm{Cs}$ in both $C$. serpentina and $P$. scripta was within the range of that found in fish. Concentrations of mercury were also similar in turtles and sunfish, whereas concentrations ${ }^{90} \mathrm{Sr}$ were higher in the turtles than in fish. Both turtle species from WOL also showed evidence of DNA damage, indicating the presence of genotoxic agents in the lake. Evidence of DNA damage was also found in sunfish collected from WOL (Sect. 5.3.4.1). Because freshwater turtles contain large fat reserves, they may be expected to contain high concentrations of PCBs (Olafsson et al. 1983). However, the actual concentrations of PCBs in the muscle of WOL turtles have not been measured. These analyses, which will be completed in 1989, will provide information needed to evaluate the potential of WOL turtles as a source of PCBs to humans who may consume them.

Although the data presented suggest C. serpentina is a better indicator of certain contaminants than $P$. scripta, advantages and disadvantages exist in using snapping turtles. Chelydra serpentina is larger in size than $P$. scripia, so ample quantities of specific tissues for residue analyses (e.g., fat for PCB analysis) are readily obtained. Chelydra serpentina is a more carnivorous species and, therefore, is expected to contain higher concentrations of contaminants that are biomagnified through food chains. Analyses for mercury and ${ }^{137} \mathrm{Cs}$ support this supposition. Overland movement between ponds was greater in $P$. scripta than in $C$. serpentina, making the latter species a better monitor for contaminants within a given pond or lake.

Disadvantages to the use of $C$. serpentina focus on the sampling and handling of these animals. Chelydra serpentina are somewhat territorial and often are not as abundant as the smaller pond turtles (e.g., Pseudemys and Chrysemys). Thus, it may be difficult to capture enough $C$. serpentina to constitute a sufficient sample size. Chelydra serpentina are very aggressive 
and dangerous to handle. If the pond or lake is large and sufficient manpower is available for field work, $C$. serpentina is recommended because of the large tissue samples and its trophic position in the ecosystem. Alternatively, $P$. scripta is preferable in small ponds where a sample size greater than three turtles is required. In any case, the characteristics of the site, the number of animals needed, and the type of contaminant to be monitored should all be considered in selecting an appropriate monitoring species.

An additional reason for including turtles in biomonitoring programs is that turtle meat is often utilized as a supplementary food source and, as such, the presence of contaminants in muscle tissue is of importance in the evaluation of a human health risk. Of the contaminants examined in WOL turtles, only ${ }^{137} \mathrm{Cs}$ was detected in muscle at above-background concentrations. Mercury concentrations in turtle muscle were $<20 \%$ of the FDA action limit. Cobalt-60 was not detected in muscle, and although ${ }^{90} \mathrm{Sr}$ concentrations were not measured in muscle, concentrations are expected to be low because the radionuclide has a stronger affinity for calciferous tissue, such as bone and shell. Therefore, any human health risk posed by ingestion of turtle meat from WOL is expected to come from exposure to ${ }^{137} \mathrm{Cs}$, and possibly PCBs.

\subsubsection{Future Studies}

The project on freshwater turtles as monitors of contaminated aquatic environments is close to completion. Analyses that remain include ${ }^{137} \mathrm{Cs}$ and ${ }^{60} \mathrm{Co}$ concentrations in liver samples from C. serpentina and PCB concentrations in muscle from both $P$. scripta and $C$.

serpentina. Sediment samples will also be collected from Bearden Creek

embayment and counted for ${ }^{90} \mathrm{Sr},{ }^{137} \mathrm{Cs}$, and ${ }^{60} \mathrm{Co}$ activity. The completed study will be published as a dissertation (L. Meyers-Schöne, University of Tennessee) and an ORNL technical manuscript. 


\title{
8. RADIOECOLOGY OF WHITE OAK LAKE
}

\author{
B. G. Blaylock, H. L. Boston, D. A. Mohrbacher, and A. E. Waters
}

The purpose of the radioecological studies on WOL is to provide information needed to determine whether exposure of humans to contaminants in WOL is significant enough to warrant remedial actions under the current conditions or under hypothetical loss of institutional control. To accomplish this task, it is necessary to have reasonably accurate estimates of concentrations and inventories of the radionuclides in the principal biotic and abiotic compartments of the WOL ecosystem. Estimates of these inventories were provided in the second annual report on the ORNL BMAP (Loar 1992b). Included in the present report is a revised estimate of these inventories based on recent measurements of the volume and area of the lake (Sect. 8.1); a study of the biomass and concentration of contaminants in aquatic macrophytes in WOL, WOC, and Melton Branch (Sect. 8.2); a census of the waterfowl population for WOL and other waste disposal ponds (as well as the results of analyses of radionuclide concentrations in waterfowl associated with these ponds) (Sect. 8.3); and radionuclide concentrations in fish from WOC (Sect. 8.4).

\subsection{RADIONUCLIDES IN THE WHITE OAK LAKE ECOSYSTEM}

B. G. Blaylock

Estimated quantities of ${ }^{137} \mathrm{Cs},{ }^{60} \mathrm{Co}$, and ${ }^{90} \mathrm{Sr}$ in the biotic and abiotic compartments of WOL were provided in the second annual report (Loar 1992b, Table 8.5). These quantities were based on an estimated surface area of $5.3 \mathrm{ha}$ and an average depth of $1 \mathrm{~m}$. Based on more recent measurements of the lake morphometry (Cox et al. unpublished data), estimates of the average depth and surface area of the lake were revised to $0.62 \mathrm{~m}$ and $6.88 \mathrm{ha}$, respectively. The revised estimates of the quantities of ${ }^{137} \mathrm{Cs}$, ${ }^{60} \mathrm{Co}$, and ${ }^{90} \mathrm{Sr}$ in the biotic and abiotic compartments of WOL are summarized in Table 8.1.

The revised estimate of the combined inventory in WOL for ${ }^{137} \mathrm{Cs},{ }^{60} \mathrm{Co}$, and ${ }^{90} \mathrm{Sr}$ is $1.61 \times 10^{13} \mathrm{~Bq}$, or $3.26 \times 10^{12} \mathrm{~Bq}$ more than the previous estimate of $1.28 \times 10^{13}$ $\mathrm{Bq}$ (Loar 1992b). The estimated $1.61 \times$ $10^{13} \mathrm{~Bq}$ does not include the radioactivity in the floodplain or previous lake bed that were exposed to radioactivity when the lake was much larger. The increased amount of sediments assumed with the larger surface area of the lake accounts for practically all of the additional $3.26 \times 10^{12}$ $\mathrm{Bq}$ in the revised inventory of radioactivity in the biotic and abiotic compartments of WOL.

This revised estimate of radioactivity in WOL demonstrates the importance of the sediment, which accounts for about 99\% of all the radioactivity in WOL. The estimated inventory of radionuclides in sediment is based on samples collected in the early 1960 s and a limited number of recent sediment samples. Although it is assumed that the quantity of actinides in WOL sediment is relatively small, some documentation of the inventory of these radionuclides will be required to complete a screening analysis of the WOL ecosystem. 
Table 8.1. Estimated inventories of ${ }^{137} \mathrm{Cs},{ }^{\infty} \mathrm{Co}$, and ${ }^{14} \mathrm{Sr}$ (in becquerels) in the abiotic and biotic compartments of White Oak Lake $\mathrm{NA}=$ Not available

\begin{tabular}{lccc}
\hline \multicolumn{1}{c}{ Compartment } & ${ }^{137} \mathrm{Cs}$ & ${ }^{80} \mathrm{Co}$ & ${ }^{80} \mathrm{Sr}$ \\
\hline Fish & $1.1 \times 10^{6}$ & $9.6 \times 10^{4}$ & $1.1 \times 10^{6}$ \\
Benthic invertebrates & $4.2 \times 10^{5}$ & $9.7 \times 10^{4}$ & $\mathrm{NA}$ \\
Emergent macrophytes & $8.4 \times 10^{6}$ & $1.1 \times 10^{6}$ & $2.3 \times 10^{7}$ \\
Sediment & $1.5 \times 10^{13}$ & $4.2 \times 10^{11}$ & $6.6 \times 10^{11}$ \\
Water & $1.7 \times 10^{8}$ & $1.3 \times 10^{7}$ & $2.2 \times 10^{8}$ \\
Total & $1.5 \times 10^{13}$ & $4.2 \times 10^{11}$ & $6.6 \times 10^{11}$ \\
& $(405)^{9}$ & $(11.4)$ & $(17.8)$ \\
\hline
\end{tabular}

${ }^{\circ} \mathrm{Ci}$.

\subsection{RADIOECOLOGY OF MACROFLORA IN WHTTE OAK LAKE \\ D. A. Mohrbacher, H. L. Boston, and \\ B. G. Blaylock}

\subsubsection{Introduction}

WOL supports several species of emergent, floating and submerged plants that potentially could colonize the entire lake. Macrophytes, which can comprise a major biotic pool of radionuclides in WOL because of their physical nature and physiological activity, can influence the retention, transport and cycling, and food-chain entry of radionuclides within an ecosystem. Macrophytes growing in dense stands can act as particulate sieves, decreasing the suspended solids concentration in the water and thereby enhancing sediment deposition. Aquatic macrophytes are able to accumulate large amounts of minerals via uptake from sediments by their roots and from the water column through submerged shoots (Agami and Waisel 1986); therefore, they may remobilize radionuclides from the sediments of WOL to the overlying water column. Whether the primary source of ${ }^{137} \mathrm{Cs}$, ${ }^{60} \mathrm{Co}$, and ${ }^{90} \mathrm{Sr}$ to macrophytes is from the water column or sediments is unknown. The eventual fate of radionuclides incorporated into aquatic plants is also largely unknown; they may reenter the system by several processes in a form that is readily available for uptake by other biota or be transported downstream (Carpenter and Lodge 1986). Figure 8.1 depicts the pathways for remobilization and possible fates of ${ }^{137} \mathrm{Cs}$ and ${ }^{60} \mathrm{Co}$ in WOL.

To evaluate the potential role of submerged plants in the dynamics of radionuclides in the WOL systen, macrophyte populations upstream from the lake in pools behind the Melton Branch weir (MEK 0.16) and the WOC weir (WCK 2.65) are being investigated. Many of the macrophytes common in WOL occur in these two pools. Because the submerged and floating macrophyte populations in WOL vary greatly from year to year, the plant populations in the weir systems will serve as surrogates for those in WOL. The 
OPAL-DWG 93M-15835

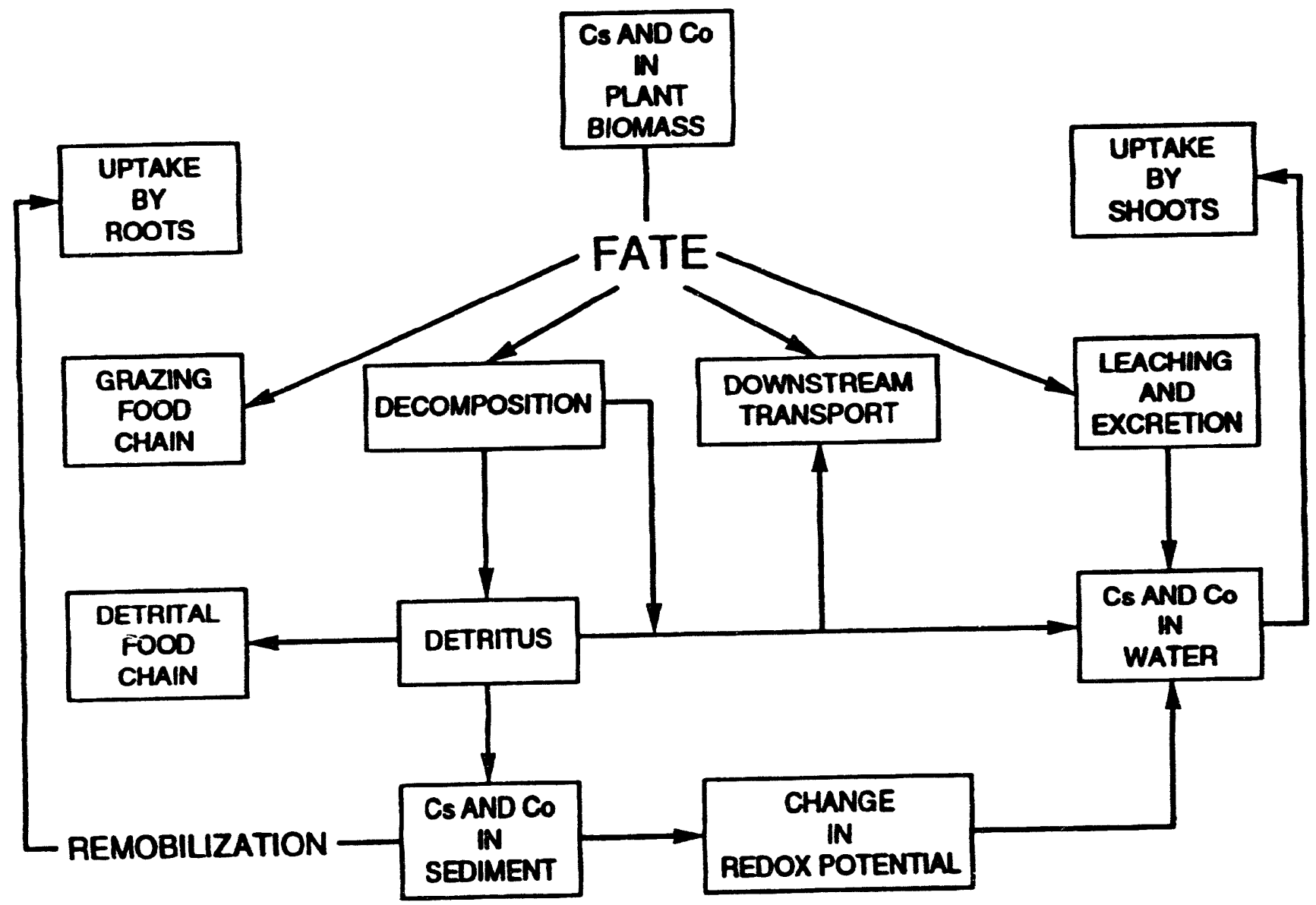

Fig. 8.1. Remobilization and Fate of Cesium-137 and Cobalt-60. 
aquatic plant populations in these small, manageable systems are more constant from year to year.

Several tasks were initiated in 1988, including (1) collection of aquatic plants from WOL for determination of radionuclide concentrations, (2) monitoring the biomass and radionuclide concentration in plants at the WOC and Melton Branch weirs as surrogates for the WOL plant populations, and (3) use of experiments to determine the contribution of sediments to the macrophyte radionuclide pool (i.e., root uptake of sediment radionuclides).

\subsubsection{Methods}

During late summer 1988, a survey was conducted in WOL to determine the composition, distribution, and contaminant content of the macrophytes. Samples of submerged and floating plants and sediment cores $(30.5 \mathrm{~cm}$ depth) were collected from the downstream, midsection, and upper end of the lake and analyzed for gamma-emitting radionuclides. Biomass was not determined due to the patchy distribution of the plants throughout the lake.

In late March 1988, WOC weir was surveyed to determine the area and average water depth. A map was computer generated, based on the resulting survey data (Fig. 8.2). The weir on Melton Branch (MB) was not mapped because it was small, shallow, and had few aquatic plants.

Samples of all plant types encountered were collected once a month from April to December at the MB and WOC weirs to determine whether any differences existed in species composition and radionuclide concentrations between the two sites. Cattails (Typha latifolia) were collected every other month. Biomass was calculated on a monthly basis from April to July for milfoil (Myriophyllum spicatum) at the WOC weir. Nine or 10 sites were randomly selected along transect lines and sampled, using a $0.17-\mathrm{m}^{2}$ bottomless aluminum can and a small garden rake to detach the above-ground portions of the milfoil. The total dry weight was determined for the entire weir and expressed on a per-unit area (measured in square meters) basis. The epiphyton clinging to the milfoil surfaces was removed for radionuclide analysis. Surface sediment samples were also collected and analyzed for radionuclides at each site where biomass was collected. All vegetation samples collected in the field were rinsed with tap water. Vegetation and sediment samples were oven dried at $60^{\circ} \mathrm{C}$ for $24-48 \mathrm{~h}$. Concentrations of ${ }^{137} \mathrm{Cs}$ and ${ }^{60} \mathrm{Co}$ were determined on a Nuclear Data 6700 microprocessor coupled to a Tennelec intrinsic germanium solid-state detector. Selected samples were sent to the ORNL Analytical Chemistry Division for ${ }^{90} \mathrm{Sr}$ determination and ICP analysis.

Reciprocal transplant studies were conducted to determine the contribution of sediment vs water column sources of ${ }^{137} \mathrm{Cs}$ and ${ }^{60} \mathrm{Co}$ to the macrophyte radionuclide pool. Uncontaminated young shoots of milfoil and Elodea canandensis were rooted in small plastic tubs containing either contaminated sediments from one of the weirs or uncontaminated (clean) sediments of the same general composition. Sand was placed on top of the sediment to prevent cross-contamination with the water. In late May, 50 plants rooted in WOC weir sediments were placed in WOC weir and 50 plants rooted in $\mathrm{MB}$ sediments were placed in the MB weir. Fifty plants rooted in clean sediments were also placed in each weir. Plant shoots and tub sediments were collected in July and early November and analyzed for their radionuclide content. In November, plant roots were also collected and analyzed. A comparison of the ${ }^{137} \mathrm{Cs}$ and ${ }^{60} \mathrm{Co}$ concentrations in shoots of plants grown in the contaminated sediments with those grown in the clean sediments 


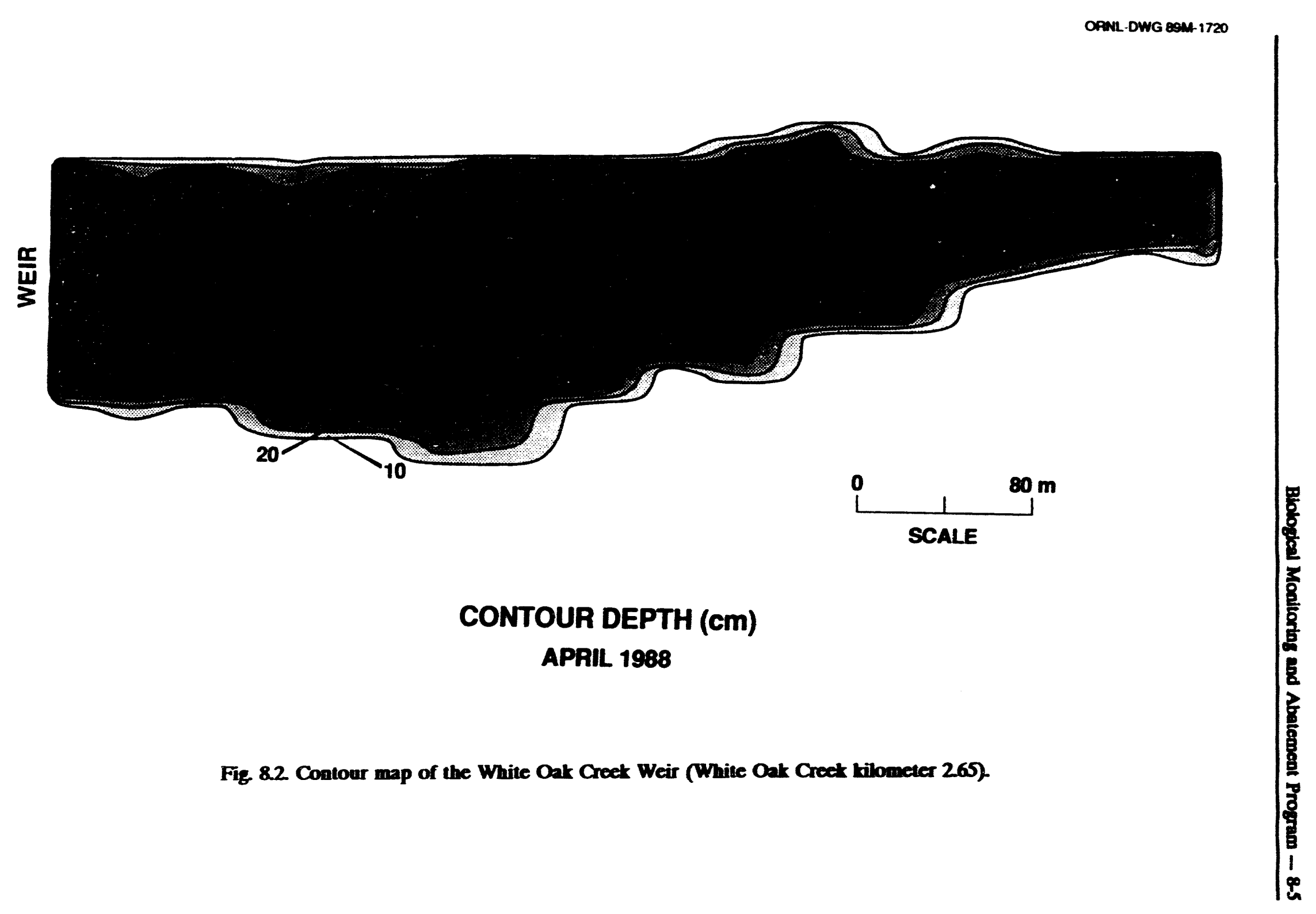


provided an estimate of the contributions of sediment and water column ${ }^{137} \mathrm{Cs}$ and ${ }^{60} \mathrm{Co}$ to the macrophyte radionuclide pool. (I.e., a greater concentration of radionuclides in the shoots of plants grown in contaminated sediment was assumed to reflect the uptake of radionuclides from the sediment in addition to uptake from the water column.)

\section{Results and Discussion}

\subsubsection{White Oak Lake survey}

Submerged and floating aquatic vegetation were abundant in WOL during late summer 1988. Milfoil and duckweeds (Lemna minor and Wolffia) were the most abundant species, covering approximately one-third of the lake surface (visual estimate). The radionuclide concentrations in milfoil were highest at the upstream end of the lake, $2.06 \times 10^{4} \mathrm{~Bq} / \mathrm{kg}$ dry wt for ${ }^{137} \mathrm{Cs}$ and $2.74 \times 10^{3} \mathrm{Bg} / \mathrm{kg}$ dry wt for ${ }^{60} \mathrm{Co}$ (Fig. 8.3). Similar concentrations of ${ }^{137} \mathrm{Cs}$ and ${ }^{60} \mathrm{Co}$ were found in milfoil from the middle of the lake and near the dam (downstream end), averaging $\sim 6.96 \times$ $10^{3} \mathrm{~Bq} / \mathrm{kg}$ dry wt for ${ }^{137} \mathrm{Cs}$ and $\sim 1.05 \times$ $10^{3} \mathrm{~Bq} / \mathrm{kg}$ dry wt for ${ }^{60} \mathrm{Co}$. Cesium-137 concentrations in milfoil at the dam and middle of the lake were one-third of those in plants at the upper end. Samples of filamentous algae (Spirogyra) and duckweed collected throughout the lake were composited separately for analysis. In both plants, ${ }^{137} \mathrm{Cs}$ concentrations were similar ( $-3.43 \times 10^{3} \mathrm{Bg} / \mathrm{kg}$ dry $\left.\mathrm{wt}\right)$, while ${ }^{60} \mathrm{Co}$ concentrations ranged from $4.81 \times$ $10^{2} \mathrm{~Bq} / \mathrm{kg}$, dry wt in algae to $9.25 \times$ $10^{2} \mathrm{~Bq} / \mathrm{kg}$ dry wt in duckweed. The concentrations of ${ }^{137} \mathrm{Cs}$ in the rooted plants were highest where sediments had the highest concentration of ${ }^{137} \mathrm{Cs}$ (Fig. 8.3). However, concentrations of ${ }^{60} \mathrm{Co}$ in plants and sediment from these regions were not correlated.

\subsubsection{White Oak Creek and Melton Branch sampling}

Discharges at the Melton Branch and WOC weirs differed in the concentration of ${ }^{137} \mathrm{Cs}$ and ${ }^{60} \mathrm{Co}$ and the ratio between the two radionuclides. Both water and sediment in WOC contained a greater proportion of ${ }^{137} \mathrm{Cs}$, while the converse was true for Melton Branch (Table 8.2). In both systems, sediments contained much higher concentrations than did water. Concentrations of ${ }^{137} \mathrm{Cs}$ and ${ }^{60} \mathrm{Co}$ in WOC are very similar to the concentrations found in WOL (Table 8.2).

\section{White Oak Creek weir}

Milfoil was the only submerged species present in significant quantity for sampling at the WOC weir. Milfoil biomass was initially sampled during April and averaged $1.46 \times 10^{-1} \mathrm{~kg}$ dry $\mathrm{wt} / \mathrm{m}^{2}$. Biomass increased during the next few months but was greatly reduced following severe storms during July (Table 8.3 ). Because vegetation did not regrow significantly during the following months, only grab samples could be collected. The mean concentration of ${ }^{137} \mathrm{Cs}$ and ${ }^{60} \mathrm{Co}$ in the milfoil collected from April to October was about $1.34 \times 10^{4}$ and $2.41 \times 10^{5} \mathrm{~Bq} / \mathrm{kg}$ dry wt respectively. Concentrations of ${ }^{137} \mathrm{Cs}$ in milfoil were substantially higher following the July storms (Table 8.3). Unlike ${ }^{137} \mathrm{Cs}$, concentrations of ${ }^{60} \mathrm{Co}$ in milfoil shoots were greatest during May and continually decreased thereafter. Strontium-90 concentrations in the milfoil ranged from $7.40 \times 10^{2}$ to $1.18 \times 10^{3} \mathrm{~Bq} / \mathrm{kg}$ dry $\mathrm{wt}$ and did not differ seasonally. 

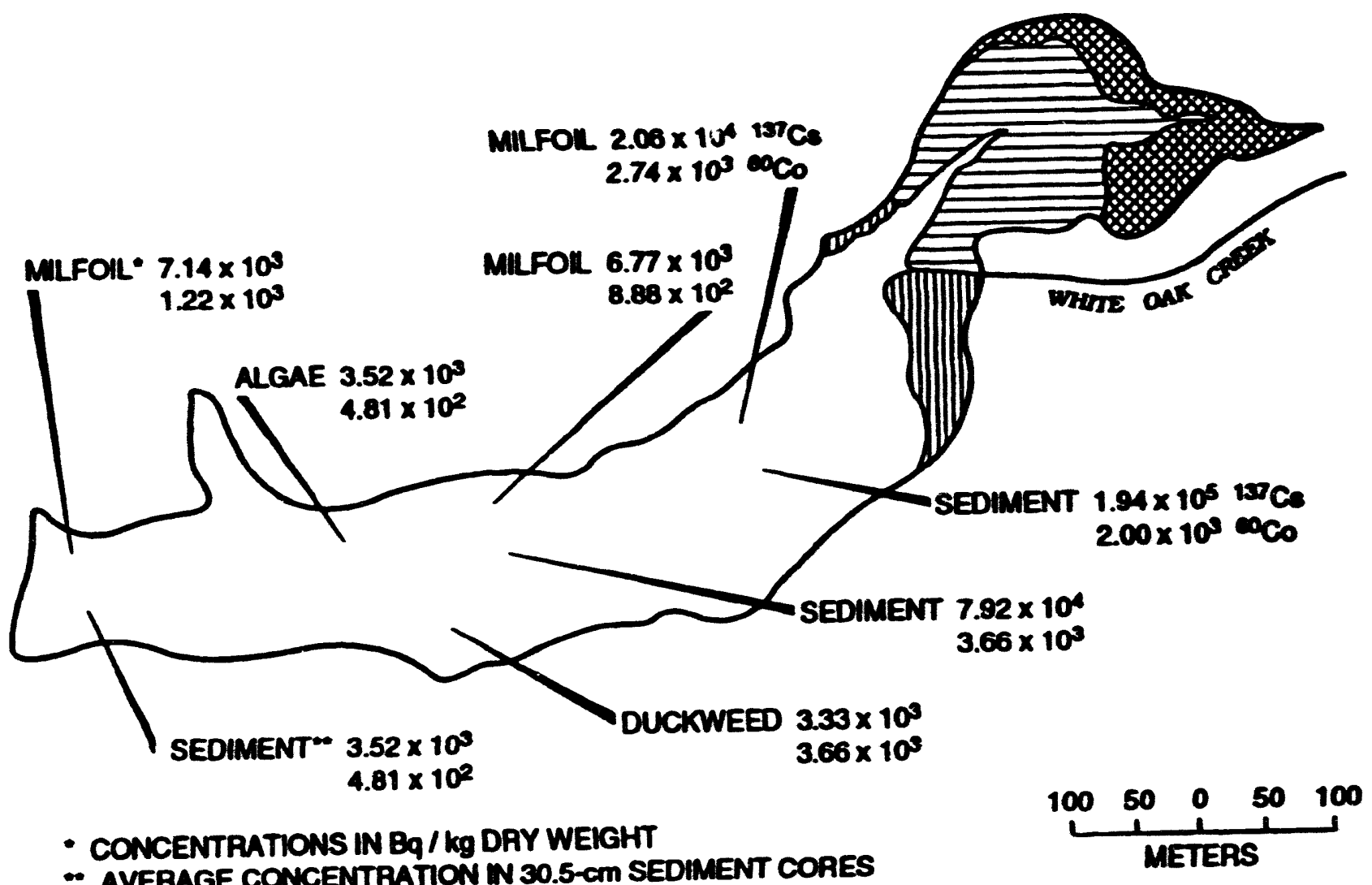

- CONCENTRATIONS IN Bq / kg DRY WETH 30.5 -cm SEDMMENT CORES

Fig 8.3. Radionuclide concentrations in the macrophytes and sodimeats in the upstream, mid-section and downstream portions of White Oak Lake. 
Table 8.2. Mean radionuclide concentrations in the water column and sediments of Melton Branch weir, White Oak Creek weir and White Oak Lake

\begin{tabular}{lccc}
\hline Location & Radionuclide & $\begin{array}{c}\text { Water } \\
(\mathrm{Bq} / \mathrm{L})\end{array}$ & $\begin{array}{c}\text { Sediment } \\
(\mathrm{Bg} / \mathrm{kg} \text { dry wt })\end{array}$ \\
\hline White Oak Lake & ${ }^{137} \mathrm{Cs}$ & $1.52 \times 10^{\circ}$ & $1.32 \times 10^{5}$ \\
& ${ }^{\circ} \mathrm{Co}$ & $7.40 \times 10^{-2}$ & $8.60 \times 10^{1}$ \\
& ${ }^{\circ} \mathrm{Sr}$ & $4.96 \times 10^{\circ}$ & $1.16 \times 10^{2}$ \\
White Oak Creek weir & ${ }^{137} \mathrm{Cs}$ & $1.52 \times 10^{\circ}$ & $1.32 \times 10^{5}$ \\
& ${ }^{\circ} \mathrm{Co}$ & $3.70 \times 10^{-2}$ & $2.26 \times 10^{3}$ \\
& ${ }^{90} \mathrm{Sr}$ & $4.14 \times 10^{\circ}$ & $8.14 \times 10^{2}$ \\
& & & $1.85 \times 10^{3}$ \\
Meiton Branch weir & ${ }^{137} \mathrm{Cs}$ & $7.40 \times 10^{-2}$ & $3.86 \times 10^{4}$ \\
& ${ }^{\circ 0} \mathrm{Co}$ & $1.04 \times 10^{\circ}$ & $6.29 \times 10^{2}$ \\
\hline
\end{tabular}

Table 8.3. Biomass and radionuclide concentration of Myriophyllum spicatum (milfoil) and associated epiphyton in White Oak Creek weir in 1988

Values are the mean $\pm 1 S D ; N D=$ Not detected;

NA $=$ Not analyzed; $N=$ Number of samples analyzed

\begin{tabular}{|c|c|c|c|c|c|}
\hline Month & $N$ & $\begin{array}{c}\text { Biomass } \\
\left(\mathrm{kg} / \mathrm{m}^{2} \text {, dry } \mathrm{w} t\right)\end{array}$ & $\begin{array}{c}{ }^{137} \mathrm{Cs} \\
(\mathrm{Bq} / \mathrm{kg}, \mathrm{dry} w \mathrm{w})\end{array}$ & $\begin{array}{c}{ }^{60} \mathrm{Co} \\
\text { (Bq/kg, dry wt) }\end{array}$ & $\begin{array}{c}{ }^{90} \mathrm{Sr} \\
(\mathrm{Bq} / \mathrm{kg}, \mathrm{dry} w t)\end{array}$ \\
\hline $\begin{array}{l}\text { April } \\
\text { milfoil } \\
\text { epiphyton }\end{array}$ & $\begin{array}{l}9 \\
9\end{array}$ & $0.146 \pm 0.064$ & $\begin{array}{c}7470 \pm 2310 \\
59600 \pm 8580\end{array}$ & $\begin{array}{c}3100 \pm 988 \\
244 \pm 285\end{array}$ & $\begin{array}{c}1090 \pm 8 \\
\text { NA }\end{array}$ \\
\hline $\begin{array}{l}\text { May } \\
\text { milfoil }\end{array}$ & 10 & $0.232 \pm 0.080$ & $8210 \pm 2530$ & $5590 \pm 2520$ & $1200 \pm 263^{\circ}$ \\
\hline $\begin{array}{l}\text { June } \\
\text { milfoil } \\
\text { epiphyton }\end{array}$ & $\begin{array}{l}9 \\
9\end{array}$ & $0.175 \pm 0.106$ & $\begin{array}{c}7220 \pm 2800 \\
53700 \pm 21500\end{array}$ & $\begin{array}{c}2080 \pm 673 \\
N D\end{array}$ & $\begin{array}{l}740 \pm 174^{a} \\
1300 \pm 463^{a}\end{array}$ \\
\hline $\begin{array}{l}\text { July } \\
\text { milfoil } \\
\text { epiphyton }\end{array}$ & $\begin{array}{l}9 \\
8\end{array}$ & $0.036 \pm 0.014$ & $\begin{aligned} 6920 & \pm 2190 \\
67300 & \pm 14800\end{aligned}$ & $\begin{array}{l}1540 \pm 673 \\
377 \pm 381\end{array}$ & $\begin{array}{l}\text { NA } \\
\text { NA }\end{array}$ \\
\hline $\begin{array}{l}\text { August } \\
\text { milfoil } \\
\text { epiphyton }\end{array}$ & $\begin{array}{l}3 \\
2\end{array}$ & $<0.010$ & $\begin{array}{l}26200 \pm 4370 \\
9810 \pm 34200\end{array}$ & $\begin{array}{c}744 \pm 266 \\
N D\end{array}$ & $\begin{array}{c}995 \pm 200 \\
\text { NA }\end{array}$ \\
\hline $\begin{array}{r}\text { October } \\
\text { milfoil }\end{array}$ & 1 & $<0.010$ & 24200 & 1340 & NA \\
\hline
\end{tabular}


The epiphyton on the surface of milfoil in WOC was sampled four times and had a higher concentration of ${ }^{137} \mathrm{Cs}$, but a lower concentration of ${ }^{60} \mathrm{Co}$, compared with the milfoil (Table 8.3). Because epiphyton appeared to be contaminated with sediment (only about $15 \%$ organic content), the high ${ }^{137} \mathrm{Cs}$ concentration in the epiphyton probably reflects this contamination. The ${ }^{90} \mathrm{Sr}$ concentration in epiphyton was determined during June only and was similar to the concentration in milfoil $\left(1.30 \times 10^{3} \mathrm{~Bq} / \mathrm{kg}\right.$ dry wt).

In addition to milfoil, filamentous green algae (Spirogyra, Oedogonium, Cladophora), duckweed and cattails were also frequently encountered at the WOC weir. Elodea, pondweed (Potomogeton foliosus), and watercress (Radicula nasturtium-aquaticum $L$.) were each encountered only once and in very small quantities. The July storms eliminated most of the vegetation, except the emergent cattails. Extensive growth of filamentous algae was common after the July storms. The concentration of ${ }^{137} \mathrm{Cs}$ in the algae increased from $5.51 \times 10^{3} \mathrm{~Bq} / \mathrm{kg}$ dry $\mathrm{wt}$ in April to $\sim 1.62 \times 10^{5} \mathrm{~Bq} / \mathrm{kg}$ dry wt in September (Table 8.4). The ${ }^{60} \mathrm{Co}$ concentration in the filamentous algae varied seasonally and was highest $(1.05 \times$ $10^{3} \mathrm{~Bq} / \mathrm{kg}$ dry wt) during April. Duckweed sampled in June and October contained $1.59 \times 10^{3}$ and $2.79 \times 10^{4} \mathrm{~Bq} / \mathrm{kg}$ dry wt of ${ }^{137} \mathrm{Cs}$ respectively. Cobalt -60 in duckweed was negligible. Strontium-90 concentrations in the filamentous algae and duckweed ranged between $5.29 \times 10^{2}$ and $1.40 \times$ $10^{3} \mathrm{~Bq} / \mathrm{kg}$ dry wt (Table 8.4).

Concentrations of ${ }^{137} \mathrm{Cs}$ in the cattails, which were sampled four times between April and December, ranged from $3.44 \times$ $10^{2}$ to $1.83 \times 10^{3} \mathrm{~Bq} / \mathrm{kg}$ dry wt; the ${ }^{60} \mathrm{Co}$ concentration was negligible. Strontium-90 concentrations in the cattails during April and July were $3.20 \times 10^{3}$ and $1.38 \times$ $10^{3} \mathrm{~Bq} / \mathrm{kg}$, dry wt respectively (Table 8.4 ).
Comparison of Plant Types at White Oak Creek weir. Concentrations of ${ }^{137} \mathrm{Cs}$ were higher in milfoil and Elodea during 1987 than during 1988 (Loar 1992b). However, incomplete washing of plant material during 1987 is suspected to have artificially elevated these values.

Concentrations of ${ }^{60} \mathrm{Co}$ and ${ }^{90} \mathrm{Sr}$ in milfoil and Elodea were comparable in both years (Loar 1992b). Concentrations of ${ }^{137} \mathrm{Cs},{ }^{60} \mathrm{Co}$ and ${ }^{90} \mathrm{Sr}$ in a sample of algae collected during July 1987 were within the range of values found during 1988 (Loar 1992b).

Concentrations of ${ }^{137} \mathrm{Cs}$ in rooted submerged plants were greater than or equal to concentrations in filamentous algae during 1987 but less than or equal to concentrations in filamentous algae in 1988. Substantial variation in the concentration of ${ }^{137} \mathrm{Cs}$ in rooted plants and algae made comparisons difficult. Cesium-137 was always lower in cattails than in other plants. Strontium-90 was similar for all plants in WOC (except for cattails sampled in April 1988). Cobalt-60 concentrations were lowest in cattails, intermediate in algae and Elodea, and highest in milfoil. There were no consistent differences in the concentration of the three radionuclides among rooted and nonrooted macrophytes.

Melton Branch weir. Cattails were collected during May, July, September, and December 1988. Concentrations of ${ }^{60} \mathrm{Co}$ ranged from $1.01 \times 10^{3}$ to $5.18 \times$ $10^{1} \mathrm{~Bq} / \mathrm{kg}$ dry wt, but concentrations of ${ }^{137} \mathrm{Cs}$ were negligible (Table 8.5 ). The concentration of ${ }^{90} \mathrm{Sr}$ in cattails was determined for samples collected during May and July 1988 and was high compared with cattails from WOC.

The concentration of ${ }^{60} \mathrm{Co}$ in filamentous algae was greater than that of ${ }^{137} \mathrm{Cs}$, as was true for other plants in Melton Branch. Cobalt-60 in algae tended to decrease with time, while ${ }^{137} \mathrm{Cs}$ reached a maximum during July. Concentrations of 
Table 8.4. Radionuclide concentrations in aquatic macrophytes collected in White Oak Creek weir in 1988

\begin{tabular}{|c|c|c|c|c|}
\hline Month/species & $n$ & $\begin{array}{c}{ }^{137} \mathrm{Ca} \\
(\mathrm{Bq} / \mathrm{kg} \text { dry wt) }\end{array}$ & $\begin{array}{c}{ }^{\infty 0} \mathrm{Co} \\
(\mathrm{Bq} / \mathrm{kg} \text { dry } w t)\end{array}$ & $\begin{array}{c}{ }^{90} \mathrm{Sr} \\
(\mathrm{Bq} / \mathrm{kg} \text { dry wt) }\end{array}$ \\
\hline \multicolumn{5}{|l|}{ April } \\
\hline $\begin{array}{l}\text { Pondweed } \\
\text { Filamentous }\end{array}$ & 1 & 4550 & 311 & 1200 \\
\hline algae & 1 & 5510 & 1050 & 629 \\
\hline Cattails & 2 & $1830 \pm 1610$ & $37 \pm 44$ & $3200 \pm 2550$ \\
\hline \multicolumn{5}{|l|}{ May } \\
\hline $\begin{array}{l}\text { Filamentous } \\
\text { algae }\end{array}$ & 2 & $12100 \pm 1770$ & $377 \pm 192$ & $1400^{\circ}$ \\
\hline \multicolumn{5}{|l|}{ June } \\
\hline $\begin{array}{l}\text { Filamentous } \\
\text { algae } \\
\text { Duckweed }\end{array}$ & $\begin{array}{l}2 \\
2\end{array}$ & $\begin{array}{c}8660 \pm 3250 \\
1590 \pm 810\end{array}$ & $\begin{aligned} 155 & \pm 218 \\
70 & \pm 15\end{aligned}$ & $\begin{array}{l}781^{\circ} \\
1200^{\circ}\end{array}$ \\
\hline \multicolumn{5}{|l|}{ July } \\
\hline Cattails & 2 & $344 \pm 4$ & $11 \pm 0$ & $1380 \pm 1170$ \\
\hline $\begin{array}{l}\text { August } \\
\text { Filamentous } \\
\text { algae } \\
\text { Elodea }\end{array}$ & $\begin{array}{l}3 \\
1\end{array}$ & $\begin{array}{c}94700 \pm 13400 \\
3850\end{array}$ & $\begin{array}{c}799 \pm 318 \\
\text { ND }\end{array}$ & $\begin{array}{l}529^{a} \\
\text { NA }\end{array}$ \\
\hline $\begin{array}{l}\text { September } \\
\text { Filamentous } \\
\text { algae }\end{array}$ & \multicolumn{3}{|c|}{ September } & NA \\
\hline Cattails & 1 & 544 & ND & NA \\
\hline $\begin{array}{l}\text { October } \\
\text { Filamentous } \\
\text { aloge }\end{array}$ & 1 & 22100 & ND & NA \\
\hline Duckweed & 1 & 27900 & ND & $\mathrm{NA}$ \\
\hline $\begin{array}{l}\text { November } \\
\text { Watercress }\end{array}$ & \multicolumn{2}{|c|}{ November } & 566 & NA \\
\hline \multicolumn{5}{|l|}{ December } \\
\hline Elodea & 1 & 6880 & 673 & NA \\
\hline Catails & 1 & 799 & ND & NA \\
\hline
\end{tabular}


Table 8.5. Radionuclide concentrations in aquatic macrophytes collected in Melton Branch weir in 1988

\begin{tabular}{|c|c|c|c|c|}
\hline Month/species & $n$ & $\begin{array}{c}{ }^{60} \mathrm{Co} \\
(\mathrm{Bg} / \mathrm{kg} \text { dry wt) }\end{array}$ & $\begin{array}{c}{ }^{137} \mathrm{Cs} \\
(\mathrm{Bq} / \mathrm{kg} \mathrm{dry} \mathrm{wt})\end{array}$ & $\begin{array}{c}{ }^{90} \mathrm{Sr} \\
(\mathrm{Bq} / \mathrm{kg} \mathrm{dry} w t)\end{array}$ \\
\hline $\begin{array}{l}\text { May } \\
\text { Pondweed } \\
\text { Cattails }\end{array}$ & $\begin{array}{l}2 \\
2\end{array}$ & $\begin{array}{l}5920 \pm 2590 \\
1010 \pm 1090\end{array}$ & $\begin{array}{c}196 \pm 89 \\
52 \pm 67\end{array}$ & $\begin{array}{l}5810^{\circ} \\
2800^{\circ}\end{array}$ \\
\hline $\begin{array}{l}\text { June } \\
\text { Filamentous } \\
\text { algae } \\
\text { Pondweed }\end{array}$ & $\begin{array}{l}2 \\
1\end{array}$ & $\begin{array}{c}13900 \pm 1070 \\
5370\end{array}$ & ${ }_{81}^{303 \pm 311}$ & $\begin{array}{l}599^{\circ} \\
\text { NA }\end{array}$ \\
\hline $\begin{array}{l}\text { July } \\
\text { Filamentous } \\
\text { algae } \\
\text { Pondweed } \\
\text { Duckweed } \\
\text { Cattails }\end{array}$ & $\begin{array}{l}1 \\
1 \\
1 \\
1\end{array}$ & $\begin{array}{c}8730 \\
8100 \\
6510 \\
455\end{array}$ & $\begin{array}{c}1240 \\
248 \\
\text { ND } \\
4\end{array}$ & $\begin{array}{l}\text { NA } \\
2000 \\
1800 \\
3400\end{array}$ \\
\hline $\begin{array}{l}\text { August } \\
\text { Filamentous } \\
\text { algae } \\
\text { Duckweed }\end{array}$ & $\begin{array}{l}1 \\
1\end{array}$ & $\begin{array}{c}9510 \\
11500\end{array}$ & $\begin{array}{l}207 \\
344\end{array}$ & $\begin{array}{l}5220 \\
4110\end{array}$ \\
\hline $\begin{array}{l}\text { September } \\
\text { Filamentous } \\
\text { algae } \\
\text { Duckweed } \\
\text { Cattails }\end{array}$ & $\begin{array}{l}1 \\
1 \\
1\end{array}$ & $\begin{array}{c}2680 \\
11500 \\
52\end{array}$ & $\begin{array}{c}307 \\
130 \\
7\end{array}$ & $\begin{array}{l}\text { NA } \\
\text { NA } \\
\text { NA }\end{array}$ \\
\hline $\begin{array}{l}\text { October } \\
\text { Filamentous } \\
\text { algae } \\
\text { Pondweed } \\
\text { Duckweed }\end{array}$ & $\begin{array}{l}2 \\
1 \\
1\end{array}$ & $\begin{array}{c}3890 \pm 344 \\
3380 \\
12300\end{array}$ & $\begin{array}{c}104 \pm 56 \\
155 \\
\text { ND }\end{array}$ & $\begin{array}{l}\text { NA } \\
\text { NA } \\
\text { NA }\end{array}$ \\
\hline $\begin{array}{l}\text { November } \\
\text { Watercress } \\
\text { Bulrush }\end{array}$ & $\begin{array}{l}1 \\
1\end{array}$ & $\begin{array}{c}4440 \\
87\end{array}$ & $\begin{array}{c}411 \\
4\end{array}$ & $\begin{array}{l}\text { NA } \\
\text { NA }\end{array}$ \\
\hline $\begin{array}{l}\text { December } \\
\text { Cattails }\end{array}$ & 1 & 116 & ND & NA \\
\hline
\end{tabular}

$\triangle N=1$.

Note: Values are the mean $\pm 1 \mathrm{SD} ; \mathrm{ND}=$ Not detected; NA $=$ Not analyzed; $n=$ Number of samples analyzed. 
${ }^{60} \mathrm{Co}$ and ${ }^{137} \mathrm{Cs}$ in duckweed were similar to those found in the filamentous algae, but temporal changes in the concentration of these radionuclides were not similar for these plants. Strontium-90 concentrations were variable in the floating, nonrooted plants.

With the exception of cattails, there were no stable populations of rooted plants at the Melton Branch weir, so samples were collected as encountered. The concentrations of ${ }^{137} \mathrm{Cs}$ and ${ }^{60} \mathrm{Co}$ in the pondweed were intermediate between the cattails and algae. Strontium-90 concentrations also varied in pondweed.

The ${ }^{60} \mathrm{Co}^{137} \mathrm{Cs}$ ratio was higher for plants in Melton Branch than plants in WOC, reflecting sediment and water column concentrations of these radionuclides at those locations (Table 8.2).

\subsubsection{Determining the sources of macrophyte radionuclides}

Rooted, submerged species have access to both water column and sediment sources of radionuclides but, according to Barko and Smart (1981), may rely almost exclusively on the sediments for their mineral nutrition. Milfoil and Elodea used in the reciprocal transplant studies initiated during May were harvested in July and November. Comparison of the radionuclide concentration of plants grown in clean sediment with concentrations in those grown in contaminated sediment allows the estimation of the contribution of sediment radionuclides to the macrophyte radionuclide pool.

The July samples indicated that milfoil and Elodea in WOC accumulated between 30 and $40 \%$ of their ${ }^{137} \mathrm{Cs}$ content from the sediments (assuming the concentration in plants in contaminated sediment minus the concentration in plants in clean sediment equals the minimum amount accumulated from the sediment). Concentrations of ${ }^{60} \mathrm{Co}$ for plants grown in clean or contaminated sediments in WOC were not different (Table 8.6).

By November, only milfoil remained at the WOC site, and plants grown in either clean or contaminated sediment had similar concentrations of ${ }^{137} \mathrm{Cs}$ and ${ }^{60} \mathrm{Co}$ (Table 8.6). On both sampling dates, experimental plants had concentrations of ${ }^{137} \mathrm{Cs}$ and ${ }^{60} \mathrm{Co}$ within the range of concentrations found in plants at the weirs. For plants in WOC these results suggest that accumulation from the water column can be sufficient to account for the entire macrophyte radionuclide pool. Interestingly, in November, the roots of milfoil grown in uncontaminated sediments in WOC (which could only acquire radionuclides from the water) contained $3.18 \times 10^{3} \mathrm{~Bq} / \mathrm{kg}$ dry wt of ${ }^{137} \mathrm{Cs}$ and 2.59 $\times 10^{2} \mathrm{~Bq} / \mathrm{kg}$ dry wt of ${ }^{60} \mathrm{Co}$. The clean sediments that the plants were grown in were also analyzed but contained no detectable ${ }^{137} \mathrm{Cs}$ and ${ }^{60} \mathrm{Co}$, suggesting that the shoots of these plants had actively translocated the radionuclides down to the roots.

At the Melton Branch weir in July, 15 to $25 \%$ of the ${ }^{60} \mathrm{Co}$ in experimental milfoil and Elodea was acquired from the sediments. Concentrations of ${ }^{137} \mathrm{Cs}$ were low and similar for both species (Table 8.6).

In November, only Elodea remained in tubs at Melton Branch. Comparison of ${ }^{137} \mathrm{Cs}$ and ${ }^{60} \mathrm{Co}$ for Elodea in clean and contaminated sediment in Melton Branch collected in November indicated that about $60 \%$ of the ${ }^{60} \mathrm{Co}$ content was sediment derived. Elodea did not accumulate a significant amount of ${ }^{137} \mathrm{Cs}$ in Melton Branch. It appears that rooted, submerged macrophytes rely largely on the water 
Table 8.6. Results of transplant studies conducted at the White Oak Creek and Melton Branch weirs

\begin{tabular}{|c|c|c|c|c|c|}
\hline & & \multicolumn{2}{|c|}{ White Oak Creek } & \multicolumn{2}{|c|}{ Melton Branch } \\
\hline & & ${ }^{137} \mathrm{Cs}$ & ${ }^{\infty 0} \mathrm{Co}$ & ${ }^{137} \mathrm{Cs}$ & ${ }^{60} \mathrm{Co}$ \\
\hline \multicolumn{6}{|c|}{ July } \\
\hline $\begin{array}{l}\text { milfoil } \\
\qquad \begin{array}{l}n=3 \\
n=3\end{array}\end{array}$ & $\begin{array}{l}\text { contaminated } \\
\text { clean }\end{array}$ & $\begin{array}{l}27700 \pm 2260 \\
19300 \pm 3890\end{array}$ & $\begin{array}{l}622 \pm 222 \\
629 \pm 111\end{array}$ & $\begin{array}{c}37 \pm 74 \\
444 \pm 222\end{array}$ & $\begin{aligned} 10800 & \pm 2920 \\
7990 & \pm 481\end{aligned}$ \\
\hline $\begin{array}{c}\text { Elodea } \\
n=3 \\
n=3\end{array}$ & $\begin{array}{l}\text { contaminated } \\
\text { clean }\end{array}$ & $\begin{array}{l}35300 \pm 3850 \\
21200 \pm 2180\end{array}$ & $\begin{array}{c}\text { ND } \\
333 \pm 592\end{array}$ & $\begin{array}{c}\text { ND } \\
148 \pm 259\end{array}$ & $\begin{array}{l}10500 \pm 1590 \\
9030 \pm 3000\end{array}$ \\
\hline
\end{tabular}

November

milfoil

$n=4 \quad$ contaminated $\quad 22000 \pm 5070 \quad 888 \pm 111$

$n=4$ clean $\quad 24200 \pm 3550 \quad 777 \pm 629$

NA NA

NA NA

Elodea

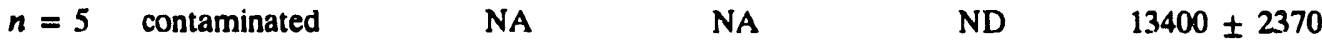

$\begin{array}{llllll}n=2 & \text { clean } & \text { NA } & \text { NA } & \text { ND } & 5400 \pm 851\end{array}$

Note: Values are in becquerels per kilogram dry wt and represent the mean \pm SD; ND $=$ not detected;

NA $=$ not analyzed; $n=$ number of samples analyzed.

column for ${ }^{137} \mathrm{Cs}$ and upon both sediment and water column for ${ }^{60} \mathrm{Co}$. The accumulation of these radionuclides by rooted plants seems related to water column concentrations for ${ }^{137} \mathrm{Cs}$ and both water column and sediment concentrations for ${ }^{60} \mathrm{Co}$.

\subsubsection{Summary}

The 1988 survey of WOL revealed an abundance of submerged and floating vegetation covering approximately one-third of the lake. The ${ }^{137} \mathrm{Cs}$ content of the most abundant species in WOL (milfoil) was highest at the upper end of the lake. The highest concentrations of ${ }^{137} \mathrm{Cs}$ occurred in those macrophytes that were collected from areas with the highest concentrations of ${ }^{137} \mathrm{Cs}$ in the sediment.
The aquatic vegetation in WOC weir contained substantial quantities of ${ }^{137} \mathrm{Cs}$ but insignificant amounts of ${ }^{60} \mathrm{Co}$, whereas in Melton Branch weir the concentration of ${ }^{60} \mathrm{Co}$ in the vegetation was considerably higher than the ${ }^{137} \mathrm{Cs}$ concentration. These differences reflect the radionuclide concentrations in the sediment and water column at these locations. The ${ }^{90} \mathrm{Sr}$ content in the macrophytes was higher at the Melton Branch weir than the WOC weir. The floating, nonrooted vegetation in the WOC weir (filamentous algae) and Melton Branch weir (filamentous algae and duckweed) contained the highest concentrations of ${ }^{137} \mathrm{Cs}$ and ${ }^{60} \mathrm{Co}$, respectively, and the emergent, rooted species (cattails and bulrush) in both weirs generally had the lowest concentrations.

In WOC weir it appears that the rooted macrophytes are better able to 
accumulate and concentrate ${ }^{137} \mathrm{Cs}$ from the water column than from sediments, even though the concentration of radionuclides in the sediment is two orders of magnitude higher than that in the water. In the Melton Branch weir, the rooted macrophytes are capable of accumulating ${ }^{60} \mathrm{Co}$ equally from both water and sediments. These results are somewhat surprising because these plants are known to obtain the bulk of their required nitrogen and phosphorus from the sediment (Barko and Smart 1981), and cesium usually behaves similarly to potassium, which is required in high concentrations. The availability of ${ }^{137} \mathrm{Cs}$ in the sediments and water column may be low due to the irreversible binding of ${ }^{137} \mathrm{Cs}$ to illitic clay particles (Lomenick and Gardiner 1965), rendering them inaccessible for absorption. Cobalt-60, however, tends to bind reversibly to organic compounds and may be more available for uptake by macrophytes. Differences in elemental concentrations in the plants, sediments, and water, specifically the major macronutrients of plants (i.e. $K, N$, and $P$ ), may provide additional information on uptake pathways of plants and any physiological differences that may exist between species. The submerged plants in WOL may serve as sources of dissolved contaminants to other biotic components of the food chain through several processes; for example, direct grazing of the plants and the leaching and excretion of radionuclides during growth, senescence, and decomposition. Future investigations will address the fate of macrophyte-associated radionuclides in the WOL system, including the determination of how much of the radioactivity associated with the plant is actually metabolically incorporated within the plant or just bound, organically or inorganically, to the outer surfaces.

\subsection{WATERFOWL POPULATIONS ASSOCIATED WITH ORNL LAKES AND PONDS}

A. E. Waters and B. G. Blaylock

\subsubsection{Introduction}

A waterfowl study was initiated in October 1987 (Loar 1992b) to determine (1) the use by waterfowl of waste disposal ponds and settling basins on the ORR, (2) the accumulation of radionuclides and other contaminants in waterfowl, and (3) the probability of waterfowl transporting these pollutants into the food chain. Previous investigations generally assumed that the waterfowl inhabiting waste disposal ponds were transient; any contamination acquired by the birds was soon excreted, and the radiation dose from consuming one of these birds after it left the ORR was therefore insignificant. Mallards collected from WOL in 1987 and analyzed for ${ }^{137} \mathrm{Cs},{ }^{60} \mathrm{Co}$, and ${ }^{90} \mathrm{Sr}$ showed low tissue concentrations of ${ }^{137} \mathrm{Cs}(140$ $\mathrm{Bq} / \mathrm{kg}$ wet $\mathrm{wt}$ ) and only trace amounts of ${ }^{60} \mathrm{Co}$, well below safe limits. These birds were assumed to be transients.

\subsubsection{Materials and Methods}

A weekly waterfowl ground census was initiated in October 1987, for 11 sites near ORNL. The census of an additional 13 sites near the K-25 Site began in October 1988. Both surveys will continue through October 1990. Census by aircraft conducted by the Tennessee Wildlife Resources Agency (TWRA) will begin pending DOE approval. The aerial census will include transects across Chickamauga, Ft. Loudoun, Tellico, Watts Bar, Melton Hill, and Norris reservoirs.

In February 1988, three American coots were collected from WOL. 
Whole-body gamma counts were conducted on the birds using an intrinsic germanium solid-state detector. The coots were then dissected and the following body tissues were analyzed for gamma-emitting radionuclides: breast, thigh, liver, GI tract, bone, crop contents, crop, feathers, feet, heart, and carcass. Breast tissue and bone were analyzed for ${ }^{90} \mathrm{Sr}$.

Between September 1988 and January 1989, nine transient ducks were collected from WOL to determine contaminant concentrations in tissues. Breast tissue, liver, bone, gastrointestinal tract, crop contents, feathers, and feet from these birds are currently being analyzed for gamma radioactivity. Strontium-90 analysis will be performed on bone samples.

To determine the interaction of Canada geese from the ORR with other local populations, 168 Canada geese were leg-banded in cooperation with TWRA and the University of Tennessee student chapter of the Wildlife Society on July 12 , 1988. No returns from hunters or kills have been reported for this cohort. During the banding process, five Canada geese captured at ORNL near Pond 3513 were sacrificed after detectable concentrations of ${ }^{137} \mathrm{Cs}$ were found in live whole-body counts on a sodium iodide detector. Bone samples are being analyzed for ${ }^{90} \mathrm{Sr}$, and various other body tissues are being analyzed for other radionuclides and contaminants.

\subsubsection{Results and Discussion}

The waterfowl species observed at the ORNL census locations are listed in Table 8.7, and the species observed at each site during the weekly census are listed in Table 8.8. Approximately 5000 observations of waterfowl have been recorded for ORNL aquatic ecosystems since the census was initiated in October 1987. In addition, other aquatic birds, including the great blue heron, green heron, belted kingfisher, and great egret have been observed at these sites. Waterfowl were observed at all ORNL aquatic sites except 7552A (Old Hydrofracture Pond) and HFIR-P (HFIR ponds). Swan Pond has the only resident population of ducks and geese but also attracts some transient waterfowl. The majority of waterfowl censused at ORNL were observed at Swan Pond and WOL. Swan Pond was utilized as a nesting site by Canada geese, and WOL was utilized as a nesting site by wood ducks.

The greatest numbers of waterfowl on WOL were observed during the fall migration period in both 1987 and 1988 (Fig. 8.4). However, more birds were observed in 1988 than 1987. In addition peak numbers of waterfowl on WOL occurred in December of both years. WOL may serve as a refuge for waterfowl during the hunting season, which usually occurs in December and January, or as a resting place during migration.

Ring-necked ducks arrived on Swan Pond in October 1987 and left in April 1988. They returned in October 1988 and seem to be following the same trend as the previous year, as shown in Fig. 8.5.

Canada geese are the primary species observed during the weekly census at the K-25 Site. Their numbers peaked at over 300 birds in December 1988 and have since declined (Fig. 8.6). Some of these birds are expected to nest at the K-25 Site this spring as they have in previous years.

The mean concentrations of ${ }^{137} \mathrm{Cs}$ and ${ }^{60} \mathrm{Co}$ in whole-body and various tissues of the three American coots collected from WOL are given in Table 8.9. Although these birds were observed on the lake for $\sim 3$ months, the concentrations of radionuclides in their tissues were below acceptable limits for human consumption. These levels were higher than the mallard 
Table 8.7. Species and locations of waterfowl observed at Oak Ridge National Laboratory, 1987-89

\begin{tabular}{|c|c|c|}
\hline Common name & Scientific name & Location ${ }^{a}$ \\
\hline American coot & Fulica americana & WOL \\
\hline American wigeon & Anas americana & WOL \\
\hline Black duck & Anas rubripes & MBW, WOCW, WOC, WOL, P7821 \\
\hline Blue-winged teal & Anas discors & WOCW, WOL \\
\hline Bufflehead & Bucephala albeola & $\mathbf{S P}$ \\
\hline Canada goose & Branta canadensis & SP, WOL, PC3513, Q2 \\
\hline Gadwall & Anas strepera & Q1, WOL \\
\hline Hooded merganser & Lophodytes cucullatus & WOL \\
\hline Lesser scaup & Aythya affinis & SP \\
\hline Mallard & Anas platyrhynchos & SP, MBW, WOCW, WOC, WOL, P7821 \\
\hline Pied-billed grebe & Podilymbus podiceps & WOL \\
\hline Red-breasted merganser & Mergus serrator & SP \\
\hline Ring-necked duck & Arthya collaris & $\mathrm{Q} 2, \mathrm{SP}$ \\
\hline Wood duck & Aix sponsa & MBW, WOCW WOC, WOL, Q1, P7821 \\
\hline
\end{tabular}

Table 8.8. Total number and location of waterfowl species observed during the weekly census of Oak Ridge National Laboratory ponds, October 1987-February 1989

\begin{tabular}{llr}
\hline \multicolumn{1}{c}{ Location } & \multicolumn{1}{c}{ Species } & $\begin{array}{c}\text { Total number } \\
\text { observed }\end{array}$ \\
\hline Kerr Hollow Quarry & Gadwall, wood duck & 8 \\
Roger's Quarry & Canada goose, ring-necked ducks \\
Swan Pond & $\begin{array}{l}\text { Canada goose, lesser scaup, mallard, } \\
\text { ring-necked duck, red-breasted }\end{array}$ & 15 \\
merganser & Black duck, mallard, wood duck \\
Melton Branch Weir & None & 488 \\
Old Hydrofracture Pond (7552A) & Black duck, blue-winged teal, mallard \\
White Oak Creek Weir & wood duck & 0 \\
White Oak Creek & Black duck, mallard, wood duck \\
White Oak Lake & American widgeon, black duck, blue- \\
winged teal, Canada goose, American cont, & 47 \\
gadwall, hooded merganser, mallard, pied- & 16 \\
billed grebe, wood duck & 2112 \\
Waste ponds (P3513) & Black duck, mallard, wood duck \\
\hline & Canada goose & 4198 \\
\hline
\end{tabular}




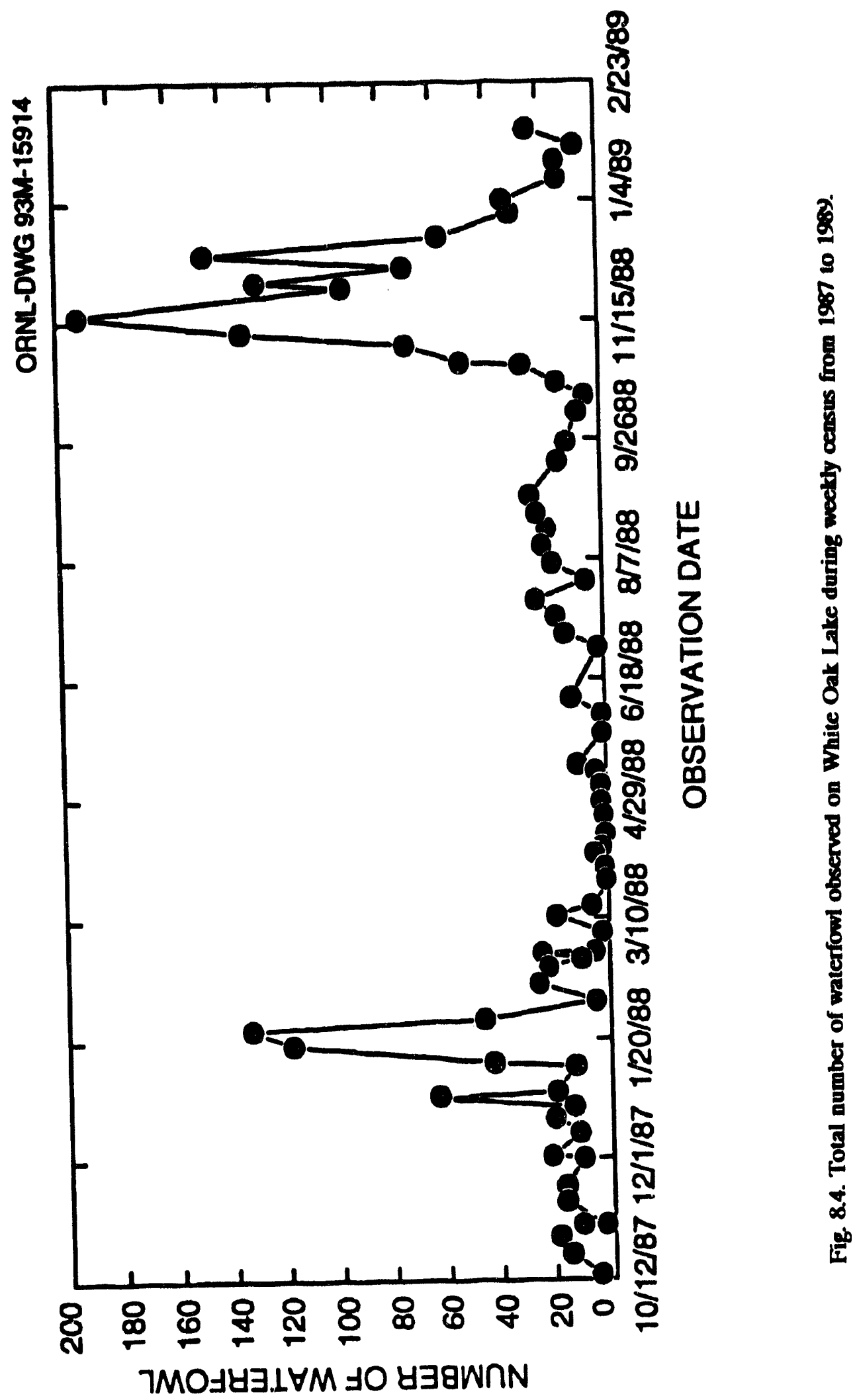




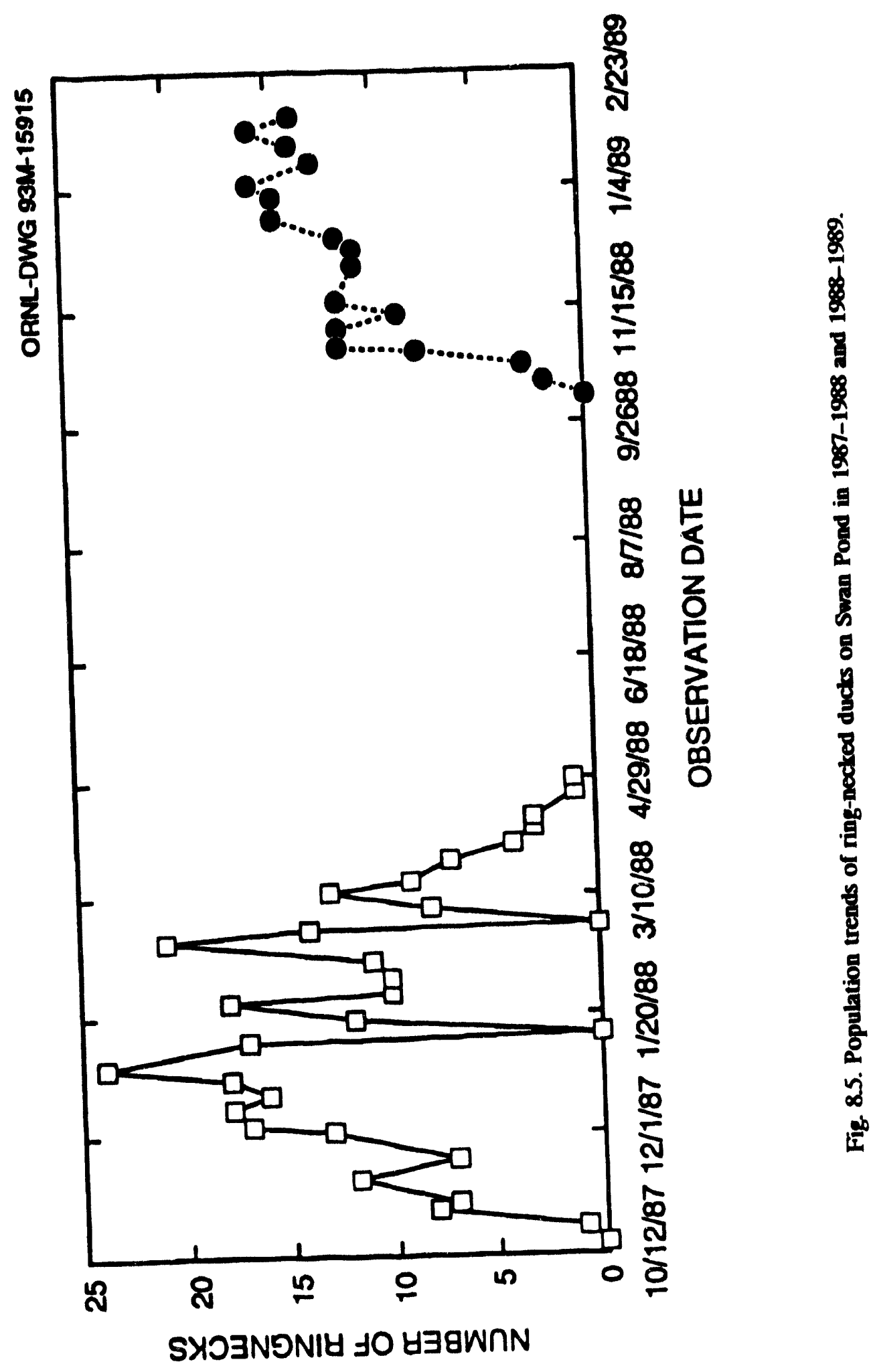




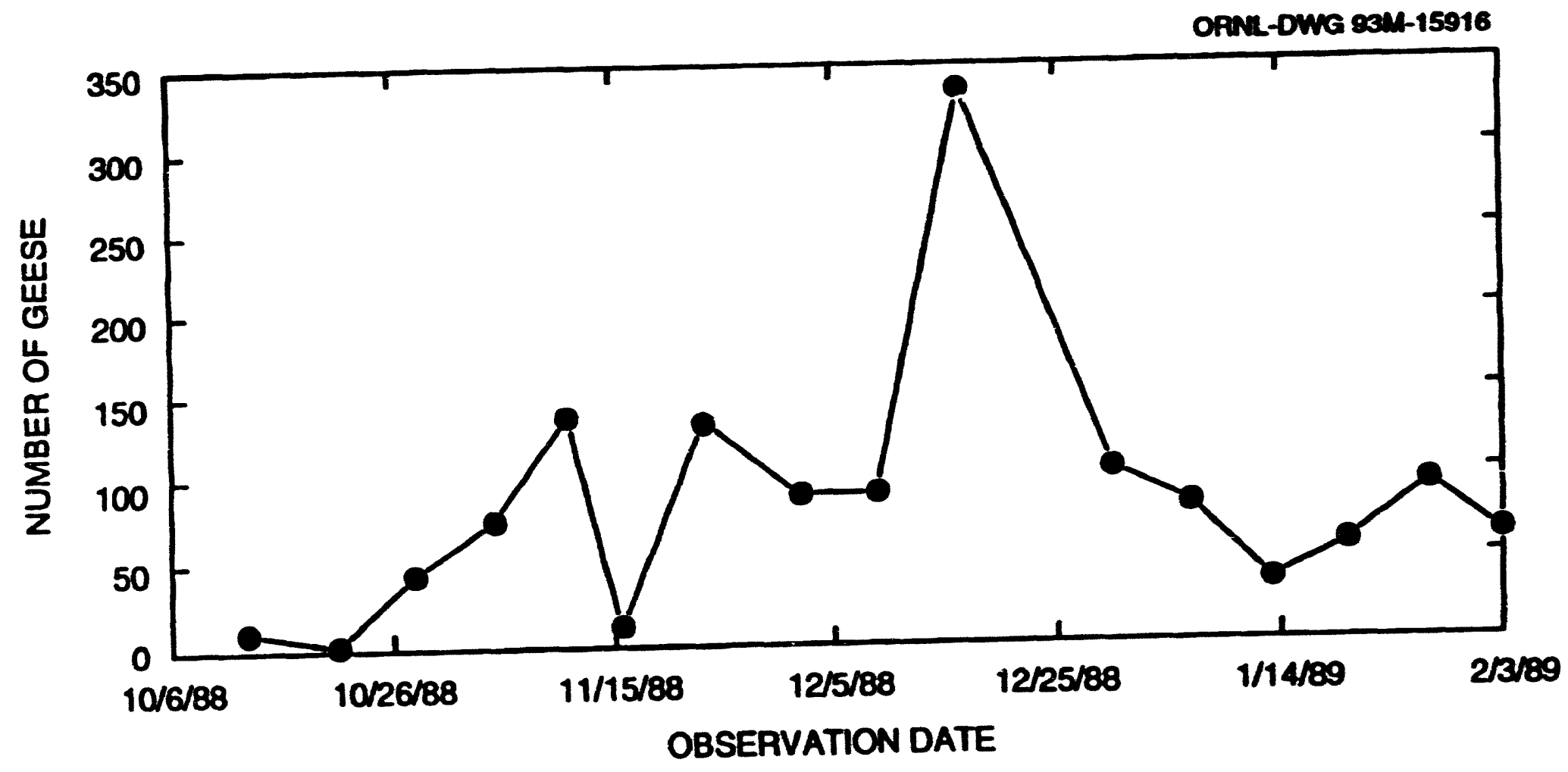

Fig 8.6. The total number of Camada Geese otserved per observation at K-25 Site desigantod siles from October 1938 
Table 89. Moan concentrations ( \pm 1 SD) of ${ }^{17} \mathrm{C}$ and ${ }^{40} \mathrm{Co}$ (in becqurels per Illogram wet woight) in American cools collected trom White Oak Lake ND $=$ Not detected

\begin{tabular}{lccc}
\hline Type of sample & $\begin{array}{c}\text { Number of birds } \\
\text { analyzed }\end{array}$ & ${ }^{137} \mathrm{C}$ & ${ }^{\infty} \mathrm{Co}$ \\
\hline Whole-body & 3 & $1457 \pm 220$ & $121 \pm 30$ \\
Breast tissue & 3 & $625 \pm 110$ & $\mathrm{ND}$ \\
Thigh tissue & 2 & $697 \pm 50$ & $\mathrm{ND}$ \\
Liver & 3 & $352 \pm 30$ & $55 \pm 8$ \\
Gl tract & 3 & $3014 \pm 2300$ & $307 \pm 230$ \\
Crop & 3 & $1085 \pm 500$ & $97 \pm 70$ \\
Crop contents & 3 & $6558 \pm 1700$ & $673 \pm 160$ \\
Bone & 3 & $364 \pm 50$ & $\mathrm{ND}$ \\
Carcass & 3 & $537 \pm 150$ & $19 \pm 8$ \\
\hline
\end{tabular}

tissues analyzed the previous year. The mean breast tissue concentration of ${ }^{137} \mathrm{Cs}$ was $625 \mathrm{~Bq} / \mathrm{kg}$ wet wt. The highest levels of ${ }^{137} \mathrm{Cs}$ were found in the GI tract and the crop contents. These birds ingested sediment which contains a significant amount of the contamination in the WOL ecosystem (Table 8.1) and probably accounts for the high concentrations of ${ }^{137} \mathrm{Cs}$ in the crop contents and GI tract. The weight of the coot with the highest ${ }^{137} \mathrm{Cs}$ concentration was $640 \mathrm{~g}$. Assuming a hunter harvests a bird with an identical ${ }^{137} \mathrm{Cs}$ concentration immediately after it leaves WOL and consumes $256 \mathrm{~g}$ of the edible tissue ( $40 \%$ of the total weight of the coot), the dose to the hunter would be approximately $.002 \mathrm{mSv}(0.22 \mathrm{mrem})$. A hunter would have to consume $99 \mathrm{~kg}$ of coot tissue to attain a dose of $1 \mathrm{mSv} / \mathrm{year}$ (100 mrem/year) (Rogers et al 1988a).

Cesium-137 was the only radionuclide detected above background levels in the five Canada geese collected near Pond 3513 at ORNL. The average breast tissue concentration was $1188 \mathrm{~Bq} / \mathrm{kg}$ wet $\mathrm{wt}$, with a maximum concentration of $1747 \mathrm{Bg} / \mathrm{kg}$ wet wt (Table 8.10). If a hunter were to consume $40 \%$ of the total weight $(2.8 \mathrm{~kg})$ of such a goose or $1120 \mathrm{~g}$ of the edible tissue from the goose with the maximum concentration of ${ }^{137} \mathrm{Cs}$ in its breast tissue, the resulting dose would be $0.02 \mathrm{mSv}$ (2.3 mrem). An individual would have to consume $42.4 \mathrm{~kg}$ of goose tissue to receive a dose rate of $1 \mathrm{mSv} /$ year (100 mrem/year) (Rogers et al. 1988b).

\subsection{RADIONUCLIDES IN FISH IN WHITE OAK CREEK}

B. G. Blaylock

\subsubsection{Introduction}

This study was initiated in 1986 to determine whether levels of radionuclides found in fish from WOL were representative of the degree of contamination found in fish from WOC and tributaries. Data on the accumulation and partitioning of ${ }^{137} \mathrm{Cs}$ were also of interest, because ${ }^{137} \mathrm{Cs}$ is a particle associated contaminant whose transport 
Table 8.10. Cesium-137 concentrations in tissues of Canada geese collected near Pond 3513 within the Oak Ridge National Laboratory complex

\begin{tabular}{lccc}
\hline & \multirow{2}{*}{ Type of sample } & Number of samples & \multicolumn{2}{c}{ Concentration $(\mathrm{Bg} / \mathrm{kg}$, wet wt) } \\
\cline { 3 - 4 } & 5 & $1188 \pm 660$ & Maximum \\
\hline Breast tissue & 5 & $626 \pm 170$ & 1747 \\
Liver & 5 & $972 \pm 260$ & 727 \\
GI tract & 4 & $864 \pm 500$ & 1295 \\
Bone & & & 1319 \\
\hline
\end{tabular}

and accumulation in this system should have much in common with the behavior of mercury and PCBs, contaminants in WOC that also are highly particle associated. In addition, the data from 1986 supported the findings of earlier investigations by Spalding and Cerling (1979) which showed that the main ORNL complex is the major source of ${ }^{137} \mathrm{Cs}$ to WOC and tributaries, and the Melton Valley facilities and SWSAs are of secondary importance.

\subsubsection{Methods}

Levels of ${ }^{137} \mathrm{Cs}$ were determined in bluegill and redbreast sunfish samples that had been collected and freeze-dried for metals analyses as part of the BMAP bioaccumulation task (Sect. 4.1). Freeze-dried fish samples were counted by the ORNL Analytical Chemistry Division using a GeLi crystal scintillation spectrometer.

\subsubsection{Results and Discussion}

In 1986, fish throughout the WOC system upstream from WOL had much higher concentrations of ${ }^{137} \mathrm{Cs}$ than fish from WOL or WOC embayment. The concentration of ${ }^{137} \mathrm{Cs}$ in bluegill sunfish from the site with the highest mean concentration (WCK 2.9) was approximately ten times the level found in the same species from WOL. The concentration of ${ }^{137} \mathrm{Cs}$ in bluegill from this same site had decreased in 1987 by almost a factor of four, and the mean concentration in fish from WOC was approximately four times the level found in the same species from WOL (Table 8.11). The 1987 results from Northwest Tributary (NTK 0.2) were similar to the 1986 results; the fish collection at this site contained a mixture of highly contaminated individuals as well as those with much lower levels of ${ }^{137} \mathrm{Cs}$. This pattern is consistent with the movement of fish into this site from nearby reaches of WOC. The results of the 1986 and 1987 analyses from the WOC system are consistent with findings from sediment surveys (Spalding and Cerling 1979) that showed that the main ORNL complex is the major source of ${ }^{137} \mathrm{Cs}$ to WOC and tributaries and that the Melton Valley facilities and SWSAs are of secondary importance. Fish were collected from these same sites in 1988 and will be analyzed to determine whether the pattern of ${ }^{137} \mathrm{Cs}$ 
Table 8.11. Levels of ${ }^{17} \mathrm{C}$ (in becquerels per kilogram dry weight) in bluegill (Lepomis macrochirus) from the White Oak Creek system, December 1987 $N=$ Number of fish analyzed

\begin{tabular}{lccc}
\hline Site & Mean \pm 1 SD & Range & $N$ \\
\hline WCK 3.5 & $6400 \pm 640$ & $5800-7600$ & 6 \\
WCK 2.9 & $7900 \pm 3400$ & $4300-1300$ & 7 \\
WCK 2.9 & $7600 \pm 1300$ & $5600-9300$ & 5 \\
WCK 2.3 & $4600 \pm 752$ & $3900-5600$ & 5 \\
WOL & $2000 \pm 530$ & $1500-2500$ & 6 \\
WCK 0.9 & $2500 \pm 300$ & $2100-2900$ & 5 \\
MEK 0.2 & 2800 & 2800 & 1 \\
NTK 0.2 & $2500 \pm 3700$ & $<85-8600$ & 6 \\
\hline
\end{tabular}

${ }^{4}$ Redbreast sunfish (L. auritus).

contamination continues to reflect releases of ${ }^{137} \mathrm{Cs}$ from the main ORNL complex.

\subsection{FUTURE STUDIES}

B. G. Blaylock, D. A. Mohrbacher, and A. E. Waters

\subsubsection{Radionuclides in White Oak Lake Ecosystem}

Estimates of the quantity of radionuclides in the compartments of the WOL ecosystem have been completed; however, as new data become available, the estimates will be revised to reflect the most current data. Invertebrate samples collected in 1988 are being analyzed and will be completed in FY 1989. These data will be used to revise the estimate of the radionuclide inventory in this biotic compartment of the WOL ecosystem.

Because approximately $99 \%$ of the ${ }^{137} \mathrm{Cs}$, ${ }^{60} \mathrm{Co}$, and ${ }^{90} \mathrm{Sr}$ in WOL is in the sediments, a reliable estimate of the quantity of radionuclides in the WOL ecosystem will not be available until a comprehensive core sampling program is completed and better estimates of the volume of contaminated sediment and concentration of radionuclides and hazardous chemicals in the sediment are obtained. In addition, the present estimate of the inventory of radioactivity in the sediment compartment of WOL includes only ${ }^{137} \mathrm{Cs},{ }^{60} \mathrm{Co}$, and ${ }^{90} \mathrm{Sr}$. Although it is assumed that the quantity of other radionuclides in WOL, including the transuranic elements, is relatively small, this assumption should be documented with reliable measurements from core samples. Core sampling of the lake sediments is not included in the present task because it will be conducted as part of the Remedial Investigation on WOC and WOL under the corrective action requirements of the Resources Conservation and Recovery Act [Sect. 3004(u)].

An inventory of the radionuclides in the WOL ecosystem will not be complete without estimates of the biotic and abiotic compartments of the floodplain and former lake bed. In FY 1989 samples of the vegetation on the floodplain and former lake bed will be collected and analyzed for ${ }^{137} \mathrm{Cs},{ }^{60} \mathrm{Co}$, and ${ }^{90} \mathrm{Sr}$. Measurements of the species composition and abundance of the plant community will be taken to estimate 
the biomass of the vegetation compartment. Soil samples from the floodplain and former lake bed will be analyzed to obtain a preliminary estimate of the radioactivity in the soil. These measurements will be used to estimate the radionuclides in the vegetation and soil compartments of the floodplain and former lake bed.

\subsubsection{Preliminary Screening of Contaminants in White Oak Lake}

A preliminary screening analysis for radionuclides and other contaminants in the WOL ecosystem has been completed (Loar et al. 1992a; Loar 1992b). These analyses indicated areas where additional environmental measurements are needed. In FY 1989, data that have become available as the result of the current sampling program will be used in an analysis of the various food-chain pathways to revise and update the previous screening analysis for radionuclides and other contaminants in WOL.

\subsubsection{Role of Aquatic Macroflora in the Radioccology of White Oak Lake}

Macrophytes are a potentially important biological pool and serve as a mechanism that influences the transport of radionuclides in WOL. During 1988, the radionuclide content in aquatic plants above the WOC and Melton Branch weirs was compared, and experiments were conducted in the weirs to determine the relative contributions of sediment and water column sources to the radionuclide pool in rooted, submerged plants. During 1989 , laboratory studies using sediment and water from WOL and uncontaminated sites will be conducted to further evaluate the sources and bioconcentration of radionuclides in aquatic plants.
Rooted aquatic plants accumulate radionuclides from both the sediment and water column, and these radionuclides are concentrated in or on plant tissues. Efforts in 1989 will focus on the fate of macrophyte-associated radionuclides, considering that the importance of these plants in radionuclide dynamics is dependent upon the fate of their radionuclide pool.

Macrophyte-associated radionuclides may exist in three different plant fractions which determine the ultimate fate of these radionuclides. Radionuclides may become associated with plant tissues by active, metabolic absorption into a nonexchangeable internal compartment; by nonmetabolic adsorption onto the external surfaces; or by becoming incorporated into an exchangeable fraction in the cell wall by passive diffusion. Laboratory studies will determine (1) distribution of ${ }^{137} \mathrm{Cs}$ and ${ }^{60} \mathrm{Co}$ between the exchangeable surface fraction and the nonexchangeable, internally incorporated fraction; and (2) fate of ${ }^{137} \mathrm{Cs}$ and ${ }^{60} \mathrm{Co}$ in these fractions during growth and upon senescence and decomposition of the plants. These investigations will contribute to an understanding of the processes involved in radionuclide incorporation by macrophytes and the extent to which macrophytes affect the accumulation, persistence, and transport of these contaminants within and out of WOL.

\subsubsection{Waterfowl Populations Associated with ORR Lakes and Ponds}

In 1988 the ORNL waterfowl census was expanded to include aquatic habitats near the K-25 Site. In 1989, the census will be expanded to include aquatic systems at the Y-12 Plant.

In spring 1989 a mallard duck experiment will be initiated on WOL to provide data relevant to the resideit 
waterfowl population that inhabits the lake and to determine contaminant uptake over time. In addition to the collection of transient waterfowl from WOL for radioanalysis, mallard ducks from WOL and Canada geese from the K-25 Site will be analyzed for mercury, heavy metals, and PCBs. Also, Canada geese on the ORR will be identified with neck bands to assess the movements of geese between different ponds on the ORR and the interaction of birds from these ponds with local flocks on Melton Hill and Watts Bar reservoirs. The neck bands will permit easy identification and evaluation of movement of individual geese between ponds. The waterfowl study will be completed in fall 1990 .

\subsubsection{Radionuclides in Fish from White Oak Creek}

Fish in the WOC system upstream from WOL were collected and analyzed for
${ }^{137} \mathrm{Cs}$ in 1986 and 1987. Results of these analyses indicated that the main ORNL complex is the major source of ${ }^{137} \mathrm{Cs}$ to WOC and its tributaries and that the Nielton Valley facilities and SWSAs are of secondary importance. Fish were collected from the same WOC sites in 1988 and are in the process of being analyzed for radionuclides and other contaminants. These results will be used to further investigate the supposition that the concentration of ${ }^{137} \mathrm{Cs}$ in fish from WOC can be correlated with changes in the waste treatment system. In addition consideration will be given to estimating the size of sunfish populations that now inhabit the pools behind the weirs that were constructed on WOC and Melton Branch for monitoring purposes. 


\title{
9. ABATEMENT PROGRAM
}

\author{
C. K. Valentine
}

In several areas efforts to abate aquatic toxicity and other impacts on aquatic environments have been and will continue to be focused on management initiatives. These areas include the following: (1) minimization of chlorine and ethylene glycol concentrations in surface streams; (2) implementation of monitoring plans that are designed to locate sources that contribute PCBs and mercury to surface streams, to characterize the sources, and to develop remedial measures; (3) improvements to existing underground wastewater piping systems, including relining and rerouting pipelines in order to enhance control of ORNL wastewater streams; (4) secondary containment/diking of tanks containing hazardous/toxic substances and of transformer oils; (5) remediation of leaking underground storage tanks; (6) enhanced interaction between ORNL Environmental Monitoring and Compliance (EMC) Section personnel and operational/construction personnel in the field on an individual, site-specific basis; (7) construction progress toward completion of the ORNL NRWTF; and (8) implementation of the Tennessee Aquatic Resources Alteration Permit (ARAP) program.

\subsection{CHLORINE REDUCTION}

It has becone evident that chlorine is or has the potential to be the principal source of toxicity to aquatic life in ORNL streams. Because the potable water system at ORNL has a chlorine content of approximately $1.8 \mathrm{ppm}$, there is always the potential for toxic levels in the stream.
Large cooling towers at ORNL continue to receive special attention through NPDES sampling. Use of chlorine as a biocide in cooling towers to ensure their proper function during warm months warrants sampling of blowdown before release to the receiving stream. Although the NPDES permit requires only quarterly sampling, chlorine is always checked; if it is not below $0.2 \mathrm{ppm}$, the blowdown is not discharged. EMC has provided guidance on several projects involving maintenance of existing cooling towers and installation of new cooling systems to ensure that chlorine discharges to ORNL streams are either prevented or are kept at levels that are as low as are reasonably achievable.

In addition to cooling towers, numerous ORNL facilities utilize oncethrough cooling water systems that are fed by the potable water system. Because some of these currently discharge into the ORNL storm drain system, they represent potential sources of chlorine in ORNL surface streams. Engineering projects are underway at ORNL to address several of the larger volume, once-through cooling water systems, including the Materials Testing Laboratory (MTL) in Building 4500S, which discharges approximately $12.6 \mathrm{~L} / \mathrm{s}$ of once-through cooling water to WOC on a fairly continuous basis. A new, closed-loop cooling system for the MTL, which will eliminate the continuous discharge of chlorinated water from that facility, is currently in the final stages of design.

Water pipeline leaks and breaks have been a source of problems in the past and most likely will continue to be a potential problem. To address this problem, two 
aerators have been purchased. The intent is to be prepared to place an aerator anywhere in the stream where chlorine levels are high and to reduce the chlorine level through dissipation. This equipment provides the capability for quick abatement of an instream chlorine problem.

\subsection{ETHYLENE GLYCOL}

There have been numerous leaks and breaks in the ethylene glycol cooling system at ORNL, particularly in the $\mathbf{4 5 0 0}$ area, during the past year. The ethylene glycol chilling system is approximately 40 years old, and the problem can be attributed to the age of the system. The presence of ethylene glycol in the streams enhances microbial growth and reduces the oxygen level. An ORNL project is currently in progress to find a substitute for ethylene glycol through the combined efforts of the Plant and Equipment, Environmental and Health Protection, Engineering, and Environmental Sciences divisions. The use of the aforementioned aerators will also help reduce the effect of ethylene glycol in the streams.

\subsection{TANK DIKING}

In the past there have been occasions when storage tanks have leaked, and the potential exists for the contents of these tanks to reach receiving streams. All aboveground tanks storing hazardous or toxic chemicals in volumes greater than $208 \mathrm{~L}$, including transformers, have been evaluated and prioritized, based on the toxicity of the contents, to assure that secondary containment of the tanks has been addressed.

\subsection{UNDERGROUND STORAGE TANKS}

During 1988, remedial action projects were initiated to address leaking underground storage tanks that were discovered at ORNL during that time. These included a gasoline storage tank in the 7000 Area and a diesel fuel tank in the 3000 Area. Remedial actions to date have included excavating and removing the leaking tanks; excavating and removing contaminated soils and water, with either decontamination or disposal, as appropriate; and utilizing underground monitoring wells to evaluate the extent of contamination and the effectiveness of the remedial measures.

\subsection{PCB/MERCURY MONITORING}

Efforts are continuing on the ORNL PCB and Mercury Monitoring Plans that are required under the ORNL NPDES permit (EPA 1986a). A formal report that documents the findings of the Mercury Monitoring Plan has been completed. A study of ORNL contributions of PCBs to surface streams is underway. Reporting schedules for progress on the plans have been established, and results are being reported to DOE.

\subsection{WASTEWATER PIPING}

Projects to repair numerous ORNL underground pipelines were completed utilizing a process which installs a formedin-place synthetic liner inside an existing pipe. Leaking pipes at the ORNL site can be problematic due to exfiltration of pipe contents or infiltration of groundwater. 
The pipeline repairs have resulted in a significant reduction of contaminants being transported into First Creek and WOC, and additional reductions are expected as further repairs are made.

\subsection{FIELD INTERFACE ACTIVITIES}

In the past the potential existed for contaminants to reach ORNL streams because of construction activities or for the streams to be adversely affected by sedimentation due to surface runoff associated with construction activities. Recently, efforts to control and inspect construction activities have increased greatly. The Field Interface Staff of EMC conducts field assessments of the construction activities of ORNL staff and contractors in order to detect and prevent potential environmental problems and to determine compliance with environmental laws and regulations. This activity involves onsite monitoring of construction activities as well as interacting with a wide range of personnel involved with these projects. Each activity is monitored to determine potential environmental problems. If problems are identified, members of the field interface staff work with those involved to address the environmental concern. This activity is also closely associated with emergency response at ORNL and has been a primary factor in preventing spills from reaching receiving streams.

\subsection{NONRADIOLOGICAL WASTEWATER TREATMENT PROJECT}

Construction work continued during 1988 on the NRWTP, which is scheduled to be completed in 1989 and operational in early 1990. The NRWTP is expected to greatly reduce the impact of ORNL facilities and operations on the aquatic environment at ORNL. The NRWTP will include a new wastewater treatment facility that will remove organics, metals, and other solids from wastewaters that currently receive minimal levels of treatment before discharge. The NRWTP also includes large, aboveground flowequalization tanks that will replace several existing surface impoundments that currently provide that function; the impoundments will then be removed from service. Wastewater from numerous ORNL buildings and processes will be routed to the NRWTP for treatment.

\subsection{AQUATIC RESOURCES ALTERATION PERMTT PROGRAM}

Beginning in 1988, the Tennessee Department of Health and Environment (TDHE) implemented the ARAP program, a new permit system which addresses projects or activities that necessitate work in a stream or streambed, work that could potentially impact a surface water environment, such as installing a bridge, weir, or culvert crossing. The TDHE must be notified before any activity of this nature may be initiated. Before issuing a permit, the TDHE may determine that an ARAP application must also be submitted for the activity. An ARAP application characterizes the stream site, describes the proposed activity, and states environmental protection measures that will be taken during the project and after the work is completed. The TDHE then issues a draft ARAP for public notice, based on the application. After resolution of any issues that may arise, a final ARAP permit is issued for the activity. The ORNL EMC 
has integrated the ARAP process into the environmental review function, thus ensuring that ORNL and the TDHE will work closely together to provide adequate protection of the aquatic environment in the course of activities at the ORNL site. 


\section{LITERATURE CITED}

Abe, S., M. Matsumi, M. Tsukioki, S. Mizukawa, T. Takahashi, Y. Iijma, Y. Itano, and F. Kosaka. 1987. Metallothionein and zinc metabolism in endotoxin shock rats. pp. 587-594. IN J. H. R. Kagi, and Y. Kojima (eds.), Metallothionein II, Experintia Supplementum Vol. 52, Birkhauser Verlag, Basel and Boston.

Adams, S. M. 1990 Status and use of bioindicators for evaluating effects of chronic stress on fish. American Fish Society Symposium 8:1-8.

Adams, S. M., and R. B. McLean. 1985. Estimation of largemouth bass, Micropterus salmoides Lacépede, growth using the liver somatic index and physiological variables. J. Fish Biol. 26:111-126.

Adams, S. M., J. E. Breck, and R. B. McLean. 1985. Cumulative stress-induced mortality of gizzard shad in a southeastern U.S. reservoir. Environ. Biol. Fishes 13:103-112.

Addison, R. F. 1984. Hepatic mixed function oxidase (MFO) induction in fish as a possible biological monitoring system. pp. 51-60. IN V. W. Cairns, P. V. Hodson, and J. O. Nriagu (eds.), Contaminant Effects on Fisheries. John Wiley and Sons, New York.

Agami, M., and Y. Waisel. 1986. The ecophysiology of roots of submerged vascular plants. Physiol. Veg. 24:607-624.

Ahnstrom, G., and K. Erixon. 1980. Measurement of strand breaks by alkaline denaturation and hydroxyapatite chromatography. pp. 403-419. IN E. C. Friedberg and P. C. Hanawalt (eds). DNA Repair, Vol. 1, part A, Dekker, New York.

Ahokas, J. T., N. T. Kärki, A. Oikari, and A. Soivio. 1976. Mixed function monooxygenase of fish as an indicator of pollution of aquatic environments by industrial effluent. Bull. Environ. Contam. Toxicol. 16:270-274.

Albers, P. H., L. Sileo, and B. M. Mulhern. 1986. Effects of environmental contaminants on snapping turtles of a tidal wetland. Arch. Environ. Contam. Toxicol. 15:39-49.

Alberts, B., D. Brag, J. Lewis, M. Raff, K. Roberts, and J. D. Watson. 1983. Molecular biology of the cell. Garland Publishing Co., New York.

Allain, C. C., L. S. Poon, C. S. G. Chan, W. Richmond, and P. C. Fu. 1974. Enzymatic determination of total serum cholesterol. Clin. Chem. 20:470-475.

Amano, H., C. T. Garten, Jr., and R. D. Lomax. 1987. A field survey of environmental tritium in areas adjacent to ORNL solid-waste storage areas. ORNL/TM-10438, Oak Ridge National Laboratory, Oak Ridge, Tennessee.

APHA (American Public Health Association). 1985. Standard methods for the evaluation of water and wastewater. 16th Edition. APHA, Washington D.C.

Anderson, D. P. 1990. Immunological indicators: effects of environmental stress on immune protection and disease outbreaks. IN S.M. Adams (ed.), Biological indicators of stress in fish. American Fisheries Society Symposium 8:38-50, Bethesda, Maryland. 
Angermeier, P. L., and J. R. Karr. 1984. Relationships between woody debris and fish habitat in a small warmwater stream. Trans. Amer. Fish. Soc. 113:716-726.

Ashwood, J. W., C. R. Olsen, I. L. Larsen, and P. D. Lowery. 1986. Sediment contamination in streams surrounding the Oak Ridge Gaseous Diffusion Plant. ORNL/TM-9791. Oak Ridge National Laboratory, Oak Ridge, Tennessee.

Bain, M. B., J. T. Finn, and H. E. Booke. 1985. Quantifying stream substrate for habitat analysis studies. N. Amer. J. Fish. Manag. 5:499-500.

Bain, M. B., J. T. Finn, and H. E. Booke. 1988 Streamflow regulation and fish community structure. Ecology 69:382-392.

Baltz, D. M., B. Vondracek, L. R. Brown, and P. B. Moyle. 1987. Influence of temperature on microhabitat choice by fishes in a California stream. Trans. Amer. Fish. Soc. 116:12-20.

Barko, J. W., and R. M. Smart. 1981. Sediment-based nutrition of submersed macrophytes. Aq. Bot. 10:339-352.

Barnthouse, L. W., and G. W. Suter II (eds.). 1986. User's manual for ecological risk assessment. ORNL-6251. Oak Ridge National Laboratory, Oak Ridge, Tennessee.

Barron, M. G., and I. R. Adelman. 1984. Nucleic acid, protein content, and growth of larval fish sublethally exposed to various toxicants. Can. J. Fish. Aquat. Sci. 41:141-150.

Bates, L. D., J. B. Berry, B. M. Eisenhower, L. G. Hill, P. E. Hollenbeck, F. J. Homan, J. M. Kennerly, L. E. McNeese, T. E. Myrick, R. E. Pudelek, P. S.Rohwer, J. R. Trabalka, H. R. Yook, and E. L. Youngblood. 1986. Preliminary ORNL long-range environmental management plan, Volume 2: Detailed information and strategy. ORNL-6141/V2. Oak Ridge National Laboratory, Oak Ridge, Tennessee.

Becker, G. C. 1983. Fishes of Wisconsin. University of Wisconsin Press, Madison, Wisconsin.

Benke, A. C. 1979. A modification of the Hynes method for estimating secondary production with particular significance for multivoltine populations. Limnol. Oceanogr. 24:168-171.

Benke, A. C. 1984. Secondary production of aquatic insects. pp. 289-322. IN V. H. Resh and D. M. Rosenberg (eds.), The Ecology of Aquatic Insects. Prager Publishers, New York.

Berkman, H. E., and C. F. Rabeni. 1987. Effect of siltation on stream fish communities. Environ. Biol. Fishes 18:288-294.

Berry, J. B., L. G. Hill, P. E. Hollenbeck, L. E. McNeese, T. E. Myrick, R. E. Pudelek, P. S. Rohwer, J. H. Smith, H. R. Yook, and E. L. Youngblood. 1987. Preliminary ORNL long-range environmental management plan: Program overview and summary. ORNL-6344. Oak Ridge National Laboratory, Oak Ridge, Tennessee. 
Blasing, T. J., K. L. Daniels, P. Y. Goldberg, B. M. Horwedel, I. L. McCollough, F. R. O'Donnell, A. E. Osborne-Lee, M. F. Tardiff, S. W. Teeters, C. K. Valentine, and D. A. Wolf. 1989. Environmental data report for the third quarter of 1988. ORNL/TM-534. Environmental Monitoring and Compliance Section, Environmental and Health Protection Division, Oak Ridge National Laboratory, Oak Ridge, Tennessee.

Blaylock, B. G., and D. A. Mohrbacher. 1993. Radionuclides in White Oak Lake ecosystem. pp. 290-297. IN J. M. Loar (ed.), Second Report on the Oak Ridge National Laboratory Biological Monitoring and Abatement Program for White Oak Creek Watershed and the Clinch River. ORNL/TM-10804 Oak Ridge National Laboratory, Oak Ridge, Tennessee.

Bligh, E. G., and W. J. Dyer. 1959. A rapid method of total lipid extraction and purification. Can. J. Biochem. Physiol. 8:911-917.

Bothwell, M. L. 1985. Phosphorus limitation of lotic periphyton growth rates: An inter-site comparison using continuous-flow troughs (Thompson River, British Columbia). Limnol. Oceanogr. 30:527-542.

Bouquegneau, J. M., Ch. Gerday, and A. Disteche. 1975. Fish mercury-binding thionein related to adaptation mechanisms. Febs Letters 55:173-177.

Bouquegneau, J. M. 1979. Evidence for the protective effect of metallothioneins against inorganic mercury injuries to fish. Buil. Environ. Contam. Toxicol. 23:218-219.

Boyle, J. W., R. Blumberg, S. J. Cotter, G. S. Hill, C. R. Kerley, R. H. Ketelle, R. L. Kroodsma, D. W. Lee, R. C. Martin, R. D. Roop, D. N. Secora, W. P. Staub, and R. E. Thoma. 1982. Environmental analysis of the operation of the Oak Ridge National Laboratory (X-10 Site). ORNL-5870. Oak Ridge National Laboratory, Oak Ridge, Tennessee.

Bradford, M. M. 1976. A rapid and sensitive method for the quantitation of protein utilizing the principle of protein dye binding. Anal. Biochem. 72:248-254.

Brady, F. O. 1982. The physiological function of metallothionein. TIBS 7:143-145.

Brady, F. O., B. Helvig, A. Funk, and A. Garrett. 1987. The involvement of catecholamines and polypeptide hormones in the multihormonal modulation of rat hepatic zinc thionein levels. pp. 555-563. IN J. H. R. Kagi, and Y. Kojima (eds.), Metallothionein II, Experintia Supplementum Vol. 52, Birkhauser Verlag, Basel and Boston.

Bremner, I. 1987. Nutritional physiological significance of metallothionein. pp. 81-107. IN J. H. R. Kagi, and Y. Kojima (eds.), Metallothionein II, Experintia Supplementum Vol. 52, Birkhauser Verlag, Basel and Boston.

Brown, D., C. Bawden, K. Chatel, and T. Parsons. 1977. The wildlife community of Iona Island Jetty, Vancouver, B. C., and heavy-metal pollution effects. Environ. Conser. 4:213-216. 
Brown, D., S. Bay, and R. Gossett. 1986. Using the natural detoxification capacities of marine organisms to assess assimilative capacity. pp. 364-382. IN R. Cardwell, R. Purdy, and R. Bahner (eds.), Aquatic Toxicology and Hazard Assessment: 7th Symposium. American Society for Testing and Materials, Philadelphia.

Bucolo, G., and H. David. 1973. Quantitative determination of serum triglycerides by the use of enzymes. Clin. Chem. 19:476-482.

Bulow, F. J. 1970. RNA-DNA ratios as indicators of recent growth rates of a fish. J. Fish. Res. Board Can. 27:2343-2349.

Burke, M. D., and R. T. Mayer. 1974. Ethoxyresorufin: Direct fluorimetric assay of a microsomal O-dealkylation which is preferentially inducible by 3-methylcholanthrene. Drug. Metab. Dispos. 2:583-588.

Burtis, C. A., W. F. Johnson, J. C. Mailen, J. B. Overton, T. O. Tiffany, and M.B. Watsky. 1973. Development of an analytical system based around a miniature fast analyzer. Clin. Chem. 19:895-903.

Cairns, J., and W. H. Van der Schalie. 1980. Biological monitoring, Part I: Early warning systems. Water Res. 14:1179-1196.

Carle, F. L., and M. R. Strub. 1978. A new method for estimating population size from removal data. Biometrics 34:621-630.

Carpenter, S. R., and D. M. Lodge. 1986. Effects of submersed macrophytes on ecosystem processes. Aq. Bot. 26:341-370.

Cerling, T. E., and B. P. Spalding. 1982. Distribution and relationship of radionuclides to stream bed gravels in a small watershed. Environ. Geol. 4:99-116.

Chang, C., R. Lauwerys, A. Bernard, H. Roels, J. Buchet, and J. Garvey. 1980. Metallothionein in cadmium-exposed workers. Environ. Res. 23:422-428.

Cowgill, U. M., K. I. Keating, and I. T. Takahashi. 1985. Fecundity and longevity of Ceriodaphnia dubia/affinis in relation to diet at two different temperatures. J. Crustacean Biol. 5:420-429.

Cox, D. K. N. Farrow, W. C. Kyker, and L. M. Stubbs. 1991 The new definitive map of White Oak Lake - Area and volume. ORNL/TM-11204. Oak Ridge National Laboratory, Oak Ridge, Tennessee.

Daniel, F. B., D. L. Haas, and S. M. Pyle. 1985. Quantitation of chemically induced DNA strand breaks in human cells via an alkaline unwinding assay. Anal. Biochem. 144:390-402.

Daniels, R. E., and J. D. Allan. 1981. Life table evaluation of chronic exposure to a pesticide. Can. J. Fish. Aquat. Sci. 38:485-494.

DEM (Department of Environmental Management). 1986. Environmental surveillance data report for the second quarter of 1986. ORNL/M-173. Oak Ridge National Laboratory, Oak Ridge, Tennessee. 
Dorhmann Company. 1984. Total Organic Carbon Systems Manual. Santa Clara, California.

Dunn, M. A., T. Blalock, and R. Cousins. 1987. Metallothionein. Proc. Soc. Exp. Biol. Med. 185:107-119.

Edgar, D. E. 1978. An analysis of infrequent hydrologic events with regard to existing streamflow monitoring capabilities in White Oak Creek watershed. ORNL/TM-6542. Oak Ridge National Laboratory, Oak Ridge, Tennessee.

Elliott, J. M. 1977. Some methods for the statistical analysis of samples of benthic invertebrates. Sci. Pub. No. 25. Freshwater Biological Association, Ambleside, England.

EPA (Environmental Protection Agency). 1976. Quality criteria for water. EPA-440/9-76023. U.S. Environmental Protection Agency, Washington, DC.

EPA (Environmental Protection Agency). 1979. Methods for chemical analysis of waters and wastes. EPA 600/4-79-020. Environmental Monitoring and Support Laboratory, U.S. Environmental Protection Agency, Cincinnati, Ohio.

EPA (Environmental Protection Agency). 1980a. Water quality criteria for toxic substances. Fed. Regist. 45:79318-79379, November 28,1980.

EPA (Environmental Protection Agency). 1980b. Interim methods for the sampling and analysis of priority pollutants in sediments and fish tissues. EPA 600/4-81-055. Environmental Monitoring and Support Laboratory, U.S. Environmental Protection Agency, Cincinnati, Ohio. $60 \mathrm{pp}$.

EPA (Environmental Protection Agency). 1984. Extraction and analysis of priority pollutants in biological tissue, Method PPB 12/83. Environmental Services Division, Region IV, Analytical Support Branch, U.S. Environmental Protection Agency, Athens, Georgia. Mimeo

EPA (Environmental Protection Agency). 1985. Ambient water quality criteria for chlorine. EPA-440/5-84/030. National Technical Information Service, Springfield, Virginia.

EPA (Environmental Protection Agency). 1986a. Authorization to discharge under the National Pollutant Discharge Elimination System, Permit No. TN0002941, Oak Ridge National Laboratory $(\widetilde{S}-10)$ and Fact Sheet, April 1, 1986. U.S. Environmental Protection Agency, Region IV, Atlanta, Georgia.

EPA (Environmental Protection Agency). 1986b. Quality Criteria for Water. EPA/440/586/001. Office of Water Regulations and Standards, U.S. Environmental Protection Agency, Washington, D.C.

Evaldi, R. D. 1986. Streamflow and specific-conductance data for Bear Creek, August 13, 1985, the Oak Ridge Reservation, Tennessee. Open-File Report 85-682. U.S. Geological Survey, Nashville, Tennessee.

Fausch, K. D., J. R. Karr, and P. R. Yant. 1984. Regional application of an Index of Biotic Integrity based on stream fish communities. Trans. Amer. Fish. Soc. 113:39-55. 
Fisher, S. G., and G. E. Likens. 1973. Energy flow in Bear Brook, New Hampshire: An integrative approach to stream ecosystem metabolism. Ecol. Monogr. 43:421-439.

Fitz, R. B. 1968. Fish habitat and population changes resulting from impoundment of Clinch River by Melton Hill Dam. J. Tenn. Acad. Sci. 43:7-15.

Fletcher, G. L, M. J. King, J. W. Kiceniuk, and R. F. Addison. 1982. Liver hypertrophy in winter flounder following exposure to experimentally oiled sediments. Comp.

Biochem. Physiol. 73C:457-462.

FDA (Food and Drug Administration). 1984a. Action level for methylmercury in fish. Fed. Regist. 49:45663.

FDA (Food and Drug Administration). 1984b. Polychlorinated biphenyls in fish and shellfish: Reduction of tolerances, Final Decision. Fed. Regist. 49:21514-21520.

Forlin, L., and T. Anderson. 1985. Storage conditions of rainbow trout liver cytochrome P. 450 and conjugating enzymes. Comp. Biochem. Physiol. 3:569-572.

Friend, D. T. C. 1961. A simple method of measuring integrated light values in the field. Ecology 42:577-580.

Friedman, K. J., D. M. Easton, and M. Nash. 1986. Temperature-induced changes in fatty acid composition of myelinated and non-myelinated axon phospholipids. Comp. Biochem. Physiol. 83B:313-319.

Garman, G. C., and T. F. Waters. 1983. Use of the size-frequency (Hynes) method to estimate annual production of a stream fish population. Can. J. Fish. Aquat. Sci. 40:2030-2034.

Glebe, B. D., and W. C. Leggett. 1981. Temporal, intra-population differences in energy allocation and use by American shad (Alosa sapidissima) during the spawning migration. Can. J. Fish. Aquat. Sci. 38:795-805.

Gorman, O. T., and J. R. Karr. 1978. Habitat structure and stream fish communities. Ecology 59:507-515.

Greeson, P. E., T. A. Ehlke, G. A. Irwin, B. W. Lium, and K. V. Slack. 1977. Methods for collection and analysis of aquatic biological and microbiological samples. Book 5 , Chapter 4A, pp. 1-332. IN U.S. Geological Survey, Techniques of Water-Resources Investigations of the United States Geological Survey. U.S. Government Printing Office, Washington, D.C.

Guttman-Bass, N., M. Bairey-Albuquerque, S. Ulitzur, A. Chartrand, and C. Rav-Acha. 1987. Effects of chlorine and chlorine dioxide on mutagenic activity of Lake Kinnereth water. Environ. Sci. Technol. 21:252-260.

Haines, T. A. 1973. An evaluation of RNA-DNA ratio as a measure of long-term growth in fish populations. J. Fish. Res. Board Can. 30:195-199.

Hamer, D. H. 1986. Metallothionein. Ann. Rev. Biochem. 55:913-951.

Hamilton, S. J., and P. Mehrle. 1986. Metallothionein in fish: Review of its importance in assessing stress from metal contaminants. Trans. Amer. Fish. Soc. 115:596-609. 
Harvey, H. R., and J. S. Patton. 1981. Solvent focusing for rapid and sensitive quantification of total lipids on chromarods. Anal. Biochem. 116:312-316.

Harvey, R. 1982. Polycyclic hydrocarbons and cancer. Amer. Sci. 70:386-393.

Hazel, J. R., and C. L. Prosser. 1974. Molecular mechanisms of temperature compensation in poikilotherms. Physiol. Rev. 54:620-677.

Heath, A. G. 1987. Water Pollution and Fish Physiology. CRC Press, Boca Raton, Florida.

Healey, F. P., and L. L. Hendzel. 1980. Physiological indicators of nutrient deficiency in lake phytoplankton. Can. J. Fish. Aquat. Sci. 37:442-453.

Heidinger, R. C., and S. D. Crawford. 1977. Effect of temperature and feeding rate on the liver-somatic index of the largemouth bass, Micropterus salmoides. J. Fish. Res. Board Can. 34:633-638.

Hening, H. 1986. Metal-binding proteins as metal pollution inciicators. Environ. Health Perspect. 65:175-187.

Henry, J. B. 1979. Clinical Diagnosis and Management by Laboratory Methods. W.B. Saunders and Co., Philadelphia.

Hile, R. 1936. Age and growth of the cisco, Leucichthys artedi (LeSeur), in the lakes of the northeastern highlands, Wisconsin. U.S. Bur. Fish. Bull. 48:211-317.

Hinton, D. E., and J. A. Couch. 1984. Pathological measures of marine pollution effects. pp. 7-32. IN H. H. Harris (ed.), Concepts in Marine Pollution Measurements. Maryland Sea Grant College, University of Maryland, College Park, Maryland.

Hoffman, F. O., B. G. Blaylock, C. C. Travis, K. L. Daniels, E. L. Etnier, K. E. Cowser, and C. W. Weber. 1984. Preliminary screening of contaminants in sediments. ORNL/TM-9370. Oak Ridge National Laboratory, Oak Ridge, Tennessee.

Hopkins, C. L. 1976. Estimate of biological production in some stream invertebrates. N. Z. J. Mar. Freshwat. Res. 10:629-640.

Horning, W. B., and C. I. Weber. 1985. Short-term methods for estimating the chronic toxicity of effluents and receiving waters to freshwater organisms. EPA/600/4-85/014. U.S. Environmental Protection Agency, Cincinnati, Ohio.

Huckabee, J. W., and B. G. Blaylock. 1973. Transfer of mercury and cadmium from terrestrial to aquatic ecosystems. pp 125-160. IN S. K. Dhar (ed.), Metal lons in Biological Systems. Adv. Exper. Med. Biol. 40.

Huryn, A. D., and J. B. Wallace. 1987. Local geomorphology as a determinant of macrofaunal production in a mountain stream. Ecology 68:1932-1942.

Huston, M. A. 1979. A general hypothesis of species diversity. Amer. Nat. 113:81-101.

Iversen, T. M. 1988. Secondary production and trophic relationships in a spring invertebrate community. Limnol. Oceanogr. 33:582-592. 
Jeffrey, S. W., and G. F. Humphrey. 1975. New spectrophotometric equations for determining chlorophylls $a, b, c_{1}$ and $c_{2}$ in higher plants, algae and natural phytoplankton. Biochem. Physiol. Pflanzen Bd. 167:191-194.

Johannesen, K. M., and J. W. DePierre. 1978. Measurements of cytochrome $P_{450}$ in the presence of large amounts of contaminating hemoglobin and methemoglobin. Anal. Biochem. 86:725-32.

Kanter, P. M., and H. S. Schwartz. 1979. A hydroxyapatite batch assay for quantitation of cellular DNA damage. Anal. Biochem. 97:77-84.

Kanter, P. M., and H. S. Schwartz. 1982. A fluorescence enhancement assay for cellular DNA damage. Molec. Pharmacol. 22:145-151.

Karr, J. R. 1981. Assessment of biotic integrity using fish communities. Fisheries 6:21-27.

Karr, J. R., and D. R. Dudley. 1981. Ecological perspective on water quality goals. Environ. Manag. 5:55-68.

Karr, J. R., K. D. Fausch, P. L. Angermeier, P. R. Yant, and I. J. Schlosser. 1986. Assessing Biological Integrity in Running Waters: A Method and its Rationale. Illinois Natural History Survey Special Publication 5.

Karr, J. R. 1987. Biological monitoring and assessment: A conceptual framework. Environ. Manag. 11:249-256.

Kasten, J. L. 1986. Resource management plan for the Oak Ridge Reservation, vol. 21: Water conservation plan for the Oak Ridge Reservation. ORNL/ESH-1/N21. Oak Ridge National Laboratory, Oak Ridge, Tennessee.

Kitchings, T., and L. K. Mann. 1976. A description of the terrestrial ecology of the Oak Ridge Fnvironmental Research Park. ORNL/TM-5073. Oak Ridge National Labora!nry, Oak Ridge, Tennessee.

Kito, H., Y. Ose, V. Mizuhira, T. Sato, T. Ishikawa, and T. Tazawa. 1982. Separation and purification of $(\mathrm{Cd}, \mathrm{Cu}, \mathrm{Zn})$-metallothioneins in carp hepato-pancreas. Comp. Biochem. Physiol. 73C:121-127.

Kito, H., T. Tazawa, Y. Ose, T. Sato, and T. Ishikawa. 1982. Formation of metallothionein in fish. Comp. Biochem. Physiol. 73C:129-134.

Kito, H., T. Tazawa, Y. Ose, T. Sato, and T. Ishikawa. 1982. Protection by metallothionein against cadmium toxicity. Comp. Biochem. Physiol. 73C:135-139.

Klaunig, J. E., M. M. Lipsky, and B. F. Trump. 1976. Biochemical and ultrastructural changes in teleost liver following subacute exposure to PCB. J. Environ. Pathol. Toxicol. 2:953-963.

Klecka, W. R. 1980. Discriminant analysis. Sage University paper series on quantitative applications in the social sciences, Series No. 07-019. Sage Publications, Beverly Hills.

Kohn, H. W. 1983. The significance of DNA-damaging assays in toxicity and carcinogenesis assessment. Ann. N.Y. Acad. Sci. 407:106-118. 
Kruger, C. C., and T. F. Waters. 1983. Annual production of macroinvertebrates in three streams of different water quality. Ecology 64:840-850.

Krumholz, L. A. 1956. Observations on the fish populations of a lake contaminated by radioactive wastes. Bull. Am. Mus. Nat. His. 110(4):281-367.

Larimore, R. W, W. F. Childers, and C. Heckrotte. 1959. Destruction and re-establishment of stream fish and invertebrates affected by drought. Trans. Amer. Fish. Soc. 88:261-285.

Larkin, P. A. 1978. Fisheries management: An essay for ecologists. Ann. Rev. Ecol. Syst. 9:57-73.

Larsson, A., C. Haux, and M. Sjobeck. 1985. Fish physiology and metal pollution: Results and experiences from laboratory and field studies. Ecotoxicol. Environ. Safety 9:250-281.

Lee, D. S., C. R. Gilbert, C. H. Hocutt, R. E. Jenkins, D. E. McAllister, and J. R. Stauffer, Jr. 1980. Atlas of North American Freshwater Fishes. North Carolina Biological Survey Publication 1980-12, North Carolina State Museum of Natural History.

Lee, R. M., S. D. Gerking, and B. Jezierska. 1983. Electrolyte balance and energy mobilization in acid-stressed rainbow trout, Salmo gairdneri, and their relation to reproductive success. Environ. Biol. Fishes 8:115-123.

Lenat, D. R. 1988. Water quality assessment of streams using a qualitative collection method for benthic macroinvertebrates. J. N. Amer. Benthol. Soc. 7:222-233.

Leonard, P. M., and D. J. Orth. 1986. Application and testing of an Index of Biotic Integrity in small, coldwater streams. Trans. Amer. Fish. Soc. 115:401-414.

Lindmann U., L. Forlin, O. Molander, and G. Axelson. 1976. Induction of drug metabolizing system in rainbow trout (Salmo gairdneri) liver by polychlorinated biphenyls (PCBs). Acta Pharmacol. Toxicol. 39:262-272.

Loar, J. M., J. A. Solomon, and G. F. Cada. 1981. Technical background information for the ORNL Environmental and Safety Report, Vol. 2: A description of the aquatic ecology of White Oak Creek watershed and the Clinch River below Melton Hill Dam. ORNL/TM-7509/V2. Oak Ridge National Laboratory, Oak Ridge, Tennessee. $198 \mathrm{pp}$.

Loar, J. M., L. M. Adams, S. M. Adams, B. G. Blaylock, H. L. Boston, M. A. Huston, B. L. Kimmel, C. R. Olsen, J. G. Smith, G. R. Southworth, A. J. Stewart, and B. T. Walton. 1991. Oak Ridge National Laboratory Biological Monitoring and Abatement Program for White Oak Creek watershed and the Clinch River. ORNL/TM-10370. Oak Ridge National Laboratory, Oak Ridge, Tennessee. 
Loar, J. M., S. M. Adams, B. G. Blaylock, H. L. Boston, M. A. Huston, B. L. Kimmel, J. T. Kitchings, C. R. Olsen, M. G. Ryon, J. G. Smith, G. R. Southworth, A. J. Stewart, B. T. Walton, H. Amano, C. T. Garten, and L. J. Meyers. 1992a. First Annual Report on the Biological Monitoring and Abatement Program at Oak Ridge National Laboratory. ORNL/TM-10399. Oak Ridge National Laboratory, Oak Ridge, Tennessee.

Loar, J. M. (ed). 1992b. Second Report on the Oak Ridge National Laboratory Biological Monitoring and Abatement Program for White Oak Creek Watershed and the Clinch River. ORNL/TM-10804. Oak Ridge National Laboratory, Oak Ridge, Tennessee.

Loar, J. M. (ed). 1992c. First Report on the Y-12 Plant Biological Monitoring and Abatement Program for East Fork Poplar Creek. Y/TS-886, Oak Ridge National Laboratory, Oak Ridge, Tennessee.

Lockhart, W. L., and D. A. Metner. 1984. Fish serum chemistry as a pathology tool. pp. 73-85. IN V.W. Cairns, P.V. Hodson, and J. O. Nriagu, (eds.), Contaminant Effects on Fisheries. John Wiley and Sons, New York.

Lomenick, T. F., and D. A. Gardiner. 1965. The occurrence and retention of radionuclides in the sediments of White Oak Lake. Health Phys. 2:567-577.

Lowe, T. P., T. W. May, W. G. Brumbaugh, and D. A. Kane. 1985. National Contaminant Biomonitoring Program: Concentrations of seven elements in freshwater fish, 19781981. Arch. Environ. Contam. Toxicol. 14:363-388.

Lowery, J. F., P. H. Counts, H. L. Edmiston, and F. D. Edwards. 1986. Water Resources Data for Tennessee, Water Year 1985. Report No. USGS/WRD/HD-86. U.S. Geological Survey, Nashville, Tennessee.

Lowery, J. F., P. H. Counts, H. L. Edmiston, and F. D. Edwards. 1987. Water Resources Data for Tennessee, Water Year 1986. Report No. USGS/WRD/HD-87/225. U.S. Geological Survey, Nashville, Tennessee.

Marouka, S., and S. Jamanaka. 1980. Production of mutagenic substances by chlorination of waters. Mutat. Res. 79:381-386.

McBee, K. and J. W. Bickham. 1988. Petrochemical-related DNA damage in wild rodents detected by flow cytometry. Bull. Environ. Contam. Toxicol. 40:343-349.

McClendon, D. D., and C. F. Rabeni. 1987. Physical and biological variables useful for predicting population characteristics of smallmouth bass and rock bass in an ozark stream. N. Amer. J. Fish. Manag. 7:46-56.

McKee, M. J., A. C. Hendricks, and R. E. Ebel. 1983. Effects of naphthalene on Benzo[a]pyrene hydroxylase and cytochrome P-450 in Fundulus heteroclitus. Aquat. Toxicol. 3:103-114.

McMaster, W. M. 1963. Geologic map of the Oak Ridge Reservation, Tennessee. ORNL/TM-713. Oak Ridge National Laboratory, Oak Ridge, Tennessee. 
McMaster, W. M. 1967. Hydrologic data for the Oak Ridge area, Tennessee. U.S. Geological Survey-Water Supply Paper No. 1839-N. U.S. Government Printing Office, Washington, D.C.

McMaster, W. M., and H. D. Waller. 1965. Geology and soils of White Oak Creek basin, Tennessee. ORNL/TM-1108. Oak Ridge National Laboratory, Oak Ridge, Tennessee.

Meyers, L. J., L. R. Shugart, and B. T. Walton. 1988. Freshwater turtles as indicators of contaminated aquatic environments. Abstract from the Society of Environmental Toxicology and Chemistry 9th Annual Meeting, Arlington, Virginia.

Meyers, L. J., S. M. Apellaniz, L. R. Shugart, and B. T. Walton. 1988a. Freshwater turtles as indicators of contaminated environments. pp. 270-286. IN J. M. Loar (ed.), Second Report on the Oak Ridge National Laboratory Biological Monitoring and Abatement Program for White Oak Creek Watershed and the Clinch River. ORNL/TM-10804. Oak Ridge National Laboratory, Oak Ridge, Tennessee.

Miller, D. L., P. M. Leonard, R. M. Hughes, J. R. Karr, P. B. Moyle, L. H. Schrader, B. A. Thompson, R. A. Daniels, K. D. Fausch, G. A. Fitzhugh, J. R. Gammon, D. B. Halliwell, P. L. Angermeier, and D. J. Orth. 1988. Regional application of an Index of Biotic Integrity for use in water resource management. Fisheries 13(5):12-20.

Minshall, G. W. 1978. Autotrophy in stream ecosystems. Bioscience 28:76\%-771.

Mortensen, E., and J. L. Simonsen. 1983. Production estimates of the benthic invertebrate community in a small Danish stream. Hydrobiologia 102:155-162.

Mount, D. I., and T. J. Norberg. 1984. A seven-day life-cycle cladoceran toxicity test. Environ. Toxicol. Chem. 3:425-434.

Munkittrick, K. R., and D. G. Dixon. 1988. Growth, fecundity, and energy stores of white sucker (Catostomus commersoni) from lakes containing elevated levels of copper and zinc. Can. J. Fish. Aquat. Sci. 45:1355-1365.

Nakano, T., and N. Tomlinson. 1967. Catecholamine and carbohydrate concentrations in rainbow trout (Salmo gairdneri) in relation to physical disturbance. J. Fish. Res. Board Can. 24:1701-1715.

NOAA (National Oceanic and Atmospheric Administration). 1985. Local climatological data: Monthly summaries for January-December 1985, Oak Ridge, Tennessee. National Climatic Data Center, Asheville, North Carolina.

NOAA (National Oceanic and Atmospheric Administration). 1986. Local climatological data: Monthly summaries for January-December 1986, Oak Ridge, Tennessee. National Climatic Data Center, Asheville, North Carolina.

NOAA (National Oceanic and Atmospheric Administration). 1987a. Local climatological data: 1986 annual summary with comparative data, Oak Ridge, Tennessee. National Climatic Data Center, Asheville, North Carolina. 
NOAA (National Oceanic and Atmospheric Administration). 1987b. Local climatological data: Monthly summaries for January-December 1987, Oak Ridge, Tennessee. National Climatic Data Center, Asheville, North Carolina.

NOAA (National Oceanic and Atmospheric Administration). 1988. Local climatological data: Monthly summaries for January-December 1988, Oak Ridge, Tennessee. National Climatic Data Center, Asheville, North Carolina.

NCCLS (National Committee for Clinical Laboratory Standards). 1979. NCCLS approved standards: ACS-1 Specification for standard protein solution (Bovine serum albumin), 2nd ed. National Committee for Clinical Laboratory Standards, Villanova, Pennsylvania.

Neff, J. M. 1978. Polycyclic Aromatic Hydrocarbons. Applied Science Publisher, Ltd., London.

Norberg, T. J., and D. I. Mount. 1985. A new fathead minnow (Pimephales promelas) subchronic toxicity test. Environ. Toxicol. Chem. 4:1388-1394.

Oakes, T. W., B. A. Kelly, W. F. Ohnesorge, J. S. Eldridge, J. C. Bird, K. E. Shanks, and F. S. Tsakeres. 1982. Technical background information for the ORNL Environmental and Safety Report, Vol. 4: White Oak Lake and Dam. ORNL-5681. Oak Ridge National Laboratory, Oak Ridge, Tennessee.

Ohio EPA (Environmental Protection Agency). 1987. Biological Criteria For the Protection of Aquatic Life, Vol. III: Standardized Biological Field Sampling and Laboratory Methods for Assessirig Fish and Macroinvertebrate Communities. Ohio Environmental Protection Agency, Division of Water Quality Monitoring and Assessment, Columbus, Ohio.

Ohio EPA (Environmental Protection Agency). 1988. Biological Criteria For the Protection of Aquatic Life, Vol. II: Users Manual for Biological Field Assessment of Ohio Surface Streams. Ohio Environmental Protection Agency, Division of Water Quality Monitoring and Assessment, Columbus, Ohio.

Olafsson, P. G., A. M. Bryan, B. Bush, and W. Stone. 1983. Snapping turtles-a biological screen for PCBs. Chemosphere 12:1525-1532.

Palumbo, A. V., P. J. Mulholland and J. W. Elwood. 1987. Simultaneous measurement of periphyton production, chlorophyll and ATP using DMSO extraction. Limnol. Oceanogr. 32:464-471.

Payne J. F., and W. R. Penrose. 1975. Induction of aryl hydrocarbon benzo[(a)]pyrene hydroxylase in fish by petroleum. Bull. Environ. Contam. Toxicol. 14:112-116.

Peterson, J. I., and D. S. Young. 1968. Evaluation of the hexokinase/glucose-6-phosphate dehydrogenase method of determining glucose in urine. Anal. Biochem. 23:301-316.

Pflieger, W. L. 1975. The fishes of Missouri. Missouri Department of Conservation, Jefferson City, Missouri. 
Platts, W. S., W. F. Megahan, and G. W. Minshall. 1983. Methods for evaluating stream, riparian, and biotic conditions. General Technical Report INT-138. U. S. Forest Service, Intermountain Forest and Range Experimental Station, Ogden, Utah.

Platts, W. S., C. Armour, G. D. Booth, M. Bryant, J. L. Bufford, P. Cuplin, S. Jensen, G. W. Lienkaemper, G. W. Minshall, S. B. Monsen, R. L. Nelson, J. R. Sedell, and J. S. Tuhy. 1987. Methods for evaluating riparian habitats with applications to management. General Technical Report INT-221. U.S. Forest Service Intermountain Research Station, Ogden, Utah.

Power, M. E., W. J. Matthews, and A. J. Stewart. 1985. Grazing minnows, piscivorous bass, and stream algae: Dynamics as a strong interaction. Ecology 66:1448-1456.

Resh, V. H., A. V. Brown, A. P. Covich, M. E. Gurtz, H. W. Li, G. W. Minshall, S.R. Reice, A.L. Sheldon, J.B. Wallace, and R. C. Wissmar. 1988. The role of disturbance in stream ecology. J. N. Amer. Benthol. Soc. 7:433-455.

Rhodes, L., E. Casillas, B. McKnight, W. Gronlund, M. Myers, O. Olson, and B. McCain. 1985. Interactive effects of cadmium, polychlorinated biphenyls, and fuel oil on experimentally exposed English sole (Parophrys vetulus). Can. J. Fish. Aquat. Sci. 42:1870-1880.

Robinson, H. W., and T. M. Buchanan. 1945. Fishes of Arkansas. The University of Arkansas Press, Fayetteville, Arkansas.

Roch, M., J. McCarter, A. Matheson, M. Clark, and R. Olafson. 1982. Hepatic metallothionein in rainbow trout as an indicator of metal pollution in the Campbell River system. Can. J. Fish. Aquat. Sci. 39:1596-1601.

Roch, M., R. Nordin, A. Austin, C. McKean, J. Deniseger, R. Kathman, J. McCarter, and M. Clark. 1985. The effect of heavy metal contamination on aquatic biota of Buttle Lake and the Campbell River drainage (Canada). Arch. Environ. Contam. Toxicol. $14: 347-362$.

Roche Diagnostic Systems. 1986. Reagent for Total Protein. Roche Diagnostic Systems Information Package, Items 44903 and 44313. Nutley, New Jersey.

Roche, H., J. Jouanneteau, and G. Peres. 1983. Effects of adaptation to different salinities on the lipids of various tissues in sea dace (Dicentrarchus labrax). Comp. Biochem. Physiol. 74B:325-330.

Rogers, J. G., K. L. Daniels, S. T. Goodpasture, C. W. Kimbrough, and E. W. Whitfield. 1988a. Environmental surveillance of the U.S. Department of Energy Oak Ridge Reservation and surrounding environs during 1987, Vol. 1: Narrative, summary and conclusions. ES/ESH-4/V1. Environmental and Safety Activities, Martin Marietta Energy Systems, Inc., Oak Ridge, Tennessee.

Rogers, J. G., K. L. Daniels, S. T. Goodpasture, C. W. Kimbrough, and E. W. Whitfield. 1988b. Environmental surveillance of the U.S. Department of Energy Oak Ridge Reservation and surrounding environs during 1987, Vol. 2: Data presentation. ESH-4/V2. Environmental and Safety Activities, Martin Marietta Energy Systems, Inc., Oak Ridge, Tennessee. 
Rydberg, B. 1975. The rate of strand separation in alkali of DNA of irradiated mammalian cells. Radiat. Res. 61:274-287.

Ryon, M. G., and J. M. Loar. 1988. A checklist of fishes on the Department of Energy Oak Ridge Reservation. J. Tn. Acad. Sci. 58(4):97-102.

SAS Institute, Inc. 1985a. SAS User's Guide: Basics, Version 5 Edition. Sas Institute, Inc., Cary, North Carolina.

SAS Institute, Inc. 1985b. SAS User's Guide: Statistics, Version 5 Edition. SAS Institute, Inc., Cary, North Carolina.

Sastry, A. N., and D. C. Miller. 1981. Application of biochemical and physiological responses to water quality monitoring. pp. 265-294. IN F.J. Vernberg, A. Calabrease, F. Thurberg, and W. Vernberg (eds.), Biological Monitoring of Marine Pollutants. Academic Press, New York.

Scandinavian Committee on Enzymes. 1974. Recommended methods for the determination of four enzymes in blood. Scand. J. Clin. Lab. Invest. 33:291-300.

Schuster, G. A. and D. A. Etnier. 1978. A manual for the identification of the larvae of the caddisfly genera Hydropsyche Pictet and Symphitopsyche Ulmer in Eastern and Central North America (Trichoptera: Hydropsychidae). EPA-600/4-78-060. Environmental Monitoring and Support Laboratory, U.S. Environmental Protection Agency, Cincinnati, Ohio.

Scott, D. E., F. W. Whicker, J. W. Gibbons. 1986. Effects of season on the retention of ${ }^{137} \mathrm{Cs}$ and ${ }^{90} \mathrm{Sr}$ by the yellow-bellied slider turtle (Pseudemys scripta). Can. J. Zool. 64:2850-2853.

Selby, D. A., J. M. Ihnat, and J. J. Messer. 1985. Effects of subacute cadmium exposure on a hardwater mountain stream microcosm. Water Res. 19:645-655.

Sheppard, J. D. 1974. Storm runoff in the vicinity of Oak Ridge, Tennessee. ORNL/TM4662. Oak Ridge National Laboratory, Oak Ridge, Tennessee.

Sherwood, C. B., and J. M. Loar. 1987. Environmental data for the White Oak Creek/White Oak Lake watershed. ORNL/TM-10062. Oak Ridge National Laboratory, Oak Ridge, Tennessee.

Shoaf, W. T., and B. W. Lium. 1976. Improved extraction of chlorophyll $a$ and $b$ from algae using dimethyl sulfoxide. Limnol. Oceanogr. 21:926-928.

Shugart, L. R., J. Holland, and R. Rahn. 1983. Dosimetry of carcinogenesis: Covalent binding of benzo[a]pyrene to mouse DNA. Carcinogenesis 4:195-198.

Shugart, L. R., J. F. McCarthy, B. D. Jimenez, and J. Daniels. 1987. Analysis of adduct formation in bluegill sunfish (Lepomis macrochirus) between benzo[a]pyrene and DNA of liver and hemoglobin of the erythrocyte. Aquat. Toxicol. 9:319-325.

Shugart, L. R. 1988a. Alkaline unwinding assay for detection of DNA damage in aquatic organisms. Mar. Environ. Res. 24:321-325. 
Shugart, L. R. 1988b. Quantitation of chemically induced damage to DNA of aquatic organisms by alkaline unwinding assay. Aquat. Toxicol. 13:43-52.

Shugart, L. R. 1990. 5-methyl deoxycytidine content of DNA from bluegill sunfish (Lepomis macrochirus) exposed to benzo[a]pyrene. Environ. Toxicol. Chem. 9:205-208.

Shul'man, G. E. 1974. Life Cycles of Fish-Physiology and Biochemistry. John Wiley and Sons, New York.

Silbergeld, E. K. 1974. Blood glucose: A sensitive indicator of environmental stress in fish. Bull. Environ. Contam. Toxicol. 11:20-25.

Simkiss, K., and K. Taylor. 1981. Cellular mechanisms of metal ion detoxification and some new indices of pollution. Aquat. Toxicol. 1:279-290.

Smith, J. G., L. A. Kszos, G. R. Southworth, J. M. Loar, M. G. Ryon, and S. M. Adams. 1993a. First Report on the Oak Ridge K-25 Site Biological Monitoring and Abatement Program for Mitchell Branch. ORNL/TM-11073. Oak Ridge National Laboratory, Oak Ridge, Tennessee.

Smith, J. G. 1992. Benthic macroinvertebrates. pp. 164-202. IN J. M. Loar (ed.), Second Report on the Oak Ridge National Laboratory Biological Monitoring and Abatement Program for White Oak Creek Watershed and the Clinch River. ORNL/TM-10804. Oak Ridge National Laboratory, Oak Ridge, Tennessee.

Smith, J. G. 1993b. Benthic macroinvertebrates. pp. 76-105. IN J. G. Smith (ed.), First Report on the Oak Ridge K-25 Site Biological Monitoring and Abatement Program for Mitchell Branch. ORNL/TM-11073. Oak Ridge National Laboratory, Oak Ridge, Tennessee.

Smith, P. W. 1979. The Fishes of Illinois. University of Illinois Press, Urbana, Illinois.

Sokal, R. R., and F. J. Rohlf. 1981. Biometry. W.H. Freeman and Company, San Francisco.

Southworth, G. R. 1992a. Bioaccumulation studies. pp. 86-114. IN J. M. Loar (ed.), First Annual Report on the Biological Monitoring and Abatement Program at Oak Ridge National Laboratory. ORNL/TM-10399. Oak Ridge National Laboratory, Oak Ridge, Tennessee.

Southworth, G. R. 1992b. Bioaccumulation studies. pp. 104-132. IN J. M. Loar (ed.), Second Report on the Oak Ridge National Laboratory Biological Monitoring and Abatement Program for White Oak Creek Watershed and the Clinch River. ORNL/TM-10804. Oak Ridge National Laboratory, Oak Ridge, Tennessee.

Spalding, B. P., and T. E. Cerling. 1979. Association of radionuclides with stream bed sediments in White Oak Creek watershed. ORNL/TM-6895. Oak Ridge National Laboratory, Oak Ridge, Tennessee. 
Steel, R. G. D., and J. H. Torrie. 1960. Prirsiples and Procedures of Statistics with Special Reference to the Biological Sciences. McGraw-Hill, Inc., New York.

Stegeman J. J., R. L. Binder, and A. Orren. 1979. Hepatic and extrahepatic microsomal electron transport components and mixed function oxygenases in the marine fish Stenotomus versicolor. Biochem. Pharmacol. 28:3431-3439.

Stewart, A. J., L. A. Kszos, B. C. Harvey, L. F. Wicker, G. J. Haynes and R. D. Bailey. 1990. Ambient toxicity dynamics: Assessments using Ceriodaphnia dubia and fathead minnow (Pimephales promelas) larvae in short-term tests. Environ. Toxicol. Chem. 9:367-379.

Strickland, J. D. H., and T. R. Parsons. 1972. A Practical Handbook of Seawater Analysis. Fisheries Research Board of Canada, Ottawa.

Stueber, A. M., D. A. Webster, I. L. Munro, N. D. Farrow, and T. G. Scott. 1981. An investigation of radionuclide release from Solid Waste Disposal Area 3, Oak Rige National Laboratory. ORNL/TM-7323. Oak Ridge National Laboratory, Oak Ridge, Tennessee.

Suter, G. W., II, A. E. Rosen, E. Linder, and D. F. Parkhurst. 1987. Endpoints for responses of fish to chronic toxic exposures. Environ. Toxicol. Chem. 6:793-809.

Suter, G. W., II, D. S. Vaughan, and R. H. Gardner. 1983. Risk assessment by analysis of extrapolation error: A demonstration for effects of pollutants on fish. Environ. Toxicol. Chem. 2:369-378.

Talmage, S. S. 1989. Comparative evaluation of several small mammal species as monitors of heavy metals, radionuclides, and selected organic compounds in the environment. Ph.D. Dissertation. University of Tennessee, Knoxville, Tennessee.

Talmage, S. S., and B. T. Walton. 1989. Comparative evaluation of small mammals as monitors of environmental toxicants. The Toxicologist 9:(1):215.

Talmage, S. S., J. G. Stout, and B. T. Walton. 1992. Small mammals as biological monitors of environmental contaminants. pp. 251-269. IN J. M. Loar (ed.), Second Report on the Oak Ridge National Laboratory Biological Monitoring and Abatement Program for White Oak Creek Watershed and the Clinch River. ORNL/TM-10804. Oak Ridge National Laboratory, Oak Ridge, Tennessee.

Taylor, P. A., A. J. Stewart, and L. Holt. 1988. Toxicity of common salts to three biotoxicity test organisms. Y/DZ-420. Oak Ridge Y-12 Plant, Oak Ridge, Tennessee.

TVA (Tennessee Valley Authority). 1985. Instream Contaminant Study, Task 4: Fish sampling and analysis. Report to U.S. Department of Energy, Oak Ridge Operations Office. Tennessee Valley Authority, Office of Natural Resources and Economic Development, Knoxville, Tennessee.

TVA (Tennessee Valley Authority). 1986. Instream Contaminant Study, Task 5: Summary Report. Report to U.S. Department of Energy, Oak Ridge Operations Office. Tennessee Valley Authority, Office of Natural Resources and Economic Development, Knoxville, Tennessee. 
Thomas, D., A. Cryer, J. De L. G. Solbe, and J. Kay. 1983. A comparison of the accumulation and protein binding of environmental cadmium in the gills, kidney, and liver of rainbow trout. Comp. Biochem. Physiol. 76C:241-246.

Thomas, D. G., A. Dingman, and J. S. Garvey. 1987. The function of metallothionein in cell metabolism. pp. 539-543. IN J. H. R. Kagi, and Y. Kojima (eds.), Metallothionein II, Experintia Supplementum Vol. 52, Birkhauser Verlag, Basel and Boston.

Tietz, N. W. 1986. Textbook of Clinical Chemistry. W. B. Saunders, Co., Philadelphia.

Trautman, M. B. 1981. The Fishes of Ohio. Ohio State University Press, Columbus, Ohio.

Travis, C. C., F. O. Hoffman, B. G. Blaylock, K. L. Daniel, C. S. Gist, and C. W. Weber. 1986. Preliminary review of TVA fish sampling and analysis report. Report of Task Group Five to Oak Ridge Task Force. Mimeo.

Volchok, H. L., and G. A. Planque (eds.). 1982. SR-01: Radiochemical strontium-90. pp. E-SR-01-01 through E-SR-01-29. IN: EML Procedure Manual (HASL-300), 26th Ed. Environmental Measurements Laboratory, U.S. Department of Energy, New York.

Waalkes, M. P., J. S. Garvey, and C. Klaassen. 1985. Comparison of methods of metallothionein quantification: Cadmium radioassay, mercury radioassay, and radioimmunoassay. Toxicol. Appl. Pharmacol. 79:524-527.

Wang, W. 1987. Factors affecting metal toxicity to (and accumulation by) aquatic organisms - Overview. Environ. Internat. 13:437-457.

Ward, P. S. 1974. Carcinogens complicate chlorine question. J. Water Pollut. Control. Fed. 46:2638-2640.

Waters, T. F. 1977. Secondary production in inland waters. Adv. Ecol. Res. 10:91-164.

Waters, T. F. 1979. Influence of benthos life history upon the estimation of secondary production. J. Fish. Res. Board Can. 36:1425-1430.

Webb, M., and K. Cain. 1982. Functions of metallothionein. Biochem. Pharmacol. 31:137-142.

Weber, C. I. (ed.). 1973. Biological field and laboratory methods for measuring the quality of surface waters and effluents. EPA 670/4-73-001. National Environmental Research Center, U.S. Environmental Protection Agency, Cincinnati, Ohio.

Wege, G. J., and R. O. Anderson. 1978. Relative weight $\left(W_{r}\right)$ : a new index of condition for largemouth bass. pp. 79-91. IN G. D. Novinger, and J. G. Dillard (eds), New Approaches to the Management of Small Impoundments. North Central Division, Amer. Fish. Soc., Special Publ. No. 5.

Williams, M. V., T. Winters, and K. S. Waddell. 1986. In vivo effects of mercury(II) on deoxyuridine triphosphate nucleotidohydrolase, DNA polymerase, and uracil-DNA glycosylase activities in cultured human cells: relationship to DNA damage, DNA repair, and cytotoxicity. Mol. Pharm. 31:200-207. 
Weston, Roy F. Inc. 1988. RCRA Appendix IX sampling and analysis project at the Oak Ridge Y-12 Plant: New Hope Pond analytical data summary. Y/SUB/888-97376/2. Oak Ridge Y-12 Plant, Oak Ridge, Tennessee.

Winge, D., J. Krasno, and A. Colucci. 1974. Cadmium accumulation in rat liver: correlation between bound metal and pathology. pp. 500-502. IN W. Hockstra, J. Suttie, H. Ganther, and W. Mertz (eds.), Trace Element Metabolism in Animals, Vol. 2. University Park Press, Baltimore, Maryland.

Zar, J. H. 1984. Biostatistical Analysis. Prentice-Hall, Inc., Englewood Cliffs, New Jersey. 


\section{APPENDIX A}

Results of QAVC Analyses of Mercury, PCBs, and Organics in Fish Samples 


\section{MERCURY}

Eight pairs of blind duplicate samples of fish muscle tissue were analyzed for mercury and showed a relatively low degree of variation; the mean coefficient of variation (CV) between sample pairs was $5 \%$ with a mean standard deviation (SD) of 0.01 $\mu \mathrm{g} / \mathrm{g}$. The mean difference between duplicate samples was $0.01 \mu \mathrm{g} / \mathrm{g}$. The multiple analyses of mercury in EPA reference fish $(n=4)$ agreed well with the expected value, averaging $2.55 \pm$ $0.05 \mu \mathrm{g} / \mathrm{g}$ (mean $\pm 1 \mathrm{SD}$ ) vs an expected value of $2.52 \mu \mathrm{g} / \mathrm{g}$; the average recovery was $101 \pm 2 \%$. Split duplicate fish samples analyzed for mercury by the ORNL Analytical Chemistry Division (ACD) and the U.S. EPA Environmental Services Laboratory in Athens, Georgia, differed somewhat. Fish analyzed by ORNL averaged $0.91 \mu \mathrm{g} / \mathrm{g}$ mercury, while those analyzed by the EPA lab averaged $1.16 \mu \mathrm{g} / \mathrm{g}$. The mean difference between individual samples analyzed by EPA and ORNL was $0.25 \mu \mathrm{g} / \mathrm{g}$, which was not significantly different from zero $(p$ $>0.05)$, and the mean CV $(17 \%)$ and SD $(0.18 \mu \mathrm{g} / \mathrm{g})$ were larger than values observed for duplicate analyses within the ORNL lab. Mercury levels in sunfish from the uncontaminated reference site (Hinds Creek) were typical of background levels in stream fish, averaging $0.09 \pm 0.03 \mu \mathrm{g} / \mathrm{g}(n=16)$.

\section{OTHER METALS}

Four pairs of blind duplicate samples were analyzed for metals, and relatively low variation was observed for those metals exceeding detection limits. Mean CVs for $\mathrm{Cd}, \mathrm{Cu}, \mathrm{Se}$, and $\mathrm{Zn}$ were $42,41,11$, and $26 \%$ respectively; mean SDs were $0.014,0.08,0.04$, and $1.8 \mu \mathrm{g} / \mathrm{g}$ respectively. The relatively high CVs are due in large part to the very low concentrations of metals in these samples. Results of analyses of reference tissues indicated good recoveries and quantitation of the metals (Table A.1).

\section{PCBs}

The results of $\mathrm{PCB}$ analyses of 16 pairs of blind duplicate fish samples were somewhat more variable than results of mercury analyses, as is generally the case. The mean difference and SD between duplicates was $0.35 \pm 0.32 \mu \mathrm{g} / \mathrm{g}$, with a mean CV of $28 \%$. The variabilities in the measurement of PCB-1254 and PCB1260 were similar, with mean differences between duplicates of 0.19 and $0.17 \mu \mathrm{g} / \mathrm{g}$, respectively; SDs were 0.17 and $0.16 \mu \mathrm{g} / \mathrm{g}$ and the mean CVs were $31 \%$ and $24 \%$ respectively. Samples of uncontaminated fish and clams were spiked with $1 \mu \mathrm{g} / \mathrm{g}$ each of PCB-1254 and PCB-1260 and analyzed along with fish or clam samples. Mean recoveries averaged $94 \pm 33 \%$ for total PCBs, and $89 \pm 40 \%$ and $98 \pm$ $29 \%(n=21)$ for PCB-1254 and PCB1260 , respectively. Samples of PCBcontaminated carp and channel catfish were homogenized and split for analysis by the ORNL/ACD laboratory and the EPA Environmental Services Laboratory, Athens, Georgia. Mean levels of total PCBs and PCB-1260 did not differ significantly in the nine samples analyzed by the two laboratories $(p>0.05$ ), but the results for PCB-1254 obtained by the EPA lab were significantly higher than those from the ORNL lab. Results averaged $1.74 \pm 1.30$ vs $1.33 \pm 1.03$, $0.73 \pm 0.65$ vs $0.39 \pm 0.32$, and $1.01 \pm$ 0.67 vs $0.94 \pm 0.75 \mu \mathrm{g} / \mathrm{g}$ for total PCBs, PCB-1254, and PCB-1260 respectively. The variability between duplicate samples analyzed by ORNL and EPA was similar 
Table A1. Analyses of reference tiesues for metals Units are measured in micrograms per gram

\begin{tabular}{|c|c|c|c|c|c|}
\hline \multirow{2}{*}{$\frac{\text { Metal }}{\text { As }}$} & \multirow{2}{*}{$\begin{array}{c}\text { Measured } \\
2.46 \\
2.51 \\
2.46\end{array}$} & \multirow{2}{*}{$\frac{\text { Expected }}{2.43}$} & \multirow{2}{*}{$\frac{\text { Samples }}{\text { Fish }}$} & \multicolumn{2}{|c|}{ Mean \% Recovery \pm SD Range } \\
\hline & & & & $102 \pm 1$ & $101-103$ \\
\hline Cd & $\begin{array}{l}0.15 \\
0.15 \\
0.16\end{array}$ & 0.16 & Fish & $96 \pm 4$ & $94-100$ \\
\hline $\mathrm{Cu}$ & $\begin{array}{l}2.22 \\
2.40 \\
2.02\end{array}$ & 2.21 & Fish & $100 \pm 9$ & $91-109$ \\
\hline $\mathrm{Cr}$ & $\begin{array}{l}0.96 \\
0.98 \\
0.50\end{array}$ & 0.58 & Fish & $93 \pm 6$ & $86-97$ \\
\hline $\mathrm{Hg}_{\mathbf{g}}$ & $\begin{array}{l}2.51 \\
2.52 \\
2.57 \\
2.61\end{array}$ & 2.52 & Fish & $101 \pm 2$ & $100-104$ \\
\hline $\mathbf{N i}$ & $\begin{array}{l}0.54 \\
0.56 \\
0.53\end{array}$ & 0.54 & Fish & $101 \pm 3$ & $98-104$ \\
\hline $\mathrm{Pb}$ & $\begin{array}{l}0.24 \\
0.25 \\
0.29\end{array}$ & 0.26 & Fish & $101 \pm 3$ & $92-112$ \\
\hline Se & $\begin{array}{l}1.25 \\
1.21\end{array}$ & 1.1 & Bovine Liver & $112 \pm 3$ & $110-114$ \\
\hline $\mathbf{Z n}$ & $\begin{array}{l}47.4 \\
43.5 \\
41.1\end{array}$ & 43.6 & Fish & $101 \pm 7$ & 94-109 \\
\hline
\end{tabular}

SSample types were:

Fish: freeze-dried fish tissue (EPA trace metals in fish, U.S. EPA, Cincinnati, Ohio)

Bovine liver: freeze-dried bovine liver National Bureau of Standards $\# 1577$.

to the variability between duplicates analyzed at ORNL, with a mean SD between duplicates of $0.29,0.25$, and 0.10 ppm and a mean CV of $22 \%, 46 \%$, and $18 \%$ for total PCBs, PCB-1254, and PCB-1260 respectively. Samples of catfish collected in 1987 from an uncontaminated site (commercial fish farm) were used as analytical controls; these exhibited very low levels of total
PCBs, averaging $0.04 \pm 0.02 \mathrm{ppm}(n=8$ samples from four fish).

Because these data were to be compared with data collected in 1986 to ascertain the presence of any year-toyear changes, archived samples of catfish collected and analyzed in 1987 were reanalyzed along with the fish collected in 1988. Results of ine reanalyses of these samples differed significantly, 
averaging $3.26 \pm 0.92$ and $2.27 \pm 0.80$ ppm $(n=8)$ in 1987 and 1988 respectively.

The samples selected for reanalysis were among those having the highest PCB concentrations in 1987. Selecting such samples for comparison of year-toyear variation in PCB analyses was an error, because such samples quite likely represent the high end of variability within individual analyses, and subsequent reanalysis would be likely to yield a lower result. Thus, year-to-year variation in analytical results is probably better than this comparison indicates.

\section{ORGANICS SCREENING ANALYSES}

\author{
Uncontaminated fish and clam
samples were spiked with a mixture of \\ Uncontaminated fish and clam
samples were spiked with a mixture of six
}

priority pollutants [PCB-1254, PCB-1260, di- $N$-butylphthalate, 2-ethylhexylphthalate, pyrene, and benzo(a)pyrenel and analyzed to ensure that these contaminants would be recovered and quantified in the extraction, cleanup, and gas chromatographic analysis. In the GC/MS analysis, the recovery of di- $N$.

butylphthalate and 2-ethylhexylphthalate averaged $57 \pm 3 \%$ and $56 \pm 7 \%$ respectively, and that of pyrene and benzo(a)pyrene averaged $63 \pm 6 \%$ and $70 \pm 7 \%$ respectively $(n=4$ for each substance). Recoveries of PAHs were better in the HPLC procedure, averaging $105 \pm 11 \%$ for pyrene and $80 \pm 12$ for benzo[a]pyrene. 


\section{APPENDIX B}

Concentrations of Contaminants in Aquatic Biota from White Oak Creek and Tributaries, White Oak Lake, and the Clinch River

November 1987 - August 1988 
Table B.1. Metals in sunfish from White Oak Creek and tributaries, White Oak Lake, and the Clinch River

\begin{tabular}{|c|c|c|c|c|c|c|c|c|c|c|c|c|}
\hline Site $^{a}$ & Date & $\mathrm{Spp}^{b}$ & Sex & No. $^{c}$ & $\begin{array}{l}W / \\
(8)\end{array}$ & $\begin{array}{l}\text { Lgth } \\
(\mathrm{cm})\end{array}$ & $\begin{array}{c}\mathrm{H}_{8} \\
(\mu \mathrm{g} / \mathrm{g})\end{array}$ & $\begin{array}{c}C d \\
(\mu g / g)\end{array}$ & $\begin{array}{c}\mathrm{Cu} \\
(\mu \mathrm{g} / \mathrm{g})\end{array}$ & $\begin{array}{c}\mathrm{Pb} \\
(\mu g / g)\end{array}$ & $\begin{array}{c}\text { Se } \\
(\mu \mathrm{g} / \mathrm{g})\end{array}$ & $\begin{array}{c}\mathrm{Zn} \\
(\mu \mathrm{g} / \mathrm{g})\end{array}$ \\
\hline WCK 3.5 & $11 / 11 / 87$ & BLUGIL & $\mathbf{M}$ & 7037 & 257.5 & 22.4 & 0.41 & 0.001 & 0.12 & 0.03 & 0.52 & 5.4 \\
\hline WCK 3.5 & $11 / 11 / 87$ & BLUGIL & $\mathbf{M}$ & 7038 & 188.2 & 20.6 & 0.37 & 0.002 & 0.16 & $<0.02$ & 0.37 & 6.9 \\
\hline wCK 3.5 & $11 / 11 / 87$ & BLUGIL & $\mathbf{M}$ & 7039 & 82.8 & 15.8 & 0.29 & 0.012 & 0.15 & $<0.02$ & 0.27 & 4.9 \\
\hline WCK 3.5 & $11 / 11 / 87$ & BLUGIL & $\mathbf{F}$ & 7040 & 43.5 & 13.5 & 0.27 & & & & & \\
\hline WCK 3.5 & $11 / 11 / 87$ & BLUGIL & $\mathbf{M}$ & 7041 & 35.5 & 13.1 & 0.23 & & & & & \\
\hline WCK 3.5 & $11 / 11 / 87$ & BLUGIL & $\mathbf{M}$ & 9241 & 133.3 & 18.2 & 0.33 & 0.004 & 0.50 & $<0.02$ & 0.06 & 3.7 \\
\hline WCK 3.5 & $11 / 11 / 87$ & BLUGIL & $\mathbf{M}$ & 9248 & 52.6 & 14.5 & 0.26 & 0.005 & 0.30 & $<0.02$ & 0.39 & 4.3 \\
\hline WCK 3.5 & $11 / 11 / 87$ & BLUGIL & $\mathbf{M}$ & 9249 & 51.6 & 14.2 & 0.22 & 0.007 & 0.17 & $<0.02$ & 0.35 & 3.9 \\
\hline WCK 2.9 & $12 / 02 / 87$ & REDBRE & $\mathbf{F}$ & 7021 & 49.5 & 14.2 & & & & & & \\
\hline WCK 2.9 & $12 / 02 / 87$ & REDBRE & $\mathbf{M}$ & 7022 & 103.9 & 18.3 & 0.47 & 0.008 & 0.24 & $<0.02$ & 0.53 & 9.2 \\
\hline WCK 2.9 & $12 / 02 / 87$ & REDBRE & $\mathbf{M}$ & 7023 & 54.8 & 15.2 & 0.29 & 0.008 & 0.17 & $<0.02$ & 0.37 & 5.5 \\
\hline WCK 2.9 & $12 / 02 / 87$ & REDBRE & $\mathbf{F}$ & 7024 & 34.6 & 12.8 & 0.28 & 0.010 & 0.19 & 0.11 & 0.39 & 7.5 \\
\hline WCK 2.9 & $12 / 02 / 87$ & REDBRE & $\mathbf{M}$ & 7025 & 83.9 & 17.4 & 0.49 & 0.014 & 0.42 & $<0.02$ & 0.49 & 5.7 \\
\hline WCK 2.9 & $12 / 02 / 87$ & REDBRE & $\mathbf{M}$ & 7026 & 79.9 & 17.0 & 0.33 & & & & & \\
\hline WCK 2.9 & $12 / 02 / 87$ & REDBRE & $\mathbf{M}$ & 7027 & 79.5 & 16.8 & 0.30 & 0.007 & 0.29 & $<0.02$ & 0.41 & 7.1 \\
\hline WCK 2.9 & $12 / 02 / 87$ & REDBRE & $\mathbf{M}$ & 7028 & 85.9 & 17.4 & 0.37 & 0.016 & 0.35 & $<0.02$ & 0.39 & 7.3 \\
\hline WCK 2.9 & $12 / 02 / 87$ & REDBRE & $\mathbf{M}$ & 7029 & 65.4 & 16.5 & 0.43 & & & & & \\
\hline WCK 2.9 & $12 / 02 / 87$ & BLUGIL & $\mathbf{M}$ & 7030 & 95.2 & 17.7 & 0.22 & 0.003 & 0.10 & $<0.02$ & 0.39 & 4.1 \\
\hline WCK 2.9 & $12 / 02 / 87$ & BLUGIL & $\mathbf{M}$ & 7031 & 149.9 & 20.2 & 0.62 & 0.007 & 0.77 & $<0.02$ & 0.51 & 8.8 \\
\hline WCK 2.9 & $12 / 02 / 87$ & BLUGIL. & $\mathbf{M}$ & 7032 & 135.0 & 20.0 & 0.49 & 0.001 & 0.13 & $<0.02$ & 0.53 & 4.3 \\
\hline WCK 2.9 & $12 / 02 / 87$ & BLUGIL & $\mathbf{M}$ & 7033 & 44.6 & 13.7 & 0.43 & 0.004 & 0.12 & $<0.02$ & 0.33 & 4.7 \\
\hline WCK 2.9 & $12 / 02 / 87$ & BLUGIL & $\mathbf{M}$ & 7034 & 56.2 & 14.7 & 0.20 & 0.014 & 0.17 & $<0.02$ & 0.25 & 6.9 \\
\hline WCK 2.9 & $12 / 02 / 87$ & BLUGIL & $\mathrm{F}$ & 7035 & 53.5 & 14.7 & 0.41 & 0.003 & 0.24 & $<0.02$ & 0.31 & 7.6 \\
\hline WCK 2.9 & $12 / 02 / 87$ & BLUGIL & $\mathbf{F}$ & 7036 & 48.9 & 14.2 & 0.36 & 0.004 & 0.29 & $<0.02$ & 0.27 & 5.7 \\
\hline WCK 2.3 & $11 / 30 / 87$ & BLUGIL & $\mathbf{M}$ & 7000 & 60.0 & 14.5 & 0.22 & & & & & \\
\hline WCK 2.3 & $11 / 30 / 87$ & BLUGIL & $\mathbf{M}$ & 7001 & 43.4 & 13.4 & & & & & & \\
\hline WCK 2.3 & $11 / 30 / 87$ & BLUGIL & $\mathbf{M}$ & 7002 & 89.2 & 16.9 & 0.28 & 0.003 & 0.10 & $<0.02$ & 0.35 & 9.2 \\
\hline WCK 2.3 & $11 / 30 / 87$ & BLUGIL & $\mathbf{M}$ & 7003 & 51.2 & 14.2 & 0.23 & 0.004 & 0.14 & $<0.02$ & 0.24 & 5.5 \\
\hline WCK 2.3 & $11 / 30 / 87$ & BLUGIL & $\mathbf{M}$ & 7004 & 51.7 & 14.0 & 0.19 & & & & & \\
\hline WCK 2.3 & $11 / 30 / 87$ & BLUGIL & $\mathrm{F}$ & 7005 & 53.0 & 14.5 & 0.05 & & & & & \\
\hline WCK 2.3 & $11 / 30 / 87$ & BLUGIL & $\mathbf{M}$ & 7006 & 49.1 & 14.0 & 0.15 & 0.002 & 0.07 & $<0.02$ & 0.24 & 4.1 \\
\hline WCK 2.3 & $11 / 30 / 87$ & BLUGIL & $\mathbf{M}$ & 7007 & 43.8 & 13.7 & & 0.004 & 0.44 & $<0.02$ & 0.39 & 5.1 \\
\hline WCK 2.3 & $11 / 30 / 87$ & BLUGIL & $\mathbf{M}$ & 7008 & 41.9 & 13.5 & 0.12 & 0.006 & 0.05 & $<0.02$ & 0.25 & 6.1 \\
\hline WCK 2.3 & $11 / 30 / 87$ & BLUGIL & $F$ & 7009 & 40.7 & 13.7 & 0.20 & 0.002 & 0.19 & $<0.02$ & 0.65 & 9.0 \\
\hline WOL & $11 / 10 / 87$ & BLUGIL & $\mathbf{M}$ & 7051 & 112.2 & 17.7 & 0.41 & 0.005 & 0.48 & $<0.02$ & 0.31 & 6.1 \\
\hline WOL & $11 / 10 / 87$ & BLUGIL & $\mathbf{M}$ & 7052 & 65.5 & 14.5 & 0.11 & 0.003 & 0.11 & $<0.02$ & 0.22 & 7.6 \\
\hline WOL & $11 / 10 / 87$ & BLUGIL & $\mathbf{M}$ & 7053 & 81.3 & 16.2 & 0.16 & & & & & \\
\hline WOL & $11 / 10 / 87$ & BLUGIL & $\mathbf{F}$ & 7054 & 100.9 & 18.0 & 0.40 & 0.003 & 0.05 & $<0.02$ & 0.18 & 9.8 \\
\hline WOL & $11 / 10 / 87$ & BLUGIL & M & 7055 & 87.4 & 17.4 & 0.33 & 0.020 & 0.16 & $<0.02$ & 0.27 & 13.3 \\
\hline WOL & $11 / 10 / 87$ & BLUGIL & $\mathbf{F}$ & 7056 & 32.2 & 16.5 & 0.29 & 0.006 & 0.08 & $<0.02$ & 0.22 & 13.3 \\
\hline WOL & $11 / 10 / 87$ & BLUGIL & $\mathbf{F}$ & 7057 & 62.3 & 15.5 & 0.25 & & & & & \\
\hline WOL & $11 / 10 / 87$ & BLUGIL & $\mathbf{M}$ & 7058 & 81.7 & 16.9 & 0.10 & 0.010 & 0.19 & 0.04 & 0.25 & 8.0 \\
\hline WOL & $11 / 10 / 87$ & BLUGIL & $\mathbf{M}$ & 7061 & 49.7 & 13.7 & & & & & & \\
\hline WCK 0.9 & $02 / 17 / 88$ & BLUGIL & $\mathbf{M}$ & 7900 & 105.0 & 17.6 & 0.06 & & & & & \\
\hline WCK 0.9 & $02 / 17 / 88$ & BLUGIL & $\mathrm{F}$ & 7901 & 61.8 & 14.5 & 0.05 & 0.007 & 0.33 & $<0.02$ & 0.24 & 5.5 \\
\hline WCK 0.9 & $02 / 17 / 88$ & BLUGIL & $F$ & 7902 & 45.5 & 13.8 & & & & & & \\
\hline WCK 0.9 & $02 / 17 / 38$ & BLUGIL & $\mathbf{F}$ & 7903 & 56.1 & 14.9 & & & & & & \\
\hline WCK 0.9 & $02 / 17 / 88$ & BLUGIL & $\mathrm{F}$ & 7904 & 91.8 & 16.2 & 0.07 & $<0.001$ & 0.51 & $<0.02$ & 0.22 & 5.3 \\
\hline WCK 0.9 & $02 / 17 / 88$ & BLUGIL & $\mathbf{F}$ & 7905 & 54.2 & 15.0 & 0.05 & 0.004 & 0.99 & 0.03 & 0.33 & 8.6 \\
\hline WCK 0.9 & $02 / 17 / 88$ & BLUGIL & $\mathbf{M}$ & 7906 & 46.6 & 13.8 & & & & & & \\
\hline WCK 0.9 & $02 / 17 / 88$ & BLUGIL & $\mathbf{M}$ & 7907 & 61.4 & 15.2 & 0.08 & 0.003 & 1.85 & $<0.02$ & 0.27 & 8.0 \\
\hline WCK 0.9 & $02 / 17 / 88$ & BLUGIL & $\mathbf{M}$ & 7908 & 70.0 & 15.6 & 0.06 & 0.002 & 0.08 & $<0.02$ & 0.41 & 6.5 \\
\hline
\end{tabular}


Table B.1 (continued)

\begin{tabular}{|c|c|c|c|c|c|c|c|c|c|c|c|c|}
\hline Site ${ }^{a}$ & Date & Spp ${ }^{6}$ & Sex & No. ${ }^{c}$ & $\begin{array}{l}W t \\
(8) \\
\end{array}$ & $\begin{array}{l}\text { Lgth } \\
(\mathrm{cm})\end{array}$ & $\begin{array}{c}H_{\xi} \\
(\mu g / g)\end{array}$ & $\begin{array}{c}C d \\
(\mu g / g)\end{array}$ & $\begin{array}{c}\mathrm{Cu} \\
(\mu \nu / 8) \\
\end{array}$ & $\begin{array}{c}\mathrm{Pb} \\
(\mu \mathrm{g} / \mathrm{g})\end{array}$ & $\begin{array}{c}\mathrm{Se} \\
(\mu \mathrm{g} / \mathrm{g})\end{array}$ & $\begin{array}{c}\mathrm{Zn} \\
(\mu \mathrm{g} / \mathrm{g})\end{array}$ \\
\hline $\begin{array}{l}\text { WCK } 0.9 \\
\text { WCK } 0.9\end{array}$ & $02 / 17 / 88$ & BLUGIL & $\underset{\mathbf{F}}{\mathbf{M}}$ & 7909 & 70.0 & 15.1 & 0.05 & 0.002 & 0.40 & $<0.02$ & 0.27 & 4.1 \\
\hline WCK 0.9 & 02/17/88 & BLUGIL & $\mathbf{F}$ & 7910 & 57.1 & 14.9 & & & & & & \\
\hline NTK 0.2 & $12 / 01 / 87$ & BLUGIL & $\mathbf{F}$ & 7012 & 66.5 & 16.0 & 0.24 & & & & & \\
\hline NTK 0.2 & $12 / 01 / 87$ & BLUGIL & $\mathbf{M}$ & 7013 & 44.9 & 14.0 & 0.16 & & & & & \\
\hline NTK 0.2 & $12 / 01 / 87$ & BLUGIL & $\mathbf{F}$ & 7014 & 124.6 & 19.2 & 0.40 & 0.007 & 0.24 & $<0.02$ & 0.43 & 6.9 \\
\hline NTK 0.2 & $12 / 01 / 87$ & BLUGIL & $\mathbf{M}$ & 7015 & 104.0 & 18.1 & 0.16 & 0.002 & 0.05 & $<0.02$ & 0.59 & 5.3 \\
\hline NTK 0.2 & $12 / 01 / 87$ & BLUGIL & $\mathbf{M}$ & 7016 & 114.7 & 18.6 & 0.16 & 0.002 & 0.08 & $<0.02$ & 0.25 & 3.7 \\
\hline NTK 0.2 & $12 / 01 / 87$ & BLUGIL & $\mathbf{M}$ & 7017 & 64.9 & 15.9 & 0.17 & 0.003 & 0.09 & $<0.02$ & 0.29 & 4.7 \\
\hline NTK 0.2 & $12 / 01 / 87$ & BLUGIL & $\mathbf{M}$ & 7018 & 96.6 & 17.9 & 0.32 & 0.001 & $<0.02$ & $<0.02$ & 0.47 & 3.9 \\
\hline NTK 0.2 & $12 / 01 / 87$ & BLUGIL & $\mathbf{M}$ & 7019 & 43.3 & 14.0 & 0.35 & & & & & \\
\hline NIK 0.2 & $12 / 01 / 87$ & BLUGIL & $\mathbf{M}$ & 7020 & 116.4 & 18.7 & & 0.012 & 0.45 & $<0.02$ & 0.49 & 11.8 \\
\hline MEK 0.2 & $01 / 21 / 88$ & BLUGIL & $\mathbf{M}$ & 7187 & 24.0 & 11.1 & 0.05 & & & & & \\
\hline MEK 0.2 & $01 / 21 / 88$ & BLUGIL & $\mathbf{M}$ & 7188 & 31.0 & 12.0 & & 0.018 & 0.17 & $<0.02$ & 0.18 & 8.8 \\
\hline MEK 0.2 & $01 / 21 / 88$ & BLUGIL & $\mathbf{F}$ & 7189 & 22.7 & 11.0 & 0.05 & 0.003 & 0.03 & $<0.02$ & 0.25 & 6.5 \\
\hline MEK 0.2 & $01 / 21 / 88$ & BLUGIL & $\mathbf{M}$ & 7190 & 15.3 & 9.6 & & & & & & \\
\hline MEK 0.2 & $01 / 21 / 88$ & BLUGIL & $\mathbf{F}$ & 7191 & 19.4 & 10.8 & & & & & & \\
\hline MEK 0.2 & $01 / 21 / 88$ & BLUGIL & $\mathbf{F}$ & 7192 & 18.1 & 10.6 & 0.05 & & & & & \\
\hline MEK 0.2 & $01 / 2\{/ 88$ & BLUGIL & $\mathbf{M}$ & 7193 & 25.3 & 11.2 & 0.05 & 0.005 & 0.14 & $<0.02$ & 0.22 & 7.5 \\
\hline MEK 0.2 & $01 / 21 / 88$ & BLUGIL & $\mathbf{F}$ & 7194 & 22.8 & 11.0 & 0.05 & & & & & \\
\hline MEK 0.2 & $01 / 21 / 88$ & BLUGIL & $\mathbf{M}$ & 7195 & 25.2 & 11.6 & 0.05 & 0.005 & 0.37 & $<0.02$ & 0.20 & 4.7 \\
\hline MEK 0.2 & $01 / 21 / 88$ & BLUGIL & $\mathbf{M}$ & 7196 & 16.1 & 10.3 & & 0.004 & 0.18 & $<0.02$ & 0.35 & 7.1 \\
\hline MEK 0.2 & $01 / 21 / 88$ & BLUGIL & $M$ & 7197 & 24.0 & 11.1 & & & & & & \\
\hline MEK 0.2 & $01 / 21 / 88$ & BLUGIL & $\mathbf{M}$ & 7198 & 26.6 & 11.5 & 0.06 & & & & & \\
\hline MEK 0.2 & $01 / 21 / 88$ & BLUGIL & $\mathbf{M}$ & 7199 & 34.5 & 12.6 & & 0.003 & 0.02 & $<0.02$ & 0.20 & 6.1 \\
\hline MEK 0.2 & $01 / 21 / 88$ & BLUGIL & $\mathbf{M}$ & 7200 & 11.4 & 9.2 & 0.10 & & & & & \\
\hline HINDSCR & $12 / 30 / 87$ & REDBRE & $\mathbf{M}$ & 7139 & 77.8 & 17.3 & 0.06 & & & & & \\
\hline HINDSCR & $12 / 30 / 87$ & REDBRE & $\mathbf{M}$ & 7138 & 61.3 & 15.6 & 0.05 & & & & & \\
\hline HINDSCR & $12 / 30 / 87$ & REDBRE & $\mathbf{M}$ & 7140 & 68.6 & 16.7 & 0.05 & & & & & \\
\hline HINDSCR & $12 / 30 / 87$ & REDBRE & $\mathbf{F}$ & 7141 & 48.9 & 15.1 & 0.11 & & & & & \\
\hline HINDSCR & $12 / 30 / 87$ & REDBRE & $\mathbf{F}$ & 7142 & 45.9 & 14.8 & 0.12 & & & & & \\
\hline HINDSCR & $12 / 30 / 87$ & REDBRE & $\mathbf{M}$ & 7143 & 38.2 & 13.4 & 0.04 & & & & & \\
\hline HINDSCR & $12 / 30 / 87$ & REDBRE & $\mathbf{F}$ & 7144 & 36.4 & 13.0 & 0.10 & & & & & \\
\hline HINDSCR & $12 / 30 / 87$ & REDBRE & $\mathbf{F}$ & 7145 & 27.2 & 13.1 & 0.16 & & & & & \\
\hline HINDSCR & $12 / 30 / 87$ & BLUGIL & $\mathbf{F}$ & 7146 & 54.6 & 15.3 & 0.08 & & & & & \\
\hline HINDSCR & $12 / 30 / 87$ & BLUGIL & $\mathbf{F}$ & 7147 & 57.5 & 15.1 & 0.08 & & & & & \\
\hline HINDSCR & $12 / 30 / 87$ & BLUGIL & $\mathbf{F}$ & 7148 & 74.8 & 16.4 & 0.11 & & & & & \\
\hline HINDSCR & $12 / 30 / 87$ & BLUGIL & . & 7149 & 58.4 & 15.0 & 0.09 & & & & & \\
\hline HINDSCR & $12 / 30 / 87$ & BLUGIL & $\mathbf{M}$ & 7150 & 42.5 & 13.4 & 0.10 & & & & & \\
\hline HINDSCR & $12 / 30 / 87$ & BLUGIL & $\mathbf{F}$ & 7151 & 51.7 & 14.9 & 0.15 & 0.004 & 0.05 & $<0.02$ & 0.31 & 6.5 \\
\hline HINDSCR & $12 / 30 / 87$ & BLUGIL & $\mathbf{F}$ & 7152 & 42.5 & 14.2 & 0.08 & & & & & \\
\hline HINDSCR & $12 / 30 / 87$ & BLUGIL & $\mathbf{F}$ & 7153 & 38.2 & 13.4 & 0.10 & & & & & \\
\hline HINDSCR & $12 / 30 / 87$ & BLUGIL & $\mathbf{M}$ & 7154 & 41.5 & 14.2 & & 0.007 & 0.05 & $<0.02$ & 0.25 & 5.9 \\
\hline HINDSCR & $01 / 21 / 87$ & BLUGIL & $\mathbf{M}$ & 6930 & 83.5 & 16.9 & & 0.004 & 0.10 & $<0.02$ & 0.50 & 5.8 \\
\hline HINDSCR & $01 / 21 / 87$ & BLUGIL & $\mathbf{M}$ & 6995 & 85.2 & 16.5 & & 0.013 & 0.17 & $<0.02$ & 0.46 & 6.5 \\
\hline HINDSCR & $01 / 21 / 87$ & BLCIGIL & $\mathrm{F}$ & 7202 & 84.2 & 16.6 & & $<0.002$ & 0.06 & $<0.02$ & 0.14 & 6.3 \\
\hline HINDSCR & $01 / 21 / 87$ & BLUGIL & $\mathbf{M}$ & 7694 & 81.6 & 16.5 & & 0.010 & 0.07 & $<0.02$ & 0.16 & 5.6 \\
\hline MHR & $11 / 11 / 87$ & BLUGIL & $\mathbf{M}$ & 6308 & 72.2 & 15.9 & 0.03 & & & & & \\
\hline MHR & $11 / 11 / 87$ & BLUGIL & $\mathbf{F}$ & 6309 & 51.9 & 15.0 & 0.10 & & & & & \\
\hline MHR & $11,11 / 87$ & BLUGIL & $\mathbf{M}$ & 6310 & 53.9 & 14.8 & 0.03 & & & & & \\
\hline MHR & $11 / 11 / 87$ & BLUGIL & $\mathbf{M}$ & 6311 & 61.0 & 14.8 & 0.03 & & & & & \\
\hline MHR & $11 / 11 / 87$ & BLUGIL & $F$ & 6312 & 34.7 & 13.0 & 0.03 & & & & & \\
\hline
\end{tabular}


B-4 - Biological Monitoring and Abatement Program

Table B.1 (continued)

\begin{tabular}{|c|c|c|c|c|c|c|c|c|c|c|c|c|}
\hline Site ${ }^{a}$ & Date & Spp ${ }^{b}$ & Sex & No. ${ }^{c}$ & $\begin{array}{l}\text { Wt } \\
(\mathrm{g}) \\
\end{array}$ & $\begin{array}{l}\text { Lgth } \\
(\mathrm{cm})\end{array}$ & $\begin{array}{c}\mathbf{H g} \\
(\mu \mathrm{g} / \mathrm{g}) \\
\end{array}$ & $\begin{array}{c}\mathrm{Cd} \\
(\mu \mathrm{g} / \mathrm{g}) \\
\end{array}$ & $\begin{array}{c}\mathrm{Cu} \\
(\mu \mathrm{g} / \mathrm{g}) \\
\end{array}$ & $\begin{array}{c}\mathrm{Pb} \\
(\mu \mathrm{g} / \mathrm{g}) \\
\end{array}$ & $\begin{array}{c}\mathrm{Se} \\
(\mu \mathrm{g} / \mathrm{g})\end{array}$ & $\begin{array}{c}\mathrm{Zn} \\
(\mu \mathrm{g} / \mathrm{g})\end{array}$ \\
\hline MHR & $11 / 11 / 87$ & BLUGIL & $\mathbf{M}$ & 6313 & 31.3 & 12.5 & 0.03 & & & & & \\
\hline MHR & $11 / 11 / 87$ & BLUGIL & $\mathbf{F}$ & 6314 & 108.8 & 18.0 & 0.04 & & & & & \\
\hline MHR & $11 / 11 / 87$ & BLUGIL & $\mathbf{M}$ & 6315 & 72.8 & 16.1 & 0.02 & & & & & \\
\hline MHR & $11 / 11 / 87$ & REDBRE & $\mathbf{F}$ & 6316 & 50.9 & 14.5 & 0.07 & & & & & \\
\hline MHR & $11 / 11 / 87$ & REDBRE & $F$ & 6317 & 41.4 & 14.1 & 0.06 & & & & & \\
\hline MHR & $11 / 11 / 87$ & REDBRE & $\mathbf{M}$ & 6318 & 68.1 & 15.8 & 0.09 & & & & & \\
\hline MHR & $11 / 11 / 87$ & REDBRE & $\mathbf{M}$ & 6319 & 98.1 & 17.7 & 0.05 & & & & & \\
\hline MHR & $11 / 11 / 87$ & REDBRE & $\mathbf{F}$ & 6320 & $\mathbf{4 0 . 2}$ & 13.9 & 0.12 & & & & & \\
\hline MHR & $11 / 11 / 87$ & REDBRE & $\mathbf{F}$ & 6321 & 56.7 & 15.0 & 0.06 & & & & & \\
\hline MHR & $11 / 11 / 87$ & REDBRE & $\mathbf{M}$ & 6322 & 71.4 & 16.0 & 0.05 & & & & & \\
\hline MHR & $11 / 11 / 87$ & REDBRE & $\mathbf{M}$ & 6323 & 92.6 & 17.5 & 0.08 & & & & & \\
\hline CRK 31.5 & $11 / 17 / 87$ & BLUGIL & $\mathbf{M}$ & 9258 & 63.2 & 15.2 & 0.02 & & & & & \\
\hline CRK 31.5 & $11 / 17 / 87$ & BLUGIL & $\mathbf{F}$ & 9271 & 32.0 & 12.0 & 0.03 & & & & & \\
\hline CRK 31.5 & $11 / 17 / 87$ & BLUGIL & $\mathbf{F}$ & 9272 & 91.0 & 17.5 & 0.10 & & & & & \\
\hline CRK 31.5 & $11 / 17 / 87$ & BLUGIL & $\mathbf{M}$ & 9273 & 60.2 & 14.9 & 0.02 & & & & & \\
\hline CRK 31.5 & $11 / 17 / 87$ & BLUGIL & $\mathbf{F}$ & 9275 & 32.6 & 12.1 & 0.01 & & & & & \\
\hline CRK 31.5 & $11 / 17 / 87$ & BLUGIL & F & 9276 & 71.0 & 15.7 & 0.02 & & & & & \\
\hline CRK 31.5 & $11 / 17 / 87$ & BLUGIL & . & 9278 & 36.5 & 12.7 & 0.03 & & & & & \\
\hline CRK 31.5 & $11 / 17 / 87$ & BLUGIL & $\mathbf{F}$ & 9296 & 48.7 & 14.2 & 0.02 & & & & & \\
\hline CRK 35.2 & $11 / 17 / 87$ & BLUGIL & $\mathbf{M}$ & 6300 & 116.9 & 17.6 & 0.04 & & & & & \\
\hline CRK 35.2 & $11 / 17 / 87$ & BLUGIL & $\mathbf{F}$ & 6301 & 47.6 & 13.8 & 0.03 & & & & & \\
\hline CRK 35.2 & $11 / 17 / 87$ & BLUGIL & $\mathbf{M}$ & 6302 & 63.8 & 14.7 & 0.03 & & & & & \\
\hline CRK 35.2 & $11 / 17 / 87$ & BLUGIL & $\mathbf{F}$ & 6303 & 57.4 & 14.9 & 0.03 & & & & & \\
\hline CRK 35.2 & $11 / 17 / 87$ & BLUGIL & $\mathbf{F}$ & 6304 & 48.9 & 13.8 & 0.01 & & & & & \\
\hline CRK 35.2 & $11 / 17 / 87$ & BLUGIL & $\mathbf{F}$ & 6305 & 64.8 & 14.2 & 0.02 & & & & & \\
\hline CRK 35.2 & $11 / 17 / 87$ & BLUGIL & $\mathbf{M}$ & 6306 & 112.7 & 18.0 & 0.05 & & & & & \\
\hline CRK 35.2 & $11 / 17 / 87$ & BLUGIL & $\mathbf{M}$ & 6307 & 101.3 & 17.9 & 0.04 & & & & & \\
\hline
\end{tabular}

${ }^{a}$ WCK = White Oak Creek kilometer; WOL = White Oak Lake; MEK = Melton Branch kilometer; NTK = Northwest Tributary kilometer; CRK = Clinch River kilometer; HINDSCR = Hinds Creek near Clinton (Anderson County), Tennessee.

${ }^{b}$ Species include bluegill (Lepomis machrochirus) and redbreast sunfish (Lepomis auritus).

${ }^{c}$ Fish identification tag number.

Note: The following metals were below the listed detection limit in all samples. Values are expressed in micrograms per gram, wet weight

$$
\begin{aligned}
& \mathrm{Sb}-<0.2 \\
& \mathrm{As}-<0.06 \\
& \mathrm{Be}-<0.02 \\
& \mathrm{Cr}-<0.1 \\
& \mathrm{Li}-<0.4 \\
& \mathrm{Ni}-<0.6 \\
& \mathrm{Ag}-<0.04 \\
& \mathrm{Th}-<0.2
\end{aligned}
$$


Table B.2. Organic contaminants in sunfish (in micrograms per gram wet wt) from White Oak Creek and tributaries and nearby reaches of the Clinch River and Melton Hill Reservoir

\begin{tabular}{|c|c|c|c|c|c|c|c|c|c|c|c|}
\hline Site & Dist. ${ }^{b}$ & Date & Spp ${ }^{c}$ & Sex & No." & $\mathbf{W} \mathbf{t}^{\prime}$ & Lgth & $\mathrm{PCB}^{h}$ & $1254^{i}$ & $1260^{\circ}$ & Other \\
\hline WCK 3.5 & 3.5 & $11 / 11 / 87$ & BLUGIL & $\mathbf{M}$ & 7037 & 257.5 & 22.4 & 0.37 & 0.26 & 0.11 & BLD \\
\hline WCK 3.5 & 3.5 & $11 / 11 / 87$ & BLUGIL & $\mathbf{M}$ & 7038 & 188.2 & 20.6 & 0.53 & 0.39 & 0.14 & BLD \\
\hline WCK 3.5 & 3.5 & $11 / 11 / 87$ & BLUGIL & $\mathbf{M}$ & 7039 & 82.8 & 15.8 & 0.34 & 0.23 & 0.11 & \\
\hline WCK 3.5 & 3.5 & $11 / 11 / 87$ & BLUGIL & F & 7040 & 43.5 & 13.5 & 0.49 & 0.38 & 0.11 & BLD \\
\hline WCK 3.5 & 3.5 & $11 / 11 / 87$ & BLUGIL & $\mathbf{M}$ & 7041 & 35.5 & 13.1 & 1.04 & 0.73 & 0.31 & \\
\hline WCK 3.5 & 3.5 & $11 / 11 / 87$ & BLUGIL & $\mathbf{M}$ & 9241 & 133.3 & 18.2 & 1.19 & 0.80 & 0.39 & BLD \\
\hline WCK 3.5 & 3.5 & $11 / 11 / 87$ & BLUGIL & $\mathbf{M}$ & 9248 & 52.6 & 14.5 & 0.47 & 0.34 & 0.13 & \\
\hline WCK 3.5 & 3.5 & $11 / 11 / 87$ & BLUGIL & $\mathbf{M}$ & 9249 & 51.6 & 14.2 & 1.16 & 0.91 & 0.25 & \\
\hline WCK 2.9 & 2.9 & $12 / 02 / 87$ & REDBRE & $\mathbf{F}$ & 7021 & 49.5 & 14.2 & 0.69 & 0.50 & 0.19 & BLD \\
\hline WCK 2.9 & 2.9 & $12 / 02 / 87$ & REDBRE & $\mathbf{M}$ & 7022 & 103.9 & 18.3 & 0.97 & 0.67 & 0.30 & BLD \\
\hline WCK 2.9 & 2.9 & $12 / 02 / 87$ & REDBRE & $\mathbf{M}$ & 7023 & 54.8 & 15.2 & 0.49 & 0.36 & 0.13 & \\
\hline WCK 2.9 & 2.9 & $12 / 02 / 87$ & REDBRE & $\mathbf{F}$ & 7024 & 34.6 & 12.8 & 0.95 & 0.69 & 0.26 & \\
\hline WCK 2.9 & 2.9 & $12 / 02 / 87$ & REDBRE & $\mathbf{M}$ & 7025 & 83.9 & 17.4 & & & & BLD \\
\hline WCK 2.9 & 2.9 & $12 / 02 / 87$ & REDBRE & $\mathbf{M}$ & 7026 & 79.9 & 17.0 & 1.34 & 0.82 & 0.52 & \\
\hline WCK 2.9 & 2.9 & $12 / 02 / 87$ & REDBRE & M & 7027 & 79.5 & 16.8 & 0.47 & 0.35 & 0.12 & \\
\hline WCK 2.9 & 2.9 & $12 / 02 / 87$ & REDBRE & $\mathbf{M}$ & 7028 & 85.9 & 17.4 & 1.17 & 0.79 & 0.38 & \\
\hline WCK 2.9 & 2.9 & $12 / 02 / 87$ & REDBRE & $\mathbf{M}$ & 7029 & 65.4 & 16.5 & 0.98 & 0.58 & 0.40 & BLD \\
\hline WCK 2.9 & 2.9 & $12 / 02 / 87$ & BLUGIL & $\mathbf{M}$ & 7030 & 95.2 & 17.7 & 0.50 & 0.35 & 0.15 & \\
\hline WCK 2.9 & 2.9 & $12 / 02 / 87$ & BLUGIL & M & 7031 & 149.9 & 20.2 & 1.10 & 0.61 & 0.49 & \\
\hline WCK 2.9 & 2.9 & $12 / 02 / 87$ & BLUGIL & $\mathbf{M}$ & 7032 & 135.0 & 20.0 & 0.86 & 0.61 & 0.25 & \\
\hline WCK 2.9 & 2.9 & $11 / 09 / 87$ & BLUGIL & $\mathbf{M}$ & 7033 & 44.6 & 13.7 & 4.20 & 0.61 & 3.60 & \\
\hline WCK 2.9 & 2.9 & $11 / 09 / 87$ & BLUGIL & $\mathbf{M}$ & 7034 & 56.2 & 14.7 & 0.92 & 0.34 & 0.58 & \\
\hline WCK 2.9 & 2.9 & $11 / 09 / 87$ & BLUGIL & $\mathbf{F}$ & 7035 & 53.5 & 14.7 & 1.60 & 1.06 & 0.54 & \\
\hline WCK 2.9 & 2.9 & $11 / 09 / 87$ & BLUGIL & $\mathrm{F}$ & 7036 & 48.9 & 14.2 & 1.10 & 0.80 & 0.30 & \\
\hline WCK 2.9 & 2.9 & $07 / 20 / 88$ & REDBRE & $\mathrm{F}$ & 7210 & 43.5 & 13.8 & 0.13 & 0.08 & 0.05 & \\
\hline WCK 2.9 & 2.9 & $07 / 20 / 88$ & REDBRE & $\mathbf{M}$ & 7211 & 64.8 & 15.1 & 0.55 & 0.32 & 0.23 & \\
\hline WCK 2.9 & 2.9 & $07 / 20 / 88$ & REDBRE & $M$ & 7212 & 109.9 & 18.0 & 2.7 & 1.7 & 1.0 & \\
\hline WCK 2.9 & 2.9 & 07/20/88 & REDBRE & $\mathbf{M}$ & 7213 & 48.5 & 14.0 & 0.32 & 0.17 & 0.15 & \\
\hline WCK 2.9 & 2.9 & $07 / 20 / 88$ & REDBRE & $\mathbf{M}$ & 7214 & 98.9 & 17.0 & 1.60 & 0.99 & 0.61 & \\
\hline WCK 2.9 & 2.9 & $07 / 20 / 88$ & REDBRE & $\mathbf{M}$ & 7215 & 99.1 & 17.6 & 1.23 & 0.76 & 0.47 & \\
\hline WCK 2.9 & 2.9 & $07 / 20 / 88$ & REDBRE & $\mathbf{M}$ & 7216 & 62.4 & 15.5 & 0.46 & 0.26 & 0.20 & \\
\hline WCK 2.9 & 2.9 & $07 / 20 / 88$ & REDBRE & $\mathbf{F}$ & 7217 & 34.4 & 12.8 & 0.15 & 0.07 & 0.08 & \\
\hline WCK 2.3 & 2.3 & $11 / 30 / 87$ & BLUGIL & $\mathbf{M}$ & 7000 & 60.0 & 14.5 & 0.43 & 0.27 & 0.16 & BLD \\
\hline WCK 2.3 & 2.3 & $11 / 30 / 87$ & BLUGIL & $\mathbf{M}$ & 7001 & 43.4 & 13.4 & 0.75 & 0.44 & 0.31 & \\
\hline WCK 2.3 & 2.3 & $11 / 30 / 87$ & BLUGIL & $\mathbf{M}$ & 7002 & 89.2 & 16.9 & 1.60 & 0.67 & 0.93 & \\
\hline WCK 2.3 & 2.3 & $11 / 30 / 87$ & BLUGIL & $\mathbf{M}$ & 7003 & 51.2 & 14.2 & 0.64 & 0.36 & 0.28 & \\
\hline WCK 2.3 & 2.3 & $11 / 30 / 87$ & BLUGIL & $\mathbf{M}$ & 7004 & 51.7 & 14.0 & 0.59 & 0.45 & 0.14 & BLD \\
\hline WCK 2.3 & 2.3 & $11 / 30 / 87$ & BLUGIL & $\mathrm{F}$ & 7005 & 53.0 & 14.5 & 0.31 & 0.24 & 0.07 & BLD \\
\hline WCK 2.3 & 2.3 & $11 / 30 / 87$ & BLUGIL & $\mathbf{M}$ & 7006 & 49.1 & 14.0 & 0.47 & 0.32 & 0.15 & \\
\hline WCK 2.3 & 2.3 & $11 / 30 / 87$ & BLUGIL & $\mathbf{M}$ & 7007 & 43.8 & 13.7 & 0.43 & 0.32 & 0.11 & \\
\hline WCK 2.3 & 2.3 & $11 / 30 / 87$ & BLUGIL & $\mathbf{M}$ & 7008 & 41.9 & 13.5 & & & & BLD \\
\hline WCK 0.9 & 0.9 & $02 / 17 / 88$ & BLUGIL & $\mathbf{M}$ & 7900 & 105.0 & 17.6 & 0.16 & 0.11 & 0.05 & \\
\hline WCK 0.9 & 0.9 & $02 / 17 / 88$ & BLUGIL & $\mathrm{F}$ & 7901 & 61.8 & 14.5 & 2.01 & 1.60 & 0.41 & \\
\hline WCK 0.9 & 0.9 & $02 / 17 / 88$ & BLUGIL & $\mathrm{F}$ & 7902 & 45.5 & 13.8 & 0.47 & 0.38 & 0.09 & \\
\hline WCK 0.9 & 0.9 & $02 / 17 / 88$ & BLUGIL & $\mathrm{F}$ & 7903 & 56.1 & 14.9 & 0.09 & 0.06 & 0.03 & \\
\hline WCK 0.9 & 0.9 & $02 / 17 / 88$ & BLUGIL & $F$ & 7904 & 91.8 & 16.2 & & & & BLD \\
\hline WCK 0.9 & 0.9 & $02 / 17 / 88$ & BLUGIL & $F$ & 7905 & 54.2 & 15.0 & 0.61 & 0.38 & 0.23 & \\
\hline WCK 0.9 & 0.9 & $02 / 17 / 88$ & BLUGIL & $\mathbf{M}$ & 7906 & 46.6 & 13.8 & 0.33 & 0.23 & 0.10 & \\
\hline WCK 0.9 & 0.9 & $02 / 17 / 88$ & BLUGIL & $\mathbf{M}$ & 7907 & 61.4 & 15.2 & & & & BLD \\
\hline WCK 0.9 & 0.9 & $02 / 17 / 88$ & BLUGIL & $M$ & 7909 & 70.0 & 15.1 & & & & BLD \\
\hline WCK 0.9 & 0.9 & $02 / 17 / 88$ & BLUGIL & $\mathbf{F}$ & 7910 & 57.1 & 14.9 & 0.33 & 0.25 & 0.08 & BLD \\
\hline WCK 0.9 & 0.9 & $02 / 17 / 88$ & BLUGIL & & 7911 & & & 0.20 & 0.15 & 0.05 & \\
\hline
\end{tabular}


B-6 - Biological Monitoring and Abatement Program

Table B.2 (continued)

\begin{tabular}{|c|c|c|c|c|c|c|c|c|c|c|c|}
\hline Site & Dist." & Date & Spp ${ }^{e}$ & Sex & No." & $w^{*}$ & Lgthe & $\mathrm{PCB}^{n}$ & $1254^{\prime}$ & 1260 & Other \\
\hline MEK 0.2 & 0.2 & $01 / 21 / 88$ & BLUGIL & $\mathbf{M}$ & 7187 & 24.0 & 11.1 & 0.05 & 0.02 & 0.03 & \\
\hline MEK 0.2 & 0.2 & $01 / 21 / 88$ & BLUGIL & $\mathbf{M}$ & 7188 & 31.0 & 12.0 & 0.06 & 0.04 & 0.02 & \\
\hline MEK 0.2 & 0.2 & $01 / 21 / 88$ & BLUGIL & $\mathbf{F}$ & 7189 & 22.7 & 11.0 & & & & \\
\hline MEK 0.2 & 0.2 & $01 / 21 / 88$ & BLUGIL & $\mathbf{M}$ & 7190 & 15.3 & 9.6 & 0.07 & 0.04 & 0.03 & \\
\hline MEK 0.2 & 0.2 & $01 / 21 / 88$ & BLUGIL & $\mathbf{F}$ & 7191 & 19.4 & 10.8 & 0.05 & 0.02 & 0.03 & \\
\hline MEK 0.2 & 0.2 & $01 / 21 / 88$ & BLUGIL & $\mathbf{F}$ & 7192 & 18.1 & 10.6 & 0.05 & 0.03 & 0.02 & \\
\hline MEK 0.2 & 0.2 & $01 / 21 / 88$ & BLUGIL & $\mathbf{M}$ & 7193 & 25.3 & 11.2 & & & & \\
\hline MEK 0.2 & 0.2 & $01 / 21 / 88$ & BLUGIL & $\mathbf{F}$ & 7194 & 22.8 & 11.0 & 0.05 & 0.03 & 0.02 & \\
\hline MEK 0.2 & 0.2 & $01 / 21 / 88$ & BLUGIL & $\mathbf{M}$ & 7195 & 25.2 & 11.6 & & & & \\
\hline MEK 0.2 & 0.2 & $01 / 21 / 88$ & BLUGIL & $\mathbf{M}$ & 7198 & 26.6 & 11.5 & 0.08 & 0.02 & 0.06 & \\
\hline MEK 0.2 & 0.2 & $01 / 21 / 88$ & BLUGIL & $\mathbf{M}$ & 7199 & 34.5 & 12.6 & 0.05 & 0.02 & 0.03 & \\
\hline MEK 0.2 & 0.2 & $01 / 21 / 88$ & BLUGIL & I & 7200 & 11.4 & 9.2 & & & & \\
\hline NTK 0.2 & $0_{-}$ & $12 / 01 / 87$ & BLUGIL & $\mathbf{F}$ & 7012 & 66.5 & 16.0 & 0.11 & 0.08 & 0.03 & BLD \\
\hline NTK 0.2 & 0.2 & $12 / 01 / 87$ & BLUGIL & $\mathbf{M}$ & 7013 & 44.9 & 14.0 & 0.68 & 0.62 & 0.06 & BLD \\
\hline NTK 0.2 & 0.2 & $12 / 01 / 87$ & BLUGIL & $\mathrm{F}$ & 7014 & 124.6 & 19.2 & 1.29 & 0.81 & 0.48 & BLD \\
\hline NTK 0.2 & 0.2 & $12 / 01 / 87$ & BLUGIL & $\mathbf{M}$ & 7015 & 104.0 & 18.1 & 0.03 & 0.02 & 0.01 & \\
\hline NTK 0.2 & 0.2 & $12 / 01 / 87$ & BLUGIL & $\mathbf{M}$ & 7016 & 114.7 & 18.6 & 0.06 & 0.04 & 0.02 & BLD \\
\hline NTK 0.2 & 0.2 & $12 / 01 / 87$ & BLUGIL & $\mathbf{M}$ & 7017 & 64.9 & 15.9 & 0.46 & 0.33 & 0.13 & \\
\hline NTK 0.2 & 0.2 & $12 / 01 / 87$ & BLUGIL & $\mathbf{M}$ & 7018 & 96.6 & 17.9 & 0.08 & 0.05 & 0.03 & \\
\hline NTK 0.2 & 0.2 & $12 / 01 / 87$ & BLUGIL & $\mathbf{M}$ & 7019 & 43.3 & 14.0 & 0.06 & 0.03 & 0.03 & \\
\hline CRK 31.5 & 31.5 & $11 / 17 / 87$ & BLUGIL & $\mathbf{M}$ & 9258 & 63.2 & 15.2 & 0.03 & 0.02 & 0.01 & \\
\hline CRK 31.5 & 31.5 & $11 / 17 / 87$ & BLUGIL & $\mathbf{F}$ & 9271 & 32.0 & 12.0 & 0.08 & 0.05 & 0.03 & \\
\hline CRK 31.5 & 31.5 & $11 / 17 / 87$ & BLUGIL & $F$ & 9272 & 91.0 & 17.5 & 0.03 & 0.02 & 0.01 & \\
\hline CRK 31.5 & 31.5 & $11 / 17 / 87$ & BLUGIL & $\mathbf{M}$ & 9273 & 60.2 & 14.9 & 0.02 & 0.01 & 0.01 & \\
\hline CRK 31.5 & 31.5 & $11 / 17 / 87$ & BLUGIL & $\mathbf{F}$ & 9275 & 32.6 & 12.1 & 0.03 & 0.02 & 0.01 & \\
\hline CRK 31.5 & 31.5 & $11 / 17 / 87$ & BLUGIL & $\mathbf{F}$ & 9276 & 71.0 & 15.7 & 0.02 & 0.02 & 0.01 & \\
\hline CRK 31.5 & 31.5 & $11 / 17 / 87$ & BLUGIL & & 9278 & 36.5 & 12.7 & 0.04 & 0.03 & 0.01 & \\
\hline CRK 31.5 & 31.5 & $11 / 17 / 87$ & BLUGIL & $\mathbf{F}$ & 9296 & 48.7 & 14.2 & 0.03 & 0.02 & 0.01 & \\
\hline CRK 35.2 & 35.2 & $11 / 17 / 87$ & BLUGIL & $\mathbf{M}$ & 6300 & 116.9 & 17.6 & 0.08 & 0.06 & 0.02 & \\
\hline CRK 35.2 & 35.2 & $11 / 17 / 87$ & BLUGIL & $\mathbf{F}$ & 6301 & 47.6 & 13.8 & 0.03 & 0.02 & 0.01 & \\
\hline CRK 35.2 & 35.2 & $11 / 17 / 87$ & BLUGIL & $\mathbf{M}$ & 6302 & 63.8 & 14.7 & 0.04 & 0.02 & 0.02 & \\
\hline CRK 35.2 & 35.2 & $11 / 17 / 87$ & BLUGIL & $\mathbf{F}$ & 6303 & 57.4 & 14.9 & 0.01 & 0.01 & 0.01 & \\
\hline CRK 35.2 & 35.2 & $11 / 17 / 87$ & BLUGIL & $\mathbf{F}$ & 6304 & 48.9 & 13.8 & 0.01 & 0.01 & 0.01 & \\
\hline CRK 35.2 & 35.2 & $11 / 17 / 87$ & BLUGIL & $\mathbf{F}$ & 6305 & 64.8 & 14.2 & 0.03 & 0.02 & 0.01 & \\
\hline CRK 35.2 & 35.2 & $11 / 17 / 87$ & BLUGIL & $\mathbf{M}$ & 6306 & 112.7 & 18.0 & 0.05 & 0.03 & 0.02 & \\
\hline CRK 35.2 & 35.2 & $11 / 17 / 87$ & BLUGIL & $\mathbf{M}$ & 6307 & 101.3 & 17.9 & 0.04 & 0.02 & 0.02 & \\
\hline MHR & & $11 / 11 / 87$ & BLUGIL & $\mathbf{M}$ & 6308 & 72.2 & 15.9 & 0.03 & 0.02 & 0.01 & \\
\hline MHR & & $11 / 11 / 87$ & BLUGIL & $\mathbf{F}$ & 6309 & 51.9 & 15.0 & 0.02 & 0.02 & 0.01 & \\
\hline MHR & & $11 / 11 / 87$ & BLUGIL & $\mathbf{M}$ & 6310 & 53.9 & 14.8 & 0.06 & 0.06 & 0.01 & \\
\hline MHR & & $11 / 11 / 87$ & BLUGIL & $\mathbf{M}$ & 6311 & 61.0 & 14.8 & 0.03 & 0.01 & 0.02 & \\
\hline MHR & & $11 / 11 / 87$ & BLUGIL & $\mathbf{F}$ & 6312 & 34.7 & 13.0 & 0.02 & 0.02 & 0.01 & \\
\hline MHR & & $11 / 11 / 87$ & BLUGIL & $\mathbf{M}$ & 6313 & 31.3 & 12.5 & 0.02 & 0.01 & 0.01 & \\
\hline MHR & & $11 / 11 / 87$ & BLUGIL & $\mathbf{F}$ & 6314 & 108.8 & 18.0 & 0.02 & 0.02 & 0.01 & \\
\hline MHR & & $11 / 11 / 87$ & BLUGIL & $\mathbf{M}$ & 6315 & 72.8 & 16.1 & 0.04 & 0.03 & 0.01 & \\
\hline MHR & & $11 / 11 / 87$ & REDBRE & $\mathbf{F}$ & 6316 & 50.9 & 14.5 & & & & \\
\hline MHR & & $11 / 11 / 87$ & REDBRE & $\mathbf{F}$ & 6317 & 41.4 & 14.1 & & & & \\
\hline MHR & & $11 / 11 / 87$ & REDBRE & $M$ & 6318 & 68.1 & 15.8 & & & & \\
\hline MHR & & $11 / 11 / 87$ & REDBRE & $\mathbf{M}$ & 6319 & 98.1 & 17.7 & 0.04 & 0.04 & 0.01 & \\
\hline MHR & & $11 / 11 / 87$ & REDBRE & $\mathrm{F}$ & 6320 & 40.2 & 13.9 & & & & \\
\hline MHR & & $11 / 11 / 87$ & REDBRE & $F$ & 6321 & 56.7 & 15.0 & & & & \\
\hline MHR & & $11 / 11 / 87$ & REDBRE & $\mathbf{M}$ & 6322 & 71.4 & 16.0 & & & & \\
\hline MHR & & $11 / 11 / 87$ & REDBRE & $\mathbf{M}$ & 6323 & 92.6 & 17.5 & & & & \\
\hline
\end{tabular}


Table B.2 (continued)

\begin{tabular}{|c|c|c|c|c|c|c|c|c|c|c|c|}
\hline Site & Dist." & Date & Spp ${ }^{c}$ & Sex & No: & $W^{\prime}$ & Lgth' & $\mathrm{PCB}^{n}$ & $1254^{\prime}$ & $1260^{\circ}$ & Other \\
\hline $\begin{array}{l}\text { HINDSCR } \\
\text { HINDSCR } \\
\text { HINDSCR }\end{array}$ & & $\begin{array}{l}12 / 30 / 87 \\
12 / 30 / 87 \\
12 / 30 / 87\end{array}$ & $\begin{array}{l}\text { REDBRE } \\
\text { REDBRE } \\
\text { REDBRE }\end{array}$ & $\begin{array}{l}\mathbf{M} \\
\mathbf{M} \\
\mathbf{M}\end{array}$ & $\begin{array}{l}7138 \\
7139 \\
7140\end{array}$ & $\begin{array}{l}61.3 \\
77.8 \\
68.6\end{array}$ & $\begin{array}{l}15.6 \\
17.3 \\
16.7\end{array}$ & $\begin{array}{l}0.01 \\
0.02 \\
0.02\end{array}$ & $\begin{array}{l}0.01 \\
0.01 \\
0.01\end{array}$ & $\begin{array}{r}<0.01 \\
0.01 \\
0.01\end{array}$ & \\
\hline $\begin{array}{l}\text { HINDSCR } \\
\text { HINDSCR } \\
\text { HINDSCR } \\
\text { HINDSCR } \\
\text { HINDSCR }\end{array}$ & & $\begin{array}{l}12 / 30 / 87 \\
12 / 30 / 87 \\
12 / 30 / 87 \\
12 / 30 / 87 \\
12 / 30 / 87\end{array}$ & $\begin{array}{l}\text { REDBRE } \\
\text { REDBRE } \\
\text { REDBRE } \\
\text { REDBRE } \\
\text { REDBRE }\end{array}$ & $\begin{array}{l}F \\
F \\
M \\
F \\
F\end{array}$ & $\begin{array}{l}7141 \\
7142 \\
7143 \\
7144 \\
7145\end{array}$ & $\begin{array}{l}48.9 \\
45.9 \\
38.2 \\
36.4 \\
27.2\end{array}$ & $\begin{array}{l}15.1 \\
14.8 \\
13.4 \\
13.0 \\
13.1\end{array}$ & $\begin{array}{l}0.02 \\
0.02 \\
0.02 \\
0.01 \\
0.02\end{array}$ & $\begin{array}{r}<0.01 \\
0.02 \\
0.01 \\
0.01 \\
0.02\end{array}$ & $\begin{array}{r}0.01 \\
<0.01 \\
0.01 \\
<0.01 \\
<0.01\end{array}$ & \\
\hline $\begin{array}{l}\text { HINDSCR } \\
\text { HINDSCR } \\
\text { HINDSCR } \\
\text { HINDSCR } \\
\text { HINDSCR } \\
\text { HINDSCR } \\
\text { HINDSCR } \\
\text { HINDSCR }\end{array}$ & & $\begin{array}{l}12 / 30 / 87 \\
12 / 30 / 87 \\
12 / 30 / 87 \\
12 / 30 / 87 \\
12 / 30 / 87 \\
12 / 30 / 87 \\
12 / 30 / 87 \\
12 / 30 / 87\end{array}$ & $\begin{array}{l}\text { BLUGIL } \\
\text { BLUGIL } \\
\text { BLUGIL } \\
\text { BLUGIL } \\
\text { BLUGIL } \\
\text { BLUGIL } \\
\text { BLUGIL } \\
\text { BLUGIL }\end{array}$ & $\begin{array}{l}F \\
F \\
F \\
M \\
M \\
F \\
F \\
F\end{array}$ & $\begin{array}{l}7146 \\
7147 \\
7148 \\
7149 \\
7150 \\
7151 \\
7152 \\
7153\end{array}$ & $\begin{array}{l}54.6 \\
57.5 \\
74.8 \\
58.4 \\
42.5 \\
51.7 \\
41.5 \\
38.2\end{array}$ & $\begin{array}{l}15.3 \\
15.1 \\
16.4 \\
15.0 \\
13.4 \\
14.9 \\
14.2 \\
13.4\end{array}$ & $\begin{array}{l}0.02 \\
0.01 \\
0.01 \\
0.03 \\
0.03 \\
0.02 \\
0.02 \\
0.02\end{array}$ & $\begin{array}{l}0.02 \\
0.01 \\
0.01 \\
0.03 \\
0.03 \\
0.02 \\
0.02 \\
0.01\end{array}$ & $\begin{array}{r}<0.01 \\
<0.01 \\
<0.01 \\
<0.01 \\
<0.01 \\
<0.01 \\
<0.01 \\
0.01\end{array}$ & \\
\hline
\end{tabular}

'Site: WCK = White Oak Creek kilometer, WOL = White Oak Lake; MEK = Meiton Branch kilometer, NTK = Northwest Tributary kilometer, CRK $=$ Clinch River kilometer, MHR $=$ Melton Hill Reservoir kilometer, HINDSCR $=$ Hinds Creek near Clinton, Anderson County, Tennessee.

'Dist. = Distance from mouth of stream.

'Species include Blugil = Bluegill Sunfish (Lepomis Macrochinus) and Redbre $=$ Redbreast Sunfish (Lepomis Auritus).

$\triangle M=$ Male, $F=$ Female, $I=$ Immature.

No. $=$ Fish identification tag number.

Wgt $=$ Fish weight, grams.

I $\mathrm{gth}=$ Fish total length, centimeters.

${ }^{n} \mathrm{EPCB}=$ Total PCBs (Sum of PCB-1254 and PCB-1260) in fish axial muscle, micrograms per gram, wet weight.

$' 1254=$ PCB-1254 (Arochlor-1254) in fish axial muscle, micrograms per gram, wet weight.

1260 = PCB-1260 (Arochlor-1260) in iish axial muscle, micrograms per gram, wet weight.

BLD $=$ Below limit of detection. 
Table B.3. Detection limits of organic compounds

\section{CAPIILARY COLUMN GCAMS}

Phenol

$<2.0$

Bis(2-chlorocthyl)ether $<2.0$

2-Chlorophenol $<2.0$

1,3-Dichlorobenzene $\quad<2.0$

1,4-Dichlorobenzene $\quad<2.0$

Benzyl alcohol $<2.0$

1,2-Dichlorobenzene $\quad<2.0$

2-Methylphenol $<2.0$

Bis(2-Chlorodisopropyl)ether $\quad<2.0$

4-Methylphenol $<2.0$

$N$-Nitroso-di-N-propylamine $\quad<2.0$

Hexachloroethane $<2.0$

Nitrobenzene $\quad<2.0$

Isophorone $\quad<2.0$

2-Nitrophenol $<2.0$

2,4-Dimethylphenol $<2.0$

Benzoic acid $<10.0$

Bis(2-chloroethoxy)methane $\quad<2.0$

2,4-Dichlorophenol $<2.0$

1,2,4-Trichlorobenzene $\quad<2.0$

Naphthalene $\quad<2.0$

4-Chloroaniline $<2.0$

Hexachlorobutradiene $\quad<2.0$

4-Chloro-3-methylphenol $<2.0$

2-Methylnaphthalene $\quad<2.0$

Hexachlorocyclapentadiene $\quad<2.0$

2,4,6-Trichlorophenol $<2.0$

2,4,5-Trichlorophenol $<10.0$

2-Chloronaphthalene $<2.0$

2-Nitroaniline $\quad<10.0$

Dimethylphthalate $\quad<2.0$

Acenaphthalene $<2.0$

3-Nitroaniline $\quad<10.0$

Acenaphthene $\quad<2.0$

2,4-Dinitrophenol $\quad<10.0$

Nitrophenol $<10.0$

Dibenzofuran $<2.0$

2,4-Dinitrotoluene $<2.0$

2,6-Dinitrotoluene $\quad<2.0$

Diethylphthalate $\quad<2.0$

4-Chlorophenyl-phenylether $\quad<2.0$

Fluorene $<2.0$

4-Nitroaniline $\quad<10.0$

4,6-Dinitro-2-methylphenol $\quad<10.0$

$N$-Nitrosodiphenylamine $\quad<2.0$

4-Bromophenyl-phenylether $<2.0$

Hexachlorobenzene $<2.0$

Pentachlorophenol $<10.0$ 
Table B.3. (continued)

\begin{tabular}{lc}
\hline COMPOUND & DETECTION LIMIT \\
\hline Phenanthrene & $<2.0$ \\
Anthracene & $<2.0$ \\
Di- $N$-Butylphthalate & $<2.0$ \\
Fluoranthene & $<2.0$ \\
Pyrene & $<2.0$ \\
Butylbenzylphthalate & $<2.0$ \\
3,3-Dichlorobenzidene & $<10.0$ \\
Benz[a]anthracene & $<2.0$ \\
Bis(2-ethylhexyl)phthalate & $<2.0$ \\
Chrysene & $<2.0$ \\
Di- $N$-octylphthalate & $<2.0$ \\
Benzo[b]fluoranthene & $<2.0$ \\
Benzo[k]fluoranthene & $<2.0$ \\
Benzo[a]pyrene & $<2.0$ \\
Indeno[1,2,3-cd]pyrene & $<2.0$ \\
Dibenz[a,h]anthracene & $<2.0$ \\
Benzo[gh,i]perylene & $<2.0$
\end{tabular}

CAPIILARY COLUMN GC/ECD

$\begin{array}{lc}\text { Alpha-BHC } & <0.02 \\ \text { Beta-BHC } & <0.04 \\ \text { Delta-BHC } & <0.04 \\ \text { Gamma-BHC } & <0.02 \\ \text { Heptachlor } & <0.04 \\ \text { Aldrin } & <0.04 \\ \text { Heptachlor epoxide } & <0.04 \\ \text { Endosulfan I } & <0.04 \\ \text { Dieldrin } & <0.04 \\ \text { 4,4'-DDE } & <0.04 \\ \text { Endrin } & <0.2 \\ \text { Endosulfan II } & <0.08 \\ \text { 4,4'-DDD } & <0.2 \\ \text { Endosulfan sulfate } & <0.2 \\ \text { 4,4'-DDT } & <0.08 \\ \text { Endrin ketone } & <0.4 \\ \text { Methoxychlor } & <0.2 \\ \text { Alpha chlordane } & <0.04 \\ \text { Gamma chlordane } & <0.04 \\ \text { Toxaphene } & <2\end{array}$

HPLC WTTH FLUORESCENCE DETECTION

Naphthalene Acenaphthene Phenanthrene Anthracene Fluoranthene Pyrene
$<0.2$

$<0.06$

$<0.02$

$<0.05$

$<0.5$

$<0.01$ 
Table B.3. (continued)

\begin{tabular}{lc}
\hline COMPOUND & DETECTION LIMIT \\
\hline Benz[a]anthracene & $<0.001$ \\
Benzo[b]fluoranthene & $<0.06$ \\
Benzo[k]fluoranthene & $<0.04$ \\
Benzo[a]pyrene & $<0.02$ \\
Dibenz[a, $h]$ anthracene & $<0.006$ \\
Benzo[gh, $i]$ perylene & $<0.02$ \\
Indeno[1,2,3-ed]pyrene & $<0.1$ \\
& \\
\hline
\end{tabular}

Optimum detection limit in 10-g sample. Sample weights varied between 5 and $10 \mathrm{~g}$; detection limits were higher in some samples. 
Bialogical Monitoring and Abatemeat Program - B-11

Table B.4. Concentu ations of PCBs and "Sr in channel catfish and givenrd shad from White Oak Creek embayl vent, lower Poplar Creek, the Clinch River, and Melton Hill Reservoir

\begin{tabular}{|c|c|c|c|c|c|c|c|c|c|c|c|}
\hline Site & ple $^{b}$ & Date & Spp ${ }^{c}$ & Sex & No." & $\begin{array}{c}\text { Weight } \\
\text { (g) }\end{array}$ & $\begin{array}{c}\text { Length } \\
\text { (cm) }\end{array}$ & $\begin{array}{l}\Sigma \mathrm{PCB}^{\prime} \\
(\mu \mathrm{g} / \mathrm{g})\end{array}$ & $\begin{array}{l}1254 \\
(\mu g / 8)\end{array}$ & $\begin{array}{l}1260^{4} \\
(\mu g / g)\end{array}$ & $\begin{array}{c}{ }^{90} \mathrm{Sr}^{1} \\
(\mathrm{~Bq}, \mathrm{~kg})\end{array}$ \\
\hline WCK 0.3 & $\mathbf{R}$ & $7 / 27 / 88$ & CH.CAT & $\mathbf{M}$ & 7270 & 780 & 45.5 & 0.45 & 0.15 & 0.30 & 140 \\
\hline WCK 0.3 & $\mathbf{R}$ & $7 / 27 / 88$ & CH.CAT & $\mathbf{F}$ & 7271 & 854 & 46.3 & 2.00 & 1.00 & 1.00 & 940 \\
\hline WCK 0.3 & $\mathbf{R}$ & $7 / 27 / 88$ & CH.CAT & $\mathbf{M}$ & 7272 & 1405 & 54.0 & 2.27 & 1.30 & 0.97 & 730 \\
\hline WCK 0.3 & $\mathbf{R}$ & $7 / 27 / 88$ & CH.CAT & $\mathbf{M}$ & 7273 & 736 & 42.0 & 0.15 & 0.08 & 0.07 & 140 \\
\hline WCK 0.3 & $\mathbf{R}$ & $7 / 27 / 88$ & CH.CAT & $\mathbf{M}$ & 7274 & 1425 & 55.2 & 0.67 & 0.27 & 0.40 & 190 \\
\hline WCK 0.3 & $\mathbf{R}$ & $7 / 27 / 88$ & CH.CAT & $\mathbf{F}$ & 7275 & 704 & 45.0 & 1.27 & 0.40 & 0.87 & 2100 \\
\hline WCK 0.3 & $\mathbf{R}$ & $7 / 27 / 88$ & CH.CAT & $\mathbf{M}$ & 7276 & 405 & 37.1 & 0.54 & 0.24 & 0.30 & 160 \\
\hline WCK 0.3 & $\mathbf{R}$ & $7 / 27 / 88$ & CH.CAT & $\mathbf{F}$ & 7277 & 411 & 36.8 & 0.31 & 0.16 & 0.15 & 400 \\
\hline CRK 32.2 & $\mathbf{R}$ & $7 / 28 / 88$ & CH.CAT & $\mathbf{M}$ & 7230 & 432 & 37.8 & 0.71 & 0.31 & 0.40 & 1100 \\
\hline CRK 32.2 & $\mathbf{R}$ & $7 / 28 / 88$ & CH.CAT & $\mathbf{F}$ & 7241 & 391 & 36.3 & 0.31 & 0.08 & 0.23 & 14 \\
\hline CRK 32.2 & $\mathbf{R}$ & $7 / 28 / 88$ & CH.CAT & $\mathbf{M}$ & 7242 & 474 & 38.0 & 0.25 & 0.14 & 0.11 & 3200 \\
\hline CRK 32.2 & $\mathbf{R}$ & $7 / 28 / 88$ & CH.CAT & $\mathbf{F}$ & 7243 & 1242 & 49.5 & 2.40 & 1.30 & 1.10 & 34 \\
\hline CRK 32.2 & $\mathbf{R}$ & $7 / 28 / 88$ & CH.CAT & $\mathbf{M}$ & 7244 & 622 & 40.7 & 0.31 & 0.09 & 0.22 & 26 \\
\hline CRK 32.2 & $\mathbf{R}$ & $7 / 28 / 88$ & CH.CAT & $\mathbf{M}$ & 7245 & 927 & 49.9 & 0.23 & 0.08 & 0.15 & 35 \\
\hline CRK 32.2 & $\mathbf{R}$ & $7 / 28 / 88$ & CH.CAT & $\mathbf{M}$ & 7247 & 340 & 30.9 & 0.20 & 0.06 & 0.14 & 1300 \\
\hline CRK 32.2 & $\mathbf{R}$ & $7 / 28 / 88$ & CH.CAT & $\mathbf{M}$ & 7248 & 849 & 42.2 & 0.22 & 0.09 & 0.13 & 150 \\
\hline CEC & C & $7 / 15 / 87$ & CH.CAT & $\mathbf{M}$ & CEC-1A & 780 & 44.5 & 0.02 & 0.02 & $<0.01$ & . \\
\hline CEC & C & $7 / 15 / 87$ & CH.CAT & $\mathbf{M}$ & CEC-1B & 780 & 44.5 & 0.06 & 0.05 & 0.01 & . \\
\hline $\mathrm{CEC}$ & C & $7 / 15 / 87$ & CH.CAT & $\mathbf{M}$ & CEC-1C & 780 & 44.5 & 0.02 & 0.02 & $<.0 .01$ & . \\
\hline CEC & C & $7 / 15 / 87$ & CH.CAT & $\mathbf{F}$ & CEC-25 & 607 & 38.7 & 0.02 & 0.01 & 0.01 & . \\
\hline CEC & C & $7 / 15 / 87$ & CH.CAT & $\mathbf{F}$ & CEC-26 & 607 & 38.7 & 0.01 & 0.01 & $<0.01$ & . \\
\hline CEC & C & $7 / 15 / 87$ & CH.CAT & $\mathbf{M}$ & CEC-4A & 1500 & 55.1 & 0.05 & 0.05 & $<0.01$ & . \\
\hline $\mathrm{CEC}$ & C & $7 / 15 / 87$ & CH.CAT & $\mathbf{M}$ & CEC-4B & 1500 & 55.1 & 0.02 & 0.02 & $<0.01$ & . \\
\hline MHR & $\mathbf{R}$ & $7 / 26 / 88$ & CH.CAT & $\mathbf{M}$ & 7218 & 740 & 45.5 & 0.20 & 0.02 & 0.18 & 38 \\
\hline MHR & $\mathbf{R}$ & $7 / 26 / 88$ & CH.CAT & $\mathbf{M}$ & 7219 & 4850 & 70.0 & 0.44 & $<0.01$ & 0.44 & 0 \\
\hline MHR & $\mathbf{R}$ & $9 / 01 / 88$ & CH.CAT & $\mathbf{F}$ & 7280 & 406 & 37.0 & 0.07 & 0.02 & 0.05 & 0 \\
\hline MHR & $\mathbf{R}$ & $9 / 01 / 88$ & CH.CAT & $\mathbf{F}$ & 7281 & 572 & 44.2 & 0.65 & 0.01 & 0.64 & 0 \\
\hline MHR & $\mathbf{R}$ & $9 / 01 / 88$ & CH.CAT & $\mathbf{M}$ & 7282 & 1888 & 53.0 & 1.61 & 0.01 & 1.60 & 37 \\
\hline MHR & $\mathbf{R}$ & $9 / 02 / 88$ & CH.CAT & $\mathbf{F}$ & 7283 & 637 & 44.8 & 0.43 & 0.04 & 0.39 & 220 \\
\hline MHR & $\mathbf{R}$ & $9 / 02 / 88$ & CH.CAT & $\mathbf{F}$ & 7284 & 6118 & 79.0 & 1.11 & 0.27 & 0.84 & 6 \\
\hline MHR & $\mathbf{R}$ & $9 / 07 / 88$ & CH.CAT & $\mathbf{F}$ & 7286 & 433 & 38.8 & 0.10 & 0.02 & 0.08 & 15 \\
\hline MHR & $\mathbf{R}$ & $9 / 07 / 88$ & CH.CAT & F & 7287 & 788 & 47.0 & 0.28 & $<0.01$ & 0.28 & 250 \\
\hline MHR & $\mathbf{R}$ & $9 / 07 / 88$ & CH.CAT & $\mathbf{M}$ & 7288 & 1306 & 54.0 & 0.29 & 0.04 & 0.25 & 12 \\
\hline CRK 15.0 & $\mathbf{R}$ & $8 / 12 / 88$ & CH.CAT & $\mathbf{M}$ & 7239 & 754 & 46.9 & 0.55 & 0.11 & 0.44 & 500 \\
\hline CRK 15.0 & $\mathbf{R}$ & $8 / 16 / 88$ & CH.CAT & $\mathbf{M}$ & 7264 & 1073 & 50.5 & 0.34 & 0.11 & 0.23 & 19 \\
\hline CRK 15.0 & $\mathbf{R}$ & $8 / 18 / 88$ & CH.CAT & $\mathbf{F}$ & 7265 & 512 & 39.2 & 0.63 & 0.16 & 0.47 & 33 \\
\hline CRK 15.0 & $\mathbf{R}$ & $8 / 18 / 88$ & CH.CAT & $\mathbf{M}$ & 7266 & 624 & 40.9 & 0.15 & 0.03 & 0.12 & 48 \\
\hline CRK 15.0 & $\mathbf{R}$ & $8 / 19.88$ & CH.CAT & $\mathbf{M}$ & 7267 & 381 & 36.4 & 0.48 & $<0.01$ & 0.48 & 33 \\
\hline CRK 15.0 & $\mathbf{R}$ & $8 / 19 / 88$ & CH.CAT & $\mathbf{M}$ & 7268 & 875 & 47.3 & 0.59 & 0.11 & 0.48 & 47 \\
\hline CRK 15.0 & $\mathbf{R}$ & $8 / 22 / 88$ & CH.CAT & $\mathbf{M}$ & 7269 & 628 & 46.4 & 0.33 & $<0.01$ & 0.33 & 1200 \\
\hline CRK 15.0 & $\mathbf{R}$ & $9 / 07 / 88$ & CH.CAT & F & 7285 & 842 & 50.4 & 0.90 & 0.23 & 0.67 & 38 \\
\hline CRK 15.0 & $\mathbf{R}$ & $8 / 12 / 88$ & CH.CAT & $\mathbf{M}$ & 7289 & 284 & 35.5 & 0.57 & $<0.01$ & 0.57 & 34 \\
\hline PCK 6.9 & $\mathbf{R}$ & $8 / 09 / 88$ & CH.CAT & $\mathbf{M}$ & 7235 & 592 & 40.4 & 0.39 & 0.16 & 0.23 & 56 \\
\hline PCK 6.9 & $\mathbf{R}$ & $8 / 09 / 88$ & CH.CAT & $\mathbf{M}$ & 7236 & 1110 & 49.8 & 0.99 & 0.28 & 0.71 & 3 \\
\hline PCK 6.9 & $\mathbf{R}$ & $8 / 10 / 88$ & CH.CAT & $\mathbf{M}$ & 7237 & 1524 & 55.5 & 1.06 & 0.08 & 0.98 & 13 \\
\hline
\end{tabular}


Table B.4. (continued)

\begin{tabular}{|c|c|c|c|c|c|c|c|c|c|c|c|}
\hline Site Sam & ple" & Date & Spp & Sex' & No." & $\begin{array}{l}\text { Weight } \\
\text { (g) }\end{array}$ & $\begin{array}{l}\text { Length } \\
(\mathrm{cm})\end{array}$ & $\begin{array}{l}\mathrm{EPCB}^{\prime} \\
(\mu \mathrm{g} / \mathrm{g})\end{array}$ & $\begin{array}{l}1254^{\prime} \\
(\mu \mathrm{g} / \mathrm{g})\end{array}$ & $\begin{array}{l}1260^{4} \\
(\mu \mathrm{g} / \mathrm{g})\end{array}$ & $\begin{array}{c}{ }^{20} \mathrm{~S} r^{4} \\
(\mathrm{~Bq} / \mathrm{kg})\end{array}$ \\
\hline PCK 6.9 & $\mathbf{R}$ & $8 / 10 / 88$ & CH.CAT & $\mathbf{M}$ & 7238 & 2282 & 62.1 & 1.31 & 0.01 & 1.30 & 24 \\
\hline PCK 6.9 & $\mathbf{R}$ & $8 / 11 / 88$ & CH.CAT & $\mathbf{M}$ & 7260 & 656 & 43.9 & 0.63 & 0.11 & 0.52 & 27 \\
\hline PCK 6.9 & $\mathbf{R}$ & $8 / 11 / 88$ & CH.CAT & $\mathbf{M}$ & 7261 & 1120 & 52.1 & 0.67 & 0.01 & 0.66 & 9 \\
\hline PCK 6.9 & $\mathbf{R}$ & $8 / 11 / 88$ & CH.CAT & $\mathbf{M}$ & 7262 & 503 & 36.7 & 0.36 & 0.10 & 0.26 & 110 \\
\hline PCK 6.9 & $\mathbf{R}$ & $8 / 11 / 88$ & CH.CAT & $\mathbf{F}$ & 7263 & 378 & 34.6 & 0.28 & 0.07 & 0.21 & 20 \\
\hline MHR & $\mathbf{F}$ & $8 / 08 / 88$ & GZSHAD & C & 88MHL1A & & & 0.41 & 0.08 & 0.33 & 10 \\
\hline MHR & $\mathbf{F}$ & $8 / 08 / 88$ & GZSHAD & C & 88MHL2 & & & 0.44 & 0.16 & 0.28 & 13 \\
\hline MHR & $\mathbf{F}$ & 8/08/88 & GZSHAD & $\mathrm{C}$ & 88MHL3 & & & 0.35 & 0.14 & 0.21 & 0.7 \\
\hline CRK 32.2 & $\mathbf{F}$ & $8 / 03 / 88$ & GZSHAD & C & 88CRX1A & & & 1.74 & 0.83 & 0.91 & 37 \\
\hline CRK 32.2 & $\mathbf{F}$ & $8 / 03 / 88$ & GZSHAD & C & 88CR X2 & & & 0.63 & 0.17 & 0.46 & 150 \\
\hline CRK 32.2 & $\mathbf{F}$ & $8 / 03 / 88$ & GZSHAD & C & $88 \mathrm{CR} \times 3$ & & & 0.58 & 0.20 & 0.38 & 130 \\
\hline WCK 0.3 & $\mathbf{F}$ & $8 / 03 / 88$ & GZSHAD & C & 88 WCK $1 A$ & & & 2.53 & 0.93 & 1.60 & 1100 \\
\hline WCK 0.3 & $\mathbf{F}$ & $8 / 03 / 88$ & GZSHAD & C & $88 W C K 2$ & & & 0.91 & 0.41 & 0.50 & 74 \\
\hline WCK 0.3 & $\mathbf{F}$ & $8 / 03 / 88$ & GZSHAD & $\mathrm{C}$ & 88 WCK3 & & & 5.50 & 2.80 & 2.70 & 980 \\
\hline WOL & $\mathbf{F}$ & $8 / 25 / 88$ & GZSHAD & C & 88WOL1A & & & 5.40 & 1.10 & 4.30 & 3900 \\
\hline WOL & $\mathbf{F}$ & $8 / 25 / 88$ & GZSHAD & $\mathrm{C}$ & 88 WOL2 & & & 6.39 & 0.49 & 5.90 & 2300 \\
\hline WOL & $\mathbf{F}$ & $8 / 25 / 88$ & GZSHAD & $\mathrm{C}$ & 88WOL3 & & & 6.30 & 3.60 & 2.70 & 2700 \\
\hline PCK 6.9 & $\mathbf{F}$ & $8 / 22 / 88$ & GZSHAD & C & 88PCK1A & & & 4.37 & 0.17 & 4.20 & 35 \\
\hline PCK 6.9 & $\mathbf{F}$ & $8 / 22 / 88$ & GZSHAD & C & 88PCK2 & & & 2.80 & 1.10 & 1.70 & 20 \\
\hline PCK 6.9 & $\mathbf{F}$ & $8 / 22 / 88$ & GZSHAD & $\mathrm{C}$ & 88PCK 3 & & & 1.76 & 0.56 & 1.20 & 0 \\
\hline CRK 15.0 & $\mathbf{F}$ & $8 / 17 / 88$ & GZSHAD & $\mathrm{C}$ & 88CRK1A & & & 0.58 & 0.21 & 0.37 & 48 \\
\hline CRK 15.0 & $\mathbf{F}$ & $8 / 17 / 88$ & GZSHAD & C & 88CRK2 & & & 0.93 & 0.21 & 0.72 & 18 \\
\hline CRK 15.0 & F & $8 / 17 / 88$ & GZSHAD & C & 88CRK3 & & & 0.94 & 0.30 & 0.64 & 380 \\
\hline
\end{tabular}

-Site: $\mathbf{W C K}=$ White Oak Creek kilometer; $\mathrm{CRK}=$ Clinch River kilometer; $\mathrm{CEC}=\mathrm{A}$ commercial catfish farm, used as a control site, $\mathrm{MHR}=$ Melton Hill Reservoir; $\mathrm{PCK}=$ Poplar Creek kilometer; WOL = White Oak Lake.

' $R=$ regular; $C=$ control; $F=$ food organism

'Species: Ch. cat $=$ Channel catfish (Ictalurus punctatus); Gzshad=Gizzard shad (Dorosoma cepedianum)

$\mathcal{M}=$ Male, $\mathrm{F}=$ Female; $\mathrm{C}=$ composite sample (sex not differentiated)

No. $=$ Fish identification tag number.

Total PCBs (sum of PCB-1254 and PCB-1260) in fish axial muscle, measured in micrograms per gram wet weight.

oPCB-1254 (Arochlor-1254) in fish axial muscle, measured in micrograms per gram wet weight.

"PCB-1260 (Arochlor-1260) in fish axial muscle, measured in micrograms per gram wet weight.

'Strontium-90 in fish vertebrae, measured in becquerels per kilogram dry weight. 
APPENDIX C

Production/Biomass Ratios and Cohort Production Intervals for Estimating Benthic Invertebrate Annual Production 
Tuble C.1. Annual production/olomases (P/B) ration and cohort production intervals (CPI) used for annunl production cetimntex for benthic ivvertebrates from

White Ont Creek waterhod, My 1986 through April 1987

Unless otherwise noted, values given for the higher taxa were also used for their respective lower taxa

\begin{tabular}{|c|c|c|}
\hline Taxon & $\mathbf{P} / \mathbf{B}^{-}$ & $\underset{\text { (month) }}{\text { CPI }}$ \\
\hline $\begin{array}{l}\text { Turbellaria } \\
\text { Nematoda } \\
\text { Oligochacta } \\
\text { Isopoda } \\
\text { Amphipoda } \\
\text { Decapoda } \\
\text { Hydracarina }\end{array}$ & $\begin{array}{r}6.0 \\
10.0 \\
10.0 \\
5.0 \\
5.0 \\
1.5 \\
10.0\end{array}$ & $\begin{array}{r}10.0 \\
6.0 \\
6.0 \\
12.0 \\
12.0 \\
36.0 \\
6.0\end{array}$ \\
\hline $\begin{array}{l}\text { Insecta } \\
\quad \text { Collembola }\end{array}$ & 10.0 & 6.0 \\
\hline $\begin{array}{l}\text { Ephemeroptera } \\
\text { Baetidae } \\
\text { Bactis } \\
\text { Centroptilum } \\
\text { Pseudocloeon } \\
\text { Caenidae } \\
\text { Ephemerellidae } \\
\text { Ephemeridae } \\
\text { Heptageniidae } \\
\text { Leptophlebiidae } \\
\text { Oligoneuriidae } \\
\text { Siphlonuridae }\end{array}$ & $\begin{array}{r}5.0 \\
10.0 \\
10.5 \\
6.5 \\
7.5 \\
10.0 \\
6.0 \\
5.0 \\
5.0 \\
6.5 \\
10.0 \\
10.0\end{array}$ & $\begin{array}{r}12.0 \\
6.0 \\
3.0 \\
9.0 \\
8.0 \\
6.0 \\
10.0 \\
12.0 \\
12.0 \\
9.0 \\
6.0 \\
6.0\end{array}$ \\
\hline $\begin{array}{l}\text { Odonata } \\
\text { Anisoptera } \\
\text { Zygoptera }\end{array}$ & $\begin{array}{l}2.5 \\
5.0\end{array}$ & $\begin{array}{l}24.0 \\
12.0\end{array}$ \\
\hline $\begin{array}{l}\text { Plecoptera } \\
\text { Capnidae } \\
\text { Chloroperlidae } \\
\text { Alloperla } \\
\text { Leuctridae } \\
\text { Nemouridae } \\
\text { Peltoperlidae } \\
\text { Perlidae } \\
\text { Eccoptura xanthenes } \\
\text { Perlesta } \\
\text { Perlodidae } \\
\text { Taeniopterygidae }\end{array}$ & $\begin{array}{r}5.0 \\
10.0 \\
5.0 \\
3.5 \\
6.7 \\
10.0 \\
3.5 \\
5.0 \\
2.5 \\
10.0 \\
5.0 \\
10.0\end{array}$ & $\begin{array}{r}12.0 \\
6.0 \\
12.0 \\
18.0 \\
9.0 \\
6.0 \\
18.0 \\
12.0 \\
24.0 \\
6.0 \\
12.0 \\
6.0\end{array}$ \\
\hline $\begin{array}{l}\text { Tomiptera } \\
\text { Corixidae } \\
\text { Gerridae } \\
\text { Veliidae }\end{array}$ & $\begin{array}{r}5.0 \\
40.0 \\
40.0\end{array}$ & $\begin{array}{r}12.0 \\
1.5 \\
1.5\end{array}$ \\
\hline
\end{tabular}


Table C.1. (continued)

\begin{tabular}{|c|c|c|}
\hline Taxon & P/Bי & $\underset{\text { (month) }}{\text { CPI }}$ \\
\hline $\begin{array}{l}\text { Megaloptera } \\
\text { Nigronia } \\
\text { Sialis }\end{array}$ & $\begin{array}{l}2.5 \\
5.0\end{array}$ & $\begin{array}{l}24.0 \\
12.0\end{array}$ \\
\hline Neuroptera & 10.0 & 6.0 \\
\hline $\begin{array}{l}\text { Trichoptera } \\
\text { Glowsocomatidae }\end{array}$ & $\begin{array}{r}5.0 \\
10.0\end{array}$ & $\begin{array}{r}12.0 \\
6.0\end{array}$ \\
\hline \multicolumn{3}{|l|}{ Hydropaychidae } \\
\hline Diplectrona modesta & 5.0 & 12.0 \\
\hline Hydropsyche & 11.0 & 4.7 \\
\hline Hydroptilidae & 7.5 & 8.0 \\
\hline Lepidostomatidae & 6.0 & 10.0 \\
\hline Leptoceridae & 7.5 & 8.0 \\
\hline Ceraclea & 6.0 & 10.0 \\
\hline Limnephilidae & 5.0 & 12.0 \\
\hline Goera & 6.0 & 10.0 \\
\hline Neophylax & 6.0 & 10.0 \\
\hline Philopotamidac & 10.0 & 6.0 \\
\hline Phryganeidae & 5.0 & 12.0 \\
\hline Polycentropodidae & 5.0 & 12.0 \\
\hline Psychomyildae & 5.0 & 12.0 \\
\hline Rhyacophilidae & 5.0 & 12.0 \\
\hline \multicolumn{3}{|l|}{ Coleoptera } \\
\hline Dryopidae & 2.5 & 24.0 \\
\hline Dytiscidae & 10.0 & 6.0 \\
\hline Elmidae & 2.5 & 24.0 \\
\hline Stenelmis" & 1.8 & 24.0 \\
\hline Eubriidae & 5.0 & 12.0 \\
\hline Gyrinidae & 5.0 & 12.0 \\
\hline Hydrophilidae & 21.0 & 2.8 \\
\hline Psephenidae & 2.5 & 24.0 \\
\hline Ptilodactylidae & 2.5 & 24.0 \\
\hline Staphylinidae & 5.0 & 12.0 \\
\hline Hymenoptera & 5.0 & 12.0 \\
\hline Diptera & 5.0 & 12.0 \\
\hline Ceratopogonidae & 10.0 & 6.0 \\
\hline Chaoboridae & 10.0 & 6.0 \\
\hline \multicolumn{3}{|l|}{ Chironomidae } \\
\hline \multicolumn{3}{|l|}{ Chironominae } \\
\hline Chironomini & 15.0 & 4.0 \\
\hline Tanytarsini & 26.0 & 2.3 \\
\hline Diamesinae & 10.0 & 6.0 \\
\hline Orthocladinae & 24.0 & 3.0 \\
\hline Tanypodinae & 17.1 & 3.5 \\
\hline Culicidae & 65.0 & 1.0 \\
\hline Dixidae & 15.0 & 4.0 \\
\hline Empididae & 5.0 & 12.0 \\
\hline
\end{tabular}




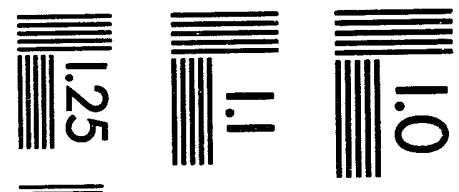

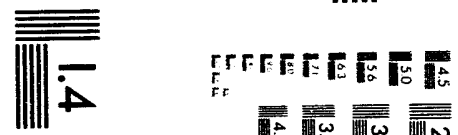

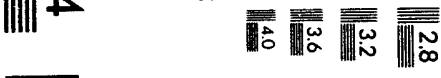

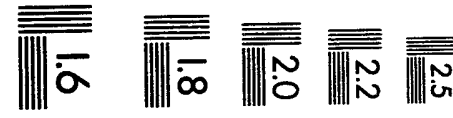



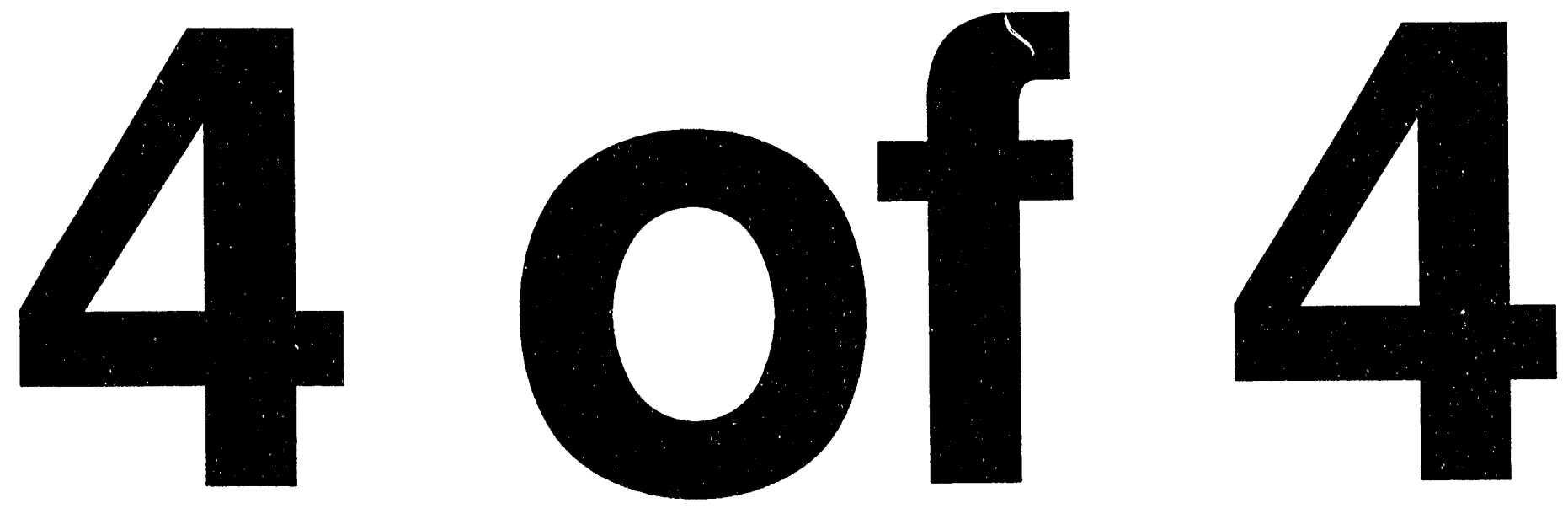
Table C.1. (continued)

\begin{tabular}{ccc}
\hline Taxon & $\mathrm{P} / \mathrm{B}^{\mathrm{a}}$ & $\begin{array}{c}\text { CPI } \\
(\text { month })^{b}\end{array}$ \\
\hline Psychodidae & 5.0 & 12.0 \\
Simuliidae & 15.0 & 4.0 \\
Stratiomyidae & 5.0 & 12.0 \\
Tabanidae & 6.7 & 9.0 \\
Tipulidae & 5.0 & 12.0 \\
& & \\
Gastropoda & 3.3 & 18.0 \\
Ancylidae & 8.6 & 7.0 \\
Bithynidae & 5.0 & 12.0 \\
Bivalvia & & \\
Corbiculidae & & 24.0 \\
Sphaeriidae & 2.5 & 18.0 \\
Unionidae & 3.3 & 24.0 \\
& 2.5 & \\
\hline
\end{tabular}

-Values derived from a theoretical annual P/B of 5.0 and corrected for CPI (T. F. Waters. 1977. Secondary production in inland waters. Adv. Ecol. Res. 10:91-164; and T. F. Waters, 1979. Influence of benthos life history upon the estimation of secondary production. J. Fish. Res. Board can. 36:1425-1430.)

${ }^{b}$ Values derived from published life history information. data).

${ }^{\circ}$ Empirically derived from other U.S. Department of Energy biomonitoring work (J. G. Smith, unpublished 


\section{APPENDIX D}

Methodology for Index of Biotic Integrity 
The fish population data at each site were analyzed using the Index of Biotic Integrity (IBI). The IBI evaluates "the ability to support and maintain a balanced, integrated, adaptive community of organisms having a species composition, diversity, and functional organization comparable to that of the natural habitat of the region" (Karr and Dudley 1981). The IBI includes 12 metrics (Table D.1) related to species richness and composition, trophic composition, and fish abundance and condition and was originally based on studies in the Midwest (Karr 1981, Karr et al. 1986). Application of the IBI results in a numerical value between 12 and 60 that represents a comparative descriptive evaluation of the fish community. Because of geographic differences in species distribution, many of the 12 metrics were modified when the IBI was used in different regions of the U. S. (Fausch et al. 1984, Miller et al. 1988). Also, more widespread use of the IBI has led to suggestions for replacement metrics that may better address the intent of the original metrics in a particular region (Ohio EPA 1988). These modifications have not diminished the value of the evaluation (Miller et al. 1988).

Following the suggestions of Karr et al. (1986) and the Ohio EPA (1988), modifications were made to the basic IBI metrics to reflect differences in the Clinch River system in the Oak Ridge area. Using historical surveys of the area (Krumholz 1956, Fitz 1968, Etnier 1978), regional distribution information (Lee et

Table D.1. Index of Biotic Integrity (IBI) metrics used to access stream fish communities in the Midwest

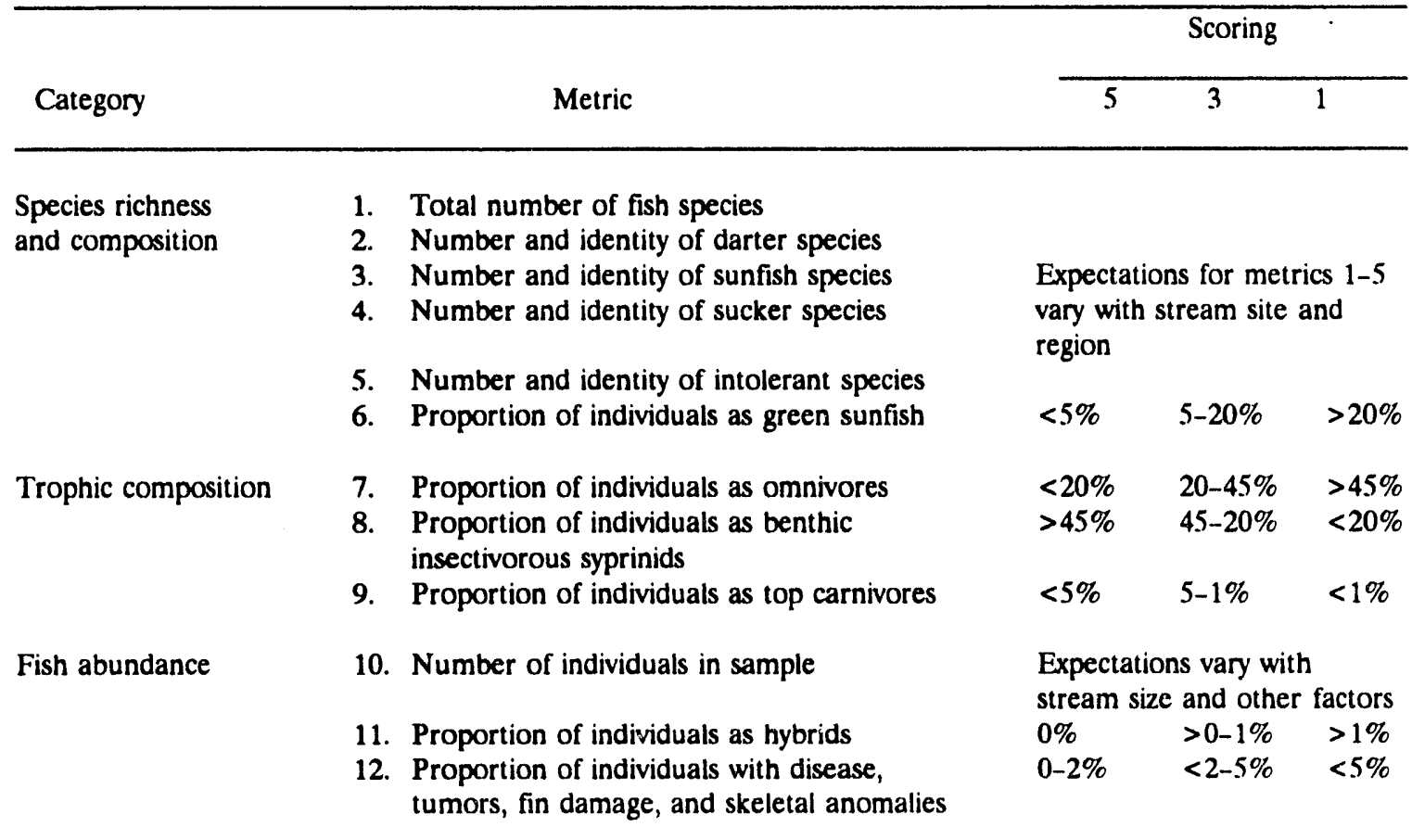

Source: J. R. Karr et al. 1986. Assessing Biological Integrity in Running Waters: $A$ Method and Its Rationale. Illinois Natural History Survey Special Publications 5. 
al. 1980, Ryon and Loar 1988, M. G. Ryon, ORNL/ESD, unpublished data), and unpublished species accounts (Etnier 1987), a baseline list of species was selected that, under the best conditions, would be present in the WOC drainage (Table D.2). These species were rated for tolerance to stream impacts, evaluated for spawning pattern, and grouped by trophic level using various sources [Smith 1979, Trautman 1981, Becker 1983, Karr et al. 1986, Etnier 1987, Ohio EPA 1987, C. Saylor, Tennessee Valley Authority (TVA), personal communication]. Also, additional fish surveys were conducted on streams in the Hinds Creek watershed, another system in the Clinch River drainage with hydrologic and geologic characteristics that are similar to WOC watershed. These surveys were performed to evaluate the relationship of fish abundance and species composition to watershed area and used the same technique that is used in the routine population surveys of streams in WOC watershed (Sect. 6.2.2) (M. G. Ryon, ORNL/ESD, unpublished data). The resulting modified IBI is shown in Table D.3.

To evaluate stream fish communities in WOC, several major changes were made in the IBI metrics originally developed by Karr et al. (1986) for midwestern streams. Metrics 5, 6, 8, 10, and 11 were modified for the Oak Ridge area, as described in the following paragraphs.

The number and identity of intolerant species (metric 5) was modified to reflect differences in species sensitivity to environmental degradation. A similar approach was used by the Ohio EPA (1987, 1988). Such an approach allowed a more flexible interpretation of this metric and, in a stream such as WOC with limited species, gave greater sensitivity to the analysis. The number of species in three categories (very, moderately, and slightly intolerant) were multiplied by $1.25,1.0$, or 0.8 , respectively, in order to obtain a value for metric 5 in Table D.3.

The proportion of green sunfish (metric 6) was changed to the proportion of tolerant species because the green sunfish is not a common species in the Clinch River drainage. The proportion of tolerant species has been used in other regions to address this same problem (Miller et al. 1988) and was even suggested as a replacement metric in the original IBI (Karr et al. 1986). The original intent of the metric, which was to indicate degradation by monitoring the changes in abundance of an extremely tolerant species, is still satisfied by using changes in the proportion of all tolerant species.

The proportion of insectivorous cyprinids (metric 8 ) is another metric that has been frequently modified for other regions (Miller et al. 1988). It was modified for the Clinch River drainage to include only percid species. This approach was similar to that used by Leonard and Orth (1986) but not as broad (all insectivores) as that used by Ohio EPA (1988). The intent of this metric was to identify impacts on the benthic invertebrate community as reflected by the abundance of insectivores. Because the Clinch River drainage had significant numbers of cyprinids and percids, adjustment of this metric to include all insectivores was deemed unnecessary.

The number of individuals in a sample (metric 10) was modified to utilize the density of fish, thereby reflecting the area sampled. This approach standardized comparisons between sites and was especially useful for the BMAP studies because routine population surveys are restricted to sampling reaches of known length. This 
Table D.2. List of species found in small streams in the Clinch River drainage near Oak Ridge, Tennessee, with information on trophic group, tolerance rankings, and lithophilic spawners

\begin{tabular}{|c|c|c|c|c|c|}
\hline \multirow{2}{*}{ Species } & \multirow{2}{*}{$\begin{array}{l}\text { Trophic } \\
\text { group }^{a}\end{array}$} & \multicolumn{4}{|c|}{ Tolerance ranking ${ }^{b}$} \\
\hline & & TOL & VIN & MIN & $\operatorname{SIN}$ \\
\hline Cyprinus carpio & OM & $\mathrm{x}$ & & & \\
\hline Campostoma anomalum & HB & & & & \\
\hline Hemitremia flammea & IN & & $\mathbf{x}$ & & \\
\hline Luxilus chrysocephalus $^{c}$ & OM & $\mathrm{x}$ & & & \\
\hline Notropis rubellus ${ }^{c}$ & IN & & $\mathbf{x}$ & & \\
\hline Phoxinus tennesseensisc & OM & & $\mathbf{x}$ & & \\
\hline Pimephales notatus & OM & & & & \\
\hline Rhinichthys atratulus ${ }^{c}$ & IN & & & & \\
\hline Semotilus atromaculatus & IN & $\mathrm{X}$ & & & \\
\hline Dorosoma cepedianum & HB & $\mathrm{x}$ & & & \\
\hline Catostomus commersonic & IN & $\mathrm{x}$ & & & \\
\hline Hypentelium nigricans ${ }^{c}$ & IN & & & $\mathrm{x}$ & \\
\hline Ameiurus melas & IN & $\mathrm{x}$ & & & \\
\hline A. natalis & $\mathrm{OM}$ & $\mathrm{x}$ & & & \\
\hline Fundulus notatus & IN & $\mathrm{x}$ & & & \\
\hline F. olivaceus & IN & & & & \\
\hline Gambusia affinis & IN & $x$ & & & \\
\hline Ambloplites rupestris & PI & & & & $x$ \\
\hline Lepomis auritus & IN & & & & \\
\hline L. cyanellus & IN & $\mathrm{x}$ & & & \\
\hline L. macrochirus & IN & & & & \\
\hline L. megalotis & IN & & & & $\mathrm{x}$ \\
\hline Micropterus dolomieu & PI & & & & \\
\hline M. punctulatus & PI & & & & \\
\hline M. salmoides & PI & & & & \\
\hline Etheostoma caeruleum ${ }^{c}$ & IN & & $\mathrm{x}$ & & \\
\hline E. duryi & IN & & & & $\mathrm{x}$ \\
\hline E. kennicotti & IN & & & & $\mathrm{x}$ \\
\hline E. rufilineatum & IN & & & $x$ & \\
\hline E. simoterum & IN & & & & $\mathrm{x}$ \\
\hline Cottus carolinae & IN & & & $\mathrm{x}$ & \\
\hline
\end{tabular}

${ }^{\sigma} \mathrm{HB}=$ herbivore, $\mathrm{IN}=$ insectivore, $\mathrm{OM}=$ omnivore, $\mathrm{PI}=$ piscivore.

${ }^{\circ} \mathrm{TOL}=$ tolerant, VIN $=$ very intolerant, MIN $=$ moderately intolerant, $\mathrm{SIN}=$ slightly intolerant .

'Lithophilic spawner. 
Table D.3. Index of Biotic Integrity (IBI) metrics used to assess fish communities in streams in the Clinch River drainage near Oak Ridge, Tennessee

\begin{tabular}{|c|c|c|c|c|}
\hline \multirow{2}{*}{ Category } & \multirow{2}{*}{ Metric } & \multicolumn{3}{|c|}{ Scoring criteria } \\
\hline & & 5 & 3 & 1 \\
\hline \multirow{6}{*}{$\begin{array}{l}\text { Species richness } \\
\text { and composition }\end{array}$} & 1. Total number of fish species ${ }^{\circ}$ & $>19$ & $19-10$ & $9-0$ \\
\hline & 2. Number and identity of darter species & $>3$ & $3-2$ & $1-0$ \\
\hline & 3. Number and identity of sunfish species & $>3$ & $3-2$ & $1-0$ \\
\hline & 4. Number and identity of sucker species & $>1$ & 1 & 0 \\
\hline & 5. Number and identity of intolerant species $^{b}$ & $>8$ & $8-4$ & $3-0$ \\
\hline & 6. Proportion of individuals as tolerant species & $<.5 \%$ & $5-20 \%$ & $>20 \%$ \\
\hline \multirow[t]{3}{*}{ Trophic composition } & 7. Proportion of individuals as omnivores & $<20 \%$ & $20-45 \%$ & $>45 \%$ \\
\hline & $\begin{array}{l}\text { 8. Proportion of individuals as insectivorous } \\
\text { cyprinids and percids }\end{array}$ & $>45 \%$ & $45-20 \%$ & $<20 \%$ \\
\hline & 9. Proportion of individuals as piscivores & $>5 \%$ & $5-1 \%$ & $<1 \%$ \\
\hline \multirow[t]{3}{*}{ Fish abundance } & $\begin{array}{l}\text { 10. Number of individuals in sample } \\
\text { (density in numbers } / \mathrm{m}^{2} \text { ) }\end{array}$ & $>3.0$ & $1.0-3.0$ & $<1.0$ \\
\hline & $\begin{array}{l}\text { 11. Proportion of individuals as lithophilic } \\
\text { spawners }^{c}\end{array}$ & $>36$ & $36-18$ & $<18$ \\
\hline & $\begin{array}{l}\text { 12. Proportion of individuals in subsamples with } \\
\text { disease (eye status, gill, and opercle) skin } \\
\text { tumors, fin damage, skeletal anomalies, or } \\
\text { external parasites. }\end{array}$ & $0-2 \%$ & $>2-5 \%$ & $<5 \%$ \\
\hline
\end{tabular}

aNumber of native species, excluding recent introductions or stocked species.

${ }^{b}$ Intolerant species ranked as very intolerant, moderately intolerant, or slightly intolerant with a correction factor of $1.25,1.0$, or 0.8 , respectively, applied to the number in each category to achieve the numbers used in the criteria rankings.

'Percentages as used in Ohio EPA (Ohio Environmental Protection Agency). 1987. Biological criteria for the protection of aquatic life. Vol. III: Standardized biological field sampling and laboratory methods for assessing fish and macroinvertebrate communities. Ohio Environmental Protection Agency, Division of Water Quality Monitoring and Assessment, Columbus, Ohio; and, Ohio Environmental Protection Agency. 1988. Biological criteria for the protection of aquatic life, Vol. II: Users Manual for biological field assessment of Ohio surface streams. Ohio Environmental Protection Agency, Division of Water Quality Monitoring and Assessment, Columbus, Ohio.

approach may affect species richness values (i.e., richness is often proportional to area sampled) but provides good estimates of population size and density. The extensive fish sampling in the Hinds Creek watershed also utilized BMAP procedures.

The proportion of hybrid individuals (metric 11) was initially incorporated into the IBI to address impacts to reproductive isolation and success (Karr et al. 1986). However, hybrids can be difficult to identify in the field and often occur at sites of high biotic integrity (Ohio EPA 1988). Consequently this metric was replaced by one that examines the proportion of simple lithophilic spawners, as suggested by Ohio EPA (1988). Because lithophilic spawners release their eggs in gravel without parental care, the proportion of the community made up of such species would be affected by increases in siltation and pollutants (Berkman and Rabeni 
1987). Although this modification reflects the concern for effects on fish reproduction contained in the original metric, it was done with some caution because many of the lithophilic spawners were also the most tolerant species (e.g., striped shiners).

The modifications in the IBI for use in the Clinch River drainage reflected changes appropriate for its application in East Tennessee. These modifications were similar to species lists used by TVA for other areas of East Tennessee (C. Saylor, TVA, personal communication) and to changes implemented by other agencies (Ohio EPA 1987, 1988). Application of the IBI for use in the Clinch River drainage is in the initial stages of development, so specific computations may change as additional reference sites are sampled (e.g., for abundance metrics) and some metrics may require additional modification. However, the descriptive classifications (very poor, poor, fair, good, or excellent) for a particular site should remain relatively unchanged because no major modifications to the IBI are anticipated.
In addition to the above IBI that was modified for the Clinch River drainage in the Oak Ridge area, another IBI developed by the Ohio EPA (1987, 1988) for use in headwater streams (drainage area less than $52 \mathrm{~km}^{2}$ ) was applied to the WOC data. In this modified IBI, the original metrics for suckers, sunfish, and top carnivores were replaced with metrics for headwater species, minnows, and pioneering species (Table D-4). Other metrics for darters, insectivores, and lithophilic spawners were modified slightly to address changes inherent in smaller stream systems. This headwater IBI was modified to fit WOC data, primarily by adjusting some parameters for drainage area, and used for comparisons with the Clinch River IBI. Because the individual metric values were based on data for 300 reference sites in Ohio, they may not be completely applicable to the WOC drainage. Thus, results of this headwater IBI evaluation must be interpreted with caution. 
Table D.4. Index of Biotic Integrity (IBI) metrics used to assess headwater fish communities in streams in the Clinch River drainage near Oak Ridge, Tennessee

\begin{tabular}{|c|c|c|c|c|}
\hline \multirow[b]{2}{*}{ Category } & \multirow[b]{2}{*}{ Metric } & \multicolumn{3}{|c|}{$\begin{array}{l}\text { Scoring } \\
\text { criteria }\end{array}$} \\
\hline & & 5 & 3 & 1 \\
\hline \multirow[t]{4}{*}{$\begin{array}{l}\text { Species richness } \\
\text { and composition }\end{array}$} & $\begin{array}{l}\text { 1. Total number of fish species } \\
\text { 2. Number and identity of darter and } \\
\text { sculpin species }\end{array}$ & \multicolumn{3}{|c|}{$\begin{array}{l}\text { Varies with drainage area } \\
\text { Varies with drainage area }\end{array}$} \\
\hline & 3. Number and identity of headwater species ${ }^{b}$ & $>3$ & $3-2$ & $1-0$ \\
\hline & $\begin{array}{l}\text { 4. Number and identity of minnow species } \\
\text { 5. Number and identity of sensitive species }{ }^{c}\end{array}$ & \multicolumn{3}{|c|}{$\begin{array}{l}\text { Varies with drainage area } \\
\text { Varies with drainage area }\end{array}$} \\
\hline & 6. Proportion of individuals as tolerant species & $<34 \%$ & $34-57 \%$ & $>57 \%$ \\
\hline \multirow[t]{2}{*}{ Trophic composition } & $\begin{array}{l}\text { 7. Proportion of individuals as omnivores } \\
\text { 8. Proportion of individuals as insectivorous }\end{array}$ & \multicolumn{3}{|c|}{$\begin{array}{l}\text { Varies with ainage area } \\
\text { Varies with drainage area }\end{array}$} \\
\hline & 9. Proportion of individuals as pioneering species" & $<30 \%$ & $30-55 \%$ & $>55 \%$ \\
\hline \multirow[t]{3}{*}{ Fish abundance } & $\begin{array}{l}\text { 10. Number of individuals in sample } \\
\text { (density in numbers } / \mathrm{m}^{2} \text { ) }\end{array}$ & $>3.0$ & $1.0-3.0$ & $<1.0$ \\
\hline & $\begin{array}{l}\text { 11. Proportion of indivirtuals as lithophilic } \\
\text { spawners }\end{array}$ & \multicolumn{3}{|c|}{ Varies with drainage area } \\
\hline & $\begin{array}{l}\text { 12. Proportion of individuals in subsamples with } \\
\text { disease (eye status, gill, and opercle) skin } \\
\text { tumors, fin damage, skeletal anomalies, or } \\
\text { external parasites. }\end{array}$ & $0-2 \%$ & $>2-5 \%$ & $<5 \%$ \\
\hline
\end{tabular}

\footnotetext{
Number of native species, excluding recent introductions or stocked species.

'Includes Tennessee dace, blacknose dace, stripetail darter, and banded sculpin.

Includes intolerant species ranked as very intolerant or moderately intolerant.

Excludes the generalized insectivores, blacknose dace and creek chub.

Includes creek chub, bluntnose minnow, fathead minnow, and redbreast sunfish.

Using abundance data developed for Oak Ridge area streams.

Source: J. R. Karr et al. 1986. Assessing Biological Integrity in Running Waters: A Method and Its Rationale. Illinois Natural History Survey Special Publications 5.
} 
APPENDIX E

Density, Biomass, and Condition Factors of Fishes

in White Oak Creek Watershed 
Table E1. Fish densities (number of fish per square meter) in White oak Creek, First

Creek, Fifth Creek, Melton Branch, and Northwest Tributary, March-April 1988

\begin{tabular}{|c|c|c|c|c|c|c|c|c|c|c|c|c|c|c|c|c|}
\hline Species & $\begin{array}{c}\text { FCK } \\
0.1 \\
\end{array}$ & $\begin{array}{c}\text { FCK } \\
0.8 \\
\end{array}$ & $\begin{array}{c}\text { FFK } \\
0.2 \\
\end{array}$ & $\begin{array}{c}\text { FFK } \\
0.4 \\
\end{array}$ & $\begin{array}{c}\text { FFK } \\
1.0 \\
\end{array}$ & $\begin{array}{c}\text { MEK } \\
0.6 \\
\end{array}$ & $\begin{array}{c}\text { MEK } \\
1.4 \\
\end{array}$ & $\begin{array}{c}\text { MEK } \\
2.1 \\
\end{array}$ & $\begin{array}{c}\text { NTK } \\
0.3 \\
\end{array}$ & $\begin{array}{c}\text { NTK } \\
1.0 \\
\end{array}$ & $\begin{array}{c}\text { WCK } \\
2.3 \\
\end{array}$ & $\begin{array}{c}\text { WCK } \\
29 \\
\end{array}$ & $\begin{array}{c}\text { WCK } \\
\mathbf{3 . 4} \\
\end{array}$ & $\begin{array}{c}\text { wCK } \\
3.9 \\
\end{array}$ & $\begin{array}{c}\text { WCK } \\
5.1 \\
\end{array}$ & $\begin{array}{c}\text { WCK } \\
6.8 \\
\end{array}$ \\
\hline \multicolumn{17}{|l|}{ Centrarchidae } \\
\hline Bluegill & 0.03 & - & NF & - & - & - & - & NF & 0.01 & - & 0.20 & - & 0.07 & - & - & - \\
\hline Redbreast sunfish & - & - & - & - & - & 0.41 & - & - & - & - & 0.12 & 0.29 & 0.73 & - & - & - \\
\hline Largemouth bass & - & 0.11 & - & - & - & - & - & - & - & - & 0.02 & 0.01 & 0.01 & - & - & - \\
\hline Warmouth & - & - & - & - & - & - & - & - & - & - & 0.03 & - & - & - & - & - \\
\hline \multicolumn{17}{|l|}{ Clupcidse } \\
\hline Gizzard shad & - & - & - & - & - & - & - & - & - & - & 0.28 & - & - & - & - & - \\
\hline \multicolumn{17}{|l|}{ Coltidae } \\
\hline Banded sculpin & - & - & - & 0.39 & 1.79 & - & - & - & - & - & - & - & - & - & - & 0.10 \\
\hline \multicolumn{17}{|l|}{ Cyprinidae } \\
\hline Carp & - & - & - & - & - & - & - & - & - & - & $<0.01$ & - & - & - & - & - \\
\hline Blacknose dace & 0.79 & 0.73 & - & 5.86 & 0.42 & 0.41 & 0.34 & - & 0.07 & 0.02 & - & 0.01 & 0.01 & - & 0.09 & 0.65 \\
\hline Central stoneroller & - & - & - & - & - & - & - & - & - & - & $<0.01$ & - & - & - & 0.17 & - \\
\hline Creek chub & - & - & - & - & - & 1.05 & 0.21 & - & - & 0.01 & - & - & 0.02 & - & 0.27 & 0.05 \\
\hline Fathead minnow & 0.03 & - & - & - & - & - & - & - & 0.01 & 0.09 & $<0.01$ & - & 0.01 & $<0.01$ & - & - \\
\hline \multicolumn{17}{|l|}{ Gasteroutcidac } \\
\hline Brook stickleback & 0.04 & - & - & - & - & - & - & - & 0.03 & - & - & - & - & - & - & - \\
\hline \multicolumn{17}{|l|}{ Ictaluridace } \\
\hline Yellow bullhead & - & - & - & - & - & - & - & - & - & - & $<0.01$ & - & - & - & - & - \\
\hline \multicolumn{17}{|l|}{ Pocciliidac } \\
\hline Western mosquitofish & - & - & - & - & - & - & - & - & 0.02 & - & - & - & 0.05 & - & - & - \\
\hline Number of species (a) & 4 & 2 & 0 & 2 & 2 & 3 & 2 & 0 & 5 & 3 & 9 & 3 & 7 & 1 & 3 & 3 \\
\hline Total denaity & 0.89 & 0.84 & 0 & 6.25 & 2.21 & 1.87 & 0.55 & 0 & 0.14 & 0.12 & 0.65 & 0.31 & 0.90 & $<0.01$ & 0.53 & 0.80 \\
\hline
\end{tabular}

- NF = no fish taken in sample.

Note: FCK = First Creek kilometer, FFK = Fifth Creek kilometer, MEK = Melton Branch kilometer, NTK $=$ Northwest Tributary kilometer, WCK $=$ White Oak Creek kilometer. 
Table E2 Fish biomass (in grams per square meter) in White Oak Creek, First Creek, Fifth Creek, Melton Branch, and Northwest Tributary, March-April 1988

\begin{tabular}{|c|c|c|c|c|c|c|c|c|c|c|c|c|c|c|c|c|}
\hline Species & $\begin{array}{c}\text { FCK } \\
0.1\end{array}$ & $\begin{array}{c}\text { FCK } \\
0.8\end{array}$ & $\begin{array}{c}\text { FFK } \\
0.2\end{array}$ & $\begin{array}{c}\text { FFK } \\
0.4\end{array}$ & $\begin{array}{c}\text { FFK } \\
1.0\end{array}$ & $\begin{array}{c}\text { MEK } \\
0.6\end{array}$ & $\begin{array}{c}\text { MEK } \\
1.4\end{array}$ & $\begin{array}{c}\text { MEK } \\
2.1\end{array}$ & $\begin{array}{c}\text { NTK } \\
0.3\end{array}$ & $\begin{array}{c}\text { NTK } \\
1.0\end{array}$ & $\begin{array}{c}\text { WCK } \\
2.3\end{array}$ & $\begin{array}{l}\text { WCK } \\
2.9\end{array}$ & $\begin{array}{c}\text { WCK } \\
3.4\end{array}$ & $\begin{array}{l}\text { WCK } \\
3.9\end{array}$ & $\begin{array}{c}\text { WCK } \\
5.1\end{array}$ & $\begin{array}{c}\text { WCK } \\
6.8\end{array}$ \\
\hline \multicolumn{17}{|l|}{ Centrarchidae } \\
\hline Bluegill & 0.09 & - & NF* & - & - & - & - & NF & $<0.02$ & - & 2.54 & - & 9.38 & - & - & - \\
\hline Redbreast sunfish & - & - & - & - & - & 0.87 & - & - & - & - & 4.76 & 7.1 & 11.29 & - & - & - \\
\hline Largemouth bass & - & 2.34 & - & - & - & - & - & - & - & - & 0.37 & 0.10 & 0.32 & - & - & - \\
\hline Warmouth & - & - & - & - & - & - & - & - & - & - & 0.68 & - & - & - & - & - \\
\hline \multicolumn{17}{|l|}{ Clupeidace } \\
\hline Gizzard shad & - & - & - & - & - & - & - & - & - & - & 3.21 & - & - & - & - & - \\
\hline \multicolumn{17}{|l|}{ Cottidace } \\
\hline Banded sculpin & - & - & - & 3.50 & 8.65 & - & - & - & - & - & - & - & - & - & - & 0.4 \\
\hline \multicolumn{17}{|l|}{ Cyprinidac } \\
\hline Carp & - & - & - & - & - & - & - & - & - & - & 1.98 & - & - & - & - & - \\
\hline Blacknose dace & 4.11 & 1.76 & - & 15.30 & 1.03 & 0.90 & 1.11 & - & 0.27 & 0.05 & - & 0.05 & $<0.02$ & - & 0.28 & 0.63 \\
\hline Central stoneroller & - & - & - & - & - & - & - & - & - & - & 0.11 & - & - & - & 1.03 & - \\
\hline Creek chub & - & - & - & - & - & 2.32 & 1.21 & - & - & $<0.04$ & - & - & 0.92 & - & 5.90 & 0.06 \\
\hline Fathead minnow & 0.06 & - & - & - & - & - & - & - & $<0.02$ & 0.12 & $<201$ & - & $<0.01$ & $<0.01$ & - & - \\
\hline \multicolumn{17}{|l|}{ Gasiéculcidac } \\
\hline Brook stickleback & 0.05 & - & - & - & - & - & - & - & 0.05 & - & - & - & - & - & - & - \\
\hline \multicolumn{17}{|l|}{ Ictaluridac } \\
\hline Yellow bullhead & - & - & - & - & - & - & - & - & - & - & 0.18 & - & - & - & - & - \\
\hline \multicolumn{17}{|l|}{ Pocciliidxe } \\
\hline Western mosquitofish & - & - & - & - & - & - & - & - & $<0.02$ & - & - & - & $<0.02$ & - & - & - \\
\hline Total bioman & 4.31 & 4.10 & 0 & 18.80 & 9.68 & 4.09 & 2.32 & 0 & 0.38 & 0.21 & 13.83 & 7.16 & 21.96 & $<0.01$ & 7.21 & 1.05 \\
\hline
\end{tabular}


Table E.3. Fish densities (number of fish per square meter) in White Oak Croek, First Creek, Fith Creek, Melton Branch, and Northwest Tributary, December 1988

\begin{tabular}{|c|c|c|c|c|c|c|c|c|c|c|c|c|c|c|c|c|}
\hline Species & $\begin{array}{c}\text { FCK } \\
0.1\end{array}$ & $\begin{array}{c}\text { FCK } \\
0.8\end{array}$ & $\begin{array}{c}\text { FFK } \\
0.2\end{array}$ & $\begin{array}{c}\text { FFK } \\
0.4\end{array}$ & $\begin{array}{c}\text { FFK } \\
1.0\end{array}$ & $\begin{array}{c}\text { MEK } \\
0.6\end{array}$ & $\begin{array}{c}\text { MEK } \\
1.4\end{array}$ & $\begin{array}{c}\text { MEK } \\
2.1\end{array}$ & $\begin{array}{c}\text { NTK } \\
0.3\end{array}$ & $\begin{array}{c}\text { NTK } \\
1.0\end{array}$ & $\begin{array}{c}\text { wCK } \\
2.3\end{array}$ & $\begin{array}{c}\text { wCK } \\
2.9\end{array}$ & $\begin{array}{c}\text { WCK } \\
3.4\end{array}$ & $\begin{array}{c}\text { WCK } \\
3.9\end{array}$ & $\begin{array}{c}\text { WCK } \\
5.1\end{array}$ & $\begin{array}{c}\text { WCK } \\
6.8\end{array}$ \\
\hline \multicolumn{17}{|l|}{ Centrurchidee } \\
\hline Bluegill & 0.01 & - & NF $=$ & - & - & - & - & NF & - & - & 0.37 & - & 0.02 & - & - & - \\
\hline Redbreast sunfish & - & - & - & - & - & 0.12 & - & - & - & - & 0.14 & 0.14 & 0.05 & - & - & - \\
\hline Largemouth bass & - & - & - & - & - & - & - & - & - & - & $<0.0$ : & - & - & - & - & - \\
\hline Warmouth & - & - & - & - & - & - & - & - & - & - & 0.05 & - & - & - & - & - \\
\hline Rock bass & - & - & - & - & - & - & - & - & - & - & $<0.01$ & - & - & - & - & - \\
\hline \multicolumn{17}{|l|}{ Cottidae } \\
\hline Banded sculpin & - & - & - & 0.17 & 2.35 & - & - & - & - & - & - & - & - & - & - & 0.17 \\
\hline \multicolumn{17}{|l|}{ Cyprinidace } \\
\hline Blacknose dace & 1.57 & 2.39 & - & 16.00 & 1.60 & 1.14 & 1.73 & - & 0.08 & 0.09 & $<0.01$ & - & 0.02 & - & 4.90 & 1.66 \\
\hline Central stoneroller & - & - & - & - & - & - & - & - & 0.01 & - & 0.02 & - & - & - & 3.23 & - \\
\hline Creek chub & - & - & - & - & - & 0.38 & 0.21 & - & - & - & - & - & - & - & 0.34 & 0.21 \\
\hline Fathead minnow & 0.01 & - & - & - & - & - & - & - & 0.01 & - & $<0.01$ & 0.01 & - & 0.09 & - & - \\
\hline \multicolumn{17}{|l|}{ Ictaluridae } \\
\hline Yellow bullhead & - & - & - & - & - & - & - & - & - & - & 0.01 & - & - & - & - & - \\
\hline \multicolumn{17}{|l|}{ Poccilifidac } \\
\hline Westem mosquitofish & 2.13 & - & - & - & - & - & - & - & 1.02 & 0.04 & 0.02 & 0.10 & 0.59 & 0.03 & - & - \\
\hline Number of species (n) & 4 & 1 & $\mathbf{0}$ & 2 & 2 & 3 & 2 & $\mathbf{0}$ & 4 & 2 & 10 & 3 & 4 & 2 & 3 & 3 \\
\hline Total density & 3.72 & 2.39 & $\mathbf{0}$ & 16.17 & 3.95 & 1.64 & 1.94 & 0 & 0.13 & 0.12 & 0.61 & 0.25 & 0.68 & 0.12 & 8.47 & 2.04 \\
\hline
\end{tabular}

$\mathrm{NF}=$ no fish taken in sample.

Note: FCK = First Creek kilometer, FFK = Fifth Creek kilometer, MEK = Melton Branch kilometer, NTK $=$ Northwest Tributary kilometer, WCK $=$ White Oak Creek kilometer. 
Table E4. Fish biomass (in grams per square meter) in White Oak Creek, First Creek, Fifth Creek, Melion Branch, and Northwest Tributary, December 1988

\begin{tabular}{|c|c|c|c|c|c|c|c|c|c|c|c|c|c|c|c|c|}
\hline Species & $\begin{array}{c}\text { FCK } \\
0.1\end{array}$ & $\begin{array}{c}\text { FCK } \\
0.8\end{array}$ & $\begin{array}{c}\text { FFK } \\
0.2\end{array}$ & $\begin{array}{c}\text { FFK } \\
0.4\end{array}$ & $\begin{array}{c}\text { FFK } \\
1.0\end{array}$ & $\begin{array}{c}\text { MEK } \\
0.6\end{array}$ & $\begin{array}{c}\text { MEK } \\
1.4\end{array}$ & $\begin{array}{c}\text { MEK } \\
2.1\end{array}$ & $\begin{array}{c}\text { NTK } \\
0.3\end{array}$ & $\begin{array}{c}\text { NTK } \\
1.0\end{array}$ & $\begin{array}{c}\text { WCK } \\
2.3\end{array}$ & $\begin{array}{c}\text { WCK } \\
2.9\end{array}$ & $\begin{array}{c}\text { WCK } \\
3.4\end{array}$ & $\begin{array}{c}\text { WCK } \\
3.9\end{array}$ & $\begin{array}{c}\text { WCK } \\
5.1\end{array}$ & $\begin{array}{c}\text { WCK } \\
6.8\end{array}$ \\
\hline \multicolumn{17}{|l|}{ Centrarchidae } \\
\hline Bluegill & 0.08 & - & NF* & - & - & - & - & NF & - & - & 3.21 & - & 1.35 & - & - & - \\
\hline Redbreast sunfish & - & - & - & - & - & 0.42 & - & - & - & - & 3.08 & 4.80 & 1.95 & - & - & - \\
\hline Largemouth bass & - & - & - & - & - & - & - & - & - & - & 0.04 & - & - & - & - & - \\
\hline Warmouth & - & - & - & - & - & - & - & - & - & - & 1.07 & - & - & - & - & - \\
\hline Rock bass & - & - & - & - & - & - & - & - & - & - & 0.02 & - & - & - & - & - \\
\hline \multicolumn{17}{|l|}{ Cottidne } \\
\hline Banded sculpin & - & - & - & 1.43 & 6.04 & - & - & - & - & - & - & - & - & - & - & 0.67 \\
\hline \multicolumn{17}{|l|}{ Cyprinidue } \\
\hline Blacknose dace & 2.28 & 2.57 & - & 17.19 & 4.55 & 1.41 & 1.60 & - & 0.22 & 0.24 & 0.01 & - & 0.07 & - & 2.68 & 1.32 \\
\hline Central stoneroller & - & - & - & - & - & - & - & - & 0.23 & - & 0.28 & - & - & - & 6.88 & - \\
\hline Creek chub & - & - & - & - & - & 2.30 & 0.75 & - & - & - & - & - & - & - & 1.05 & 0.22 \\
\hline Fathead minnow & 0.03 & - & - & - & - & - & & - & 0.01 & - & $<0.01$ & $<0.01$ & - & 0.05 & - & - \\
\hline \multicolumn{17}{|l|}{ Ictaluridae } \\
\hline Yellow bullhead & - & - & - & - & - & - & - & - & - & - & 0.20 & - & - & - & - & - \\
\hline \multicolumn{17}{|l|}{ Poccilidace } \\
\hline Western mosquitofish & 0.58 & - & - & - & - & - & - & - & 0.34 & 0.02 & 0.01 & 0.02 & 0.12 & 0.01 & - & - \\
\hline Total biomas & 2.97 & 2.57 & $\mathbf{0}$ & 18.62 & 10.59 & 4.13 & 2.35 & $\mathbf{0}$ & 0.8 & 0.26 & 7.73 & 4.82 & 3.49 & 0.06 & 10.61 & 2.21 \\
\hline
\end{tabular}

NF $=$ no fish taken in sample.
Note: FCK = First Creek kilometer, FFK = Fifth Creek kilometer, MEK = Melton Branch kilometer, NTK = Northwest Tributary kilometer, WCK = White Oak Creek kilometer. 
Table E.5. Comparison between sampling sites on White Oak Creek, First Creek, Fifth Creek,

Melton Branch, and Northwest Tributary of mean condition factors $(K)$ of

fish species collected in March-April and December 1988

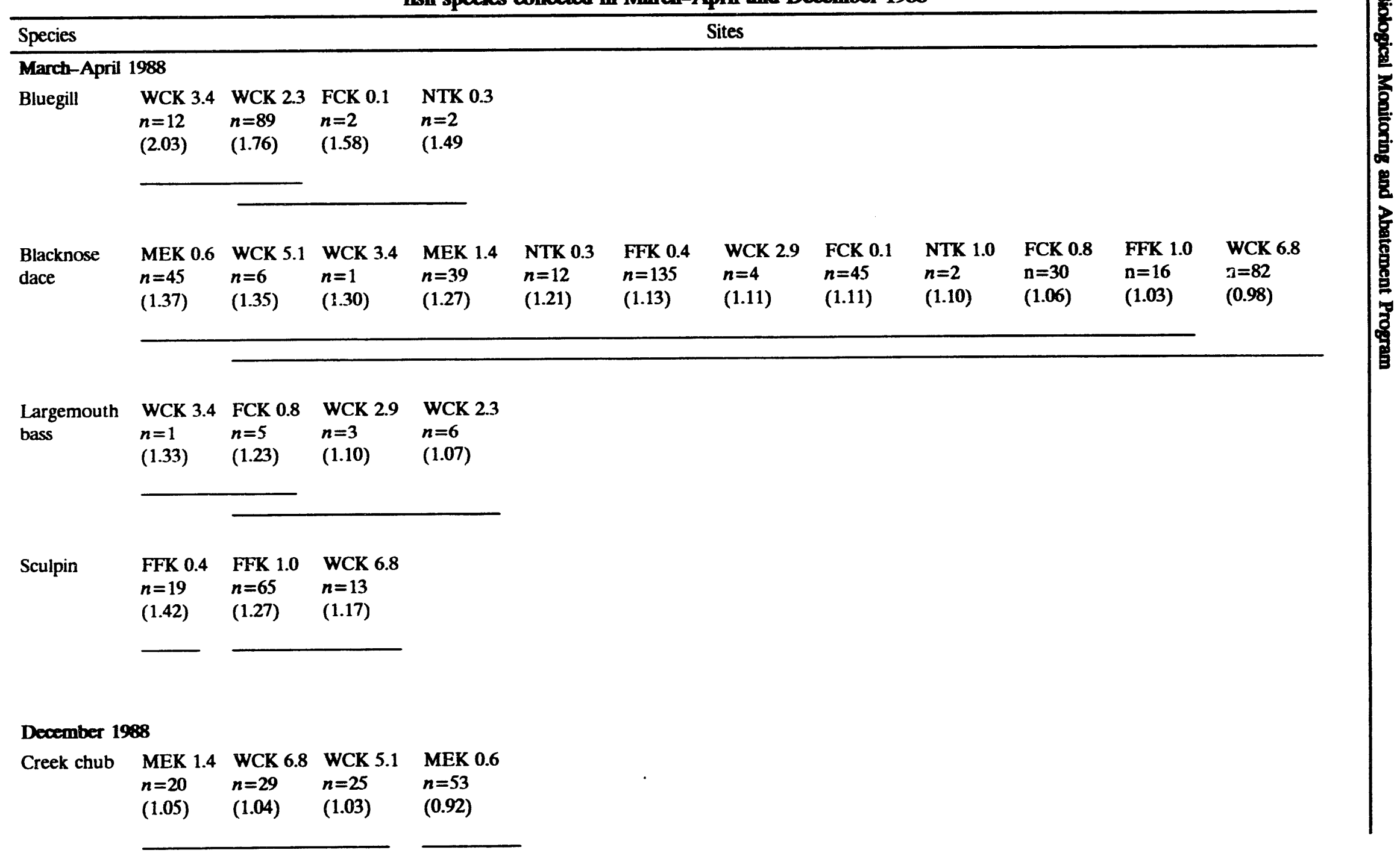


Table E.5. (continued)

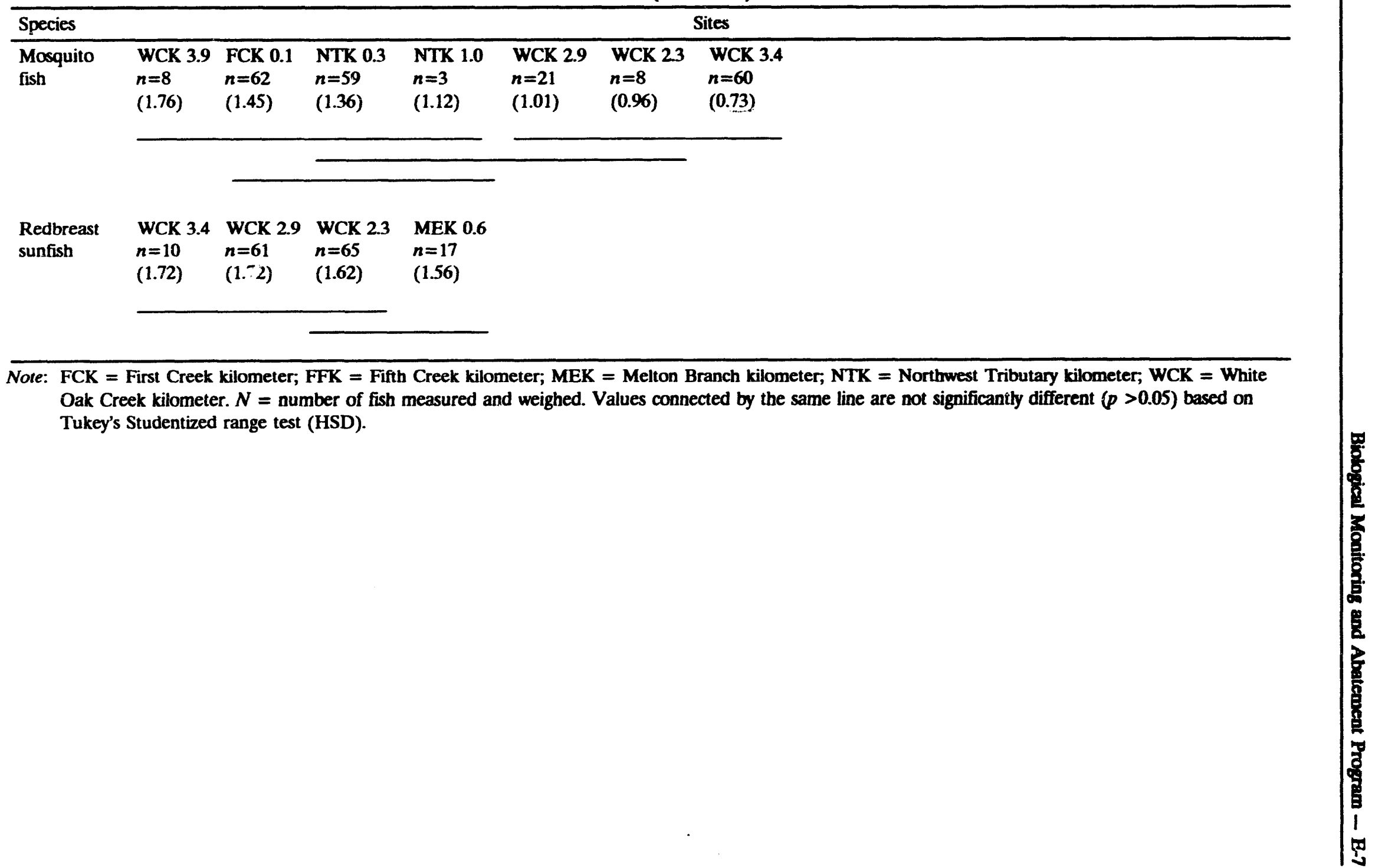




\section{APPENDIX F}

Food Habits, Contaminant Concentrations $\left({ }^{137} \mathrm{Cs},{ }^{60} \mathrm{Co}\right.$, ${ }^{90} \mathrm{Sr}$, and Mercury), and Percent Double-Stranded DNA Levels in Yellow-bellied Slider Turtles (Pseudemys scripta) and Common Snapping Turtles

(Chelydra serpentina) from White Oak Lake and

Bearden Creek Embayment 
Table F.1. Food habits of male snapping turtles (Chebydra serpentina) collected from White Oak Lake

\begin{tabular}{lrcc}
\hline \multirow{2}{*}{ Capture date } & \multicolumn{3}{c}{ GI tract components (\% volume) } \\
\cline { 2 - 4 } & Fish & Vegetation & Rocks \& Mud \\
\hline $4 / 20 / 88$ & 60 & 20 & 0 \\
$4 / 29 / 88$ & 60 & 40 & 0 \\
$4 / 29 / 88$ & 50 & 50 & 0 \\
$5 / 1 / 88$ & 15 & 85 & 0 \\
$5 / 4 / 88$ & 50 & 50 & 0 \\
$5 / 6 / 88$ & 100 & 0 & 0 \\
$5 / 7 / 88$ & 60 & 40 & 0 \\
$5 / 7 / 88$ & 5 & 95 & 0 \\
$5 / 8 / 88$ & 10 & 85 & 5 \\
$5 / 9 / 88$ & 100 & 0 & 0 \\
$5 / 14 / 88$ & 40 & 60 & 0 \\
$5 / 14 / 88$ & 50 & 50 & 0 \\
\hline
\end{tabular}

Table F.2. Cesium-137 in muscle tissue of yellow-bellied sliders (Pseudemys scripta) collected from White Oak Lake

\begin{tabular}{lccc}
\hline Capture date & $\begin{array}{c}\text { Whole body } \\
\text { wet wt } \\
(\mathrm{g})\end{array}$ & Sex & $\begin{array}{c}{ }^{137} \mathrm{Cs} \\
(\mathrm{Bq} / \mathrm{g} \text { wet wt })\end{array}$ \\
\hline $7 / 27 / 87$ & 989 & Male & 33.0 \\
$7 / 27 / 87$ & 1865 & Female & $16.6 \times 10^{-2}$ \\
$7 / 27 / 87$ & 619 & Female & $38.4 \times 10^{-2}$ \\
$8 / 11 / 87$ & 932 & Male & $5.02 \times 10^{2}$ \\
$8 / 12 / 87$ & 1820 & Female & $12.4 \times 10^{-2}$ \\
$8 / 17 / 87$ & 1687 & Female & $30.0 \times 10^{-2}$ \\
$8 / 27 / 87$ & 419 & Male & $41.5 \times 10^{-2}$ \\
$9 / 3 / 87$ & 369 & Male & $36.7 \times 10^{-2}$ \\
$9 / 3 / 87$ & 351 & Male & $55.2 \times 10^{-2}$ \\
$9 / 3 / 87$ & 834 & Male & $32.4 \times 10^{-2}$ \\
$9 / 10 / 87$ & 2750 & Female & $38.5 \times 10^{-2}$ \\
$9 / 16 / 87$ & 1487 & Female & $27.7 \times 10^{-2}$ \\
\hline
\end{tabular}


Table F.3. Cobalt-60 and ${ }^{27} \mathrm{Cs}$ in liver tissue of yellow-bellied sliders (Pseudemys scripta) collected from White Oak Lake

\begin{tabular}{lcccc}
\hline \multirow{2}{*}{ Capture date } & $\begin{array}{c}\text { Whole body } \\
\text { wet wt } \\
(\mathrm{g})\end{array}$ & Sex & \multicolumn{2}{c}{ Concentration $(\mathrm{Bq} / \mathrm{g}$ wet wt) } \\
\cline { 4 - 5 } & 989 & Male & 3.10 & $19.1 \times 10^{-2}$ \\
\hline $7 / 27 / 87$ & 1865 & Female & $8.41 \times 10^{-2}$ & $8.75 \times 10^{-2}$ \\
$7 / 27 / 87$ & 619 & Female & $11.9 \times 10^{-2}$ & $4.9 \times 10^{-2}$ \\
$7 / 27 / 87$ & 932 & Male & 66.1 & $17.2 \times 10^{2}$ \\
$8 / 11 / 87$ & 1820 & Female & $5.96 \times 10^{-2}$ & $1.21 \times 10^{-2}$ \\
$8 / 12 / 87$ & 1687 & Female & $4.63 \times 10^{-2}$ & $2.82 \times 10^{-2}$ \\
$8 / 17 / 87$ & 419 & Male & $12.9 \times 10^{-2}$ & $1.65 \times 10^{-2}$ \\
$8 / 27 / 87$ & 369 & Male & $9.41 \times 10^{-2}$ & $1.39 \times 10^{-2}$ \\
$9 / 3 / 87$ & 351 & Male & $13.1 \times 10^{-2}$ & $2.9 \times 10^{-2}$ \\
$9 / 3 / 87$ & 834 & Male & $5.56 \times 10^{-2}$ & $3.64 \times 10^{-2}$ \\
$9 / 3 / 87$ & 2750 & Female & $7.93 \times 10^{-2}$ & $3.86 \times 10^{-2}$ \\
$9 / 10 / 87$ & 1487 & Female & $6.11 \times 10^{-2}$ & $4.98 \times 10^{-2}$ \\
$9 / 16 / 87$ & & & &
\end{tabular}

Table F.4. Cesium-137 in muscle tissue of male snapping turtles (Chelydra serpentina) collected from White Oak Lake

\begin{tabular}{lcc}
\hline Capture date & $\begin{array}{c}\text { Whole body } \\
\text { wet wt } \\
(\mathrm{g})\end{array}$ & $\begin{array}{c}{ }^{137} \mathrm{Cs} \\
(\mathrm{Bq} / \mathrm{g} \text { wet wt })\end{array}$ \\
\hline $4 / 20 / 88$ & 6.80 & $23.6 \times 10^{-2}$ \\
$4 / 29 / 88$ & 13.6 & $24.5 \times 10^{-2}$ \\
$4 / 29 / 88$ & 11.1 & $29.3 \times 10^{-2}$ \\
$5 / 1 / 88$ & 9.07 & 1.37 \\
$5 / 4 / 88$ & 15.0 & $28.3 \times 10^{-2}$ \\
$5 / 6 / 88$ & 11.3 & $38.9 \times 10^{-2}$ \\
$5 / 7 / 88$ & 9.07 & $32.1 \times 10^{-2}$ \\
$5 / 7 / 88$ & 3.86 & $20.3 \times 10^{-2}$ \\
$5 / 8 / 88$ & 11.8 & $41.7 \times 10^{-2}$ \\
$5 / 9 / 88$ & 8.85 & $37.0 \times 10^{-2}$ \\
$5 / 14 / 88$ & 8.16 & $33.7 \times 10^{-2}$ \\
$5 / 14 / 88$ & 7.26 & $28.2 \times 10^{-2}$ \\
\hline
\end{tabular}


Table F.5. Strontium-90 in bone and carapace of yellow-bellied sliders (Pseudemys scripta) collected from White Oak Lake

\begin{tabular}{|c|c|c|c|c|}
\hline \multirow{2}{*}{ Capture date } & \multirow{2}{*}{ Sex } & \multirow{2}{*}{$\begin{array}{l}\text { Whole body } \\
\text { wet wt } \\
\text { (g) }\end{array}$} & \multicolumn{2}{|c|}{${ }^{00} \mathrm{Sr}(\mathrm{Bq} / \mathrm{g}$ wet $\mathrm{wr})$} \\
\hline & & & Bone & Carapace \\
\hline $7 / 27 / 87$ & Male & 989 & 144 & 142 \\
\hline $7 / 27 / 87$ & Female & 1865 & 29.6 & 42.4 \\
\hline $7 / 27 / 87$ & Female & 619 & 10.5 & 12.5 \\
\hline $8 / 11 / 87$ & Male & 932 & 4830 & 4070 \\
\hline $8 / 12 / 87$ & Female & 1820 & 2.31 & 1.65 \\
\hline $8 / 17 / 87$ & Female & 1687 & 14.8 & 21.4 \\
\hline $8 / 27 / 87$ & Male & 419 & 14.5 & 20.0 \\
\hline $9 / 3 / 87$ & Male & 369 & 12.6 & 14.7 \\
\hline $9 / 3 / 87$ & Male & 351 & 11.4 & 14.3 \\
\hline $9 / 3 / 87$ & Male & 834 & 12.5 & 17.5 \\
\hline $9 / 10 / 87$ & Female & 2750 & 16.5 & 18.5 \\
\hline $9 / 16 / 87$ & Female & 1487 & 16.1 & 17.4 \\
\hline
\end{tabular}

Table F.6. Strontium-90 in bone and carapace of yellow-bellied sliders

(Pseudemys scripta) collected from Bearden Creek embayment $\mathrm{ND}=$ Not detected $\left(<3.7 \times 10^{-2} \mathrm{~Bq} / \mathrm{g}\right.$ wet $\left.\mathrm{wt}\right)$

\begin{tabular}{|c|c|c|c|c|}
\hline \multirow{2}{*}{ Capture date } & \multirow{2}{*}{ Sex } & \multirow{2}{*}{$\begin{array}{l}\text { Whole body } \\
\text { wet wt } \\
(\mathrm{g})\end{array}$} & \multicolumn{2}{|c|}{${ }^{90} \mathrm{Sr}(\mathrm{Bq} / \mathrm{g}$ wet $\mathrm{wt})$} \\
\hline & & & Bone & Carapace \\
\hline $8 / 31 / 87$ & Male & 435 & $12.0 \times 10^{-2}$ & $11.4 \times 10^{-2}$ \\
\hline $9 / 1 / 87$ & Male & 412 & ND & ND \\
\hline $9 / 1 / 87$ & Female & 2865 & $28.0 \times 10^{-2}$ & ND \\
\hline $9 / 1 / 87$ & Female & 834 & ND & ND \\
\hline $9 / 14 / 87$ & Male & 1079 & 1.04 & 1.18 \\
\hline $9 / 14 / 87$ & Male & 477 & $4.7 \times 10^{-2}$ & $16.0 \times 10^{-2}$ \\
\hline $9 / 14 / 87$ & Male & 1162 & ND & ND \\
\hline $9 / 15 / 87$ & Male & 746 & ND & ND \\
\hline $9 / 15 / 87$ & Female & 1312 & $7.0 \times 10^{-2}$ & ND \\
\hline $9 / 16 / 87$ & Female & 1350 & ND & ND \\
\hline $9 / 17 / 87$ & Female & 1101 & $5.8 \times 10^{-2}$ & ND \\
\hline $9 / 18 / 87$ & Female & 642 & ND & $4.7 \times 10^{-2}$ \\
\hline
\end{tabular}


Table F.7. Strontium-90 in bone and carapace of male snapping turtles (Chebutra serpentina) collected from White Oak Lake

\begin{tabular}{cccc}
\hline \multirow{2}{*}{ Capture date } & $\begin{array}{c}\text { Whole body } \\
\text { wet wr } \\
(\mathrm{g})\end{array}$ & \multicolumn{2}{c}{ soSr (Bq/g wet wt) } \\
\cline { 3 - 4 } & 6.80 & Bone & Carapace \\
\hline $4 / 20 / 88$ & 13.6 & 1.70 & 1.32 \\
$4 / 29 / 88$ & 11.1 & 41.4 & 30.6 \\
$4 / 29 / 88$ & 9.07 & 17.7 & 22.5 \\
$5 / 1 / 88$ & 15.0 & 47.2 & 46.0 \\
$5 / 4 / 88$ & 11.3 & 12.9 & 12.0 \\
$5 / 6 / 88$ & 9.07 & 10.9 & 15.3 \\
$5 / 7 / 88$ & 3.86 & 12.7 & 11.9 \\
$5 / 7 / 88$ & 11.8 & 16.5 & 17.8 \\
$5 / 8 / 88$ & 8.85 & 14.6 & 16.0 \\
$5 / 9 / 88$ & 8.16 & 14.6 & 17.3 \\
$5 / 14 / 88$ & 7.26 & 14.1 & 15.4 \\
$5 / 14 / 88$ & & 11.9 & 12.9 \\
\hline
\end{tabular}

Table F.8. Strontium-90 in bone and carapace of snapping turtles (Chelyctra serpertina) from Bearden Creek embayment $\mathrm{ND}=$ Not detected $\left(<3.7 \times 10^{-2} \mathrm{~Bq} / \mathrm{g}\right.$ wet $\left.\mathrm{wt}\right)$

\begin{tabular}{llccc}
\hline \multirow{2}{*}{ Capture date } & Sex & $\begin{array}{c}\text { Whole body } \\
\text { wet wt } \\
\end{array}$ & $(\mathrm{g})$ & \multicolumn{2}{c}{ 90 Sr (Bq/g wet wt) } \\
\cline { 4 - 5 } & Female & 4.99 & Bone & Carapace \\
\hline $5 / 29 / 88$ & Female & 4.54 & ND & ND \\
$5 / 1 / 88$ & Female & 4.31 & $20.6 \times 10^{-2}$ & ND \\
$5 / 9 / 88$ & Male & 11.6 & ND & ND \\
$5 / 10 / 88$ & Male & 9.07 & ND & ND \\
$5 / 27 / 88$ & Male & 10.4 & ND & ND \\
$5 / 30 / 88$ & Male & 4.99 & ND & ND \\
$6 / 7 / 88$ & Male & 7.94 & $17.4 \times 10^{-2}$ & $17.3 \times 10^{-2}$ \\
$7 \pi / 88$ & Male & 6.80 & $21.1 \times 10^{-2}$ & $20.6 \times 10^{-2}$ \\
$7 / 12 / 88$ & & & &
\end{tabular}


Table F.9. Total inorganic and organic mercury in tissues of common snapping turtles (Chelyctra serpentina) from White Oak Lake

\begin{tabular}{|c|c|c|c|}
\hline Capture date & $\begin{array}{c}\text { Whole body } \\
\text { wet wt } \\
\text { (8) }\end{array}$ & Tissue & $\underset{(\mu \mathrm{g} / \mathrm{g} \text { wet } w t)}{\mathrm{Hg}}$ \\
\hline $4 / 20 / 88$ & 6.80 & $\begin{array}{l}\text { Kidney } \\
\text { Muscle }\end{array}$ & $\begin{array}{l}0.32 \\
0.11\end{array}$ \\
\hline $4 / 29 / 88$ & 13.6 & $\begin{array}{l}\text { Kidney } \\
\text { Muscle }\end{array}$ & $\begin{array}{l}1.28 \\
0.15\end{array}$ \\
\hline $4 / 29 / 88$ & 11.1 & $\begin{array}{l}\text { Kidney } \\
\text { Muscle }\end{array}$ & $\begin{array}{l}4.38 \\
0.10\end{array}$ \\
\hline $5 / 1 / 88$ & 9.07 & $\begin{array}{l}\text { Kidney } \\
\text { Muscle }\end{array}$ & $\begin{array}{l}1.11 \\
0.10\end{array}$ \\
\hline $5 / 4 / 88$ & 15.0 & $\begin{array}{l}\text { Kidney } \\
\text { Muscle }\end{array}$ & $\begin{array}{l}0.57 \\
0.18\end{array}$ \\
\hline $5 / 6 / 88$ & 11.3 & $\begin{array}{l}\text { Kidney } \\
\text { Muscle }\end{array}$ & $\begin{array}{l}1.35 \\
0.32\end{array}$ \\
\hline $5 / 7 / 88$ & 9.07 & $\begin{array}{l}\text { Kidney } \\
\text { Muscle }\end{array}$ & $\begin{array}{l}2.06 \\
0.24\end{array}$ \\
\hline $5 / 7 / 88$ & 3.86 & $\begin{array}{l}\text { Kidney } \\
\text { Muscle }\end{array}$ & $\begin{array}{l}0.56 \\
0.11\end{array}$ \\
\hline $5 / 8 / 88$ & 11.8 & $\begin{array}{l}\text { Kidney } \\
\text { Muscle }\end{array}$ & $\begin{array}{l}0.24 \\
0.27\end{array}$ \\
\hline $5 / 9 / 88$ & 8.85 & $\begin{array}{l}\text { Kidney } \\
\text { Muscie }\end{array}$ & $\begin{array}{l}0.25 \\
0.15\end{array}$ \\
\hline $5 / 14 / 88$ & 8.16 & $\begin{array}{l}\text { Kidney } \\
\text { Muscle }\end{array}$ & $\begin{array}{l}0.97 \\
0.12\end{array}$ \\
\hline $5 / 14 / 88$ & 7.26 & $\begin{array}{l}\text { Kidney } \\
\text { Muscle }\end{array}$ & $\begin{array}{l}0.51 \\
0.17\end{array}$ \\
\hline
\end{tabular}


Table F.10. Total inorganic and organic mercury in tissues of common snapping turtles (Chebydra seppentina) from Bearden Creek embayment

\begin{tabular}{|c|c|c|c|c|}
\hline Capture date & Sex & $\begin{array}{l}\text { Whole tody } \\
\text { wet wt } \\
\text { (8) }\end{array}$ & Tissue & $\underset{(\mu \mathrm{g} / \mathrm{g} \text { wet } w t)}{\mathrm{Hg}_{\mathrm{g}}}$ \\
\hline $4 / 29 / 88$ & Female & 4.99 & $\begin{array}{l}\text { Kjaney } \\
\text { Muscle }\end{array}$ & $\begin{array}{l}0.16 \\
0.07\end{array}$ \\
\hline $5 / 1 / 88$ & Female & 4.54 & $\begin{array}{l}\text { Kidney } \\
\text { Muscle }\end{array}$ & $\begin{array}{l}0.19 \\
0.06\end{array}$ \\
\hline $5 / 9 / 88$ & Female & 4.31 & $\begin{array}{l}\text { Kidney } \\
\text { Muscle }\end{array}$ & $\begin{array}{l}0.28 \\
0.06\end{array}$ \\
\hline $5 / 10 / 88$ & Male & 11.6 & $\begin{array}{l}\text { Kidney } \\
\text { Muscle }\end{array}$ & $\begin{array}{l}0.24 \\
0.10\end{array}$ \\
\hline $5 / 27 / 88$ & Male & 9.07 & $\begin{array}{l}\text { Kidney } \\
\text { Muscle }\end{array}$ & $\begin{array}{l}0.24 \\
0.07\end{array}$ \\
\hline $5 / 30 / 88$ & Male & 10.4 & $\begin{array}{l}\text { Kidney } \\
\text { Muscle }\end{array}$ & $\begin{array}{l}1.07 \\
0.20\end{array}$ \\
\hline $6 / 7 / 88$ & Male & 4.99 & $\begin{array}{l}\text { Kidney } \\
\text { Muscle }\end{array}$ & $\begin{array}{l}0.24 \\
0.12\end{array}$ \\
\hline $7 / 788$ & Male & 7.94 & $\begin{array}{l}\text { Kidney } \\
\text { Muscle }\end{array}$ & $\begin{array}{l}0.33 \\
0.12\end{array}$ \\
\hline $7 / 12 / 88$ & Male & 6.80 & $\begin{array}{l}\text { Kidney } \\
\text { Muscle }\end{array}$ & $\begin{array}{l}0.33 \\
0.08\end{array}$ \\
\hline
\end{tabular}

Table F.11. Fraction of double-stranded (ds) deosyribonucleic acid (DNA) in liver of male snapping turtles (Chebytra serpentina) from White Oak Lake

\begin{tabular}{ccc}
\hline Capture date & $\begin{array}{c}\text { Whole body } \\
\text { wet wr } \\
(\mathrm{g})\end{array}$ & $\begin{array}{c}\text { DNA } \\
\text { (fraction ds) }\end{array}$ \\
\hline $4 / 20 / 88$ & 6.80 & 0.654 \\
$4 / 29 / 88$ & 13.6 & 0.432 \\
$4 / 29 / 88$ & 11.1 & 0.701 \\
$5 / 1 / 88$ & 9.07 & 0.490 \\
$5 / 4 / 88$ & 15.0 & 0.782 \\
$5 / 6 / 88$ & 11.3 & 0.568 \\
$5 / 7 / 88$ & 9.07 & 0.696 \\
$5 / 7 / 88$ & 3.86 & 0.727 \\
$5 / 8 / 88$ & 11.8 & 0.441 \\
$5 / 9 / 88$ & 8.85 & 0.624 \\
$5 / 14 / 88$ & 8.16 & 0.595 \\
$5 / 14 / 88$ & 7.26 & 0.598 \\
\hline
\end{tabular}


Table F.12 Fraction of double-stranded (ds) deaxyribonucleic acid in liver of snapping turtles (Chebydra sespentina) from Bearden Creek embayment

\begin{tabular}{lccc}
\hline Capture date & Sex & $\begin{array}{c}\text { Whole body } \\
\text { wet } w t \\
(\mathrm{~g})\end{array}$ & $\begin{array}{c}\text { DNA } \\
\text { (fraction ds) }\end{array}$ \\
\hline $4 / 29 / 88$ & Female & 4.99 & 0.866 \\
$5 / 1 / 88$ & Female & 4.54 & 0.798 \\
$5 / 9 / 88$ & Male & 4.31 & 0.868 \\
$5 / 10 / 88$ & Male & 11.6 & 0.907 \\
$5 / 27 / 88$ & Male & 9.07 & 0.862 \\
$5 / 30 / 88$ & Male & 10.4 & 0.832 \\
$6 / 7 / 88$ & Male & 4.99 & 0.951 \\
$7 / 7 / 88$ & Male & 7.94 & 1.0 \\
$7 / 12 / 88$ & Male & 6.80 & 0.921 \\
\hline
\end{tabular}




\section{APPENDIX G}

\section{Errata}


Errata addendum to the Second Report on the Oak Ridge National Laboratory Biological Monitoring and Abatement Program for White Oak Creek Watershed and the Clinch River (ORNL/TM-10804).

(1) The original report incorrectly omitted the data on the following table, "Estimate of fish population size and biomass in White Oak Lake, May 1987," which replaces Table F-1 in your copy of that report. Table F-1, "Checklist of benthic macroinvertebrate taxa collected from White Oak Creek watershed, May through October 1986," may be retained as relevant ancillary data for purposes of comparison.

(2) It should also be noted that in Table 6-11 of the Second Report, "Fish species composition in White Oak Creek, First Creek, Fifth Creek, Melton Branch, and Northwest Tributary, January-December 1987," a datum appears in the wrong column. For the species, rock bass (Ambloplities rupestris), the table should correctly indicate that fish were collected twice at White Oak Creek kilometer (WCK) 2.3, not at Northwest Tributary kilometer (NTK) 1.0, as it currently shows. 
Table F-1. Estimate of fish population size and biomass in White Oak Lake (WOL) May 1987

\begin{tabular}{|c|c|c|c|c|c|c|c|c|c|}
\hline \multirow[b]{2}{*}{ Species ${ }^{a}$} & \multirow[b]{2}{*}{$\mathbf{M}$} & \multirow[b]{2}{*}{ C } & \multirow[b]{2}{*}{$\mathbf{R}$} & \multirow{2}{*}{$\hat{\mathbf{N}}$} & \multirow{2}{*}{$\begin{array}{c}95 \% \\
\text { CI }\end{array}$} & \multirow{2}{*}{$\begin{array}{l}\text { Mean weight } \\
\text { per individual } \\
(\mathbf{k g})\end{array}$} & \multicolumn{2}{|c|}{ Biomass } & \multirow{2}{*}{$\begin{array}{c}95 \% \\
\text { CI }\end{array}$} \\
\hline & & & & & & & $(\mathrm{kg})$ & (kg/ha) & \\
\hline Bluegill & 2,032 & 863 & 101 & 17,363 & 3,101 & 0.037 & 642.43 & 121.21 & 4.38 \\
\hline Carp & 102 & 100 & 17 & 600 & 237 & 1.55 & 930.00 & 175.47 & 17.15 \\
\hline Gizzard shad & 607 & 327 & 15 & 13,233 & 6,460 & 0.063 & 833.68 & 157.30 & 7.20 \\
\hline Golden shiner & 30 & 12 & 1 & 360 & 339 & 0.044 & 15.66 & 2.95 & 0.80 \\
\hline Largemouth bass & 226 & 112 & 44 & 575 & 120 & 0.405 & 232.88 & 43.94 & 4.66 \\
\hline Redbreast sunfish & 100 & 56 & 27 & 207 & 25 & 0.119 & 24.63 & 4.65 & 1.29 \\
\hline Redear sunfish & 190 & 33 & 4 & 1,568 & 1,427 & 0.064 & 100.20 & 18.91 & 3.36 \\
\hline Warmouth & 68 & 86 & 6 & 975 & 719 & 0.042 & 41.24 & 7.78 & 1.58 \\
\hline Yellow bass & 4 & 5 & 1 & 20 & 16 & 0.170 & 3.4 & 0.64 & 0.12 \\
\hline Fathead minnow & 1 & $\mathbf{0}$ & $\mathbf{0}$ & - & - & 0.003 & - & - & -- \\
\hline Freshwater drum & 1 & $\mathbf{0}$ & $\mathbf{0}$ & -- & -- & 0.249 & - & - & - \\
\hline Green sunfish & 1 & $\mathbf{0}$ & $\mathbf{0}$ & - & -- & 0.073 & - & - & - \\
\hline Rock bass & 1 & $\mathbf{0}$ & $\mathbf{0}$ & - & - & 0.130 & - & - & - \\
\hline Smallmouth buffalo & 1 & $\mathbf{0}$ & $\mathbf{0}$ & -- & - & 3.000 & - & - & - \\
\hline Spotted gar & 17 & $\mathbf{0}$ & $\mathbf{0}$ & - & - & 0.375 & - & - & - \\
\hline Spotted sucker & 1 & $\mathbf{0}$ & $\mathbf{0}$ & - & - & 0.472 & - & - & - \\
\hline Threadfin shad & 8 & $\mathbf{0}$ & $\mathbf{0}$ & - & $\cdots$ & 0.0215 & - & - & - \\
\hline Yellow bullhead & 5 & $\mathbf{0}$ & $\mathbf{0}$ & - & - & 0.198 & -- & - & - \\
\hline TOTAL & 3,395 & 1,594 & 216 & 34,091 & - & 7,015 & $2,824.12$ & 532.85 & \\
\hline
\end{tabular}

Note: Population size is determined by the formula, $\hat{\mathbf{N}}=\mathrm{MC} / \mathrm{R}$, where $\hat{\mathbf{N}}=$ population estimate, $\mathrm{M}=$ total number of marked fish, $\mathrm{C}=$ total number of fish in the recapture sample, and $R=$ the number of marked fish that were recap
$\hat{\mathbf{N}} \times$ mean weight per individual for the surface area of White Oak Lake $(5.3 \mathrm{ha})$ 
Table 6-11. Fish species composition in White Oak Creek, First Creek, Fith Creek, Melton Branch, and Northwest Tributary, January-December 1987

\begin{tabular}{|c|c|c|c|c|c|c|c|c|c|c|c|c|c|c|c|}
\hline Species & $\begin{array}{c}\text { FCK } \\
0.1\end{array}$ & $\begin{array}{c}\text { FCK } \\
0.8\end{array}$ & $\begin{array}{c}\text { FFK } \\
0.2\end{array}$ & $\begin{array}{c}\text { FFK } \\
0.4\end{array}$ & $\begin{array}{c}\text { FFK } \\
1.0\end{array}$ & $\begin{array}{c}\text { MEK } \\
0.6\end{array}$ & $\begin{array}{c}\text { MEK } \\
1.4\end{array}$ & $\begin{array}{c}\text { MEK } \\
2.1\end{array}$ & $\begin{array}{c}\text { NTK } \\
0.3\end{array}$ & $\begin{array}{c}\text { NTK } \\
1.0\end{array}$ & $\begin{array}{c}\text { WCK } \\
2.3\end{array}$ & $\begin{array}{c}\text { WCK } \\
2.9\end{array}$ & $\begin{array}{c}\text { WCK } \\
3.4\end{array}$ & $\begin{array}{c}\text { WCK } \\
3.9\end{array}$ & $\begin{array}{cc}\text { WCK WCK } \\
5.16 .8\end{array}$ \\
\hline
\end{tabular}

Centrarchidae

Bluegill

(Lepomis macrochinus)

Redbreast sunfish

(L. auritus)

Largemouth bass

(Micropterus salmoides)

Spotted bass

(M. punctulatus)

Warmouth

(L. gulorus)

Rock bass

(Ambloplities mpesaris)

Cottidae

Banded sculpin

(Cottus carolinae)

Cyprinidae

Carp

(Cyprinus carpio)

Blacknose dace

(Rhinichthys atratulus)

Central stoneroller

(Campostoma anomalum)

Creek chub

(Semotilus atromaculatus)

Fathead minnow

(Pimephales promelas)

$\begin{array}{llllllllllllll}2 & - & \mathrm{NF} & - & - & - & - & - & 3 & 2 & 3 & 2 & 3 \\ 1 & - & - & - & - & 3 & - & - & - & - & 3 & 3 & 3 \\ - & - & - & - & - & - & - & - & 1 & - & 1 & - & 1 \\ - & - & - & - & - & - & - & - & - & - & 3 & - & - \\ - & - & - & - & - & - & - & - & - & - & 2 & - & -\end{array}$

Gasterosteidae
Brook stickleback
(Culaea inconstans)

Ictaluridae

Yellow bullhead

(Ictalurus natalis)

Poeciliidae

Mosquitofish

(Gambusia affinis)

$\begin{array}{llllllllllllllll}3 & 3 & - & 3 & 3 & 3 & 1 & 2 & 3 & 2 & 1 & 2 & 3 & 3 & 3 & 3 \\ 1 & 3 & - & - & - & 2 & 1 & 1 & 1 & 1 & - & 1 & 2 & 2 & 3 & 3 \\ 2 & - & - & - & - & - & - & - & 2 & 2 & 2 & 3 & 2 & 2 & 3 & -\end{array}$

Number of species (N)

Numbers represent the number of sampling periods $(n=3)$ that a given species was collected at the site. WCK $=$ White Oak Creek kilometer, FCK $\approx$ First Creek kilometer; FFK $=$ Fifth Creek kilometer, MEK $=$ Melton Branch kilometer, NTK $=$ Northwest Tributary kilometer; BFK = Brushy Fork kilometer.

NF = no fish taken in sample. 
ORNL/TM-11358

\section{INTERNAL DISTRIBUTION}

1-2. S. M. Adams

3. T. L. Ashwood

4-5. R. D. Bailey

6. L. A. Baron

7. L. D. Bates

8-9. B. G. Blaylock

10-11. H. L. Boston

12. E. B. Bryant

13. T. W. Burwinkle

14. G. F. Cada

15. S. W. Christensen

16. R. B. Clapp

17. R. B. Cook

18. J. H. Cushman

19. N. H. Cutshall

20. L. R. Dole

21. C. B. Duncan

22. J. W. Evans

23. D. E. Fowler

24. M. L. Frank

25. H. R. Gaddis

26. C. W. Gehrs

27. M. S. Greeley

28. P. L. Henry

29. S. G. Hildebrand

30-31. W. R. Hill

32-41. R. L. Hinzman

42. D. D. Huff

43-44. M. A. Huston

45. D. S. Jones

46. P. Kanciruk

47. B. L. Kimmel

48. L. A. Kszos

49. A. J. Kuhaida

50-51. J. M. Loar
52. C. E. Nix

53. F. R. O'Donnell

54. P. T. Owen

55. P. D. Parr

56-57. M. J. Peterson

58. R. Petrie

59. T. L. Phipps

60. C. D. Runck

61-62. M. G. Ryon

63-64. E. M. Schilling

65. P. A. Scofield

66. J. A. Shaakir-Ali

67. F. E. Sharples

68-69. K. L. Shepard

70. D. S. Shriner

71-72. L. R. Shugart

73-74. J. G. Smith

75-76. G. R. Southworth

77. M. M. Stevens

78-79. A. J. Stewart

80. S. H. Stow

81. G. W. Suter

82. J. H. Swanks

83-84. C. K. Valentine

85. C. S. Walker

86-87. B. T. Walton

88. J. A. Watts

89. T. J. Williams

90. Central Research Library

91-105. ESD Library

106. ER Document Management Center

107-108. Laboratory Records Department

109. Laboratory Records-RC

110. ORNL Patent Office

111. ORNL Y-12 Technical Library 


\section{EXTERNAL DISTRIBUTION}

112. L. Chang, U.S. Environmental Protection Agency, 26 W. Martin Luther King Drive, Cincinnati, OH 45268

113. K. M. Charko, Bechtel National, Inc., RI/FS Team, Wing B, P.O. Box 350, Oak Ridge, TN 37831

114. J. W. Chason, Science Applications International Corp., 301 Laboratory Road, Oak Ridge, TN 37831

115. B. Cook, Tennessee Department of Environment and Conservation, DOE Oversight Division, 761 Emory Valley Road, Oak Ridge, TN 37830

116. M. T. Fagg, T.W.R.A., Ellington Agricultural Center, P.O. Box 40747, Nashville, TN 37204

117. R. N. Farvolden, Professor, Department of Earth Sciences, University of Waterloo, Waterloo, Ontario N2L 3G1 Canada

118. D. W. Freckman, Director, College of Natural Resources, Colorado State University, 101 Natural Resources Building, Fort Collins, CO 80523

119. W. Goldsmith, Radian Corporation, 120 S. Jefferson Circle, Oak Ridge, TN 37831

120. R. C. Harriss, Institute for the Study of Earth, Oceans, and Space, Science and Engineering Research Building, University of New Hampshire, Durham, NH 03824

121. G. Y. Jordy, Director, Office of Program Analysis, Office of Energy Research, ER-30, G-226, U.S. Department of Energy, Washington, DC 20545

122. D. A. Mohrbacher, Advanced Sciences, Inc., 165 Mitchell Road, Oak Ridge, TN 37830

123. A. Patrinos, Director, Environmental Sciences Division, Office of Health and Environmental Research, ER-74, U.S. Department of Energy, Washington, DC 20585

124. C. M. Pettway, Knoxville College, Knoxville, TN 37921

125. R. C. Sleeman, Department of Energy Oak Ridge Operations Office, P.O. Box 2001, Oak Ridge, TN 37831

126. A. E. Waters, Breedlove, Dennis \& Associates, Inc., Winter Park, FL 32789

127. F. J. Wobber, Environmental Sciences Division, Office of Health and Environmental Research, ER-74, U.S. Department of Energy, Washington, DC 20585

128. Office of Assistant Manager for Energy Research and Development, U.S. Department of Energy Oak Ridge Operations Office, P.O. Box 2001, Oak Ridge, TN 37831-8600

129-130. Office of Scientific and Technical Information, P.O. Box 62, Oak Ridge, TN 37831 

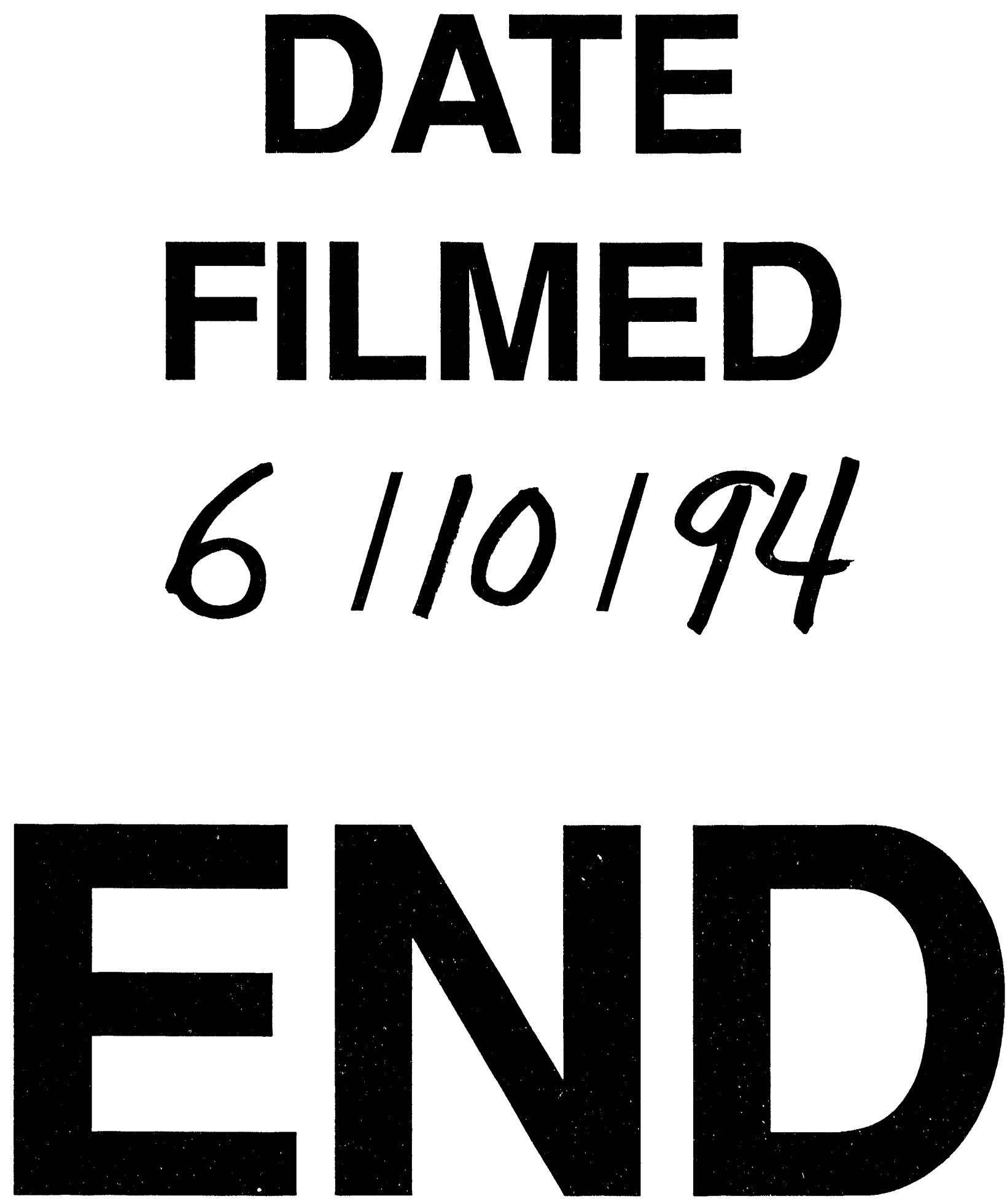

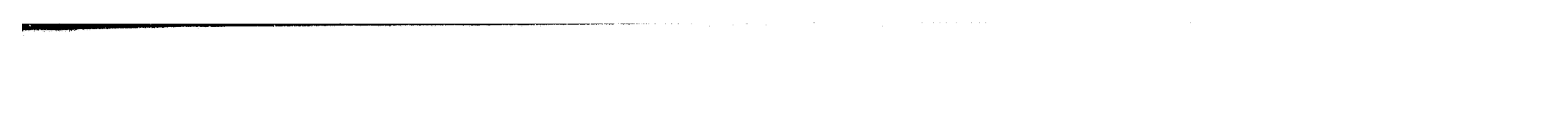

A

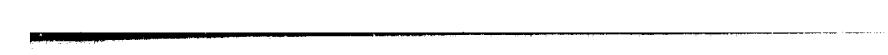

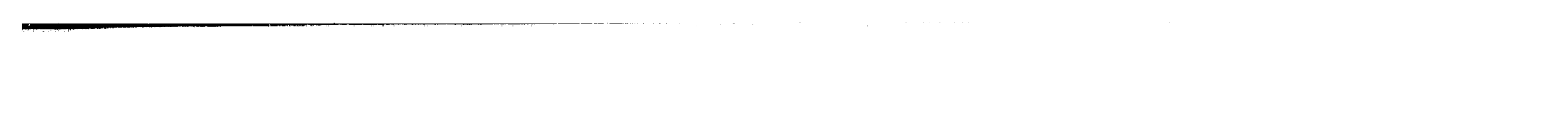

